Alternativas de cuidado a usuários de drogas na América Latina: desafios e possibilidades de ação pública

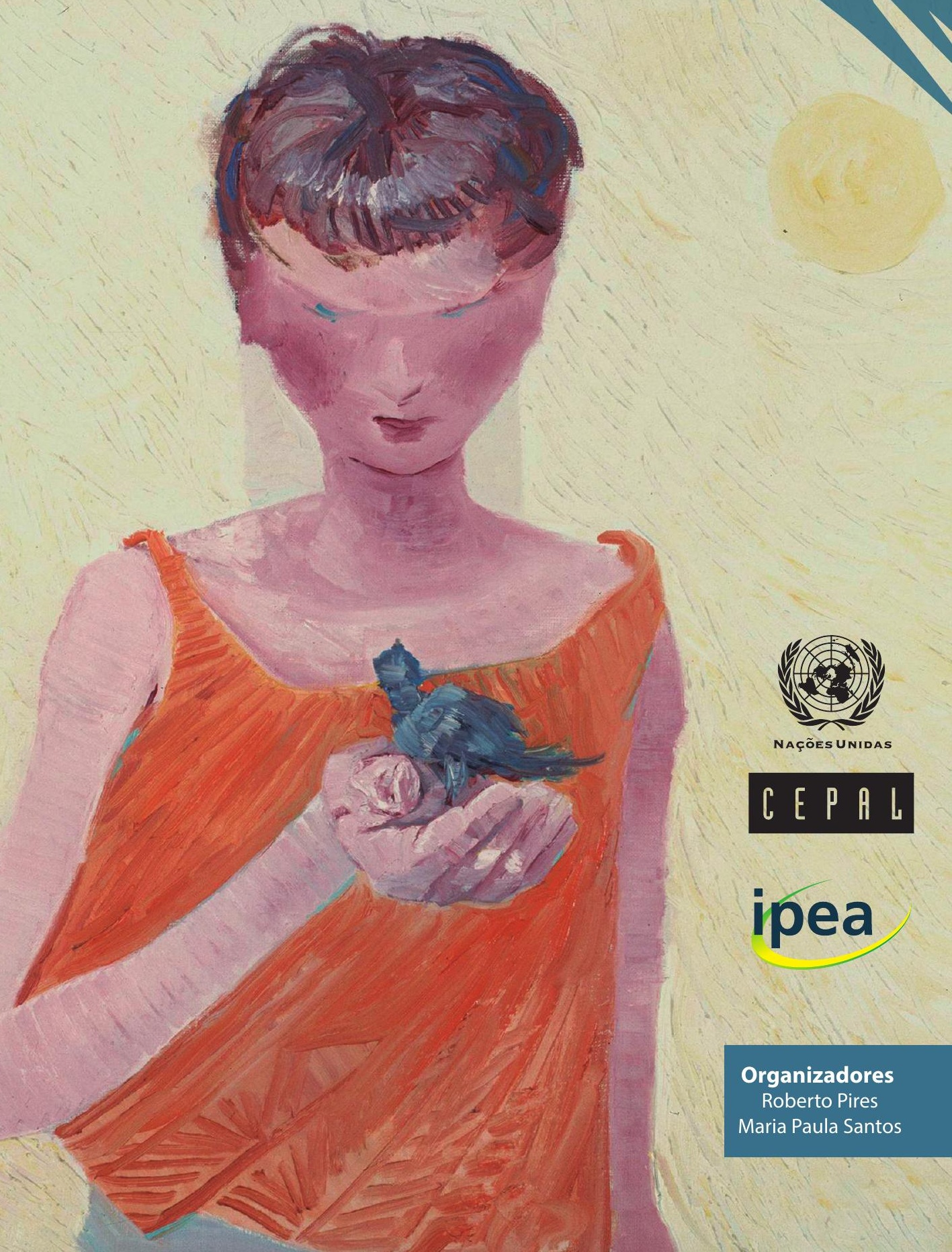





\section{Alternativas de cuidado}

a usuários de drogas na América Latina: desafios e possibilidades de ação pública 


\section{Governo Federal}

\section{Ministério da Economia}

Ministro Paulo Guedes

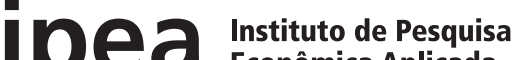 Econômica Aplicada}

Fundação pública vinculada ao Ministério da Economia, o Ipea fornece suporte técnico e institucional às ações governamentais - possibilitando a formulação de inúmeras políticas públicas e programas de desenvolvimento brasileiros - e disponibiliza, para a sociedade, pesquisas e estudos realizados por seus técnicos.

\section{Presidente}

Carlos von Doellinger

Diretor de Desenvolvimento Institucional

Manoel Rodrigues Junior

Diretora de Estudos e Políticas do Estado, das Instituições e da Democracia

Flávia de Holanda Schmidt

Diretor de Estudos e Políticas

Macroeconômicas

José Ronaldo de Castro Souza Júnior

Diretor de Estudos e Políticas Regionais, Urbanas e Ambientais

Nilo Luiz Saccaro Júnior

Diretor de Estudos e Políticas Setoriais de Inovação e Infraestrutura

André Tortato Rauen

Diretora de Estudos e Políticas Sociais

Lenita Maria Turchi

Diretor de Estudos e Relações Econômicas

e Políticas Internacionais

Ivan Tiago Machado Oliveira

Assessor-chefe de Imprensa e Comunicação

André Reis Diniz

Ouvidoria: http://www.ipea.gov.br/ouvidoria

URL: http://www.ipea.gov.br 
Alternativas de cuidado a usuários de drogas na América Latina: desafios e possibilidades de ação pública 
C Instituto de Pesquisa Econômica Aplicada - ipea 2021

(C) Comissão Econômica para a América Latina e o Caribe - CEPAL, Nações Unidas 2021

LC/BRS/TS.2021/3

\section{EQUIPE TÉCNICA}

\section{Organizadores}

Roberto Rocha C. Pires (IPEA)

Maria Paula Gomes dos Santos (IPEA)

Autores dos capítulos

Maria Paula Gomes dos Santos

Roberto Rocha C. Pires

Luiza Gomes Luz Rosa

Milena Karla Soares

Florencia Corbelle

Andrés Góngora

Johanna Salazar

Ramiro Borja

Angélica Ospina-Escobar

Clara Musto

Alternativas de cuidado a usuários de drogas na América Latina : desafios e possibilidades de ação pública / organizadores: Roberto Pires, Maria Paula Santos. - Brasília: IPEA; CEPAL, 2021.

327 p. : il., color.

Inclui Bibliografia.

ISBN: 978-65-5635-018-9

1. Usuário de Drogas. 2. Problemas Sociais. 3. Políticas Públicas. 4. Transtornos Relacionados ao Uso de Substâncias. 5. América Latina. I. Pires, Roberto. II. Santos, Maria Paula. III. Instituto de Pesquisa Econômica Aplicada. IV. Comissão Econômica para a América Latina e o Caribe.

CDD 362.1098

Ficha catalográfica elaborada por Andréa de Mello Sampaio CRB-1/1650

A obra retratada na capa deste livro, Alternativas de Cuidado a Usuários de Drogas na América Latina: desafios e possibilidades de ação pública, é a tela Menina com Pássaro, de Candido Portinari (1903-1962), datada de 1956. Além da inegável beleza e expressividade de suas obras, Portinari tem importância conceitual para um instituto de pesquisas como o Ipea. 0 "pintor do novo mundo", como já foi chamado, retratou momentos-chave da história do Brasil, os ciclos econômicos e, sobretudo, o povo brasileiro, em suas condições de vida e trabalho: questões cujo estudo faz parte da própria missão do Ipea.

A Diretoria de Estudos e Políticas do Estado, das Instituições e da Democracia (Diest) agradece ao Projeto Portinari pela honra de usar obras do artista em sua produção.

Direito de reprodução gentilmente cedido por João Candido Portinari.

DOI: http://dx.doi.org/10.38116/978-65-5635-018-9

As publicações do Ipea estão disponíveis para download gratuito nos formatos PDF (todas) e EPUB (livros e periódicos). Acesse: http://www.ipea.gov.br/portal/publicacoes

As opiniões emitidas nesta publicação são de exclusiva e inteira responsabilidade dos autores, não exprimindo, necessariamente, 0 ponto de vista do Instituto de Pesquisa Econômica Aplicada ou do Ministério da Economia e da Comissão Econômica para a América Latina e o Caribe.

É permitida a reprodução deste texto e dos dados nele contidos, desde que citada a fonte. Reproduções para fins comerciais são proibidas.

Os Estados-membros das Nações Unidas e suas instituições governamentais podem reproduzir este estudo sem autorização prévia. É solicitado, apenas, que mencionem a fonte e informem à CEPAL sobre essa reprodução.

Este estudo foi elaborado no âmbito do Programa Executivo de Cooperação entre a CEPAL e o Ipea. 


\section{SUMÁRIO}

\section{APRESENTAÇÃO}

\section{CAPÍTULO 1}

POLÍTICAS DE ATENÇÃO A PESSOAS QUE FAZEM USO PROBLEMÁTICO DE SUBSTÂNCIAS PSICOATIVAS EM CONTEXTOS DE EXTREMA DESIGUALDADE SOCIAL: DESAFIOS E POSSIBILIDADES DE AÇÃO EMERGENTES

NA AMÉRICA LATINA

Maria Paula Gomes dos Santos

Roberto Rocha C. Pires

Luiza Gomes Luz Rosa

\section{CAPÍTULO 2}

CEM ANOS DE REGULAÇÃO DO CONSUMO DE DROGAS NA AMÉRICA LATINA: O QUE NOS DIZEM AS TRAJETÓRIAS DE ARGENTINA, BRASIL, URUGUAI, COLÔMBIA E MÉXICO?

Milena Karla Soares

\section{CAPÍTULO 3}

POLITIICAS PÚBLICAS Y ABORDAJE INTEGRAL TERRITORIAL DE LOS

CONSUMOS PROBLEMÁTICOS: LAS EXPERIENCIAS DEL DIAT JUANA

AZURDUY Y EL DTC BARRIO CEIBO, PROVINCIA DE BUENOS AIRES.

Florencia Corbelle

\section{CAPÍTULO 4}

POLÍTICAS DE CUIDADO A USUÁRIOS DE ÁLCOOL E OUTRAS DROGAS

NO BRASIL: EVOLUÇÃO HISTÓRICA E DESAFIOS DE IMPLEMENTAÇÃO ....103 Maria Paula Gomes dos Santos

Roberto Rocha C. Pires

\section{CAPÍTULO 5}

CENTROS DE ESCUCHA EN COLOMBIA: POLÍTICAS Y ESCENARIOS PARA LA REDUCCIÓN DE DAÑOS EN COMUNIDADES LOCALES............................143

Andrés Góngora Johanna Salazar

Ramiro Borja 


\section{CAPÍTULO 6}

EL SISTEMA DE ATENCIÓN Y CUIDADO AL USO PROBLEMÁTICO

DE DROGAS EN MÉXICO: AISLAMIENTO, ESTIGMATIZACIÓN

Y DESAMPARO

.203

Angélica Ospina-Escobar

\section{CAPÍTULO 7}

POLÍTICAS DE ATENCIÓN A USUARIOS PROBLEMÁTICOS

DE SUSTANCIAS PSICOACTIVAS: EL CASO URUGUAYO

Clara Musto

\section{CAPÍTULO 8}

TENDÊNCIAS E DESAFIOS DAS POLÍTICAS DE CUIDADO

A USUÁRIOS DE DROGAS NA AMÉRICA LATINA

Roberto Rocha C. Pires

Maria Paula G. dos Santos

Luiza Luz Rosa 


\section{APRESENTAÇÃO}

A gestáo de uma unidade de pesquisa tem, entre seus desafios centrais, a composição de um portfólio de projetos relevante e de impacto. Em um instituto governamental de pesquisa e análise de políticas públicas, com décadas de história e de contribuiçóes a diversas áreas, como é o caso do Ipea, torna-se ainda mais importante contar com projetos aptos a fomentar discussōes robustas, ampliar o debate sobre temas de interesse público e viabilizar processos de tomada de decisão melhor informados. Esses elementos definem a relevância e o potencial de impacto de cada projeto.

O olhar que os organizadores e autores aportam a esta publicação traz todos esses elementos. Este livro, ao consolidar os achados do projeto Desigualdades Sociais e Implementação de Políticas Públicas na América Latina: políticas de atenção e cuidado a pessoas que fazem uso problemático de substâncias psicoativas, reúne qualidades que merecem destaque.

A capacidade de renovar o olhar sobre as politicas públicas e perceber espaços possiveis para contribuições inovadoras. A partir de uma pesquisa que demandou o entendimento pioneiro e profundo de um dos modelos de assistência a usuários problemáticos de drogas - a pesquisa sobre o perfil das comunidades terapêuticas brasileiras $^{1}$, , os organizadores desta obra avançaram ao investigar, de forma mais ampla, os distintos modos de atenção e cuidado a esse público, que frequentemente está entre os mais vulneráveis da população, em muitas dimensões.

A construção de olhares ampliados, que contemplam o desenho e a implementação das políticas assistenciais. Se tantas vezes o foco das pesquisas em políticas públicas recai sobre seus resultados e impactos, analisados sob lentes frequentemente míopes, este livro inova também ao integrar, em suas análises, aspectos ligados não apenas à formulação, mas também à implementação dessas políticas - momento em que frequentemente se intensificam e se reconstroem alguns dos problemas sociais que as políticas públicas deveriam resolver ou amenizar.

A conexão de olhares com diferentes pontos iniciais de observação. Problemas sociais complexos demandam respostas complexas, cuja formulação é muitas vezes subótima, quando feita a partir de um ponto de vista exclusivo. Se há no Ipea a vantagem comparativa de se agregarem formações e acúmulos de experiência bastante heterogêneos, entre times de pesquisadores, não é raro que processos de trabalho segmentados dificultem o melhor uso desses ativos. Torna-se assim ainda mais especial receber a proposta, acompanhar o desenvolvimento e acolher

1. Ver Santos (2017; 2018). 
os resultados de um projeto que contemplou, desde o seu início, a integração espontânea de diferentes grupos de pesquisa, vinculados a distintas linhas de investigação de nossa instituição.

A integração de olhares latino-americanos. Ao ter aproveitado de forma exemplar a profícua parceria que une, há décadas, o Ipea e a Comissão Econômica para a América Latina e o Caribe (CEPAL), o trabalho que deu origem a esta publicação debruçou-se sobre a experiência de diversos países do continente - Argentina, Brasil, Colômbia, México e Uruguai - com políticas de atenção a pessoas que fazem uso problemático de drogas. $\mathrm{O}$ ato de associar realidades heterogêneas, que têm como principal característica comum as desigualdades sociais, impulsiona o potencial de alcance e a contribuição da obra: a partir das experiências documentadas, o livro conecta os diferentes olhares em um impecável trabalho de integração analítica. É válido celebrar, para além dos artigos e das análises que esta obra consolida, a formação de uma rede de pesquisa cujos debates, trocas e diálogos não se encerram aqui.

Esses olhares reunidos, sobre um campo de política pública que atende segmentos vulneráveis da população e que se encontra, como tantas outras áreas, também vulnerável, no momento em que se atravessa uma crise global do conhecimento, são aqui exaltados, posto que exemplares. Que possamos seguir contribuindo para o desenvolvimento nacional com renovados, ampliados, conectados e integrados olhares. Que os esforços de realização deste trabalho possam elevar o nível de informação de gestores de políticas públicas e da sociedade, bem como contribuir para a implementação de políticas públicas mais justas e efetivas.

Em nome do Ipea, agradeço à CEPAL pela parceria institucional, que viabilizou esta obra. Desejo uma boa leitura a todos e a todas.

Flávia Schmidt

Diretora da Diretoria de Estudos e Políticas do Estado, das Instituiçóes e da Democracia (Diest) do Ipea

\section{REFERÊNCIAS}

SANTOS, M. P. G. dos (Coord.). Perfil das comunidades terapêuticas brasileiras. Brasília: Ipea, mar. 2017. (Nota Técnica Diest, n. 21). Ipea, 2018.

(Org.). Comunidades terapêuticas - temas para reflexão. Rio de Janeiro: 


\title{
POLÍTICAS DE ATENÇÃO A PESSOAS QUE FAZEM USO PROBLEMÁTICO DE SUBSTÂNCIAS PSICOATIVAS EM CONTEXTOS DE EXTREMA DESIGUALDADE SOCIAL: DESAFIOS E POSSIBILIDADES DE AÇÃO EMERGENTES NA AMÉRICA LATINA
}

\author{
Maria Paula Gomes dos Santos 1 \\ Roberto Rocha C. Pires ${ }^{2}$ \\ Luiza Gomes Luz Rosa ${ }^{3}$
}

\section{INTRODUÇÃO}

O consenso internacional em favor da proscrição do uso de produtos a que hoje chamamos drogas, e que se estabeleceu há cerca de cem anos, desdobrou-se, no âmbito doméstico de diversos países, em leis que criminalizavam consumidores, produtores e comerciantes desses produtos, ainda que as motivaçóes para tal proscrição tenham decorrido de consideraçóes de ordem sanitária - ou seja, de que aqueles produtos seriam nocivos à saúde dos seres humanos. Muito tempo se passou (mais de cinquenta anos) até que agravos à saúde associados ao consumo de drogas entrassem na agenda política mundial, ${ }^{4}$ enfatizando a necessidade dos estados nacionais desenvolverem políticas públicas e programas de assistência à saúde das pessoas que fazem uso problemático de drogas.

Como já revelado por outros estudos (CEDD, 2014), a ação assistencial do Estado dirigida a usuários de drogas, na América Latina, constituiu-se historicamente a partir de moralidade punitivista, evidenciada pela estabilidade, na maioria dos países, de regimes proibicionistas; assim como pela hegemonia de respostas assistenciais ancoradas na reclusão prolongada - e, muitas vezes, forçada - de usuários de drogas, em hospitais psiquiátricos, clínicas e comunidades terapêuticas. $\mathrm{O}$ tema ganha complexidade ainda maior quando se considera a severidade das desigualdades que estruturam essas sociedades e a grande magnitude de seus segmentos populacionais destituídos de todas as formas de capital (econômico, social, cultural e político).

1. Técnica de planejamento e pesquisa na Diretoria de Estudos do Estado, Instituições e Democracia (Diest) do Ipea.

2. Técnico de planejamento e pesquisa na Diest/lpea.

3. Pesquisadora no Subprograma de Pesquisa para o Desenvolvimento Nacional (PNPD) na Diest/lpea.

4. 0 que foi feito por meio do protocolo de 1972, incorporado à Convenção Única de Entorpecentes da Organização das Nações Unidas (ONU), de 1961. Ver UN (1961). 
Nas ruas de grandes e pequenas cidades latino-americanas, é cada vez mais evidente - e objeto de pânico moral - a presença de existências que experimentam, além dos danos decorrentes de usos problemáticos de drogas, o acúmulo de incontáveis desvantagens sociais.

Não obstante, nas últimas décadas, emerge na região um conjunto de novas respostas a estes problemas, ensejando renovados modos de atenção e cuidado aos consumos problemáticos de drogas, em especial daqueles segmentos mais vulneráveis da população. Trata-se de experiências que partem de uma perspectiva de direitos, com ênfase no tratamento em liberdade e na reinserção social dos usuários, por meio do acesso a bens e serviços públicos, e na reorganização das relaçóes desses usuários com as substâncias e o meio social em que vivem, em linha com a perspectiva da redução de danos (RD). A partir da emergência dessas experiências, o debate sobre modelos assistenciais previstos nas políticas públicas de cuidado a usuários de drogas, na região, assume grande relevância, na medida em que coloca em relevo o imperativo da garantia de direitos fundamentais às suas populaçóes - um dos pilares da democracia, a qual ainda resta pendente de consolidação em muitos de nossos Estados nacionais.

A ideia que deu origem a esta publicação surgiu dessa trama que, entretecendo o uso problemático de drogas com as múltiplas vulnerabilidades sociais que afetam grandes contingentes da população latino-americana, tem produzido, no contexto de desenvolvimento capitalista tardio de nossos países, vidas precarizadas e descartáveis - situação que os Estados nacionais teriam o dever de mitigar, por meio de políticas públicas. Para compreender como esses estados têm enfrentado tal questão, este projeto, fruto de parceria entre a Comissão Econômica para a América Latina e Caribe (CEPAL) e o Ipea, pretendeu sistematizar informaçóes sobre o estado da arte de políticas e programas de assistência a usuários de drogas, em alguns países da região, e analisar os impactos destes na redução, ou reprodução, de suas históricas desigualdades sociais. Assim, este livro visa complementar debates já desenvolvidos sobre a regulação da produção, da distribuição e da comercialização de substâncias psicoativas (SPAs), como é o caso de CEDD (2014), por meio do foco exclusivo nas políticas públicas de atenção e cuidado aos usuários, objeto ainda carente de análises mais sistemáticas na regiáo.

Os capítulos aqui reunidos dirigem o olhar não apenas para o desenho dessas políticas, mas também para sua implementação. Pois, se a análise do desenho das políticas nos permite identificar seus pressupostos e objetivos gerais, é o olhar sobre a implementação - momento em que finalmente os frutos da política chegam a seus beneficiários - que nos possibilita compreender seus desfechos. Porque é no contexto da implementação que entram em ação as instituiçôes e as pessoas que convertem diretrizes gerais e abstratas em bens e serviços concretos (Pressman e Wildavsky, 1973). Porém, como já demonstrado pela literatura, essa conversão é condicionada 
pelo contexto político institucional, pelos arranjos de financiamento e articulação, pela cultura das instituiçôes implementadoras, bem como pelas disposiçôes e pelos valores dos agentes institucionais que interagem diretamente com o público beneficiário (Hill e Hupe, 2014). Nesse sentido, instituiçôes e agentes, mediante suas práticas nos guichês de entrega dos benefícios de uma política, contribuem mais - ou menos - para a consecução dos objetivos estatais. Além disso, sua cultura e seus valores revelam também percepçōes e moralidades presentes na própria sociedade, indicando os desafios simbólicos e subjetivos colocados à concretização dos ideais de transformação social investidos nas políticas públicas.

Apresenta-se, neste livro, experiências de políticas e programas de assistência a usuários de drogas em cinco países: Argentina, Brasil, Colômbia, México e Uruguai. Os capítulos estruturam-se em torno de duas preocupaçóes: a primeira, de oferecer um panorama da trajetória das políticas de atenção a usuários de drogas em cada país, bem como dos arranjos institucionais montados para operá-las; a segunda, de trazer dados empíricos originais sobre programas e serviços assistenciais, em que se detalha sua implementação, por meio de: i) seus instrumentos de ação; ii) suas articulaçôes institucionais; e iii) as práticas de seus agentes de linha de frente. Procura-se ainda destacar a potência e os desafios dessas iniciativas, no contexto de cada um dos países.

Além de apresentar cada uma das contribuições aqui reunidas - o que será feito na terceira seção deste capítulo -, pretendemos, na próxima seção, trazer à reflexão as tendências comuns ao conjunto dos países, na abordagem das pessoas que fazem usos problemáticos de SPAs.

\section{A CONSTITUIÇÃO DO ESTATUTO DO USUÁRIO DE DROGAS NA REGIÃO LATINO-AMERICANA: ENTRE A SUJEIÇÃO CRIMINAL E O ACESSO A DIREITOS}

As políticas de regulação do uso de drogas, adotadas nos países aqui analisados, evoluíram de forma bastante semelhante, ao longo do tempo, uma vez que foram igualmente condicionadas pela agenda internacional formulada em torno desse tema - à qual se deve a própria origem da problematização política da chamada questão das drogas - e pelos interesses comerciais e geopolíticos dos Estados Unidos na região.

Se é verdade que o proibicionismo nasceu de considerações médicas acerca do potencial nocivo de certas substâncias para a saúde das populaçôes, também é fato que sua constituição como uma agenda internacionalizada se deveu aos esforços dos Estados Unidos para estender ao mundo a condenação moral aos "estados alterados de consciência", promovida pelos seus movimentos sociais puritanos domésticos, que vicejavam desde o século XIX, e cujo primeiro grande êxito foi a imposição, naquele país, da chamada Lei Seca, entre 1920 e $1933^{5}$ (Rodrigues, 2008).

5. Lei que proibiu a produção, o comércio e o consumo de bebidas alcoólicas. 
Assim, aos primeiros acordos internacionais, estabelecidos no início do século XX, ${ }^{6}$ seguiram-se convençôes internacionais antidrogas, realizadas ao longo desse século, ${ }^{7}$ em que os interesses estratégicos dos Estados Unidos na América Latina, e sua política de guerra às drogas, desempenharam papel determinante. No contexto da Guerra Fria, ${ }^{8}$ pretendiam os Estados Unidos afastar os países da região do "perigo comunista", representado pela expansão da influência soviética, sobretudo após a revolução cubana de 1959. Por sua vez, em 1961, a Organização das Naçôes Unidas (ONU) realizaria, em Nova Iorque, a Convenção Única de Entorpecentes, a qual consagrou o proibicionismo como padrão internacional de abordagem do tema das drogas e, estabelecendo a distinção entre paises consumidores e paises produtores, criou as condições para a interferência internacional nos países latino-americanos que mantinham o cultivo de plantas usadas na produção e no consumo de substâncias proscritas (Carvalho, 2015).

A influência norte-americana seria assegurada ainda pelo apoio dos Estados Unidos ao estabelecimento de regimes ditatoriais na América do Sul, no período: no Brasil, entre 1964 a 1985; na Argentina, de 1966 a 1973; e no Uruguai, de 1973 a $1985 .{ }^{9}$ Esses regimes promoveriam o recrudescimento do punitivismo, com a atualização, nos diversos países, de leis e normas proibicionistas. Em 1973, o México sanciona seu código sanitário; em 1974, Colômbia, Uruguai e Argentina promulgam suas leis sobre estupefacientes; e, em 1976, o Brasil sancionou sua Lei de Tóxicos. O Uruguai também imporia uma nova lei de drogas, em 1974, mantendo, contudo, sua tradição de não criminalização do uso dessas substancias. ${ }^{10}$ Entretanto, já contava com previsão de tratamento compulsório a usuários, desde a edição da Lei no 9.581/1936 (Lei de Assistência a Psicopatas) (Musto, neste volume).

A história do governo de usuários de SPAs nesses países, ao longo do século XX, caracterizou-se, portanto, pela implementação de leis e normas repressivas e punitivas, que produziram a sujeição criminal dessas pessoas (Misse, 1999). Ao mesmo tempo, do ponto de vista médico, tais pessoas seriam qualificadas como doentes, o que selava seu destino à reclusão, se não ao cárcere, a instituiçôes manicomiais. A interveniência

6. Acordos de Xangai, em 1909; Haia, em 1912; e Genebra, em 1925 e 1936. Ver Carvalho (2015) e Rodrigues (2008). 7. Além da Convenção Única de Entorpecentes da ONU em 1961, sucederam-se as de 1971 e 1988. Ver Carvalho (2015) e Rodrigues (2008).

8. Em 1961, a ONU estabelece a convenção, e os Estados Unidos declaram guerra às drogas.

9. A Colômbia experimentara um regime político fechado bem antes, entre 1954 e 1957. A partir da década de 1970, e apesar de certa estabilidade democrática, o país conviveu com as vicissitudes do grande poder armado conquistado pelos cartéis do narcotráfico (de Cali e Medellín), bem como dos combates desencadeados pela organização guerrilheira Forças Armadas Revolucionárias da Colômbia (as FARC). Enquanto os embates com o narcotráfico foram se reduzindo ao longo dos anos 1990, com a morte e o encarceramento de suas principais lideranças, as relações do estado colombiano com as FARC somente chegariam a bom termo na década de 2000, em função de negociações políticas para um processo de paz, iniciadas em 1998.

10. No Uruguai, o consumo de drogas nunca foi penalizado. Não obstante, em 1934, o país criminalizou o tráfico de substâncias entorpecentes e, em 1937, estabeleceu o monopólio estatal sobre a produção e a distribuição destas (Garat, 2013 apud Musto, neste volume). 
das desigualdades sociais nesse quadro determinou, desde sempre, que a legislação proibicionista servisse como dispositivo de controle das classes subalternas - tidas como "perigosas" -, compostas em sua maioria por grandes contingentes de populaçóes indígenas e africanas - ou afrodescendentes -, escravizadas durante o regime colonial e relegadas à própria sorte. A desigualdade do tratamento penal conferido às diferentes classes sociais tem sido um atributo comum de todas as sociedades aqui consideradas.

Tomando-se de empréstimo a periodização proposta por Soares (neste volume), pode-se dividir a história das iniciativas assistenciais voltadas a pessoas com transtornos decorrentes do uso de drogas, nos países aqui sob análise, em três fases, a saber: i) período higienista (anos 1920 a 1960); ii) período de guerra às drogas (anos 1970 a 1980); e iii) período dos movimentos de descriminalização elou despenalização, inaugurado a partir do final dos anos 1980. O período higienista seria caracterizado pela predominância da imposição de penas de prisão ou de reclusão manicomial, em contextos em que inexistiam expectativas de direitos para essas pessoas, fato compatível com a percepção generalizada, à época, de que problemas sociais eram caso de polícia.

O período de guerra às drogas (anos 1960 a 1980), fortemente marcado pela dominância de regimes autoritários, coincidiu com o de maior disseminação mundial do uso de algumas SPAs entre a juventude de classe média - em particular a canábis e o LSD -, ocasionada pelos movimentos de contracultura. Torna-se, assim, mais comum e preocupante o desenvolvimento de transtornos psíquicos e sociais associados ao consumo de drogas. A insistência dos estados nacionais, em oferecer apenas respostas penais a esses transtornos, abriu espaço para o florescimento de ofertas de cuidado por iniciativa da sociedade civil, muitas destas de cunho religioso, cujo foco é posto unicamente na promoção da abstinência de drogas, por meio da reforma moral dos "dependentes químicos". Ganham então protagonismo as "irmandades anônimas" (Narcóticos Anônimos e Alcoólicos Anônimos), as comunidades terapêuticas e, ainda, clínicas médicas privadas, com programas de recuperação que aliam tecnologias forjadas a partir da psicologia cognitivo-comportamental, com aquelas oriundas das irmandades anônimas - como os doze passos da serenidade. ${ }^{11}$ À exceção das "irmandades anônimas”, a assistência oferecida pela maioria dessas instituiçóes assenta-se na mesma lógica dos tratamentos manicomiais, pautada na reclusão dos usuários em instituiçóes fechadas e voltada à produção da abstinência - lógica esta que reverbera fortemente o viés punitivista da abordagem penal ao uso de drogas e que favorece a violação dos direitos humanos dos usuários.

11. Essas experiências seriam consubstanciadas no modelo Minesotta, organizado inicialmente nos Estados Unidos e difundido no Brasil e nos demais países, na década de 1980, a exemplo da Clínica Serena. Ver Vaissman, Ramôa e Serra (2008) e Santos e Pires, neste volume. 
O reconhecimento de tais direitos, e das necessidades de cuidado e assistência a esses sujeitos, apenas começaria a ganhar a esfera pública ao final dos anos 1980, quando da desmobilização dos regimes autoritários nos países analisados. Conforme apontado nos diversos capítulos desta publicação, pode-se tributar aos movimentos de abertura política, à constitucionalização de direitos individuais e sociais - a exemplo do direito à saúde - e ao fortalecimento do controle de constitucionalidades pelas cortes de justiça as inflexóes, ocorridas desde então, nesses países, no sentido da descriminalização ou despenalização de usuários de drogas (Soares, neste volume).

Ao mesmo tempo, no campo assistencial, a introdução da estratégia de redução de danos, empregada com êxito em países europeus, para a contenção da pandemia do vírus HIV, entre usuários de drogas injetáveis, ganharia a atenção mundial. Voltada inicialmente à troca de seringas utilizadas no consumo dessas drogas, a RD desenvolveu-se com base nos pressupostos de que o uso de psicoativos tem estado historicamente entranhado na vida social (Escohatado, 1997) e que seu consumo não vai deixar de existir, mesmo que seja criminalizado (Acselrad, 2015). Ao não estabelecer a abstinência como único objetivo do cuidado, a estratégia visa, pragmaticamente, a mitigar prejuízos decorrentes do uso de SPA, colocando-se como uma proposta de "cuidado para além das drogas" (Centro de Convivência é de Lei, 2015), que procura engajar usuários em um projeto de autocuidado.

A RD representou, assim, importante ruptura com o paradigma de assistência a usuários de drogas, até entâo prevalecente, por garantir a esses sujeitos maiores margens de liberdade para decidirem sobre seus percursos terapêuticos. Esta penetraria em todos os países aqui estudados, com mais ou menos intensidade em cada território; e, em muitos casos, por meio de programas de combate à Aids apoiados pela Organização Mundial da Saúde (OMS).

Paralelamente, ganharia também evidência na regiáo o tratamento de base comunitária, modelo de intervenção sobre situaçóes de sofrimento social, nas quais se inclui o consumo problemático de drogas (Góngora et al., neste volume; Corbelle, neste volume). Tal modelo parte do pressuposto de que as vulnerabilidades que incidem sobre os sujeitos - inclusive usuários de drogas - decorrem da estrutura e da densidade de suas redes sociais - entendidas como o conjunto de laços que conectam os sujeitos entre si e às instituiçóes da vida social. Assim, a chave para suprimi-las - ou mitigá-las - está no fortalecimento de laços positivos com suas redes familiares, comunitárias e institucionais, capazes de combater ou prevenir sua marginalização e exclusão social. Isso implica a superação de modelos assistenciais pautados em reclusão e confinamento de usuários, em favor de sua livre circulação no território, com o apoio de agentes que contribuam para o incremento de conexôes que lhes proporcionem segurança, proteção e demais direitos de cidadania. ${ }^{12}$

12. A metodologia do tratamento de base comunitária (TBC), assim como a epistemologia que lhe dá origem (epistemología de la complejidad ética y comunitaria - ECO 2), é explicada mais detalhadamente no capítulo de Góngora et al., neste volume, e em Machín (2010). 
Nas últimas décadas, modelos de cuidado de base comunitária orientados pela redução de danos ganharam maior espaço nas políticas nacionais de assistência a pessoas afetadas pelo uso de drogas, na América Latina, ainda que, na maioria das vezes, em pequena escala e com baixo financiamento público. Os textos aqui reunidos também revelam que, apesar de sua presença nos diversos países, esses modelos permanecem, em todos os casos, pressionados e confrontados pelas terapêuticas tradicionais.

\section{PROCESSO DE PESQUISA E OS CAPÍTULOS DO LIVRO}

Para enfrentar o desafio e compreender a evolução das políticas de atenção a pessoas que fazem uso problemático de SPAs na América Latina, o projeto de pesquisa que deu origem a este livro baseou-se na operação de uma rede que reuniu pesquisadores residentes em cada um dos países abordados. Por meio do apoio da CEPAL ao projeto, foi possível compormos essa rede com pesquisadores detentores de trajetórias acadêmicas reconhecidas no campo das políticas sobre drogas em cada contexto nacional. O projeto foi coordenado por pesquisadores do Ipea que se dedicam aos temas das políticas sobre drogas, bem como das políticas sociais e de estudos sobre implementação de políticas.

Por meio da constituição dessa rede de pesquisa, pudemos desenvolver estudos tanto em nível macro-histórico (trajetória das políticas e panorama institucional das ofertas) quanto no nível micro (etnografias de experiências emergentes de serviços e dispositivos), na Argentina, no Brasil, na Colômbia, no México e no Uruguai. Ao longo do desenvolvimento do projeto, o grupo de pesquisadores teve oportunidades de reunião e discussão coletiva dos casos, por meio de oficina presencial e webinário, além de trocas de e-mails e feedback sobre os textos em produção. Isso permitiu a cada um dos pesquisadores compreender seu caso nacional à luz das semelhanças e diferenças com as outras experiências estudadas. Esse processo foi chave também para a construção de uma visão que transcende as especificidades dos casos, reveladora de traços mais gerais que caracterizam a evolução das políticas de atenção a usuários problemáticos de drogas na América Latina.

Foi a partir desse diálogo e dessa reflexão coletiva que se desenvolveram os capítulos que compóem este livro, que trazem tanto o exame detido de cada experiência nacional, como também interpretaçôes transversais aos casos. O capítulo 2, de Milena Soares, que se segue a este, oferece uma interpretação sobre o percurso histórico da regulação do uso de drogas, nos cinco países considerados, destacando as semelhanças e as diferenças entre os casos. Sua leitura permite, de partida, a compreensão da aderência da região ao regime de controle sobre SPAs, construído nos foros internacionais, e a força da influência norte-americana na região. Chama atenção também, nessa interpretação, o papel relevante que as cortes constitucionais e tribunais de justiça vêm tendo, no processo de abertura a concepçóes menos proibicionistas e mais orientadas ao cuidado dos usuários. 
Os capítulos 3 a 7 tratam de cada um dos cinco países estudados (Argentina, Brasil, Colômbia, México e Uruguai), seguindo um roteiro semelhante, o qual favorece esforços de análise comparativa. Todos esses capítulos se iniciam com uma contextualização histórica das políticas de atenção aos consumos problemáticos, bem como uma descrição sobre o panorama contemporâneo das ofertas existentes. Isso permite enxergarmos o quadro mais amplo que caracteriza cada país, em perspectiva histórica e político-institucional. Em seguida, são apresentadas as estratégias metodológicas adotadas no processo de pesquisa dos casos empíricos de serviços e dispositivos estudados - como os centros de atenção psicossocial álcool e drogas (Caps AD) no Distrito Federal (DF), Brasil (Santos e Pires, neste volume); os centros de atención primaria en adicciones (Capas), em San Luis Potosí, México (Ospina-Escobar, neste volume); os dispositivos integrales de abordaje territorial (Diat) e os dispositivos de tratamiento comunitario (DTC) na região metropolitana (RM) de Buenos Aires, Argentina (Corbelle, neste volume); os centros de escucha em Bogotá e Cali, Colômbia (Gongora et al., neste volume); e o Achique de Casavalle, na zone norte de Montevideo, Uruguai (Musto, neste volume). ${ }^{13}$ Por fim, esses capítulos discutem os resultados das pesquisas de campo, apontando os avanços obtidos e os desafios pendentes, com especial consideração à questôes relacionadas às desigualdades sociais e ao acesso e usufruto dos serviços.

Por fim, o capítulo 8 traça uma sistematização do mencionado processo de reflexão coletiva e internacional. Tomando como base as discussões apresentadas no capítulos anteriores, o capitulo conclusivo argumenta que está em marcha na América Latina um processo de complexificação e diversificação das ofertas de atenção e cuidado a usuários problemáticos de drogas, no interior do qual emergiram novas modalidades de cuidado, em cada país, portadoras de potencialidades, no que diz respeito a uma perspectiva de direitos e às possibilidades de tratamento em liberdade, guiadas por horizontes que se expandem para além da abstinência e voltados à inserção, à articulação e à circulação socioespacial dos sujeitos. A abordagem das potências é, por fim, complementada com reflexão crítica sobre os limites e os desafios que vêm sendo enfrentados na implementação das novas abordagens, como as precariedades materiais, as tensóes relacionais e as dificuldades na ampliação e na garantia de acesso aos setores vulnerabilizados. A identificação desses desafios fornece pistas importantes para uma agenda de pesquisa e intervenção pública voltada ao fortalecimento e à consolidação das abordagens emergentes de atenção aos consumos problemáticos na América Latina.

13. 0 sentido das siglas e das experiências pode ser acessado em cada um dos respectivos capítulos. 
Políticas de Atenção a Pessoas que Fazem Uso Problemático de Substâncias Psicoativas em Contextos de Extrema Desigualdade Social: desafios e possibilidades de ação emergentes na América Latina

\section{REFERÊNCIAS}

ACSELRAD, G. Quem tem medo de falar sobre drogas? Saber mais para se proteger. Rio de Janeiro: FGV, 2015.

CARVALHO, J. C. A América Latina e a criminalização das drogas entre 1960-1970: prenúncios de outra guerra por outra América. Revista Unifeso: humanas e sociais, Teresópolis, v. 2, n. 2, p. 78-98, 2015.

CEDD - COLECTIVO DE ESTUDIOS DROGAS Y DERECHOS. En busca de los derechos: usuarios de drogas y las respuestas estatales en América Latina. México: Cide, jul. 2014.

CENTRO DE CONVIVÊNCIA É DE LEI. Caderno do redutor e da redutora de danos. São Paulo: Centro de Convivência É de Lei, 2015. Disponível em: $<$ https://bit.ly/2JZrGpy>. Acesso em: 7 dez. 2020.

ESCOHATADO, A. O livro das drogas: usos e abusos, desafios e preconceitos. São Paulo: Editora Dynamis, 1997.

GARAT, G. Un siglo de políticas de drogas en Uruguay. Montevideo: FES, 2013.

HILL, M. J.; HUPE, P. L. Implementing public policy: an introduction to the study of operational governance. London: Sage, 2014.

MACHÍN, J. Modelo ECO2: redes sociales, complejidad y sufrimiento social. Redes: revista hispana para el análisis de redes sociales, v. 18, n. 12, p. 305325, jun. 2010.

PRESSMAN, J.; WILDAVSKY, A. Implementation: how great expectations in Washington are dashed in Oakland; or, why it's amazing that federal programs work at all, this being a saga of the economic development administration as told by two sympathetic observers who seek to build morals on a foundation. California: University of California Press, 1973.

RODRIGUES, T. Tráfico, guerra, proibição. In: LABATE, B. C. et al. (Orgs.). Drogas e cultura: novas perspectivas. Salvador: EDUFBA, 2008.

UN - UNITED NATIONS. Single convention on narcotic drugs. Final act of the United Nations Conference. New York: UN, 1961. Disponível em: <https:// bit.ly/2VPJzty>. Acesso em: 7 dez. 2020.

VAISSMAN, M.; RAMÔA, M.; SERRA, A. Panorama do tratamento dos usuários de drogas no Rio de Janeiro. Saúde em Debate, Rio de Janeiro, v. 32. n. 78-7980, p. 121-132, 2008. 


\section{BIBLIOGRAFIA COMPLEMENTAR}

LABATE, B. C. et al. (Orgs.). Drogas e cultura: novas perspectivas. Salvador: EDUFBA, 2008. 


\section{CEM ANOS DE REGULAÇÃO DO CONSUMO DE DROGAS NA AMÉRICA LATINA: O QUE NOS DIZEM AS TRAJETÓRIAS DE ARGENTINA, BRASIL, URUGUAI, COLÔMBIA E MÉXICO?}

Milena Karla Soares ${ }^{1}$

\section{INTRODUÇÃO}

Este capítulo tem como objetivo analisar as trajetórias históricas das políticas de regulação do uso de drogas em países selecionados da América Latina: Argentina, Brasil, Uruguai, Colômbia e México, com especial atenção às disposiçóes jurídicas (leis, normas e decisóes das cortes constitucionais) sobre uso e posse para uso, da década de 1920 aos dias atuais. A análise teve como ponto de partida os relatórios parciais de pesquisa do projeto Arranjos Institucionais para Atenção ao Uso Problemático de Drogas (Corbelle, 2019; Musto, 2019; Góngorra, Salazar e Borja, 2019; Ospina-Escobar, 2019), coordenado pelo Ipea em parceria com a Comissão Econômica para a América Latina e o Caribe (CEPAL). Buscou-se literatura adicional quando se fez necessário complementar informaçóes apresentadas pelos consultores. Quanto aos contextos brasileiro e internacional, partiu-se de levantamento realizado anteriormente no projeto de pesquisa Monitoramento dos Efeitos da Nova Política Uruguaia de Regulaçâo do Mercado de Cannabis Sobre a Zona de Fronteira (Ipea, 2017).

Há semelhanças nas trajetórias históricas das políticas de regulação do uso drogas, nos países contemplados nesta análise, observando-se tendências comuns quanto aos momentos e direcionamentos das reformas. De modo geral, três fatores se destacam na explicação das convergências: i) a existência de acordos internacionais sobre o tema, que remontam a 1912; ii) a interferência dos Estados Unidos da América na definição das políticas nacionais de drogas nos países da América Latina, em especial a partir da política de guerra às drogas, do final da década de 1960; e iii) o fortalecimento de instituições democráticas e de controle constitucional em países latino-americanos, a partir da década de 1980.

1. Técnica de desenvolvimento e administração na Diretoria de Estudos e Políticas do Estado, das Instituições e da Democracia (Diest) do Ipea. 
Em relação ao primeiro fator, ao longo do século XX, as drogas foram progressivamente alçadas à categoria de problema global que requer um modelo de regulação uniforme e controle por agências internacionais. Neste sentido, acordos internacionais impulsionaram e definiram os contornos das políticas de drogas ao redor do mundo. O regime internacional de drogas teve início em 1912, com a Primeira Convenção Internacional do Ópio. Embora nenhum dos países latino-americanos estivesse representado nas negociaçóes dessa convençáo, dezoito $^{2}$ deles assinaram o protocolo de adesão a ela. Esse regime foi consolidado e aprimorado e, atualmente, assenta-se em três convençôes: Convenção Única Sobre Entorpecentes (1961, emendada pelo protocolo de 1972); Convenção Sobre Substâncias Psicotrópicas (1971); e Convenção Contra o Tráfico Ilícito de Entorpecentes e Substâncias Psicotrópicas (1988), das quais os cinco países analisados são signatários (United Nations, 2020).

Somando-se à uniformização prescrita pelas convenções internacionais, a interferência dos Estados Unidos é uma constante nas trajetórias dos países analisados, com a finalidade de padronizar e alinhar as políticas locais ao paradigma internacional e coibir eventuais desvios e experimentação de alternativas. Como será visto ao longo do texto, em 1940 os Estados Unidos impuseram embargo econômico ao México como represália à experimentação da política de dispensários para toxicômanos, ${ }^{3}$ e, em especial a partir do final da década de 1960, coordenou esforços diplomáticos, militares e de ajuda financeira para promover a ideologia de guerra às drogas no território dos países produtores na América Latina (Rodrigues, 2008).

Por fim, a partir da leitura dos relatórios parciais de pesquisa (Corbelle, 2019; Musto, 2019; Góngora, Salazar e Borja, 2019; Ospina-Escobar, 2019), salta aos olhos a importância dos movimentos de abertura política, da constitucionalização de direitos individuais e sociais (a exemplo do direito à saúde) e do fortalecimento do controle de constitucionalidades pelas cortes de justiça, como fatores que impulsionaram as inflexôes no período mais recente em direção à maior liberdade $\mathrm{e}$ autonomia dos usuários de drogas.

Considerando-se um século de história dos regimes nacionais e internacionais de controle de drogas, podem-se distinguir três períodos, intitulados período higienista, guerra às drogas e movimento de descriminalizaçâo elou despenalizaçâo. No período higienista (décadas de 1920 a 1960) prevaleceu a visão médico-sanitária para lidar com o problema. O período de guerra às drogas (décadas de $1960 \mathrm{a}$

2. Os países latino-americanos que aderiram à Convenção Internacional do Ópio de 1912 foram os seguintes: em 1912, Costa Rica, México, Guatemala, Panamá, Equador, Honduras, Haiti, Venezuela, Brasil, Argentina e Paraguai; em 1913, Colômbia, Cuba, Bolívia, Chile, Nicarágua e Peru; em 1914, Uruguai (United Nations, 2020).

3. Toxicomania e toxicômanos correspondem à terminologia empregada à época. 
1980) foi caracterizado pela escalada da abordagem de securitização ${ }^{4}$ do problema. Por fim, o período de movimento de descriminalização e/ou despenalização (década de 1980 aos dias atuais), em que há um crescente ativismo para reforma das políticas de drogas, embora o paradigma de guerra às drogas não esteja superado. A divisão entre os períodos atende a fins didáticos e, portanto, não é estanque. Por esse motivo, a duplicidade das décadas de 1960 e 1980 na transição entre um período e outro.

O texto está organizado em seis seçóes. Após essa introdução, na seção 2, busca-se um olhar sobre o todo, utilizando-se de uma linha do tempo para demonstrar graficamente as inflexóes das políticas de regulação do uso de drogas nos últimos cem anos, nos cinco países analisados. Na sequência, as seçóes 3, 4 e 5 tratam, respectivamente, dos períodos higienista, guerra às drogas e movimento de descriminalização e/ou despenalização, trazendo mais detalhes sobre o contexto e o desenvolvimento histórico de cada país em particular. Por fim, a seção 6 conclui o capítulo.

\section{LINHA DO TEMPO}

A figura 1 representa as trajetórias das políticas nacionais de regulação do uso de drogas dos cinco países analisados, ao longo dos últimos cem anos. O eixo horizontal traz o período considerado, em intervalos de dez anos. $\mathrm{O}$ eixo vertical elenca três formas de enquadramento legal dos usuários de drogas, em uma escala cujos extremos são, por um lado, a completa liberdade e autonomia e, por outro, a privação de liberdade (encarceramento) dos usuários. Agrupadas em uma categoria intermediária, encontram-se políticas que restringem a autonomia do usuário pela via médica e/ou jurídica.

Os marcos jurídicos em que prevalecem a liberdade e a adesão voluntária ao tratamento são indicativos de políticas que valorizam a autonomia do usuário e seu direito ao livre desenvolvimento da personalidade. Em contraponto, a imposiçáo de pena privativa de liberdade (encarceramento) acontece quando o usuário é tomado por criminoso, seja de forma expressa, com a criminalização de condutas como consumo habitual, embriaguez ou posse para uso próprio, seja de forma implícita, pela criminalização da posse sem distinção entre usuários e traficantes. Por fim, pode ocorrer restrição da autonomia pela via médica ou jurídica, ${ }^{5}$ com a imposição de tratamentos compulsórios (se o usuário é percebido como doente) ou de penas alternativas ao encarceramento (quando o uso de drogas é tratado como delito de baixo potencial ofensivo).

4. Nesse contexto, securitização refere-se aos processos de construção de ameaças existenciais que colocam em risco a segurança humana, nacional ou internacional (Crick, 2012; Farret, 2014; Martinez e Lira, 2015).

5. Ressalta-se que essa categoria intermediária agrupa políticas que restringem a autonomia tanto pela via jurídica (criminalização e imposição de penas alternativas ao encarceramento) quanto pela via médica (imposição de tratamento/ internação). Esse agrupamento justifica-se por haver certa sobreposição dessas vias, com, por exemplo, a imposiçãa de penas alternativas com finalidade terapêutica. De todo modo, a figura 1 deve ser lida com cuidado. Observe-se que no caso do Uruguai nunca houve criminalização/pena alternativa, mas sim tratamento compulsório dos usuários. 
FIGURA 1

Linha do tempo: marcos jurídicos da regulação do uso de drogas - Argentina, Brasil, Uruguai, Colômbia e México (décadas de 1920 a 2010)

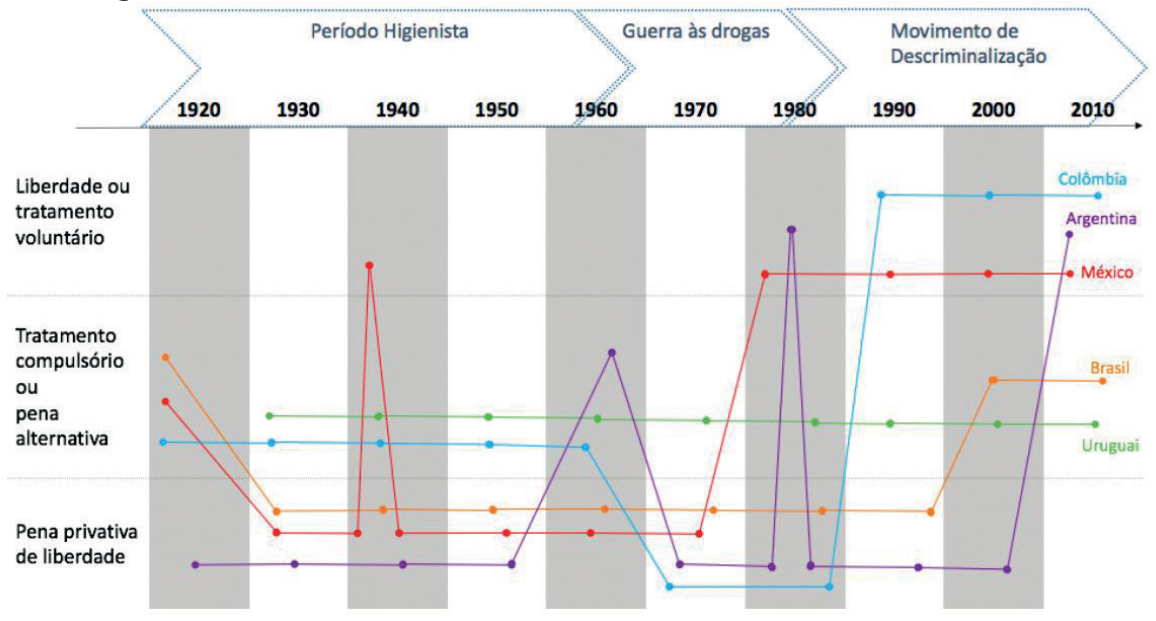

Fontes: Para o Brasil, Decretos nos 4.294/1921, 20.930/1932, 385/1968 e 5.726/1971, Decretos-lei nos 891/1938 e 2.848/1940, Leis nos 6.368/1976, 11.343/2006 e 13.840/2019; para a Argentina, Corbelle (2019); para o Uruguai, Musto (2019); para a Colômbia, Góngorra, Salazar e Borja (2019); para o México, Ospina-Escobar (2019).

Elaboração da autora.

Obs.: Figura reproduzida em baixa resolução e cujos leiaute e textos não puderam ser padronizados e revisados em virtude das condições técnicas dos originais (nota do Editorial).

Desconsiderando-se a constante da política do Uruguai e os movimentos de pico (México na década de 1940 e Argentina nas décadas de 1960 e 1980), pode-se dizer que, de modo geral, as linhas da figura 1 desenham uma trajetória em formato de vale com platôs de alturas diferentes. O extremo inferior se encontra na década de 1970, período em que quatro dos cinco países aplicavam pena privativa de liberdade aos usuários. Em contraste, na década de 1920 apenas um país (Argentina) apenava os usuários com pena privativa de liberdade, enquanto o marco jurídico nos demais previa tratamento compulsório ou pena alternativa. Já na década de 2010, nenhum dos cinco países adota política de encarceramento de usuários, contando-se três países (Colômbia, Argentina e México) que asseguram a liberdade dos usuários e o acesso a tratamento de forma voluntária e dois países (Uruguai e Brasil) que seguem na alternativa intermediária de tratamento compulsório e/ou pena alternativa para usuários. 


\section{PERÍODO HIGIENISTA}

Na primeira metade do século XX, a autoridade médico-sanitária consolidou-se como instrumento de controle social, via promoção da higiene social para melhoramento da raça. Segundo a ideologia higienista, o uso problemático de drogas era uma anormalidade patológica, à semelhança de outras formas de degeneração de grupos perigosos (homossexuais, mendigos, alcóolatras) e de raças menos desenvolvidas (em síntese, povos não europeus: indígenas das américas, africanos, asiáticos). É nesse contexto que surgem as primeiras medidas de controle de drogas e controle dos usuários de drogas, empreendidas por uma elite de viés racista e colonialista (Rodrigues, 2008).

No cenário internacional, o regime de controle de drogas assentou-se na autoridade médica como instância de definição da legalidade/ilegalidade dos comportamentos individuais, em associação com o poder de polícia, instância de controle social. O objetivo do regime era garantir a disponibilidade de drogas para uso legítimo (médico, científico e industrial), ao passo em que proibia e buscava coibir o uso ilegitimo (recreativo ou uso tradicional) (McAllister, 2012; Room e Reuter, 2012). A adesão dos cinco países analisados à Convenção Internacional do Ópio, em 1912, e a criação da Liga das Naçôes, após 1920, deram impulso às reformas e/ou criação das leis nacionais sobre drogas, visando padronizar os instrumentos regulatórios ao redor do mundo.

De modo geral, durante o período higienista, os países distribuíam-se em dois grupos: de um lado, Colômbia e Uruguai optaram por tratamento compulsório e/ou pena alternativa, de outro, Argentina, Brasil e México optaram pela pena privativa de liberdade, sendo que México e Brasil o fizeram a partir da década de 1930 e Argentina já na década de 1920 . Observa-se um breve período de excepcionalidade no México, na década de 1940, quando se deu a experimentação de uma política alternativa inovadora, fracassada devido a embargo comercial dos Estados Unidos.

QUADRO 1

Marcos jurídicos da regulação do consumo de drogas (décadas de 1920 a 1960)

\begin{tabular}{|c|c|c|c|c|c|}
\hline \multirow{2}{*}{ País } & \multicolumn{5}{|c|}{ Marco jurídico ${ }^{1}$} \\
\hline & 1920 & 1930 & 1940 & 1950 & 1960 \\
\hline Argentina & $\begin{array}{l}\text { Lei no } 11.309 / 1924 \text { - } \\
\text { Não cuida de condutas } \\
\text { relacionadas ao usuário } \\
\text { ou à mera posse. } \\
\text { Lei no } 11.331 / 1926 \text { - } \\
\text { Criminaliza posse por } \\
\text { pessoas não autorizadas, } \\
\text { indistintos usuários e } \\
\text { traficantes. } \\
\text { Pena privativa de liber- } \\
\text { dade: } 6 \text { meses a } 2 \text { anos. }\end{array}$ & $\begin{array}{l}\text { Edito da Polícia Federal de } 15 \\
\text { de julho de } 1932 \text { - Criminaliza } \\
\text { embriaguez e outras intoxicações. } \\
\text { Pena privativa de liberdade: } 15 \\
\text { a } 30 \text { dias (se lugar público) ou } \\
9 \text { a } 15 \text { dias (se edifício privado). }\end{array}$ & & $\begin{array}{l}\text { Regramento de } \\
\text { Procedimentos } \\
\text { Contravencionais } \\
\text { absorve Edito da } \\
\text { Polícia Federal da } \\
\text { década de } 1930 .\end{array}$ & $\begin{array}{l}\text { Lei no } 17.567 / 1968- \\
\text { Diferencia usuário e } \\
\text { traficante, descriminaliza } \\
\text { a posse de dose para } \\
\text { consumo pessoal. } \\
\text { Lei no } 17.711 / 1968 \text { - } \\
\text { Inclui hipótese de inter- } \\
\text { dição civil por uso de } \\
\text { entorpecentes no Código } \\
\text { Civil de 1869, permitindo } \\
\text { a internação compulsiva } \\
\text { de "toxicômanos". }\end{array}$ \\
\hline
\end{tabular}




\begin{tabular}{|c|c|c|c|c|c|}
\hline \multirow{2}{*}{ País } & \multicolumn{5}{|c|}{ Marco jurídico ${ }^{1}$} \\
\hline & 1920 & 1930 & 1940 & 1950 & 1960 \\
\hline Brasil & $\begin{array}{l}\text { Decreto nº.294/1921- } \\
\text { Criminaliza embriaguez } \\
\text { habitual } \\
\text { Pena: internação em } \\
\text { estabelecimento cor- } \\
\text { recional de } 3 \text { meses } \\
\text { a } 1 \text { ano. }\end{array}$ & $\begin{array}{l}\text { Decreto no 20.930/1932- } \\
\text { Criminaliza posse de dose } \\
\text { superior à terapêutica e sem } \\
\text { prescrição médica, indistintos } \\
\text { usuários e traficantes. } \\
\text { Pena privativa de liberdade: } 3 \\
\text { a } 9 \text { meses. } \\
\text { Decreto-lei no } 891 / 1938 \text { - Inter- } \\
\text { nação compulsória, por decisão } \\
\text { judicial, tempo determinado } \\
\text { ou indeterminado. Criminaliza } \\
\text { posse sem prescrição médica, } \\
\text { indistintos usuários e traficantes } \\
\text { Pena privativa de liberdade: } \\
1 \text { a } 4 \text { anos. }\end{array}$ & $\begin{array}{l}\text { Decreto-lei no 2.848/1940 } \\
\text { (Código Penal) - Crimina- } \\
\text { liza posse sem autorização } \\
\text { ou em desacordo com } \\
\text { determinação legal ou } \\
\text { regulamentar, indistintos } \\
\text { usuário e traficante. } \\
\text { Pena privativa de li- } \\
\text { berdade: } 1 \text { a } 5 \text { anos. }\end{array}$ & & $\begin{array}{l}\text { Decreto no } 385 / 1968- \\
\text { Criminaliza expressa- } \\
\text { mente a posse para } \\
\text { uso próprio. } \\
\text { Pena privativa de } \\
\text { liberdade: } 1 \text { a } 5 \text { anos. }\end{array}$ \\
\hline Uruguai & & $\begin{array}{l}\text { Lei no 9.692/1937 - Internação } \\
\text { compulsória de usuários, por } \\
\text { determinação judicial após } \\
\text { exame médico, de } 2 \text { meses } \\
\text { a } 2 \text { anos. }\end{array}$ & & & \\
\hline Colômbia & $\begin{array}{l}\text { Lei no 11/1920 - Não } \\
\text { há disposição quanto } \\
\text { ao usuário ou quanto } \\
\text { à mera posse. } \\
\text { Lei no } 118 / 1928 \text {, art. } \\
\text { 6o - Tratamento for- } \\
\text { çado para usuários, } \\
\text { por determinaçãa da } \\
\text { autoridade sanitária. }\end{array}$ & $\begin{array}{l}\text { Lei no 95/1936 - Medidas de } \\
\text { segurança para usuários (reclusão } \\
\text { em manicômio criminal, colônia } \\
\text { agrícola, liberdade vigiada). } \\
\text { Resolução do Departamento } \\
\text { Nacional de Higiene no 95/1938 } \\
\text { - Restringe a venda de folhas } \\
\text { de coca às drogarias. }\end{array}$ & & $\begin{array}{l}\text { Resolução no } \\
546 / 1948 \text { - } \\
\text { Proibição das } \\
\text { chicherias. }\end{array}$ & \\
\hline México & & $\begin{array}{l}\text { Código Penal de } 1931 \text { - Crimi- } \\
\text { naliza a posse em desacordo } \\
\text { com disposições sanitárias, } \\
\text { indistintos usuários e traficantes. } \\
\text { Pena privativa de liberdade: } 6 \\
\text { meses a } 7 \text { anos. }\end{array}$ & $\begin{array}{l}\text { Por quatro meses (feve- } \\
\text { reiro a junho de 1940) } \\
\text { experimentação de } \\
\text { política de dispensários } \\
\text { para dependentes. }\end{array}$ & & \\
\hline
\end{tabular}

Fontes: Para o Brasil, legislações citadas; para a Argentina, Corbelle (2019); para o Uruguai, Musto (2019); para a Colômbia, Góngorra, Salazar e Borja (2019); para o México, Ospina-Escobar (2019).

Elaboração da autora.

Nota: 1 São elencados os normativos e as decisões judiciais considerados relevantes para explicar os direcionamentos da política de drogas em relação ao usuário, particularmente quanto às mudanças nas categorias desenvolvidas na figura 1 (liberdade/ tratamento; tratamento compulsório/pena alternativa; pena privativa de liberdade). Não se trata, portanto, de um rol exaustivo das alterações legais dos países.

\subsection{Colômbia e Uruguai}

A Colômbia iniciou o controle de drogas em $1920 .{ }^{6}$ Em um primeiro momento, a legislação preocupava-se em estabelecer o monopólio e os limites do exercício das profissões de médico, veterinário, dentista e farmacêutico - únicas autorizadas a prescrever substâncias psicoativas - penalizando as infraçóes com multa. Nos anos seguintes, o modelo proibicionista foi sendo aprimorado e aprofundado. Em 1928, ${ }^{7}$ previa-se tratamento compulsório para pessoas que fizessem o uso 
indevido; e, a partir de $1936,{ }^{8}$ criminalizou-se o consumo, com a imposição de medidas de segurança - reclusão em manicômio judicial, colônia agrícola, liberdade vigiada, entre outras.

Se, por um lado, não se aplicava pena privativa de liberdade, por outro, a política de drogas colombiana não deixava de ser estigmatizante e elitista. A criminalização de práticas dos povos indígenas explicita o viés colonialista do período. $\mathrm{Na}$ ótica dos médicos higienistas, os principais problemas eram o hábito de mascar coca e o consumo da chicha (bebida alcóolica obtida da fermentação de milho), costumes tradicionais dos povos andinos. Em 1938, ${ }^{9}$ a folha de coca passou a ser considerada substância médica, sendo seu uso, portanto, condicionado à prescrição, o que relegou os usos tradicionais à ilegalidade, sujeitos à criminalização e a medidas de segurança junto aos usuários, nos termos da lei penal. Por sua vez, atribuía-se ao consumo de chicha a ocorrência de graves perturbaçóes somáticas e psíquicas, traduzidas em uma doença peculiar denominada chichismo. As chicherias foram proibidas em 1948, ${ }^{10}$ a partir de uma regulação extremamente restritiva, que, na prática, privilegiava a indústria de bebidas alcóolicas de tradição europeia (cerveja, vinho), em detrimento da produção artesanal de chicha (Góngora, Salazar e Borja, 2019).

No Uruguai, a preocupação com a higiene social e a importância de atores das classes médicas e policiais no impulso das reformas legais assemelham-se aos demais países analisados. Na criação do Ministério da Saúde, em 1934, ${ }^{11}$ a este foi atribuída a competência de "polícia da prostituição e dos vícios sociais" (Uruguay, 1934) - supressão de prostíbulos, tratamento obrigatório de doenças venéreas, toxicomanias, alcoolismo, e outros vícios sociais que diminuem a capacidade dos indivíduos. A partir da edição da lei de drogas de 1937, ${ }^{12}$ instituiu-se a internação compulsória de usuários problemáticos, a critério do juiz, após avaliação médica da enfermidade. Tal qual o caso colombiano, embora a política não utilizasse o encarceramento de usuários como instrumento regulatório, a obrigatoriedade de submissão a tratamento acabava por estigmatizar os consumidores de drogas (Musto, 2019).

\subsection{Argentina, México e Brasil}

$\mathrm{Na}$ Argentina, o uso problemático de drogas era considerado uma anormalidade patológica de indivíduos e grupos degenerados com pré-disposiçóes delitivas, aos quais se somavam alcóolatras, homossexuais, moradores de rua e vadios. Estes indivíduos representavam uma ameaça à ordem social e, portanto, deveriam ser isolados da sociedade em asilos psiquiátricos e/ou prisóes. Nesse período, foram

\footnotetext{
8. Lei no 95/1936.

9. Resolução no 95/1938, do Departamento Nacional de Higiene.

10. Resolução no 546/1948.

11. Lei oㅡ 9.202/1934.

12. Lei no 9.692/1937.
} 
apresentados diversos projetos de lei propondo internação obrigatória de toxicômanos, mas não houve êxito nesse sentido. Por seu turno, na década de 1920, foram instituídas as primeiras leis sobre o controle da oferta de drogas, ${ }^{13}$ resultantes de campanhas de médicos higienistas, da polícia e da imprensa escrita, além da necessidade de atender às convençôes internacionais. Em 1926, criminalizou-se a posse de narcóticos, sem diferenciar entre usuário e traficante. Ao mesmo tempo, em 1932, um edito da Polícia Federal classificou como delito os atos de embriaguez e intoxicação, tanto em locais privados quanto em locais públicos, conferindo legitimidade às incursóes policiais para controle da ordem e moralidade. Este edito foi incorporado ao Reglamento de Procedimientos Contravencionales, decreto-lei que vigorou de 1956 a 1998. Em 1968, a Argentina vivenciou a despenalização da posse para uso, instituindo-se a possibilidade de interdição civil e internação compulsória dos toxicômanos encaminhados a centros de tratamento por ordem policial ou judicial. Entretanto, tal movimento durou pouco e, em 1973, a pena privativa de liberdade foi restabelecida (Corbelle, 2010; 2019).

O Brasil também inovou a legislação penal a partir da década de $1920,{ }^{14}$ consignando internação compulsória em estabelecimento correcional a quem "embriagar-se por hábito, de tal modo que, por atos inequívocos, se torne nocivo ou perigoso a si próprio, a outrem, à ordem pública” (Brasil, 1921, art. 3o). $\mathrm{Na}$ década de 1930 e $1940^{15}$ foram editadas novas leis, as quais adicionaram a criminalização da posse injustificada de certas substâncias (sem prescrição médica), sem diferenciar a figura do usuário da do traficante, além de manter a possibilidade de internação compulsória do toxicômano.

No México, a resposta estatal ao uso problemático dependia do nível social do indivíduo. Inicialmente, aqueles com acesso à prescrição médica eram considerados pacientes toxicômanos; portanto, poderiam ter acesso às substâncias de forma legal, ao passo que usuários pobres, sem acesso a prescriçôes médicas, eram institucionalizados em prisôes ou hospitais psiquiátricos. A distinção entre categorias de usuários desaparece gradualmente. Já no Código Penal de 1931, criminalizava-se tanto o comércio ilegal quanto a toxicomania. Em 1940, a experimentaçáo de uma política alternativa à criminalização fracassou, devido à pressão externa dos Estados Unidos. Por um curto período (fevereiro a junho de 1940), instituiu-se uma política de dispensários de heroína, morfina e cocaína para toxicômanos a Cidade do México. Entretanto, os Estados Unidos impuseram um embargo comercial e suspenderam a exportação de narcóticos ao México, inviabilizando a continuidade do programa. Dessa forma, o México foi compelido a abandonar a inovação, retomando o paradigma repressivo (Ospina-Escobar, 2019).

13. Leis nos 11.179/1921 (Código Penal), 11.309/1924 e 11.331/1926.

14. Decreto no $4.294 / 1921$.

15. Decretos nos 20.930/1932 e 891/1938 (Lei de Fiscalização de Entorpecentes), Decreto-lei no 2.848/1940 (Código Penal). 


\section{GUERRA ÀS DROGAS}

A característica distintiva desse período é o discurso de securitização, em que as drogas são entendidas como uma ameaça à segurança da humanidade, à segurança nacional e à segurança internacional ${ }^{16}$ (Crick, 2012). Não se trata de uma ruptura, mas da adiçấo de mais uma camada ao modelo higienista-proibicionista, paulatina e progressivamente construído ao longo da primeira metade do século XX.

A expressão "guerra às drogas" remete à política estadunidense, sob a presidência de Richard Nixon (1969-1974), que reconheceu o abuso de drogas como “inimigo público número 1" e declarou uma guerra global contra essa "ameaça mortal”, passando a combater o problema, tanto no âmbito doméstico quanto internacional (Nixon, 1973). Na lógica estadunidense, a raiz do uso problemático de drogas em seu país estava na disponibilidade (oferta) destas substâncias, que tinha início com a produção em países estrangeiros. O intuito da ofensiva de guerra às drogas seria evitar que substâncias provenientes de países produtores chegassem ao território norte-americano.

Adicionalmente, a mera sombra do poder estadunidense era um fator a induzir os países latino-americanos a se alinharem, a exemplo da doutrina Respice Polum, que predominou na atuação diplomática da Colômbia, ao longo do século XX, em que se prescreve o alinhamento incondicional à política externa dos Estados Unidos (Santos, 2010).

Em 1973, o Congresso dos Estados Unidos enviou uma missão especial de estudos à América Latina, que identificou assim o problema:

A atitude permissiva que prevalece por toda a América Latina em relaçáo a contrabando e corrupção, a existência de sistemas judiciais fracos e a frouxa aplicação da lei combinam-se para tornar a América Latina o grande condutor de drogas ilícitas que ela é hoje (Murphy e Steele, 1973, p. 2, tradução nossa). ${ }^{17}$

16. No plano internacional, as partes da Convenção Única sobre Entorpecentes, de 1961, reconheceram que "toxicomania é um grave mal para o indivíduo e constitui um perigo social e econômico para a humanidade, conscientes de seu dever de prevenir e combater esse mal" - preâmbulo da convenção de 1961 (UNODC, 2013). Na mesma linha, a Convenção sobre Substâncias Psicotrópicas, de 1971, passou a incluir as substâncias sintéticas sob o regime de controle internacional, com o objetivo de "prevenir e combater o abuso de tais substâncias e o tráfico ilícito a que dão ensejo, considerando que medidas rigorosas são necessárias para restringir o uso de tais substâncias para fins legítimos" preâmbulo da convenção de 1971 (UNODC, 2013). Já a Convenção contra o Tráfico llícito de Entorpecentes e Substâncias Psicotrópicas, de 1988, foi motivada pela preocupação com "a magnitude e a crescente tendência da produção, da demanda e do tráfico ilícitos de entorpecentes e de substâncias psicotrópicas, que representam uma grave ameaça à saúde e ao bem-estar dos seres humanos e que têm efeitos nefastos sobre as bases econômicas, culturais e políticas da sociedade" - preâmbulo da convenção de 1988 (UNODC, 2013).

17. No original: "The permissive attitude that prevails throughout Latin America toward smuggling and corruption, the existence of weak judicial systems and lax law enforcement have combined to make Latin America the major conduit of illicit drugs that it is today" (Murphy e Steele, 1973, p. 2). 
Com base nesse entendimento, os Estados Unidos passaram a empreender esforços diplomáticos e coordenar cooperação, treinamento e ajuda financeira, de modo a persuadir os países latino-americanos a implementarem as convençóes internacionais antidrogas e o combate ao narcotráfico internacional. O Bureau of Narcotics and Dangerous Drugs (atualmente Drug Enforcement Administration - DEA) estabeleceu escritórios regionais em países da América Latina, inicialmente na Argentina (responsável por todos os países da América do Sul e do Panamá) e no México (responsável pela América Central, excluindo Panamá) (Murphy e Steele, 1973). Não por acaso, foi em solo argentino que surgiu o Acordo Sul-Americano de Estupefacientes e Psicotrópicos (ASEP), ${ }^{18}$ em 1973, que visava à harmonização da legislação penal sobre drogas nos países da América do Sul, entre eles Argentina, Brasil, Colômbia e Uruguai.

Embora o foco primordial da guerra às drogas seja a repressão da oferta ilícita, a retórica de drogas como ameaça existencial acabou por influenciar também a resposta estatal ao consumo de drogas. Observa-se que, na década de 1970, quatro dos cinco países analisados haviam adotado pena privativa de liberdade para a posse de drogas, mesmo que para uso próprio. A única exceção foi o Uruguai, que deu continuidade à política de tratamento compulsório.

QUADRO 2

Marcos jurídicos da regulação do uso de drogas (décadas de 1960 a 1980)

\begin{tabular}{|c|c|c|c|}
\hline \multirow{2}{*}{ País } & \multicolumn{3}{|c|}{ Marco jurídico ${ }^{1}$} \\
\hline & 1960 & 1970 & 1980 \\
\hline Argentina & $\begin{array}{l}\text { Lei no 17.567/1968 - } \\
\text { Descriminaliza posse para consu- } \\
\text { mo pessoal. } \\
\text { Lei no } 17.711 / 1968 \text { - } \\
\text { Inclui hipótese de interdição } \\
\text { civil por uso de entorpecentes no } \\
\text { Código Civil de 1869, permitindo } \\
\text { a internação compulsiva de } \\
\text { "toxicômanos". }\end{array}$ & $\begin{array}{l}\text { Lei no 20.509/1973 - Derrogou a } \\
\text { Lei no 17.567/1968 e restabeleceu } \\
\text { a Lei no } 11.331 / 1926 \text { - } \\
\text { Criminaliza posse por pessoas não } \\
\text { autorizadas, indistintos usuários e } \\
\text { traficantes. } \\
\text { Pena privativa de liberdade: } 6 \\
\text { meses a } 2 \text { anos. } \\
\text { Lei no } 20.771 / 1974 \text { - } \\
\text { Criminaliza expressamente a posse } \\
\text { para uso pessoal. } \\
\text { Pena privativa de liberdade: } 1 \text { a } \\
6 \text { anos. }\end{array}$ & $\begin{array}{l}\text { Corte Suprema de Justiça, 1986, } \\
\text { "Fallos" (julgamentos) Bazterrica } \\
\text { e Capalbo: descriminalização da } \\
\text { posse para uso pessoal. } \\
\text { Lei no } 23.737 / 1989 \text { - } \\
\text { Criminaliza expressamente a posse } \\
\text { para uso pessoal. } \\
\text { Pena privativa de liberdade: } 1 \text { mês } \\
\text { a } 2 \text { anos. }\end{array}$ \\
\hline Brasil & $\begin{array}{l}\text { Decreto no } 385 / 1968 \text { - } \\
\text { Criminaliza expressamente a posse } \\
\text { para uso próprio. } \\
\text { Pena privativa de liberdade: } 1 \text { a } \\
5 \text { anos. }\end{array}$ & $\begin{array}{l}\text { Decreto } \mathrm{n}^{0} 5.726 / 1971 \text { - Crimina- } \\
\text { liza expressamente a posse para } \\
\text { uso próprio. } \\
\text { Pena privativa de liberdade: } 1 \text { a } \\
6 \text { anos. } \\
\text { Lei no } 6.368 / 1976 \text { - } \\
\text { Criminaliza expressamente a posse } \\
\text { para uso próprio. } \\
\text { Pena privativa de liberdade: } 6 \\
\text { meses a } 2 \text { anos. }\end{array}$ & \\
\hline
\end{tabular}

(Continua)

18. De acordo com o Documento final da III Conferência de Estados Partes, fizeram parte da ASEP os seguintes países: Argentina, Bolívia, Brasil, Colômbia, Chile, Equador, Peru, Uruguai e Venezuela (Brasil, 1981). 


\begin{tabular}{|c|c|c|c|}
\hline \multirow{2}{*}{ País } & \multicolumn{3}{|c|}{ Marco jurídico ${ }^{1}$} \\
\hline & 1960 & 1970 & 1980 \\
\hline Uruguai & & $\begin{array}{l}\text { Decreto-lei no } 14.294 / 1974 \text { - } \\
\text { Internação ou tratamento } \\
\text { ambulatorial compulsórios, por } \\
\text { determinação judicial após exame } \\
\text { médico, sem disposição quanto } \\
\text { ao prazo. }\end{array}$ & \\
\hline Colômbia & & $\begin{array}{l}\text { Decreto no } 1.188 / 1974 \text { - Crimina- } \\
\text { liza expressamente a posse para } \\
\text { uso pessoal. } \\
\text { Pena privativa de liberdade: } 1 \text { mês } \\
\text { a } 2 \text { anos. }\end{array}$ & $\begin{array}{l}\text { Lei no } 30 / 1986 \text { - Criminaliza } \\
\text { expressamente a posse para uso } \\
\text { pessoal. } \\
\text { Pena privativa de liberdade: } 30 \\
\text { dias; ou } 1 \text { mês a } 1 \text { ano se reinci- } \\
\text { dente nos últimos } 12 \text { meses. } \\
\text { Lei estabelece quantidades máxi- } \\
\text { mas de posse para uso. }\end{array}$ \\
\hline México & $\begin{array}{l}\text { 1967: as penas foram agravadas } \\
\text { (León et al., 2018). }\end{array}$ & $\begin{array}{l}\text { 1974: caso o usuário seja } \\
\text { dependente, não há pena. Para } \\
\text { não dependentes, pena privativa } \\
\text { de liberdade de } 6 \text { meses a } 3 \text { anos } \\
\text { (León et al., 2018). }\end{array}$ & \\
\hline
\end{tabular}

Fontes: Para o Brasil, legislações citadas; para a Argentina, Corbelle (2019); para o Uruguai, Musto (2019); para a Colômbia, Góngorra, Salazar e Borja (2019); para o México, Ospina-Escobar (2019).

Elaboração da autora.

Nota: ${ }^{1}$ Normas e decisões judiciais consideradas relevantes para explicar os direcionamentos da política de regulação do uso de drogas, particularmente quanto às mudanças nas categorias desenvolvidas na figura 1 (liberdade/tratamento; tratamento compulsório/pena alternativa; pena privativa de liberdade). Não se trata, portanto, de um rol exaustivo das alterações legais dos países.

\subsection{Argentina, Brasil e Colômbia}

$\mathrm{Na}$ Argentina, houve reformas legais em 1968, 1973 e $1974 .{ }^{19}$ Como visto na análise anterior, em 1968 a Argentina vivenciou breve período de despenalização da posse para uso. Já em 1973, derrogou-se a lei de 1968, possivelmente por influência da ASEP, restabelecendo-se a penalização da posse indistintamente, para usuários e traficantes. Em 1974, nova lei traz a previsão expressa da pena privativa de liberdade para posse, ainda que para uso pessoal (Corbelle, 2019).

Já no Brasil, foram editadas normas em 1968, 1971 e $1976 .{ }^{20}$ Em todas elas, a posse para uso próprio foi criminalizada, com a diferença de que, nas normas de 1968 e de 1976, não havia diferenciação entre usuário e traficante, enquanto a lei de 1976 endureceu as penas para tráfico e diminuiu a pena para posse para uso próprio.

$\mathrm{Na}$ Colômbia, foram várias as reformas legais no período, entre as quais se destacam o Primeiro Estatuto Nacional de Estupefacientes, em 1974, ${ }^{21}$ o qual estrutura uma legislação esparsa, editada nas décadas anteriores, e $o$ Segundo Estatuto 
Nacional de Estupefacientes, em 1986, ${ }^{22}$ que aumentou as penas e fixou quantidades máximas para uso pessoal. A lei de 1974 penalizou a posse para uso, embora atenuando a pena privativa de liberdade - comparativamente às condutas relacionadas à oferta -; e instituiu o tratamento obrigatório. Os critérios para diferenciação entre usuário e traficante variaram: entre 1974 e 1986, a condição de traficante era presumida, exigindo-se perícia médico-legal para se comprovar a farmacodependência. Em 1986, a lei fixou valores máximos do que seria considerado dose pessoal, com a finalidade de uso próprio, e reduziu a pena privativa de liberdade para usuários (Góngora, Salazar e Borja, 2019).

\subsection{Uruguai}

De modo semelhante, o Uruguai incorporou as diretrizes do ASEP, em 1974. ${ }^{23}$ Entretanto, ao contrário dos demais países que participam do acordo, não criminalizou o usuário. Por sua vez, deu continuidade à política anterior, de internação compulsória de usuários, após avaliação de seu estado mental, bem como de suas condiçôes econômicas e sociais. A distinção entre usuário e traficante ficava a critério da convicção moral do juiz do caso (Musto, 2019).

\subsection{México}

Como visto, o México também foi alvo da ofensiva de guerra às drogas, sediando uma das agências do Bureau of Narcotics and Dangerous Drugs (atual DEA). De acordo com o relatório da missão especial do Congresso estadunidense, a colaboração do governo dos Estados Unidos com o México envolvia treinamento e investimento em equipamentos, aeronaves e veículos (Murphy e Steele, 1973). Em 1967, as penas por crimes de drogas foram agravadas. Já em 1974, houve a despenalização do uso para pessoas dependentes, concomitantemente a uma redução do tempo de prisão para os não dependentes e aumento da pena para condutas relacionadas à oferta de drogas (León et al., 2018).

\section{MOVIMENTO DE DESCRIMINALIZAÇÃO E/OU DESPENALIZAÇÃO}

Nesse capítulo, convencionou-se chamar de descriminalização elou despenalização o movimento que se iniciou nos anos 1980 e se estende até os dias atuais. Entende-se aqui como descriminalização a descaracterização de determinadas condutas como crimes, ao passo que despenalização se aplica a condutas que permanecem criminalizadas, embora sobre elas não incida pena privativa de liberdade. É um período marcado por disputas, avanços e retrocessos na experimentação de novos modelos

22. Lei ํㅡ 30/1986.

23. Decreto-lei no 14.294/1974. 
de regulação do uso, de cuidado aos usuários e, de modo incipiente, experimentação de alternativas à regulação da oferta de drogas.

No cenário internacional, o regime tem sido progressivamente questionado e minado - o que foi feito de forma explícita na Assembleia Geral das Nações Unidas (AGNU) de 2016, principalmente a partir da regulaçáo do mercado de cannabis em diversos países, em clara ofensa aos preceitos das convençóes. O consenso internacional está abalado e há pressão pela sua reforma (Paiva, 2018).

Em relação aos usuários, o período foi marcado por mudanças em direção à maior autonomia e liberdade do usuário, por meio da descriminalização e/ou despenalização, além da adoção de políticas de redução de danos, particularmente no contexto de redução do contágio do vírus da imunodeficiência humana (HIV) em usuários de drogas injetáveis (Room e Reuter, 2012). As políticas de cuidado pautadas pela redução de danos contrapóem-se àquelas que buscam tão somente promover a abstinência, pois consideram que o uso de drogas é um exercício de liberdade de escolha individual, não se constituindo em algo imoral ou intrinsicamente ruim. Nos países da América Latina, esta linha de pensamento encontrou terreno fértil com a redemocratização e a constitucionalização dos direitos individuais e sociais, principalmente nos casos de Argentina, Colômbia e México, e, em menor grau, no Brasil, como se verá adiante.

Entretanto, antes de passar a análise dos casos de cada um dos países, faz-se necessária uma ressalva para prevenir um excessivo otimismo quanto ao alcance das reformas desse último período analisado: a descriminalização e/ou despenalização do usuário não implica imediata superação do paradigma de guerra às drogas. É preciso distinguir entre regulação do uso e regulação da oferta, e, no que tange à última, persiste a regulação via proibição e encarceramento de traficantes. A experimentação de modelos alternativos à proibição da oferta é incipiente $\mathrm{e}$ limita-se ao mercado de cannabis. ${ }^{24}$ Em verdade, nos casos de Colômbia, México e Brasil, a descriminalização/despenalização do usuário de drogas se deu simultaneamente à manutenção ou ao agravamento das sançôes criminais para a conduta de tráfico e acirramento da militarização do combate à oferta de drogas.

$\mathrm{Na}$ Colômbia, foi intenso o financiamento dos Estados Unidos para militarizaçáo do combate ao narcotráfico naquele país, por meio dos chamados Plano Colômbia (1999-2007) e Plano Colômbia II (2007-2013), cujo foco era a erradicação das plantaçôes de coca, via fumigação, com glifosato, das regiôes produtoras, e a militarização do combate às organizaçôes do tráfico, ou do "narco-terrorismo"

24. Destaca-se o Uruguai como primeiro país a regular toda a cadeia produtiva de cannabis a nível nacional, além do Canadá e de Unidades Federativas dos Estados Unidos da América (Colorado, Washington, Alasca, Oregon, Califórnia, Maine, Massachusetts, Nevada, Michigan, Illinois e Vermont) (Obradovic, 2019). 
(Santos, 2010). Embora a corte constitucional tenha proibido a aspersão de glifosato em 2017, com o intuito de proteger a saúde da população, o governo retomou as aspersóes em 2019 (Góngora, Salazar e Borja, 2019).

No México, paralelamente à descriminalização do usuário, observou-se o acirramento do combate ao tráfico, via criminalização e penas mais duras. Entre os anos 1980 e 2000, o México tornou-se uma importante rota de tráfico de cocaína proveniente da regiấo andina, em direção aos Estados Unidos, o que resultou na escalada do poder econômico e político das organizaçóes criminosas, acompanhada pela violência endêmica, decorrente de disputas territoriais e atuação de milícias (León et al., 2018). O pânico causado por essa onda de insegurança levou o governo a adotar medidas cada vez mais repressivas para lidar com o problema das drogas. A partir de 2006, o governo iniciou uma guerra contra as drogas com uma série de operações militares de combate ao narcotráfico (León et al., 2018).

Finalmente, no Brasil, a despenalização do usuário foi acompanhada pelo aumento das penas para condutas relativas ao tráfico de drogas. Ademais, na ausência de critérios objetivos de distinção entre condutas de posse para uso e posse para tráfico de drogas, os sistemas de justiça atuam de forma seletiva, ao utilizar critérios raciais e socioeconômicos para diferenciar usuários e traficantes, resultando no encarceramento de usuários pelo crime de tráfico (Haber e Maciel, 2018; Jesus et al., 2011; Semer, 2019).

Retomando o foco de análise para a regulação do consumo de drogas, na última década os países podem ser divididos em dois grupos. De um lado, Argentina, Colômbia e México, onde prevalece a autonomia da vontade dos cidadãos para uso de drogas e/ou tratamento. De outro lado, Uruguai e Brasil, onde se mantém a possibilidade de tratamento compulsório e/ou pena alternativa.

QUADRO 3

Marcos jurídicos da regulação do consumo de drogas (décadas de 1980 a 2010)

\begin{tabular}{|c|c|c|c|c|}
\hline \multirow{2}{*}{ País } & \multicolumn{4}{|c|}{ Marco jurídico ${ }^{1}$} \\
\hline & 1980 & 1990 & 2000 & 2010 \\
\hline Argentina & $\begin{array}{l}\text { Corte Suprema } \\
\text { de Justiça, 1986, } \\
\text { "Fallos" (julgamentos) } \\
\text { Bazterrica e Capalbo - } \\
\text { Descriminalização da } \\
\text { posse para uso. } \\
\text { Lei no } 23.737 / 1989 \text { - } \\
\text { Criminaliza expres- } \\
\text { samente aposse } \\
\text { para uso } \\
\text { Pena privativa de } \\
\text { liberdade: } 1 \text { mês a } \\
2 \text { anos. }\end{array}$ & & $\begin{array}{l}\text { Corte Suprema de } \\
\text { Justiça, 2009, "Fallo" } \\
\text { (julgamento) Arriola - } \\
\text { Descriminalização da } \\
\text { posse para uso. }\end{array}$ & \\
\hline
\end{tabular}


Cem Anos de Regulação do Consumo de Drogas na América Latina: o que nos dizem as trajetórias de Argentina, Brasil, Uruguai, Colômbia e México?

\begin{tabular}{|c|c|c|c|c|}
\hline \multirow{2}{*}{ País } & \multicolumn{4}{|c|}{ Marco jurídico ${ }^{1}$} \\
\hline & 1980 & 1990 & 2000 & 2010 \\
\hline Brasil & & & $\begin{array}{l}\text { Lei no 11.343/2006 - } \\
\text { Despenalização da } \\
\text { posse para uso } \\
\text { Imposição de } \\
\text { penas alternativas: } \\
\text { advertência sobre os } \\
\text { efeitos das drogas, } \\
\text { prestação de serviços } \\
\text { à comunidade, ou } \\
\text { comparecimento a } \\
\text { programa ou curso } \\
\text { educativo. } \\
\text { Lei no } 10.216 / 2001 \\
\text { (Lei da Reforma Psi- } \\
\text { quiátrica) - Estabelece } \\
\text { critérios e mecanismos } \\
\text { de controle para } \\
\text { internação involuntá- } \\
\text { ria para tratamento } \\
\text { psiquiátrico. }\end{array}$ & $\begin{array}{l}\text { Lei no 13.840/2019- } \\
\text { Altera a Lei no } \\
11.343 / 2006 \text { para } \\
\text { incluir a possibilidade } \\
\text { de internação involun- } \\
\text { tária para tratamento } \\
\text { do usuário ou de- } \\
\text { pendente de drogas } \\
\text { e o acolhimento } \\
\text { voluntário em comuni- } \\
\text { dade terapêutica que } \\
\text { visam abstinência. }\end{array}$ \\
\hline Uruguai & & & & $\begin{array}{l}\text { Lei no 19.172/2013 - } \\
\text { Regulamenta o } \\
\text { mercado de cannabis, } \\
\text { inclusive autoplantio e } \\
\text { produção por coope- } \\
\text { rativas de usuários. }\end{array}$ \\
\hline Colômbia & $\begin{array}{l}\text { Lei no 30/1986 - Cri- } \\
\text { minaliza expressamen- } \\
\text { te a posse para uso. } \\
\text { Pena privativa de } \\
\text { liberdade: } 30 \text { dias; } \\
\text { ou } 1 \text { mês a } 1 \text { ano } \\
\text { se reincidente nos } \\
\text { últimos } 12 \text { meses. } \\
\text { Lei estabelece quan- } \\
\text { tidades máximas de } \\
\text { posse para uso. }\end{array}$ & $\begin{array}{l}\text { Corte Constitucional, } \\
\text { Sentença C-221 de } 1994 \\
\text { - Descriminalização do } \\
\text { uso ou porte para uso e } \\
\text { inconstitucionalidade do } \\
\text { tratamento compulsório. }\end{array}$ & & \\
\hline México & & & $\begin{array}{l}\text { Lei Contra o Microtráfi- } \\
\text { co de } 2009 \text { (Ley contra } \\
\text { el narcomenudeo) - } \\
\text { Descriminalizou a posse } \\
\text { para uso. Não há perse- } \\
\text { cução penal ou medida } \\
\text { restritiva de direitos, } \\
\text { desde que obedecidas } \\
\text { as quantidades máxi- } \\
\text { mas definidas em lei. }\end{array}$ & $\begin{array}{l}\text { Suprema Corte de } \\
\text { Justiça, de } 2018 \text { - } \\
\text { Reconhece o direito } \\
\text { ao uso adulto de } \\
\text { cannabis. (Ospina- } \\
\text {-Escobar, 2019) }\end{array}$ \\
\hline
\end{tabular}

Fontes: Para o Brasil, legislações citadas; para a Argentina, Corbelle (2019); para o Uruguai, Musto (2019); para a Colômbia, Góngorra, Salazar e Borja (2019); para o México, Ospina-Escobar (2019).

Elaboração da autora.

Nota: ${ }^{1}$ Normas e decisões judiciais consideradas relevantes para explicar os direcionamentos da política de regulação do uso de drogas, particularmente quanto às mudanças nas categorias desenvolvidas na figura 1 (liberdade/tratamento; tratamento compulsório/pena alternativa; pena privativa de liberdade). Não se trata, portanto, de um rol exaustivo das alterações legais dos países. 


\subsection{Argentina, Colômbia e México}

$\mathrm{Na}$ Argentina, o primeiro impulso de descriminalização veio com a redemocratização, em 1983. Durante a ditadura militar (1976-1983), a criminalização dos usuários foi instrumentalizada para encarceramento e controle de jovens subversivos, o que fez com que a reforma da política de drogas compusesse a pauta de direitos humanos, no processo de redemocratização. Desse modo, a despenalização da posse para uso e a necessidade de consentimento do usuário para seu tratamento foram logo propostas em projeto de lei, embora este não tenha chegado a prosperar. A descriminalização da posse para uso ocorreu, de fato, por determinaçáo da Corte Suprema de Justiça, em 1986 (casos Bazterrica e Capalbo).

Essa abordagem durou pouco, devido a condiçôes internacionais. A assinatura da Convenção contra o Tráfico Ilícito de Entorpecentes e Substâncias Psicotrópicas, em 1988, a classificação da Argentina como país produtor pelos Estados Unidos e o condicionamento de ajuda financeira à aderência à guerra às drogas resultaram em um retrocesso, com a edição de lei em $1989,{ }^{25}$ a qual penaliza a posse para uso, com a possibilidade de substituição ou complementação por medida de segurança, curativa ou educativa. No ano seguinte (1990), a Corte Suprema reverteu seu posicionamento anterior e afirmou sua concordância com a nova lei (casos Montalvo e Ernesto). Apenas em 2009, a Corte Suprema voltou a declarar a inconstitucionalidade da criminalização da posse para uso (caso Arriola) (Corbelle, 2010; 2019).

De modo semelhante, na Colômbia, as inovaçóes mais significativas no marco jurídico ocorreram por determinaçáo jurisdicional. Em 1994, a Corte Constitucional colombiana declarou inconstitucional a penalização do consumo e do porte de dose mínima, bem como a submissão a tratamento compulsório. ${ }^{26}$ Em 2015, houve despenalização do cultivo de até vinte plantas controladas para uso pessoal. ${ }^{27}$ Por fim, em 2016, afirmou-se que o mero uso de substâncias psicoativas não configura causa para demissão de um trabalhador. ${ }^{28} \mathrm{O}$ posicionamento da corte deve ser compreendido como resultante da democratização trazida pela Constituição de 1991 e pela consolidaçáo da República da Colômbia como um Estado democrático de direito, plural e multicultural, fundado na garantia dos direitos humanos e individuais, na qual o fortalecimento da Corte Constitucional exerceu um papel fundamental (Borda, 1991; Yepes e Duque, 2012).

25. Lei ํㅜ 23.737/1989.

26. Sentença C-221/1994.

27. Sentença de 17 de junho de 2015 - Casación 44891, referindo-se a plantas de maconha ou plantas das quais se possa extrair cocaína, morfina, heroína, ou qualquer outra droga que produza dependência

28. Sentença C-336/2016. 
Entretanto, o posicionamento progressista da Corte Constitucional da Colômbia parece encontrar resistência em outros setores da sociedade, e, ao menos em duas oportunidades, a Corte foi chamada a reafirmar seu entendimento para refutar a retomada da penalização do uso de drogas por iniciativas dos poderes Legislativo e Executivo. Em 2009, um ato legislativo propôs a proibição do consumo, ${ }^{29}$ ato declarado inconstitucional em 2012. ${ }^{30}$ Adicionalmente, uma lei de 2016 buscava penalizar o consumo de drogas em espaços públicos, ${ }^{31}$ norma igualmente declarada inconstitucional em $2019^{32}$ (Góngora, Salazar e Borja, 2019).

No México, um marco importante da flexibilização da regulação do uso de drogas foi a chamada Lei Contra o Microtráfico (Ley Contra el Narcomenudeo), ${ }^{33}$ que descriminalizou o usuário e estabeleceu-se uma tabela de quantidades máximas para caracterização de consumo pessoal. Desde então, não há persecução penal ou imposição de medida restritiva de direitos a pessoas classificadas como fármaco-dependentes ou consumidoras. O Ministério Público deve informar ao usuário sobre a localização de centros de tratamento médico, ou de prevenção de dependência. Adicionalmente, deve-se reportar o caso às autoridades de saúde. Mais recentemente, em 2018, uma sentença da Suprema Corte de Justiça do México reconheceu o direito ao uso adulto de cannabis, com fundamento no direito ao livre desenvolvimento da personalidade. Entretanto, até o momento, não há legislação regulamentando o assunto (Ospina-Escobar, 2019).

Por seu turno, embora não tenha havido mudança no marco jurídico, observam-se sinais de retrocesso na política de drogas mexicana, com a instrumentalização dos chamados tribunais de drogas para a promoção do encarceramento de pessoas que usam drogas (Ospina-Escobar, 2019). Em sua concepção original, estes tribunais (Tribunais para Tratamento de Dependência) representam uma alternativa ao encarceramento, para pessoas que cometem crimes (que não crimes de drogas) e que fazem uso problemático de álcool e/ou outras drogas, por meio da suspensão condicional do processo. Em que pese o piloto do programa (implementado na regiāo de Nuevo León, a partir de 2009) ter estabelecido o foco em crimes de violência doméstica, cometidos em associação com o uso problemático de álcool, a expansão do programa para outras regiōes foi acompanhada de uma mudança de foco, que, na prática, tem resultado na criminalização de jovens usuários de drogas, em particular, da cannabis (Hernández, 2016).

29. Acto Legislativo 2/2009.

30. Sentença C-491/2012.

31. Lei ำ 1.801/2016.

32. Sentença C-253/2019.

33. Decreto publicado no Diário Oficial de la Federación, de 20 de agosto de 2009. 


\subsection{Brasil e Uruguai}

No Brasil, o processo de redemocratização na década de 1980 foi acompanhado por um breve ímpeto reformista com relação à regulação do uso de drogas, por iniciativa do Poder Executivo. ${ }^{34}$ Contudo, este ímpeto não chegou a produzir mudanças no marco jurídico naquele momento, e foi logo interrompido por renovado ânimo proibicionista, a partir da celebração da Convenção contra o Tráfico Ilícito de Entorpecentes e Substâncias Psicotrópicas, de 1988. Àquela altura, o Brasil foi objeto de constantes pressóes internacionais, tendo em vista sua classificação como país de trânsito, de produção de substâncias químicas utilizadas como insumo da produção de drogas e de lavagem de dinheiro (Carvalho, 1996).

Desse modo, apenas em $2006^{35}$ foi possível promover a despenalização do usuário, por meio de uma nova lei de drogas, que suspendeu a pena privativa de liberdade para usuários, instituindo as penas de advertência, prestação de serviços à comunidade e medida educativa. ${ }^{36} \mathrm{~A}$ lei estabeleceu ainda que compete ao juiz do caso decidir se a droga em posse do indiciado destina-se, ou não, ao uso pessoal. Embora tivesse o intuito de desonerar o sistema carcerário e oferecer resposta penal alternativa aos usuários, a nova lei acabou intensificando o problema do encarceramento, devido à ausência de critérios objetivos para diferenciar traficante e usuário (como quantidades e limites para a posse de substâncias), somada à perversa seletividade do sistema penal brasileiro, que tende a encarcerar e controlar grupos populacionais tradicionalmente tomados como alvo da ação policial - pessoas negras, pobres e residentes em bairros periféricos (Haber e Maciel, 2018; Jesus et al., 2011; Karam, 2006; Semer, 2019; IBCCRIM, 2016).

Por sua vez, mudanças recentes no marco jurídico de regulação do uso de drogas no Brasil apontam para o enfraquecimento do cuidado via redução de danos e fortalecimento dos modelos que buscam abstinência. Em 2019, ${ }^{37}$ foi incluída previsão legal expressa para o acolhimento (voluntário) em comunidades terapêuticas que visem à abstinência, além da possibilidade de internação involuntária em unidades de saúde ou hospitais gerais, por decisão médica. Embora já existisse previsão legal para internação involuntária na Lei de Reforma Psiquiátrica de 2001,

34. De acordo com Machado (2006, p. 40): "Em 1988, o Conselho Federal de Entorpecentes (Confen) publicou 0 documento Política Nacional na Questão das Drogas, cujo conteúdo refletiu o cenário de redemocratização vivido no Brasil. 0 documento propôs uma mudança no tratamento destinado ao assunto, buscando estabelecer uma abordagem 'destituída de preconceitos', de 'certezas absolutas', 'do discurso aterrorizante', de maneira a ampliar o debate sobre a questão das drogas, adequando 'o Confen às propostas de uma sociedade moderna e democrática' (...). Sem minimizar a importância das ações repressivas, o documento propôs uma abordagem centrada na pessoa e em suas motivações, e não na droga. Algumas ações previstas nas Leis nํㅗ 5.726/1971 e 6.368/1976 foram questionadas nesse documento, como as prisões e as internações dos usuários de drogas".

35. Lei $n=11.343 / 2006$.

36. Na prática, a aplicação de penas alternativas acontecia desde o advento da Lei o 9.099/1995 (Lei dos Juizados Especiais), antes da despenalização promovida pela Lei no 11.343/2006. A posse para uso classificava-se como infração de menor potencial ofensivo, o que facultava a imposição de penas não privativas de liberdade (Karam, 2006).

37. Lei $n=13.840 / 2019$. 
a reafirmação desse mesmo instituto na Lei de Drogas está a sinalizar o anseio de ampliação da aplicação de internaçóes involuntárias para tratamento de usuários ou dependentes de drogas.

Em que pese o Uruguai haver se posicionado como progressista no cenário internacional, por assumir a vanguarda de experimentação de modelos alternativos de regulação de cannabis, esse posicionamento não se aplica às demais drogas. $\mathrm{Na}$ década de 2010, o Uruguai permanece com a mesma política que utilizava no início do século anterior, sem movimentos em uma direção ou outra: o Uruguai nunca criminalizou ou apenou o usuário com privação de liberdade, entretanto, em se tratando de indivíduos considerados dependentes químicos pelo juiz, permanece a possibilidade de tratamento compulsório prevista em lei. O país também passou por um processo de redemocratização, na década de 1980, com o término da ditadura civil-militar (1973-1985). Entretanto, a política de drogas não foi um tema relevante para a redemocratização, tendo em vista que aquele país já adotava uma política comparativamente mais liberal, em que a posse para uso não era considerada crime. Portanto, o movimento em direção à maior autonomia e liberdade dos usuários não ocorreu (Musto, 2019).

\section{CONCLUSÃO}

A análise comparada das trajetórias da regulação do consumo de drogas evidenciou similaridades devido a fatores externos comuns aos países considerados: a existência de um regime de controle internacional, que estabeleceu os moldes das regulaçóes domésticas, e o interesse dos Estados Unidos na definiçẫo das políticas internas na América Latina. Além disso, destacou-se a relevância das instituiçôes democráticas e cortes constitucionais como motores das reformas recentes em direção à autonomia e liberdade dos usuários, particularmente nos casos de Colômbia, Argentina e México. Nesse sentido, políticas proibicionistas e repressivas parecem ter maior afinidade com regimes políticos autoritários, e, portanto, não resistiriam quando confrontadas com os princípios de direitos humanos, individuais e sociais.

Com relação ao futuro da regulação do consumo de drogas nesses países, de forma cautelosa e longe de qualquer ambiçáo prospectiva, pode-se dizer táo somente que, se esses fatores foram cruciais no passado, eles continuarão a ser relevantes no futuro. A política de drogas foi, e continua sendo, um campo em disputa. Como visto na seção 5, a aberta contestação dos preceitos das convençóes, no cenário internacional, levanta questóes sobre a continuidade do modelo, além de incertezas sobre como eventuais mudanças impactariam as políticas nacionais.

Embora as linhas do tempo representadas na figura 1 indiquem uma trajetória em direção a políticas nacionais que respeitem a autonomia e a liberdade do usuário, não há garantias de que essa tendência perdure. Os movimentos de 
descriminalização/despenalização não ocorreram sem resistência. $\mathrm{Na}$ Colômbia, a corte constitucional foi chamada a se manifestar sobre a mesma matéria mais de uma vez, reafirmando seu entendimento pela despenalização frente a inovaçóes legais que buscavam apenar o usuário. Na Argentina, a descriminalização, em 1986, por determinação da Corte Suprema de Justiça, foi revertida por lei, em 1989, e, apenas vinte anos depois, a corte voltou a declarar a inconstitucionalidade da criminalização da posse para uso. No México, a instituição de tribunais de drogas sinaliza um retrocesso ao facultar a criminalização de usuários. No Brasil, as recentes alteraçôes da lei de drogas privilegiam o modelo de cuidado pautado na abstinência e enfatizam a possibilidade de internação involuntária, indicando uma tendência de regulaçōes mais repressivas em relação ao usuário. Por sua vez, o Uruguai parece ser uma exceção, pela estabilidade da política de regulação de consumo pautada na internação compulsória de usuários considerados problemáticos, sem grandes inflexôes ao longo do período analisado.

\section{REFERÊNCIAS}

BRASIL. Decreto no 14.969 , de 3 de setembro de 1921. Approva o regulamento para a entrada no paiz das substancias toxicas, penalidades impostas aos contraventores e sanatorio para toxicômanos. Rio de Janeiro, Diário Oficial da Uniáo. 3 de setembro de 1921.

. Ministério da Justiça. Ministério das Relaçôes Exteriores. Documento Final de la III Conferencia de Estados Partes del Acuerdo Sudamericano sobre Estupefacientes y Psicotrópicos. Brasília, 17-20 nov. 1981.

BORDA, O. F. La acidentada marcha hacia la democracia participativa en Colombia. Analisis Politico, n. 14, p. 46-58, 1991.

CARVALHO, S. A política criminal de drogas no Brasil. 1996. Dissertação (Mestrado) - Universidade Federal de Santa Catarina, Florianópolis, 1996.

CORBELLE, F. La construcción del consumidor de drogas en el proceso judicial. 2010. Tesis (Licenciatura) - Universidad de Buenos Aires, Buenos Aires, 2010.

Proyecto Desigualdades Sociais e Implementação de Políticas Públicas na América Latina: políticas de atenção e cuidado a pessoas que fazem uso problemático de substâncias psicoativas. Argentina: Ipea/CEPAL, 2019. (Relatório parcial de pesquisa).

CRICK, E. Drugs as an existential threat: an analysis of the international securitization of drugs. International Journal of Drug Policy, n. 23, p. 407-414, 2012.

FARRET, N. K. A securitização do narcotráfico nos Estados Unidos e a influência no Brasil. Conjuntura Global, v. 3, n. 4, p. 226-232, 2014. 
GÓNGORA, A.; SALAZAR, J.; BORJA, R. Del higienismo a la reducción de dańos: políticas de reducción del consumo de drogas en Colombia, siglo XX y XXI. Relatório parcial de pesquisa. Colombia, 2019.

HABER, C. D.; MACIEL, N. C. As sentenças judiciais por tráfico de drogas na cidade e Regiāo Metropolitana do Rio de Janeiro. Cadernos de Segurança Pública, v. 10, n. 10, 2018.

HERNÁNDEZ, T. T. R. La expansión de los tribunales de drogas en México. Cuadernos de Trabajo del Monitor del Programa de Política de Drogas, n. 21, 2016. IBCCRIM - INSTITUTO BRASILEIRO DE CIÊNCIAS CRIMINAIS. UNGASS 2016 e os 10 anos da Lei no 11.343/2006. Boletim IBCCRIM, v. 286, p. 1, 2016. IPEA - INSTITUTO PESQUISAS ECONÔMICAS APLICADAS. Monitoramento dos efeitos da nova política uruguaia de regulaçáo do mercado de cannabis sobre a zona de fronteira: percepção das autoridades de segurança e dos atores do sistema de justiça criminal. Brasília: Ipea, 2017. (Relatório de Pesquisa).

JESUS, M. G. M. et al. Prisáo provisória e lei de drogas: um estudo sobre os flagrantes de tráfico de drogas na cidade de São Paulo. São Paulo: NEV, 2011.

KARAM, M. L. A Lei no 11.343/2006 e os repetidos danos do proibicionismo. In: LABATE, B.C. et al. (Orgs.). Drogas e cultura: novas perspectivas. Salvador: Edufba, 2006. p. 105-119.

LEÓN, E. Z. P. et al. La política de drogas em México: causa de una tragedia nacional, Revista Pensamiento Penal, 8 out. 2018. Disponível em: <https://bit. ly/2JIuzvd>. Acesso em: 17 fev. 2020.

MCALLISTER, W. B. Reflections on a century of International Drug Control. In: COLLINS, J. (Ed.). Governing the drug war. London: LSE, 2012. (LSE Ideas Special Report, SR014).

MACHADO, A. R. Uso prejudicial e dependência de álcool e outras drogas na agenda da saúde pública: um estudo sobre o processo de constituição da política pública de saúde do Brasil para usuários e outras drogas. 2006. Dissertação (Mestrado) - Universidade Federal de Minas Gerais, Belo Horizonte, 2006.

MARTINEZ, E. D. M; LIRA, M. P. O. O processo de dessecuritização do narcotráfico na Unasul. Contexto Internacional, v. 37, n. 2, p. 661-691, 2015.

MURPHY, M. F. STEELE, R. H. The world narcotics problem: the Latin American perspective. Washington: U.S. Government Printing Office, 1973.

MUSTO, C. Panorama de los tratamientos para usuarios problematicos de drogas en Uruguay. Relatório parcial de pesquisa. Uruguay, 2019. 
NIXON, R. Message to the Congress Transmitting Reorganization Plan 2 of 1973 Establishing the Drug Enforcement Administration. The American Presidency Project, 1973. Disponível em: <https://www.presidency.ucsb.edu/node/256311>. Acesso em: 14 fev. 2020.

OBRADOVIC, I. From prohibition to regulation: a comparative analysis of the emergence and related outcomes of new legal cannabis policy models (Colorado, Washington State and Uruguay). International Journal of Drug Policy, v. 102590, n. 15, 2019. DOI: <10.1016/j.drugpo.2019.11.002>.

OSPINA-ESCOBAR, A. Arreglos institucionales para la atención al uso problemático de drogas en México. Relatório parcial de pesquisa. México, 2019.

PAIVA, L. G. M. Panorama internacional das políticas sobre drogas. Boletim de Análise Político-Institucional, n. 18, p. 99-106, 2018.

RODRIGUES, T. Tráfico, guerra, proibição. In: LABATE, B. C. et al. (Org.). Drogas e Cultura: novas perspectivas, p. 91-103, 2008.

ROOM, R.; REUTER, P. How well do international drug conventions protect public health? Lancet, n. 379, p. 84-91, 2012.

SANTOS, M. Passado e presente nas relaçôes Colômbia-Estados Unidos: a estratégia de internacionalização do conflito armado colombiano e as diretrizes da política externa norte-americana. Revista Brasileira de Política Internacional, n. 53 , v. $1,2010$.

SEMER, M. S. Sentenciando tráfico: pânico moral e estado de negação formatando o papel dos juízes no grande encarceramento. 2019. Tese (Doutorado) - Universidade de São Paulo, São Paulo, 2019.

UNODC - UNITED NATIONS OFFICE ON DRUGS AND CRIME. The international Drug Control Conventions. New York: United Nations, 2013. Disponível em: <https://bit.ly/3arqlkO >.

UNITED NATIONS. Narcotic Drugs and Psychotropic Substances. In:

Multilateral treaties deposited with the Secretary-General. 2020. cap. 6. Disponível em: <https://bit.ly/3qUWZ5Z>. Acesso em: 14 fev. 2020.

URUGUAY. Ley no 9.202, de 12 jan. 1934. Ley orgânica de Salud Publica. Disponível em: <https://bit.ly/3ap05aA >.

YEPES, R. U.; DUQUE, L. M. Constitución de 1991, justicia constitucional y cambio democrático: un balance dos décadas después. Cahiers des Amériques Latines, n. 71, p. 33-53, 2012. 


\section{POLÍTICAS PÚBLICAS Y ABORDAJE INTEGRAL TERRITORIAL DE LOS CONSUMOS PROBLEMÁTICOS: LAS EXPERIENCIAS DEL DIAT JUANA AZURDUY Y EL DTC BARRIO CEIBO, PROVINCIA DE BUENOS AIRES ${ }^{1}$}

Florencia Corbelle ${ }^{2}$

\section{INTRODUCCIÓN}

Este capítulo presenta los resultados del estudio de caso de dos dispositivos de abordaje territorial de los consumos problemáticos de la Secretaría de Políticas Integrales sobre Drogas de la Nación Argentina (Sedronar) ubicados en la zona norte del Área Metropolitana de Buenos Aires (Amba): ${ }^{3}$ el Dispositivo Integral de Abordaje Territorial Juana Azurduy (en adelante, DIAT JA) y el Dispositivo de Tratamiento Comunitario Barrio Ceibo (en adelante, DTC BC). ${ }^{4}$ Ambos dispositivos - esto es, los DIAT y los DTC - son producto de la acumulación y yuxtaposición de una serie de experiencias de intervención y políticas de implementación reciente en Argentina que han implicado un quiebre con los modelos dominantes en prevención y asistencia de los consumos problemáticos, ${ }^{5}$ y deben comprenderse en el marco de un cambio de paradigma en la materia, cuyo primer hito normativo es la sanción de la Ley de Salud Mental en 2010.

La investigación que aquí se narra se centró en el análisis de las modalidades de atención y cuidado a personas en situación de consumo problemático de sustancias en estos dos dispositivos, haciendo especial hincapié en las relaciones y estrategias

1. La autora agradece a Silvana Garbi y Ana Candil por su atenta lectura y valiosos comentarios. Las opiniones vertidas son de exclusiva responsabilidad de la autora.

2. Doctora en Antropología en el Programa de Antropología Política y Jurídica - Instituto de Ciencias Antropológicas, Facultad de Filosofía y Letras de la Universidad de Buenos Aires; y consultora bajo el Programa de Cooperación de la Comisión Económica para América Latina y el Caribe (CEPAL) y del Ipea.

3. El Amba es la zona urbana común que conforman la Ciudad de Buenos Aires y cuarenta municipios que constituyen su conurbación sobre la Provincia de Buenos Aires (Ver, anexo B).

4. Todos los nombres propios han sido modificados para preservar la identidad de las personas que colaboraron con la investigación.

5. Pawlowicz et al. (2011) distinguen tres modelos de atención que representan diferentes saberes y prácticas sobre los procesos de salud/enfermedad/atención: el médico hegemónico, que se caracteriza por su identificación ideológica con la racionalidad científica, el sostenimiento de prácticas individuales, y su eficacia pragmática orientada a la curación y a los factores biológicos; el alternativo subordinado, propio de las comunidades terapéuticas que, pese a ser subsidiario al anterior, integra prácticas en las que se concibe la salud de forma global y holística y tiene como objetivo modificar la "personalidad adictiva" a través de una nueva socialización; y, el modelo de auto-atención, presente en los programas de Doce Pasos, donde el diagnóstico y la atención son realizados por pares en base a la experiencia. 
que los equipos de trabajo establecen con y crean junto a diferentes instituciones, organizaciones y actores tanto estatales como locales, toda vez que esta política pública no tiene como eje rector a las sustancias ni como norte el abstencionismo, así como tampoco mide el éxito o fracaso de las intervenciones terapéuticas de acuerdo a la existencia o no de "recaídas". Al contrario, el modelo de abordaje integral territorial en el que se inscriben estas iniciativas (Astolfi Romero et al., 2019) ha sido diseñado e implementado con el objetivo de reducir el sufrimiento (entendido como vulneración histórica de derechos) de quienes atraviesan situaciones de consumo problemático de sustancias desde una perspectiva de reducción de riesgos y daños, a partir del desarrollo de estrategias comunitarias y el fortalecimiento de redes locales. Ello así porque, desde este modelo se concibe que son las oportunidades de circulación por redes institucionales e intersubjetivas las que generan las condiciones de posibilidad para el acceso, la restitución y el ejercicio de los derechos, constituyéndose las mismas, de este modo, en el núcleo de una diversidad de propuestas que comprenden el fortalecimiento de la integración comunitaria como un proceso potencialmente terapéutico (Sedronar, 2017b; Tufró y Carroli, 2018).

El objetivo de este capítulo es entonces, a partir de la descripción de las prácticas, actividades cotidianas, metodologías, técnicas e instrumentos de trabajo desplegados por los equipos del DIAT Juana Azurduy y el DTC Barrio Ceibo, analizar los principales avances, conquistas y resultados, pero también limitaciones, obstáculos y desafíos que enfrenta la atención y cuidado a personas en situación de consumo problemático en estos dispositivos. Se retomarán, para ello, aportes recientes del campo de estudio de las políticas públicas y, en particular, de las denominadas políticas sociales (Cravino, 2008; Gupta y Ferguson, 2006; Rofman y Foglia, 2015; Rose, 2007; Shore, 2010; entre otros) así como bibliografía específica del campo de la atención de los consumos problemáticos (Barros et al., 2018; Bordoni y Ramírez, 2018; Camarotti y Kornblit, 2015; Candil, 2011; Capriati et al., 2015; entre otros). En otras palabras, a partir de una investigación de carácter etnográfico ofrecemos un análisis situado de dos experiencias, esto es, una lectura de las prácticas, acciones e intervenciones de los equipos DIAT y DTC a la luz de la política pública en la que se inscriben estos dispositivos, así como de la historia más amplia de las políticas de drogas y, en especial, las políticas de atención y cuidado a personas que hacen uso problemático de sustancias en Argentina. Pero también, en el marco de las transformaciones que han tenido lugar en la política pública de las últimas décadas, caracterizadas por la diversificación, territorialización e institucionalización de la "participación ciudadana" así como por la incorporación, a principios de siglo, de un enfoque de derechos a las políticas sociales (Abramovich, 2006; Rofman y Foglia, 2015).

Para ello, en el primer apartado, se reconstruye la historia de las políticas de atención y cuidado a personas que hacen uso problemático de sustancias psicoactivas en Argentina. Luego, en un segundo apartado, se describe la actual oferta 
asistencial, se presentan las principales características de los DIAT y los DTC, y se brinda información sobre las consultas y el perfil sociodemográfico de sus usuarios/as. A continuación, se explica la metodología y las técnicas de investigación empleadas y se relata brevemente el trabajo de campo realizado. El cuarto apartado, se centra en las modalidades de atención y cuidado que despliegan los equipos del DIAT Juana Azurduy y el DTC Barrio Ceibo. Allí, se describen los municipios y barrios donde se trabaja, se reconstruye brevemente la historia de los dispositivos, y se detallan las características de los equipos y su labor cotidiana (prácticas, actividades y metodología de trabajo), con el objetivo de dar cuenta de las conquistas, limitaciones y desafíos de estos dispositivos en tanto puesta en práctica local del modelo de abordaje integral territorial de la Dirección Nacional de Abordaje Estratégico (DNAE) de la Sedronar. Por último, el capítulo concluye con algunas reflexiones a modo de comentarios finales.

\section{POLÍTICAS DE ATENCIÓN Y CUIDADO A PERSONAS QUE HACEN USO PROBLEMÁTICO DE SUSTANCIAS PSICOACTIVAS EN ARGENTINA. UN RECORRIDO HISTÓRICO.}

\subsection{Higienistas, policías y "toxicómanos" (fines siglo XIX - 1960)}

La construcción social del "problema de la droga" en Argentina data de principios del siglo XX y fue fruto, principalmente, del esfuerzo mancomunado de la institución policial y médicos higienistas que respondieron a las preocupaciones de una elite moral obsesionada con el desorden y la "insalubridad criminalidad" (Salessi, 1995; Tiscornia, 2000). En este contexto, la "toxicomanía" fue caracterizada como una aflicción con propensiones delictivas por lo que la suerte de "toxicómanos" y "narcotizantes" no fue diferente a la de los "vagos", "mendigos", "alcohólicos" y "homosexuales" (Weissmann, 2005). Considerados portadores de una especie de "estado de peligrosidad", se trataba de personas que estuviesen o no cometiendo un delito, era preciso encerrar y aislar para evitar el contagio por imitación o sugestión y, de este modo, neutralizar la amenaza que suponían para la sociedad. La policía contaba, para ello, desde 1921 con un Gabinete de Toxicología. Sin embargo, más allá de una ley que reglamentaba el ejercicio de la farmacia y una ordenanza que limitaba la importación y prohibía la venta libre de medicamentos que contuvieran opiáceos, cannabis o cocaína, no existían normativas que regularan el flujo de estas sustancias (Corbelle, 2019).

Fue recién a principios de la década de 1920, que médicos higienistas, la policía y la prensa escrita desarrollaron una incansable campaña para suplir este vacío legal, donde se percibe la influencia de la legislación regional y las convenciones internacionales. Así, pese a que la toxicomanía no era considerada un problema sanitario ni social relevante en Argentina, se sancionaron en 1924 y 1926 las 
primeras leyes penales en la materia. No obstante, pese a demandas reiteradas de ciertos sectores de la corporación médica, no se crearon dispositivos de atención específicos (Corbelle, 2019).

\subsection{El modelo represivo-terapéutico (1960-1982)}

Las primeras respuestas terapéuticas en Argentina datan de las décadas de 1960 y 1970, años en que no sólo se difunde el consumo de sustancias psicoactivas entre la juventud de clase media (Manzano, 2014), sino que aumentan significativamente las detenciones a artistas, estudiantes universitarios y jóvenes hippies que hacían uso de anfetaminas y marihuana. Ello así porque, si bien la dictadura de Juan Carlos Onganía (1966-1970) había introducido una reforma del Código Penal, donde - en línea con la Convención Única de Estupefacientes (1961) - no se penaba la tenencia para consumo, esta iniciativa había sido secundada por una reforma del Código Civil, donde se permitía la declaración de inhabilitación y la internación compulsiva de los "toxicómanos". Además, se facultaba a la policía a detener usuarios/as y derivarlos a un centro de tratamiento sin necesidad de tener orden previa del juzgado o contar con la presencia de un médico para evaluar el estado del supuesto intoxicado; en tanto que, los jueces podían ordenar, tras el análisis de un médico legista, la internación compulsiva de los "toxicómanos" por el tiempo que el personal de salud estimase necesario (Corbelle, 2019).

En este contexto surgen, entonces, las primeras instituciones abocadas al abordaje del consumo de sustancias psicoactivas, a saber: el Fondo de Ayuda Toxicológica (FAT) creado, en 1966, en el marco de la cátedra de Toxicología de la Facultad de Medicina de la Universidad de Buenos Aires; el CEPRETOX, que resultó de un convenio firmado, ese mismo año, entre dicha cátedra y la Secretaría de Salud Pública del Ministerio de Bienestar Social; el Servicio de Toxicomanías del Hospital José T. Borda, primera institución en ofrecer servicios de internación; y el CENARESO, cuya creación fue alentada por la Comisión Nacional de Toxicomanías y Narcóticos $(\mathrm{CONATON})^{6}$ en el marco de un movimiento internacional promovido por la Organización de Naciones Unidas que fomentaba el establecimiento centros asistenciales y de investigación en materia de adicciones. De esta época también datan otras importantes iniciativas de la sociedad civil conocidas como "comunidades de vida".

En lo que respecta al FAT y el CEPRETOX ofrecían, aunque desde diferentes enfoques, tratamientos ambulatorios. El primero, desde la sociología crítica, proponía problematizar el significado social del consumo de sustancias; mientras que, el CEPRETOX adoptó un enfoque psiquiátrico-toxicológico. El Servicio del Hospital Borda y el CENARESO, en cambio, ofrecían servicios de internación. En el Hospital Borda se combinaban aspectos psiquiátricos con la implementación de actividades recreativas; en tanto que, el CENARESO brindaba asistencia

6. Primer organismo nacional en reunir en su seno funciones preventivas, asistenciales y represivas. 
integral desde un enfoque psico-socio-cultural. Esto es, servicios de diagnóstico, tratamiento ambulatorio e internación y, en las etapas finales del tratamiento, un proceso de resocialización (Camarotti, Jones y Di Leo, 2017; Levin, 2013; Touzé, 2006). No obstante, como ocurría en el Servicio del Hospital Borda, la internación adquiría con frecuencia un carácter obligatorio (Weissmann, 2005). De hecho, en el Hospital, si bien se hablaba de terapias novedosas y pregonaba el trabajo grupal y la horizontalidad, en la práctica se recibían personas - en su mayoría jóvenes usuarios de marihuana - derivadas por las fuerzas de seguridad y el sistema judicial en contra de su voluntad. De modo que, con la creación de estas instituciones podría decirse que se pusieron finalmente en funcionamiento en plena década del setenta aquellos ansiados "laboratorios vivos" de principios de siglo, donde un público cautivo era observado por profesionales de diversas disciplinas con el objetivo de desentrañar las causas de la "adicción" y realizar recomendaciones al poder político (Corbelle, 2019); Levin, 2013).

Por último, en cuanto a las "comunidades de vida", se trataba de iniciativas de fuerte impronta religiosa y organizadas alrededor de la figura de "ex-adictos", que proponían un proyecto terapéutico alternativo a la atención en hospitales psiquiátricos guiado por la máxima de la "recuperación de la vida correcta" (Galante et al., 2013; Touzé, 2006). En 1982, algunas de ellas se constituirían en el Centro de Rehabilitación Cristiano de Adicciones "Programa Andrés", primera comunidad terapéutica (CT) de Argentina.

\subsubsection{La campaña anti-subversiva}

Al promediar la década del setenta, en línea con el nuevo discurso de la "seguridad nacional", el modelo terapéutico-represivo adquirió ribetes de "campaña antisubversiva”. En 1974, se sancionó la Ley no 20771, que estableció que el control del tráfico y consumo de drogas era un asunto de seguridad y defensa nacional y aumentó las penas y conductas incriminadas. La tenencia de estupefacientes para uso personal fue nuevamente penada y se incluyó la posibilidad de imponer junto a la pena una "medida de seguridad curativa" a las personas dependientes (Corda, Galante y Rossi, 2014; Corbelle, 2019). Para ello se creó, en 1979, el Centro de Recuperación de Toxicómanos en la Unidad Penitenciaria No1 del Servicio Penitenciario Federal (Touzé, 2006).

El saldo de esta política fue el hostigamiento y persecución policial, la criminalización y el encarcelamiento de jóvenes usuarios. Ello hizo de la sustitución de este paradigma represivo un tema en la agenda de importantes referentes de los derechos humanos durante los últimos años de la dictadura cívico-militar (19761983) y los primeros años del gobierno democrático. 


\subsection{El retorno a la democracia (1983-1988)}

En los ańos ochenta, con el retorno de la democracia y a contrapelo del clima de intolerancia reinante, se propusieron desde los diferentes poderes del estado medidas alternativas al paradigma vigente. En la Cámara de Senadores se consensuó un proyecto de ley de avanzada que despenalizaba la tenencia y cultivo para consumo personal y dejaba asentada la necesidad de contar con consentimiento para iniciar un tratamiento (Corbelle, 2019); entretanto, la Corte Suprema de Justicia de la Nación declaraba en 1986 inconstitucional la penalización de la tenencia para consumo y el Poder Ejecutivo Nacional reemplazaba a la CONATON por la Comisión Nacional para el Control del Narcotráfico y el Abuso de Drogas (CONCONAD), que abandonó el enfoque represivo de su antecesora en favor de una perspectiva educativo-sanitaria.

En este sentido, la CONCONAD no sólo subvencionó investigaciones e implementó programas educativos, de prevención y capacitación que consideraban al usuario no ya como un delincuente sino como un joven cuyo entorno estaba en crisis y al que había que facilitarle los medios necesarios para su curación y reinserción social; sino que también, incorporó a su estructura institucional un comité asesor conformado por ONG que trabajaban en la temática. Además, estas organizaciones comenzaron a recibir subsidios para trabajar en prevención y/o tratamiento de las "adicciones" y se otorgaron becas de formación en el Pogetto Uomo (modelo italiano de CT), con el objetivo de profesionalizar la oferta asistencial, en un momento en el cual en organismos y foros internacionales comenzaba a valorar la participación de las ONG en la prevención y tratamiento (Aureano, 1998; Camarotti, Jones y Di Leo, 2017; Levin, 2013; Touzé, 2006).

Como resultado de estas políticas, en esos años proliferaron las ONG especializadas y, en 1986, se creó la Federación de Organizaciones no Gubernamentales de la Argentina para la Prevención y Tratamiento del Abuso de Drogas (Camarotti, Jones y Di Leo, 2017; Garbi, 2012; Touzé, 2006).

\subsection{La Sedronar (1989-2007)}

A fines de los ochenta, la política de drogas comenzó a modificarse producto de una serie de condicionamientos externos que se conjugaron con la difícil situación económica que el país transitaba (Corbelle, 2019). Estos cambios cristalizaron en el gobierno de Carlos Saúl Menem en la sanción de la actual Ley no 23737 (1989), que aumentó las penas y las conductas tipificadas como delito, y en la creación de la Sedronar, que inauguró una nueva etapa en materia de abordaje de las "adicciones" en la que dominaron los discursos preventivos y las políticas asistenciales de cuño represivo ligadas a la persecución del "narcotráfico". En materia preventiva, las campañas adoptaron un tono de advertencia para quienes nunca habían 
consumido y de amenaza de ser alcanzados por la ley penal a quienes lo hacían; mientras que, en lo asistencial se procuró facilitar la rehabilitación de personas que, carentes de recursos, no podían acceder a un tratamiento. Cabe recordar que, hasta ese entonces, las internaciones en el sector público se efectuaban únicamente en los hospitales psiquiátricos y el CENARESO (Camarotti, Jones y Di Leo, 2017; Corda, Galante y Rossi, 2014; Garbi, 2012; Touzé, 2006).

A tal efecto, se creó a tono con las políticas neoliberales de la década - basadas en la planificación descentralizada, la privatización y reestructuración administrativa de los servicios sociales y la focalización del gasto social -, el Programa de Subsidios para Asistencia Individual en el Tratamiento de Adictos con Internación en Institutos No Gubernamentales, más conocido como becas de la Sedronar. El Programa, que se encuentra aún vigente, tiene alcance nacional y consiste en el subsidio a personas de bajos recursos económicos para que efectúen tratamientos en ONG conveniadas, en tanto que la Secretaría, a través del CEDECOR, presta el servicio de atención y diagnóstico, define la modalidad de tratamiento, posee consultorios externos y, en caso de requerirse un tratamiento residencial, es la encargada de realizar las correspondientes derivaciones a ONG conveniadas que operan, en su mayoría, con el modelo de comunidad terapéutica.

El financiamiento de los tratamientos mediante el régimen de becas, la ayuda financiera a los centros asistenciales, el aumento de la demanda de tratamientos por derivación judicial, producto de la aplicación de las "medidas de seguridad curativas" previstas por la ley penal, y la obligación impuesta a las obras sociales y los servicios de medicina prepaga, en 1995 y 1996 respectivamente, de prestar tratamientos médicos, psicológicos y farmacológicos a las personas que dependan física o psíquicamente del uso de estupefacientes, contribuyeron al crecimiento de la oferta asistencial existente. ${ }^{7}$ Estas instituciones, públicas y privadas, fueron adoptando distintos modelos de atención, modalidades de tratamiento y formas de trabajo, pero, en su mayoría, las respuestas se enmarcaron en el paradigma abstencionista de atención de los consumos problemáticos.

De hecho, el abstencionismo fue el único enfoque existente hasta mediados de los 90, cuando la expansión de la epidemia del VIH/Sida dejó al descubierto su incapacidad de hacer frente a las problemáticas de los/as usuarios/as de sustancias psicoactivas por vía inyectable. Por ese entonces, comenzaron a surgir en Argentina los primeros programas de reducción de daños (PRD) que, partiendo de la

7. Esto llevó a la Sedronar a elaborar junto al Ministerio de Salud normas mínimas de habilitación y, luego, de categorización de los centros, así como la creación de programas básicos de tratamiento. Estas normas fueron, al poco tiempo, redefinidas y ampliadas por otras resoluciones y, más recientemente, en un esfuerzo por adecuar la oferta asistencial a los lineamientos establecidos por la Ley de Salud Mental (2010) y el Plan Integral para el abordaje de Consumos Problemáticos (2014). No obstante, al no ser normas vinculantes su incumplimiento supone, como máximo, la pérdida del convenio con la Secretaría. 
premisa de que el abandono del uso no siempre era posible ni deseado, brindaron información, promovieron la adopción de prácticas de cuidado de sí y de consumo seguras y fomentaron la participación de los/as usuarios/as como promotores/as reductores/as de daños y su organización en defensa de sus derechos como ciudadanos/as (Inchaurraga et al., 2003; Touzé et al., 1999). No obstante, si bien los PRD crecieron con el correr de los años, no se logró desarrollar planes y programas de alcance nacional, quedando las acciones a cargo de ONG, universidades y municipios con financiamiento internacional (Corda, Galante y Rossi, 2014).

A principios del 2000, la expansión del "paco" ${ }^{8}$ entre niños, niñas y adolescentes dejó nuevamente al descubierto las falencias de la oferta asistencial dando lugar a la conformación de grupos de mujeres conocidas como "Madres contra el Paco". Estas mujeres se organizaron para reclamar al Estado un mayor control de la oferta en los barrios, pero sobre todo mejoras en materia asistencial. Esto se tradujo, en la mayor parte de los casos y en línea con el modelo de intervención dominante, en demandas concretas de incremento de los tratamientos residenciales y en la férrea defensa de instrumentos de la justicia penal y civil (i.e. "medidas de seguridad curativa" y la denominada "protección de persona"), cuestionados por otros sectores, como recursos que facilitaban el acceso a la asistencia sociosanitaria (Corda, Galante y Rossi, 2014; López Bouscayrol, 2017). Como respuesta a sus demandas, en la Ciudad de Buenos Aires, se creó el Plan de Atención Integral sobre Consumo y Dependencia de PBC y se abrieron los Centros de Asistencia Social en Adicciones (CASAS).

\subsection{Un nuevo paradigma en materia de atención de los consumos problemáticos}

A fines de la década del 2000, en el marco de la revisión de las metas fijadas en la Sesión Especial sobre Drogas de la Asamblea General de Naciones Unidas (UNGASS) de 1998, las demandas de reforma a las actuales políticas de drogas y las propuestas alternativas respetuosas de los derechos humanos y basadas en la evidencia ganaron peso en la región. En Argentina, en particular, se desarrolló un debate en torno al modelo de intervención estatal vigente impulsado por diversas organizaciones de la sociedad civil que lograron el respaldo de sectores de los poderes ejecutivo, legislativo, y judicial (Corbelle, 2019). En este sentido, se creó en 2008, en el seno del Poder Ejecutivo Nacional, el Comité Científico Asesor en

8. Cuando los/as usuarios/as dicen fumar 'pasta base', o paco, en general, están haciendo referencia a tres tipos distintos de sustancias: la primera, más conocida como crack, que procede de la mezcla de clorhidrato de cocaína con bicarbonato de sodio; la segunda es la pasta extraída luego del proceso de maceración de las hojas de coca (mezclada con sustancias de corte); y la tercera, conocida como paco, consiste en los residuos que dejaría el proceso de elaboración de clorhidrato de cocaína (TNI, 2006).

9. Facultad prevista en el artículo 482 del antiguo Código Civil de internar personas en establecimientos con orden judicial, por disposición de la autoridad policial o de sus familiares. A partir de la sanción de la Ley Nacional de Salud Mental este mecanismo de internación involuntaria quedó en desuso. 
Materia de Control de Tráfico Ilícito de Estupefacientes, Sustancias Psicotrópicas y Criminalidad Compleja. El Comité, apoyaba, entre otras cuestiones, la despenalización de la tenencia para consumo, y promovía enfoques alternativos para el abordaje de los consumos problemáticos. Al año siguiente, la Corte Suprema de Justicia de la Nación declaró la inconstitucionalidad de la penalización de la tenencia para consumo; y, entre 2010 y 2011 , se presentaron diversos proyectos de reforma integral a la ley de drogas en el Congreso de la Nación (Corbelle, 2019).

Ese mismo año se sancionó, la Ley Nacional de Salud Mental (2010). Esta ley fue un hito en la materia no sólo porque reconoció a las "adicciones" como parte integrante de las políticas de salud mental y a las personas usuarias como sujetos de derecho; sino porque, además, implicó un viraje en el modelo de atención desde una lógica asistencial y curativa hacia otra comunitaria y preventiva con eje en la protección de derechos y la promoción de lazos sociales. En este sentido, se caracterizó a la internación como un recurso terapéutico excepcional, se jerarquizaron las modalidades de abordaje interdisciplinario e intersectorial y en el decreto reglamentario, se enumeró dentro de los "servicios de salud" la reducción de daños (Corda, Galante y Rossi, 2014). Poco tiempo después, tuvo lugar otra importante modificación en el marco normativo con la sanción, en 2014, del Plan Integral para el Abordaje de los Consumos Problemáticos de Drogas (IACOP). Entre sus aportes, se destaca la introducción de una mirada amplia respecto a los consumos problemáticos y de una impronta comunitaria y de inclusión social tomando como puntos de intervención prioritaria los sectores con mayores niveles de vulnerabilidad. Pare ello, se proponía la creación de centros comunitarios y dispositivos de integración educativos y laborales. No obstante, esta ley nunca fue reglamentada.

La Sedronar no permaneció ajena estos cambios. A principios de 2014, se inició un proceso de readecuación de sus objetivos y estructura organizativa, circunscribiendo su actividad a las funciones de prevención, capacitación y asistencia y quitando de su órbita las tareas relacionadas a la lucha contra el narcotráfico, que fueron transferidas al Ministerio de Seguridad (Decreto no 48/14). Más aún, ese mismo año, la Secretaría brindó reconocimiento y financiamiento, mediante un programa de subsidios, a diferentes experiencias de abordaje comunitario llevadas adelante por organizaciones eclesiales y sociales como Casas de Atención y Acompañamiento Comunitario (Resolución no 266/14) ${ }^{10}$ y desde la Presidencia de la Nación se presentó el Programa de Fortalecimiento para el Tratamiento de

10. Algunas de estas y otras experiencias han sido sistematizadas por Capriati et al. (2015), con el objetivo de ampliar y fortalecer el modelo de abordaje integral comunitario construido por Camarotti y Kornblit (2015). Este modelo de abordaje se caracteriza por tomar en cuenta el contexto social, cultural y económico en que se dan las prácticas de consumo, priorizar la prevención inespecífica y la promoción de la salud a nivel grupal, promover la integralidad, estimular la participación comunitaria, buscar la reducción de los riesgos que acompañan al consumo y la transformación de las condiciones que lo favorecen o facilitan, trabajar desde un enfoque transdisciplinario y multisectorial y con las redes que componen el entramado social, y actuar de manera descentralizada en los espacios sociales donde se desarrolla la vida cotidiana y en proximidad con las personas que atraviesan situaciones de consumo problemático. 
Adicciones Recuperar Inclusión (PRI), con fuerte énfasis en la participación e integración comunitaria, cuya ejecución quedó a cargo de la Secretaría. En los años siguientes, bajo los lineamientos del PRI y del "nuevo paradigma de la salud social" formulado por el entonces secretario de la Sedronar (Ferreyra, 2019), se crearon cuatro nuevos dispositivos: las Casas Educativas Terapéuticas (CET), los Centros Preventivos Locales de Adicciones (CePLA), los Puntos de Encuentro Comunitario (PEC), y el Programa de Apoyo a la Integración Socio-Laboral (PAIS).

Las CET fueron pensadas como dispositivos de integración comunitaria para la atención y tratamiento de personas que se encontraban en situación de consumo problemático. Estos dispositivos proponían un abordaje integral que involucraba a diferentes sectores y colectivos sociales y, tenía por objetivo, además de ofrecer atención y tratamiento, promover la inserción educativa, la formación e inserción laboral y la participación en actividades artísticas, culturales, deportivas y recreativas, en pos de la construcción de un proyecto de vida saludable (Sedronar, 2014a). Los CePLA, en cambio, - y de manera complementaria - eran dispositivos de prevención y contención abiertos a la comunidad, aunque especialmente destinados a jóvenes entre los 12 y los 24 años en situación de vulnerabilidad. La propuesta se materializaba en actividades de recreación, formación y concientización así como en el acompañamiento personal. Su principal objetivo era constituirse en "lugares de pertenencia" para, desde allí, generar herramientas para la construcción y el fortalecimiento de un proyecto de vida a través de un proceso de empoderamiento personal y comunitario (Sedronar, 2014b).

Los PEC, a diferencia de las CET y los CePLA, operaban bajo un modelo de abordaje comunitario y tenían como objetivo fortalecer actores y organizaciones locales para el desarrollo de tareas de prevención, asistencia y acompañamiento en sus comunidades. Para ello, se establecieron equipos operativos conformados por referentes locales y referenciados en espacios comunitarios accesibles en diferentes puntos del país que eran asistidos por organizaciones locales, recibían el apoyo técnico de la Secretaría, y se encontraban articulados en una Red Federal (Sedronar, 2015).

En lo que respecta al PAIS, su objetivo era promover la integración de jóvenes, de 16 a 24 años, que hubieran sido atendidos por consumo problemático y se encontraran desempleados, mediante el desarrollo de una estrategia terapéutica basada en el trabajo, la educación y la recreación que les permitiera construir un proyecto de vida saludable. Para ello, se proponía el desarrollo de actividades de trabajo terapéutico (en artes, deporte u oficios) complementadas por otras educativas y recreativas y la creación de un sistema de "ingreso estímulo" para sostener la participación de los/as jóvenes que formaran parte del Programa (Resolución no 204/15). 


\subsubsection{Algunos cambios}

A fines de 2015, con el cambio de gobierno, el país se realineó en el plano internacional con las posturas prohibicionistas y su retórica belicista de combate al narcotráfico. Esto se tradujo, en el ámbito local, en una serie de medidas de carácter punitivo y sumamente regresivas destinadas a "erradicar de narcotráfico" que se conjugaron, en línea con un remozado prohibicionismo, con medidas respetuosas de los derechos humanos en materia de ayuda socio-sanitaria a los/as usuarios/as (Argentina, 2016).

En este marco, las CET, los CePLA y el PAIS se reconfiguraron en el denominado Dispositivo Integral de Abordaje Territorial (Resolución no 150-E/17); y en diez PEC se llevó a cabo una experiencia piloto con la metodología de Tratamiento Comunitario. Sin embargo, pese a la existencia de continuidades en lo que hace a infraestructura, recursos humanos, y experiencia acumulada, se perciben notables diferencias entre las propuestas institucionales. De hecho, la nueva gestión de la Secretaría caracterizó la "herencia" como problemática y realizó una intensa labor de capacitación con el objetivo de adecuar el trabajo en los dispositivos al modelo de abordaje propuesto por la DNAE con eje en la promoción, la restitución y el ejercicio de derechos y la inclusión social como procesos potencialmente terapéuticos (Astolfi Romero et al., 2019; Sedronar, 2017b).

\section{LOS DISPOSITIVOS DE ABORDAJE TERRITORIAL DE LA SEDRONAR}

\subsection{Las iniciativas territoriales en contexto: acceso, marco legal y oferta asistencial}

El marco legal actualmente vigente en Argentina es sumamente contradictorio. Por un lado, la Ley no 23737 - esto es, la ley de drogas -, contempla la aplicación de "medidas de seguridad curativas" a "personas dependientes" como complemento de la encarcelación, sustituto de la pena o alternativa al proceso, pudiendo reimponerse la pena o reanudarse el proceso en caso de incumplimiento. Es decir, admite la posibilidad de someter por vía judicial a una persona a un tratamiento compulsivo de desintoxicación y rehabilitación por tiempo indeterminado. ${ }^{11}$ Por otro lado, desde la sanción de la Ley de Salud Mental (2010) y posterior sanción del Plan IACOP (2014), tanto el inicio como la permanencia de las personas en un tratamiento son voluntarios, por principio rige el consentimiento informado y las personas tienen derecho a tomar decisiones relacionadas a su atención y tratamiento. En esta línea, la internación involuntaria es concebida, en la Ley de Salud Mental y el Código Civil y Comercial de la Nación (2015), como un recurso terapéutico excepcional - esto es, en caso de que no sean posibles los abordajes ambulatorios.

11. Históricamente, esta demanda de atención por derivación judicial ha sido receptada por centros residenciales conveniados con la Sedronar, que operan bajo la modalidad de CT. 
Es más, sólo puede realizarse cuando a criterio del equipo de salud exista una situación de riesgo cierto e inminente para sí o para terceros, debe extenderse por el tiempo más breve posible y ser supervisada periódicamente.

Este mosaico legal se entrelaza, a su vez, de manera compleja con la oferta asistencial. En Argentina, tienen injerencia en esta materia diferentes poderes y sectores del estado, a saber: el sistema de salud, la Sedronar, el Poder Judicial y en algunos casos desarrollo social. En lo que respecta al sistema de salud está conformado por tres subsectores interrelacionados: el privado, compuesto por prestadores individuales y empresas de medicina prepaga, al que accede la población de altos y medianos ingresos; las obras sociales, que cubren la atención de los trabajadores a través del seguro de salud que proveen los sindicatos de cada rama; y el público, gratuito y disponible para todas las personas - pero especialmente destinado a la atención de quienes no tienen acceso a los otros subsectores - que se encuentra organizado en distintos ámbitos: nacional, provincial y municipal (Corda, Galante y Rossi, 2014; Touzé, 2006). ${ }^{12}$

En cuanto a la oferta del sector privado, prevalece la contratación de servicios de terceros que brindan principalmente tratamientos ambulatorios bajo la modalidad de consultorio externo, centros de día y noche. Las internaciones breves para desintoxicación se realizan en centros y clínicas psiquiátricas o polivalentes; y, en el caso de requerirse un tratamiento residencial, la opción más frecuente son las comunidades terapéuticas. En cuanto al sector público, a los servicios que brinda el sistema de salud en hospitales generales, hospitales monovalentes, centros de salud mental, centros de atención primaria de la salud y centros de día, se suman la oferta asistencial de la Sedronar, en algunos casos dispositivos dependientes de desarrollo social y también dispositivos especializados dependientes de los estados provinciales y municipales. Este sector, al igual que el privado, se caracteriza por la fuerte predominancia de los tratamientos ambulatorios que se ofrecen mayormente bajo la modalidad de consultorio externo y hospital de día tanto en establecimientos específicos para el tratamiento de los consumos problemáticos (hospitales especializados en salud mental y/o consumos problemáticos, centros de salud mental, centros de día, dispositivos en unidades penitenciarias, municipales y provinciales, etc.) como en establecimientos polivalentes (hospitales generales, centros de atención primaria de la salud, centros de integración comunitaria, etc.). En lo que respecta a los servicios de internación, existen programas de desintoxicación en algunos pocos hospitales generales y en hospitales monovalentes donde se atienden urgencias y realizan internaciones breves para trabajar momentos de crisis; mientras

12. De acuerdo a los datos del último Censo Nacional de Centros de Tratamiento realizado por el Observatorio Argentino de Drogas (2018), el $71 \%$ de los centros censados pertenece al sector público, el $13 \%$ al privado y el $4 \%$ es de gestión mixta. Independientemente del sector al que pertenecen, el 71,4\% de ellos se concentra en las provincias de Buenos Aires (51\%), Córdoba (9\%), Ciudad de Buenos Aires (7\%) y Santa Fe (5\%). 
que, la oferta de tratamientos residenciales a largo plazo se reduce a la brindada por los hospitales especializados en salud mental y/o consumos problemáticos (sobre todo para personas con comorbilidad psiquiátrica) y por ONG financiadas por el sistema de becas de la Sedronar (y en menor medida becas provinciales), que operan en su mayoría bajo el modelo de CT (OAD, 2018).

No obstante, este abanico de respuestas terapéuticas, como vimos, se ha ampliado en los últimos años, con el surgimiento de abordajes territoriales, integrales y comunitarios, que brindan tanto los dispositivos de abordaje territorial de la Sedronar (DIAT y DTC) como una diversidad de organizaciones sociales y eclesiales, muchas de ellas oficialmente reconocidas como Casas de Atención y Acompañamiento Comunitario (CAAC).

\subsection{El modelo de abordaje integral territorial de la Sedronar}

Los dispositivos de abordaje territorial de la Sedronar se encuentran bajo la órbita de la Dirección Nacional de Abordaje Estratégico (DNAE) dependiente de la Subsecretaría de Abordaje Integral (ver anexo C). A fines de 2019, culminando la gestión, la Dirección publicó un informe donde presentó el Modelo de Abordaje Integral Territorial como "guía y sustento de las acciones que implementan los dispositivos de la DNAE” (Tufró, 2019, p. 7). Allí, se define a las problemáticas de consumo desde una perspectiva relacional, esto es, "como un fenómeno plural, que tiene múltiples manifestaciones" dependiendo de las prácticas, representaciones, saberes, subjetividades, sustancias y contextos (Astolfi Romero et al., 2019, p. 13). No obstante, la DNAE, siguiendo los lineamientos del Plan IACOP, priorizó en sus intervenciones a los sectores que presentan mayores niveles de vulnerabilidad social y, en particular, a los/as niños, nińas y adolescentes (Astolfi Romero et al., 2019).

En este sentido, la Dirección se propuso, en concreto,

"atender la singularidad de cada territorio y desentrañar los modos locales de significados dados al consumo (...) [fomentando el desarrollo, antes que de] una respuesta unívoca y lineal (...) de múltiples respuestas que atiendan a la complejidad del escenario social en cuestión. Respuestas comunitarias que trabajen con y desde los territorios vulnerabilizados, que resulten accesibles para la población que reside en ellos, y que trabajen de manera integral en todas las dimensiones de la vida de los sujetos" (Astolfi Romero et al., 2019, p. 33).

A tal efecto, se crearon los DIAT y los DTC concebidos como "respuestas estratégicas y complementarias" y se delinearon una serie de principios rectores para guiar el abordaje, a saber: universalidad de los derechos, integralidad, reducción de vulnerabilidades, trabajo en red e intersectorialidad, accesibilidad y bajo umbral, participación social y comunitaria, perspectiva de género y enfoque intercultural (Astolfi Romero et al., 2019). 


\subsection{Los Dispositivos Integrales de Abordaje Territorial (DIAT)}

Los DIAT son centros preventivos asistenciales de carácter gratuito y régimen ambulatorio, cogestionados por ONG, municipios o gobiernos provinciales y dirigidos a personas sin cobertura médica en situación de vulnerabilidad frente al consumo de sustancias. El objetivo principal de estos dispositivos es el abordaje integral de los consumos problemáticos orientado a generar condiciones de posibilidad para el acceso, la restitución y el ejercicio de derechos entendiendo esto como un proceso potencialmente terapéutico. Para ello, se propicia la generación de espacios de umbral mínimo de exigencia, se promueve el desarrollo de estrategias comunitarias y se contribuye al fortalecimiento de las redes territoriales, en la medida en que se comprende que "las oportunidades de circulación por redes institucionales e intersubjetivas otorgan las herramientas para construir proyectos propios, individuales y colectivos, que reducen el padecimiento de los sujetos que atraviesan dicha problemática" (Sedronar, 2017a, p. 2).

Los DIAT están constituidos por un equipo técnico interdisciplinario, operadores/as y docentes talleristas y se ordenan en función de tres ejes: abordaje territorial, asistencia y promoción. El eje abordaje territorial parte del reconocimiento de los aportes que pueden hacer diversas instituciones y actores con inserción en la comunidad en el diseño de estrategias para dar respuestas a la problemática. Esta planificación de estrategias abierta a la comunidad, interactoral e intersectorial requiere de un conocimiento del territorio y de la construcción de redes tanto institucionales como intersubjetivas. En este sentido, las acciones llevadas a cabo por el dispositivo se entienden como resultado de la construcción dialéctica entre una diversidad de actores locales y el equipo DIAT (Sedronar, 2017a).

En lo que respecta al eje asistencial se propone un desplazamiento del modelo abstencionista a otro que pone el foco en el límite al padecimiento, entendido este como resultado de la histórica vulneración de derechos. En otras palabras, se trata de una propuesta asistencial de carácter interactoral e intersectorial dirigida a generar acciones pasibles de constituirse en intervenciones terapéuticas en tanto posibiliten la construcción de un proyecto de vida y la inclusión comunitaria. La propuesta se encuentra organizada en "momentos" no cronológicos - i.e. primera escucha, construcción de indicadores, lectura de riesgos, diseño de estrategias, lectura de efectos -, y es conducida por el equipo interdisciplinario responsable de generar espacios propicios para el proceso de primera escucha (construcción de indicadores, lectura de riesgos y diseño de estrategias) así como de diseñar, coordinar, evaluar y, en caso de ser necesario, re-direccionar las estrategias de intervención sobre situaciones problemáticas concretas (Sedronar, 2017b). 
Por último, el eje promoción y protección de derechos alberga todas aquellas iniciativas que apuntan al fortalecimiento de lazos sociales a partir de la puesta en cuestión de ciertos imaginarios comunitarios sobre los consumos y los/as usuarios/as. Se destacan en particular las propuestas formativas que son entendidas - sean culturales, deportivas, artísticas o recreativas - como un derecho inalienable y no como un medio para alejar a las personas de situaciones consideradas potencialmente riesgosas o dañinas. Es decir, se trata de acciones y actividades orientadas al reconocimiento de los/as usuarios/as como sujetos de derecho, buscando poner en juego otras miradas y discursos así como intervenir sobre supuestas "trayectorias obligadas" favoreciendo la reconstrucción del tejido social (Sedronar, 2017a).

Estas tres dimensiones no se conciben como separadas, sino que se busca desde los dispositivos abordar la integralidad de las personas desde una perspectiva de derechos conjugando, para ello, actividades comunitarias, recreativas, culturales, deportivas, de formación, trabajo y escucha interdisciplinaria.

\subsection{Los Dispositivo de Tratamiento Comunitario (DTC)}

Los DTC operan con la metodología de Tratamiento Comunitario, basada en el meta-modelo ECO2 (Machín, 2010; Milanese, 2016). ${ }^{13}$ Esto es, un "modelo para construir modelos" y una metodología que localmente dieron lugar a un dispositivo territorial de bajo umbral de acceso que tiene como norte el encuentro entre procesos comunitarios e institucionales con el objetivo de intervenir sobre diferentes situaciones de "sufrimiento social", ${ }^{14}$ y mejorar las condiciones de vida de las personas en situación de alta vulnerabilidad y sus comunidades (Sedronar, 2017b). A tal efecto, el dispositivo propone crear, visibilizar y fortalecer redes locales, en otras palabras, promover "la reorganización de los recursos comunitarios, con el fin de incrementar sus competencias en materia de prevención, contención y reducción de riesgos y daños en relación a los consumos de sustancias y otras situaciones críticas asociadas" (Tufró y Carroli, 2018, p. 3). En este sentido, la destinataria de la política pública es la comunidad - definida como el "conjunto de redes sociales que definen y animan un territorio geográficamente delimitado" (Sedronar, 2017b, p. 89) - y la unidad mínima de intervención, los sujetos (parceros/as $)^{15}$ con sus respectivas redes.

13. Para una historia de la creación, implementación, difusión y evolución del esquema terapéutico de la metodología de Tratamiento Comunitario y el modelo Epistemología de la Comunidad/Ética y Comunitaria (ECO2), véase Machín (2010), Milanese (2016), Fergusson y Góngora (2012), entre otros.

14. Este encuentro es definido en términos de corresponsabilidad e interdependencia entre procesos de arriba hacia abajo - i.e. las políticas - y procesos de abajo hacia arriba - la participación protagónica y los productos de las comunidades -, lo que implica, siguiendo a Tufró y Carroli (2018), una coordinación de los objetivos de la metodología de TC con los lineamientos políticos de la DNAE.

15. "Parcero un término que existe en diferentes culturas y contextos geográficos. Su significado inmediato es: socio, aliado, coequipero, partner y trata de representar con una sola palabra el sentido de la relación de ayuda: (a) la persona que necesita ayuda, ya de hecho, con su necesidad, ayuda a la persona que está en condición de dar ayuda (se trata de una relación de reciprocidad, aunque el contenido de las dos relaciones pueda ser diferente)" (Sedronar, 2017b, p. 87). 
Para ello, la metodología de TC distingue cinco tipos de redes del dispositivo: la red subjetiva comunitaria (RSC), la red operativa $(\mathrm{RO})$, la red de recursos comunitarios (RRC), la red de lideres de opiniones formales y no formales (RLO) y la minoría activa (MA). La RSC está constituida por todas las personas con las cuales los/as miembros del equipo del DTC tienen relaciones amistosas. La $R O$, por los/as miembros del equipo, sus relaciones internas y las relaciones que mantienen con los nodos de la $R S C$ que participan en la implementación de actividades del dispositivo. Por su parte, la $R R C$ está conformada por todas las personas, organizaciones e instituciones que pueden constituirse en recursos para el TC, y las relaciones entre ellas; mientras que, la $R L O$ está conformada por las personas con capacidad de influenciar la opinión y la conducta de los/as otros/as miembros de la comunidad y las relaciones entre ellas. Por último, la $M A$ está constituida por los/as actores/ actrices y agentes comunitarios/as que siguen desarrollando actividades e iniciativas después que el equipo se ha ido. La $M A$ es el producto estratégico del TC, lo que todo equipo operativo debe tener como horizonte de trabajo (Milanese, 2016).

Los equipos de TC están conformados por personas con distintos perfiles (profesionales, operadoras/es, talleristas, referentes locales) y acompañados por tutores/as técnicos/as de la Sedronar. Realizan actividades de trabajo en calle, creación, visibilización y articulación de redes locales, seguimiento de casos, y acciones de vinculación - léase, organización y participación en actividades comunitarias ${ }^{16}$ (Sedronar, 2017b; Tufró y Carroli, 2018). Este trabajo se organiza en cinco ejes complementarios: prevención-organización, asistencia básica y reducción de daños, educación-rehabilitación, cura médica y psicológica, y ocupación y trabajo. El primer eje tiene por objetivo crear y organizar y, una vez creado, mantener y fortalecer el dispositivo, generando para ello modalidades de trabajo compartidas, y estableciendo algunos conceptos y finalidades mínimas. El eje asistencia básica y reducción de daños tiene como finalidad mejorar las condiciones de vida de las personas, desplegando para ello, entre otras, acciones de reducción de riesgos y daños. El eje educación-rehabilitación supone articular procesos educativos formales y no formales con el objetivo de enriquecer los conocimientos y competencias de las personas favoreciendo al mismo tiempo la ejecución de iniciativas en los demás ejes del dispositivo. El eje cura médica y psicológica incluye las acciones que se despliegan desde el campo de la salud física y metal para hacer frente a una situación de consumo problemático. El último eje, ocupación y trabajo, busca promover la integración social por medio de la creación de capacidades laborales, fuentes y oportunidades de trabajo (Sedronar, 2017b).

16. Las acciones de vinculación son uno de los principales instrumentos de trabajo del TC y pueden ser de carácter organizativo, de asistencia inmediata, de educación no formal, culturales, o a ser desplegadas en el área laboral o sanitaria (Milanese, 2016). Las acciones de vinculación "tienen un objetivo táctico: hacer de inmediato, junto con la comunidad o con alguno de sus miembros, algo que sea concretamente o simbólicamente útil para la comunidad; y un objetivo estratégico: construir y fortalecer relaciones que conduzcan la construcción de redes." (Sedronar, 2017b, p. 98). 
El trabajo del dispositivo se apoya además en el Sistema Estratégico de Tratamiento (SET), una herramienta diseñada para realizar el diagnóstico de la comunidad y conocer en profundidad sus dinámicas. El SET está compuesto por ocho procesos de trabajo que se encuentran articulados y constituyen una parte central del trabajo cotidiano de los equipos, a saber: acciones de vinculación con la comunidad local y sus líderes de opinión, análisis de las buenas prácticas y de los proyectos comunitarios que han fracasado, reconstrucción de la historia de la comunidad, recolección de información sociológica, identificación y trabajo con los "temas generadores" (i.e. tópicos sobre los que habla la gente), desarrollo de estrategias de anclaje y objetivación de las representaciones sociales, comprensión de los mitos y ritos de la comunidad, y conocimiento de la lógica de los conflictos comunitarios (Milanese, 2016; Sedronar, 2017b).

El dispositivo cuenta, asimismo, con otras herramientas de registro, sistematización y evaluación del proceso que le permiten al equipo demostrar su trabajo y dar cuenta de los cambios en las condiciones de vida de las personas que atraviesan situaciones de consumo problemático y sus comunidades (Sedronar, 2017b; Tufró y Carroli, 2018).

\subsection{Sobre la demanda}

Actualmente, hay 62 DIAT en 19 de las 23 provincias del país y en la Ciudad de Buenos Aires y 32 DTC con presencia en 13 provincias del país. La mayoría de ellos se encuentra en la provincia de Buenos Aires, principalmente en el Amba que cuenta con 15 DIAT y 13 DTC. Entre 2016 y 2019, un total de 23.298 personas consultaron en los DIAT y 4.045 personas en los DTC. El principal motivo de acercamiento a los DIAT fue realizar actividades promocionales $(47 \%) \mathrm{y}$, luego, iniciar un tratamiento por consumo en el dispositivo (20\%). En el caso de las consultas en los DTC, el 33\% tuvo como objetivo obtener orientación económica, social y/o legal (Astolfi Romero et al., 2019).

Por otra parte, muchas de estas personas - i.e. el $48 \%$ en los DIAT y el $65 \%$ en los DTC - sufrían, al momento de la primera consulta al menos una vulneración en sus derechos. Específicamente, en los DTC el 47\% manifestó problemas de accesibilidad - esto es, vulneraciones en el acceso a la educación, la salud, la documentación, el trabajo, la vivienda y programas sociales -, mientas que, en los DIAT la problemática registrada con mayor recurrencia fue la violencia $(28 \%)$ que presentó un porcentaje similar en los DTC (22\%). Además, un 27\% de los/ as usuarios/as de los DIAT y un $26 \%$ en los DTC refirieron estar atravesando situaciones de consumo problemático. Entre ellos/as, el 56\% en los DIAT y el 66\% en los DTC mencionó tener problemas con el consumo de alcohol. Además, en los DIAT el 50\% de ellos/as usaba marihuana, el 45\% cocaína y el 20\% manifestó consumo problemático de pasta base o paco. En el caso de los DTC, el 35\% de 
las personas con consumo problemático de sustancias usaba marihuana, el 14\% cocaína, un $14 \%$ refirió consumo problemático de alcohol y pastillas, y un $13 \%$ de pasta base o paco. La mayoría de estas personas eran hombres de más de 25 años, aunque también es significativo el porcentaje de niños, niñas y adolescentes (NNyA) que manifestaron experimentar esta problemática tanto en los DIAT (17\%) como en los DTC (18\%). Estas cifras, no obstante, puede explicarse, en parte, por la preponderancia de la población joven entre los/as usuarios/as de los dispositivos: el 65\% de los/as usuarios/as de los DIAT y 57\% de los DTC eran menores de 25 años, y el 38\% de los/as usuarios/as de los DIAT y el 36\% en los DTC, NNyA (Astolfi Romero et al., 2019). ${ }^{17}$

Por último, respecto al género, el $46 \%$ de las personas que consultaron en los DIAT fueron mujeres y el $53 \%$ varones, y en los DTC el 52\% mujeres, el $47 \%$, varones y un $0,3 \%$ refirió otra identidad de género.

\section{METODOLOGÍA}

La investigación que aquí se presenta es resultado del trabajo de campo de carácter etnográfico desarrollado, entre septiembre y noviembre de 2019, en dos dispositivos de abordaje territorial de la Sedronar: el DIAT JA y el DTC BC, emplazados en municipios ${ }^{18}$ aledaños en la zona norte del Amba. El trabajo de campo se organizó en tres etapas (exploratoria, trabajo de campo en territorio y sistematización y análisis de datos) y combinó diferentes técnicas: observación participante, realización de entrevistas abiertas y en profundidad y relevamiento de material documental y fuentes secundarias.

Durante la etapa exploratoria predominaron las tareas de relevamiento documental y las conversaciones formales y entrevistas con funcionarios y empleados de la Sedronar. Se consultaron resoluciones, manuales, documentos, boletines estadísticos e informes de la Sedronar, se recabó y sistematizó información proveniente de diferentes fuentes sobre los municipios y barrios en donde se encuentran

17. Es importante aquí tener presente que, de acuerdo con un reciente estudio del OAD (2017), únicamente el 8,3\% de la población entre 12 y 65 años hizo uso de alguna sustancia psicoactiva ilícita en el último año, mientras que el $68 \%$ refirió haber consumido alcohol y el 31,3\% tabaco. Entre las sustancias psicoactivas ilegales, se destaca el consumo de marihuana $(7,8 \%)$, seguido del consumo de cocaína $(1,5 \%)$, tranquilizantes y estimulantes sin prescripción médica $(0,8 \%)$, alucinógenos $(0,6 \%)$, éxtasis $(0,3 \%)$, pasta base $(0,1 \%)$ e inhalables $(0,1 \%)$. En lo que respecta al género el estudio indica que el consumo de tabaco, alcohol, marihuana y demás drogas ilícitas es significativamente mayor entre los varones. En cuanto a los grupos de edad, las tasas más altas de consumo de tabaco se encuentran entre las personas de 18 y 49 años con porcentajes cercanos al 35\%. En el caso del alcohol, se observa que el mayor consumo se registra entre las personas de 18 a 24 años $(78,9 \%)$ y de 25 a 34 años $(73,8 \%)$, pero se registran tasas elevadas (i.e. que superan el $50 \%$ ) en todos los grupos etarios. El consumo de marihuana ocurre principalmente entre las edades de 18 a $24(15,9 \%)$ y 25 a 34 años (13,3\%) y el mayor consumo de cocaína se observa entre las personas de 18 a 24 años (3\%), siendo las tasas son inferiores al 2\% entre los adultos de 25 a 49 años y al 0,5\% entre los 12 y 17 años y entre los 50 y 65 años. Por último, el consumo de pasta base/paco no supera el 0,4\% entre las personas de 18 a 14 años, el grupo etario que utiliza con más frecuencia esta sustancia.

18. La provincia de Buenos Aires se divide territorial y administrativamente en municipios también denominados partidos. Los partidos se encuentran divididos en localidades, una de las cuales es sede del gobierno municipal y suele llevar el mismo nombre que el partido. 
emplazados estos dispositivos, ${ }^{19}$ y se realizó una búsqueda bibliográfica de ponencias, artículos e informes producidos sobre los DIAT y los DTC. Se mantuvo, asimismo, una conversación formal con la directora nacional de Abordaje Estratégico y la coordinadora de Estrategias de Abordaje de la Sedronar, con quienes se consensuó los dispositivos en que se llevaría a cabo la pesquisa, ${ }^{20}$ y se realizaron entrevistas abiertas y en profundidad a la tutora técnica del DIAT JA y el tutor técnico del DTC BC. Además, se participó de una jornada de capacitación para los equipos de Tratamiento Comunitario de todo el país que tuvo lugar los días 17 y 18 de septiembre en la sede central de la Sedronar.

La segunda etapa consistió en la realización de trabajo de campo en el DIAT JA y en el DTC BC. El trabajo de campo en el DIAT JA se llevó a cabo entre fines de septiembre y mediados de octubre. El DIAT JA, a diferencia de la mayor parte de los DIAT, no posee edificio propio por lo que esto implicó la observación participante de las actividades del equipo de trabajo en los espacios - sedes y bases seguras - que posee el dispositivo en diferentes barrios del municipio. Concretamente, se participó durante dos semanas de los espacios de escucha y acompañamiento que se desarrollan en el Centro de Referencia (CDR) y en los consultorios del Centro de Prevención de las Adicciones (CPA), ${ }^{21}$ en el centro del municipio, así como en las tres bases seguras del dispositivo emplazadas dos de ellas en localidades del municipio, y la tercera en Villa Ombú en un partido vecino. Además se participó de las clases del nivel I y II del curso de capacitación en prevención de los consumos problemáticos y promoción de la salud que dictaban miembros del equipo DIAT para titulares del Programa Hacemos Futuro del Ministerio de Salud y Desarrollo Social de la Nación. ${ }^{22}$ La participación en estos espacios estuvo acompańada del registro de la metodología de trabajo, las prácticas, las actividades y los modos de intervención del equipo frente a casos y demandas puntuales así como de la realización de entrevistas y conversaciones formales e informales, algunas individuales otras colectivas, con los/as integrantes del equipo y algunos/as usuarios/as del dispositivo.

19. Nos referimos a estadísticas sociodemográficas, publicaciones sobre la historia de los municipios e informes sobre las características y problemáticas de los barrios en donde trabajan estos dispositivos elaborados, entre otros, por el INDEC, la Sedronar, la Subsecretaría Social de Tierras, Urbanismo y Vivienda del Ministerio de Infraestructura y Servicios Públicos y la Subsecretaría de Política y Coordinación Económica del Ministerio de Economía del Gobierno la Provincia de Buenos Aires. 20. Los plazos, las distancias, el conocimiento previo de los municipios y la existencia de un vínculo previo con el tutor técnico del DTC BC, quien a su vez mantiene una buena relación con la tutora técnica del DIAT JA jugaron un papel central en el proceso de selección de los dispositivos. De hecho, la existencia de esta trama de relaciones no sólo facilitó el ingreso al campo; sino que, se mostró crucial para la continuidad de la investigación cuando se experimentaron algunas dificultades en la comunicación con la DNAE. En este sentido, si bien el diálogo con dicha Dirección continuó desarrollándose en términos cordiales, una vez acordada la realización del trabajo de campo en los dispositivos, no resultó posible realizar las entrevistas concertadas con la Dirección, así como tampoco la visita al DIAT Rivadavia previamente pactada. 21. Son centros especializados que dependen de la Subsecretaría de Determinantes Sociales de la Salud y Enfermedad Física, Mental y Adicciones (SADA) del Ministerio de Salud de la provincia de Buenos Aires.

22. Se trata de un programa nacional de ingreso social que resulta de la fusión de programas anteriores. Los beneficiarios como contraprestación deben terminar sus estudios o capacitarse en oficios. La capacitación en prevención de los consumos problemáticos y promoción de la salud resultó de una articulación entre el Ministerio de Salud y Desarrollo Social y la Sedronar 
En lo que respecta al trabajo de campo en el DTC BC, este se llevó a cabo entre mediados de octubre y principios de noviembre. El DTC BC desarrolla sus actividades de miércoles a viernes y tiene como base segura la Biblioteca Popular del barrio - en adelante, la Biblioteca. De modo que, el trabajo de campo consistió en acudir a la base segura y acompañar las diferentes actividades que efectuó el equipo en el transcurso de esas dos semanas. Específicamente, se realizaron recorridas por el barrio, se presenciaron las reuniones semanales de equipo, se participó del Espacio de reflexión para adolescentes (ERA), y se asistió al taller de cerámica para jóvenes "La Alfarería", que acompañan integrantes del equipo del DTC para propiciar espacios de escucha y diálogo. En este marco, se conversó con las cuatro integrantes del equipo Sedronar, con algunos/as jóvenes que asisten a estos espacios y con vecinas y otras personas que acuden y/o trabajan en la Biblioteca, especialmente, con los/as responsables de la programación y docentes del centro juvenil, dentro del cual se incluyen las actividades del DTC. Pero además, gran parte de la labor semanal estuvo signada por la organización del festival temático de fin de año de la Biblioteca donde los diferentes espacios y talleres muestran su trabajo. Este año la temática escogida fue "derechos" y desde el ERA se propuso una batalla de freestyle. Esto implicó participar y colaborar en el diseño del proyecto y acompañar una volanteada por el barrio. Al igual que en el transcurso del trabajo de campo en el DIAT JA, la participación en estos espacios estuvo acompañada del registro de la metodología de trabajo, las prácticas, las actividades y los modos de intervención del equipo frente a casos y demandas puntuales.

Por último, la tercera etapa de trabajo fue de sistematización y análisis tanto de los datos recabados y producidos durante la etapa exploratoria - i.e. relevamiento de material documental y fuentes secundarias, conversaciones, entrevistas y observación participante en las jornadas de capacitación de TC - como de aquellos recabados y producidos durante el trabajo de campo en los dispositivos: notas de campo, conversaciones, entrevistas y planillas de registro y sistematización e informes producidos por los equipos de trabajo.

\section{LAS MODALIDADES DE ATENCIÓN Y CUIDADO A PERSONAS EN SITUACIÓN DE CONSUMO PROBLEMÁTICO DE SUSTANCIAS EN EL DIAT JA Y EL DTC BC}

\subsection{EI DIAT JA}

\subsubsection{Características socio-demográficas del partido}

El DIAT JA está ubicado en el partido homónimo, situado en el norte del Amba. Según el Censo Nacional de Población, Hogares y Viviendas 2010 (Indec, 2010), el partido cuenta con una población de 163.240 habitantes, lo que lo convierte 
en el menos poblado del Gran Buenos Aires (GBA). ${ }^{23}$ El 23,6\% de esta población son $\mathrm{NNyA}$ de 0 a 14 ańos, y el 16,8\% adolescentes y jóvenes entre 15 y 24 años, esto es, una población relativamente joven con cifras cercanas a las que se registran en promedio en el GBA.

La población del partido está expuesta a muy heterogéneas condiciones de vida. Esto se expresa en altos niveles de polarización en el acceso a los servicios, así como en la distribución del ingreso. De hecho, de acuerdo al Censo de 2010 (Indec, 2010), el 9,2\% de los hogares registra al menos un indicador de Necesidades Básicas Insatisfechas (NBI) ${ }^{24}$ No obstante, la disparidad en cuanto al nivel socioeconómico no presenta una distribución espacial azarosa en el municipio. Como señala un reciente estudio sociodemográfico, el corredor norte de nivel socioeconómico alto, que se inicia en el norte de la CABA y continúa en el Amba, se adentra, pero se discontinúa en Juana Azurduy, donde emergen importantes zonas de nivel socioeconómico bajo (Chiara, 2019).

Los datos aportados por este estudio se condicen con el Registro Público Provincial de Villas y Asentamientos Precarios (RPPVAP), donde se contabilizan actualmente en Juana Azurduy un total de 23 villas y asentamientos precarios, ubicados en su mayor parte en la zona oeste y noroeste del municipio. En estos barrios, de acuerdo con el Censo 2010 (Indec, 2010), el porcentaje de personas entre 0 y 14 años asciende a 34,5\%, 3 de cada 10 hogares se encuentran hacinados y el $24,48 \%$ presenta NBI.

\subsubsection{Historia y características del dispositivo}

En el partido de Juana Azurduy el DIAT sustituyó al CePLA que antes funcionaba en el municipio y comenzó a operar bajo los lineamientos del modelo de abordaje integral territorial de la DNAE. Sin embargo, la creación del DIAT JA no implicó únicamente un cambio en los objetivos o en el modelo de abordaje adoptado; sino que, al menos en este caso, fue además resultado de un proceso más amplio de reestructuración - i.e. cierre y traslado de los equipos - de los seis dispositivos hasta entonces existentes en el segundo cordón de la zona norte del Amba. Es así que, entre los actuales integrantes del equipo del DIAT JA, que abrió formalmente sus puertas en julio de 2017, quienes tienen mayor antigüedad proceden de equipos de la zona, pero no del equipo del CePLA que funcionaba anteriormente en el municipio.

23. El GBA comprende a la Ciudad de Buenos Aires y 24 partidos de la Provincia de Buenos Aires. 24. Son aquellos hogares que presentan al menos uno de los siguientes indicadores: una vivienda de tipo precaria, no tienen ningún tipo de retrete, viven más de tres personas por cuarto, hay algún/a niño o niña en edad escolar (6 a 12 años) que no asiste a la escuela; y, por último, hay cuatro o más personas por miembro ocupado y, además, el/la jefe/a no ha completado tercer grado de escolaridad primaria. 
El DIAT JA se caracteriza por no tener edificio propio. En este sentido, el primer espacio que consiguieron gestionar en el municipio fue en el Centro de Referencia (CDR), ${ }^{25}$ una edificación ubicada en la zona céntrica del partido, que alberga oficinas de diferentes dependencias y programas del estado nacional. Allí, el DIAT comparte con empleados del Ministerio de Salud y Desarrollo Social de la Nación un sector de atención al público y con la Secretaría Nacional de la Niñez, Adolescencia y Familia (SENAF) una minúscula oficina, que utilizan para mantener conversaciones privadas. Las características edilicias del CDR han llevado a que el DIAT ordene su trabajo únicamente en torno a dos ejes: abordaje territorial y asistencia. Por otra parte, la ubicación y horario de atención del CDR (9 a 14hs), de escasa accesibilidad para los sectores de más bajos recursos que residen en zonas alejadas del centro, ha empujado al equipo a construir bases seguras en diferentes barrios del partido. Así, a diferencia de la mayor parte de los DIAT, JA no posee un eje promocional, pero sí presencia en gran parte del municipio. ${ }^{26}$

Actualmente, el equipo posee tres bases seguras, además del espacio en el CDR a donde acuden los miércoles de 9 a 13hs. y las oficinas que presta el Centro de Prevención de las Adicciones (CPA) local los lunes por la tarde de 15 a 18hs para cubrir el contra turno en la zona céntrica del partido. Dos de ellas están ubicadas en o próximas a las principales villas y asentamientos precarios de Juana Azurduy en el norte y oeste del municipio y abren sus puertas los martes por la tarde. La tercera está ubicada en Villa Ombú en un partido limítrofe a donde se acude los miércoles y jueves durante el mediodía y primeras horas de la tarde. Todos son Espacios de Primera Escucha (EPE) y acompañamiento. ${ }^{27}$

Por otra parte, el equipo dicta el curso de capacitación en prevención de los consumos problemáticos y promoción de la salud para titulares del Programa $\mathrm{Ha}$ cemos Futuro. El objetivo del curso es que los grupos formados puedan diseñar e implementar propuestas de abordaje comunitario. Pero además, estos espacios se constituyen en instancias de escucha y encuentro ideales para trabajar las representaciones estereotipadas del consumo de sustancias así como para desplegar estrategias

25. Los CDR son espacios de gestión que funcionan como delegaciones del Ministerio de Salud y Desarrollo Social de la Nación, donde se brinda asesoramiento para facilitar el acceso a programas y servicios, se organizan talleres de capacitación e impulsan estrategias de desarrollo junto a organizaciones sociales.

26. El DIAT posee presencia en las zonas oeste, norte y centro del municipio. En el curso de estos años, el equipo intentó ingresar a dos barrios ubicados en el este y sur del municipio, pero sin resultados positivos. De hecho, en 2018 comenzó a funcionar en la zona sur un DTC, pero dadas las características del barrio - i.e. "muy cerrado sobre sí mismo", "muy individualista"- la experiencia culminó a mediados de 2019.

27. La "primera escucha" es el proceso que habilita la construcción de un diagnóstico situacional a partir del relevamiento de aspectos observables, históricos, sociales y contextuales. Estos aspectos en su conjunto permiten construir indicadores y determinar si la persona que se acerca al dispositivo se encuentra expuesto a riesgos asociados a la práctica de consumo de sustancias, alguna situación de vulneración de derechos, violencia de género, comunitaria, institucional y/o bien a problemáticas de salud mental sin tratamiento. De este modo, se identifican aquellas situaciones que requieren de una intervención inmediata y se diseñan estrategias de abordaje singulares en función a un criterio de prioridades que darán lugar a la posterior lectura de sus efectos (Sedronar, 2017b). 
de acompañamiento, asesoramiento y contención ante situaciones particulares de consumo problemático y violencia (Astolfi Romero et al., 2019). El equipo, asimismo, forma parte de la mesa de instituciones que trabajan con problemáticas de consumo del municipio, de la que participan representantes del CPA y el CAAC local, el centro convivencial terapéutico del municipio, una ONG que ofrece atención en adicciones, el Centro Sociocomunitario de Responsabilidad Penal Juvenil de la provincia de Buenos Aires (CESOC) y, en ocasiones, de algunas iglesias evangelistas; y asesora al Consejo Local de Niñez constituido por ONG del partido.

\subsubsection{El trabajo del DIAT Juana Azurduy}

El equipo del DIAT JA está conformado por siete personas, todas ellas profesionales, aunque de diferente formación y trayectoria: tres psicólogos/as, dos trabajadoras sociales, una técnica en minoridad y familia y un técnico en comunicación y psicología social y operador socioterapéutico. Algunos/as de ellos/as poseen experiencia de trabajo en barrios vulnerables, en CT, con niños y niñas institucionalizados y/o en prevención y atención comunitaria y otros/as no la tienen. El equipo, algo menor que el de otros DIAT, es coordinado por una referente territorial ${ }^{28}$ y acompańado desde "sede central" por un/a referente técnico/a de abordaje territorial, y otro/a de asistencia técnica. ${ }^{29}$ En cuanto a las condiciones laborales, los/as referentes se encuentran contratados por la Sedronar, mientras que los/as integrantes de los equipos perciben una beca estímulo por la que deben cubrir 30 horas semanales. ${ }^{30}$

En los EPE, el equipo trabaja en duplas. Si bien cada uno de estos espacios tiene sus particularidades, lo cierto es que en todos ellos se realiza un seguimiento de las personas que se acercan solicitando ayuda y asesoramiento. Este seguimiento, dependiendo del/los motivo/s que originó/aron la consulta, el diagnóstico situacional realizado a partir del proceso de primera escucha y la lectura de riesgos correspondiente, puede consistir en acompañar un proceso de internación, realizar un seguimiento psico-socio-asistencial en el dispositivo y/o articular con otras instituciones, organizaciones locales y oficinas del estado para ofrecer respuesta a diferentes demandas y necesidades del/la consultante. Estas estrategias se elaboran

28. Los/as referentes territoriales tienen como función la coordinación de los equipos, la gestión de los recursos y la articulación entre la Sedronar y la contraparte local. Son responsables de propiciar la participación del dispositivo en las redes locales, planificar las actividades en conjunto con los equipos de trabajo, y mantener un intercambio constante con los referentes del nivel central con el objetivo de revisar, ampliar y/o construir las estrategias de abordaje, así como también acompañar en la recolección de información que permita nutrir el modelo de abordaje (Astolfi Romero et al., 2019).

29. La tarea de estas duplas consiste en colaborar en la construcción y monitoreo de diagnósticos y en la planificación y gestión de las estrategias de inserción comunitaria de los equipos; acompañar las propuestas y prácticas llevadas a cabo por los equipos; articular con distintas áreas institucionales; y construir y realizar un seguimiento de las herramientas de intervención de los dispositivos (Astolfi Romero et al., 2019).

30. Como es de público conocimiento, en los últimos años se incrementó significativamente el costo de vida en Argentina, pero el monto de la beca no ha sido actualizado. Esto llevó a la renuncia de becarios/as y en algunos dispositivos se acordó, entre ellos JA, una reducción en la cantidad de horas que las/os trabajadores/as deben cubrir semanalmente a fin de facilitar la obtención de otras fuentes de ingreso. De hecho, hoy en día, todos/as los/as miembros del equipo tienen dos o tres trabajos. 
tomando en cuenta el posicionamiento del dispositivo en las redes locales y, luego, a partir de la lectura de sus efectos, pueden ser (o no) modificadas. Por otra parte, si bien el DIAT JA no posee el eje promoción y protección de derechos, organiza y participa de actividades formativas (talleres de poesía, teatro, juegos, etc.) en articulación con instituciones y organizaciones con asiento en el municipio.

En lo que respecta al acompañamiento psico-socio-asistencial se trata de la actividad que ocupa la mayor parte del tiempo y estructura el trabajo cotidiano de las duplas de todas las sedes y bases seguras del dispositivo. El acompańamiento tiene un carácter presencial y se organiza mediante un sistema de citas, aunque es habitual que acudan personas sin cita previa. La frecuencia de los encuentros es muy variable: puede ser de una, dos o tres veces por semana o incluso tener un carácter mensual. En sí, el acompañamiento consiste en un espacio de escucha que toma la forma de un encuentro cara a cara entre el/la usuario/a del dispositivo y la persona o dupla que lo asiste y puede durar unos pocos minutos o bien extenderse por el lapso de una hora, dependiendo de la forma de trabajo de la dupla (en donde incide su composición profesional), la cantidad de personas que se acercaron al dispositivo, y también las necesidades del/la consultante. Dicha instancia presencial se complementa además con la disponibilidad permanente vía celular de los/as integrantes del equipo que acompañan al/la usuario/a del dispositivo.

En el desarrollo de esta tarea y como parte de su trabajo en el eje abordaje territorial del dispositivo, el equipo construye asimismo vínculos con instituciones y organizaciones que le permiten afianzar el seguimiento de estas trayectorias singulares, pero también generar condiciones para la creación, visibilización y/o fortalecimiento de redes locales, la organización de actividades de prevención y promoción y la construcción de diagnósticos territoriales. En este sentido, el DIAT ha articulado desde su creación tanto con organismos e instituciones del estado como con organizaciones no gubernamentales y comunitarias (anexo C). La mayor parte de las articulaciones ha sido con organismos e instituciones del estado nacional y provincial y organizaciones no gubernamentales o comunitarias. Por el contrario, la articulación con el municipio ha sido dificultosa para el equipo que se ha encontrado la mayor parte de las veces con negativas tanto por parte de las autoridades como de los/as empleados/as. En cuanto a las áreas de trabajo de las instituciones y organismos, la mayoría proviene del campo de la educación y la niñez destacándose, entre ellas, las escuelas; seguidas de aquellas que provienen del campo de la salud mental y/o física: el hospital local, los centros de salud municipales, el CPA, otros dispositivos de la Sedronar (i.e. CAAC, CEDECOR, DTC) y organizaciones no gubernamentales y comunitarias que abordan la problemática del consumo de sustancias. 
Estas articulaciones pueden consistir en la organización de reuniones y actividades conjuntas o bien como parte de las estrategias de abordaje integral frente a situaciones puntuales. En este último caso, se destaca el trabajo conjunto con el CAAC, el Centro de Acceso a Justicia, ${ }^{31}$ el CPA, el Programa Hacemos Futuro y el CEDECOR, ante el cual se tramitan las becas de la Sedronar para tratamientos residenciales en CT. Ahora bien, el contacto de estas instituciones y organizaciones con el DIAT no tiene la misma frecuencia ni adquiere las mismas características en todas sus sedes y bases seguras.

\section{Del trabajo en las sedes y bases}

El DIAT Juana Azurduy tiene dos sedes céntricas, una en el CDR y otra en las oficinas que del CPA local, y tres bases seguras: dos de ellas ubicadas en el noroeste y oeste del municipio, que llamaremos Santa Clara y La Floresta, respectivamente, y, otra ubicada en Villa Ombú. Como adelantamos, todas las sedes y bases funcionan como EPE, no obstante, cada una posee una impronta propia que responde, entre otras cuestiones, a las características del barrio donde se encuentra emplazada, la institución que hace de sede/base segura, las relaciones que se establecen con referentes y organizaciones con asiento local, y la formación, trayectoria y forma de trabajo de la dupla asignada. Lamentablemente, por razones de espacio no podremos ahondar en muchas de las aristas que hacen a estas especificidades, lo que, de todas formas, no impide caracterizar, aunque más no sea brevemente, el trabajo en cada uno de estos espacios.

La sede del CDR tiene la particularidad de compartir edificio con múltiples oficinas del estado, pero además de ser el lugar de trabajo de la referente del dispositivo. De ahí que, el equipo del CDR no sólo se vincula de manera frecuente con desarrollo social, el Centro de Acceso a Justica (CAJ) y la ANSES ${ }^{32}$ con cuyos/as empelados/as mantienen un trato cotidiano; sino que, además, oficia de mediador cuando desde la otra sede o alguna de las bases seguras se requiere articular con dichos programas y organismos. La generación de estas instancias de articulación puede responder a la identificación de situaciones de violencia que se trabajan de manera conjunta con el CAJ, cuestiones ligadas a la Asignación Universal por Hijo (AUH) que se tramitan ante la ANSES, problemas de documentación que se derivan al Registro de las Personas y/o bien a demandas de ayuda material que se encaminan a "desarrollo social". Ante situaciones de vulneración de derechos de NNyA se recurre, en cambio, al Servicio Local de Protección y Promoción de los Derechos del Niño, Niña y Adolescente. ${ }^{33}$

31. Son oficinas que brindan un servicio de atención legal primaria.

32. La Administración Nacional de la Seguridad Social (ANSES) es un organismo descentralizado que tiene a su cargo la administración de las prestaciones y los servicios nacionales de la Seguridad Social.

33. Órgano administrativo encargado de ejecutar programas, planes, servicios y toda otra acción que procure la prevención, asistencia, protección y/o restablecimiento de los derechos de NNyA. Recibe denuncias e interviene de oficio. 
En lo que respecta a las situaciones de consumo problemático, el equipo articula a menudo con el $\mathrm{CPA}^{34}$ a no ser que la consulta sea realizada por un/a $\mathrm{NNyA}$. En estos casos, se contacta a la actual o última institución educativa, y, de evaluarse la necesidad de un tratamiento ambulatorio bajo la modalidad de hospital de día, se articula con el centro convivencial terapéutico del municipio que trabaja con adolescentes y jóvenes de 11 a 21 años con problemas de consumo de sustancias psicoactivas. Por otra parte, la presencia de la referente del DIAT y de una sede descentralizada del CEDECOR en el edificio, conspiran para que el equipo del CDR centralice las solicitudes de becas a la Sedronar para tratamientos residenciales en CT. ${ }^{35}$ Por último, esta sede recibe del CESOC y varios juzgados "pedidos de evaluación” en el marco de causas abiertas en la justicia local.

A diferencia de la sede del CDR, el EPE que funciona los lunes por la tarde en las oficinas del CPA no es muy concurrido. La dupla responsable, no obstante, entiende que es importante conservarlo dado que allí acuden quienes "no pueden ir a otro lado" ya sea porque las bases seguras no están ubicadas cerca de sus domicilios o lugares de trabajo; o, por el contrario, debido a que por su cercanía a dichos espacios las personas prefieren concurrir al "centro" para que la gente del barrio no sepa que acude al dispositivo. En síntesis, este EPE se caracteriza, antes que por recibir nuevos consultantes, por oficiar de punto de encuentro para personas con quienes ya se tiene contacto. Los días en que no hay cita agendada, la dupla sale a realizar "trabajo territorial". Este consiste, sobre todo, en acercarse a conversar con los/as directivos/as y gabinetes pedagógicos de las escuelas del distrito donde ofrecen talleres para docentes, niños, niñas y adolescentes. No obstante, también han trabajado el tema en cooperativas e incluso se firmó un convenio con una importante fábrica local, a raíz de un estudio que arrojó que el $60 \%$ de sus empleados se encontraba atravesando situaciones de consumo problemático. En el marco del convenio, diez trabajadores solicitaron asistencia y hoy en día son acompañados por el DIAT. Algunos de ellos acuden al EPE y dos, por decisión del equipo, fueron derivados a CT.

En lo que respecta a los otros dos EPE que funcionan en el municipio, Santa Clara y La Floresta, ambos tienen como base segura una capilla. En este sentido, ambas duplas han tejido un sólido vínculo con los/as respectivos/as referentes de las instituciones religiosas. Pero además, ambos equipos mantienen buenas relaciones con ONG y centros barriales de su zona. En el caso de La Floresta, fue por algunos meses particularmente significativo el trabajo en conjunto con un centro barrial a pocas cuadras de la base segura que ofrece apoyo escolar y talleres a nińos, niñas, adolescentes y jóvenes. De hecho, el centro, ubicado en una de las villas más

34. Si bien el CPA debería poder ofrecer becas provinciales, lo cierto es que éstas son escasas y, por ende, el equipo del CDR suele colaborar con la gestión de sus solicitudes de becas ante la Sedronar.

35. Al momento de realizar el trabajo de campo, el DIAT JA había derivado un total de 7 personas a CT. 
grandes del municipio, llegó a fungir como base segura. No obstante, pocos meses después se decidió retornar a la capilla debido a que, si bien el centro realiza "un buen trabajo con los jóvenes (...) no tiene representatividad en el barrio" a raíz de un histórico conflicto por tierras. Además, la única oportunidad en que el DIAT solicitó cupo en un taller para un joven del barrio con escasa contención familiar, si bien lo recibieron, luego de un tiempo decidieron - por "no dar con el perfil del lugar" - quitarle la vacante. Actualmente, aunque las relaciones se hayan tornado más distantes, la dupla realiza, aun así, visitas periódicas al centro.

En lo que respecta al EPE Santa Clara, la dupla trabaja codo a codo con Marta, la referente de la Capilla. Marta organiza grupos de madres y padres de usuarios/ as, adolescentes y preadolescentes, realiza actividades recreativas con los chicos/ as más pequeños/as, y ha organizado junto a la dupla del DIAT varias jornadas de juego y una obra de teatro. El equipo mantiene, asimismo, buenas relaciones con la referente de otra capilla cercana, quien coordina un grupo de mujeres jóvenes y les "envía chicas" que acuden al EPE motivadas por problemáticas de consumo, embarazo no deseado y situaciones de violencia. Pero lo cierto es que, el trabajo de este EPE ha estado, principalmente, signado por la presencia de un CAAC a pocas cuadras de la base. Allí, han funcionado históricamente grupos de ayuda coordinados por el párroco, un psicólogo y operadores religiosos que, hasta principios de 2019, les "derivaban" buena parte de los jóvenes que participaban del dispositivo. En ese momento, miradas diferentes sobre los consumos llevaron a un distanciamiento en las relaciones y varios jóvenes dejaron de asistir al EPE. No obstante, la reciente salida de los operadores religiosos del espacio parece traer nuevos aires. Se han conformado nuevos grupos y el vínculo parece recomponerse.

"Ombú" es la última base segura que incorporó el DIAT Juana Azurduy. Villa Ombú se encuentra en un partido lindero, pero a escasa cuadras del CDR. La presencia del dispositivo en este barrio se dio en el marco de un convenio firmado en 2019 con la Secretaría de Integración Socio-Urbana (SISU) del Ministerio de Salud y Desarrollo Social de la Nación y el Organismo Provincial de Integración Social y Urbana (OPISU), una entidad autárquica en la órbita del Ministerio de Jefatura de Gabinete de Ministros de la Provincia de Buenos Aires, encargada de diseñar la planificación para la progresiva "creación de barrios" en los asentamientos y villas en mayor estado de precariedad del conurbano. El OPISU está organizado en torno a tres ejes: integración urbana, social y socio-productiva. El DIAT colabora, específicamente, en el desarrollo del eje integración social desde el EPE y el dictado del curso para titulares del Programa HF.

La base segura está emplazada en uno de los tres containers del OPISU desplegados a un costado de la canchita ubicada al "fondo" del barrio. Allí, funciona el EPE en tanto que el curso para titulares del Programa HF se dicta en la capilla del barrio. 
Pese a estar en otro municipio, en materia de acompañamiento de situaciones de consumo problemático, Ombú articula con organizaciones e instituciones no muy distintas al resto de las sedes y bases seguras del DIAT, esto es, con el centro de atención primaria de la salud y el grupo de consumos problemáticos de la capilla local, el CPA de Juana Azurduy y el CEDECOR descentralizado. No obstante, cuando se requiere articular con otros programas y agencias del estado - i.e., la ANSES, el Registro Nacional de las Personas y el Centro de Asistencia a Víctimas y Acceso a Justica (CAVAJ), entre otras - las mismas se enmarcan en el despliegue territorial del OPISU. ${ }^{36}$

La presencia disuasiva de la Policía de la Provincia de Buenos Aires en las inmediaciones constituye uno de los principales desafíos de este EPE. En este sentido, además de haber adicionado un tercer día de EPE en una fundación que trabaja con niños y niñas a pocos metros de una de las entradas al barrio, sus integrantes entienden que es preciso no permanecer ocultos/as en la oficina sino por el contrario hacerse ver "desfilando" por la vereda asfaltada sobre la que se montan los containers del OPISU. De momento, la estrategia parece haber rendido sus frutos ya que, si bien se trata de la base segura más reciente del DIAT JA, cuenta con una proporción semejante a las demás sedes y bases seguras en materia de cantidad de consultas activas.

\section{De las herramientas de intervención}

Los trabajadores y la coordinación del DIAT deben completar, como parte de su trabajo cotidiano, una serie de planillas y documentos: la Hoja de Primer Contacto (HPC), la hoja de ruta, la herramienta de seguimiento, la planilla de articulación y la herramienta de evaluación de procesos. En su conjunto, estas constituyen un acervo de herramientas de suma utilidad para el diagnóstico, seguimiento y evaluación de la población atendida, así como de las acciones y prácticas del dispositivo. Aun así, su compleción insume un tiempo considerable al equipo.

La HPC forma parte del diagnóstico inicial y la completa el equipo a lo largo de varias entrevistas que le permiten conocer la situación de manera integral. Su principal objetivo es informar sobre los modos de acceso al dispositivo y las relaciones socio-afectivas del/la consultante, así como detectar vulnerabilidades en el acceso a derechos, la existencia de situaciones de violencia y/o de consumo problemático. De esta forma, permite, por un lado, obtener datos para la elaboración de diagnósticos territoriales; y, por el otro, orienta la escucha y fomenta la construcción de estrategias de abordaje integrales (Astolfi Romero et al., 2019).

36. En el marco del OPISU se despliegan, además de las mencionadas oficinas del estado, toda una serie de programas, entre otros, de reinserción escolar y terminalidad educativa, culturales, de "innovación social y emprendedurismo" así como servicios de consultorio jurídico. 
Parte de esta información luego será volcada en la hoja de ruta que es, en cierta forma, una "historia clínica tradicional" $y$, en este sentido, un informe que puede ser entregado a otros organismos y al/la usuario/a si este/a así lo requiere. En la hoja de ruta se registra el motivo de consulta, la situación de acceso a derechos, las características relevantes de la situación particular de la persona, las probables causas de padecimiento, la valoración de riesgos y las sugerencias clínicas que de ello se derivan. Con el correr del tiempo, se debe consignar asimismo el recorrido del/la usuario/a en el dispositivo, la "lectura de efectos" que puede conducir a definir o redefinir las estrategias, y las modificaciones que se producen en el motivo de consulta inicial.

En lo que respecta a la herramienta de seguimiento y la planilla de articulaciones, se centran en el trabajo del dispositivo. La primera resume la labor que realiza el equipo con los/as consultantes. Concretamente, su objetivo es facilitar el análisis de los espacios y la participación de los/as usuarios/as en el dispositivo. Para ello, se consigna el tipo de consulta (directa, indirecta o Hacemos Futuro), la fecha de alta y cierre, y su estado: activa, inactiva, cierre con proceso o cierre con articulación. ${ }^{37}$ También se registra la frecuencia con la que el/la consultante asiste al dispositivo, en qué área lo hace, cuál es la dupla que lo/a asiste y si se ha articulado con otras instituciones y, de ser así, con cuáles. La planilla de articulaciones, por su parte, se centra en los vínculos que el equipo establece con diferentes organismos e instituciones estatales y organizaciones no gubernamentales y comunitarias. Allí, se consignan las áreas en las que trabaja la institución/organización con la que se articuló, el objetivo y tipo de articulación, para facilitar la evaluación y, de ser necesario, ajustar la participación del dispositivo en las redes locales.

Por último, la herramienta de evaluación de procesos, construida al final de la gestión, tiene por objetivo medir el impacto de la política en función del acceso, la restitución y el ejercicio de derechos. Para ello, la herramienta se organiza en torno a ejes que se corresponden con la situación de acceso a derechos. En cada eje se despliegan los diagnósticos, las acciones, las articulaciones y sus efectos, lo que permite visualizar el armado de estrategias integrales y medir su impacto subjetivo, visibilizar las acciones comunitarias y revisar las prácticas del equipo (Astolfi Romero et al., 2019).

37. Las categorías activa e inactiva indican si la persona se encuentra (o no) en contacto actual con el DIAT; la categoría cierre con proceso indica que se ha dado un cierre a la consulta y el/la consultante ha podido resolver la situación que originó la consulta; mientras que, la categoría cierre con articulación se refiere a aquellas situaciones en que se ha articulado con otras instituciones u organizaciones y que aún no se ha resuelto la situación que llevó a la persona a buscar asistencia en el dispositivo. 


\section{Algunas cifras}

Desde que abrió sus puertas hasta junio de 2019, el DIAT recibió 89 consultas directas $(\mathrm{CD})$ y 32 indirectas $(\mathrm{CI})$; mientras que, 77 personas, en su gran mayoría mujeres (96\%), participaron del curso para titulares del Programa Hacemos Futuro (HF). El principal motivo de las consultas directas e indirectas fue buscar asesoramiento para iniciar un tratamiento por consumo problemático, aunque, en menor medida, también se registraron como motivo de consulta situaciones de violencia de género e intrafamiliar. El $44 \%$ de las consultas (directas e indirectas) fueron realizadas por mujeres y el $56 \%$ por hombres. Las CD fueron mayormente realizadas por hombres (74\%) y las CI por mujeres (91\%). Los hombres buscaron en su mayoría asesoramiento por problemas de consumo, en tanto que las mujeres se acercaron al dispositivo por situaciones de violencia o bien para consultar sobre el consumo de familiares, generalmente, hombres. Por otra parte, la población resultó ser bastante más añosa que en otros DIAT, lo que se explica por la ausencia del eje promocional y, por ende, del dictado de talleres. Además, la totalidad de usuarios/as del dispositivo son usuarios/as de sustancia psicoactivas.

Las consultas por consumo problemático fueron, en su mayoría, por consumo de alcohol y cocaína. En el caso de la marihuana, si bien se registra un uso frecuente, quienes trabajan en el dispositivo aseguran que su consumo no es problematizado. Por otra parte, afirman que en el municipio prácticamente no se observa consumo de paco, pero se ha detectado cerca de la base segura Santa Clara el uso de pegamentos que entienden se explica por tratarse de un "barrio de carpinteros". En cuanto a los pedidos de internación, afirman que son escasos y que en su mayoría provienen de los/as familiares del/la usuario/a, en tanto que los/as usuarios/as suelen solicitar iniciar tratamientos de carácter ambulatorio.

Actualmente, el DIAT JA posee 49 consultas activas (aproximadamente, diez por sede/ base), 24 consultas inactivas, 23 cierres con articulación y 106 cierres con proceso.

\subsubsection{De conquistas, límites y desafíos}

Analizar las conquistas, límites y desafíos que enfrenta el DIAT JA supone atender a las prácticas, acciones e intervenciones del equipo a la luz de la historia más amplia de las políticas de atención y cuidado a personas que hacen uso problemático de sustancias en Argentina. En este sentido, el modelo de abordaje que se propone desde la DNAE para estos dispositivos es resultado de la acumulación y yuxtaposición de una serie de experiencias de intervención que, como vimos, han implicado un quiebre con los modelos dominantes - i.e. modelo médico hegemónico, alternativo subordinado y de auto-atención (Pawlowicz et al., 2011) -; un cambio de paradigma en la materia que, por otra parte, ha ido incrementando su nivel de institucionalidad a partir el dictado de resoluciones y, sobre todo, la sanción 
de la Ley de Salud Mental, en 2010, y el Plan IACOP, en 2014. Pero también, las características del modelo de la DNAE deben comprenderse en el marco de profundas transformaciones en las formas de gobierno que, desde la década del 90, tuvieron lugar en Argentina, en particular, en el campo de las políticas sociales.

Estas transformaciones, que iniciaron en las sociedades europeas en la década del 70, fueron objeto de debate en los estudios sobre políticas públicas y han sido caracterizadas como una privatización o marketización de los servicios públicos y funciones del estado o bien como una transferencia de las técnicas de gobierno "a lo Foucault" a entidades no gubernamentales (Gupta y Ferguson, 2006; Rose, 2007), pero también hay quienes entienden se trata de una forma "más cooperativa" de gobernar caracterizada por la participación y articulación entre actores y organizaciones estatales y no gubernamentales en el diseño, implementación y evaluación de las políticas (Mayntz, 2001; Ziccardi, 2008). Entretanto, la producción académica local se ha concentrado en el análisis de las características particulares que estos cambios han ido adquiriendo con el curso de los años, identificando, no obstante, una tendencia a la diversificación, la territorialización y la institucionalización de la "participación ciudadana" (Rofman y Foglia, 2015).

En lo que respecta a la DNAE, esta ha incorporado de manera explícita esta nueva forma de gobernar (o gobernanza) a través de los principios de la cogestión, ${ }^{38}$ la adopción de un enfoque integral, el fortalecimiento de la participación social y comunitaria, el trabajo en red y la articulación entre diferentes sectores y ámbitos de gobierno desde un marco de corresponsabilidad (Astolfi Romero et al., 2019). De hecho, la participación y articulación intersectorial, como se propone desde la formulación de la política, no se reduce a espacios circunscriptos ni instrumentos de consulta; sino que supone el desarrollo de redes locales y estrategias conjuntas, donde la circulación se presenta como el instrumento clave para el acceso, la restitución y el ejercicio de derechos y para la integración social y comunitaria (Sedronar, 2017b).

En este sentido, el DIAT JA en sus tres años de vida supo, en conformidad con estos lineamientos, construir presencia en gran parte del municipio y ha articulado con una porción sustantiva de los organismos, instituciones y organizaciones no gubernamentales y comunitarias con presencia en el partido. De hecho, puede afirmarse que el equipo ha logrado insertarse, sobre todo, en las redes formales locales, generando en el seguimiento de casos puntuales condiciones para el acceso, la

38. Esta cogestión se define en términos de contribución tanto en materia de recursos, - i.e. la Sedronar brinda "las capacitaciones y recursos humanos, la cogestión local aporta los materiales para el quehacer cotidiano (...), el mantenimiento de la infraestructura y, en algunos casos, recursos humanos" -, como de "miradas" - i.e. "la Sedronar aporta la mirada de las políticas integrales sobre drogas (...) y los lineamientos de intervención generales, los municipios y organizaciones suman la mirada local, anclada en las problemáticas de ese territorio o comunidad en particular" (Astolfi Romero et al., 2019, p. 97). 
restitución y el ejercicio de derechos y procesos de integración social y comunitaria. Es más, para algunos/as actores/actrices y burocracias estatales el dispositivo se ha constituido, en el proceso, en el referente local en la materia, lo que se aprecia en las derivaciones y consultas que recibe de una diversidad de agencias e instituciones estatales. Entre ellas, se destacan las escuelas del distrito y el CESOC, lo que resulta particularmente significativo dada la gran cantidad de NNyA que habita en el municipio y, por supuesto, los objetivos de la política. En otras palabras, el trabajo en red y la articulación intersectorial, al igual que el bajo umbral de acceso, la perspectiva de derechos, el enfoque integral, intercultural y de género, no cabe duda han otorgado un "nuevo aire" a la oferta asistencial del municipio.

Sin embargo, la implementación del modelo en JA presenta algunas dificultades. Una de las primeras cuestiones a destacar, en este sentido, es que el dispositivo continúa favoreciendo, en líneas generales, el acceso de personas adultas, en su mayor parte hombres, en situación de vulnerabilidad y consumo problemático de sustancias. Si bien esto no dista demasiado de lo que ocurre en los demás DIAT, donde el 35\% de las personas que asisten al dispositivo tienen más de 25 ańos, en JA los porcentajes son bastante más elevados, lo que es explicado por la inexistencia del eje promocional en el dispositivo. De hecho, en JA la falta de edificio y, por ende, de oferta formativa propia - aunadas a la existencia de un equipo reducido que, debido a las malas condiciones laborales, trabaja pocas horas semanales destinadas en su mayor parte a la tarea de acompañamiento psico-socio-asistencial en las sedes y bases del dispositivo - se han constituido en verdaderos obstáculos para cumplir con algunos objetivos de la política como ofrecer una asistencia integral, fortalecer las redes informales, visibilizar respuestas comunitarias y fomentar el acceso de la población más joven del municipio.

Aun así, el equipo ha logrado desarrollar una serie de actividades que se mostraron efectivas en acrecentar la accesibilidad de NNyA y mujeres, creando al mismo tiempo vínculos con referentes comunitarios/as y ampliando la oferta formativa. En lo que respecta a los/as $\mathrm{NNyA}$ esto ha sido resultado, en gran medida, del trabajo realizado con las escuelas (sede CPA) y la participación en actividades comunitarias, así como de la organización de jornadas de juego y pintadas de murales (Santa Clara), talleres de poesía (La Floresta) y teatro (Santa Clara); mientras que, en el caso de las mujeres, ha sido el dictado del curso para titulares del Hacemos Futuro el que ha colaborado a incrementar su accesibilidad al dispositivo. Cierto es que la mayor parte de las asistentes al curso no ha experimentado en persona situaciones de consumo problemático. No obstante, el equipo ha sabido generar espacios de encuentro y escucha propicios para trabajar las representaciones sociales estereotipadas sobre los consumos y los/as usuarios/as así como para conversar sobre situaciones cotidianas que viven las asistentes en carne propia o con sus hijos/as y demás familiares. De todos modos, pese a los esfuerzos del equipo, indudablemente, 
sin edificio propio, condiciones de contratación dignas, y fondos destinados al desarrollo de las propuestas de abordaje comunitario elaboradas por los/as titulares del HF como proyecto de fin de cursada, difícilmente, estas acciones y estrategias puedan profundizarse y los objetivos del curso efectivamente concretarse.

Por otro lado, amén de estas conquistas - como hemos visto, no libres de obstáculos - hemos registrado, en una serie de hechos, situaciones y casos que involucran a distintos/as consultantes, problemáticas, sedes/bases, instituciones y organizaciones con las que se ha articulado, ciertas dificultades en el trabajo llevado a cabo por el equipo del DIAT JA que arrojan luz sobre lo que entendemos constituyen importantes limitaciones y desafíos de este modelo de abordaje. A saber, las tensiones que existen entre dependencias de diferentes jurisdicciones del estado, y entre éstas y distintas organizaciones sociales, sobre todo, cuando no tienen el mismo signo político/partidario; las que genera la existencia de diversas concepciones sobre el consumo, los/las usuarios/as y lo que implica un "buen" abordaje de los consumos problemáticos; como así también las que se producen como resultado de lógicas de funcionamiento, prácticas y rutinas que, enraizadas en largas tradiciones institucionales, producen y reproducen violaciones a los derechos humanos. A continuación, presentamos algunos hechos, situaciones y casos.

\section{El hospital provincial}

Emiliana acude a la sede del CDR desde diciembre de 2017. Agustina, quien realiza el seguimiento, cuenta que asiste de manera intermitente. Por ello, en 2018, se intentó que iniciara un tratamiento ambulatorio en el CPA local para ver si daba mejores resultados, pero abandonó el espacio. Emiliana tiene 39 años, dos hijos que no ve y consume sustancias desde los 13 . Además, tiene una mala relación con su madre y con su hermana y ha sido víctima de numerosas situaciones de violencia. Su pareja la golpea y "no la deja construir lazos", no la deja visitar a sus amistades así como tampoco al operador comunitario y a la psicóloga de una ONG local que ofrece atención en "adicciones" a la que comenzó a asistir este año. No obstante, su única demanda es "dejar de consumir".

Hace un tiempo, su pareja la "molió a golpes" en medio de la calle, la dejó inconsciente y los vecinos tuvieron que llamar a la ambulancia que la llevó al hospital local donde permaneció varios días internada. Emiliana dijo que se había caído y los médicos que la atendieron no hicieron la denuncia. Esta "omisión", lejos de tratarse de un hecho aislado, fue presentada como una práctica recurrente de los médicos que atienden en el hospital de la zona. De hecho, la dupla a cargo de la base segura Santa Clara narró varios episodios similares con los médicos de diferentes servicios del nosocomio. 
Uno de estos casos tuvo como protagonistas a Marta la referente de la Capilla y a uno de los hijos de Cintia. Cintia es una vecina que acude a la base segura Santa Clara. La mujer vive con sus siete hijos e hijas a los que deja con frecuencia solos en la casa y "se va a consumir a lo del novio". De modo que, casi todos los mediodías los/as hijos/as de Cintia acuden con hambre a Marta, que les da el almuerzo. Cintia hizo un intento por cambiar la situación y estuvo internada con todos/as sus hijos/ as en una CT, pero a los dos días abandonó el lugar y hoy día la situación no ha mejorado. De hecho, la semana anterior a que comenzara el trabajo de campo, Marta encontró que uno de los nińos tenía una pediculosis severa y los piojos le habían comenzado a lastimar el cráneo, por lo que lo llevó al hospital de la zona. Allí, le curaron las heridas, le dieron unos medicamentos y lo mandaron a su casa. Pero, pese a la insistencia de Marta, los médicos se negaron a dar intervención al Servicio Local de Niñez. Al enterarse de lo ocurrido, el equipo del DIAT también quiso realizar la denuncia, pero, como Cintia vive al lado de la Capilla y esta es la base segura del dispositivo, tuvieron que consultarlo con el párroco quien se opuso rotundamente por temor a las amenazas, pero también "porque su mirada religiosa tiende a favorecer la continuidad de la familia”.

\section{EI CAAC local}

El CAAC local trabaja desde una perspectiva abstencionista. Para el equipo DIAT tener miradas diferentes no es necesariamente negativo; al contrario, por momentos puede ser positivo, "por ejemplo, se acerca un chico con problemas de consumo, va los grupos de la Capilla y allá le hablan de la importancia de los vínculos. Nosotras, en cambio, lo vemos doblado de dolor y le insistimos, por ahí, que se vaya a hacer ver los pulmones". En pocas palabras, pueden complementarse. De todas formas, la posibilidad de articular con el CAAC tiene límites claros. De hecho, la "lógica abstencionista" en la mayor parte de los casos aparece en el discurso de los/as trabajadores/as como una perspectiva con la que hay que lidiar. Ello queda en evidencia, claramente, en el caso de Fernando.

Fernando es un joven que

"tenía serios problemas de consumo, pero que andaba muy bien. Me acuerdo que comentó en una reunión [del CAAC] que había tomado alcohol en la cena con la mamá y ya lo amonestaron... Y el pibe estaba re bien y se había tomado una copa de vino con la mamá, nada más (...) Nosotras estábamos al tanto, y no lo vimos como un problema. Entonces, entienden que nosotras incitamos al consumo o no lo vemos como algo negativo. (...) Es muy extremo, cuentan que conocieron a alguien y lo primero que les preguntan es si consume. Si toma, tenés que dejarlo. Si tus amigos toman hay que dejarlos. ¿Sabés qué frase usan? ¡La cocaína se disfraza de mujer!”. 
No obstante, las consecuencias no se limitan a desacuerdos entre los/as trabajadores/as de los dispositivos. La existencia de valores y concepciones diferentes sobre el consumo, los/las usuarios/as y lo que implica un "buen" abordaje de los consumos problemáticos no constituye, para el equipo DIAT, necesariamente un problema. Es más, se entiende que para algunos/as jóvenes este tipo de acompañamiento puede resultar efectivo. De hecho, el CPA local y el centro convivencial terapéutico del municipio con los que a menudo articulan, también tienen una "lógica abstencionista". El problema para los/as trabajadores del DIAT surge entonces cuando, como ocurrió con Fernando, por prácticas propias de esta "lógica" todas las instituciones pierden contacto con el/la consultante.

\section{Salud y consumo problemático en el municipio}

El DIAT JA ha intentado, en varias oportunidades, articular con el Servicio Local de Niñez, los centros de salud ${ }^{39}$ y el centro convivencial terapéutico del municipio. Con este último, en algunos casos lo ha logrado, pero no se trata de un proceso que se encuentre "aceitado", al contrario, hay que trabajarlo "caso a caso". En cambio, con otros actores y organismos municipales los resultados de la articulación han sido directamente frustrantes para el equipo y contraproducentes para el/la consultante. Esto ocurrió en el caso de Andrés, donde la articulación con el Servicio Local trajo aparejada un distanciamiento en los frágiles vínculos que el DIAT había logrado establecer con el chico y su familia.

Andrés es un adolescente que vive en la zona oeste del municipio. No tiene partida de nacimiento ni documento de identidad, sus vínculos familiares no son estrechos y ya hace algunos años se encuentra en situación de consumo problemático de sustancias. Quien se acercó por primera vez a la base segura La Floresta fue su madre, aunque tiempo después lo hizo el propio Andrés solicitando ser internado. El equipo, tras evaluar el pedido, decidió acompañar el proceso de internación, quedando la referente del dispositivo a cargo de gestionar un turno en la sede central de la Sedronar con el CEDECOR infantil, para su evaluación y posterior derivación. No obstante, si bien el joven acudió a las primeras citas, cuando se encontró un lugar apropiado para efectivizar la derivación, Andrés no fue más. En 2019, Andrés volvió a entrar en contacto con el DIAT. Esta vez, frente a una situación puntual de vulneración de derechos, el equipo dio intervención al Servicio Local que tomó el caso, pero en lugar de propiciar que, en relación a su situación de consumo, el joven continuara en relación con el DIAT, decidió derivarlo al CPA.

Durante mi trabajo de campo en el dispositivo, la madre se puso nuevamente en contacto con el equipo DIAT. Al parecer, la trabajadora del CPA responsable de atender al joven, aún no lo había visto y en los próximos días se iba tres semanas de

39. Todos los centros de salud y postas sanitarias de Juana Azurduy dependen del municipio. 
vacaciones con lo cual no iba a poder recibirlo. Informada de la situación, la referente del dispositivo conversó el caso con Héctor, el representante del CEDECOR descentralizado, pero tratándose de un menor de edad se resolvió comunicar el caso a "sede central". Por su parte, Héctor se ofreció a reunirse con Andrés la siguiente semana. Sin embargo, en la fecha pautada se presentó únicamente su madre. Tras la reunión, se acordó rediseñar la estrategia de abordaje: Héctor acompañaría a la madre al único centro de salud con servicio de salud mental del municipio para intentar articular con ese dispositivo.

El equipo atribuye las dificultades que se han presentado en la articulación con el Servicio Local a las diferencias políticas existentes entre la gestión nacional y la municipal. De hecho, estas tensiones han sido explicitadas, en más de una oportunidad, por los/as trabajadores/as de algunos centros de salud municipales que se niegan a articular con el dispositivo, arguyendo que dadas las diferencias políticas no hay ningún tipo de diálogo posible. Ahora bien, estos impedimentos no se han presentado únicamente en los intentos de articulación con otras dependencias del estado, sino que también han dificultado la relación con algunas organizaciones no gubernamentales y comunitarias que entienden que las diferencias políticas con el "macrismo" son inexpugnables.

En síntesis, las políticas de promoción, restitución y ejercicio de derechos que apelan a la articulación intersectorial, participación social y comunitaria, aunque constituyen un aporte significativo a la oferta asistencial existente, no constituyen procesos unívocos ni lineales. Al contrario, se inscriben en municipios y comunidades concretos configurados por relaciones de poder particulares entre una diversidad de actores/actrices, instituciones estatales y organizaciones sociales con objetivos e intereses propios y que, por otra parte, en muchos de estos casos, despliegan disímiles acciones y prácticas y poseen diferentes concepciones sobre los consumos problemáticos.

En este sentido, los hechos, situaciones y casos antes narrados dan cuenta, por un lado, de diferencias político/partidarias que no sólo han impedido el desarrollo de estrategias conjuntas y el fortalecimiento de redes territoriales que permitirían el deseado reemplazo de la lógica individual del "caso a caso"; sino que incluso han llegado a comprometer las posibilidades de acceso de los/as usuarios/as del DIAT a propuestas formativas (en centros barriales, ONG locales) y a los efectores de salud municipales. Pero también, por otro lado, los episodios relatados muestran cómo diferentes concepciones sobre el consumo, los/as usuarios/as y lo que se entiende por un "buen" abordaje de los consumos problemáticos, así como sobre la familia, las relaciones afectivas y la amistad - con las cuales se "lidia", generalmente, con relativa eficacia - bien pueden resultar en el alejamiento de algunos/as usuarios/as del DIAT y demás dispositivos impactando negativamente en sus trayectorias terapéuticas. Así y todo, uno de los mayores desafíos para los/as trabajadores/as 
del DIAT y problemas para las poblaciones más vulnerables del municipio - y, en particular, para los/as usuarios/as del dispositivo - lo constituyen no tanto las diferencias político/partidarias o las diferentes prácticas y concepciones en torno a los consumos problemáticos, sino antes bien las lógicas, prácticas y rutinas institucionales que reproducen prácticas violatorias de los derechos humanos, máxime siendo la institución en cuestión el único efector en salud de complejidad en el partido.

Es entonces, frente a este complejo escenario, que creemos importante preguntarnos, ¿qué se entiende por articulación intersectorial, participación social y comunitaria? ¿cuáles son las experiencias de participación y articulación que pueden ser y son valoradas como exitosas? ¿cómo construir articulación con actores/ actrices, prácticas y dispositivos política y conceptualmente distantes? ¿en quiénes recae esta responsabilidad? ¿y la gestión de los conflictos que emergen de dichos esfuerzos? Volveremos sobre estas cuestiones más adelante, en el apartado del DTC Barrio Ceibo y en las reflexiones finales.

\subsection{El DTC BC}

\subsubsection{Barrio Ceibo, partido de Manuela Pedraza: características socio-demográficas}

El DTC BC está ubicado en el partido de Manuela Pedraza, en el norte del Amba. $\mathrm{Al}$ igual que en Juana Azurduy, la población del municipio está expuesta a heterogéneas condiciones de vida, pero presenta una composición socioespacial un poco más homogénea. Así, si bien existen desiguales condiciones de acceso a los servicios y sectores de la población con bajos ingresos, según el Censo 2010 (Indec, 2010), únicamente el 3,7\% de los hogares registraba algún indicador de NBI. La mayoría de ellos con asiento en alguna de las 16 villas y asentamientos del municipio que se concentran en las zonas noroeste y norte del partido. Con 6.29 hectáreas, Villa Ceibo, donde se localiza el dispositivo, es la tercera más grande del municipio. El barrio linda con Villa Esperanza y un mercado central; y se encuentra a una cuadra de una de las principales "zonas rojas" del municipio.

Según el Censo 2010 (Indec, 2010), Villa Ceibo cuenta con 2704 habitantes. El 30,4\% de esta población son NNyA de 0 a 14 ańos, y el 14,2\% adolescentes y jóvenes entre 15 y 24 años. En lo que respecta a las condiciones habitacionales, el barrio está conformado por 704 hogares, el 20,9\% de los cuales presenta NBI. Pero además, los/as vecinos/as destacan entre las principales problemáticas habitacionales la falta de títulos de propiedad, las carencias del servicio de recolección de basura, el desborde de cloacas, las sobrecargas y cortes de electricidad, la falta de gas natural, el mal estado del asfalto y la ausencia de iluminación en los pasillos. Otras problemáticas del barrio según refieren sus habitantes son el mal funcionamiento del centro de atención primaria a la salud local, los altos niveles de deserción escolar, los elevados índices de violencia de género, la existencia de casos de homo y transfobia, y el consumo de alcohol en exceso (OAD, 2019). 


\subsubsection{Historia y características del dispositivo}

El DTC BC era anteriormente un Punto de Encuentro Comunitario (PEC). El PEC abrió sus puertas en noviembre de 2014 y, en abril de 2017, se implementó la metodología de TC. El punto de partida del dispositivo en lo que refiere a su inserción en la comunidad y su actual base segura es la Biblioteca Popular. Esta institución abrió sus puertas en 1986 y, a 30 años de su creación, "es un espacio respetado, que goza de buena reputación. Si algo es impulsado por la biblioteca, es garantía de confianza para la mayoría de lxs vecinxs" (EDTCBC, 2018, p. 5). Hoy en día, la institución ofrece múltiples actividades y propuestas abiertas a la comunidad, entre otras: programas de terminalidad educativa, educación formal, alfabetización, ludoteca, talleres de radio, comunicación visual, creatividad, arte y promoción de los $\mathrm{DDHH}$, gimnasia, zumba y ajedrez.

Los primeros contactos del DTC con la comunidad se dieron, específicamente, a partir de mujeres que trabajan en la Biblioteca. De hecho, con estas referentes se realizaron las primeras recorridas por el territorio, que le permitieron al equipo comenzar a conocer a los/as vecinos/as y obtener información sobre el barrio, su historia y sus habitantes. Por otra parte, ya existía en la Biblioteca, en el marco del PEC, un espacio de encuentro para jóvenes que fue retomado y ampliado por el nuevo equipo de la Sedronar. Así, a partir de estas actividades y en torno a la estructura organizativa de la Biblioteca se fueron construyendo, a lo largo de 2017, la incipiente red de recursos comunitarios y la red subjetiva comunitaria del dispositivo, donde se evidencia el contacto mayoritario que el equipo tuvo, desde un inicio, con la población femenina del barrio (EDTCBC, 2017).

En 2018, como parte de la elaboración de un primer diagnóstico territorial, ${ }^{40}$ el equipo identificó dos problemáticas acuciantes en "La Ceibo": una gran cantidad de personas indocumentadas y altas tasas de deserción escolar. Esto lo llevó, por un lado, a organizar en conjunto con la Biblioteca y el Registro Provincial de las Personas (REPROPER) un operativo de documentación; y, por el otro, a un trabajo estrecho con las instituciones educativas locales en el marco del cual se articuló con un programa nacional de reinserción escolar (DALE), y con los equipos distritales de inclusión y de infancias y adolescencias en riesgo (EDI y EDIA). Ambas actividades, resultaron no sólo útiles para la comunidad y sus miembros, sino además centrales para que el dispositivo salga de la base segura y amplíe sus redes, consolidando su presencia en el territorio.

40. A modo de complemento del diagnóstico territorial realizado por el equipo, el OAD efectuó, en 2019, un Diagnóstico Integral Comunitario en base a un análisis FODA (Fortalezas, Oportunidades, Debilidades y Amenazas) con el objetivo de realizar una caracterización del barrio desde un enfoque técnico-comunitario, lo que estimuló la participación de la comunidad y contribuyó al desarrollo del SET del dispositivo. 
Por otra parte, el equipo generó ese mismo año diferentes propuestas lúdico-recreativas y formativas que se sumaron al prexistente taller de jóvenes. Estos fueron pensados como espacios de encuentro y contención que tenían por objetivo promover la inclusión de nuevos sectores poblacionales al dispositivo, así como fomentar hábitos saludables y ampliar los intereses de los/as participantes. Concretamente, se organizó la pintada del mural "Darío por siempre", ${ }^{41}$ se creó un "grupo de chicas" ${ }^{42}$ y se armó una huerta en la Biblioteca. ${ }^{43}$ No obstante, estas acciones de vinculación, por la asistencia discontinua de los/as jóvenes, la falta de recursos materiales, la ausencia de objetivos claros y/o la asignación de tareas y responsabilidades algo difusa, no lograron sostenerse en el tiempo (EDTCBC, 2018). De todas formas, lo cierto es que tanto estas actividades como el exitoso proyecto de cooperativa "La Alfarería", un taller organizado por la Biblioteca y acompañado por el DTC donde adultos/as y jóvenes aprenden cerámica o costura y reciben un salario social complementario, fueron las que en su conjunto permitieron que, en el transcurso de 2018, el dispositivo construyera y fortaleciera su vínculo con los niños/as, adolescentes y jóvenes del barrio.

Actualmente, el DTC funciona tres veces por semana. Como veremos a continuación, desarrolla actividades de vinculación en la Biblioteca, trabajo de calle y seguimiento de casos, participa de forma periódica en la Mesa de Género y la Mesa del Consejo Local de Nińez del municipio, y organiza jornadas en espacios comunitarios e institucionales.

\subsubsection{El trabajo del DTC Barrio Ceibo}

El equipo del DTC BC está conformado por cuatro mujeres que presentan perfiles profesionales diversos: una es licenciada en Cs. de la Comunicación y las otras tres, estudiantes avanzadas de las carreras de psicología, comunicación y derecho, además, una de ellas es vecina del barrio. El equipo cuenta, asimismo, con el apoyo de un tutor de la Sedronar que acompaña en la elaboración del plan de abordaje, en la utilización de las herramientas de sistematización y durante el proceso de evaluación; y dispone de la colaboración de un referente de asistencia

41. El proyecto surgió a raíz del asesinato de Darío en una villa cercana que afectó profundamente a sus amigos/as muchos/as de los/as cuales se juntaban a tomar alcohol y fumar marihuana en las inmediaciones de la Biblioteca. La pintada se presentó como una oportunidad para tramitar la tristeza de estos/as jóvenes, pero también para acercarse a un sector de la población con el que la Biblioteca y el equipo de DTC tenía una relación distante. No obstante, pese a que los encuentros para planificar la actividad perfilaban la construcción de un espacio de vinculación, finalizado el mural la relación volvió a sus cauces habituales.

42. En el "grupo de chicas", al que asistían un promedio de 8 jóvenes entre los 10 y los 15 años, se compartían desayunos, películas, manualidades, dibujos, conversaciones y tiempo para realizar tareas escolares.

43. Desde este espacio, se buscó llegar a un segmento de jóvenes a los que no se lograba convocar y reunir a parceros/as que no formaban parte aún de la red operativa. Se pensó también que el proyecto podía tener una veta laboral autogestiva, fomentar una cultura respetuosa con el ambiente, convocar nuevos/as vecinos/as, propiciar pautas conductuales beneficiosas, contribuir a mejorar la alimentación y empoderar a otros/as actores de la comunidad como líderes de opinión (EDTCBC, 2018). 
técnica que acompaña la implementación y evaluación de las practicas territoriales y sus efectos (Astolfi Romero et al., 2019). En cuanto a las condiciones laborales, los/as referentes se encuentran contratados por la Secretaría, mientras que los/as integrantes de los equipos perciben una beca estímulo por la que deben cubrir 30 hs semanales de trabajo.

Los propósitos del equipo en el barrio son generar espacios de acompañamiento y escucha, promover la restitución de derechos vulnerados de los/as usuarios/as del dispositivo y aumentar la accesibilidad a servicios de salud (Astolfi Romero et al., 2019). Para ello, el equipo desarrolla una serie de actividades - i.e. trabajo de calle, creación, visibilización y articulación de redes, seguimiento de casos y actividades de vinculación - y mantiene reuniones semanales. Las reuniones constituyen un aspecto central del dispositivo ya que le permiten al equipo diseñar, evaluar y, en caso de ser necesario, modificar las estrategias de intervención adoptadas. A tal efecto, se comparte la situación de los/as parceros/as, se evalúan las prácticas y acciones realizadas, se actualizan las herramientas de intervención, y se planifican las próximas tareas: recorridas por el territorio, organización de jornadas, participación en eventos comunitarios, etc.

En lo que respecta a las actividades, si bien cada una posee su especificidad, todas tienen como objetivo táctico propiciar la emergencia de espacios de escucha activa y bajo umbral de acceso orientados dar una respuesta a las demandas y necesidades de la población, al mismo tiempo que se busca realizar "algo útil para la comunidad" e implementar los ejes del TC. En este sentido, el equipo sostiene dos acciones de vinculación de carácter laboral y formativo periódicas en la base segura. Una de ellas es el proyecto de cooperativa "La Alfarería", que es organizado por la Biblioteca, pero acompańado por el equipo con el objetivo de establecer lazos de confianza y generar oportunidades de diálogo con los/as jóvenes. La otra es el Espacio de Reflexión para Adolescentes (ERA) coordinado por el DTC, que se desarrolla los jueves por la tarde en la base segura. Este, como bien indica su nombre, se trata de un espacio en el cual, mientras se merienda y desarrolla la actividad que proponen las coordinadoras para cada encuentro, se conversa y reflexiona sobre diferentes temas. Los tópicos más recurrentes son las amistades, las relaciones amorosas y los problemas que ello trae con familiares y jóvenes del barrio y "de afuera", aunque también las coordinadoras suelen preguntar por la escuela, hablan sobre "métodos de cuidado", violencia de género e imparten contenidos previstos en la Ley de Educación Sexual Integral. Además, el equipo realiza seguimiento de casos, en general, mediante visitas domiciliarias semanales ( $y$, en menor medida, por vía telefónica) que, en tanto suponen transitar el barrio, se presentan también como una oportunidad para encontrarse con parceros/as y vecinos/as y profundizar el trabajo de calle. Por último, este trabajo se complementa con recorridas territoriales, 
la asistencia a las mesas municipales de Género y del Consejo Local de Niñez, y el desarrollo de actividades de vinculación más puntuales. ${ }^{44}$

Ahora bien, en el desarrollo de estas actividades existe, amén de un objetivo táctico, un componente estratégico, que es la construcción de redes. Esto quiere decir que, cuando el equipo desarrolla actividades de trabajo en calle, seguimiento de casos o de vinculación, uno de sus objetivos es también crear, visibilizar y fortalecer las redes del/a parcerola y del dispositivo. Pero además significa que, cuando una persona se acerca con una demanda o necesidad específica, la estrategia de intervención y acompańamiento tanto a nivel individual como comunitario se piensa con las personas e instituciones - i.e. $R O, R R C, R L O$ y $R R C$ del dispositivo y $R S$, $R P$ y $R L O$ dellla parcerola - que pueden ser parte de y disponen de los medios adecuados para dar respuesta. Dicho de otro modo, la capacidad de dar respuesta del dispositivo se encuentra estrechamente ligada al trabajo de creación, visibilización $y$ articulación de redes que lleva adelante el equipo.

En este sentido, el DTC BC ha trabajado concienzudamente para ampliar sus redes. De hecho, como se indica en los informes anuales, la $R S C$ del dispositivo pasó de 38 a 149 nodos en el lapso de un año, incorporando sobre todo a personas que no tenían vínculo previo con la Biblioteca. Mientras que, en el caso de la $R R C$, la reconstrucción realizada a partir de los informes, notas de campo y entrevistas a integrantes del equipo, ${ }^{45}$ permite inferir que el equipo ha articulado en su trabajo cotidiano con numerosas instituciones y organizaciones locales. La mayor parte de estos nodos institucionales son programas e instituciones del estado provincial, organizaciones no gubernamentales y comunitarias, e instituciones del estado municipal, que provienen tanto del campo de la educación y la niñez - en su mayoría, escuelas - como del campo de la salud mental. Entre estas últimas, se destaca el trabajo conjunto con el CPA, otros dispositivos de la Sedronar (CAAC zona norte de Manuela Pedraza, y DIAT Juana Azurduy) y centros de psicopatología, psicopedagogía y orientación familiar.

De todas formas, pese al trabajo y esfuerzo realizado, el objetivo del dispositivo es que los/as parceros/as no se vinculen a la $R R C$ únicamente a través del equipo, a fin de propiciar y alcanzar la tan mentada autonomía comunitaria. Esta meta se presenta dificultosa tanto para los/as habitantes del barrio como para las integrantes

44. Al momento de realizar el trabajo de campo, se estaban planificando dos actividades: una jornada en el jardín de Villa Esperanza (con el objetivo de trabajar los derechos de los NNyA y contenidos de la Ley de Educación Sexual Integral con madres y padres de La Ceibo y Esperanza) y la participación en el festival temático de fin de año de la Biblioteca, donde los diferentes espacios y talleres muestran su trabajo, y desde el ERA se propuso una batalla de freestyle (que en términos prácticos supuso para los jóvenes que participan del espacio presentar un proyecto, diseñar volantes y repartirlos por el barrio). Además, se estaba analizando la posibilidad de organizar una jornada o mini-festival y un taller de freestyle, breaking y graffiti con el proyecto itinerante de la Sedronar "Ritmo, barrio y poesía".

45. Como no se dispone de los datos generados por el dispositivo, la reconstrucción de la $R R C$ se centró en las instituciones y organización antes que en los/as actores/actrices que la integran. 
del equipo. Ello así porque, por un lado, las peticiones de los/as habitantes reproducen muchas veces las prácticas y representaciones tradicionales en torno a la gestión de las vulnerabilidades, y, en particular, el consumo y su abordaje, donde "expertos" escuchan, aconsejan y, si la situación reviste mayor complejidad, derivan a otro efector más específico. Por el otro, porque el propio equipo tiende a reproducir ese lugar de expertise, sobre todo, cuando se encuentra realizando seguimiento de casos. En este sentido, las integrantes manifiestan que deben aprehender que "las respuestas no necesariamente deben surgir y ser ejecutadas por el equipo, sino que debemos promover que las redes se activen y tomen parte en la resolución o en la construcción de respuestas" (EDTCBC, 2017, p. 3). No obstante, la construcción de una $R O$ y la identificación de líderes de opinión que podrían facilitar este paulatino desplazamiento, todavía se encuentran en proceso. De hecho, durante el trabajo de campo se pudo advertir cómo la $R O$ continuaba estando conformada únicamente por el equipo de TC y los/as trabajadores/as de la Biblioteca.

En esta línea, resulta de suma utilidad para el dispositivo evaluar la evolución de sus redes y el lugar que en ellas ocupan las integrantes del equipo. Para ello, la metodología de TC utiliza matrices de adyacencia que, pese a su gran complejidad, son sólo una de las tantas herramientas de intervención que posee el dispositivo.

\section{De los instrumentos de intervención}

Como parte de su trabajo cotidiano, los equipos de TC al igual que los DIAT, deben completar una serie de planillas y documentos: el Diario de Campo, la Hoja de Primer Contacto (HPC), la Planilla de Red Subjetiva Comunitaria o matriz de adyacencia, la Planilla de Seguimiento de Procesos Personales (SPP) o diario de procesos personales, el Sistema Estratégico de Tratamiento (SET), el Sistema Estratégico de Resultados (SER) y, la herramienta de evaluación de procesos que ya hemos explicado. Estas herramientas de registro, sistematización y evaluación del dispositivo, insumen un tiempo considerable al equipo, pero constituye una parte central del proceso. Ello así en la medida en que no sólo permiten obtener datos sobre las problemáticas de la comunidad, sino que ayudan a planificar las intervenciones y evaluar las acciones del equipo y resultados del TC.

El Diario de Campo es un registro detallado de todas las actividades desarrolladas, los encuentros hechos y las observaciones realizadas. En este sentido, en tanto contiene información sobre la comunidad, la construcción del dispositivo y el trabajo con los/las parceros/as, es un instrumento clave en el proceso de investigación en acción que permite construir otras herramientas como el SET, la $R S C$ y la HPC. El SET, como ya fue explicado, es una herramienta diseñada para realizar el diagnóstico de la comunidad y conocer en profundidad sus dinámicas; 
la Planilla RSC o matriz de adyacencia ${ }^{46}$ es la herramienta de sistematización y medición del proceso de construcción de redes del dispositivo; mientras que, la HPC, al igual que la Planilla de SPP, son herramientas para el trabajo con los/as parceros/as. Específicamente, la HPC recaba información sobre el primer contacto (datos del/la parcero/a, sus relaciones socio-afectivas, vulnerabilidades en el acceso a derechos, situaciones de violencia y/o de consumo problemático) como así también sobre las características de la demanda, las respuestas ofrecidas, y cuáles han sido sus resultados; en tanto que, la Planilla de SPP, o en su versión local diario de procesos personales, se abre cuando, a raíz de estos primeros encuentros, se advierte que la persona requiere de un acompañamiento personalizado. Allí, se recopila entonces información sobre el trabajo que el equipo realiza con algunos/as parceros/as y sus redes, lo que facilita el análisis y evaluación del proceso de seguimiento.

Por último, el SER responde a la necesidad de esclarecer cuáles son los resultados del TC. Concretamente, la herramienta relaciona la información sobre las condiciones de vulnerabilidad observadas al momento del primer contacto tanto con las actividades y los procesos implementados durante el TC (variable independiente) como con una variable dependiente que incluye siete categorías de riesgos o situaciones en las que se quiere producir un cambio (Serrano, Barros y Milanese, 2017). Así, al mismo tiempo que permite sistematizar las prácticas, favorece la reflexión sobre algunos contextos de vulnerabilidad, y facilita la evaluación de los procesos personales y de redes.

\section{Algunas cifras}

Desde su creación y hasta fines del 2018, el DTC BC había generado 103 HPC, 32 SPP y 12 SER. Para el Informe de Gestión 2018 se sistematizaron los datos de $99 \mathrm{HPC}$. De los datos allí consignados se desprende que la mitad de las personas que se acercaron al dispositivo lo hicieron para pedir orientación, información o bien solicitar formación o capacitación. En cuanto a las condiciones de la persona al primer contacto priman las vulnerabilidades categorizadas como sociales $(56,7 \%)$, aunque también se registran situaciones de violencia $(15,2 \%)$ y de consumo problemático de sustancias (18\%). En relación a estas últimas, un 23\% de los/ as parceros/as manifestó hacer uso de marihuana y un $15 \%$ de cocaína ${ }^{47}$ mientras que, un $15 \%$ mencionó tener problemas con el consumo de alcohol y un 13\% con el consumo de alcohol y pastillas (EDTCBC, 2018).

Respecto al perfil sociodemográfico de los/as usuarios/as del DTC, el 59,6\% son mujeres, el 37,4\% hombres y un 3\% refiere otra identidad de género. La mayor

46. La matriz de adyacencia permite medir, entre otras cuestiones, amplitud y densidad de una red, así como el grado de centralidad de los nodos que la componen

47. Además, en un $28 \%$ de los casos el equipo advierte que existe uso de alguna/s sustancia/s, sin poder identificar cuál/es de todas ellas. 
parte tiene entre 10 y 17 años (33,3\%), y entre 24 y 36 años (32\%), mientras que, únicamente, el $11 \%$ tiene entre 18 y 23 ańos. Por otra parte, es importante mencionar que el equipo percibe una relación entre el género del/la consultante y la situación que lo/la motiva a acercarse al dispositivo. Así, advierten que los hombres se acercan por situaciones que los afectan a ellos mismos; mientras que, las mujeres acuden en su mayoría por terceros, generalmente familiares hombres, y, cuando consultan por ellas mismas, suele ser por cuestiones de género. De hecho, los seguimientos personalizados, involucran en su mayor parte a mujeres que atraviesan situaciones de violencia de género o vinculadas a la maternidad como, por ejemplo, abandono escolar por parte de alguno/a de sus hijos/as, temor a que algún/a hijo/a esté consumiendo y demandas vinculadas con la prevención de embarazos.

A fines de 2019, se contabilizaban aproximadamente 40 parceros/as activos/ as $\mathrm{y}$ un total de 11 seguimientos personalizados, 10 de ellos a mujeres del barrio.

\subsubsection{De conquistas, límites y desafíos}

Como ya hemos señalado, los DIAT y los DTC forman parte de una misma política pública que tiene por objetivo principal el abordaje territorial integral de los consumos problemáticos orientado a la promoción, la restitución y el ejercicio de derechos como procesos potencialmente terapéuticos (Astolfi Romero et al., 2019). No obstante, si desde los DIAT la propuesta es proveer una asistencia integral propiciando, en este sentido, el fortalecimiento de las redes locales, la elaboración de estrategias comunitarias, así como la articulación con diferentes organismos e instituciones del estado y organizaciones sociales; en los DTC se trata, en cambio, de mejorar las condiciones de vida de las personas en situación de alta vulnerabilidad y sus comunidades promoviendo, para ello, "la reorganización de los recursos comunitarios" (Tufró y Carroli, 2018). En pocas palabras, el objetivo, en este último caso, es que no sea el equipo sino la comunidad la que ofrezca respuestas posibles a través de sus redes. Más aún, el horizonte del TC es la conformación de una minoría activa (MA) que continúe desarrollando actividades e iniciativas, con posterioridad a que el equipo se haya retirado. De este modo, aquello que se reviste de proceso democratizador, participación, y empoderamiento (Camarotti y Kornblit, 2015), demanda como contracara una comunidad "bien organizada", capaz de autogobernarse, que se erige en motor y es considerada, aunque más no sea en parte, responsable de su propio cambio - y, por ende, factible de ser (aunque no por ello necesariamente) culpada de su fracaso (Candil, 2011).

Este deslizamiento hacia lo comunitario, por supuesto, no es novedoso. De hecho, es una parte central de las transformaciones que, como mencionábamos, se han producido en las formas de gobierno de los países occidentales desde la década de los años 70 (Gupta y Ferguson, 2006; Rose, 2007). Es más, debe inscribirse en el ámbito local en el marco del creciente protagonismo que han adquirido la 
"comunidad" y lo "territorial" en el campo de las políticas sociales en las últimas décadas (Cravino, 2008; Rofman y Foglia, 2015; entre otros). No obstante, esta "reconfiguración compleja del territorio de gobierno" (Rose, 2007), lejos está de ser homogénea. Sin ir más lejos, en el modelo de la DNAE conviven, como vimos, dos propuestas bien diferentes. Por un lado, los DIAT, un dispositivo de base territorial que promueve la participación social y comunitaria y la articulación intersectorial en pos de ofrecer un abordaje integral; y, por el otro, los DTC, donde nos encontramos con que la comunidad ya no sólo se constituye en territorio de gobierno, sino, antes bien, en una manera de gobierno (Rose, 2007), es decir, donde ya no se trata de gobernar en, con y desde, sino a través de ella. En síntesis, un dispositivo en el cual la participación deja de ser deseable para volverse necesaria.

Ciertamente, una propuesta de estas características supone un enorme desafío al momento tanto de implementar como de medir y evaluar los avances, obstáculos y desafíos que enfrenta cada dispositivo. Para ello, la metodología de TC posee una gran cantidad de herramientas de intervención que facilitan la elaboración de diagnósticos territoriales, la sistematización de demandas y la recopilación de información sobre el trabajo y prácticas que realizan los equipos. Pero además, emplea complejos instrumentos de cálculo - que miden y evalúan procesos, redes y riesgos - que permiten esclarecer el impacto del dispositivo en términos de reducción de vulnerabilidades (i.e. principal objetivo de la política), como así también dar cuenta de la evolución de las redes, esto es, del proceso de construcción del dispositivo. Esta producción se complementa, por otra parte, con la información volcada en los informes de gestión, en donde los equipos describen el trabajo realizado en el año y relatan experiencias "exitosas".

De ponderar el trabajo del DTC BC en estos términos, podríamos decir que el equipo ha ampliado significativamente su $R S C$ y, en cuanto a la $R R C$, ha articulado con una gran cantidad de instituciones estatales y organizaciones sociales y comunitarias de la zona. De hecho, podríamos afirmar que, al igual que el DIAT JA, el equipo ha conseguido insertarse en las redes locales, generando en casos puntuales condiciones para el acceso, la restitución y el ejercicio de derechos. Más aún, si bien encuentran serias dificultades para establecer vínculos con la población de jóvenes entre 18 y 24 años, gran parte de los/as parceros/as son mujeres lo que indica que se ha logrado mejorar los niveles de accesibilidad de esta población no sólo al dispositivo sino también a sus derechos. Sin embargo, lo cierto es que aquello que es generalmente definido en términos de "logro" - i.e. conseguir que una parcera comience a utilizar métodos anticonceptivos y asista a su primera consulta ginecológica, lograr que otra parcera realice un test de embarazo - aun de suponer un cambio concreto en la vida de estas personas, no sólo se presenta algo magro si se piensa en términos de resultados de una política pública; sino que continúa teniendo al equipo como facilitador del proceso. Por lo tanto, en términos 
de los objetivos de la metodología que se emplea, la conformación de una $M A$ se encuentra lejos. En otras palabras, si bien los/as habitantes de Villa Ceibo acuden al equipo, reproducen con frecuencia las representaciones tradicionales en torno a la gestión de las vulnerabilidades, resistiéndose a devenir "sujetos activos de su propio gobierno" (Rose, 2007).

Ahora bien, más allá del cumplimiento o no cumplimiento de los objetivos específicos del dispositivo, comprender las conquistas, límites y desafíos del DTC $\mathrm{BC}$ requiere dejar de lado miradas normativas - centradas en constatar si la implementación se corresponde o no con lo que sería "deseable" - y, en cambio, analizar las formas en que el dispositivo es efectivamente puesto en práctica. En el caso del DIAT, adoptar esta perspectiva nos permitió dar cuenta de toda una serie de actividades y estrategias de tipo promocional que eran desplegadas por el equipo, pese a que la DNAE y los/as propios/as trabajadores/as del dispositivo sostenían que en Juana Azurduy no había eje de promoción y protección de derechos puesto que no había edificio ni docentes/talleristas; pero también, entender que aquello que recibe el nombre de "articulación" y "participación social y comunitaria" adquiere múltiples significados y modalidades, conlleva enormes esfuerzos, y se traduce en una diversidad de prácticas cotidianas con disímiles consecuencias prácticas. En suma, volviendo al dispositivo de Barrio Ceibo, interesa no sólo atender al grado de desarrollo de las actividades (i.e. trabajo de calle, creación, visibilización y articulación de redes, seguimiento de casos y acciones de vinculación) previstas en el marco de la política, sino también a las características que adquieren los espacios, relaciones y redes que son creados, visibilizados y fortalecidos por el dispositivo.

Para ello, traemos a continuación una serie de episodios, conversaciones y reflexiones que dan cuenta de algunas dificultades que se le presentaron al equipo durante su trabajo cotidiano - como así también de otras posibles, pero con las que no tuvieron que enfrentarse -, que entendemos bien pueden ser pensadas, asimismo, como obstáculos con los que fácilmente pueden encontrarse otros dispositivos que operan con la metodología de TC. Nos referimos, por un lado, a la persistencia de representaciones sociales excluyentes entre quienes participan de las actividades de vinculación del dispositivo; y, por el otro, a la existencia de conflictos comunitarios que no parece factible tengan un desenlace constructivo en el corto o mediano plazo.

\section{Incomodidad y maltrato en "La Alfarería"}

Rocío, integrante del DTC, cuenta en el marco de una charla con Valeria, otra integrante del dispositivo, que habló con Daniela, una joven del barrio. Lo hizo porque se había enterado que Daniela le había pegado a Tatiana, su mamá y parcera del dispositivo. En el transcurso de la charla, cuenta que la joven le confesó que la madre la maltrataba verbal y psicológicamente. Y que, además, le comentó 
que "no quiere ir más al taller. Que le gusta, pero que no quiere ir más, porque se siente incómoda”. Rocío, por su parte, se ofreció a hablar con Tatiana. Dicha conversación, como prometido, tuvo lugar ese mismo día. Al comienzo de la charla, explicó Rocío que la madre de Daniela, imaginando sobre qué tema versaría, se apresuró a aclarar que su hija "le causa muchos problemas y la hace enojar". Ante la actitud defensiva de Tatiana, Rocío decidió "enfriar” la situación y decir que el motivo de la charla era hablar sobre su ausencia, en el último tiempo, al taller de cerámica. Esto aparentemente relajó a la mujer que le manifestó que, si bien "le gusta mucho la cerámica, no se siente cómoda y que las demás mujeres le hacen vacío”. Además, Rocío comentó que aprovechó la oportunidad para conversar sobre la situación de consumo que atraviesa Tatiana, quien le aseguró que estaba consumiendo menos y que ahora le importaba si su beba tenía leche y pañales. Al terminar su relato, Rocío agregó que Victoria, su vecina, tampoco está yendo al taller, que no quiere volver, y que le manifestó que "para maltratos, para sentirse golpeada, ya tiene suficiente en casa”.

Valeria, tras escuchar atentamente a Rocío, le preguntó, en primer lugar, por la red de Daniela y, en cuanto a Tatiana, sugirió proponerle que asista al CAAC de la zona para que tenga algún espacio de contención y comparta con otras mujeres. Luego, Roció y Valeria conversaron sobre la falta de compañerismo en el taller y la necesidad de trabajar en ello. Si bien en esta en esa oportunidad no se diseñó ninguna estrategia concreta, se acordó en que se debía suspender una clase para "generar un espacio de confianza".

\section{Enemistades ancestrales}

Una de las cuestiones que más llamó mi atención al comenzar el trabajo de campo en este dispositivo fue la aparente inexistencia de impedimentos para los/as vecinos/ as de circular libremente por el barrio. Luego, conversando con las integrantes del equipo, éstas confirmaron que efectivamente no había grandes disputas entre sectores, bandas enemistadas o peleas entre familias que resultaran en enfrentamientos violentos o perturbaran de algún modo el acceso a espacios comunitarios o la libre circulación por las calles. Sin lugar a dudas, esto representa una gran ventaja para el desarrollo del dispositivo; pero, al mismo tiempo, invita a preguntarse, qué ocurre en otros barrios donde hay bandas, familias o incluso sectores enteros de la "comunidad" enfrentados.

Al compartir mi inquietud con el equipo, la respuesta de quienes poseían experiencia de trabajo en otros barrios no tardó en llegar: cuando existen conflictos comunitarios que no parece factible que tengan un desenlace constructivo en el corto o mediano plazo, queda en evidencia la "fragilidad del dispositivo". Ello así en la medida en que, en muchas de estas situaciones construir relaciones de parcería con determinados/as actores/actrices clausura toda posibilidad de interactuar con 
otros/as. De modo que, el dispositivo acaba ofreciendo respuestas parciales que reproducen lógicas y conflictos locales, socavando la posibilidad de que algunos sectores o miembros de la comunidad accedan a recursos y derechos de los que el estado debe ser garante.

En síntesis, los DTC se inscriben en relaciones sociales y dinámicas barriales que operan como facilitadores y obturadores del acceso a recursos estatales, en definitiva, a los derechos que el estado debe garantizar a los habitantes. Es más, aun cuando las relaciones sociales y dinámicas barriales no implican serias barreras en el acceso al dispositivo para los/as habitantes del barrio, la oportunidad de circulación por redes institucionales e intersubjetivas tampoco genera necesariamente condiciones de posibilidad para el acceso, la restitución y el ejercicio de derechos o procesos de integración comunitaria. Ello así toda vez que, entre otras cuestiones que retomaremos en las conclusiones de este trabajo, existen - o persisten pese a los esfuerzos del equipo - en las instituciones y organismos estatales tanto como en las organizaciones y espacios comunitarios, representaciones, lógicas y prácticas estigmatizantes, cuando no - como es el caso del hospital provincial de Juana Azurduy, pero también del Centro de Atención Primaria de la Salud de Barrio Ceibo - directamente violatorias de los derechos humanos.

Cabe entonces preguntarse, ¿posee la circulación por redes institucionales e intersubjetivas potencial terapéutico? ¿Genera ésta condiciones de posibilidad para el acceso, la restitución y el ejercicio de los derechos? La respuesta a estos interrogantes, lejos de ser sencilla, entendemos, requiere apartarse de aquellas miradas ingenuas que promueven la participación comunitaria como esencialmente benévola y antídoto para todos los males sociales - sea la fuerza del mercado, la excesiva centralización y burocratización del estado moderno, o sea la fragmentación de los lazos sociales -, y atender a los diferentes contextos sociales, políticos y económicos en los que esta participación es propiciada.

\section{CONSIDERACIONES FINALES}

En este capítulo nos propusimos analizar, a partir de la descripción de las prácticas, actividades y metodologías de trabajo desplegadas por los equipos del DIAT Juana Azurduy y el DTC Barrio Ceibo, las principales conquistas, límites y desafíos que enfrentan la atención y cuidado a personas en situación de consumo problemático en estos dispositivos, en el marco de la historia de las políticas de atención en Argentina como así también de las más amplias transformaciones que han tenido lugar en las políticas sociales en el país en los últimos años.

En este sentido, hemos visto, por un lado, que el modelo de abordaje integral territorial en que se inscriben estos dispositivos es producto de la acumulación y yuxtaposición de una serie de experiencias de intervención y políticas de implementación reciente en Argentina que han implicado un quiebre con los modelos dominantes en 
materia de atención y cuidado de los consumos problemáticos - i.e. modelo médico hegemónico, alternativo subordinado y de auto-atención (Pawlowicz et al., 2011). Estas experiencias, descriptas por Capriatti et al. (2015) y sistematizadas por Camarotti y Kornblit (2015) en el denominado modelo de abordaje integral, lejos están no obstante de ser homogéneas. De hecho, las iniciativas que se describen e inscriben en dicho modelo son tanto estatales como de la sociedad civil, ofrecen una diversidad de modalidades de atención y entremezclan lógicas y prácticas muy disímiles (Capriatti et al., 2015).

Por otra parte, y pese a estas diferencias, al igual que ha sido identificado en otros campos de las denominadas políticas sociales, la tendencia en materia de atención y cuidado de los consumos problemáticos parecer ser hacia la institucionalización y territorialización de la "participación ciudadana" (Rofman y Foglia, 2015), pero también hacia lo "comunitario" (Candil, 2011; Cravino, 2008). De ello da cuenta la sanción de la Ley de Salud Mental (2010) y el Plan IACOP (2014), así como la creación de diferentes programas y el dictado de resoluciones donde, entre otras cuestiones, se reconocieron experiencias de abordaje comunitario llevadas a cabo por organizaciones eclesiales y sociales y se crearon dispositivos territoriales dependientes de la propia Sedronar (i.e. CET, CePLA, PEC y PAIS). De hecho, la reconfiguración de estos dispositivos en 2017 profundizó esta tendencia en la medida en que no sólo la DNAE elaboró un modelo propio y llevó a cabo un intenso proceso de capacitación para adecuar el trabajo en los dispositivos al modelo de abordaje propuesto; sino que, además, aumentó tanto la cantidad de dispositivos como los niveles de accesibilidad y otorgó a la participación social y comunitaria un lugar central en la implementación de la política. Más aún, la integración comunitaria, como vimos, continuó siendo uno de los pilares de la política y se mantuvo la preocupación por la integralidad e intersectorialidad así como el enfoque de derechos que caracterizó a la política pública de la gestión anterior (Abramovich, 2006; Rofman y Foglia, 2015).

No obstante, el proyecto de país en que se inscribe esta propuesta es bien diferente. Ya no se trata, como explican Rofman y Foglia (2015), de un modelo de desarrollo afincado en la recuperación del papel del Estado en el plano económico y social y en el crecimiento del mercado interno acompañados por la reorientación de las políticas sociales hacia un enfoque de derechos. Al contrario, el diseño e implementación del modelo de abordaje integral territorial se dio en el marco de un gobierno neoliberal responsable de un inusitado endeudamiento externo, el desplome de la industria nacional, el aumento del desempleo y la pobreza, y la aplicación de políticas de recorte presupuestario que se tradujeron en un rápido desfinanciamiento y desmantelamiento de las políticas sociales. En este contexto, la articulación intersectorial y la participación comunitaria como vías para el acceso, la restitución y el ejercicio de derechos, principales objetivos del modelo de abordaje de la DNAE, perdieron la institucionalidad que supieron tener en la política pública del período 2003-2015. 
Así las cosas, en un gobierno en, con y desde la comunidad, como se propone en los DIAT, el esfuerzo de la articulación intersectorial - con miras a promover el acceso, la restitución y el ejercicio de derechos - queda mayormente a cargo, como vimos, de los/as trabajadores/as del dispositivo; mientras que, en los DTC esta empresa, que aún está en manos de los equipos, en un futuro recaería idealmente en la "comunidad". Es más, en estos últimos dispositivos, la participación comunitaria, ante la ausencia de políticas universales o de amplio alcance territorial y presupuestario con un impacto social y económico significativo para sus destinatarios, parece erigirse en la principal sino única respuesta del estado. En otras palabras, frente a situaciones de vulnerabilidad, la receta es la participación social y reorganización de los recursos comunitarios, lo que, en muchos casos puede implicar, como señalamos al presentar el DTC Barrio Ceibo, la reproducción de relaciones y dinámicas barriales que socavan la posibilidad de que algunos sectores o miembros de la comunidad accedan a recursos y derechos de los que el estado debe ser garante. Pero además, en un contexto de retirada de los organismos, los programas y las burocracias estatales responsables de ejecutar las políticas sociales y de retorno a posturas prohibicionistas y una retórica belicista de combate al narcotráfico, la consolidación de la presencia de la Sedronar en los barrios populares, a partir del reconocimiento de los dispositivos de la DNAE como referentes estatales, aunada a la permanencia (con aumento de facultades y mayor discrecionalidad) de las fuerzas de seguridad (Pita, Corbelle y Brescia, 2019), bien puede abonar al refuerzo de estereotipos de larga data que ligan juventud, pobreza, drogas y delincuencia.

En síntesis, si bien el modelo de abordaje de la DNAE, que tiene por principios rectores la universalidad de los derechos, la integralidad, la reducción de vulnerabilidades, el trabajo en red e intersectorial, la accesibilidad y el bajo umbral, la participación social y comunitaria, la perspectiva de género y el enfoque intercultural, es parte de un cambio paradigmático y necesario en las políticas públicas en materia de cuidado y atención de los consumos problemáticos, y aunque, en particular, el DIAT JA y el DTC BC han logrado posicionarse como referentes locales en la materia e insertarse en redes locales, conseguido aumentar los niveles de accesibilidad, y, en casos puntuales, generado las condiciones para el acceso, la restitución y el ejercicio de derechos y procesos de integración comunitaria; lo cierto es que, sin un estado que garantice y tenga por objetivo ampliar el acceso a derechos de la población, la política en cuestión corre el riesgo de no ser más que un cascarón vacío. En otras palabras, la articulación intersectorial, el trabajo en red, y la participación social y comunitaria no son benévolas per se. Antes bien, se requiere de un contexto en que están dadas las condiciones de posibilidad para el acceso, la restitución y el ejercicio de derechos, de modo que la circulación por redes institucionales e intersubjetivas pueda desplegar su potencial terapéutico. 


\section{REFERENCIAS}

ABRAMOVICH, V. Una aproximación al enfoque de derechos en las estrategias y políticas de desarrollo. Revista CEPAL, n. 88, p. 35-50, 2006.

ARGENTINA. Ministerio de Seguridad de la Nación. Acuerdo Argentina sin Narcotráfico. Presidencia de la Nación, 2016.

ASTOLFI ROMERO, C. et al. Modelo de abordaje integral territorial de los consumos problemáticos: una experiencia de política pública. Sedronar, 2019.

AUREANO, G. R. La construction politique du toxicomane dans l'Argentine post-autoritaire: un cas de citoyenneté à basse intensité. Tesis (de Doctorado) Université de Montréal, Montréal, Canada, 1998.

BARROS, R. et al. Justificación y viabilidad del Tratamiento comunitario. Acta Psiquiátrica y Psicológica de América Latina, v. 64, n. 3, p. 185-197, 2018.

BORDONI, M.; RAMÍREZ, R. Abordaje Territorial: una aproximación desde las experiencias de trabajo de equipos DIAT y TC desplegados a lo largo del territorio argentino. In: JORNADAS NACIONALES DE DEBATE INTERDISCIPLINARIO EN SALUD Y POBLACIÓN, 13., 2018, Buenos Aires, Argentina. Anais... Buenos Aires, 2018.

CAMAROTTI, A. C.; DI LEO, P. F.; JONES, D. Entre dos mundos: abordajes religiosos y espirituales de los consumos de drogas. Ciudad Autónoma de Buenos Aires: Teseo Press, 2017.

CAMAROTTI, A. C.; KORNBLIT, A. L. Abordaje integral comunitario de los consumos problemáticos de drogas: construyendo un modelo. Salud colectiva, v. 11, n. 2, p. 211-221, 2015.

CANDIL, A. ¿Gobernar la comunidad? Reflexiones sobre la letra escrita de una política social que aborda el consumo de drogas en el Área Metropolitana de Buenos Aires. Revista Regional de Trabajo Social, v. 25, n. 52, p. 30-37, 2011. CAPRIATI, A. et al. La prevención de los consumos problemáticos de drogas desde una perspectiva comunitaria: un modelo para armar. Revista Argentina de Salud Pública, v. 6, n. 22, p. 21-28, 2015.

CHIARA, C. Distribución espacial de la población de Juana Azurduy: una aproximación a partir de los tipos de hábitat. Trabajo final (Especialista en Demografía Social) - Universidad Nacional de Luján, Buenos Aires, Argentina, 2019.

CORBELLE, F. La construcción social del 'problema de la droga' en Argentina, 1919-2018. Revista Ingesta, v. 1, n. 1, p. 14-40, 2019. 
CORDA, A. R.; GALANTE, A.; ROSSI, D. Personas que usan estupefacientes en Argentina: de delincuentes/enfermos a sujetos de derechos. Buenos Aires: Intercambios; Facultad de Ciencias Sociales de la Universidad de Buenos Aires, 2014.

CRAVINO, M. C. Teorías del barrio. In: Vivir en la villa: relatos, trayectorias y estrategias habitacionales. Los Polvorines: Universidad Nacional de General Sarmiento. 2008.

EDTCBC - EQUIPO DISPOSITIVO TRATAMIENTO COMUNITARIO BARRIO CEIBO. Informe Final 2017. Buenos Aires, 2017. Mimeografiado.

Informe de Gestión 2018 - Dispositivos de Tratamiento Comunitario Ceibo, Manuela Pedraza. Buenos Aires, 2018. Mimeografiado.

FERGUSSON, S.; GÓNGORA, A. La relación entre personas y drogas y los dispositivos de inclusión social basados en la comunidad: críticas y perspectivas desde América Latina. In: CONFERENCIA ANUAL DEL COPOLAD, 2., 2012, Bruselas. Anais... Bruselas, 2012.

FERREYRA, F. G. Un nuevo paradigma en salud social: el Programa Recuperar Inclusión en la Sedronar del sacerdote Molina (2013-2015). De Prácticas y discursos, v. 8, n. 11, p. 3-28, 2019.

GALANTE, A. et al. Del adicto recuperado al operador socioterapéutico: la importancia de la intervención estatal en los procesos de profesionalización. In: JORNADAS DE SOCIOLOGÍA DE LA UBA, 10., 2013, Buenos Aires. Anais... Buenos Aires, 2013.

GARBI, S. L. La administración de la palabra en las Comunidades Terapéuticas. In: EPELE, M. Padecer, cuidar, tratar: estudios socio-antropológicos sobre consumo problemático de drogas. Buenos Aires: Antropofagia, 2012.

GUPTA, A.; FERGUSON, J. Spatializing states: towards an ethnography of neoliberal governmentality. American Ethnologist, v. 29, n. 4, p. 981-1002, 2002.

INCHAURRAGA, S. et al. Drogas: haciendo posible lo imposible - experiencia de reducción de daños en Argentina. Rosario: CEADS-UNR; ARDA, 2003.

INDEC - INSTITUTO NACIONAL DE ESTADÍSTICAS Y CENSOS. Censo Nacional de Población, Hogares y Vivienda 2010. Buenos Aires: INDEC, 2010.

LEVIN, L. G. Pastores, psicólogos y psiquiatras - disputas en los tratamientos públicos para adictos en la Argentina, 1970-2005. Eä Journal, v. 5, n. 1, 2013.

LÓPEZ BOUSCAYROL, M. Analizando rutinas y prácticas estatales - Políticas públicas en materia de drogas: la transición del CePLA al DIAT. In: REUNIÓN DE ANTROPOLOGÍA DEL MERCOSUR, 12., 2017, Misiones, Argentina. Anais... Misiones, 2017. 
MACHÍN, J. Modelo ECO2: redes sociales, complejidad y sufrimiento social. REDES - Revista hispana para el análisis de redes sociales, v. 18, n. 12, 2010.

MANZANO, V. Política, cultura y el problema de las drogas en la Argentina, 1960-1980s. Apuntes de investigación del CECYP, v. 24, n. 1, p. 51-78, 2014.

MAYNTZ, R. El Estado y la sociedad civil en la gobernanza moderna. Revista del CLAD Reforma y Democracia, n. 21, 2001.

MILANESE, E. Tratamiento Comunitario - Manual de trabajo I. Brasil: Associação de Formação e Reeducação Lua Nova, 2016.

OAD - OBSERVATORIO ARGENTINO DE DROGAS. Estudio nacional en población de 12 a 65 años, sobre consumo de sustancias psicoactivas - Informe de Resultados $\mathbf{N}^{\circ}$ 1: magnitud del consumo de sustancias a nivel nacional. Argentina: Sedronar, 2017.

. Censo Nacional de Centros de Tratamiento. Argentina: Sedronar, 2018. . Diagnóstico Integral Comunitario Barrio Ceibo - Manuela Pedraza. Buenos Aires: Sedronar, 2019.

PAWLOWICZ, M. P. et al. Dispositivos de atención para usuarios de drogas: heterogeneidad y nudos problemáticos. In: BLANCK, E. (Coord.). Panorámicas de salud mental a un ańo de la sanción de la Ley nacional no 26.657. Buenos Aires: Eudeba, 2011.

PITA, M. V.; CORBELLE, F.; BRESCIA, F. Las formas de la violencia policial: anatomía y gramática del poder policial en los barrios populares de la Ciudad de Buenos Aires. Ciudad de Buenos Aires: Malón, 2019.

ROFMAN, A.; FOGLIA, C. La participación ciudadana local en la historia argentina reciente (de los '90 a la actualidad): asistencia, movilización, institucionalización. Revista Estado y Políticas Públicas, n. 5, p. 41-61, 2015.

ROSE, N. ¿La muerte de lo social? Re-configuración del territorio de gobierno. Revista Argentina de Sociología, v. 5, n. 8, p. 111-150, 2007.

SALESSI, J. Médicos maleantes y maricas. Rosario: Beatriz Viterbo, 1995.

SEDRONAR - SECRETARÍA DE POLÍTICAS INTEGRALES SOBRE DROGAS DE LA NACIÓN ARGENTINA. Manual Casas Educativas Terapéuticas (CET). Buenos Aires: Sedronar, $2014 a$.

. Manual Centros Preventivos Locales en Adicciones (CePLA). Buenos Aires: Sedronar, 2014b. 
Modelo de Abordaje Comunitario (MAC) - La experiencia de la Red Federal de Puntos de Encuentro Comunitario (PEC). Buenos Aires: Sedronar, 2015.

Dispositivos integrales de abordaje territorial (DIAT). Sedronar, 2017a. Seminario de formación sobre estrategias de abordaje territorial - módulos 1 a 3. Buenos Aires: Sedronar, 2017b. v. 1-2.

SERRANO, I.; BARROS, R.; MILANESE, E. Sistema Estratégico de Resultados (SER): Manual 2017. RAISSS, 2017.

SHORE, C. La antropología y el estudio de la política pública: reflexiones sobre la "formulación" de las políticas. Antípoda, n. 10, p. 21-49, 2010.

TISCORNIA, S. Poder de policía, costumbres locales y derechos humanos en Buenos Aires de los 90. Revista Antropolítica, n. 9, p. 101-118, 2000.

TOUZÉ, G. Saberes y prácticas sobre drogas: el caso de la pasta base de cocaína. Buenos Aires: Intercambios Asociación Civil, 2006.

TOUZÉ, G. et al. Prevención del VIH/SIDA en usuarios de drogas. Buenos Aires: Intercambios Asociación Civil, 1999.

TNI - TRANSNATIONAL INSTITUTE. El paco bajo la lupa: el mercado de la pasta base de cocaína en el Cono Sur. TNI Briefing series, n. 4, 2006.

TUFRÓ, F. Presentación. In: ASTOLFI ROMERO, C. et al. Modelo de abordaje integral territorial de los consumos problemáticos: una experiencia de política pública. Sedronar, 2019.

TUFRÓ, F.; CARROLI, M. Tratamiento Comunitario, una experiencia de registro, sistematización, y evaluación de abordaje territorial integral. In: JORNADAS NACIONALES DE DEBATE INTERDISCIPLINARIO EN SALUD Y POBLACIÓN, 13., 2018, Buenos Aires, Argentina. Anais... Buenos Aires, 2018.

WEISSMANN, P. Toxicomanías: historia de las ideas psicopatológicas sobre el consumo de drogas en la Argentina. Mar del Plata: Universidad Nacional de Mar del Plata, 2005.

ZICCARDI, A. Las políticas y los programas sociales de la ciudad del siglo XXI. Papeles de Población, v. 14, n. 58, p. 127-139, 2008.

\section{BIBLIOGRAFÍA COMPLEMENTAR}

ARGENTINA. Ley no11.309. Modificación de los artículos 204 y 205. Anales de Legislación Argentina, v. 1820-1942, p. 190, 1924. 
. Ley no 11.331 . Modificación de la Ley n⿳o 11.309 sobre tráfico de alcaloides. Anales de Legislación Argentina, v. 1820-1942, p. 195, 1926.

. Código Civil de la República Argentina. 1968.

. Ley no 17.567. Reforma del Código Penal. En: Anales de Legislación Argentina, v. XXVII-C 1967, p. 2867-2910, 1968.

. Ley no 20.771. Estupefacientes - Concepto - Penas para quienes intervengan en la producción, venta y/o tráfico - Diversos supuestos de comisión del delito - Modificación del código penal. Anales de Legislación Argentina, v. XXXIV-D 1974, p. 3312-3313.

. Ley no 23.737, de 21 de septiembre de 1989. Modificación al Código Penal - Narcotráfico. Buenos Aires, 10 oct. 1989.

. Ley no 24.455, de 8 de febrero de 1995. Prestaciones obligatorias que deberán

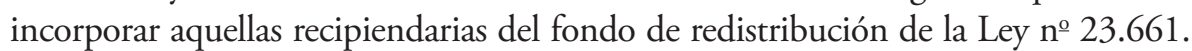
Buenos Aires, 1 mar. 1995.

. Ley no 24.754, de 28 de noviembre de 1996. Establécese que las empresas o entidades que presten dichos servicios deberán cubrir, como mínimo, determinadas "prestaciones obligatorias" dispuestas por las obras sociales. Buenos Aires, 23 dec. 1996.

. Ley no 26.657, de 25 de noviembre de 2010. Ley Nacional de Salud Mental. Buenos Aires, 2 dic. 2010.

. Ley no 26.934, de 30 de abril de 2014. Plan Integral para el Abordaje de los Consumos Problemáticos (Plan IACOP). Buenos Aires, 28 mayo 2014.

. Código Civil y Comercial de la Nación. Buenos Aires: Infojus, 2014.

BUENOS AIRES. Ministerio de Infraestructura y Servicios Públicos de la Provincia de Buenos Aires. Subsecretaría Social de Tierras, Urbanismo y Vivienda. Registro Público Provincial de Villas y Asentamientos Precarios (RPPVAP). Buenos Aires, 2012.

PRESIDENCIA DE LA NACIÓN. Decreto no 48/14, de 14 de enero de 2014. Modifica el Decreto no 357/2002. Buenos Aires, 17 ene. 2014.

. Decreto no 518/14, de 9 de abril de 2014. Apruébase la estructura organizativa de primer nivel operativo. Buenos Aires, 16 abr. 2014.

. Decreto no 228/16, de 21 de enero de 2016. Declárase la Emergencia de Seguridad Pública. Buenos Aires, 22 ene. 2016.

. Decreto no 1249/16, de 7 de diciembre de 2016. Emergencia nacional en materia de adicciones. Buenos Aires, 12 dic. 2016. 
. Decreto $\mathrm{n}^{\circ}$ 683/18, de 23 de julio de 2018. Sustituyense los articulos $1^{\circ}$, 3o, 23 y 24 del decreto no 727/2006. Buenos Aires, 24 jul. 2018.

SEDRONAR - SECRETARÍA DE POLÍTICAS INTEGRALES SOBRE DROGAS DE LA NACIÓN ARGENTINA. Resolución no 41/92, [s.d.].

. Resolución no 266/14, de 26 de junio de 2014. Apruebese el programa integral de atencion, asistencia e integracion de personas que presentan un consumo problematico de sustancias que como anexo i forman parte integral de la presente. Buenos Aires, 19 ago. 2014.

Resolución no 204/15, de 15 de octubre de 2015. Apruébese el Programa de apoyo a la integración socio-laboral (Programa PAIS) que como anexo i forma parte integral de la presente resolución. Buenos Aires, 22 oct. 2015.

. Resolución no 150-E/17, de 21 de abril de 2017. Deroguense las resoluciones Sedronar n⿳⺈ 316 del 19 de noviembre de 2015 y 352 del 30 de noviembre de 2015. Apruebese el programa dispositivos integrales de abordaje territorial (DIAT) que como anexo (IF- 2017-06932543-APN-Sedronar) integra la presente resolucion. Buenos Aires, 26 abr. 2017.

. Boletín estadístico y geográfico de los dispositivos de abordaje territorial: DIAT y DTC. Buenos Aires: Sedronar, 2018.

SEDRONAR; Ministerio de Salud de la Nación. Resolución conjunta no 160-3/95,

. Resolución conjunta no 361-153/97, de 11 de junio de 1997. Establécense normas de categorización para aquellos establecimientos que brindan Servicios Preventivos - Asistenciales en Drogadependencia. Buenos Aires, data de publicação.

. Resolución conjunta no 362-154/97, 11 de junio de 1997. Apruébase el Programa Terapéutico Básico para el Tratamiento de la Drogadicción que deberá ser cumplimentado por todas las Obras Sociales y Asociaciones de Obras Sociales del Sistema Nacional del Seguro de Salud incluidas en la Ley no 23.660 y las empresas o entidades prestadoras de servicios de medicina prepaga. Buenos Aires, 23 jul. 1997.

SEDRONAR; Secretaría de Gobierno de Salud. Resolución conjunta nº 5/2019, de 14 de junio de 2019. Apruebanse las pautas para la organizacion y funcionamiento de establecimientos de tratamiento en consumos problematicos y lineamientos de adecuacion institucional, mencionadas en el anexo I. Buenos Aires, 18 jun. 2019. 
ANEXO A

\section{SIGLAS Y ABREVIATURAS}

ANSES Administración Nacional de la Seguridad Social

CAAC Casas de Atención y Acompañamiento Comunitario

CAJ Centro de Acceso a Justicia

CAPS Centro de Atención Primaria de la Salud

CDR Centro de Referencia

CEDECOR Centro de Orientación en Adicciones

CePlA Centros Preventivos Locales de Adicciones

CET Casas Educativas Terapéuticas

CESOC Centro Sociocomunitario de Responsabilidad Penal Juvenil

CPA Centro de Prevención de las Adicciones

CT Comunidad Terapéutica

DIAT Dispositivo Integral de Abordaje Territorial

DNAE Dirección Nacional de Abordaje Estratégico

DTC Dispositivo de Tratamiento Comunitario

ECO2 Epistemología de la Comunidad/Ética y Comunitaria

EDI Equipo Distrital de Inclusión

EDIA Equipo Distrital de Infancias y Adolescencias

$\mathrm{OAD} \quad$ Observatorio Argentino de Drogas

OPISU Organismo Provincial de Integración Social y Urbana

PAIS Programa de Apoyo a la Integración Socio-Laboral

PEC Puntos de Encuentro Comunitario

Plan IACOP Plan Integral de Abordaje de los Consumos Problemáticos

Programa HF Programa Hacemos Futuro

REPROPER Registro Provincial de las Personas

SISU Secretaría de Integración Socio-Urbana

SEDRONAR Secretaría de Políticas Integrales sobre Drogas

TC Tratamiento Comunitario 


\section{ANEXO B}

MAPA B. 1

Localización de los estudios de caso

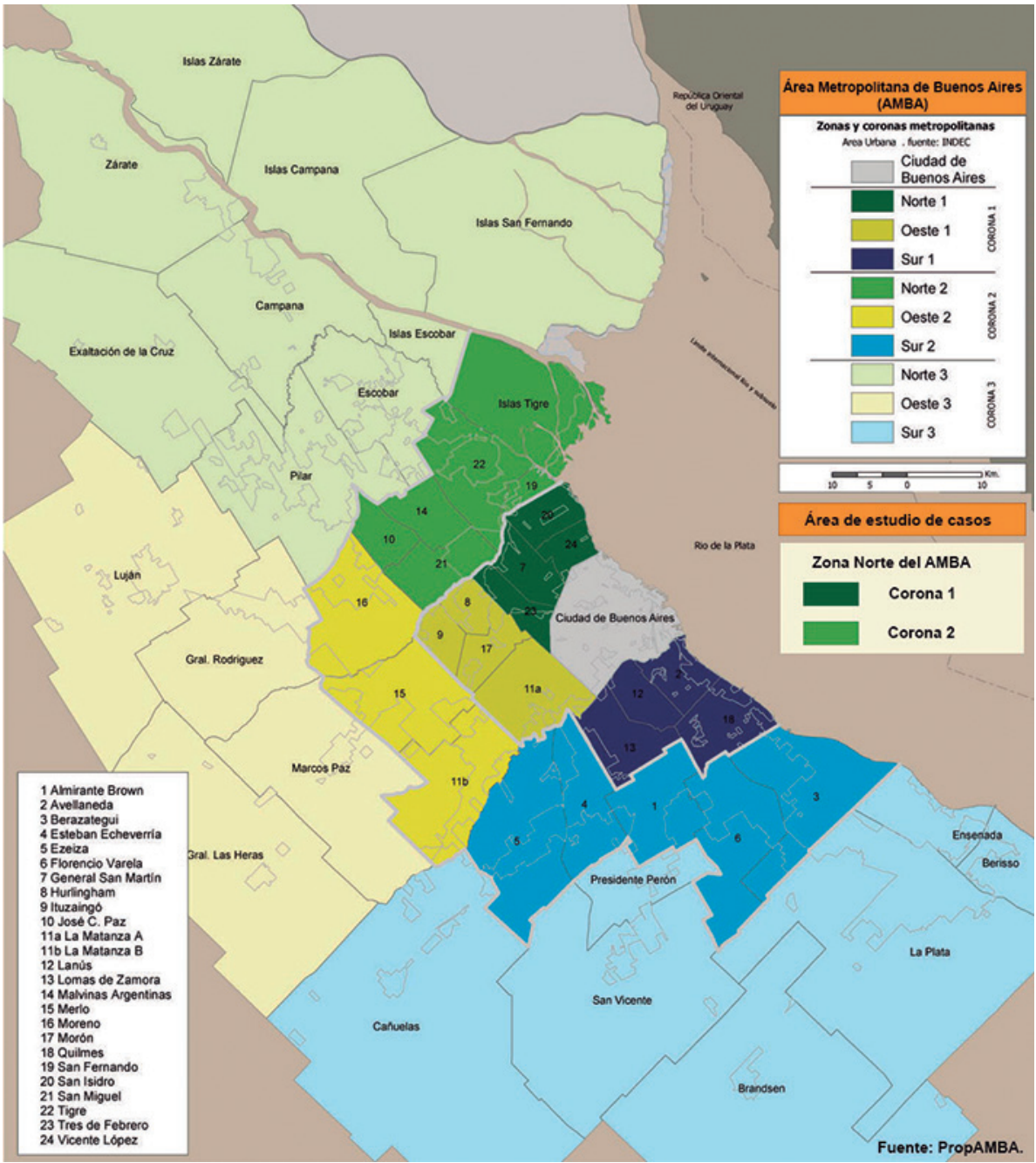

Fonte: PropAmba. 


\section{ANEXO C}

FIGURA C.1A

\section{Sedronar DIAT DTC}

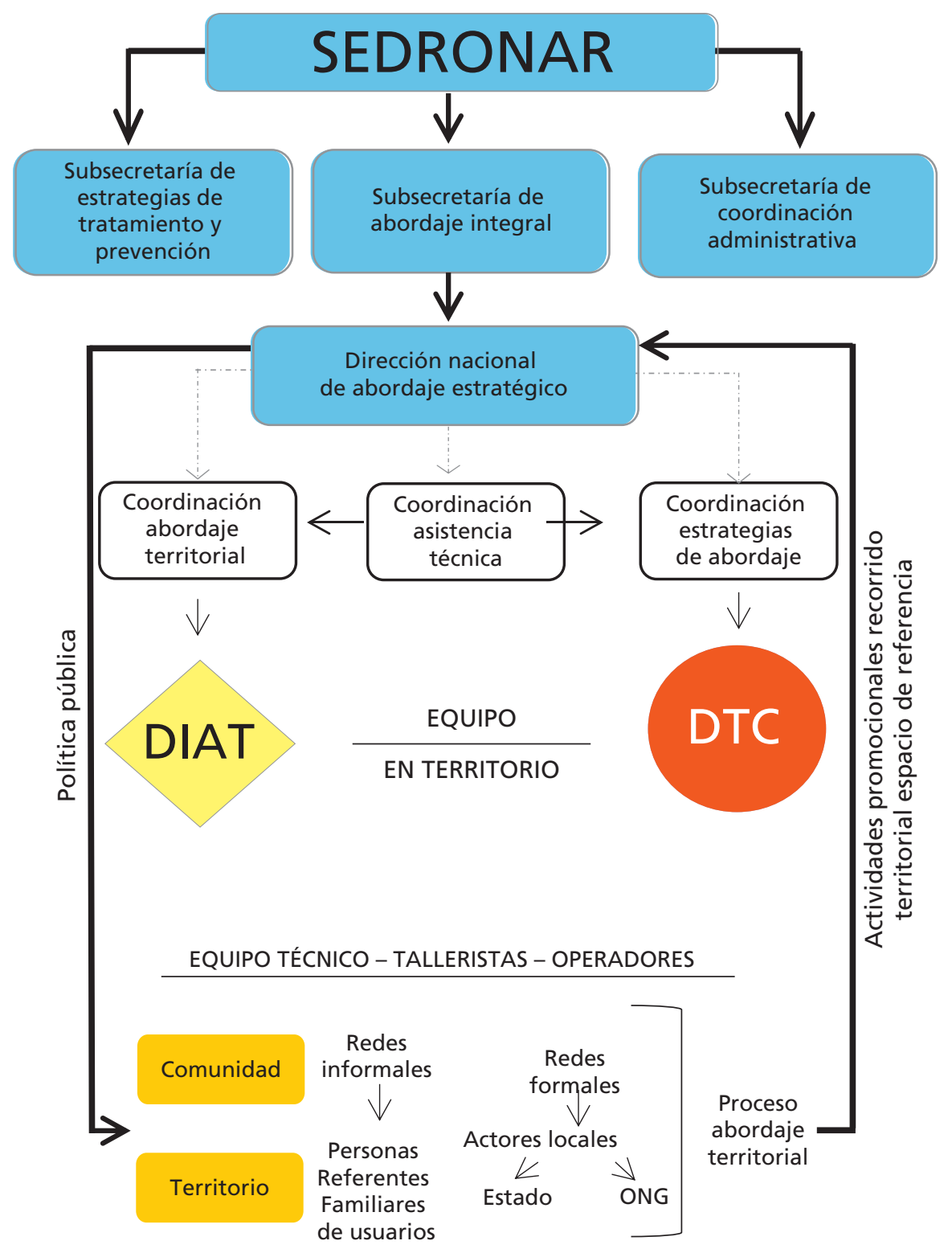




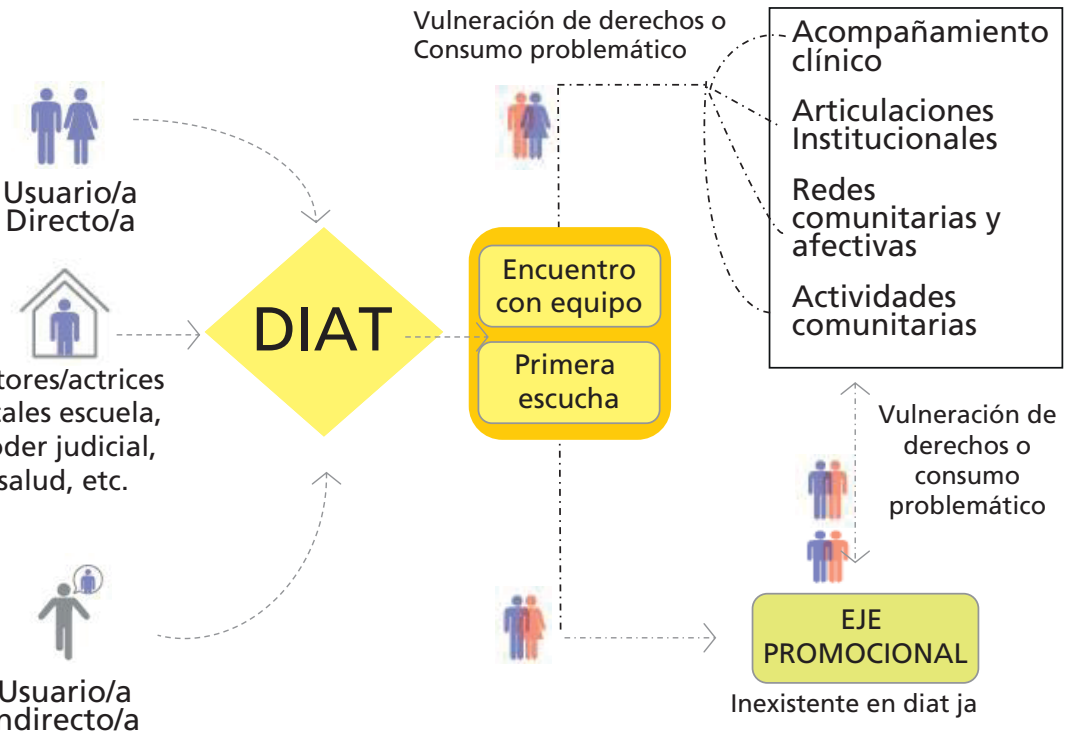

Espacios de escucha activa y bajo umbral de acceso

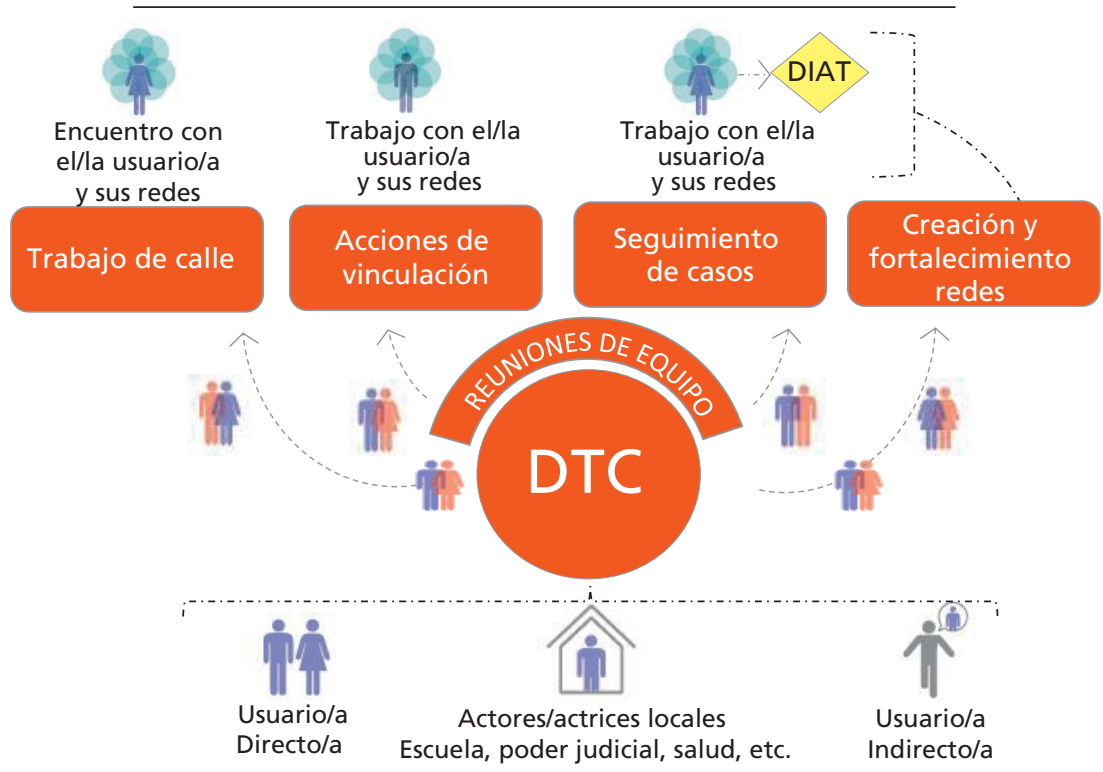

Elaboración de la autora. 
FIGURA C.2

DIAT JA

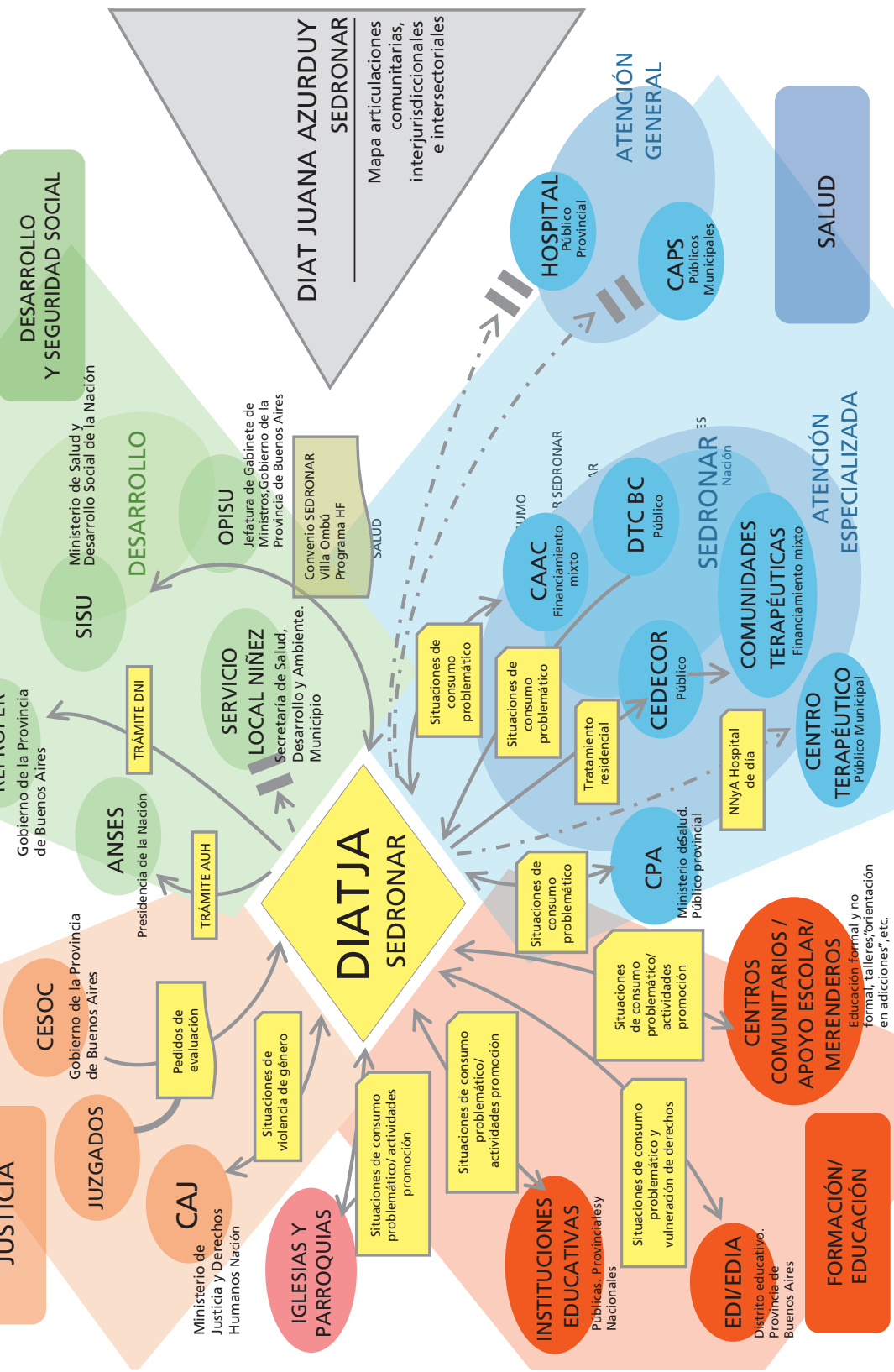

Elaboración de la autora. 
FIGURA C.3

DTC BC

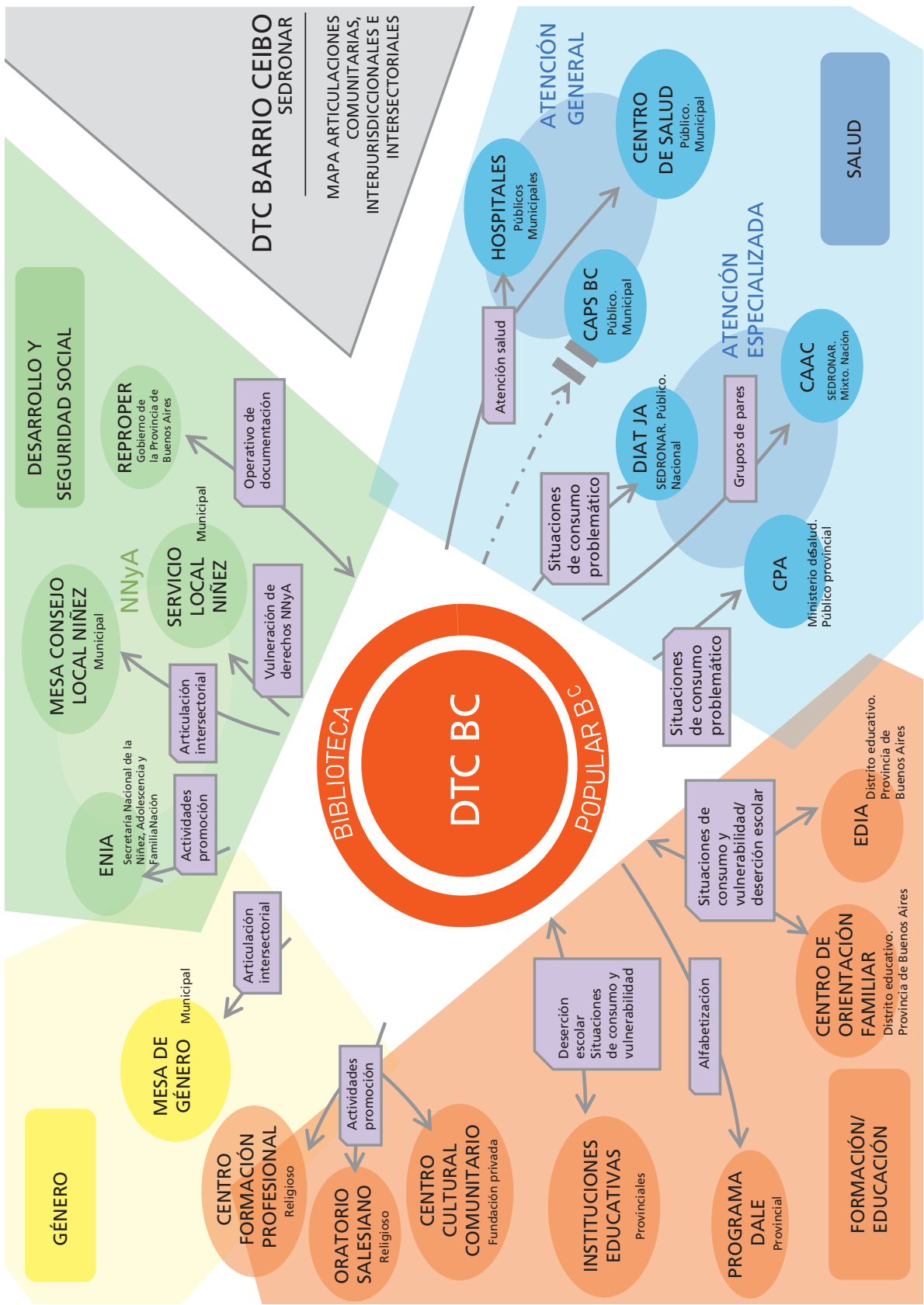




\section{POLÍTICAS DE CUIDADO A USUÁRIOS DE ÁLCOOL E OUTRAS DROGAS NO BRASIL: EVOLUÇÃO HISTÓRICA E DESAFIOS DE IMPLEMENTAÇÃO}

Maria Paula Gomes dos Santos ${ }^{1}$

Roberto Rocha C. Pires ${ }^{2}$

\section{INTRODUÇÃO}

Por quase todo o século XX, as aproximaçóes do Estado brasileiro com as pessoas identificadas como usuários de drogas se deram, predominantemente, por meio de seu braço penal. Desde que internalizou, em legislação pátria, acordos e convenções internacionais que recomendavam maior controle sobre a produção, o comércio e o uso de determinadas substâncias (hoje conhecidas como drogas), no início dos anos 1920, o Brasil passou a impor, a estas pessoas, penas privativas de liberdade, em cárceres comuns ou manicômios. Somente no fim daquele século que as necessidades de cuidados específicos a este público ganhariam espaço em agendas governamentais, tornando-se objeto de políticas públicas assistenciais.

Nesse meio tempo, cuidados aos chamados toxicômanos ${ }^{3}$ eram providos por instituiçóes médicas, filantrópicas e religiosas, que muitas vezes emulavam experiências mais ou menos bem-sucedidas em outros países (principalmente nos Estados Unidos), todas elas voltadas ao propósito de promover a abstinência e a "reinserção" de tais pessoas na sociedade, como sujeitos disciplinados, economicamente produtivos e politicamente dóceis.

A partir do novo século, uma reforma da política brasileira de saúde mental ${ }^{4}$ reorientaria o modelo assistencial a pessoas em sofrimento mental, tendo em vista reduzir a centralidade das internações psiquiátricas em favor da intensificação de cuidados de base comunitária, ${ }^{5}$ em serviços abertos. Estas mesmas providências

1. Técnica de planejamento e pesquisa na Diretoria de Estudos do Estado, Instituiç̧ões e Democracia (Diest) do Ipea.

2. Técnico de planejamento e pesquisa na Diest/lpea.

3. Utilizamos neste estudo a terminologia empregada ao longo de grande parte do século XX.

4. Lei no 10.216/2001 (Brasil, 2001).

5. Segundo Góngora, Salazar e Borja (2020): "O Tratamento Baseado na Comunidade (TCC) (...) propõe uma abordagem do problema do consumo de drogas a partir de um modelo sistêmico (denominado ECO2) segundo o qual a vulnerabilidade dos usuários de drogas está fortemente relacionada à estrutura e densidade de suas redes sociais" (Machín, 2010; 2011; Milanese, 2005; 2010; 2012). 
seriam, em seguida, estendidas à assistência de usuários de álcool e outras drogas (Brasil, 2003). Além do cuidado em liberdade, a nova política do Ministério da Saúde (MS) para este público instituiria a redução de danos (RD), como princípio e ética do cuidado: a Política de Atenção Integral a Usuários de Alcool e outras Drogas - Pauad (Brasil, op. cit.). Esta política seria implementada em todo o território nacional até os dias atuais, por meio do Sistema Único de Saúde (SUS).

Em 2006, uma mudança na legislação sobre drogas ${ }^{6}$ estabeleceria a diferenciação penal entre os crimes de tráfico e uso de drogas, abolindo penas privativas de liberdade para usuários e atribuindo ao Estado a responsabilidade de pôr à disposição destes, serviços de assistência à saúde. Por certo, estas mudanças não resultaram no desaparecimento da criminalização do usuário de drogas, nem das instituições assistenciais fechadas ou de tratamentos focados exclusivamente na abstinência no país. De um lado, como demonstrado por diferentes autores, agentes da base dos sistemas brasileiro de justiça e segurança pública, com sua persistente seletividade penal, permaneceriam tratando, como traficantes, aqueles usuários que provêm dos estratos sociais mais vulneráveis da sociedade (Boiteux, 2006; Campos, 2015). De outro, modelos assistenciais pautados na internação e na abstinência continuariam recebendo financiamento público e exercendo forte apelo sobre a sociedade, a despeito de seu sucesso controverso (Santos, 2018).

Os abalos ocorridos no ambiente político brasileiro nos últimos anos, que levaram ao impeachment presidencial de 2016 e à reorientação de diversas políticas públicas nacionais, propiciaram também uma nova inflexão nas políticas sobre drogas. Desde então, novos regulamentos ${ }^{7}$ têm determinado a proscrição das práticas de $\mathrm{RD}$, recolocando a centralidade da abstinência e das internaçóes em meio fechado nos programas de assistência a usuários de drogas do país. Este processo, ainda em curso, se dá em meio a muitos conflitos e resistências - entre $\mathrm{o}$ atual governo federal, de um lado, e os governos subnacionais e as organizaçóes da sociedade civil (OSCs), de outro -, amplificando um confronto entre modelos de cuidado que, à análise de sua camada mais profunda, revela um dissenso maior, em torno do estatuto social das drogas e do lugar social de seus usuários.

Este capítulo visa traçar as grandes linhas desse quadro e abordar, em detalhes, a implementação da Pauad de 2003. Esta política representou uma mudança de paradigma na atenção a pessoas com problemas decorrentes do consumo de substâncias psicoativas, não só porque deslocou o primado da abstinência, mas também porque traz implícito, em sua concepçáo, o desafio de restituir os direitos de cidadania a estas pessoas. Considerando este desafio, nos interessa também, por intermédio da

6. Lei no 11.343/2006 (Brasil, 2006).

7. No dia 11 de abril de 2019, o presidente Bolsonaro assinou o Decreto no 9.761/2019, aprovando a nova Política Nacional sobre Drogas (PNAD) e revogando inteiramente o Decreto no 4.345, de 26 de agosto de 2002. 
análise das práticas cotidianas de sua implementação, refletir sobre as possibilidades e os limites desta política, de assegurar ou restituir o acesso destas pessoas aos seus direitos fundamentais.

O capítulo inicia-se com uma breve recuperação histórica sobre a evolução do estatuto jurídico dos usuários de drogas no país (seção 1), bem como da oferta de assistência e cuidado a estas pessoas (seção 2). Em seguida, apresenta-se a política do MS de atenção integral a usuários de álcool e outras drogas, instituída no início dos anos 2000 (seção 3). Dando continuidade, analisamos a implementação desta política na realidade do Distrito Federal (seção 4). Por fim, discutimos alguns achados da pesquisa feita no DF, que se mostram relevantes para a compreensão dos desafios apresentados no processo de transformação das modalidades de atenção e cuidado pretendidas pela Pauad, de 2003, com especial atenção para as suas repercussóes no atendimento aos segmentos vulnerabilizados da população (seção 5).

\section{HISTÓRICO DA REGULAÇÃO DO USO DE DROGAS NO BRASIL}

A trajetória das políticas de regulação do uso de substâncias denominadas drogas no Brasil não se distingue muito da de outros países, principalmente os da região latino-americana. Em grande medida, estas políticas têm origem em preocupaçóes de setores da medicina com os efeitos hiatrogênicos de substâncias utilizadas na prática médica, desde o fim do século XIX, como analgésicos - a morfina e a cocaína.

A essas preocupaçôes, e também a movimentos geopolíticos protagonizados pelas naçóes então mais poderosas, seguiram-se acordos e convençôes internacionais que incitaram os países signatários à proscrição do uso de determinadas substâncias, os quais se sucederam, a longo do século XX, ampliando cada vez mais o leque de substâncias proscritas e o número de países envolvidos. Foi assim que, em pouco mais de cem anos, um vigoroso mercado internacional de substâncias psicoativas foi substituído por um consenso internacional em torno da proibição do uso e da produção do comércio destas (Rodrigues, 2008).

No Brasil, a primeira norma repressiva ao uso da maconha havia sido editada na primeira metade do século XIX: "É proibida a venda e o uso do 'pito de pango', ${ }^{8}$ bem como a conservação dele em casas públicas: os contraventores serão multados, a saber, em $20 \$ 000$, e os escravos, e mais as pessoas que deles usarem, em três dias de cadeia" (Petuco, 2019, p. 46 apud Robinson, 1999, p. 116). ${ }^{9}$

Essa medida dirigia-se, entretanto, às classes populares - majoritariamente integradas por pessoas negras e escravizadas, às vezes forras - que, na capital do Império, mantinham o costume de se reunirem em "rodas" para fumar o tal pito.

8. Como era então conhecido o cigarro de maconha.

9. Art. 7o da Lei de Posturas da Cidade do Rio de Janeiro. 1830. Câmara Municipal do RJ. 
Tinha-se aí mais uma entre diversas iniciativas destinadas à criminalização de um extenso rol de práticas socioculturais cultivadas por aquelas pessoas, tais como a capoeira e os rituais sagrados de matriz africana (Petuco, 2019; Souza, 2016).

Segundo Adiala (2016), a representação hegemônica sobre o uso de substâncias, hoje denominadas drogas, como patologia definida em categoria diagnóstica específica - a toxicomania - teria sido a pedra de toque para o movimento de repressão ao seu uso e é neste sentido, portanto, que se pode dizer que o estatuto social do uso de drogas é essencialmente medicalizado (Fiore, 2006, p. 41). Na virada do século XIX para o XX, o morfinismo e o cocainismo seriam identificados como "vícios elegantes", visto que afetavam as classes mais abastadas (Adiala, 2016). À mesma época, o alcoolismo também seria considerado problemático, mas sobretudo quando presente nas classes populares (Santos, 1995 apud Petuco, 2019). Teorias higienistas e eugenistas, muito influentes então, fomentavam a percepção de que a toxicomania, o alcoolismo e o canabismo provocavam "taras degenerativas", causadoras da desgenerescência das famílias e da própria espécie (Adiala, 2016; Petuco, 2019; Santos, 1995). Segundo Boiteux e Pádua (2014, p. 66), "essa visão higienista do período serviu de inspiração para a internação obrigatória que hoje existe como política pública”.

A sugestão de controle, pelos estados nacionais, sobre a morfina, a cocaína e os seus derivados adviria das primeiras Conferências do Ópio, do início do século XX - Xangai, em 1909; e Haia, em 1912 (Adiala, 2016; Carvalho, J., 2014). Mas o Brasil só internalizaria estas recomendaçóes em 1921, quando foi instituída, pela primeira vez, em território brasileiro, a proibição da venda não expressamente autorizada destas substâncias. ${ }^{10} \mathrm{O}$ mesmo decreto determinaria também a construção de um sanatório para internação dos toxicômanos (Adiala, 2016, p. 89). A figura jurídica deste espaço seria tipificada, "pela primeira vez, numa legislação brasileira" (Fiore, 2006, p. 30), ainda no mesmo ano.

A consolidação das políticas repressivas ao uso de diversas substâncias psicoativas se daria a partir dos anos 1930, quando se inicia o longo governo do presidente Getúlio Vargas. ${ }^{11}$ Num contexto político doméstico caracterizado pela crescente redução das liberdades individuais e coletivas, e diante de um cenário internacional de avanço da coordenação entre países liderada pela Liga das Nações, ${ }^{12}$ o governo de Vargas ratifica recomendações da Convenção de Genebra de

10. Por meio do Decreto o 4.294/1921.

11. Getúlio Vargas foi presidente da República do Brasil em dois períodos: de 1930 a 1945 e de 1951 a 1954. Chegou ao seu primeiro e longo mandato por meio de um golpe de estado, que passou à história com o nome de Revolução de 1930. A despeito do forte viés autoritário de seu governo, foi responsável pela grande arrancada da industrialização brasileira, assim como pela atribuição de direitos sociais à classe trabalhadora. Visto ao mesmo tempo como ditador e "pai dos pobres", Vargas seria eleito, com ampla margem de favoritismo, à presidência da República seis anos após ter sido apeado do poder. Cometeu suicídio em 1954, devido a acusações de corrupção que atingiram seu governo.

12. Criada em 1919, após a Primeira Guerra Mundial. 
$1931,^{13}$ não só limitando a fabricação e distribuição de morfina, cocaína, heroína e canabis, mas criando também as comissóes nacional e estaduais de controle de entorpecentes (Carvalho, J., 2014; Souza, 2016; Boiteux e Pádua, 2014). Todas as normas editadas no período previam pena de prisão aos infratores (comerciantes), ou sua internação compulsória em hospícios (usuários).

Segundo o jurista Carvalho, S. (2014), a década de 1950 consolida o estereótipo moral do consumidor de drogas como "devasso", "degenerado" e "perigoso". Somente na década de 1960, quando o uso de algumas substâncias (especialmente, canabis e LSD) dissemina-se entre a juventude, na esteira da contracultura, que se difunde o "pânico moral que deflagrará intensa produção legislativa em matéria penal” (Carvalho, J., 2014, p. 64-65, grifo nosso). Ainda segundo o jurista, neste momento, avança a "ideologia da diferenciação", segundo a qual caberia à legislação penal fazer distinção entre as condutas de uso e de tráfico de drogas. A primeira, devendo ser tratada como doença e a segunda como delinquência. Contudo, as normas brasileiras do período manteriam, até 1976, o mesmo tratamento penal para usuários e comerciantes, prevendo para ambos pena privativa de liberdade em prisôes ou manicômios. ${ }^{14}$

Em 1976, com a edição da Lei de Drogas, o uso e o tráfico passariam a receber tratamentos distintos. Em seu art. 16, esta lei estabelecia a criminalização de condutas implicadas no uso de substâncias; ${ }^{15}$ e no art. 12 , figurariam as condutas associadas ao tráfico e às penas decorrentes. ${ }^{16}$ Esta lei daria o tom da política de drogas no país pelos trinta anos seguintes, vindo a ser substituída em 2006 (Lei no 11.343/2006), quando o país experimentava um ambiente político democrático.

A nova regulação trazia como novidade a suspensão de penas privativas de liberdade para usuários, embora aumentasse o tempo de encarceramento e o valor das multas atribuídas àqueles incriminados como traficantes. Ainda que mantida sua classificaçáo como crime, o uso ou a posse de drogas para uso pessoal, objeto do art. 28, passou a ser penalizado com as chamadas "penas alternativas", a saber: "I - advertência sobre os efeitos das drogas; II - prestação de serviços à comunidade; III - medida educativa de comparecimento a programa ou curso educativo"

13. Decreto no $113 / 1934$.

14. Decreto no $385 / 1968$.

15. "Adquirir, guardar ou trazer consigo, para o uso próprio, substância entorpecente ou que determine dependência física ou psíquica, sem autorização ou em desacordo com determinação legal ou regulamentar", penalizadas com "detenção, de 6 (seis) meses a 2 (dois) anos, e pagamento de (vinte) a 50 (cinqüenta) dias-multa" (Brasil, 1976).

16. "Importar ou exportar, remeter, preparar, produzir, fabricar, adquirir, vender, expor à venda ou oferecer, fornecer ainda que gratuitamente, ter em depósito, transportar, trazer consigo, guardar, prescrever, ministrar ou entregar, de qualquer forma, a consumo substância entorpecente ou que determine dependência física ou psíquica, sem autorização ou em desacordo com determinação legal ou regulamentar". Pena: "Reclusão, de 3 (três) a 15 (quinze) anos, e pagamento de 50 (cinquenta) a 360 (trezentos e sessenta) dias-multa" (Brasil, 1976). 
(Brasil, 2006). As condutas relativas ao tráfico, tratadas principalmente no art. 33, ${ }^{17}$ tornaram-se passíveis de penas de "Reclusão de 5 (cinco) a 15 (quinze) anos e pagamento de 500 (quinhentos) a 1.500 (mil e quinhentos) dias-multa" (Brasil, 2006).

De acordo com Campos (2015, p. 31), os legisladores teriam visado, com essa norma, remeter usuários de drogas para o sistema de saúde, deslocando-os do sistema de justiça criminal. Com efeito, a mesma lei determinaria a criação de um Sistema Nacional de Políticas de Drogas (Sisnad), prevendo "medidas para prevenção do uso indevido, atenção e reinserção social de usuários e dependentes de drogas" (Brasil, 2006, art. 1º). As atividades de atenção a usuários e dependentes de drogas, por sua vez, deveriam observar:

I - respeito ao usuário e ao dependente de drogas, independentemente de quaisquer condiçóes, observados os direitos fundamentais da pessoa humana, os princípios e diretrizes do Sistema Único de Saúde e da Política Nacional de Assistência Social;

II - a adoçáo de estratégias diferenciadas de atenção e reinserção social do usuário e do dependente de drogas e respectivos familiares que considerem as suas peculiaridades socioculturais;

III - definição de projeto terapêutico individualizado, orientado para a inclusão social e para a redução de riscos e de danos sociais e à saúde;

IV- atenção ao usuário ou dependente de drogas e aos respectivos familiares, sempre que possível, de forma multidisciplinar e por equipes multiprofissionais;

V- observância das orientaçóes e normas emanadas do Conad; ${ }^{18}$

VI - o alinhamento às diretrizes dos órgãos de controle social de políticas setoriais específicas (Brasil, 2006, art. 22).

Enfatizando o respeito aos direitos fundamentais, às peculiaridades socioculturais e à singularidade das pessoas enquadradas como usuários ou dependentes de drogas, e a observância das diretrizes das políticas de saúde e assistência social, a lei aponta para uma abordagem assistencial ao usuário, em lugar da resposta penal, até então praticada no país.

Ao lado dessas determinaçóes, a legislação incidente sobre os cuidados em saúde mental, aprovada alguns anos antes (Lei da Reforma Psiquiátrica), ${ }^{19}$ estabelecera que internaçóes hospitalares aconteçam somente "quando os recursos

17. "Importar, exportar, remeter, preparar, produzir, fabricar, adquirir, vender, expor à venda, oferecer, ter em depósito, transportar, trazer consigo, guardar, prescrever, ministrar, entregar a consumo ou fornecer drogas, ainda que gratuitamente, sem autorização ou em desacordo com determinação legal ou regulamentar" (Brasil, 2006).

18. Conselho Nacional de Políticas sobre Drogas.

19. Lei no 10.216/2001, conhecida como Lei da Reforma Psiquiátrica 
extra-hospitalares se mostrarem insuficientes" (Brasil, 2001), instituindo, em seu lugar, a atenção psicossocial de base comunitária. Este modelo seria estendido, logo em seguida, às pessoas com problemas decorrentes do uso de álcool e outras drogas, ${ }^{20}$ que passariam a contar com serviços públicos específicos para sua condição, subordinados à orientação da mesma política de saúde mental e seus órgãos gestores. Conforme será mais detidamente apresentado na próxima seção, o modelo de cuidado proposto por tal política, para esta clientela, deveria ainda adotar os princípios da $\mathrm{RD}$.

Todas essas medidas apontavam para uma redefiniçấo do estatuto dos usuários de álcool e outras drogas na sociedade brasileira, na direção de sua progressiva descriminalização e do resgate dos direitos de cidadania destas pessoas. No entanto, o alcance deste novo paradigma não se revelou tão amplo e efetivo como prometido, seja porque repetidas vezes, muitos usuários de drogas acabam sendo classificados como traficantes, pelos operadores do sistema de justiça criminal - o que tem resultado numa escalada das taxas de encarceramento (Boiteux, 2006; Campos, 2015) -; seja porque o modelo de cuidado psicossocial de base comunitária, previsto tanto na Lei de Drogas, como na Lei da Reforma Psiquiátrica, jamais se tornou hegemônico nos serviços de assistência a usuários de drogas do país, sempre interpelado por instituiçôes, grupos de interesse e até mesmo por usuários, apegados a modelos de tratamento tradicionais, baseados em internaçóes e na abstinência de substâncias.

Nos últimos anos, em decorrência de radicais mudanças na direção das políticas públicas brasileiras, ${ }^{21}$ os serviços públicos de saúde mental de base comunitária vêm sendo progressivamente ameaçados de desmonte, vítimas de subfinanciamento, em favor da retomada das estratégias de cuidado ancoradas em internaçóes. No caso da política assistencial para usuários de álcool e drogas, este redirecionamento revela e concretiza o recuo dos processos, até então em curso, de devoluçấo de direitos e garantias individuais a estes sujeitos.

Na próxima seção, apresentamos os modelos institucionais de cuidado a pessoas com problemas associados ao uso de álcool e outras drogas praticados no país, ao longo do último século, com destaque para aquele que foi preconizado pelo MS, a partir de 2003, cuja implementação será analisada na seção 4, com base em nossas pesquisas recentes.

20. Essa política será tratada na seção 3 deste capítulo.

21. Decorrente da chegada de coalizões conservadoras o governo federal. 


\section{A OFERTA DE CUIDADO A USUÁRIOS DE DROGAS NO BRASIL: MODELOS, INSTITUIÇÕES E ARRANJOS EM PERSPECTIVA HISTÓRICA}

Até meados do século $\mathrm{XX}$, as principais providências em relação a pessoas afetadas por uso problemático de drogas, no Brasil, eram o seu encarceramento ou a internação em manicômios e hospitais psiquiátricos, onde estas pessoas se submetiam a terapêuticas semelhantes às aplicadas a indivíduos com transtornos mentais: contenção e medicação psiquiátrica (Machado e Miranda, 2007; Vaissman, Ramôa e Serra, 2008). Nos anos de 1960 e 1970, começavam a se tornar populares também os grupos de ajuda mútua voltados à conquista e manutenção da abstinência: Alcoólicos Anônimos (AA) ${ }^{22}$ e, logo depois, os Narcóticos Anônimos (NA). ${ }^{23}$

Conhecidos também como "irmandades", esses grupos promovem encontros semanais entre pares (pessoas que se consideram igualmente "adictas" ao álcool ou a outras drogas), que compartilham entre si suas experiências, de forma a se ampararem mutuamente. Entre eles, o uso abusivo de álcool e outras drogas é considerado "uma doença incurável, progressiva e fatal, de base física e espiritual," que suspende ou compromete a vontade dos sujeitos de interromper o uso de substâncias (mesmo reconhecendo os prejuízos deste uso) podendo levá-los à "loucura ou à morte prematura" (Campos, 2009; Alcoólicos Anônimos, 2002).

Essas irmandades norteiam-se pela "filosofia" dos doze passos: um roteiro de etapas sucessivas, a serem vencidas numa trajetória de reforma moral dos indivíduos afetados. O primeiro passo implica o reconhecimento, pelo sujeito, de sua impotência perante as drogas/o álcool e a perda do controle sobre a própria existência. Do segundo passo até o sexto, apela-se a um ser superior, única entidade capaz de devolver a sanidade e remover os defeitos do apelante. Constata-se aí que, mesmo que não se configurem como grupos religiosos stricto sensu, estas irmandades articulam discursos de fundo religioso. ${ }^{24}$

Entre o fim dos anos 1950 e início dos 1960, adeptos dos AAs organizariam as primeiras comunidades terapêuticas (CTs) nos Estados Unidos, ${ }^{25}$ levando os princípios do tratamento entre pares e os doze passos para espaços residenciais de convivência comunitária (Goti, 1990; De Leon, 2014; Fracasso, 2011). Estas instituiçôes chegariam ao Brasil poucos anos depois, pelas mãos de organizaçôes religiosas, católicas e evangélicas, e se espalhariam pelo país desde então. Atualmente, há cerca de 2 mil CTs em todas as regióes do país (Ipea, 2017).

22. De origem norte-americana, os AAs surgiram nos anos 1930 e foram introduzidos no Brasil em 1947. Segundo diversos autores, estes grupos descenderiam de grupos religiosos que se reuniam para ler a bíblia. Sua institucionalização como irmandades voltadas à promoção da abstinência de bebidas alcoólica teria derivado da percepção de que grande parte daqueles que se reuniam em torno da leitura da bíblia haviam renunciado ao hábito de beber (Aguiar, 2011; Goti, 1990; Fracasso, 2012; Campos, 2004).

23. Adaptação do modelo dos AAs a usuários de outras drogas, introduzido no país em 1978.

24. Há indicações de que seus fundadores - William Griffith Wilson (Bill W.), corretor da Bolsa de Nova York, e Robert Smith (Dr. Bob), médico cirurgião de Akron, Ohio - se uniram ao grupo evangélico Oxford, que já fazia um trabalho de reforma moral e combate ao alcoolismo, nos anos 1920-1930.

25. Segundo alguns autores, as primeiras CTs teriam sido a Synanon (Califórnia, em 1958) e DayTop Village (Nova York, em 1963). 
Localizadas, frequentemente, em sítios ou fazendas distantes dos centros urbanos, as CTs realizam internaçóes de longa permanência (de seis a doze meses), por meio das quais executam um programa de reforma moral dos sujeitos, com base no tripé "espiritualidade, trabalho e disciplina". Os internos têm horários determinados para acordar, comer, cuidar da higiene pessoal e participar de atividades em grupo, como oraçóes e estudos religiosos; além de cuidar da limpeza do estabelecimento, cozinhar e, por vezes, realizar trabalhos agrícolas, agroindustriais, artesanais e de construção civil (Ipea, 2017). O trabalho é percebido, no campo das CTs, como parte fundamental da aquisição da disciplina pessoal e disposiçóes essenciais para a construção de um novo sujeito (Santos, 2018; Brandão, 2017; Rui, 2012). Constituídas como organizaçôes privadas ou não governamentais, estas entidades recebem financiamento público de diversos estados e municípios brasileiros, assim como do governo federal. ${ }^{26}$ Dirigidas e operadas, em grande medida, por pessoas que passaram pelo mesmo processo (chamados de "conselheiros", "monitores" ou "coordenadores"), muitas CTs contam, atualmente, com "equipes técnicas", formadas por psicólogos, assistentes sociais, médicos e outros profissionais das áreas de saúde, serviço social e educação (Ipea, 2017).

Essa configuração - que mescla "conselheiros leigos" com "equipes técnicas", na condução dos programas de recuperação, fazendo uso dos doze passos - tornou-se conhecida como Modelo de Minesotta, ${ }^{27}$ e foi introduzida no Brasil pelo psicólogo John Burns ${ }^{28}$ que na década de 1980 inaugurou um próspero negócio de clínicas médicas privadas especializadas no tratamento de adiç̧ôes, hoje presentes em todo o país e muito procuradas por grandes empresas, para encaminhamento de seus funcionários com problemas associados ao uso de álcool e outras drogas (Vaissman, Ramôa e Serra, 2008; Burns, 2002).

Irmandades anônimas, CTs e Modelo Minesotta consistem, assim, de metodologias assemelhadas - mais ou menos religiosas, em grande medida assentadas na estratégia dos doze passos, e exclusivamente focadas na abstinência de substâncias - que se difundiram e ganharam grande respeitabilidade ao longo dos anos, no Brasil. Em todas elas, as representaçôes acerca dos usos problemáticos de álcool e outras drogas deslizam sobre um eixo simbólico em que, de um lado, está a categoria de doença incurável e, de outro, a de defeito moral. Analogamente, compartilham a ideia de que a recuperação do indivíduo depende de uma reforma moral, que passa pela aceitação de seu comportamento inadequado (o primeiro passo dos doze), o qual não se restringe ao uso de substâncias, mas envolve também egocentrismo, irresponsabilidade,

26. Não há informações de quando os estados e municípios iniciaram este financiamento. 0 governo federal, embora já houvesse aportado recursos em outras ocasiões, estabeleceu um programa de grande alcance com este objetivo em 2010, que se tem expandido bastante desde 2018.

27. Uma vez que descende de experiência realizada no Willmar State Hospital, do estado americano de Minesotta. Para mais detalhes, ver: <https://bit.ly/3n9lskz> e Spicer (1993).

28. Também ex-alcoolista. 
desonestidade e até sexualidades problemáticas (De Leon, 2014; Canônico, Nunes e Santos, 2018; Campos, 2004). À exceção das clínicas privadas que adotam o modelo Minesotta, as demais instituiçóes tendem a ser acionadas também porque seus serviços não implicam gastos financeiros elevados.

Ao fim dos anos 1980, num clima de redemocratização do país, o Conselho Federal de Entorpecentes (Confen), órgão colegiado vinculado ao Ministério da Justiça e envolvido no desenho da política sobre drogas, implementaria uma linha de ação de incentivos aos centros de referência em prevenção e tratamento ao uso de drogas (CRRs), voltados não só ao tratamento, mas também ao desenvolvimento de pesquisas e à formação de pessoal qualificado para atendimento clínico no campo (Machado e Miranda, 2007). Assim, a partir da coordenação de serviços e programas existentes ou em desenvolvimento em universidades, órgáos públicos subnacionais e até instituições privadas ${ }^{29}$ o Confen inaugurava um espaço de produção técnico-científica e de práticas inovadoras de cuidado e assistência a pessoas com problemas associados ao uso de álcool e outras drogas (Machado e Miranda, 2007; Petuco, 2019).

Segundo Petuco (2019, p. 211), os encontros entre essas instituiçóes, patrocinados pelo Confen, tiveram como resultado "a constituição e o fortalecimento de um território de controvérsias teórico-ético-metodológicas”, que permitiriam o adensamento conceitual das práticas de cuidado. De acordo com este mesmo autor, os vários CRRs nutriam suas experiências com aportes da psicanálise, do behaviorismo e das ideias de Olivenstein, psiquiatra francês que desde os anos 1970 desenvolvia, no seu Centro Marmottan, de Paris, uma abordagem inédita com usuários de drogas, a partir da percepção de que a relação problemática com determinadas substâncias não resultava apenas das características de cada substância, ou de cada pessoa, mas da interação entre pessoas (em sua singularidade), substâncias e contextos de uso (Olivenstein, 1985; 1988; 1990).

Seria também com o apoio decisivo do Confen que a RD - estratégia de prevenção do contágio do HIV entre usuários de drogas injetáveis (UDI), adotada com sucesso por diversos países europeus - seria efetivamente incorporada ao bem-sucedido programa de DST/Aids do MS brasileiro, a partir de 1994 (Machado e Miranda, 2007). Por meio deste programa, se multiplicariam as organizações não governamentais (ONGs), financiadas por recursos públicos e internacionais, que praticariam a RD nas cenas abertas de uso de drogas no país (Passos e Souza, 2011;

29. São eles: Programa de Orientação e Atendimento a Dependentes (Proad) do Departamento de Psiquiatria da Escola Paulista de Medicina da Universidade Federal de São Paulo (Unifesp); o Centro de Orientação sobre Drogas e Atendimento a Toxicômanos (Cordato) da Universidade de Brasília (UnB); o Núcleo de Estudos e Pesquisas em Atenção ao Uso de Drogas (Nepad) da Universidade Estadual do Rio de Janeiro (Uerj); o Centro de Estudos e Terapia do Abuso de Drogas (Cetad) da Universidade Federal da Bahia (UFBA); e o Centro Brasileiro de Informações sobre Drogas Psicotrópicas (Cebrid) do Departamento de Psicobiologia da Escola Paulista de Medicina da Universidade Federal de São Paulo (Unifesp). Centro Mineiro de Toxicomania (CMT), em Minas Gerais, e Centro Eulâmpio Cordeiro de Recuperação Humana (CECRH), em Pernambuco; e Unidade de Dependência Química do Hospital Mãe de Deus, de Porto Alegre (este, privado). 
Petuco, 2019), disseminando assim informaçóes sobre saúde, ofertando insumos para o uso seguro de drogas e, se necessário, facilitando o acesso de usuários a serviços de saúde e assistência social.

O pressuposto da RD é que o acesso a cuidados de qualquer tipo, por pessoas que fazem uso problemático de drogas, favorece ao autocuidado, à progressiva diminuição do consumo de substâncias e, até mesmo, a conquista da abstinência, se esta for desejada pelo usuário. Tal estratégia, portanto, destituiria o primado da abstinência, como único objetivo do cuidado a usuários de drogas. ${ }^{30}$

A RD seria incorporada à Pauad, de 2003, vindo a constituir-se em um dos princípios orientadores do programa de saúde mental para estas pessoas. Segundo Petuco (2019), esta política seria o resultado do encontro entre a RD e a reforma psiquiátrica brasileira - movimento que alterou institucionalmente o modelo de cuidado às pessoas em sofrimento psíquico. Consagrada por lei e aprovada no parlamento brasileiro (Lei no $10.216 / 2001$ ), esta reforma substituiria a assistência hospitalar (até então, o lócus privilegiado de cuidado à saúde mental) por serviços públicos multiprofissionais, de atenção psicossocial e base comunitária - os Centros de Atenção Psicossocial (Caps), equipamentos estratégicos de atenção, responsáveis também por articular toda a rede de serviços de saúde, assistência, educação, entre outros, que, nos diversos territórios, ofertariam cuidados e condiçóes para o desenvolvimento pessoal de sua clientela. Entre os objetivos da reforma psiquiátrica estava a conquista de um lugar social positivo e não segregado para os ditos loucos - ou seja, a sua desestigmação (Amarante, 2007).

A Pauad, adotada a partir de 2003 , se constituiria na versão dessa reforma para a assistência às pessoas com problemas relacionados ao consumo de álcool e outras drogas, como se verá na próxima seção.

\section{A POLÍTICA DO MINISTÉRIO DA SAÚDE DE ATENÇÃO INTEGRAL A USUÁRIOS DE ÁLCOOL E OUTRAS DROGAS}

\subsection{Desenho, conceitos organizadores e histórico recente}

A Pauad organiza-se segundo os mesmos princípios e diretrizes da Política de Saúde Mental, instituída pela reforma psiquiátrica, a saber: desospitalização/ desinstitucionalização, que implica deslocamento do lócus do cuidado, de uma instituição fechada para serviços abertos, de base comunitária; atenção psicossocial, ou seja, a provisão de cuidados que incidam não somente sobre o corpo ou psiquismo dos sujeitos, mas também sobre sua integração ao corpo social (Rotelli, 2001); cuidado por meio redes intersetoriais, a ser provido por serviços diversos,

30. Tendo em vista, inclusive, que: i) as pessoas têm o direito moral de usar drogas (pois isto não tem grandes impactos coletivos); ii) algumas pessoas usarão drogas, independentemente do fato desta conduta ser ou não criminalizada; e iii) qualquer que seja a regra jurídico-legal, pessoas que usam drogas podem precisar de cuidados. 
de base territorial e comunitária. A estes princípios e diretrizes, o cuidado específico a pessoas com problemas relacionados ao uso de álcool e outras drogas deve adotar a lógica ampliada da $\mathrm{RD}$, estratégia que visa, principalmente, promover o engajamento dos usuários em práticas e rotinas de autocuidado e autorregulação, objetivos considerados mais relevantes do que a busca exclusiva da abstinência de substâncias psicoativas.

Esta seção detalhará cada um desses princípios/diretrizes, a partir da análise de sua enunciaçáo no documento base da política (Brasil, 2003) e da literatura sobre saúde mental e reforma psiquiátrica, tendo em vista a análise posterior dos dados empíricos coletados nos Centros de Atenção Psicossocial para Álcool e Outras Drogas (Caps-AD) do Distrito Federal.

\subsubsection{Desospitalização e desinstitucionalização}

Muito cara à reforma psiquiátrica, a premissa da desospitalização implica redução da centralidade das internaçóes hospitalares - em especial, as de longa permanência - para o cuidado de pessoas com sofrimento mental. Praticada desde as origens da psiquiatria, a reclusão dos "alienados" era, para Philippe Pinel, o principal meio à disposição da medicina a permitir um diagnóstico acurado de cada paciente e, assim, administrar-lhes a terapêutica adequada. A sobrevivência do dispositivo de internaçáo, na assistência em saúde mental, se assenta na percepção da periculosidade do louco, dos riscos que sua presença impóe ao convívio social e da necessidade de contê-lo e discipliná-lo para curá-lo - razão pela qual o hospital psiquiátrico (manicômio, nosocômio, hospício, asilo) se impóe como dispositivo central de gestão da loucura.

Apesar disso, Amarante (2007) afirma,

Após a Segunda Guerra, a sociedade dirigiu seus olhares para os hospícios e descobriu que as condiçóes de vida oferecidas aos pacientes psiquiátricos ali internados em nada se diferenciavam daqueles dos campos de concentraçáo: o que se podia constatar era a absoluta ausência de dignidade humana! Assim nasceram as primeiras experiências de reformas psiquiátricas (p. 40).

Ao longo da segunda metade do século XX, torna-se evidente, para diversos observadores, que as instituiçóes psiquiátricas eram incapazes de reduzir o sofrimento mental das pessoas, provocando inclusive o seu agravamento, ao tempo em que criavam oportunidades para violaçóes dos seus direitos individuais e humanos.

A partir de movimentos surgidos nos Estados Unidos e na Europa (Inglaterra, França e Itália), as bases da psiquiatria seriam profundamente interrogadas. Experimentos como as CTs (Maxwell Jones) e a antipsiquiatria (David Cooper, Ronald Laing e Aaron Esterson), na Inglaterra; a psiquiatria institucional francesa (Tosquelles); a psiquiatria democrática italiana (Franco Basaglia) e a psiquiatria comunitária americana (Caplan); buscavam superar o caráter totalizador e segregador da reclusão manicomial. 
No Brasil, é a psiquiatria democrática italiana, implementada por Basaglia e Rotelli, que exerce maior influência. Basaglia, membro do Partido Comunista em seu país, associava a opressão exercida pela psiquiatria à opressão do proletariado pela classe dominante. Segundo Andrade (1992), sua grande influência entre nós pode ser atribuída ao fato de sua passagem por aqui se ter dado no mesmo momento em que se multiplicavam as lutas pela redemocratização do país e pela reforma do sistema nacional de saúde (a reforma sanitária).

Nesse ambiente de contestação ao regime militar e de batalhas pela universalização do acesso aos serviços de saúde, profissionais e estudantes da área de saúde denunciam as péssimas condiçóes das unidades psiquiátricas brasileiras, e organizam uma frente contra a exclusão social e a violência destas instituições. Esta frente, que deu origem à luta antimanicomial, propunha a eliminação do hospital psiquiátrico como recurso terapêutico, e a desmobilizaçáo de todas as instituiçôes que delimitam um lugar para o louco às margens da sociedade.

Nesse sentido, a ideia de desinstitucionalização assume sentido mais amplo que a de desospitalização, na medida em que prevê a abolição não só do manicômio, mas também de todas as práticas postas "a serviço da disciplinarização dos corpos, da rotulação e da estigmatização dos loucos” (Padilha e Moraes, 2010, p. 2).

Como coroamento desses embates, transcorridos pari passu ao processo de redemocratização do país, o Congresso Nacional brasileiro aprova, em 2001, a Lei no 10.216 , que "dispóe sobre a proteção e os direitos das pessoas portadoras de transtornos mentais e redireciona o modelo assistencial em saúde mental" (Brasil, 2001). A partir desta norma - que estabelece a reforma psiquiátrica brasileira - as internaçôes só podem ocorrer "quando os recursos extra-hospitalares se mostrarem insuficientes” (Brasil, op. cit., art. 4º). Tendo instituído as modalidades de internaçâo voluntária, involuntária e compulsória, a lei determinou também que

a internação involuntária deverá, no prazo de setenta e duas horas, ser comunicada ao Ministério Público Estadual pelo responsável técnico do estabelecimento no qual tenha ocorrido, devendo esse mesmo procedimento ser adotado quando da respectiva alta (Brasil, op. cit., art. 8ㅇ, $\$ 1$ ㅇ).

Com esta providência, a lei apresenta obstáculos para que as internaçóes psiquiátricas sejam expedientes corriqueiros de reclusão de indesejáveis, e assegura às pessoas com sofrimento psíquico uma instância jurídica que garanta seus direitos individuais. Estas diretrizes também passaram a orientar a Pauad, a partir de 2003.

\subsubsection{Atenção psicossocial}

Segundo Costa-Rosa, Yassi e Luzio (2003, p. 4), o termo psicossocial agrega aspectos psíquicos e sociais ao objeto de trabalho da psiquiatria, vindo a 
aspirar ao estatuto de conceito, a partir do momento em que lhe são acrescentadas as contribuiçóes de movimentos de crítica mais radical à psiquiatria, como a antipsiquiatria, a psiquiatria democrática e alguns aspectos originários da psicoterapia institucional (p. 4).

Nesse sentido, o termo reflete mudanças não só no "objeto" do cuidado, mas também "na forma de conceber e estruturar as relações terapêuticas, que têm, por sua vez, implicaçóes éticas radicalmente distintas das práticas asilares" (Costa-Rosa, Yassi, e Luzio, 2003).

Assim, o objeto do cuidado deixa de ser uma "doença”, supostamente instalada num corpo ou num "cérebro", e passa a ser a "existência-sofrimento", necessariamente atravessada por determinantes socioculturais e políticos (Rotelli, 2001; Costa-Rosa, 2000). Daí que a atenção psicossocial não prioriza a administração de medicamentos ou a reclusão dos pacientes, mas a "escuta" deste sujeito e de seus sintomas, não para que sejam removidos, mas reintegrados à sua constituição subjetiva (Costa-Rosa, 2000).

A partir dessa ótica, a produção do cuidado deve envolver toda a experiência subjetiva da pessoa que sofre, com suas diversas demandas, e requer, portanto, uma atenção ampla. O exercício do cuidado não é mais tarefa apenas de médicos, mas também de equipes multiprofissionais e interdisciplinares - compostas inclusive por assistentes sociais, terapeutas ocupacionais, artistas etc. - que, intercambiando saberes e práticas, possam dar conta das diversas dimensóes das existências-sofrimento (Rotelli, 2001). Do mesmo modo, estas existências deixam de ser tratadas como passivas, nos processos de produção da saúde, devendo assumir papel cada vez mais ativo no seu tratamento, junto com suas famílias e seu círculo próximo de relaçóes sociais.

Nos marcos da regulamentação da reforma psiquiátrica brasileira, a atenção a pessoas em sofrimento psíquico passa a se dar nos chamados serviços substitutivos ao manicômio, entre os quais, os Caps: equipamentos públicos, instalados no território de circulação de sua clientela, articulados ao conjunto de serviços sociais disponibilizados à população - não só os de saúde, mas também de assistência social, educação, lazer, habitação, acesso ao trabalho, entre outros. Os Caps tornam-se pontos de atenção especializada desta rede, com diferentes portes e capacidades, inclusive a de realizar acolhimento noturno, por períodos breves, em ocasióes de crise. Para atenção integral às pessoas com problemas decorrentes do uso de álcool e outras drogas, o MS instituiu, em 2004, os Caps-AD e, em 2011, a Rede de Atenção Psicossocial (Raps), visando "ampliar e diversificar os serviços do SUS para a atenção às pessoas com necessidades decorrentes do consumo de álcool, crack e outras drogas e suas famílias", numa perspectiva intersetorial (Brasil, 2011). 


\subsubsection{Cuidado integral por meio de redes intersetoriais}

Às diretrizes da desospitalização/desinstitucionalização e da atenção psicossocial, a política determina ainda a intersetorialidade do cuidado, tendo em vista que a política

deve ser oferecida em todos os níveis de atenção, privilegiando os cuidados em dispositivos extra-hospitalares, como o Centro de Atenção Psicossocial para Álcool e Drogas (Caps-AD), devendo também estar inserida na atuação do Programa de Saúde da Família, Programa de Agentes Comunitários de Saúde, Programas de Redução de Danos e da Rede Básica de Saúde (Brasil, 2003, p. 18).

Para tanto, instituiu-se a Raps, com os seguintes componentes:

I - atenção básica em saúde, formada pelos seguintes pontos de atenção:

a) Unidade Básica de Saúde;

b) equipe de atenção básica para populações específicas:

1. Equipe de Consultório na Rua;

2. Equipe de apoio aos serviços do componente atenção residencial de caráter transitório;

c) Centros de Convivência;

II - atenção psicossocial especializada, formada pelos seguintes pontos de atenção:

a) Centros de Atençáo Psicossocial, nas suas diferentes modalidades;

III - atenção de urgência e emergência, formada pelos seguintes pontos de atenção:

a) Samu 192;

b) Sala de Estabilização;

c) UPA 24 horas;

d) portas hospitalares de atenção à urgência/pronto socorro;

e) Unidades Básicas de Saúde, entre outros;

IV - atenção residencial de caráter transitório, formada pelos seguintes pontos de atenção:

a) Unidade de acolhimento;

b) Serviços de Atenção em Regime Residencial;

V - atenção hospitalar, formada pelos seguintes pontos de atenção:

a) enfermaria especializada em Hospital Geral;

b) serviço Hospitalar de Referência para Atenção às pessoas com sofrimento ou transtorno mental e com necessidades decorrentes do uso de crack, álcool e outras drogas;

VI - estratégias de desinstitucionalização, formada pelo seguinte ponto de atenção:

a) Serviços Residenciais Terapêuticos; e

VII - reabilitação psicossocial (Brasil, 2011). 
A articulação de redes, entre órgãos e agentes de distintos setores de políticas públicas, costuma ser proposta para tratar e enfrentar problemas complexos: "fenômenos multidimensionais e multideterminados, com efeitos persistentes e sem solução fácil” (Bichir e Canato, 2019, p. 243). Este é o caso do uso problemático de substâncias psicoativas e da saúde mental como um todo. Não obstante, são imensos os desafios encontrados para pôr em prática estas articulaçóes, como constatado pela literatura. Conflitos e disputas entre instituiçóes e agentes têm marcado as experiências de efetivaçáo da cooperação intersetorial em diversas políticas públicas, corroborando a hipótese teórica de que a cooperação não é uma tendência natural e requer incentivos e condiçóes especiais para que ocorra (Bichir e Canato, 2019).

\subsubsection{A lógica ampliada da RD}

Ainda conforme a Pauad, os dispositivos de cuidado a pessoas com problemas decorrentes do uso de substâncias psicoativas

devem fazer uso deliberado (...) da lógica ampliada de redução de danos, realizando uma procura ativa e sistemática das necessidades a serem atendidas, de forma integrada ao meio cultural e à comunidade em que estáo inseridos (Brasil, 2003, p. 6).

Isso porque

A dependência das drogas é transtorno em que predomina a heterogeneidade, já que afeta as pessoas de diferentes maneiras, por diferentes razóes, em diferentes contextos e circunstâncias (op. cit., p. 8).

Nesse sentido, o documento sustenta que uma política eficaz para o setor precisa "reconhecer o consumidor, suas características e necessidades, assim como as vias de administração de drogas" (Brasil, 2003).

\section{E buscar}

novas estratégias de contato e de vínculo com ele e seus familiares, para que se possa desenhar e implantar múltiplos programas de prevenção, educação, tratamento e promoção adaptados às diferentes necessidades (Brasil, 2003).

A RD comparece, então, como uma lógica a orientar o cuidado a usuários de álcool e drogas nas Raps, em contraste com as terapêuticas centradas na abstinência, que pautaram os tratamentos até então. 
A abstinência não pode ser (...) o único objetivo a ser alcançado. Aliás, quando se trata de cuidar de vidas humanas, temos de, necessariamente, lidar com as singularidades, com as diferentes possibilidades e escolhas que são feitas. As práticas de saúde, em qualquer nível de ocorrência, devem levar em conta esta diversidade. Devem acolher, sem julgamento, o que em cada situação, com cada usuário, é possível, o que é necessário, o que está sendo demandado, o que pode ser ofertado, o que deve ser feito, sempre estimulando a sua participação e o seu engajamento (Brasil, 2003, p. 10).

Aqui a abordagem da RD oferece um caminho promissor. E por quê?

Porque reconhece cada usuário em suas singularidades, traça com ele estratégias que estão voltadas náo para a abstinência como objetivo a ser alcançado, mas para a defesa de sua vida. Vemos aqui que a redução de danos se oferece como um método (no sentido de methodos, caminho) e, portanto, não excludente de outros. Mas, vemos também que o método está vinculado à direção do tratamento e, aqui, tratar significa aumentar o grau de liberdade, de co-responsabilidade daquele que está se tratando. Implica, por outro lado, o estabelecimento de vínculo com os profissionais, que também passam a ser corresponsáveis pelos caminhos a serem construídos pela vida daquele usuário, pelas muitas vidas que a ele se ligam e pelas que nele se expressam (Brasil, 2003, p. 10).

As primeiras experiências de RD ocorreram em países europeus, nos anos 1980, com vistas ao controle da transmissão de HIV/Aids entre UDI, com significativo sucesso. Com o mesmo propósito, a RD foi adotada no Brasil pelo Programa Nacional de DST/Aids do MS, a partir de 1994. Talvez por isso uma de suas práticas mais conhecidas seja a troca ou distribuição de insumos para consumo seguro de drogas. Também fazem parte desta estratégia as terapias substitutivas, que propóem, no processo de cuidado, a troca de algumas substâncias por outras, cujos danos sejam avaliados como menores.

Outras práticas de RD visam ainda promover a cidadania dos usuários de drogas - em particular, os mais vulneráveis, em situação de rua - no sentido de levá-los a reconhecerem a si próprios como sujeitos de direitos e acessarem os serviços assistenciais públicos. A estratégia, portanto, engloba diferentes açóes destinadas a mitigar prejuízos decorrentes do uso de álcool e outras drogas, e seu diferencial consiste em não exigir, de saída, que o usuário se mantenha abstinente (Marlatt, 1999). Neste sentido, pretende ser uma proposta de "cuidado para além das drogas" (Fórum Estadual de Redução de Danos de São Paulo, 2015), que procura engajar usuários num projeto de autocuidado. 
Tendo em vista estes princípios, a Pauad poderia ser assim resumida:

proporcionar tratamento na atenção primária, garantir o acesso a medicamentos, garantir atençáo na comunidade, fornecer educação em saúde para a população, envolver comunidades/famílias/usuários, formar recursos humanos, criar vínculos com outros setores, monitorizar a saúde mental na comunidade, dar mais apoio à pesquisa e estabelecer programas específicos (...) em uma perspectiva ampliada de saúde pública (Brasil, 2003, p. 11).

\subsubsection{Inflexões recentes}

A relevância da Pauad se afirma por diversas razōes. Primeiramente, porque ela inaugura uma tomada de posiçáo do Estado brasileiro, por meio do MS, acerca de demanda antiga, mas até então desatendida, de uma linha de cuidado especializado a pessoas que sofrem de afliçóes decorrentes do uso de álcool e outras drogas. Até seu advento, o país náo dispunha de uma política assistencial dedicada a esta populaçáa, servindo-se apenas de ofertas da medicina privada ou de iniciativas de grupos filantrópicos e religiosos.

Em segundo lugar, essa política romperia paradigmas tradicionais do cuidado a usuários de substâncias psicoativas - até então baseados em internação e abstinência - ao introduzir a assistência em liberdade, sob a lógica da $\mathrm{RD}$, em serviços de base comunitária - os Caps-AD e a Raps. Portanto, para além de estabelecer um novo modelo de assistência à saúde, esta política também incide sobre uma agenda mais ampla, de garantia e restituição de direitos a pessoas historicamente estigmatizadas e sujeitas a criminalização, interdição e exclusão.

Não obstante, precisamente por apresentar respostas contra-hegemônicas a questóes socialmente sensíveis, a Pauad tem sido desde sempre questionada, seja em sua eficácia, seja em seus pressupostos; e, após sobreviver por quase vinte anos num ambiente de disputas políticas, econômicas e morais, encontra-se hoje sob risco de descaracterização. Em 2019, o governo federal editou a chamada "Nova Política de Drogas", recomendando o abandono da estratégia de RD pelos Caps-AD. Do mesmo modo, ampliou significativamente o financiamento federal a CTs, cujo modelo de cuidado, assentado na abstinência e em internaçóes de média e longa permanência, conflita frontalmente com princípios basilares da Pauad de 2003. A edição dessas medidas sugere que está em curso um processo de esvaziamento da política de atenção a usuários de drogas aqui analisada. Esse esvaziamento, no entanto, não tem ocorrido na ausência de conflitos e enfrentamentos. Além de críticas por parte de profissionais e movimentos sociais, diversos governos municipais, responsáveis pela gestão das Raps e dos Caps-AD no nível local, têm resistido às novas prescriçôes e mantido os serviços orientados pela lógica da $\mathrm{RD}$. 


\section{A IMPLEMENTAÇÃO DA PAUAD NO CONTEXTO DO DISTRITO FEDERAL}

A oferta de cuidado a pessoas que fazem uso problemático de álcool e outras drogas no Distrito Federal está a cargo da Raps, que é vinculada à Secretaria de Estado de Saúde (SES) do governo do Distrito Federal. A coordenação e gestão técnica da Raps é de responsabilidade da Diretoria de Serviços de Saúde Mental (Disam), unidade orgânica de assessoramento superior subordinada à Subsecretaria de Atenção à Saúde (SAS). A gestão operacional destes equipamentos (recursos materiais e humanos), no entanto, é feita pelas superintendências das regióes de saúde (SRS), que são sete: centro sul, sul, norte, leste, oeste, sudoeste e central. Cada um dos sete Caps-AD está situado em uma destas sete regiôes de saúde (tabela 1). Entre os Caps-AD, três são do tipo III e quatro, do tipo II. ${ }^{31}$

Desde o início da implementação da Política de Atenção em Álcool e Outras Drogas no Distrito Federal, a implantação, o funcionamento e a gestão dos Caps-AD se dão por administração direta, isto é, sem a interveniência de entidades terceiras, como organizações sociais ou filantrópicas. ${ }^{32}$ Suas equipes profissionais são compostas de servidores públicos distritais, recrutados por concursos públicos e regidos pelo regime jurídico único dos servidores públicos civis. ${ }^{33}$

TABELA 1

Tipologia, área de abrangência e população estimada - Caps-AD do Distrito Federal

\begin{tabular}{|c|c|c|c|c|}
\hline Tipologia & $\begin{array}{l}\text { Caps-AD } \\
\text { (unidades) }\end{array}$ & $\begin{array}{l}\text { Região de } \\
\text { saúde }\end{array}$ & Abrangência & $\begin{array}{c}\text { População coberta } \\
\text { (aproximadamente) }\end{array}$ \\
\hline \multirow{4}{*}{ Caps-AD ॥ } & Guará & Centro sul & $\begin{array}{l}\text { Guará, Estrutural, Riacho Fundo I e II, Candangolândia, } \\
\text { Núcleo Bandeirante, Park Way, SA I. }\end{array}$ & 315.342 \\
\hline & Santa Maria & Sul & Gama e Santa Maria. & 290.226 \\
\hline & Sobradinho & Norte & Planaltina, Sobradinho I e II, Fercal. & 378.729 \\
\hline & Itapoã & Leste & $\begin{array}{l}\text { Paranoá, Itapoã, São Sebastião, Jardim Botânico, Jardim } \\
\text { Mangueiral. }\end{array}$ & 231.167 \\
\hline \multirow{3}{*}{ Caps-AD III } & Ceilândia & Oeste & Ceilândia, Brazlândia. & 526.871 \\
\hline & Samambaia & Sudoeste & $\begin{array}{l}\text { Samambaia, Taguatinga, Recanto das Emas, Águas Claras, } \\
\text { Areal, Arniqueiras, Vicente Pires. }\end{array}$ & 792.962 \\
\hline & Candango & Central & $\begin{array}{l}\text { Asa Norte, Asa Sul, Lago Norte, Lago Sul, Cruzeiro, Octogonal, } \\
\text { Vila Planalto, Vila Telebrasília, Sudoeste, Varjão. }\end{array}$ & 436.912 \\
\hline Total & & & & 2.972 .209 \\
\hline
\end{tabular}

Elaboração dos autores.

31. Os tipos de Caps foram definidos pela Portaria no 336, de 19 de fevereiro de 2002, e modificados pela Portaria no 3.588 , de 21 de dezembro de 2017.

32. Com recursos próprios e de transferências do governo federal. Importante ressaltar que essa forma de gestão não constitui uma regra geral. Em outros municípios, como Rio de Janeiro ou Recife, por exemplo, alguns serviç̧os são mantidos em cogestão entre o órgão público e as organizações da sociedade civil.

33. Lei no 8.112, de 11 de dezembro de 1990. 
Esse número de unidades foi alcançado após a implementação do Programa Crack, é possivel vencer, pelo governo federal, o qual destinou novos recursos financeiros ao MS para expansão destes equipamentos, nas diversas Unidades da Federação (UFs). Até então, o Distrito Federal contava com apenas dois Caps-AD do tipo II (Guará e Sobradinho).

No mesmo período, o Distrito Federal contava com cerca de 25 CTs (Codeplan, 2013). Em 2019, treze destas comunidades possuíam convênios, ou termos de parceria, firmados com o governo distrital, por meio da Secretaria de Estado de Justiça e Cidadania (Sejus). Estas parcerias são normatizadas e fiscalizadas pelo Conselho de Política sobre Drogas do Distrito Federal (Conen/DF), órgão colegiado vinculado à Sejus. Os recursos para financiamento das CTs provêm do Fundo Antidrogas do Distrito Federal (Funpad). A maioria das CTs do Distrito Federal foi fundada nos anos 2000, mas algumas delas datam de décadas anteriores. Quase todas ofertam vagas para o público masculino acima de 18 anos, somente uma acolhe mulheres. O número de vagas oferecidas por cada CT varia de 20 a 120.

Nosso propósito, nesta seção, é analisar três temas estratégicos que se apresentam como desafios importantes para a implementaçáo da Pauad. O primeiro refere-se às formas de entendimento da categoria $\mathrm{RD}$ pelos profissionais dos Caps-AD, e as transformaçôes destas representações em práticas clínicas junto aos usuários. O segundo diz respeito às articulaçóes de redes intersetoriais de serviços nos territórios abrangidos pelos Caps-AD. E, por fim, o terceiro desafio, apresenta-se como um desdobramento específico das articulaçoos interinstitucionais e diz respeito às relaçóes de cooperação e conflito entre Caps-AD e CTs no Distrito Federal. Antes, porém, apresenta-se brevemente a perspectiva analítica e a metodologia adotadas no estudo.

\subsection{Perspectiva analítica e metodologia}

A literatura acadêmica sobre implementação de políticas públicas tem mostrado que, entre sua concepção e desenho, e a efetiva prestação de bens e serviços à população, estas intervençóes sofrem alteraçóes, seja em função dos arranjos organizacionais montados para a sua implementação, seja em função da cultura e dos valores próprio das organizaçóes e dos agentes implementadores - estes estão na última ponta do processo, chamados por Lipsky (1980) de "burocracia de nível de rua” (Cavalcanti, Lotta e Pires, 2019; Lipsky, 1980; Pressman e Wildavsky, 1973). É o caso, principalmente, de políticas e programas concebidos e desenhados em instâncias administrativas nacionais, mas implementados por administraçóes locais.

\section{A Política do Ministério da Saúde de Atenção Integral a Usuários de Álcool e outras} Drogas, de 2003, é, portanto, um caso interessante de aplicação desse arcabouço teórico (Brasil, 2003). Formulada pelo governo federal, esta política é implementada por estados e municípios, os quais, por previsão constitucional, gozam de 
autonomia, frente ao governo federal, para organizar e gerir a oferta de serviços públicos em seus territórios. Ao fazê-lo, podem promover adaptaçôes e alteraçôes não só em função de percepçóes e orientações políticas diversas, mas também da cultura de suas organizações e dos funcionários que interagem diretamente com os beneficiários (Cavalcanti, Lotta e Pires, 2019; Lipsky, 1980; Pressman e Wildavsky, 1973). A formação profissional destes funcionários, bem como:

seus princípios de justiça e ordem, seus valores sobre o bem comum e o serviço público, sua atençáo a realidades sociais e psicológicas, ou a ignorância sobre uma ou outra, todos produtos de um habitus profissional, influenciam a maneira pela qual eles responderão às injunçóes do estado e se comportarão com o seu público" (Fassin et al., 2015, p. 6, tradução nossa).

A pesquisa, portanto, visou observar como as diretrizes estabelecidas pelo MS, por meio da Pauad, têm sido recepcionadas e postas em prática no território do Distrito Federal, seja em função do modelo de gestão adotado pelo governo local, seja como resultado das características dos agentes que prestam os serviços de atenção psicossocial. Procurou-se compreender, ainda, em que medida as diretrizes da política convivem ou interagem com os serviços de orientação diversa, ofertados em seu território (como as CTs).

A investigação adotou metodologia predominantemente qualitativa, embora algumas informaçóes quantitativas tenham sido coletadas e venham a compor a narrativa analítica que se procurou construir, sobre os serviços pesquisados. A estratégia de pesquisa adotada foi a observação do funcionamento dos equipamentos prestadores do serviço analisado - os Caps-AD do Distrito Federal -, bem como de entrevistas semiestruturadas com profissionais, gestores e usuários destes centros. Além desses atores, foram entrevistados dirigentes de algumas CTs localizadas no Distrito Federal e financiadas pelo governo distrital, que mantêm interaçôes com os Caps-AD.

Os setes Caps-AD do Distrito Federal foram visitados por cerca de quinze dias, em média, cada um. Durante as visitas, observamos as rotinas de operação dos serviços em salas de espera e recepção, grupos terapêuticos, reuniôes de equipes; assembleias de usuários; e realizamos entrevistas com gerentes, profissionais e usuários. A amostra de profissionais não foi desenhada para ser estatisticamente representativa da população dos Caps-AD do Distrito Federal, mas para maximizar a diversidade de perfis profissionais (Trost, 1986), ao garantir, no mínimo, cinco tipos de profissionais de diferentes formaçôes, em cada unidade de Caps-AD estudada.

Em todas as entrevistas, utilizamos um roteiro semiestruturado e pré-formulado. Nas entrevistas com os gerentes, solicitamos também o preenchimento de formulários, visando obter informações quantitativas sobre a gestão dos serviços, tais como: número de profissionais de cada Caps- $\mathrm{AD}$, sua carga horária e formação, serviços e programas ofertados no equipamento, infraestrutura do serviço, entre 
outras. Aplicamos também um questionário sociométrico a gerentes e profissionais, com a finalidade de sistematizar informaçóes sobre suas articulaçóes com outros dispositivos do território e sobre o efetivo funcionamento das redes de serviço preconizadas pela política. A análise das entrevistas foi feita com suporte de software para exame de dados qualitativos e a partir de orientaçóes da teoria fundamentada em dados (Charmaz, 2006).

\subsection{Dificuldades com a implementação da RD}

As entrevistas realizadas com os profissionais dos Caps-AD apontaram a existência de algumas dificuldades, entre eles, de entendimento e operacionalização da categoria $\mathrm{RD}$ em sua prática cotidiana. ${ }^{34}$ Estas dificuldades foram justificadas por três elementos, basicamente: i) a RD seria um conceito novo e de difícil apreensão; ii) as oportunidades de capacitação oferecidas pela SES aos profissionais, sobre este tema, teriam sido escassas; e iii) o caráter contra-hegemônico da RD, isto é, sua contraposição a abordagens terapêuticas tradicionais e, portanto, às expectativas de usuários, familiares e até de profissionais.

Segundo os entrevistados, as poucas oportunidades de discussão coletiva entre gestores e profissionais dos Caps-AD do Distrito Federal, em prol de um entendimento comum acerca da $\mathrm{RD}$, impuseram grandes desafios à operacionalização deste conceito na prática clínica. Assim, por meio da análise das entrevistas realizadas com profissionais dos sete Caps- $\mathrm{AD}$, procuramos identificar as diferentes posturas valorativas, bem como as linhas de ação apontadas por eles. Para tanto, as entrevistas foram analisadas em sua totalidade, mas consideradas principalmente as respostas dadas a uma das perguntas de nosso roteiro semiestruturado, qual seja: O que o(a) sr.(sra.) pensa em relação à abordagem da redução de danos?

A primeira constatação que vale mencionar é a de que, na falta de um entendimento comum, a implementação da $\mathrm{RD}$ se dá sob muitas imprecisóes, interrogaçóes e indefiniçốes; e, diante das urgências cotidianas, esta zona de imprecisóes acaba ocupada por percepçóes idiossincráticas, marcadas frequentemente por posturas valorativas - gosto/não gosto; acredito/não acredito; e por linhas de ação que variam entre os diversos profissionais, inclusive aqueles atuantes em um mesmo serviço.

$\mathrm{O}$ conceito [de $\mathrm{RD}$ ] vai sendo construído com a experiência, com a prática. E cada um enxerga a prática de uma forma, cada um enxerga a experiência de uma forma. Eu acho que, entre a gente, entre a própria equipe, tem, sim, conceituação diferente do que é redução de danos (Psicóloga Caps-AD \#1).

Encontramos, essencialmente, três posturas valorativas com relação à RD: a primeira, denominada de postura de resistência, foi manifestada por profissionais que disseram se opor à RD, mesmo reconhecendo que a "lógica da RD” é uma diretriz estratégica da política que estấo encarregados de implementar. Para justificar tal

34. Dos profissionais entrevistados, $61 \%$ mencionaram algum tipo de dificuldade nesse sentido. 
postura, disseram "não ver sentido" na sua adoção, ou "não acreditar que funcione" e "não abrir mão, na clínica, da busca pela abstinência". Por sua vez, encontramos uma segunda postura valorativa, denominada entusiasta, em um grupo de profissionais que se mostram entusiastas da $R D$, definindo-a como "algo importante", em que "acreditam" e que traz resultados melhores do que abordagens focadas exclusivamente na abstinência.

Ainda assim, uma terceira postura se mostrou bem mais frequente no conjunto das entrevistas: a postura pragmática, caracterizada pela resposta depende. Neste caso, a aplicação da RD deve depender do "desejo do paciente" e/ou da "avaliação que os profissionais fazem do paciente".

A última postura desafia leituras mais lineares e esquemáticas, pois se desdobra em duas vertentes. A primeira - depende do desejo do paciente - traduz um princípio que é muito caro ao modelo de clínica proposto pela reforma psiquiátrica: a autonomia do paciente para decidir sobre o percurso de seu tratamento, o que, no caso da clínica com usuários de $\mathrm{AD}$, é a própria justificativa para a adoção da RD. ${ }^{35} \mathrm{~A}$ segunda vertente-depende da avaliação que os profissionais fazem do paciente - remete, por sua vez, à responsabilidade e à autoridade dos profissionais de saúde frente ao "caso", relativizando o princípio da autonomia do paciente. Chama a atenção, aqui, o fato de que, em algumas entrevistas, estas duas vertentes aparecem no discurso de um mesmo profissional, indicando a tensão e ambiguidade que atravessam a perspectiva destes agentes, ao considerar a orientação da política para a $\mathrm{RD}$, por um lado; e sua posição profissional, de outro. A certa altura da entrevista, uma profissional coloca, para si mesma, a pergunta para a qual não encontra resposta fácil: "e quando o desejo do paciente não coincide com o desejo do profissional?"

Além das posturas valorativas, procuramos investigar também como os profissionais operacionalizam o princípio da $\mathrm{RD}$, em suas práticas assistenciais cotidianas - ou seja, quais linhas de ação adotam no trabalho clínico, tendo em vista tal princípio. Identificamos, então, duas linhas de açáo distintas: a primeira, chamamos de $R D$ de escopo ampliado; a outra, $R D$ como caminho para abstinência.

A $R D$ de escopo ampliado se ancora no entendimento de que o resgate da cidadania do paciente - e não o uso de drogas, em si - é o objetivo mais relevante do cuidado. Assim, a RD é vista como estratégia que favorece à apropriação crescente, pelos pacientes, de seus direitos sociais, por meio do acesso a bens e serviços ofertados pelo Estado - saúde, educação, transferências de renda, habitação etc. Vale lembrar que, conforme estabelecido pela política, o Caps-AD tem o mandato para propiciar este acesso, uma vez que é considerado serviço estratégico de articulação de redes intersetoriais de serviços aos seus usuários. 
Pra mim, [redução de danos] é quando ele consegue se reinserir socialmente. Porque o uso, muitas vezes, tira eles da sociedade; e eles ficam ali, marginalizados. Aí, ele vai se aproximando do próprio Estado - já que antes ele nem entrava em uma instituiçáo pública, entende? Às vezes, ele consegue um benefício da assistência, um 'auxílio vulnerabilidade', aluga um quarto; e com o que sobra, ele compra uma roupa. É um benefício pra ele comprar, ir acessando, se aproximando aos poucos (Assistente social Caps-AD \#7).

Segundo essa compreensão, a potência da $\mathrm{RD}$ reside na possibilidade de aproximação dos pacientes com a face providencial do Estado, entendida como etapa de um processo de reinserção social. Para tanto, o trabalho do profissional envolve (re)tecer redes de apoio social e institucional, junto com os pacientes, facilitando seu acesso às ofertas públicas.

Para os profissionais que adotam a linha de ação da RD como caminho para a abstinência, a cessação do uso de drogas constitui-se no objetivo principal e meta final do cuidado. A RD é apenas um meio para se chegar a este fim.

$\mathrm{Na}$ verdade, a redução de danos é uma estratégia do tratamento. Ela não pode ser considerada meta final. Eu, particularmente, vejo que o ideal para o tratamento da dependência química é a abstinência, sem dúvida. (...) Porém, muitas vezes a gente não consegue isso. Então, a gente usa a estratégia da redução de danos. Então, a redução de danos não é um fim, ela é um meio (MCLI Caps-AD \#4).

Desse modo, cabe ao profissional indicar a $\mathrm{RD}$ àqueles pacientes que não desejam, ou não se veem em condiçóes de interromper o uso de substâncias imediatamente, na expectativa de que, com a continuidade do tratamento, eles adquiram este desejo ou as condiçóes para realizar a abstinência.

A linha de ação que denominamos $R D$ de escopo ampliado é a que guarda maior aderência com as diretrizes da política, ${ }^{36}$ na medida em que mira em ganhos pessoais e sociais que estão além do consumo de substâncias. Nesta perspectiva, a restituição de direitos aos usuários é considerada parte importante para a reversão ou mitigação dos prejuízos que adquiriram ao longo de seus percursos de uso problemático de drogas.

Por seu turno, a linha de ação $R D$ como caminho para abstinência revela a resiliência, entre alguns profissionais, das concepçóes hegemônicas sobre o uso de drogas e as necessidades dos usuários. De acordo com esta linha, o uso problemático de substâncias psicoativas é definido por uma categoria diagnóstica - a dependência química - cujo tratamento depende da abstinência. No caso dos profissionais que se identificam com esta percepção, assim como aqueles que manifestam a postura resistente à $\mathrm{RD}$, antes examinada, as inovaçóes propostas pela Pauad, de 
2003, foram parcialmente filtradas e transformadas numa versão conservadora do princípio da $\mathrm{RD}$.

Esse achado confirma o que autores como Lipsky (1980) e outros haviam apontado, a respeito da implementação de políticas: as suas inúmeras possibilidades de transformação e adaptação, quando operacionalizadas pelos agentes situados na linha de frente das organizaçóes implementadoras, os chamados burocratas do nivel da rua, encarregados da interação direta com os cidadãos beneficiários da política. Do mesmo modo, demonstra-se aqui, mais uma vez, o caráter sempre incerto dos processos de implementação, que permitem que disputas em torno de modelos e paradigmas de políticas não se encerrem no momento de sua formulação, mas que se prolonguem no microcontexto das operaçôes cotidianas das organizaçóes e seus agentes.

\subsection{0 desafio das articulações em redes intersetoriais}

Tal como discutido anteriormente, a Pauad de 2003 e suas regulamentações posteriores definiram que a atenção aos consumos problemáticos de substâncias psicoativas, além de se orientar pela lógica da $\mathrm{RD}$, deveria ser integral, envolvendo a formação de redes intersetoriais de cuidado. Nesse sentido, a Raps deveria articular, em seus territórios de abrangência, serviços e instituiçóes nas áreas de saúde (básica e especializada), assistência social, abrigamento temporário e habitação, educação, emprego e renda, além de lazer, cultura e recreação, entre outros.

A produção e manutenção dessas redes requer interações contínuas entre os profissionais e trabalhadores dos diversos serviços e instituiçóes, para que conjuntamente possam oferecer aos usuários um cuidado integral. Dada a complexidade das situações associadas aos consumos problemáticos de substâncias psicoativas - envolvendo dimensões relativas não apenas ao cuidado à saúde, mas também à reinserção social e econômica dos atendidos - as articulaçóes em rede tornam-se estratégias imprescindíveis à resolução dos casos. Não obstante, produzir e manter estas redes impóe enormes desafios práticos, que emergem nos processos de implementação. A pesquisa empírica conduzida nos sete Caps-AD do Distrito Federal confirmou essas expectativas e permitiu maior compreensão das dificuldades concretas enfrentadas.

Por meio de questionário sociométrico, identificou-se a ocorrência de demandas feitas e recebidas pelos Caps-AD aos serviços e às instituiçôes que integram formalmente as redes de atenção. Os resultados sintéticos podem ser visualizados nas tabelas 2 e $3 .{ }^{37}$ Esses dados permitem uma apreciação do estado das relaçóes interinstitucionais, nas quais os Caps-AD estudados se inserem. Um dos pontos

37. Observou-se uma variação pouco expressiva entre os perfis relacionais dos sete Caps-AD estudados. Por isso, optamos pela apresentação da tabela com os resultados agregados para o conjunto das setes unidades pesquisadas. 
que mais chama a atenção diz respeito à localização das CTs em posiçóes elevadas nas duas tabelas, o que será objeto de análise específica na subseção seguinte.

De forma geral, constatou-se que as instituiçóes com as quais os Caps-AD mais interagem no cotidiano de suas operaçôes (linhas superiores das tabelas 2 e 3), seja fazendo ou recebendo demandas, estão associadas às áreas da saúde (interações com outras unidades de Caps, unidades básicas de saúde - UBS, hospitais e Serviço de Atendimento Móvel de Urgência - Samu), da assistência social (Centro de Referência em Assistência Social - Cras, Centro de Referência Especializado em Assistência Social - Creas e os conselhos tutelares) e do sistema de justiça (Defensoria Pública, Tribunais ou Ministério Público). Isto sugere que as operações cotidianas dos Caps-AD estão imersas, predominantemente, em um circuito médico-assistencial-jurídico. Trata-se de um circuito institucional, por meio do qual os usuários acessam recursos muitas vezes essenciais para sua estabilização.

Não obstante, numa perspectiva de efetivaçáo da integralidade, cabe notar a flagrante incipiência de relaçôes entre os Caps-AD e outros serviços nas áreas de educação, cultura, emprego e geração de renda, além de instituiçóes da sociedade civil - que figuram na porção inferior das tabelas 2 e 3 . A presença limitada destes componentes, no conjunto das relaçóes estabelecidas pelos Caps-AD, é indicativa de fragilidades das redes intersetoriais de atenção, tal como prescritas nos documentos formais da política. Mais do que evidenciar um descompasso entre prescrição e ação, estas deficiências repercutem diretamente na qualidade da atenção dispensada aos usuários, os quais encontram poucos recursos e oportunidades de formação, capacitação profissional, inserção socioeconômica, recreação e envolvimento comunitário, a partir dos Caps-AD e das Raps no Distrito Federal. 
Políticas de Cuidado a Usuários de Álcool e Outras Drogas no Brasil: evolução histórica e desafios de implementação

\section{TABELA 2 \\ Tipos de instituições e serviços para os quais os Caps-AD fizeram demandas - proporção média das setes unidades ( $2^{\circ}$ sem./2018) \\ (Em \%)}

\begin{tabular}{|c|c|}
\hline Tipos de instituições e serviços & Proporção média \\
\hline CTs & 98 \\
\hline Caps-AD (outras unidades) & 95 \\
\hline UBS & 88 \\
\hline Caps (outras modalidades, não AD) & 76 \\
\hline Órgãos de justiça (Defensoria, TJDFT'1/Seruq, ${ }^{2}$ Ministério Público) & 75 \\
\hline Hospital psiquiátrico & 73 \\
\hline Hospital geral (enfermaria especializada ou serviço de referência em saúde mental e AD) & 73 \\
\hline Samu 192 & 69 \\
\hline Cras & 69 \\
\hline Conselho tutelar & 66 \\
\hline Creas & 56 \\
\hline Unidade de acolhimento & 52 \\
\hline UPA 24 horas ou pronto-socorro/urgência & 51 \\
\hline Outros (especificar) & 39 \\
\hline Polícia & 38 \\
\hline Equipe de Consultório na Rua & 37 \\
\hline ONGs & 36 \\
\hline Centro POP4 & 35 \\
\hline Escolas & 26 \\
\hline Unidades de internação (sistema socioeducativo) & 25 \\
\hline Igreja ou instituição religiosa & 21 \\
\hline Centros de convivência e cultura & 19 \\
\hline Cooperativas, empresas de economia solidária ou iniciativas de geração de emprego e renda & 16 \\
\hline Outros (especificar) & 16 \\
\hline
\end{tabular}

Fonte: Pires e Santos (2020).

Notas: ${ }^{1}$ Tribunal de Justiça do Distrito Federal e dos Territórios.

${ }^{2}$ Serviço de Assessoramento a Magistrados sobre Usuários de Drogas.

${ }^{3}$ Unidade de Pronto Atendimento.

${ }^{4}$ Centro de Referência Especializado para Pessoas em Situação de Rua. 
TABELA 3

Tipos de instituições e serviços dos quais os Caps-AD receberam demandas - proporção média das setes unidades (2으. sem./2018)

(Em \%)

\begin{tabular}{|c|c|}
\hline Tipos de instituições e serviços & Proporção média \\
\hline Órgãos de justiça (Defensoria, TJDFT/Seruq, Ministério Público) & 93 \\
\hline Caps-AD (outras unidades) & 87 \\
\hline Caps (outras modalidades, não AD) & 84 \\
\hline CTs & 84 \\
\hline UBS & 80 \\
\hline Conselho tutelar & 78 \\
\hline Hospital geral (enfermaria especializada ou serviço de referência saúde mental e AD) & 73 \\
\hline Hospital psiquiátrico & 67 \\
\hline Equipe de Consultório na Rua & 63 \\
\hline Creas & 59 \\
\hline Cras & 55 \\
\hline UPA 24 horas ou pronto-socorro/urgência & 55 \\
\hline Samu 192 & 51 \\
\hline Unidades de internação (sistema socioeducativo) & 43 \\
\hline Unidade de acolhimento & 40 \\
\hline Igreja ou instituição religiosa & 40 \\
\hline Polícia & 38 \\
\hline Escolas & 36 \\
\hline Centro POP & 33 \\
\hline ONGs & 29 \\
\hline Cooperativas, empresas de economia solidária ou iniciativas de geração de emprego e renda & 14 \\
\hline Outros (especificar) & 14 \\
\hline Centros de convivência e cultura & 7 \\
\hline Outros (especificar) & 4 \\
\hline
\end{tabular}

Fonte: Pires e Santos (2020).

As deficiências na formação e manutenção de redes intersetoriais, apontadas anteriormente, se devem a variados fatores. Em alguns casos, nota-se que instituiçóes e serviços podem simplesmente ser escassos (ou instáveis) nos territórios de 
abrangência dos Caps-AD, dificultando a manutenção dessas interaçôes. ${ }^{38}$ Porém, em muitas outras situaçóes, percebeu-se que a concretização de interações dependia muito do interesse e da disponibilidade dos trabalhadores dos outros serviços e das instituiçôes previstas na rede. Por meio das entrevistas com as profissionais e os gerentes dos Caps-AD no Distrito Federal, pudemos compreender que, mesmo diante de suas intenções de estabelecer relaçôes interinstitucionais no cuidado dos pacientes atendidos, elas enfrentavam grandes dificuldades, manifestas sob a forma de má vontade, resistência, discriminação e tentativas de evitar a vinculação com o público usuário de drogas.

As tensões relacionais em torno do atendimento à clientela específica dos Caps-AD - usuários de drogas - apareceram, inclusive, nos relatos sobre interaçóes com serviços e equipamentos de saúde, que normativamente integram as redes de atenção, e têm responsabilidades institucionais e legais de prestar serviços a este público. As entrevistadas foram enfáticas ao apontar as dificuldades que enfrentam no encaminhamento dos pacientes sob os seus cuidados, para outros serviços de saúde, tal como exemplifica o relato de uma gerente:

e eu já tive vários embates com profissionais, principalmente quando nós estávamos no [hospital regional], porque eu ia a pé lá, e o médico falava "Não! [problemas com drogas] É falta de vergonha na cara! Eu estou com um monte de gente aqui para atender. Eu vou abrir mão, para atender esse, que é pura falta de vergonha na cara? (Gerente Caps-AD 2).

Para além das dificuldades envolvidas em ativar, mobilizar e responsabilizar os serviços da rede pelo tratamento integral dos usuários, identificou-se ainda outro tipo de tensão relacional, que tem a ver, por sua vez, com conflitos em torno das distintas concepçóes sobre usos de substâncias e dos métodos de cuidado e atenção mais adequados aos usuários, tal como será abordado na subseção a seguir.

\subsection{0 antagonismo cooperativo entre Caps-AD e CTs}

Conforme mencionado antes, hoje, no país, há grandes conflitos entre atores políticos e institucionais que habitam o campo das políticas de cuidado a usuários de álcool e outras drogas. Estes conflitos se dão em torno de princípios e também dos métodos aplicados no cuidado a esta clientela, opondo defensores de modelos pautados na internação e na abstinência, como única meta de cuidado - caso das $\mathrm{CT}$; àqueles que preconizam o cuidado de base comunitária com RD - como o realizado pelos Caps-AD.

Enquanto essa disputa é bastante visível no plano nacional, sabemos relativamente pouco sobre como se dáo os encontros e desencontros entre estes dispositivos

38. Ao longo da pesquisa, por exemplo, ouvimos diversos relatos sobre a interrupção do trabalho das Equipes de Consultório na Rua nas áreas de abrangência dos Caps-AD. Este fato impediu o prosseguimento dessa articulação tão importante e impossibilitou o desenvolvimento da ação destas equipes no território. 
no nível dos territórios, onde de fato se organiza e se efetiva a prestação de serviços aos cidadáos. Com o intuito de suprir esta lacuna, nossa pesquisa teve também a preocupação de analisar as relaçóes entre Caps-AD e CTs, no âmbito da Raps do Distrito Federal.

Em nosso primeiro dia de pesquisa de campo, verificamos uma intensiva cooperação cotidiana entre estas instituiçóes, constatação que se repetiu a cada novo Caps-AD visitado. Ainda que nem sempre pacífica, a prática de encaminhamento de pacientes, pelos Caps-AD às CTs, é tão comum quanto a recepção, pelos Caps-AD, de pessoas internadas nas $\mathrm{CT}$ s para consultas individuais e participação nas atividades terapêuticas ali ofertadas.

Cabe reconhecer, nesse caso, a presença de um fator institucional que contribui, em certa medida, para esta prática. Desde 2011, as CTs foram incorporadas às Raps (Brasil, 2011), como serviços de atenção em regime residencial, favorecendo a emergência de conexóes e intercâmbio entre os Caps-AD e estas entidades. Porém, este fato, por si só, não é suficiente para explicar a cooperação constatada, uma vez que ela náo ocorre em outras cidades. ${ }^{39}$ No caso do Distrito Federal, o governo local instituiu um programa próprio de financiamento público de CTs, à semelhança do governo federal, em função do qual os Caps-AD tornaram-se porta de entrada para as CTs financiadas. Isto é, para que uma CT recebesse financiamento distrital pelo acolhimento de usuários, estes deveriam ser, primeiramente, examinados pelos Caps-AD. Caso a equipe destes considerasse necessário, o usuário poderia ser encaminhado às CTs. Este fluxo prevaleceu até o início de 2018. Desde então, os Caps-AD foram deslocados da função de porta de entrada e qualquer profissional médico (vinculado ao SUS ou não) passou a ter o poder de solicitar internaçóes em CTs. ${ }^{40}$

Não obstante, o recurso às CTs, por parte dos Caps-AD do Distrito Federal, manteve-se como prática usual, pelo menos até o fim de nossa pesquisa de campo (abril de 2019). Como explicar esse fato? Como compreender as razóes e condições de sustentação desta cooperação, em condiçôes de forte tensão entre os agentes?

Para elucidar essas questóes, recorremos ao trabalho de Sanyal (1991), que analisou o contexto institucional de implementação de programas de geração de renda, em Bangladesh, os quais envolviam o fornecimento de crédito e assistência técnica para famílias em situação de vulnerabilidade. $\mathrm{O}$ autor observou, neste caso, que os principais atores envolvidos - agências do governo, ONGs locais e organismos internacionais financiadores - não apenas apresentavam concepções distintas sobre o sentido dos programas de geração de renda, mas também eram

39. Conforme pudemos constatar, não há cooperação entre Caps-AD e CTs nas cidades do Rio de Janeiro e de Recife, apesar das pressões sofridas neste sentido pelos gestores das Raps destas cidades.

40. Essa mudança certamente tem relação com as constantes desavenças entre profissionais dos Caps-AD e das CTs, bem como com o fortalecimento político das CTs, em nível nacional, e as mudanças promovidas na Pnad, desde 2017 (Brasil, 2019). 
bastante críticos quanto ao papel e à atuação dos demais parceiros. Apesar disso, estes mesmos atores continuavam a trabalhar juntos, inclusive em novos projetos.

Sanyal (1991) denominou esse fenômeno de "antagonismo cooperativo", e suas hipóteses para explicá-lo são de duas ordens: i) a manutenção da cooperação se deve à ausência de alternativas melhores, ou a incentivos que compensem o mal-estar derivado do conflito; e ii) esta cooperação, embora aparentemente conflituosa, cumpre funçôes latentes importantes (não explicitadas no discurso institucional) para um subgrupo de agentes que operam nestas instituiçóes.

Com base nessas hipóteses, identificamos duas possibilidades explicativas para a cooperaçáo entre Caps-AD e CT verificada no DF. A primeira remete às lacunas da Raps naquele território. Como se pode constatar na seção 3 deste capítulo, a portaria que instituiu a Raps ${ }^{41}$ previa, em sua composição, uma série de equipamentos assistenciais às pessoas usuárias de álcool e outras drogas, entre os quais a unidade de acolhimento (UA): pontos de atenção integral (24 horas, sete dias da semana), que, além de garantir moradia, devem oferecer acompanhamento terapêutico e protetivo, educação, além de convivência familiar e social aos usuários, por um período de até seis meses. Este acolhimento é voluntário e o usuário é autorizado a entrar e sair livremente do equipamento, conforme seus interesses e suas necessidades. $\mathrm{O}$ acesso é regulado pelos Caps- $\mathrm{AD}$, a partir do seguinte fluxo: após o encaminhamento do paciente à UA, pelo Caps-AD, os profissionais das duas unidades estabelecem, junto com o acolhido, o projeto terapêutico singular (PTS) deste, que deve compreender o seu acompanhamento clínico e psicossocial e de sua família. Para tanto, Caps-AD e UAs devem articular-se com outros serviços de saúde ou de outros setores. Porém, conforme identificado pela pesquisa, a implementação de UAs no Distrito Federal nunca se completou.

A gente tenta na medida do possível manter uma relação próxima a essas comunidades porque a gente sabe que o governo não tem outra coisa a oferecer, não tem um plano $B$. Não tem residência terapêutica, só tem uma Unidade de Acolhimento, (...) assim mesmo, não funciona adequadamente (Gerente, Caps-AD C., grifo nosso).

Com efeito, até a finalização de nosso trabalho de campo, só havia uma UA para adultos na jurisdição do Distrito Federal, a qual oferecia apenas doze vagas, que raramente estavam disponíveis. Além disso, a rede não contava com nenhuma unidade de residência terapêutica ${ }^{42}$ para a clientela dos Caps-AD, e os abrigos vinculados ao Sistema Único de Assistência Social (Suas) também eram poucos e insuficientes para atender à demanda por moradia na região. Esta lacuna, ou falha de rede, foi enfaticamente apontada pelos profissionais dos Caps-AD entrevistados e apresentada como principal justificativa para os encaminhamentos às CTs de pacientes em situação de rua e/ou com laços sociais e familiares rompidos.

41. Portaria MS ํo 3.088/2011 (Brasil, 2011).

42. Outro dispositivo residencial previsto na Raps. 
é o único recurso que a gente conta. Esse paciente [que] é morador de rua, (...) quer um lugar para ficar seguro. Paciente que tem problemas, que náo consegue ficar em casa, (...) que precisa de um ambiente seguro para fazer desintoxicação (...) É o lugar que a gente mais encaminha (...), é o lugar que mais acolhe (Enfermeira, Caps-AD G).

Em analogia à segunda hipótese de Sanyal (1991), observamos também que a cooperação intensiva entre Caps-AD e CTs relaciona-se com uma heterogeneidade cognitiva, entre os profissionais dos Caps-AD, acerca das CTs. Ou seja, ainda que muitos percebam os métodos e as práticas das últimas como francamente dissonantes do modelo dos Caps-AD, outros entendem que há complementaridade entre as duas instituiçóes. Para estes, o envolvimento dos Caps-AD com as CTs não é necessariamente indesejável, e as relaçôes entre eles podem ser entendidas como uma forma de "divisão do trabalho". Antes que rivais ou incompatíveis, estas instituiçóes são compreendidas, por alguns profissionais, como dispositivos que efetivamente se complementam, no âmbito da rede de serviços.

não se trata de comparar, mas, sim, de entender como uma rede (...). É um trabalho que se faz em conjunto. Tem momentos que a gente precisa das CT e tem momentos que elas também precisam da gente (...). É uma parceria (Farmacêutica, Caps-AD B).

A complementaridade pode ser compreendida também como parte de uma sequência do próprio tratamento, que se inicia na CT e prossegue no Caps-AD, depois de cumprido o período de internaçáo.

Eles saem da internação [e], se não vem direto para um tratamento continuado, se ele fica solto, a chance dele recair é altíssima. Então, cada vez mais, eu tenho visto a importância desse paciente sair de qualquer internação que ele esteja, e já estar vinculado a um outro serviço. Porque aí ele continua se sentindo protegido (Terapeuta ocupacional, Caps-AD G).

Embora a complementariedade entre os dois dispositivos seja uma possibilidade plausível e eventualmente interessante para os usuários, o alívio das tensóes entre os agentes de cada modelo não parece estar no horizonte, ao menos no curto prazo. A própria condução da Pauad, tanto em nível nacional, quanto no Distrito Federal, atua no sentido de acirramento das divergências e disputas, quando, por exemplo, amplia crescentemente o financiamento às CTs, mantendo o subfinanciamento dos Caps-AD. Por sua vez, a permanência desse padrão antagônico nas relaçóes entre Caps-AD e CTs pode ter implicaçóes negativas importantes para os usuários. As controvérsias em torno da disjuntiva RD versus abstinência são centrais neste sentido.

Também há que se considerar que o recurso às CTs como componente de abrigamento da Raps, diante da indisponibilidade de UAs, pode acabar impondo uma segmentação das opções assistenciais, em função do grau de vulnerabilidade social em que se encontrem os pacientes. Os mais vulneráveis - para quem 
a falta de abrigo pode ser determinante, inclusive, da possibilidade de receber cuidados - tendem a ser encaminhados para internação nas CTs, enquanto os que detêm mais recursos podem desfrutar dos benefícios do tratamento em liberdade. Delineia-se, assim, um efeito perverso de produção, ou reprodução de desigualdades sociais, a partir de um serviço que se pretende universal.

\section{CONSIDERAÇÕES FINAIS}

A história da regulação sobre os usos de drogas, no Brasil, desenvolveu-se, assim como nos demais países da região, a partir de um paradigma higienista, que se transmutou em proibicionista, ao longo do século XX, por força de pressôes da comunidade internacional e em especial dos Estados Unidos que, a partir dos anos 1970, declararam guerra às drogas. Em função disso, até o fim daquele século, a aproximação do Estado aos usuários de drogas limitava-se à imposição de medidas punitivas, ainda que travestidas, por vezes, de tratamento (compulsório), o qual era administrado em instituiçóes manicomiais.

Esse quadro sofreria alteraçóes lentas e parcimoniosas durante os últimos quarenta anos, em função, sobretudo, da introdução da RD no enfrentamento da epidemia mundial de HIV entre UDI. Experimentada com sucesso nos países europeus, a RD se revelou uma estratégia para o controle dos agravos à saúde associados ao uso de drogas, não só mais pragmática, mas também mais eficiente (Marllat, 1999; Nadelman et al., 1997; O'Hare, 1994 apud Fiore, 2006), o que levou à sua adoção por autoridades sanitárias em várias partes do mundo. Além disso, ela se consolidaria como um enfoque mais humanista, posto que não impõe a abstinência compulsória, respeitando a autonomia e a liberdade de escolha dos sujeitos que pretende cuidar (Fiore, 2006). No Brasil, incorporada ao bem-sucedido Programa Nacional de DST/Aids do MS brasileiro, nos anos 1990 , ensejou a multiplicação de agentes redutores de danos, por meio de OSC (Passos e Souza, 2011), que desenvolveram práticas e estratégias de cuidado para "além das drogas", voltadas a usuários em situações de grande vulnerabilidade social (Fórum Estadual de Redução de Danos de São Paulo, 2015).

A RD foi incorporada à Pauad no começo do novo século, momento de grande euforia democrática no país, pela chegada ao poder, pela primeira vez em sua história, de um partido operário, contribuindo, em grande medida, para o desenvolvimento do braço assistencial do Estado junto a usuários de drogas. Nutrida também por experiências da terapia de base comunitária, que se disseminavam pela América Latina e por reflexôes impulsionadas pelos movimentos da reforma psiquiátrica e da luta antimanicomial, a Pauad de 2003 seria construída com forte inspiração libertária e grande sensibilidade às desigualdades sociais persistentes no país. Neste sentido, a institucionalização da atenção psicossocial conferiria à política maior musculatura para enfrentar as situaçóes de desamparo material e simbólico que afetam 
grandes contingentes da população brasileira. Neste sentido, a política brasileira, assentada na atenção psicossocial, reafirma, em suas diretrizes, as responsabilidades da política de saúde quanto à proteção e promoção social - responsabilidades estas que se revelam incontornáveis no contexto desigual brasileiro.

A implementação da Pauad ocorreu de forma descentralizada nos estados e municípios e foi regulada por pactos entre gestores das diversas UFs - arranjo institucional determinado pela Constituiçấo Federal de 1988 (CF/1988) -, anunciava assim novas promessas de efetivação da ação pública, bem como grandes desafios. No campo das promessas, há que se mencionar: a de ampla cobertura territorial, em função de sua escala nacional; a garantia de fluxo estável de recursos, a partir da possibilidade de cofinanciamento dos serviços pelas três esferas de governo; ações capilarizadas, pelo papel implementador dos governos locais; e a disseminação de uma nova cultura assistencial, a partir de um novo olhar sobre as drogas, e a criação de um novo lugar social para os usuários.

Por seu turno, os desafios não seriam poucos. A reduzida capacidade de controle centralizado, pelo MS, da implementação da política, que se faz na ponta - inerente ao arranjo descentralizado proposto - ampliaria as margens para reinterpretação e modificação das diretrizes da política, quando da sua tradução em práticas clínicas, conforme visto no caso da operacionalização do conceito de $\mathrm{RD}$, pelos profissionais dos Caps-AD do Distrito Federal. O caráter contra-hegemônico desta estratégia, e a liberalidade com que admite a manutenção do uso de drogas pelas pessoas sob cuidado, manteria acesa a controvérsia em torno de sua moralidade e efetividade, seja no âmbito do saber médico (Fiore, 2006), seja na percepção de gestores locais e inclusive da própria população (Worcman e Morganti, 2019). Este fator impactaria negativamente a esperada estabilidade do fluxo de recursos para os serviços assistenciais locais, e, ao fim, se mostrou um ponto de grande vulnerabilidade da política, diante da chegada de coalizóes políticas conservadoras ao Poder Executivo da União.

Por sua vez, o desafio de superação ou mitigação das desigualdades sociais, por meio da atenção psicossocial integral e universal, esbarraria em obstáculos expressivos, tais como as falhas das redes de serviços sociais - não só da Raps, mas também dos diversos programas setoriais - na medida em que tais redes dependem de incentivos que nem sempre operam ou que o fazem em direçôes não desejadas, como se viu no caso da cooperação antagonística entre Caps-AD e CT no Distrito Federal. 
Políticas de Cuidado a Usuários de Álcool e Outras Drogas no Brasil: evolução histórica e desafios de implementação

\section{REFERÊNCIAS}

ADIALA, J. C. Uma nova toxicomania: o vício de fumar maconha. In: MACRAE, E.; ALVES, W. C. (Org.). Fumo de Angola: canabis, racismo, resistência cultural e espiritualidade. Salvador: Edufba, 2016. p. 85-102.

AGUIAR, E. S. A dimensão educativa em narcóticos anônimos: uma perspectiva sociocomunitária. Revista de Ciências da Educação, Americana, Ano XIII, n. 24, p. 505-531, jan.-jul. 2011.

AMARANTE, P. Saúde mental e atençáo psicossocial. Rio de Janeiro: Editora Fiocruz, 2007. 120 p.

ANDRADE, M. Democratização no hospital psiquiátrico: um estudo da Colônia Juliano Moreira nos anos oitenta. 1992. Dissertação (Mestrado) - Programa de Pós-Graduação em Saúde Coletiva da Universidade do Estado do Rio de Janeiro (UERJ). Rio de Janeiro, 1992.

BICHIR, R.; CANATO, P. Solucionando problemas complexos? Desafios da implementação de políticas intersetoriais. In: PIRES, R. R. C. (Org.). Implementando desigualdades. Reprodução de desigualdades na implementação de políticas públicas. Rio de Janeiro: Ipea, 2019.

BOITEUX, L. A nova lei antidrogas e o aumento da pena do delito de tráfico de entorpecentes. São Paulo: IBCCrim, out. 2006. (Boletim, n. 167). Disponível em: <https://bit.ly/2Wazl78>.

BOITEUX, L.; PÁDUA, J. P. Respuestas estatales al consumidor de drogas ilícitas em Brasil: um análisis crítico de las políticas públicas (penales y civiles) para los consumidores. [s.l.]: CEDD, 2014. p. 65-79.

BRANDÃO, B. Do governo de corpos ao autogoverno de almas: drogas, crime e fé num centro de recuperação pentecostal. Tese (Doutorado) - Pontifícia Universidade Católica do Rio de Janeiro, Rio de Janeiro, 2017.

BRASIL. Lei no 6.368, de 21 de outubro de 1976. Dispóe sobre medidas de prevenção e repressão ao tráfico ilícito e uso indevido de substâncias entorpecentes ou que determinem dependência física ou psíquica, e dá outras providências. Diário Oficial da Uniáo, Brasília, 1976. Disponível em: <https://bit.ly/34cNJQE>.

. Lei no 10.216 , de 6 de abril de 2001. Dispóe sobre a proteção e os direitos das pessoas portadoras de transtornos mentais e redireciona o modelo assistencial em saúde mental. Diário Oficial da Uniāo, Brasília, 2001. Disponível em: <https://bit.ly/3mhLKAP>.

- Ministério da Saúde. A Política do Ministério da Saúde para a atenção integral a usuários de álcool e outras drogas. Brasília: MS, 2003. Disponível em: <https://bit.ly/34fk7Ct>. 
. Lei no 11.343, de 23 de agosto de 2006. Institui o Sistema Nacional de Políticas Públicas sobre Drogas - Sisnad; prescreve medidas para prevenção do uso indevido, atenção e reinserção social de usuários e dependentes de drogas; estabelece normas para repressão à produção não autorizada e ao tráfico ilícito de drogas; define crimes e dá outras providências. Diário Oficial da Uniáo, Brasília, 2006. Disponível em: <https://bit.ly/3oO4ERB>.

. Ministério da Saúde. Portaria no 3.088, de 26 de dezembro de 2011. Institui a Rede de Atenção Psicossocial para pessoas com sofrimento ou transtorno mental e com necessidades decorrentes do uso de crack, álcool e outras drogas, no âmbito do Sistema Único de Saúde. Brasília: MS, 2011. Disponível em: <https:// bit.ly/34bvjzO>.

. Decreto no 9.761, de 11 de abril de 2019. Aprova a Política Nacional sobre Drogas. Diário Oficial da Uniáo, Brasília, 2019. Disponível em: <https:// bit.ly/3oU1NXo>.

BURNS, J. E. O caminho dos doze passos: tratamento da dependência de álcool e outras drogas. 2. ed. São Paulo: Ediçóes Loyola, 2002.

CAMPOS, E. A. de. As representações sobre o alcoolismo em uma associação de ex-bebedores: os Alcoólicos Anônimos. Caderno de Saúde Pública, v. 20, n. 5 , p. 1379-1387, 2004.

CAMPOS, M. S. Pela metade: as principais implicaçóes da nova lei de drogas no sistema de justiça criminal em São Paulo. 2015. Tese (Doutorado) - Universidade de São Paulo, São Paulo, 2015.

CANÔNICO, L.; NUNES, M. C.; SANTOS, M. P. G. S. Tempo e subjetivação em comunidades terapêuticas. In: SANTOS, M. P. G. (Org.). Comunidades terapêuticas: temas para reflexão. Brasília: Ipea, 2018.

CARVALHO, J. A emergência da política mundial de drogas: o Brasil e as primeiras conferências internacionais do ópio. Oficina do Historiador, Porto Alegre, v. 7, n. 1, jan./jun., p. 153-176, 2014.

CARVALHO, S. A política criminal de drogas no Brasil: estudo criminológico e dogmático da Lei no 11.343/2006. São Paulo: Saraiva, 2014.

CAVALCANTI, S.; LOTTA, G.; PIRES, R. Contribuiçóes dos estudos sobre burocracia de nível de rua. In: PIRES, R.; LOTTA, G; OLIVEIRA, V. (Orgs.). Burocracia e políticas públicas no Brasil: interseções analíticas. Brasília: Ipea, 2019. CHARMAZ, K. Constructing grounded theory: a practical guide through qualitative analysis. London: Sage Publications, 2006. 
Políticas de Cuidado a Usuários de Álcool e Outras Drogas no Brasil: evolução histórica e desafios de implementação

CODEPLAN - COMPANHIA DE PLANEJAMENTO DO DISTRITO FEDERAL. Mapeamento e identificaçáo das metodologias das instituiçóes de tratamento e reinserçáo social de usuários de álcool, crack e outras drogas no Distrito Federal. Brasília: Codeplan, 2013.

COSTA-ROSA, A. O modo psicossocial: um paradigma das práticas substitutivas ao modo asilar. In: AMARANTE, P. (Org.). Ensaios: subjetividade, saúde mental, sociedade. Rio de Janeiro: Editora Fiocruz, 2000. p. 141-168.

COSTA-ROSA, A.; LUZIO, C. A.; YASUI, S. Atenção psicossocial: rumo a um novo paradigma na saúde mental coletiva. 2003. Disponível em: <encurtador. com.br/hyBDH>.

DE LEON, G. A comunidade terapêutica: teoria, modelo e método. São Paulo: Ediçôes Loyola, 2014.

FASSIN, D. et al. At the heart of the state: the Moral World of Institutions. PlutoPress, 2015. Disponível em: <www.plutobooks.com>.

FIORE, M. Uso de drogas: controvérsias médicas e debate público. São Paulo: Mercado das Letras, 2006.

FÓRUM ESTADUAL DE REDUÇÃO DE DANOS DE SÃO PAULO. Caderno do redutor e da redutora de danos. São Paulo: Centro de Convivência É de Lei, 2015. Disponível em: <encurtador.com.br/nCDKW>.

FRACASSO, L. Características da comunidade terapêutica. In: FEBRACT - FEDERAÇÃO BRASILEIRA DE COMUNIDADES TERAPÊUTICAS. Drogas e álcool: prevenção e tratamento. Campinas: Komedi, 2012. p. 272-289.

GOTI, M. E. La comunidad terapéutica: un desafío a la droga. Buenos Aires: Nueva Visión, 1990.

GÓNGORA, A.; SALAZAR, J.; BORJA, R. Políticas y escenarios para la reducción de daños en comunidades locales. Estudios de caso. Ipea/CEPAL, 2020.

IPEA - INSTITUTO DE PESQUISA ECONÔMICA APLICADA. Perfil das comunidades terapêuticas brasileiras. Nota Técnica, Rio de Janeiro, n. 21, mar. 2017.

LIPSKY, M. Street-level bureaucracy: dilemmas of the individual in public services. New York: Russell Sage Foundation, 1980.

MACHADO, A. R.; MIRANDA, P. S. C. Fragmentos da história da atenção à saúde para usuários de álcool e outras drogas no Brasil: da Justiça à Saúde Pública. História, Ciências, Saúde - Manguinhos, Rio de Janeiro, v. 14, n. 3, p. 801-821, jul.-set. 2007. 
MACHÍN, J. Modelo ECO2: redes sociales, complejidad y sufrimiento social. Revista hispana para el análisis de redes sociales, v. 18, n. 12, jun. 2010. Disponível em: <https://bit.ly/3qUx26e>.

. Redes sociales e incidencia en política pública: estudio comparativo México /Colombia. México: CAFAC, 2011.

MARLATT, G. A. Redução de danos no mundo: uma breve história. In: MARLATT, G. A. (Org.). Reduçáo de danos: estratégias práticas para lidar com comportamentos de alto risco. Porto Alegre: Artes Médicas Sul, 1999.

MILANESE, E. Interregional Cooperation to establish a common response to drug use and its consequences in Latin America and the Caribbean. Freiburg: Caritas Germany, 2005.

Tratamiento comunitario de las adicciones: anotaciones teóricas. In: ENCUENTRO DE LA RECOISS: REDES E INCIDENCIA POLÍTICA, 5. 2010, Panamá. Anais... Panamá: Universidad de las Américas, 2010.

. Tratamento cumitário: manual de trabalho I. Brasil: Secretaria Nacional de Politicas de Drogas; Instituto Empodera, 2012.

NADELMAN, E. et al. Verbete harmful reduction. In: LOWINSON, J. H. Substance abuse - a comprehensive textbook. Baltimore: Williams e Wilkinz, 1997.

O'HARE, P. Redução de danos: alguns princípios e ação prática. In: MESQUITA, F.; BASTOS, F. I. Drogas e Aids: estratégias de redução de danos. São Paulo: Hucitec, 1994.

OLIVENSTEIN, C. O destino do toxicômano. São Paulo: Almed, 1985.

. A droga. São Paulo: Brasiliense, 1988.

OLIVENSTEIN, C. (Org.). A clínica do toxicômano: a falta da falta. Porto Alegre: Artes Médicas, 1990.

PADILHA, C. S.; MORAES, R. Franco Rotelli: contribuiçóes para repensar o paradigma psiquiátrico. In: ENCONTRO DOS RESIDENCIAIS TERAPÊUTICOS E PROGRAMA DE VOLTA PRÁ CASA, 2., Porto Alegre, 2010. Anais... Porto Alegre: UFRGS, 2010. Disponível em: <https://bit.ly/349wlfy>.

PASSOS, E.; SOUZA, T. P. Redução de danos e saúde pública: construções alternativas à política global de "guerra às drogas". Psicologia e Sociedade, Minas Gerais, v. 23, n. 1, p. 154-162, 2011.

PETUCO, D. O pomo da discórdia? Drogas, saúde e poder. Curitiba: Editora CRV, 2019.

PIRES. R.; SANTOS, M. P. Análise comparativa das metodologias de cuidado a usuários problemáticos de SPAs: Comunidades Terapêuticas e Centros de 
Atenção Psicossocial para Álcool e outras Drogas - CAPS AD (Distrito Federal). Brasília: FAP-DF, 29 maio 2020. (Relatório da Pesquisa).

PRESSMAN, J.; WILDAVSKY, A. Implementation: how great expectations in Washington are dashed in Oakland; or, why it's amazing that federal programs work at all, this being a saga of the economic development administration as told by two sympathetic observers who seek to build morals on a foundation. Berkeley: University of California Press, 1973.

ROBINSON, R. O grande livro da cannabis. Rio de Janeiro: Jorge Zahar, 1999. RODRIGUES, T. Tráfico, guerra, proibição. In: LABATE, B. C. et al. (Orgs.). Drogas e cultura: novas perspectivas. Salvador: Edufba, 2008.

RUI, T. Corpos abjetos: etnografia em cenários de uso e comércio de crack. 2012. Tese (Doutorado) - Programa de Pós-graduação em Antropologia Social, Universidade Estadual de Campinas, São Paulo, 2012.

ROTELLI, F. Desinstitucionalização, uma outra via. In: ROTELLI, F.; LEONARDIS, O.; MAURI, D. (Orgs.). Desinstitucionalizaçáo. Sáo Paulo: Ed. Hucitec, 2001, p. 17-59.

SANTOS, F. S. D. Alcoolismo: a invençâo de uma doença. Dissertação (Mestrado) - Departamento de História, Universidade Estadual de Campinas, Campinas, 1995.

SANTOS, M. P. G. (Org.). Comunidades terapêuticas - temas para reflexão. Rio de Janeiro: Ipea, 2018.

SANYAL, B. Antagonistic cooperation: a case study of nongovernmental organizations, government and donors' relationships in income-generating projects in Bangladesh. World Development, v. 19, p. 1367-1379, 1991.

SOUZA, J. E. L. São mesmo analfabetos e sem cultura: repressão à maconha, criminalização da pobreza e racismo em Salvador, nas décadas de 1940 e 1950. In: MACRAE, E.; ALVES, W. C. (Orgs.). Fumo de Angola - canabis, racismo, resistência cultural e espiritualidade. Salvador: Edufba, 2016. p. 133-155.

SPICER, J. The Minnesota Model The evolution of the multidisciplinary approach to addiction recovery. Center City: Hazelden Educational Materials, 1993. (6th ed.).

TROST, J. E. Statistically nonrepresentative stratified sampling: A sampling technique for qualitative studies. Qualitative sociology, v. 9, n. 1, p. 54-57, 1986.

VAISSMAN, M.; RAMÔA, M.; SERRA, A. S. V. Panorama do tratamento dos usuários de drogas no Rio de Janeiro. Saúde em Debate, Rio de Janeiro, n. 78, 79 e 80, p. 121-132, 2008. Disponível em: <https://bit.ly/2Kswi7z>.

WORCMAN, N.; MORGANTI, R. O proibicionismo introjetado. In: PIRES, R. (Org.). Implementando desigualdades. Brasília: Ipea, 2019. 


\section{BIBLIOGRAFIA COMPLEMENTAR}

FERREIRA, A. B. H. Novo dicionário eletrônico Aurélio. Versão 5.0. Positivo Informática Ltda., 2004.

KURLANDER, P. A. Os doze passos na comunidade terapêutica. Disponível em: <https://bit.ly/2Wgs71y>. Acesso em: 20 nov. 2012.

LEVINSTEIN, E. The morbid cravin for morphia: (die murphiumsucht). London: Smith, Elder \& Co, 1878.

LIMA, J. F. S. Morphinomania por abuso de injecçóes hipodérmicas. Gazeta Médica da Bahia, Salvador, n. 98, p. 297-310, 1879.

MACRAE, E.; COUTINHO, W. A. (Org.). Fumo de Angola - canabis, racismo, resistência cultural e espiritualidade. Salvador: Edufba, 2016.

MOREIRA, J.; PEIXOTO, A. A classificação das moléstias mentais do Dr. Emil Kraepelin. Arquivos brasileiros de psiquiatria, neurologia e ciências afins, Rio de Janeiro, n. 2, p. 204-216, 1905.

PINHEIRO, A. R. Morphinomania. 1907. Tese (Doutorado) - Faculdade de Medicina do Rio de Janeiro, Rio de Janeiro, 1907.

ROCHA, I. Maconha: coletânea de trabalhos brasileiros. 2. ed. Rio de Janeiro: Ministério da Saúde; Serviço Nacional de Educação Sanitária, 1958.

ROTELLI, F. A instituição inventada. In: DELGADO, J. (Org./Trad.). A loucura na sala de jantar. Santos: Editora Resenha, 1991.

SARTI, T. R. R. M. Maratonas e rambles: a emergência dos tóxicos como problema social no início do século XX. 2015. Dissertação (Mestrado) - Departamento de História, Universidade Estadual de Campinas, Campinas, 2015. 


\section{CENTROS DE ESCUCHA EN COLOMBIA: POLÍTICAS Y ESCENARIOS PARA LA REDUCCIÓN DE DAÑOS EN COMUNIDADES LOCALES}

Andrés Góngora'

Johanna Salazar²

Ramiro Borja ${ }^{3}$

\section{INTRODUCCIÓN}

En este capítulo le seguimos la pista a las transformaciones e implementación de un modelo para intervenir situaciones de sufrimiento social (incluyendo el consumo problemático de drogas) denominado Epistemología de la Complejidad Ética y Comunitaria (ECO2) ${ }^{4}$ y a una de sus derivaciones, el Tratamiento Basado en la Comunidad (CBT, por sus siglas en inglés). En Colombia dichas estrategias constituyeron el marco teórico y técnico del Modelo de inclusión social para personas consumidoras de SPA desarrollado en 2007 como parte integral de la Política Nacional para la Reducción del Consumo de Sustancias Psicoactivas y su Impacto (PNRC). Actualmente, los fundamentos del ECO2 y del CBT forman parte de los modelos de atención implementados por buena parte de las organizaciones que desarrollan proyectos con enfoque de reducción de riesgos y daños y han sido incorporados en las líneas de acción de la más reciente política para la prevención y atención del consumo de drogas (Colombia, 2019). Desde el punto de vista de los sistemas y políticas de salud, el ECO2 y el CBT parten de tres premisas: en primer lugar, que es imposible pensar "un mundo sin drogas" y que en consecuencia los tratamientos no pueden tener como punto de partida la abstinencia; en segundo lugar, que el Estado y los servicios de salud deben proveer a los usuarios de drogas de los medios para que el consumo sea lo menos perjudicial posible y en tercer lugar, que la mitigación de las consecuencias

1. Doctor en antropología social por el Programa de Pósgrado en Antropología Social del Museo Nacional (PPGAS/ Museu Nacional) de la Universidad Federal del Rio de Janeiro (UFRJ); y consultor bajo el Programa de Cooperación de la Comisión Económica para América Latina y el Caribe (CEPAL) y del Ipea.

2. Graduada en Antropología por la Universidad Nacional de Colombia.

3. Mágister en biopolítica global por la Universidad de Laponia.

4. Su hipótesis de partida es que la red social de una persona "altamente vulnerable" al abuso de drogas está constituida por relaciones que ponen en riesgo su salud y su integridad física. De ahí que modificando la estructura y las características de esta red (es decir interviniendo a la comunidad y no solamente al individuo) pueden superarse la exclusión y el sufrimiento social desencadenados por la interacción entre personas y drogas. La historia detallada y los fundamentos de este modelo pueden encontrarse en Machín (2010); sobre su incidencia política en América Latina véase Machín (2011). 
nocivas del uso de drogas se facilita significativamente si se modifica el tipo y la estructura de relaciones que componen las redes sociales de cada individuo (Góngora, 2012; Fergusson y Góngora, 2012).

El texto está dividido en tres secciones, más allá de esta introducción y de las conclusiones. En sección 2, presentamos una aproximación histórica, basada en fuentes secundarias, a las políticas de consumo de sustancias psicoactivas en Colombia. En esta revisión se describen los desarrollos legislativos realizados durante los siglos XX y XXI en términos de reducción de la demanda de drogas, así como del control y manejo de los problemas de gobierno relacionados con dichas sustancias. ${ }^{5}$ Un punto de inflexión en esta historia es la llegada de la reducción de daños a Colombia hacia el año 2000 y su posterior adopción como tecnología de gobierno. Esta manera de entender la relación entre personas y drogas tomó forma institucional en la Política Nacional para la Reducción del Consumo de Sustancias Psicoactivas, lanzada en el año 2007 como alternativa a los enfoques exclusivamente punitivos y medicalizados (Góngora, 2016). Las transformaciones y ajustes hechos a los modelos, servicios y estrategias de atención, desde la redacción de la política nacional de 2007, hasta su última actualización realizada a comienzos de 2019, serán objeto de discusión al final de esta sección. Por fin, son apresentadas las conclusiones finales.

En la sección 3, que antecede a la presentación de los estudios de caso, analizamos los antecedentes históricos y los principios teóricos y metodológicos del ECO2 y del CBT. Con el propósito de facilitar la comprensión de los datos de campo presentados en la siguiente sección, nos detendremos en las transformaciones que han tenido estos modelos en Colombia, evidenciando la singularidad de los escenarios locales y la manera creativa en que los equipos de operadores y técnicos han adaptado estas estrategias de intervención social a la dinámica de sus comunidades.

En la sección 4 describimos algunas prácticas por medio de la cuales se implementa la política de reducción del consumo en Colombia en tres dispositivos comunitarios de inclusión social. Para esto se analizó, por un lado, la experiencia de creación cultural y reducción de daños del Instituto Distrital para la Protección de la Niñez y Juventud (Idipron) y el colectivo Free Soul en Bogotá y, por otro lado, el trabajo de un centro de escucha y del programa de reducción de riesgos y dańos dirigidos por la Corporación Viviendo en la ciudad de Cali. En ambas ciudades se realizaron observaciones de campo sistemáticas, se elaboraron registros fotográficos y se revisaron documentos digitales e impresos relacionados con la operación cotidiana de los servicios mencionados. Los hallazgos permiten ofrecer un panorama sobre la potencialidad de este tipo de dispositivos, pero también muestran las dificultades de implementación en el marco de políticas de salud y trabajo de corte neolibe-

5. Esta revisión fue posible gracias el excelente trabajo de recopilación de leyes e investigaciones realizado por el portal $<$ mamacoca.org>, uno de los sitios de Internet más importantes sobre políticas de drogas en el mundo. 
ral que imperan en Colombia desde la década de 1990. La potencia del trabajo comunitario de prevención, reducción de daños e inclusión social se ve limitada por la flexibilización laboral, los problemas de contratación y la precarización de la atención en salud. Aún así, las comunidades y las organizaciones de la sociedad civil siguen construyendo alianzas y movilizando recursos para aprender a convivir y a mitigar los efectos del denominado "problema de las drogas".

\section{POLÍTICAS DE ATENCIÓN AL CONSUMO DE DROGAS EN COLOMBIA}

\subsection{Siglos $\mathrm{XX}-\mathrm{X} \mathrm{I}^{6}$}

Durante el Siglo XX, las políticas para regular el consumo de sustancias psicoactivas articularon el prohibicionismo y la medicalización. El consumo fue, en primer lugar, una preocupación higienista -con una marcada ideología racista y de clase- que poco a poco transformó las costumbres y la visión de la salud pública y, posteriormente, un asunto relacionado con la legalidad de la producción, la distribución y el uso de sustancias como el alcohol, el tabaco, los fármacos y las plantas con potencial psicoactivo.

A inicios del siglo XX se llevó a cabo una persecución oficial contra la producción y consumo de chicha; popular bebida de fermento de maíz, considerada por las autoridades salubristas como causa de perturbaciones psíquicas en los sectores populares. Mientras el comercio de otras bebidas alcohólicas consideradas más higiénicas, como la cerveza, se abría paso a mediados del siglo, el expendio popular de chicha quedó confinado a la clandestinidad (Socarrás, 1976). Durante estas primeras décadas el sistema público de control de las drogas se orientó a separar el mercado de los medicamentos del mercado de las sustancias declaradas ilícitas (Góngora, 2012). Se inició entonces la judicialización de expendedores y distribuidores irregulares (Ley no 116 de 1937) con la legitimación de dictámenes farmacéuticos que establecieron listas de sustancias proscritas (Ley no 11 de 1920). En esta época, además de la naciente preocupación por la dependencia a las llamadas drogas heróicas (morfina, heroína y cocaína), el principal problema "higiénico-social" que se intentó combatir fue el mambeo o masticación de hoja de coca. Tal práctica fue catalogada por los especialistas en higiene pública como el principal "vicio" y "enfermedad" de los pueblos indígenas y campesinos de todo el país (Bonilla, 1945, p. 430). En las legislaciones, convenciones y tratados de la época los consumidores de drogas eran vistos como sujetos carentes de salud y cordura. Parámetros de higiene y "buen comportamiento" definieron entonces la posición del consumidor de drogas como enfermo y loco. Paulatinamente, los denominados usuarios de estupefacientes se convirtieron en infractores de la ley, al ser

6. En el anexo A se presenta una tabla-resumen con principales hitos jurídicos y administrativos relativos a las políticas de atención a los usuarios de drogas desarrolladas durante los siglos XX y XXI en Colombia. 
considerados culpables de "delitos contra la salud pública" y sancionados con reclusión en manicomios criminales y colonias agrícolas, trabajos forzados, prohibición de estar en ciertos lugares públicos, arrestos y libertad vigilada (Hincapié, 1989). A lo largo de las siguientes décadas la "toxicomanía" continuó siendo considerada como una condición a la que debía imponérsele atención médica para alcanzar la cura o rehabilitación del consumidor (Vázquez Chacón, 1982).

Durante la década de 1960 inició la atención sistemática del consumo de drogas mediante la cual se pusieron al servicio del Estado conocimientos provenientes de las ciencias biomédicas y la administración pública. En 1963 se creó la Sección de Salud Mental del Ministerio de Salud para coordinar la investigación psicopatológica a nivel individual y colectivo con la creación y cumplimiento de normatividad técnica de identificación, prevención y tratamiento de problemas de higiene mental y alcoholismo. El mismo año la Academia Nacional de Medicina introdujo el término farmacodependencia, y poco después, en 1968, propuso capacitar al personal médico y psiquiátrico, y a maestros, sacerdotes y líderes comunitarios, para la difusión de campañas de prevención.

La transformación más importante de las últimas tres décadas del siglo XX en la producción y consumo de drogas fue la consolidación del tráfico de cocaína; en los años setenta los narcotraficantes empezaron a crear inmensos laboratorios para el procesamiento de cocaína, lo que junto con el cultivo industrial de coca, amapola y marihuana generó una problemática de control territorial y seguridad pública. Así es como las plantas declaradas ilegales y sus derivados tomaron relevancia en el conflicto armado y la violencia en Colombia, especialmente de la mano de la expansión internacional de los carteles de cocaína durante la década de 1980. Además, apareció el bazuco (residuo de pasta básica análogo al crack) impactando barrios marginalizados y usuarios de drogas en alto grado de vulnerabilidad social.

En esa misma época surgió la estructura actual del sistema nacional de control de estupefacientes con el Estatuto Nacional de 1974 quedando especificadas las estrategias de prevención, tratamiento y rehabilitación. Desde el punto de vista de los usuarios, la criminalización del porte de drogas les planteaba la situación de recibir castigo como traficante o declararse farmacodependientes. Desde la política antidrogas se endureció la persecución a los cultivos de uso ilícito, se implementaron las fumigaciones aéreas, se persiguió la fabricación y distribución de psicoactivos y se fortaleció el poder combativo y represivo de fuerzas militares y de policía.

En 1986 con la Ley no 30, el Estatuto Nacional de Estupefacientes sufrió varias modificaciones. En general se hizo un ajuste en la terminología para efectos del control de lo lícito y la persecución de lo ilícito. Las sustancias se dividieron en drogas, psicotrópicos, estupefacientes, precursores y medicamentos y el consumo se vio definido en términos de abuso, adicción o drogadicción, dependencia sicológica, 
dosis terapéutica y dosis de consumo personal (Ley no 30 de 1986). En ese contexto fue creado el Consejo Nacional de Estupefacientes, órgano adscrito al Ministerio de Justicia, para concentrar y dirigir las acciones contra la producción, comercio y uso de sustancias generadoras de dependencia. Avances cruciales de dicha ley fueron la penalización atenuada de la llamada "dosis personal" de drogas, al igual que la definición de "plantación" como el cultivo de 20 o más plantas controladas. Ambas definiciones serían claves en décadas siguientes, al ser reinterpretadas a la luz del derecho constitucional posterior.

\subsection{Enfoque de salud pública y derechos humanos}

En 1991, con la nueva Constitución Política, se cambió el paradigma jurídico que regía desde finales del siglo XIX y se reconoció a la República de Colombia como un estado de derecho con instituciones modernas y garantías individuales. La nueva Carta respondió a una gran movilización popular encabezada por líderes juveniles y forjó las bases para la implementación de varios acuerdos de paz realizados con diferentes grupos guerrilleros a finales de los ańos ochenta y principios de los noventa. Las comunidades indígenas ganaron autonomía jurídica y territorial y los grupos afrocolombianos, siguiendo un camino similar, adquirieron también el derecho a territorios colectivos.

En el marco de las libertades individuales se instituyó el derecho al libre desarrollo de la personalidad, hito fundamental que produjo toda una nueva jurisprudencia sobre temas polémicos como los derechos de la población LGBT y la reglamentación de la dosis personal de drogas. No hay que perder de vista que la Constitución del 91, tal como ocurrió en otros países de la región, incluyó un diseño político basado en el pluralismo y el multiculturalismo, al tiempo que incorporó importantes reformas de cuño neoliberal a la estructura estatal, proceso comúnmente denominado ajuste estructural (Larvie, 1998). Como consecuencia de esa nueva manera de entender la administración pública y para abrirle un mayor espacio a la economía de mercado, se reformó el sistema de salud con la Ley no 100 de 1993. Las reformas hechas a dicho sistema a partir de la década de 1990 buscaban hacer sustentable un modelo de competencia administrada derivado directamente de la propuesta del Banco Mundial, llamado pluralismo estructurado. La legislación estableció así un nuevo sistema de salud sobre principios de privatización descentralización y competencia administrada (Useche, 2008; Abadía-Barreto y Oviedo, 2008, 2009).

Con la sentencia C-221 de 1994 proclamada por la Corte Constitucional se despenalizó definitivamente el consumo y el porte de la dosis mínima de drogas ilícitas. Según la Corte los ciudadanos mayores de edad pueden decidir si consumen o no sustancias psicoactivas y el Estado no tiene competencia para prohibir este tipo de decisión. Con este fallo se salvaguardó el derecho al libre desarrollo de la 
personalidad consagrado en el artículo 16 de la Constitución Política (Comisión Asesora, 2015). De igual manera la sanción consistente en recluir a los consumidores en instituciones médicas quedó abolida y el tratamiento pasó a ser una medida consentida y decidida por el usuario. De esta manera la visión sobre el consumo fue comprendida a la luz de otras escalas y matices: "De acuerdo con la Corte, el consumo de drogas prohibidas, e incluso un uso problemático a las mismas, no es en sí misma una conducta que dañe a terceros y, en algunos casos, ni siquiera implica una afectación a la salud personal" (Comisión Asesora, 2015).

En 1996 se creó el Sistema Nacional de Prevención de Consumo de Estupefacientes, para acoger las políticas públicas y programas de gobierno dirigidos a la infancia y la juventud, así como para atender a los problemas relacionados con el abuso y uso indebido de sustancias psicoactivas. Este nuevo, trajo consigo una mirada sistémica del consumo que implicó tener en cuenta los contextos de uso, las historias y trayectorias de los consumidores y las características farmacológicas de las drogas. Las líneas de acción del sistema fueron pensadas como un proceso lineal que incluía: tratamiento, educación, información y rehabilitación.

En los últimos años del siglo XX se crearon las Unidades de Atención Integral de las Conductas Adictivas (UAICA), comunidades terapéuticas integradas a los hospitales psiquiátricos de la red pública (llamados luego de la reforma a la salud de 1993: Empresas Sociales del Estado) para promover la salud mental. El Ministerio de Salud comenzó a incorporar gradualmente la estrategia de reducción de daños (Colombia, 1998) aunque sin rutas de implementación ni marcos conceptuales claros pues persistían los tratamientos reclusorios de los centros de desintoxicación (que generalmente usan fármacos sustitutos) y a las comunidades terapéuticas, muchas de las cuales recurren a curas espirituales basadas en preceptos teológicos y morales (Machín, 2010; Milanese, 2007; Góngora, 2012).

\subsection{La nueva política}

a continuación, describimos el desarrollo e implementación de la política de atención al consumo de psicoactivos que se ha venido construyendo en Colombia a partir de la primera década del siglo XXI. Si bien este proceso no se ha dado de manera lineal, es posible notar una incorporación constante de técnicas y tecnologías de gobierno (Foucault, 2007) basadas en la reducción de daños. Aunque esto no significa que los enfoques de orientación prohibicionista y medicalizada hayan desaparecido.

Uno de los elementos distintivos de la nueva política de reducción del consumo de psicoactivos en Colombia tiene que ver con la incorporación de la perspectiva de la reducción de daños. Esto se dio gracias a la difusión de una forma de intervención social desarrollada en varios países de América Latina, denominada 
Tratamiento de Base Comunitaria (CBT por sus siglas en inglés) (Machín, 2010; 2011). El CBT propone un abordaje al problema de la farmacodepencia basado en un modelo sistémico (llamado ECO2) según el cual la vulnerabilidad de los usuarios de drogas está fuertemente relacionada con la estructura y densidad de sus redes sociales (Colombia, 2007a). De modo que, por ejemplo, un habitante de calle de Bogotá con dependencia al bazuco, puede mejorar su condición si se trabaja en las comunidades locales que constituyen su entorno a través de acciones de asistencia básica e inclusión social. El CBT es una modalidad de reducción de daños, pues parte del principio según el cual la abstinencia no es necesariamente ni el punto de partida, ni el único resultado satisfactorio de un tratamiento. El CBT fue implementado por primera vez en Ciudad de México y luego llevado a otros países de la región (Milanese, Merlo y Machín, 2000; Milanese, Merlo y Laffay 2001; Milanese, 2009; 2010; 2012; Machín, 2010; 2011). Llegó a Colombia a través del proyecto "Viviendo" del Secretariado Nacional de Pastoral Social y Caritas en 1999, y comenzó a implementarse en el año 2001 en una ONG que laboraba en la principal zona de trabajo sexual y venta de drogas de Bogotá.

Entre 2004 y 2006 las organizaciones de la sociedad civil que implementaban el CBT preparaban la transición del financiamiento del proyecto, hasta entonces dependiente de fondos de la cooperación internacional. En desarrollo de lo que se considera un proceso natural a ese tipo colectividades, buscaron hacer sustentable su propuesta por medio de acciones de incidencia política. Al efecto se constituyó una red nacional de organizaciones no gubernamentales (RAISSS Colombia) para operar el CBT e incidir en el Estado y convertir en política pública el modelo de reducción de daños que difundían e implementaban (Góngora, 2013a). Para alcanzar su objetivo, dichas organizaciones diseńaron, junto con el ministerio encargado de regir la salud pública, un modelo de inclusión social para personas afectadas por el consumo problemático de drogas (Colombia, 2007a; 2007b). En la práctica este modelo, lanzado en el año 2007, institucionalizó la reducción de daños en Colombia (Góngora, 2013a), incluyendo el concepto análogo de mitigación como instrumento transversal de prevención y tratamiento del consumo problemático de psicoactivos.

La Ley no 1566 de 2012 instituyó jurídicamente la nueva política, incluyendo su componente de mitigación, y su implementación pasó a ser una obligación legal además de un deber político y administrativo. Esta misma ley garantizó, por primera vez, la atención a personas farmacodependientes en el sistema general de salud, especialmente en lo referido a servicios de desintoxicación y tratamiento. La norma también estableció la necesidad de un consentimiento libre e informado, con ciertas formalidades, para garantizar que las personas farmacodependientes no sean obligadas a recibir tratamiento alguno en contra de su voluntad. 
En el año 2015, una sentencia de la Corte Suprema de Justicia (CSJ-Radicación 44891) aclaró que, de acuerdo con lo contemplado en la Ley no 30 de 1986, el cultivo de menos de 20 plantas controladas (coca, amapola o marihuana) no puede ser considerado una plantación y en consecuencia está despenalizado, en cuanto sea para uso personal. En el año 2016 sucedieron varios hechos notables que modificaron permanentemente el panorama de las políticas de drogas en el país. En primer lugar, se expidió un nuevo Código de Policía (Ley no 1801 de 2016) que tipifica el consumo de psicoactivos como infracción administrativa condonable mediante multas que a su vez resultan conmutables por cursos breves de "cultura ciudadana". Esto, en la práctica, produjo una persecución constante a los usuarios y aumentó la represión policial en las calles y parques de las principales ciudades. Por otra parte, en el marco de los Acuerdos de Paz firmados entre el gobierno nacional y las FARC-EP en 2016, se estableció la necesidad de buscar alternativas a la represión violenta de la oferta de drogas, de aumentar la participación de las comunidades afectadas por la oferta y la demanda, y de tratar el consumo problemático como asunto de salud pública.

En 2017 la Corte Constitucional prohibió la fumigación de cultivos de coca con glifosato, por sus consecuencias negativas para la salud (T-236 de 2017), al menos hasta que el gobierno pudiera probar su inocuidad. Ese mismo ańo se legalizó el acceso a derivados medicinales del cannabis (Decreto 613 de 2017), aunque con una regulación excesiva y de difícil acceso para pequeños y medianos emprendimientos.

A inicios del año 2019 el nuevo gobierno respondió a las preocupaciones por el aumento en los cultivos de coca reanudando las aspersiones aéreas con glifosato. No obstante, el Ministerio de Salud expidió la Resolución 89 de 2019 adoptando nominalmente una nueva política pública para regular el consumo de drogas, pero que de hecho mantiene y ratifica los desarrollos del Modelo de inclusión e incorpora, explícitamente, el concepto de reducción de daños. Como puede apreciarse en anexo C, la reducción de daños aparece como una de las dos líneas de acción del eje de tratamiento integral, mientras que la ampliación y fortalecimiento de redes sociales y comunitarias y la inclusión social efectiva son ahora líneas de acción de un eje de la política llamado rehabilitación integral e inclusión social. En las siguientes páginas mostraremos la vinculación de estos conceptos con los desarrollos teóricos y metodológicos propuestos por el modelo ECO2 y el CBT desde finales de la década de 1980 hasta el presente.

Para finalizar esta revisión cabe mencionar que la Corte Constitucional de Colombia, mediante la sentencia C-253 de 2019, anuló la prohibición general del consumo de psicoactivos en espacios públicos, hasta entonces una infracción administrativa castigada con multas conmutables, y ordenó que las restricciones se den sólo cuando sea estrictamente necesarias. Pese a las últimas decisiones judiciales, el debate en torno a la aspersión con glifosato y a las restricciones del consumo en espacios públicos continúa vigente. 


\section{EL CBT Y LA REDUCCIÓN DE DAÑOS EN COLOMBIA}

Si bien las primeras experimentaciones que dieron origen al Modelo ECO2 surgieron en México en 1989, ${ }^{7}$ la consolidación de esta estrategia se dio sólo hasta 1994 cuando varias organizaciones de la sociedad $\operatorname{civil}^{8}$ y un grupo de expertos europeos ${ }^{9}$ se reunieron en torno a un proceso de investigación en la acción para el tratamiento y cura de las farmacodependencias en poblaciones gravemente excluidas. Con base en este trabajo se presentó una propuesta a la Unión Europea que fue acogida y financiada. Luego, en 1996, esta iniciativa sería apoyada por Cáritas Alemana y el Gobierno alemán reconociendo su carácter innovador, pues se trataba de un proyecto de investigación y no sólo de intervención social, que había introducido el tema y la práctica de la reducción de daños. De allí salieron las bases del modelo ECO2. Durante 1996 y 1997 se desarrolló lo que se denominó "clínica comunitaria" a través del trabajo de calle y de un proceso de investigación acción participativa con comunidades locales en Ciudad de México. En 1998 se unieron Panamá, El Salvador, Nicaragua, Chile y Colombia a la propuesta de trabajo de la clínica comunitaria a partir del modelo ECO2 y, en 1999, se organizó en México el primer diplomado a través de CAFAC (el centro de formación construido para la difusión y formación de este estilo de investigación en la acción). En 1999 se consolidó la primera red de organizaciones que intervienen en situaciones de sufrimiento social (REMOISSS) compuesta por 22 entidades de varios estados mexicanos.

En 2001, con apoyo de Cáritas Alemana y la UE se inició el proyecto llamado Community Based Treatment (CBT) con experiencias piloto en México, Colombia, Brasil y Costa Rica. Una de las herramientas comunes de este proyecto fueron los centros de escucha que se describirán a profundidad en las páginas siguientes. Durante los años 2002 y 2003 se fueron consolidando más redes de trabajo nacionales y organizaciones centroamericanas comenzaron a organizarse en una red llamada RECOISS que agrupa organizaciones de la sociedad civil de la región que trabajan en situaciones de sufrimiento social. En 2004 se dio otro cambio importante cuando se unió UNESCO a la propuesta. Se hizo entonces una investigación comparativa (Milanese, 2005) patrocinada por Cáritas Alemana y UNESCO que incluyó aspectos relacionados con educación en tratamientos basados en la comunidad. A partir de este momento comenzó a plantearse que la educación (formal y no formal) era un elemento clave en los procesos exitosos y que en adelante sería uno de los componentes del CBT. En 2005 se consolidó RAISSS, red que agrupó a organizaciones de la sociedad civil de Colombia, Brasil, Chile, México y Centroamérica. En ese mismo ańo nacieron los centros de formación de dicha red, siguiendo el ejemplo mexicano y dados los resultados de una evaluación comparativa que consideró estratégico la alianza con instituciones de educación superior para dar sostenibilidad a la propuesta.

7. Esta cronología se basa en: Fergusson y Góngora (2012), Milanese (2012), Colombia (2013a) y Góngora (2013a).

8. Hogar Integral de Juventud, Cultura Joven, CEJUV, Cáritas Arquidiócesis de México.

9. Brigitte Laffay (Francia), Roberto Merlo (Italia), Efrem Milanese (Italia) y Vicenzo Castelli (Italia). 
En 2007 se construyó el Modelo de inclusión social (Colombia, 2007a) en Colombia, que nació de la experiencia del centro de escucha de la Fundación Procrear en Bogotá y que luego se difundió en otras ciudades del país a través de la red RAISSS Colombia y de la Corporación Viviendo. Este Modelo pasó a ser parte integral de la Politica Nacional para la Reducción del Consumo de Drogas de Colombia (Colombia, 2007b) incorporando, por primera vez, los lineamientos del CBT y del ECO2 dentro de una política pública de escala nacional. Este avance permitió importantes desarrollos técnicos y políticos en el país y sirvió como ejemplo de incidencia política para las organizaciones aliadas de la región. En 2009 y 2010 se vincularon a la propuesta de formación en Estrategias de Inclusión Social Uruguay, Bolivia, Perú y Argentina. Al mismo tiempo en Colombia se realizó un ejercicio de experimentación del modelo, incorporado desde entonces a la política pública, para sacarlo de los barrios marginalizados y llevarlo a colegios, barrios menos vulnerables y universidades, con inversión estatal. ${ }^{10}$

El plan nacional correspondiente a los años 2009 y 2010 (CNRDD, 2008) fue el primero en proponerse la implementación de la nueva política, pero no llegó ejecutarse completamente ni produjo una evaluación formal. El plan aprobado para el periodo 2011-2014 corrió con una suerte similar al anterior (Colombia, 2014b). Posteriormente la Ley no 1566 de 2012 instituyó jurídicamente la nueva política y su implementación pasó a ser una obligación legal además de un deber político y administrativo. Ese mismo año avanzó la implementación territorial de la nueva política, principalmente por parte de la Alcaldía Mayor de Bogotá por medio de proyectos de reducción de daños como Échele cabeza y los Centros de Atención Móvil a Drogodependencia (CAMAD) (Góngora, 2018).

Puesto que durante los primeros ańos del siglo XXI las redes de ONG que operan y soportan el CBT y el modelo ECO2 venían trabajando en diferentes ciudades del país, en el año 2014 ya existía cierta evidencia sobre los impactos positivos de tales intervenciones. Sobre esa base se construyó el Plan Nacional de Acción (2014-2021) para implementar la nueva política, estrategia que continúa ejecutándose, alcanzando mayores niveles de implementación que los planes anteriores (Colombia, 2014b).

\subsection{Evolución del CBT}

El CBT puede ser definido como un conjunto de acciones, instrumentos y prácticas organizadas en un proceso, cuyo objetivo es promover la mejoría de las condiciones de vida tanto de las personas que abusan de las drogas y viven en una situación de

10. Para mayor información véase el blog "zonas de mitigación", disponible en: <http://zonasdemitigacion.blogspot.com>; y la página del Programa de Descentralización del Ministerio de Salud y Protección Social (MSPS) y UNODC, disponible en: <http://www.descentralizadrogas.gov.co/Pol\%C3\%ADticanacional.aspx>. 
exclusión grave, ${ }^{11}$ como de las comunidades locales a las cuales los consumidores de drogas pertenecen (Milanese, 2012). El CBT ${ }^{12}$ nació de un modelo lineal de finales de los años 1980 en el cual prevención, tratamiento, rehabilitación y reinserción constituían una serie de pasos sucesivos y lineales (Milanese, 2010).

La implementación progresiva del modelo y las evaluaciones continuas hicieron posible una revisión sistemática que mostró las transformaciones del tratamiento comunitario, hasta alcanzar el esquema actual de acciones simultáneas y multidimensionales. Lo que se observa es la combinación de diversos elementos: i) la integración social (también definida como inclusión social) abarca todo el proceso, desde la prevención hasta el tratamiento, constituye su fundamento y una precondición para la existencia de las demás componentes; ii) la reducción de daños ha sido incluida en una categoría más llamada asistencia básica; y iii) la educación y la rehabilitación son ahora simultáneas y constituyen la base sobre la cual se apoyan el tratamiento médico y psicológico. Estos tres elementos se entrelazan en un contexto de simultaneidades e interconexiones. Según Milanese (2010), es posible imaginar este esquema en forma tridimensional: los cimientos del edificio serían las políticas de inclusión social, el piso que da directamente a la calle serían las acciones de prevención y de asistencia básica, el primer piso estaría constituido por la educación y la rehabilitación (entendida como educación) y el último piso de este edificio sería el lugar de la terapia médica y psicológica.

Durante los últimos años de implementación del CBT se pasó de un modelo basado en intervenir situaciones específicas de vulnerabilidad ${ }^{13}$ (vida de calle, abuso de drogas), a una mirada relacional basada en el concepto de exclusión social, del cual las vulnerabilidades son manifestaciones particulares. Desde esta perspectiva la inclusión social es promovida como una estrategia para crear condiciones de vida más equitativas para personas y comunidades a través de procesos de trabajo en red que articulan recursos institucionales y comunitarios. Los especialistas que diseñan e implementan proyectos y programas inspirados en el CBT sostienen que la inclusión social promueve la transformación de los significados culturales que estigmatizan a los usuarios de drogas y permite conectar diferentes sectores promoviendo políticas de drogas basadas en el enfoque de derechos.

11. Aunque como se verá más adelante en los últimos años ha comenzado a implementarse en comunidades educativas y escenarios que no están necesariamente marginalizados.

12. Esta síntesis se basa en Milanese (2010), Fergusson y Góngora (2012) y Colombia (2013a).

13. Una definición sencilla y operativa de vulnerabilidad aparece en la PNRC: "no tener la capacidad de prever, responder, adaptarse y reponerse ante la presencia de un riesgo específico" (Colombia, 2008, p. 15). 


\subsection{Los centros de escucha}

La puesta en marcha de los dispositivos de intervención social de la política en comunidades locales se realiza a través de los denominados centros de escucha. Para hacer un análisis más preciso de las adaptaciones que ha sufrido el modelo al ser implementado por actores locales en contextos políticos y sociales específicos, es pertinente hacer un breve repaso sobre la manera en que estos centros fueron concebidos y estructurados.

Pensar la prevención como organización es proponer un diálogo entre el concepto salubrista clásico (prevención universal, selectiva e indicada) y la teoría sociológica de la ecología del desarrollo humano (Milanese, 2012). Esto quiere decir que la prevención ocurre siempre en un contexto operativo, en un escenario complejo y fluido de interacción entre actores, que puede ser comprendido mejor por medio de la teoría de redes sociales. ${ }^{14}$ En el CBT dicho contexto operativo es llamado dispositivo, y es entendido como un conjunto de acciones para interconectar redes, actores y recursos en una comunidad local. Una vez establecido el dispositivo en un territorio local es posible implementar un servicio. Un servicio puede ser definido como una modalidad de respuestas a las necesidades de todos los actores involucrados en el tratamiento comunitario (Milanese, 2009) favoreciendo la emergencia de demandas que no se hallaban explícitas (Milanese, 2012). En el tratamiento comunitario se han operado principalmente dos tipos de servicios: i) los centros de escucha y ii) los drop in o centros de acogida de bajo umbral. En Colombia ambos tipos de servicio han sido llamados tanto por las organizaciones de la sociedad civil como por las agencias estatales que los promueven y operan: centros de escucha.

En los centros de escucha es posible materializar el dispositivo de trabajo del CBT a través de acciones de enganche, de activación de redes, de articulación y del despliegue continuo de procesos de investigación (Milanese, 2012; Colombia, 2013). Los centros de escucha deben estar abiertos a toda la comunidad y ubicarse lo más cerca posible a los lugares en que se desarrolla la vida cotidiana. Aunque hay variaciones relativas a la infraestructura institucional en donde operan, el equipo de los centros de escucha debe ser mixto, esto es, integrado por operadores pares (usuarios y exusuarios de drogas), actores comunitarios y profesionales de distintas disciplinas, pero en especial de las ciencias sociales, humanas y de la salud.

14. Sobre el ECO2 y el enfoque de redes sociales véase Machín (2010); sobre la teoría de redes sociales pueden consultarse los textos clásicos de la escuela de Manchester (Barnes, 1954; Mitchell, 1973); sobre el network analysis véase el trabajo de Scott (1991) y sobre América Latina véanse los estudios aplicados de Lomnitz (2003). Para una descripción detallada de la bibliografía relacionada con "terapia de redes" véase Milanese (2005; 2010; 2012). Una lectura antropológica de la vida social del ECO2 y el CBT y su impacto en la política de drogas de Colombia puede leerse en Góngora (2013a; 2016). 
En Colombia se han desarrollado dispositivos en colegios, instituciones de protección, universidades, prisiones y barrios marginales con diferentes características. Esto hizo que los centros de escucha fueran tomando diferentes formas y adaptándose a las particularidades de distintas comunidades locales y normas de salud pública. Algunos adquirieron más formalidad, tornándose mucho más sedentarios, pudiendo responder a una mayor heterogeneidad de demandas tales como: i) escucha y evaluación de necesidades; ii) realización de programas de alfabetización y de educación sobre VIH/Sida y drogas; iii) orientación sobre consumo y sexo seguros; iv) entrega de preservativos y programas de intercambio de jeringas y agujas; v) acciones de asistencia básica incluyendo alimentación, primeros auxilios, ropero, lavandería, duchas, alojamiento, etc.; vi) acciones de atención primaria en salud; y vii) programas de inserción laboral. Otros, por el contrario, optaron por estrategias mucho más heterodoxas tales como: i) trabajar mayoritariamente con operadores pares; ii) desarrollar acciones de prevención y reducción de daño en diferentes espacios institucionales y comunitarios con equipos móviles; iii) buscar alianzas con instituciones educativas y culturales, ampliando así las redes de recursos; e iv) incluir la creación artística y cultural como estrategia de inclusión social. En las siguientes páginas se describirán algunos procesos que dan cuenta de estos diferentes desarrollos en la ciudad de Cali, a través del caso de la Corporación Viviendo, y en Bogotá, con la descripción de la experiencia del Idipron y el Colectivo Free Soul.

\section{DISPOSITIVOS COMUNITARIOS DE INCLUSIÓN SOCIAL}

Los resultados de la pesquisa de campo presentada a continuación apuntan a describir las practicas por medio de la cuales se implementa la política de reducción del consumo de drogas en Colombia en tres dispositivos comunitarios de inclusión social. Para esto se realizó, en primer lugar, una revisión conceptual e histórica con el propósito de situar el modelo de intervención social que sustenta la propuesta de las organizaciones estudiadas. En segundo lugar, se llevó a cabo un trabajo de campo durante los meses de octubre y noviembre de 2019 en las ciudades de Bogotá D.C. y Cali, en el cual se aplicaron técnicas etnográficas consistentes en la realizaron entrevistas semiestructuradas, observaciones de campo y diálogos con usuarios, técnicos y operadores.

En Bogotá se decidió observar y participar en una experiencia liderada por Susana Fergusson, experta en trabajo comunitario y reducción de daños, quien fuera en años anteriores asesora de los ministerios de salud y del interior y una de las especialistas que participó en la construcción de la política nacional para la reducción del consumo de drogas. ${ }^{15}$ En el momento del trabajo de campo ella

15. Para un análisis socio-antropológico de la trayectoria de esta especialista y su papel en el desarrollo de la reducción de daños y las políticas de drogas en Colombia, véase: Góngora (2012; 2013a; 2013b; 2016). 
se desempeñaba como educadora del Idipron y dirigía un proyecto artístico, pedagógico e investigativo fruto de una alianza interinstitucional. Dicho proyecto viene siendo desarrollado por Susana y un grupo de jóvenes exhabitantes de calle pertenecientes al colectivo Free Soul, quienes adelantan un proceso de reducción de daños cuya principal característica y estrategia metodológica es la creación de proyectos artísticos y culturales.

Durante los meses de octubre y noviembre de 2020 se acompañaron las prácticas cotidianas de este colectivo mientras operaba el piloto de un espacio de memoria en la antigua "Calle del Bronx" en el centro de Bogotá orientado por el Museo Nacional de Colombia. Paralelamente, se trabajó con la coordinadora del proyecto en un proceso de evaluación que consistió en implementar un instrumento del CBT (denominado Evaluación Periódica y de Paso) que ayudó a entender las transformaciones en la vida individual y sociales de cada uno de los jóvenes de Free Soul. Los ítems del instrumento de evaluación se complementaron y transformaron en siete entrevistas semiestructuradas que permitieron analizar cualitativamente ciertos aspectos considerados importantes en el proceso de reducción de daños de cada joven. También se analizaron las entrevistas realizadas a Susana y a los jóvenes por el Programa de Fortalecimiento de Museos del Ministerio de Cultura que en ese momento se encontraba produciendo una serie de videoclips sobre la experiencia de este colectivo y su impacto en diferentes espacios culturales y sociales de la ciudad.

Procurando un alcance más cercano a la escala nacional y queriendo tener en cuenta un caso de reducción de daños que fuese un ejemplo claro y formal de implementación de la política pública correspondiente, se decidió trabajar con la Corporación Viviendo en la ciudad de Cali. Durante los meses de octubre y noviembre de 2019 uno de los investigadores del equipo se trasladó a la capital del Valle del Cauca para realizar la pesquisa. Allí se llevaron a cabo entrevistas semiestructuradas a miembros del equipo de la Corporación Viviendo: dos fueron hechas en la sede administrativa de la Corporación, una en el centro de escucha del barrio Llano Verde y cinco en el servicio de reducción de daños del Barrio Sucre, particularmente en el punto de intercambio de material para uso de drogas inyectables.

A continuación, presentamos los resultados del trabajo de campo con las organizaciones que realizan acciones de reducción de daños en Bogotá y Cali y ofrecemos algunas conclusiones del estudio mostrando las diferentes tensiones y posibilidades en la implementación de las estrategias gubernamentales estudiadas. 


\subsection{La experiencia del Idipron y el colectivo Free Soul en Bogotá}

"La L" o calle del Bronx, ubicada en el centro de Bogotá, fue un lugar reconocido durante varios años como epicentro de tráfico de drogas, violencia extrema, explotación sexual y hogar de cientos de habitantes de la calle (véase anexo D). El 28 de mayo de 2016 el lugar fue desalojado por la Alcaldía Mayor para tomar control del territorio. Los habitantes de calle fueron llevados en camiones y dejados en otras ciudades, otros fueron trasladados a albergues e instituciones de protección y otros arrinconados por la Policía hasta terminar refugiados en uno de los ríos canalizados de la ciudad (Góngora et al., 2019). Algunos jóvenes habitantes de "La L" fueron acogidos en el Idipron, donde un equipo de educadores estaba desarrollando una propuesta de reducción de daños como alternativa terapéutica y de inclusión social.

El Idipron, creado por el acuerdo 80 del Concejo de Bogotá en 1967, es una institución que se encarga de acoger ayudar a los niños, niñas, adolescentes y jóvenes (de aquí en adelante NNAJ) en condiciones de fragilidad social por su situación de vida en calle o en riesgo de habitarla (Idipron, 2017). Para atender y acoger a los NNAJ interesados en entrar en este programa, el Idipron cuenta con casas o Unidades de Protección Integral (UPIS) en las cuales se desarrollan diferentes procesos según las necesidades de los usuarios. Van desde acciones inmediatas para establecer vínculos y superar algunos problemas del día a día, evitando así la vida en calle, hasta ofrecer procesos complejos que requieren una interacción permanente. En las diferentes modalidades de atención (terreno, internado o externado), se espera que los educadores que lideran los procesos en las casas establezcan vínculos fuertes que les permita conocer no solo los problemas de los NNAJ, sino también sus habilidades, pasiones e intereses abriendo caminos para superar sus dificultades. El modelo pedagógico sigue una serie de pasos según la fortaleza del vínculo y necesidad del usuario: amistad, acogida, personalización, socialización y autonomía y autogobierno (véase el anexo E).

Entre 2014 y 2015 en el Idipron se creó el componente de mitigación dentro del área de salud, con el objetivo de desarrollar acciones orientadas a reducir los riesgos y los dańos biopsicosociales derivados del consumo de SPA (Idipron, 2017). Dada la naturaleza religiosa y asistencialista que caracterizó por muchos años al Instituto, la mitigación se planteó como una experiencia diferente para afrontar la problemática del consumo, aceptando que no era posible que la abstinencia fuera el requisito indispensable para iniciar una relación terapéutica.

Como parte del grupo que asumió la implementación del componente en mención estuvo Susana Fergusson, quien llevó una perspectiva más técnica y pragmática de la salud pública y la reducción de daños y Leonardo Torres, artista plástico quien, por su experiencia en el trabajo con poblaciones en condición de vulnerabilidad, fue invitado a crear proyectos artísticos para hacer procesos 
de reducción de daños. Este grupo comenzó a trabajar en una de las casas del Idipron llamada La Rioja, a donde llegó la mayoría de la población juvenil expulsada de la antigua "Calle del Bronx" que buscaba acogerse a los diferentes programas que esta institución ofrecía. Según Susana, la primera misión fue elaborar un manual de convivencia puesto que, si bien La Rioja fue un "oasis" en medio de la "guerra de la calle" generada por el desalojo del Bronx, la casa atravesaba una situación relacional violenta y compleja (Fergusson, 2017). Aunque nunca se aplicó formalmente, este manual ayudó a entender los conflictos acaecidos dentro de la institución, entendida en términos del CBT como una comunidad con sus propias lógicas y dinámicas internas. Las principales tensiones tuvieron que ver con el autoritarismo de algunos educadores, varios de ellos "resocializados" en el propio Idipron bajo un modelo de matices castrenses y religiosas propio de las comunidades terapéuticas; la alta conflictividad, traducida en riñas, pandillerismo, conductas ilícitas y confrontaciones entre usuarios y funcionarios; el alto consumo de drogas por parte de los jóvenes, especialmente de bazuco, cocaína y marihuana $\mathrm{y}$, como parte de este mismo problema, la falta de una estrategia no represiva para regular el uso de psicoactivos.

Ante esta perspectiva Susana y su equipo diseñaron acciones de trabajo comunitario inspiradas en el CBT para lograr establecer vínculos con los jóvenes. Lo primero que se hizo fue instalar un "lugar de escucha" ubicando una cafetera en la antigua enfermería. El café propició la creación de un espacio de interlocución y de escucha que con el tiempo fue muy valorado. Este primer acercamiento permitió reconocer que en territorios muy hostiles existen situaciones que hacen aún más densa la labor de atención, cuidado y acompañamiento. Por un lado, estos jóvenes tenían historias de violencias, desplazamiento, policonsumo de SPA, ilegalidad y fragilidad en sus redes de apoyo; y, por otro lado, la atención por parte de las instituciones, sobre todo las de salud, era discontinua y deficiente; aumentando la angustia, la ansiedad, la depresión y la rabia. El proceso de reducción de daños en La Rioja, invitó a pensar otras formas de acercamiento y relacionamiento con el fenómeno del consumo con jóvenes en situación de vulnerabilidad grave. El grupo de mitigación propuso avanzar en la flexibilización de algunas normas y abrir espacios para actividades de mejoramiento de autocuidado, reducción de consumo, búsqueda de alternativas de sustento y promoción de talentos y habilidades.

\subsubsection{Rap para liberar almas y combatir el olvido}

Los integrantes del colectivo Free Soul se conocieron en el año 2008 cuando eran adolescentes y la vida los llevó a habitar la calle del "Bronx", conocida por ellos como "El Pedazo" o "La L". En el año 2010, se emocionaron con la idea de hacer música pues como ellos mismos dicen "teníamos muchos visajes [situaciones difíciles] en la cabeza que queríamos decir". Esta actividad que iniciaron de manera 
espontánea se empezó a consolidar en 2011 con la participación en la primera intervención cultural en el Bronx programada por la Alcaldía Mayor de Bogotá. En el año 2016, ya en el Idipron y luego de haber vivido el desalojo del "Bronx", tuvieron la oportunidad de grabar su primer sencillo. Con esta motivación comenzaron su proceso institucional y fundaron formalmente el colectivo de Hip Hop Free Soul que significa: "libres de humo, libres de la bazuca, soltados por el diablo" (Colectivo Free Soul, 2017).

Alrededor de la cafetera Susana conoció los talentos de los jóvenes entre ellos el rap, y abrió un espacio para que Smith, Yan Carlos y Conde pudieran ensayar. También descubrió la preocupación de este grupo por saber qué había pasado con las personas, amigos y conocidos que vivían en "La L" después del desalojo. A partir de esta inquietud surgió el proyecto Renovando el olvido que se gestó a partir de un trabajo asesorado por antropólogos para hacer recorridos nocturnos y recolectar información sobre la situación de los habitantes de calle después del "Bronx". Este material serviría luego para elaborar una propuesta artística que les permitió contar estas historias a través del hip hop. El proyecto, ganó una beca otorgada por el Instituto Distrital para las Artes -IDARTES.

Durante el 2017 el grupo de mitigación y el colectivo Free Soul (con sus integrantes haciendo las veces de operadores pares) trabajó en las casas del Idipron en procesos de comunicación y creación artística con los recursos de la beca. Los jóvenes propusieron un ejercicio de cartografía social en la cual se visitarían las ruinas de "La L" para rescatar algunas de las historias del "Pedazo". Ante la imposibilidad de hacer estos recorridos, se inició un ejercicio de memoria y reconstrucción del lugar, pero, como las narrativas y descripciones no eran lo suficientemente comprensibles, se planteó la posibilidad de construir una maqueta. Este ejercicio de memoria para reconstruir la espacialidad de "La L", mostró que, aunque el lugar ya no existía físicamente, continuaba presente en los cuerpos y en las experiencias de muchas personas (Góngora et al., 2019).

Posteriormente, a través del vínculo entre uno de los antropólogos del Museo Nacional de Colombia que venía apoyando el proceso fue posible exponer la maqueta al público. El contacto con el museo facilitó el diálogo entre la curaduría de etnografía, el Idipron y el área de comunicación educativa para llevar la pieza a un espacio museográfico llamado Wiki. Se trataba de una sala-prototipo diseñada para hablar sobre fenómenos, situaciones, puntos geográficos e hitos históricos de la historia de Colombia. Allí los jóvenes de Free Soul y otros compañeros del Idipron se encargaron de exponer la maqueta de "La L" y socializar sus experiencias de vida con los visitantes. Para la jefa del área educativa esta propuesta generó muchos cuestionamientos en cuanto a la inclusión, la mediación, el derecho y la ciudadanía. El equipo del museo tuvo que pasar por un proceso de sensibilización 
para que los nuevos huéspedes no fueran discriminados y al tiempo fue necesario capacitar a los jóvenes para dialogar con los visitantes. Según Susana, la experiencia constituyó un proceso de circulación social en el cual los pares y sus compañeros de La Rioja ingresaron a un espacio antes vedado y pudieron relacionarse con personas ajenas a su entorno. En el museo los jóvenes expusieron sus experiencias y fueron reconocidos y valorados por personas que nunca imaginaron las consecuencias del desplazamiento y la marginalización provocadas la renovación urbana.

La maqueta fue considerada un objeto privilegiado para hablar con los públicos acerca de los estragos de la "guerra contra las drogas" en Colombia desde la perspectiva de las personas que habitaron una de las "ollas" 16 más grandes del país. Debido al éxito de la exposición, la curaduría decidió que la maqueta podría ocupar un lugar en la sala renovada donde se contarían las principales confrontaciones de la historia de Colombia. Dada la escala de la pieza original, el museo les propuso a los jóvenes de Free Souly del Idipron construir otra maqueta, de menor tamaño, y ensamblarla en el museo. Así nació el proyecto "Historias de la L: ensamblando un mundo en un modelo a escala”. Según Winder, uno de los operadores pares, el objetivo de dicha muestra fue hacer que el público visitante construyera los personajes y los lugares recreados en la maqueta y de este modo "entender mejor las vivencias y memorias de los jóvenes".

Este reto permitió que el grupo entrara en la tras escena de las exposiciones, aprendiera a construir guiones, textos de apoyo y a traducir al lenguaje expositivo sus realidades, lenguajes y experiencias. Fue un proceso en el cual los jóvenes fueron mediadores y a la vez creadores. En el museo conocieron personas de diferentes procedencias, condiciones sociales, ocupaciones y nacionalidades, ensayaron nuevas maneras de comunicarse y pensar otras formas de conexión con la vida y con las drogas (Góngora et al., 2019).

\subsubsection{Buscando financiamiento}

El Idipron tiene dentro de sus políticas la productividad individualidad y un sistema de ahorro (obligatorio) para ser usado una vez la persona salga de la institución. Pero la dinámica en la casa de La Rioja ya no estaba siendo benéfica para los jóvenes de Free Soul, entre otras cosas porque el proceso de lograr autonomía ya comenzaba a pedir independencia, lo que implicó buscar financiamiento. Uno de los primeros movimientos en este sentido tuvo que ver con proyecto de centros de escucha liderado por el Ministerio del Interior. La iniciativa se llamó Laboratorios creativos de convivencia y consistió en acompañar procesos comunitarios relacionados con prácticas artísticas relacionadas con memoria y convivencia en diferentes municipios afectados por el conflicto armado. Luego, en 2018, el colectivo forjó

16. Cracolândia en portugués. 
una alianza con el proyecto Ruinas latinoamericanas liderado por la antropóloga chilena Francisca Márquez, quién se interesó en el trabajo realizado en "La L" y lo incluyó en su estudio comparativo materialidad y memoria. En la misma época surgió la posibilidad de postular la exposición de la maqueta al premio Ibermuseos de Educación. El proyecto ocupó el segundo lugar entre todas las instituciones museales de América Latina, Portugal y España. El jurado reconoció que se trataba de un proyecto interesante a nivel internacional pues demostraba que un museo nacional era capaz de desarrollar trabajos comunitarios, promover la inclusión y modificar algunas de las dinámicas excluyentes de los espacios de circulación artística y cultural.

El dinero del premio sirvió para que los jóvenes sintieran que el trabajo en el ámbito cultural podía ser una vía para que poblaciones históricamente discriminadas, como los usuarios de drogas, generen ingresos y encuentren escenarios para combatir el estigma y la discriminación. Sin duda el trabajo remunerado es un elemento fundamental del proceso de inclusión social con los jóvenes. Como plantea Smith: "Teníamos el trabajito pero no alcanzaba para pagar almuerzos, ni arriendos, entonces llega el premio de Ibermuseos y ahí quedamos más tranquilos... ahí empieza otra etapa. De mi parte me siento metido en la sociedad, empiezo a ser un ciudadano... Saco mi cédula [documento de identidad], empiezo a recibir su mensualidad, tengo la rutina de levantarme, camellar [trabajar], salir, así se va aprendiendo."

Durante este proceso el colectivo Free Soul se fue consolidado como un grupo de creación cultural e investigación en la acción que promueve procesos de inclusión social y reducción de daños. En 2019, el Museo Nacional de Colombia, el Idipron y el colectivo Free Soul fueron invitados por la Fundación Gilberto Alzate Avendaño (FUGA), entidad encargada del plan de renovación urbana del centro de Bogotá, para construir el espacio de memoria en la antigua "Calle del Bronx". Así surgió el proyecto Co-laboratorio de Creación y Memoria La Esquina Redonda (MNC, 2019). Durante ese año los jóvenes y el equipo del Idipron obtuvieron los permisos para entrar e instalarse en un local de una de las pocas casas que aún no habían sido demolidas por la Empresa de Renovación Urbana. Allí se realizaron diferentes acciones de animación comunitaria y llegaron jóvenes de todas las casas del Idipron a aprender sobre la historia de Bogotá, a cantar temas de Hip Hop y a reflexionar sobre la vida y el consumo de drogas en el antiguo "Bronx". Poco a poco, el lugar se fue adquiriendo la forma de un centro de escucha. De hecho, uno de los espacios previstos para La Esquina Redonda, es uno de estos centros atendido por jóvenes pares exhabitantes de calle y educadores del Idipron. 


\subsubsection{Reducción de daños: conexión entre instituciones, personas y drogas}

"Como sabemos, venimos de situaciones de consumo fuerte donde la abstinencia no nos ha ayudado para nada. Últimamente hemos visto que el arte es la mayor herramienta de reducción de daño y de inclusión social” (Entrevista Yan Carlos, 2019).

El colectivo Free Soul ha sido una experiencia en la cual la música junto a otras expresiones artísticas y culturales funcionaron como aglutinantes y detonadores de un proceso de inclusión social y de reducción de daños. Según Susana, el arte "abrió la puerta" para pensar acciones pedagógicas, terapéuticas y laborales y además propició la interacción en nuevos territorios en donde el diálogo con otras poblaciones permitió "romper barreras y estigmas".

La reducción de daños propone un uso responsable y menos nocivo de las sustancias psicoactivas. El equipo de Idipron propuso una reducción del consumo de bazuco sustituyendo esta sustancia por cannabis. Pese a la resistencia de la institución a este tipo de procesos, se logró generar una reflexión frente a los espacios para usar drogas y las posibilidades terapéuticas del cannabis y su relación con la disminución del consumo problemático a través de varias acciones que incluyeron el permiso de salir de la casa para fumar y usar gotas con alto contenido de CBD para conciliar el sueño. Una vez los jóvenes se independizaron aprendieron a cultivar sus propias plantas. Las crisis y las recaídas hicieron parte del proceso. Hubo momentos de alta tensión en los que algunos volvieron a usar "bazuco" o se vieron envueltos en riñas y conflictos. Según Susana, estas fueron situaciones que el colectivo logró superar a través de actividades de soporte, del componente terapéutico para trabajar los traumas y duelos fruto de violencias y pérdidas, de la reducción del consumo y de la promoción del uso responsable de sustancias psicoactivas.

Existe un punto álgido que no depende ni de los usuarios, ni del equipo que los acompaña. Se trata de la sustentabilidad de este tipo de procesos. Por un lado, se cuenta con la contratación de los técnicos especialistas en mitigación y reducción de daños, aunque cabe aclarar que trabajan como "prestadores de servicios". Esto hace que haya muchas interrupciones en los procesos y que estas personas no cuenten con garantías laborales completas. Por otro lado, y a pesar de que el Idipron mantiene varios convenios con empresas púbicas para que los jóvenes accedan a la vida laboral, en buena parte de los casos no hay continuidad, los ingresos son muy bajos o los cupos son manejados por los funcionarios según su conveniencia. Adicionalmente, como varios de estos jóvenes no cuenta con experiencia laboral ni con recursos para pagar su seguridad social, es muy difícil contratarlos como operadores pares en proyectos formales. ${ }^{17}$ Dichas condiciones

17. Esto se debe en parte a la flexibilización laboral y a las políticas neoliberales en salud vigentes en Colombia desde inicios de la década de 1990. La privatización del sistema de salud obliga a los "prestadores de servicios" a asumir el pago de su seguridad social. A esto hay que sumarle la pérdida de garantías laborales relacionadas con la "tercerización" en la implementación de políticas públicas y modelos de atención en salud. 
estructurales fragilizan la continuidad de los procesos, diseminando incertidumbre y desesperanza. La flexibilización en los contratos laborales, la discontinuidad de los apoyos a los proyectos por los cambios institucionales, el poco interés del gobierno por la investigación social, la cultura y las artes, dificultan la permanencia y hacen precarias las posibilidades de trabajo y capacitación para las poblaciones, sobre todo, la más vulnerables.

Las instituciones pese a las contradicciones crean espacios para pensar y direccionar los procesos potenciando saberes y habilidades. El Idipron permitió incluir la lógica de la reducción de daños y el consumo responsable. El Museo Nacional hizo un trabajo de mediación para incluir la historia y las memorias de quienes nunca habían estado representados, brindándoles a los jóvenes exhabitantes de calle un lugar para contar sus historias y exponer sus puntos de vista. IDARTES, patrocinó un proyecto comunitario reconociendo expresiones artísticas de base cuyas intenciones no eran solamente estéticas sino también terapéuticas y sociales. La FUGA le abrió campo al componente comunitario en el antiguo "Bronx" para explorar las conexiones y potencialidades de la reducción de daños y la producción artística y cultural.

La gestión de las relaciones y redes compuestas por personas, instituciones y sustancias psicoactivas constituye la base de este modelo de intervención social que intenta, a su manera, seguir los lineamientos de la política pública de prevención y atención al consumo de SPA. Pero en esta propuesta, a diferencia de los anteriores esquemas del CBT, el concepto integrador es la circulación, entendida como la posibilidad de abrir espacios de inclusión, de hacer que los usuarios de drogas en situación de alta vulnerabilidad se desplacen espacial y socialmente para conectarse con otras personas y contextos (Figura 8). Se entiende además que, en el caso de los jóvenes del Idipron, su interés por la música, el tejido y otras artes, ha sido fundamental, pues mostrar su potencial creativo los posiciona como agentes y les permite hacer escuchar sus puntos de vista ayudando a transformar estereotipos negativos y prácticas estigmatizantes. De igual manera, el cambio en las políticas de drogas y la apertura del mercado del cannabis medicinal permite incorporar una serie de prácticas de autocuidado y reducción daños en usuarios gravemente afectados por el consumo de "bazuco" y otras drogas de mala calidad. Por tal razón, en este esquema se mantiene la atención psicológica, pero, de manera paralela, se trabaja con distintas posibilidades terapéuticas, se habla entonces de medicinas. Otro elemento importante en esta reconceptualización tiene que ver con poner en el centro la investigación en la acción, más que la educación. Se trata, según este equipo de pares y profesionales, de hacer que las preguntas relacionadas con las problemáticas locales, incluyendo el impacto del consumo de drogas, surjan de las propias comunidades en lugar de ser impuestas por especialistas. 
Plantearse estas incógnitas, investigar las respuestas y generar estrategias de difusión de conocimiento por medio de expresiones artísticas y culturales, abre un nuevo camino para pensar la inclusión social.

\subsection{Reducción de riesgos y daños y centros de escucha en Cali}

La Corporación Viviendo es una entidad colombiana privada sin ánimo de lucro, orientada al desarrollo humano integral. Esta organización tiene una sede administrativa y varios dispositivos comunitarios a lo largo del país, de los cuales una parte significativa está en Santiago de Cali. Para ilustrar el funcionamiento general de este tipo de organización centramos la observación en dos espacios específicos. El primero en el barrio Sucre, donde desde 2015 la Corporación ofrece servicios de reducción de daños orientados a usuarios de heroína. Este servicio es presentado por los profesionales de campo como un modelo de país. El segundo, es un centro de escucha ubicado en el barrio Llano Grande que funciona desde 2018. Si bien los centros de escucha y los servicios de reducción de daños no son idénticos, ambos constituyen las modalidades fundamentales de atención comunitaria al consumo de drogas en Colombia y pueden ser analizados de manera comparativa.

A continuación, se presenta una descripción de los barrios Sucre y Llano Verde, donde tienen lugar las acciones prevención y atención al consumo de SPA. Luego se considerará la red operativa y el funcionamiento del programa de reducción de riesgos y daños del barrio Sucre, y de los centros de escucha en general. Posteriormente analizaremos las relaciones entre sistematización y financiamiento de dichas modalidades de intervención social. Esta ruta ofrece una comprensión de la implementación de las líneas de acción de la política nacional de atención al uso de sustancias psicoactivas (Colombia, 2019) basadas en el CBT, en el Modelo de inclusión social (Colombia, 2007a) y en sus posteriores desarrollos.

El barrio Sucre está ubicado en la Comuna 9 (véase anexo F), en el centro de la ciudad. Caracterizado por la presencia de "inquilinatos" 18 y locales dedicados al comercio informal e ilegal, el barrio es reconocido como epicentro del microtráfico y del consumo de sustancias psicoactivas (Municipio de Santiago de Cali, 2008). En el sector transita una población significativa de habitantes de calle y se ha detectado la presencia de pandillas dedicadas al hurto y a la venta de armas. De igual manera, se reportan conflictos constantes entre los grupos delincuenciales y riesgos de desplazamiento intraurbano relacionados con la implementación de proyectos de renovación urbana (OCHA, 2014).

18. Lugares donde se rentan habitaciones por días. Sus precios son bajos en comparación con hostales y similares. Por lo general albergan poblaciones marginalizadas y flotantes. 
Por su parte el barrio Llano Verde está ubicado en la Comuna 15 (véase anexo G), al oriente de la ciudad de Cali. Nació en 2013 como proyecto de vivienda gratuita para víctimas de desplazamiento forzado en el marco del conflicto armado. La población afrocolombiana que se ha asentado allí por causa del conflicto proviene de la costa pacífica y del suroccidente del país, lo que enriquece la pluralidad étnica y cultural del barrio. Este proyecto urbanístico se destinó igualmente para víctimas de desastres naturales, dado que limita con un jarillón o dique del río Cauca. Su ubicación cercana al dique es estratégica pues facilita el transporte informal, aunque persisten los problemas de movilidad debido a la mala planeación. La asignación de las viviendas no ha sido suficiente para generar una mejora en la calidad de vida. Además, hay una elevada tasa de feminicidios y otras violencias (OCHA, 2014). Los programas de seguridad de la alcaldía no ofrecen la cobertura requerida, y los problemas asociados con la criminalidad y expendio y consumo de drogas son una amenaza para los demás habitantes del barrio, quienes resultan siendo discriminados y asociados con dichas conductas delictivas (OCHA, 2014).

Tanto en Sucre como en Llano verde, la comunidad cuenta con la presencia frecuente de instituciones gubernamentales y no gubernamentales que trabajan en diferentes áreas de la asistencia social, ${ }^{19}$ pero, dichas iniciativas, son insuficientes y desarticuladas. La Oficina para la Coordinación de los Asuntos Humanitarios (OCHA) de la ONU documentó la situación humanitaria de estos sectores en 2014 y propuso fortalecer los "comités interinstitucionales", la "descentralización administrativa” e impulsar la participación política de los variados sectores de la comunidad (OCHA, 2014). No obstante, las problemáticas sociales continúan agudizándose.

\subsubsection{La Red Operativa}

El Grupo de Salud Mental y Convivencia Social, subdivisión de la Secretaría de Salud Pública Municipal, es la autoridad responsable de coordinar la operación de los centros de escucha que operan en sectores como Llano Verde, así como de la supervisión del programa de reducción de riesgos y daños del barrio Sucre. El esquema administrativo y contractual del Programa y del Centro son muy similares. Apoyándose en sus distintos grupos, la Secretaría coordina el trabajo de ciertas Empresas Sociales del Estado (ESE) ${ }^{20}$ para realizar el plan de acción del sector salud. A su vez la ESE del territorio correspondiente contrata a una organización no gubernamental como operadora para que ejecute lo previsto para cada centro

19. La oferta de servicios incluye: uso del tiempo libre, cuidado del medio ambiente, construcción de infraestructura social, convivencia familiar, educación, emprendimiento, prevención del consumo, atención psicosocial, autoprotección, salud, veeduría y participación, nutrición, formación en derechos, comunicación, paz, habilidades para la vida y alojamiento. 20. Entidades mediante las que el Estado colombiano presta servicios públicos, principalmente de salud. Podrían corresponder a un solo establecimiento, como un hospital, pero suelen abarcar una red de hospitales y centros de salud. Funcionan con autonomía administrativa y recursos separados, es decir de manera relativamente independiente a los gobiernos nacional y municipal. 
o programa. Finalmente, la organización operadora, en este caso, la Corporación Viviendo, contrata equipos de profesionales y técnicos para realizar las acciones necesarias para el funcionamiento de los servicios.

Los equipos de contratistas del Programa de Reducción de Riesgos y Daños y de los centros de escucha están organizados de manera parecida. Ambos están conformados por profesionales de campo, operadores comunitarios y pares. Los primeros son funcionarios que provienen del área de las humanidades, frecuentemente de psicología, trabajo social o sociología, y realizan todas las actividades propias del centro o servicio, y los segundos son los que realizan la interconexión entre los servicios y la comunidad. Los operadores trabajan con público en general, mientras que los pares se relacionan más con los sectores de la población más discriminados y excluidos. Existe una coordinación territorial que se encarga de crear y mantener los vínculos institucionales, supervisar la sistematización y planear acciones. Lejos del terreno, como parte de la sede administrativa, está la coordinación general, quien supervisa y dirige la labor de los equipos que componen los ocho centros de escucha de la ciudad de Cali. Esta coordinación mantiene contacto con instancias institucionales de financiamiento y veeduría, integra la sistematización de los distintos centros de escucha en documentos de síntesis, asesora y forma a los equipos, sosteniendo en general la gestión de calidad y las labores administrativas.

Como dijimos anteriormente el programa de reducción de riesgos y daños y los centros de escucha se relacionan tanto con actores comunitarios excluidos, como con quienes los excluyen. Por esto se emplean los dos tipos de operadores dado que los pares facilitan las relaciones con los sectores que la comunidad excluye, mientras que los comunitarios son personas que tienen reconocimiento general y se ocupan de las relaciones con diferentes sectores. En general, la diferencia entre las funciones de los operadores pares y comunitarios es la siguiente: mientras que en el caso del operador comunitario existen acuerdos definidos, cuando se trabaja con pares es necesario acordar constantemente con cada uno de ellos sus responsabilidades diarias. Esto porque hay pares cuyas rutinas no corresponden a dinámicas laborales y el cumplimiento de metas y horarios puede resultarles extraño e inconveniente. Por otro lado, buena parte de los pares comparten la experiencia de haber consumido sustancias psicoactivas y de haber vivido en la calle. El caso del operador par de Llano Verde es una excepción a la regla. Él, al contrario de otros pares, no es consumidor. Su calidad de par radica en ser un estudiante, habitante del barrio, que trabajó en una Zona de Orientación Escolar $(\mathrm{ZOE})^{21}$ de un colegio cercano y conoce la metodología intervención. Con todo, las diferencias operativas parecen señalar que se procura cierta flexibilidad en el trabajo del operador par en comparación con el comunitario.

21. Un dispositivo comunitario, así como los centros de escucha, pero adaptado a los entornos educativos. 


\subsubsection{Funcionamiento del programa de reducción de riesgos y daños en Sucre}

El Programa inició en 2015, respondiendo a un diagnóstico según el cual el consumo de heroína en el barrio era de magnitud importante y necesitaba una intervención urgente. Desde entonces lo más característico de esta iniciativa es el intercambio de material usado para el consumo de heroína y el servicio piloto de administración de metadona. El intercambio corresponde a la línea de atención comunitaria o consumo en menor riesgo, mientras que el tratamiento con metadona pertenece a la línea llamada clinica. ${ }^{22}$ Esta situación específica ha generado modificaciones en el funcionamiento del CBT, ya que, en su propuesta original, el marco de necesidades y respuestas debe surgir desde la comunidad. La coordinadora del Programa explica que, bajo las condiciones de Sucre, para garantizar los servicios a las personas que se inyectan fue necesario "imponer los servicios desde afuera" y por "iniciativa técnica" porque, como bien lo afirma, "la misma comunidad tiene resistencias; no acepta el consumo de sustancias, ni mucho menos el consumo de heroína en el espacio público, ni que exista además un programa que no lo erradique, sino que ayuda a que se sostenga”.

Desde el punto de vista conceptual, el enfoque poblacional del Programa diverge de la teoría de redes y de los planteamientos del tratamiento comunitario que inspiraron el Modelo de inclusión social. Lo anterior porque el CBT entiende el consumo (y el tratamiento) desde una perspectiva sistémica y no como una acción individual desconectado de las redes comunitarias. Desde esa postura sería difícil entender por qué la atención se focaliza en un segmento poblacional y en la sustitución de sustancias sin desarrollar procesos comunitarios de inclusión social.

Desde el inicio del programa en 2015, el equipo de la Corporación Viviendo ha ido analizando las acciones necesarias para hacerlo sostenible y eficaz. Hacia el 2018 se tomó la decisión de fortalecer la articulación con la comunidad. Esto implicó trabajar más en cambiar las representaciones sociales que la comunidad local tiene sobre el consumo de drogas (una acción prevista en el CBT pero que aquí fue revelándose como una necesidad dada la naturaleza y origen del programa). De modo que, aunque la atención a los usuarios de heroína constituye el eje del programa, fue necesario comenzar a desarrollar ciertas acciones dirigidas a otros sectores. De esa manera, el programa de reducción de riesgos y daños incorporó algunos elementos del CBT y del Modelo de inclusión, principalmente aquellos relacionados con crear redes de soporte comunitarias que hicieran viable la instalación de servicios adicionales para inyectores, integrando una nueva función al modelo

22. La administración de este fármaco es un procedimiento terapéutico que apunta a reemplazar, reducir, o mantener el consumo de heroína, sustituyéndolo total o parcialmente de manera supervisada y técnica. La sustancia se emplea bajo el argumento de que sus propiedades moleculares bloquean o limitan la acción farmacológica de la heroína en el cerebro, lo que posibilita que la sustitución sea exitosa. Este tratamiento es una forma de mitigación, pues la metadona es un psicoactivo que genera dependencia en el usuario, pero los riesgos y daños asociados con ésta son significativamente inferiores que los asociados con la heroína. 
de atención denominada articulación comunitaria. En seguida consideraremos los ejes o funciones del Programa, comenzando por los servicios focalizados en los usuarios de drogas y terminando con las acciones de articulación comunitaria.

- Acceso a material higiénico de inyección: el usuario de heroína por vía inyectada normalmente se acerca al espacio donde se presta el servicio. También puede suceder que mientras el equipo recoge de la calle las jeringas usadas, contacte por primera vez a algún usuario. Una vez la persona consumidora inicia su contacto con el Programa, se le pide que muestre dónde se inyecta, para verificar que consume. Hecho esto, el usuario puede acceder a un kit con material higiénico, que incluye jeringas nuevas, agua destilada, y otros elementos como cazoleta y filtro, para inyectarse de manera menos riesgosa. Posteriormente se inicia el proceso de acogida que consiste en una entrevista voluntaria en la cual se indaga por su situación sociodemográfica, trayectoria de consumo y tratamiento, y redes familiares, entre otros temas. Surtida la acogida, se le asigna al usuario un código de identificación con el que puede regresar periódicamente a recibir kits adicionales. Después del enganche el usuario puede acceder directamente a otros cuatro servicios: atención psicológica, escucha activa, formación y ocupación del tiempo libre. A través de estas puertas de entrada al tratamiento la persona puede seguir un proceso de acompańamiento, y acceder a otras rutas de atención psicosocial, procurando la restitución de derechos ante autoridades administrativas o judiciales.

- Atención psicológica: se da únicamente por solicitud voluntaria. Puede ser de corta duración (cuando se trata de emergencias) o constituir un proceso terapéutico. Frecuentemente se orienta a la mitigación de los impactos del consumo y a la atención de conflictos emocionales. Puede resultar en la remisión a un tratamiento en el sistema salud o en la derivación a Escucha activa: procedimiento menos formal que la atención psicológica. Permite una expresión libre de la persona que usa el servicio, quien, dicho coloquialmente, puede entonces "desahogarse". Frecuentemente da lugar a demandas de atención en salud, cedulación (trámites de documentos de identidad) o alojamiento. Las demandas se atienden a través de la activación directa de otras rutas, o del acompańamiento. La coordinadora territorial menciona que todos los profesionales de campo pueden hacer escucha activa, aunque su profesión no sea la psicología.

- Acompañamiento: un miembro del equipo literalmente va junto con el usuario del servicio, para facilitar que éste gestione cierta necesidad por sus propios medios, y cultivar su autonomía. Por ejemplo, se acompaña a la persona para que acuda puntualmente a cierta cita médica, yendo a su hogar para invitarle a asistir, verificando que lleve la documentación correcta al sitio correspondiente, conduciéndole hasta allí, etc. Se espera que el acompańamiento resulte en la activación de otras rutas. 
- Activación de otras rutas: frecuentemente resulta de la atención psicológica; por ejemplo, una persona decide solicitar al sistema general de salud un tratamiento para dejar por un tiempo de consumir, o para condiciones relacionadas como VIH y Hepatitis C. El usuario puede ser remitido como resultado de la atención psicológica, o puede llegar mediante el acompañamiento.

- Formación: Esta acción se relaciona principalmente con prácticas de inyección menos riesgosas, como el uso de cazoleta y filtro. Igualmente, con el manejo de sobredosis, para lo que se sugiere el uso del fármaco naloxona, entre otros aspectos.

- Ocupación del tiempo libre: incluye lo previsible, como talleres de dibujo y lectura, que atienden a los intereses propuestos por los propios usuarios del servicio. También hay otros elementos como el Muro Exprésate donde quien lo desee puede comentar los temas que desee de manera anónima, inclusive para criticar al Programa. Además, hay un componente de ejercicio de la ciudadanía y los derechos, que culmina lo relacionado con el ocio. Entre otras acciones, los pares usuarios de heroína se han sentado a discutir y formular los derechos de los usuarios de psicoactivos en general, y en especial en salud mental. Este trabajo está publicado en el punto de atención, en la forma de carteleras. Se espera que gradualmente resulte en grupos de usuarios empoderados ante las autoridades.

- Restitución de derechos: Se trata de la garantía de cierto derecho reconocida y prestada eficazmente. Puede darse en el proceso de activación de otras rutas; cuando la ruta se interrumpe indebidamente en algún punto, el caso se gestiona mediante cartas formales y remitiendo el caso a Secretaría de Salud.

- Articulación comunitaria: éste es el componente de carácter secundario, que resuena con el tratamiento comunitario propio de los centros de escucha. Se refiere a la atención a la comunidad en general y al fortalecimiento de redes comunitarias, incluye trabajo con vecinos, familias y personas cuidadoras de los usuarios de psicoactivos, e inclusive se ofrece formación a funcionarios (p.ej., agentes de policía) y empresas.

La articulación comunitaria es una función compleja que amerita aclaración. Incluye aspectos de escucha activa y de atención psicológica dirigida a que la comunidad fortalezca sus vínculos con las personas consumidoras. Por ejemplo, la psicóloga del equipo ha organizado un grupo de apoyo para personas cuidadoras, en el que pueden compartir sus experiencias. Sin embargo, funciones como el acompańamiento, la activación de otras rutas, o la ocupación del tiempo libre no se despliegan completamente para la comunidad no consumidora; recordemos que no se trata de asumir el papel de un centro de escucha. La articulación comunitaria implica también realizar acciones de educación no formal. Esto beneficia a la 
comunidad en general, con temas como el manejo de sobredosis con naloxona y la comprensión de la complejidad del consumo. La educación se imparte a través de la interacción individual, por ejemplo, se dialoga con los vecinos aprovechando encuentros cotidianos. El equipo se ha encargado de ir hablando directamente con los vecinos para conocer su comprensión del problema, las soluciones que proponen, y reconocer limitaciones como el hecho de que el consumo de heroína seguirá existiendo. Adicionalmente se da a través de acciones formalmente definidas como educativas, como talleres informativos dirigidos a empresas o instituciones estatales: por ejemplo, se invita a la Policía Nacional a cooperar, explicando lo que puede suceder cuando un usuario de heroína queda retenido y luego sufre un síndrome de abstinencia.

La función de articulación comunitaria tiene una razón de ser muy clara: El equipo ha percibido resistencias en la comunidad en torno al uso de la heroína, sus usuarios, y el programa mismo. Quizás el ejemplo que mejor sirve para ilustrar esta situación es la posible ubicación de una sala de consumo controlado ${ }^{23}$ en el barrio, lo que sería una experiencia pionera en Colombia. Las resistencias al respecto han sido tenidas en cuenta por el equipo del programa, que ha respondido desarrollando encuestas para objetivar las opiniones de los vecinos. En general la realización de encuestas empieza por explicar en qué consiste una sala de consumo. Explicado lo anterior, se indaga en la actitud que la comunidad tiene frente a la instalación de uno de estos espacios en el barrio. Al momento de nuestro trabajo de campo la encuesta no estaba terminada, pero los avances le permitieron al equipo del Programa formular algunas hipótesis: la comunidad del barrio Sucre comprende el concepto de sala de consumo y se muestra interesada, percibiéndolo como una manera válida de evitar que el uso de heroína suceda "a la vista de todos". Esto porque no es extraño ver a personas dormidas en la calle luego de haber consumido heroína y todo esto preocupa a los vecinos. Por supuesto les interesa saber qué hacer en caso de sobredosis, y sienten "pesar" por lo que pueda pasar con "los muchachos".

Sin embargo, según postula la psicóloga del equipo, los usuarios no son percibidos por los vecinos como una parte de la comunidad del barrio Sucre. Algunos de ellos consideran que los usuarios son un grupo que "llega al sector", afectando a sus residentes. Aparece claramente la figura de la invasión y del agente externo que daña el barrio. De modo que la comunidad comprende por qué puede ser razonable abrir una sala de consumo, pero rechaza la idea de ubicarla en el sector. $\mathrm{Al}$ respecto algunas personas sugieren que el consumo sea permitido, pero en un lugar lejano y preferiblemente separado de las áreas urbanas. Es importante resaltar que según la profesional entrevistada no toda la comunidad piensa de esa manera.

23. Un centro para que las personas usuarias de ciertas sustancias psicoactivas, la heroína en este caso, puedan ir a inyectarse su dosis personal, bien sea autónomamente o con la ayuda de personal preparado para ello. Estas salas se instalan con el fin de disminuir los riesgos para la salud y acercar a los usuarios a otros servicios. 
En el relato administrativo, evidente en la caracterización oficial (Alcaldía de Cali, 2008, p. 16) y en el informe de la OCHA (2014), se considera que el barrio Sucre es un sector caracterizado por el consumo. Pero esa observación es una forma de estigmatización que preocupa a los habitantes del sector, pues llega a limitar su acceso al empleo. Entonces no sorprende que para una parte de los vecinos sea importante contender contra el relato administrativo que relaciona a su barrio y a ellos mismos con las drogas ilícitas. La respuesta que se elabora entonces es un contrarrelato en que el barrio se ve invadido a la fuerza por los consumidores que traen problemas y que por esta razón están afectando a sus habitantes legítimos.

Los retos de la articulación comunitaria también pasan por la cooperación interinstitucional. En principio una de las tareas de todo dispositivo comunitario es transformar las representaciones que los líderes y redes del barrio tienen en torno al consumo de psicoactivos. Esto con el fin de reducir el estigma y facilitar la inclusión de los consumidores. Sin embargo, según la coordinadora del Programa, existe el riesgo de que algunos equipos acepten las representaciones existentes en las comunidades, aunque en alguna medida sean excluyentes, procurando que los vecinos más conservadores no interfieran con el trabajo.

\subsubsection{Funcionamiento de los centros de escucha: caso Llano Verde}

Según comenta la coordinadora de los ocho centros que opera la Corporación Viviendo, en Cali, los cinco ejes de atención al consumo de drogas son: asistencia básica, organización de subredes, salud y terapia, trabajo, y educación. Los centros de escucha de otros lugares, al igual que otros dispositivos comunitarios como las $\mathrm{ZOE}$ y las ZOU, ${ }^{24}$ cuentan con ejes equivalentes en concordancia con el modelo ECO2 y el CBT. De todas formas, es importante aclarar que los nombres pueden variar y no es extraño que sus contenidos no coincidan exactamente. Para la coordinadora general, un centro de escucha se caracteriza por diferenciarse de los modelos de intervención social prediseñados por expertos que luego se aplican a un entorno comunitario. Por el contrario, cada centro se construye con la comunidad y en el territorio. Desde el diagnóstico inicial se sostienen espacios de diálogo con los actores locales en que se les solicita la información necesaria para el centro teniendo en cuenta críticas y puntos de vista diversos. Estos son los insumos para diseñar la intervención. El modelo parte de la base de que cada comunidad, y cada persona en situación de sufrimiento social en el interior de esta, tiene aquello que la coordinadora general denomina "voz propia".

24. Son dispositivos comunitarios al igual que los centros de escucha, pero se caracterizan por operar en cierto tipo de instituciones: Las Zonas de Orientación Escolar corresponden a instituciones de educación básica y secundaria (colegios o escuelas de primaria y bachillerato). Las Zonas de Orientación Universitaria corresponden a instituciones de educación superior como universidades o centros de educación técnica y tecnológica. 
$\mathrm{Al}$ saber de la coordinadora del centro en Llano Verde, se trata de "no estar sentados en la silla y esperar a que la gente llegue" sino salir a buscar a la comunidad para lograr construir "relaciones genuinas". Dichas relaciones tendrían una característica que las distinguiría de aquellas que se tejen en torno al programa de Sucre. En el Programa las relaciones serían más “instrumentalizadas", mientras que en los centros de escucha se forjan vínculos de parcería $^{25}$ La escucha sería el fundamento de dicha parcería en la medida en que quien capta las demandas debe ser capaz de suspender provisionalmente sus preceptos morales, tal como ocurre con las representaciones sociales que vinculan consumo y delincuencia. Bajo esta particular lectura del CBT y el Modelo de inclusión la "voz propia" funciona como metáfora maestra e hilo conductor de los distintos ejes.

Adicionalmente, el propósito de cada eje es propiciar un efecto de interrelación en red para que la comunidad local cree cierta capacidad de respuesta. ${ }^{26}$ Por esta razón dimensiones como el trabajo y la educación están concebidos como la capacidad de la comunidad para generar respuestas a las situaciones de sufrimiento social en términos de difusión de conocimientos y productividad. Por tales razones, el equipo de coordinación de este centro de escucha considera que desarrollar con la comunidad local un trabajo que tenga en cuenta los cinco ejes que se explorarán a continuación es la mejor manera de reducir el estigma frente a los usuarios de drogas. Implica hacer que la comunidad "abra la mirada" y comprenda que sus propias capacidades educativas y laborales son una respuesta válida a la vulnerabilidad asociada al uso problemático de psicoactivos y situaciones conexas. Los centros de escucha en Cali contemplan las siguientes funciones:

- Asistencia básica: se refiere al mejoramiento de condiciones de higiene, salud, alimentación y seguridad. Cuando este tipo de asistencia se despliega aisladamente, no genera transformaciones sostenibles, pero responde a necesidades urgentes. Sin la asistencia básica sería difícil contar con la cooperación de la comunidad local. Si bien los equipos en territorio no suelen contar con una oficina o espacio definido, los funcionarios del centro de escucha se ocupan de prestar asistencia básica directa, recorriendo el territorio y realizando visitas domiciliarias. Como se mencionó anteriormente, dentro del programa de reducción de riesgos y daños, el CBT y los lineamientos del Modelo de inclusión cuentan como instrumentos desarrollados en función de los servicios para usuarios de heroína. En los centros de escucha, por el contrario, un servicio de intercambio

25. En Colombia, en este contexto, las palabras "parce", "parcero" y similares aluden a una amistad especialmente fuerte y cercana.

26. De acuerdo con el Modelo de inclusión, la prevención, la mitigación y el tratamiento, son las estrategias de la atención al consumo. Igualmente, con una importancia paralela a éstas, la generación de capacidad de respuesta se refiere a las condiciones técnicas, institucionales y financieras que las complementan. 
de material para inyección es apenas una actividad de reducción de daño enmarcada dentro del eje de asistencia básica.

- Salud y terapia: tiene algunos elementos que el equipo del Centro puede administrar directamente, como la escucha activa y la terapia psicológica formal. Éste también incluye la derivación hacia otras instancias de respuesta, como los servicios médicos del sistema de salud para ciertas medidas de desintoxicación, terapias sostenidas orientadas al cese del consumo u otras necesidades.

- Trabajo: es un eje importante dada la precarización económica de la comunidad local determinada por la falta de oferta laboral, la informalidad y la existencia de las economías ilegales que se constituyen como fuente de ingreso. De ahí que el centro procure establecer oportunidades de acceso a trabajos formales y a emprendimientos.

- Educación: incluye elementos formales e informales, sean referidos a las situaciones de sufrimiento social, o a la educación secundaria general.

- Organización de subredes: se entiende como la gestión de una red de recursos comunitarios. Esta actividad consiste en inventariar las respuestas que la comunidad y la administración pública ofrecen en el territorio. El equipo que realiza esta tarea es denominado red operativa. Sus recursos son muy importantes porque permiten conectar al proyecto con los líderes de opinión e instituciones locales que constituyen la red subjetiva comunitaria. A nivel individual, está la denominada red subjetiva, constituida por las personas más cercanas a los usuarios del centro. Es precisamente sobre este entramado que recaen varias de las acciones de reducción de daños. Existen también otros tipos de redes de diferentes escalas que vinculan actores externos a la comunidad local.

Un ejemplo del tipo de acciones por medio de las cuales se realiza la organización de subredes es la Feria de Servicios. Durante el trabajo de campo en Llano Verde fue posible presenciar este evento que se realiza semestralmente. Conviene recurrir a esta actividad para ilustrar las prácticas relacionadas con el trabajo en red. La feria se realizó en un parqueadero ubicado al lado de la cancha de fútbol del barrio. Allí se instalaron varias carpas, algunas correspondientes a entidades de la Alcaldía, como la Secretaría de Vivienda. Otras albergaron a organizaciones comunitarias y sociales. Una organización de adultos mayores aprovechó el espacio para publicitar las artesanías que fabrican sus integrantes. También hizo presencia la Fundación Batuta, que ofrece formación musical, y sería un ejemplo que conecta con el eje educación. 
Durante los días anteriores el equipo del centro de escucha había invitado a las personas de la comunidad, en efecto ese día varias llegaron allí, para inscribirse en la carpa correspondiente al servicio institucional o comunitario de su interés. Según el equipo del centro de escucha la feria de servicios es útil para conformar la red de recursos comunitarios que las carpas simbolizan. También es una oportunidad para que el equipo trabaje sobre sus relaciones con la comunidad, inclusive en los días previos dedicados a la convocatoria; lo que en términos de redes contribuye a conectar a la red operativa con la red subjetiva comunitaria. Cuando la feria de servicios no se está realizando, el equipo del centro visita los hogares de los vecinos, realiza acciones de canalización y los invita a participar en actividades de animación comunitaria.

\subsubsection{Sistematizar para recoger evidencias}

Los componentes clínico y comunitario del programa de reducción de daños están bajo supervisión de la Secretaría Municipal de Salud de Cali. Cuando una persona se acerca al Centro o al Programa, en un primer momento se intenta establecer una relación de confianza. Si esto ocurre se invita al usuario a responder una entrevista estructurada corta. Realizada la entrevista, se abre un caso con el fin de monitorear los avances a nivel individual. Los casos individuales luego se sintetizan en informes presentados a la Secretaría periódicamente. Éstos deben ser adecuados para la evaluación de los productos, resultados e impactos de cada proyecto en el transcurso de un mes o de un año. La información así generada luego circula en otras instancias. Por ejemplo, la Alcaldía la emplea para definir los resultados de su gestión o el Concejo para debatirlos. Así las acciones de los servicios se transforman en datos.

Puesto que las formas de sistematización están enmarcadas en la lógica de la supervisión, no se analiza en detalle ambas posibilidades, sino que, a modo de ilustración, el foco está en los centros de escucha. En estos dispositivos la información sistematizada puede clasificarse en dos grandes categorías. De un lado está el despliegue general del centro consistente en la actualización del diagnóstico elaborado al inicio del proyecto. Dicho diagnóstico se ocupa de caracterizar varios aspectos de la comunidad y del territorio tales como: historia, representaciones sociales, ideas sobre el éxito y el fracaso de las intervenciones sociales, conflictos y otros aspectos culturales relevantes. La parte general también comprende un análisis de subredes, para identificar a líderes formales e informales que influyen en la opinión de la comunidad, entendiéndolos como recursos articulables al centro. De esta manera se determina cuáles son sus relaciones con los distintos actores de la comunidad y se describe el impacto de estos vínculos en el desarrollo del proyecto. Finalmente, la información del análisis de subredes se organiza en matrices de adyacencia. Esto contribuye a dar un fundamento estratégico al centro. 
El segundo aspecto importante de esta forma de sistematización es el tratamiento dado a los casos individuales. El instrumento clave para esto es la Hoja de Primer Contacto (HPC), que se llena a través de una entrevista durante el primer encuentro formal con el usuario. Se trata de un cuestionario que indaga por las demandas del usuario, identifica el contexto socioeconómico y su red de recursos, describe algunos hábitos relacionados con el consumo de drogas y determina las respuestas que el Centro ha de proponer. Si se generan demandas breves, éstas pueden ser atendidas mediante orientación, información, acompañamiento, canalización a otros servicios o escucha activa. Si las demandas son más complejas, y se relacionan con mayor vulnerabilidad, se aplican ciertos instrumentos de seguimiento como los comités de caso. En esta instancia se analizan los casos individuales mediante los llamados seguimientos de procesos personales (SPP) en que se registra cuáles actores se han involucrado con el caso y qué respuestas han sido generadas. También se tienen en cuenta los diarios clínicos, documentos que dan cuenta de los procesos formales de atención psicológica. Toda esta actividad se va registrando en diarios de campo realizados sistemáticamente.

\subsubsection{El financiamiento y las eternas crisis del trabajo comunitario}

Los centros de escucha sufren de cierta inseguridad financiera. El programa de reducción de daños también atravesó esas dificultades, pero no ha logrado suficiente estabilidad. A primera vista lo que sucede es que los procesos de contratación deben comenzar y terminar en un mismo año o vigencia fiscal. Entonces, los primeros meses del año suelen emplearse en los preámbulos administrativos relacionados con la planeación y el presupuesto, luego en los procesos de selección y contratación, y solo se llega al punto de la ejecución de contratos meses después. Aunque al final se giran los fondos de todo el año y no sólo de los últimos meses, hay períodos de tiempo en que los proyectos están desfinanciados. Ante esta eventualidad las organizaciones operadoras y los contratistas deben prestar recursos propios a los proyectos, o gestionar alternativas. Para un directivo de la organización operadora, lo ideal, a fin de potenciar el impacto, es que la contratación sea plurianual.

Se dice que todos los miembros de los equipos comparten una actitud solidaria ante las situaciones de sufrimiento social. Esta idea cobra un peso tangible al considerar la cuestión del financiamiento, pues formar parte de estos equipos significa no permitir que el proyecto se acabe en los meses en que no hay recursos, sosteniendo las relaciones con las comunidades. Lo que esto implica es que la mayoría de los contratistas ha vivido la experiencia de trabajar sin recibir remuneración durante varios meses, inclusive en el programa de reducción de riesgos y daños. Entre tanto, las personas de la comunidad sufren la inestabilidad pues continúan con la expectativa de suplir sus demandas. Esto genera frustración y dificulta que la gente recupere la confianza en el equipo. 
Lograr un financiamiento estable depende en parte de que exista voluntad política por parte de la administración pública. Las entidades estatales son las responsables de tomar las decisiones de planeación, presupuesto y contratación, principalmente la Secretaría de Salud, la Alcaldía y el Concejo municipal. Una vez el Concejo decide incluir una modalidad de atención en la política pública del municipio, el alcalde queda obligado a definir cómo implementarla a lo largo de su mandato de cuatro años, incluyéndola en el Plan de Desarrollo. A su turno la Secretaría debe asumir un rol en dicha implementación, estableciéndolo en su Plan Estratégico Institucional, para luego presupuestar el financiamiento necesario en un marco anual y plurianual y ejecutar dicho presupuesto mediante procesos anuales de contratación.

Debido a esto, para el profesional encargado de la coordinación de pares en Sucre, el factor decisivo para alcanzar la estabilidad financiera del Programa fue su inclusión, por decisión del Concejo de Cali, en la política municipal de atención al consumo de drogas. Lograrlo, dependió de la colaboración de todo el equipo en el proceso de sistematización de resultados. Con la evidencia lista los gestores del Programa pudieron presentar su estrategia de manera precisa y persuasiva. Sobre esa base la información se transmitió por los canales regulares, del equipo hacia la Secretaría de Salud como entidad supervisora. Luego, según especula el profesional, debió existir alguna gestión de la Secretaría ante el Concejo, para que éste finalmente tomara la decisión esperada.

La Corporación Viviendo ha hecho una gestión similar para financiar los centros de escucha, sin lograr los mismos resultados. Según comenta el director de la organización, se han desarrollado los mismos procesos de incidencia política procurando llevarlos más lejos, inclusive a instancias nacionales, a través de un senador de la República, pero esto ha resultado infructuoso. Esto a pesar de que el modelo de los centros de escucha forman parte integral de la política nacional de reducción del consumo de drogas desde hace más de una década. El asunto es que haber logrado ese nivel de incidencia no garantiza recursos a escala local.

Aunque la sistematización y evaluación de resultados en los centros de escucha se lleva a cabo de manera constante y cuidadosa esto no garantiza la continuidad del financiamiento pues, como se ha venido sugiriendo, el asunto no es estrictamente técnico. Adicionalmente, esta falta de regularidad hace que en ocasiones los procesos de intervención tengan que llevarse a cabo en pocos meses cumpliendo con las metas previstas para todo el año y haciendo más desgastante la sistematización. Por ejemplo, se espera que los equipos de los centros de escucha logren cierto grado de contacto con la comunidad, expresado en el número de Hojas de Primer Contacto (HPC) diligenciadas. Esto hace que, para cumplir con los indicadores de resultado, los operadores deban diligenciar un número elevado de HPC en un tiempo insuficiente. Toda esta lógica contribuye a presionar a los contratistas para trabajar durante algún tiempo sin recursos, pues de lo contrario la organización de la que son parte, corre el riesgo de dejar de operar los servicios. 
Los centros de escucha y el Programa atraviesan el mismo escenario administrativo: comparten ritmos de contratación, tipo de entidades contratantes y supervisoras, procedimientos de planeación, presupuesto, contratación, modelos de incidencia política, lógica general de sistematización y supervisión. No obstante, el Programa recibe recursos de manera continua. Esto tiene dos explicaciones. Por una parte, existe una narrativa consolidada sobre la heroína como la droga más peligrosa y devastadora. Esta narrativa no depende de los equipos territoriales ni administrativos, sino que se corresponde a relaciones sociales más abarcadoras. De cierto modo, la influencia del cine y los medios de comunicación, pero también las campañas de salud han posicionado la idea de que es necesario ofrecer a los usuarios de heroína servicios de intercambio de jeringas y terapias de sustitución de sustancias, para evitar graves crisis de salud pública. Por eso no es extraño que el programa que se ocupa de atender específicamente a los consumidores de heroína reciba un financiamiento más estable.

Por otra parte, el fraccionamiento de los proyectos y la multiplicación de las organizaciones operadoras también podría responder a los problemas de sustentabilidad. El caso de Sucre es ilustrativo al respecto: según relató el coordinador de pares, inicialmente las líneas comunitaria y clínica del Programa eran operadas por la misma organización. En un primer momento este trabajo lo hizo Acción Técnica Social (ATS) en el marco del Proyecto Cambie, que ha establecido servicios similares en otras ciudades de Colombia. ATS comenzó por acercarse a la Corporación Viviendo, ya instalada en Cali, y le propuso realizar un diagnóstico y, de ser necesario, promover los servicios para usuarios de heroína. La relación entre ambas organizaciones ha sido fluida pues hacen parte de la sección colombiana de la Red Americana de Intervención en Situaciones de Sufrimiento Social (RAISSS). ATS estableció el Programa y Corporación Viviendo eventualmente lo heredó. Sin embargo, hace alrededor de un año el Programa se fraccionó: aunque el componente de intercambio de metadona ha funcionado en otro lugar y con otro equipo, ahora además es coordinado por una persona distinta y operado por una tercera organización llamada Pilsen Wellness Center. Adicionalmente las organizaciones operadoras han gestionado cofinanciamiento mediante la cooperación internacional con Open Society Foundation para garantizar el suministro de naloxona y similares pues los recursos estatales no son constantes.

\section{CONCLUSIONES}

Los dispositivos comunitarios han encontrado barreras debido a la estigmatización de los usuarios de drogas, a la llegada de gobiernos autoritarios, a la reiteración de acciones represivas y a la inseguridad laboral y financiera propiciada por políticas neoliberales. No obstante, la reflexión general que dejan los últimos años de experiencias de intervención social basadas en el CBT y en el Modelo de inclusión social en Colombia, señalan un impacto importante en las diferentes escalas y ámbitos 
de implementación de las políticas públicas para la prevención y reducción del consumo de drogas. Actualmente, y a pesar de la intensificación de las estrategias represivas de la "lucha antidrogas", los elementos básicos de la reducción de daños y del tratamiento comunitario persisten en la Política Integral para la Prevención y Atención del Consumo de Sustancias Psicoactivas del 2019.

En seguida, y con base en los casos expuestos en estas páginas, se sintetizan las principales prácticas por medio de las cuales se implementa la política objeto de análisis en tres escenarios comunitarios distintos. Se destacarán las posibilidades y tensiones inferidas en la investigación en relación con los procesos de inclusión social de usuarios de drogas en condición de vulnerabilidad.

\subsection{Posibilidades: circulación, trabajo e inclusión}

Los abordajes comunitarios son heterogéneos. Son mezcla, apropiación y efecto de la interacción entre las distintas comunidades, territorios y corrientes de intervención social. Las experiencias de la Corporación Viviendo en los barrios Sucre y Llano Verde de la ciudad de Cali, muestran cómo diferentes estilos de reducción de daños pueden dialogar de acuerdo con las necesidades específicas de las comunidades locales. Así, un servicio de sustitución de sustancias, que desde el punto de vista conceptual se aparta de los postulados sistémicos de CBT, puede irse transformando, paulatinamente, en un dispositivo de escucha, optimizando los recursos disponibles para la salud pública y la voluntad política de los gobernantes locales. Esta es una estrategia de sustentabilidad llevada a cabo por instituciones que han sabido posicionar un modelo terapéutico basado en la gestión de redes sociales, frente al confinamiento, la exigencia de la abstinencia y el enfoque individualista de muchos centros de atención. A pesar de las contingencias económicas de los centros de escucha como el de Llano Verde, la Corporación, junto con las redes de instituciones aliadas y operadores solidarios (quienes muchas veces trabajan sin sueldo para proteger los vínculos comunitarios), ha podido mantener y ampliar durante casi dos décadas la apuesta por los dispositivos de inclusión social. De hecho, se constituye como una de las instituciones más destacadas en el desarrollo e implementación de intervenciones inspiradas en el modelo ECO2 y el tratamiento comunitario adaptadas a diferentes contextos. En otras palabras, los centros de escucha y servicios de reducción de daños se relacionan con los modelos de la política nacional, pero no como moldes, es decir series uniformes y replicables, sino como prototipos que se pueden reorganizar de manera experimental y tentativa.

En la experiencia del Idipron y el colectivo Free Soul la circulación resultó ser un instrumento adecuado para promover la inclusión social. Esto puede ser entendido como un proceso de adaptación en doble vía. Los usuarios transforman los espacios por donde circulan y al tiempo se acomodan a dichos escenarios, generando conexiones con diferentes actores. El campo de la producción artística y cultural resultó fructífero para impulsar cambios en variadas escalas: para los 
jóvenes significó hallar un espacio de interlocución válido donde situar sus puntos de vista y compartir sus memorias sobre el conflicto y la violencia, poniendo el sufrimiento en palabras y símbolos que propician empatía. De igual manera, este proceso permitió incluir una contranarrativa -en este caso las historias soterradas del narcotráfico y la guerra contra las drogas en Colombia- dentro del relato de construcción de nación materializado en los guiones del Museo Nacional. Así, los proyectos creativos con poblaciones estigmatizadas y altamente vulnerables aportan a la transformación de representaciones sociales. La circulación social y espacial de este tipo de productos es a la vez un acto estético, político y terapéutico.

La manera de pensar la inclusión, a través del adaptarse y adaptar, se manifiesta también en las experiencias de producción de conocimiento. Los jóvenes del Idipron se planearon una pregunta relacionada con su realidad social e histórica y para resolverla encontraron apoyo en profesionales solidarios e interesados por los mismos temas. Dicha sinergia, cuyo abordaje metodológico tiene sus raíces en la investigación acción participativa (IAP), se potencia y despliega cuando hay proyectos que propicien la mejoría de las condiciones de vida. Esto se consigue buscando financiamiento y construyendo redes interinstitucionales; trascendiendo el ámbito de la salud pública y conectando la cultura, la educación y la pedagogía; buscando lenguajes que lleguen a muchos tipos de interlocutores. La creación artística, en este caso, es un idioma para la difusión del saber que debe ser valorado, inclusive económicamente.

Por supuesto ambas modalidades no se dan aisladamente. De hecho, convergieron con el retorno de Free Soul a "La L". Este ha sido el punto culminante, hasta ahora, de la circulación social y espacial de estos jóvenes. El proyecto de renovación urbana del antiguo "Bronx", aunque incorpora una avasalladora lógica de gentrificación, ha traído a un grupo de exhabitantes del barrio de vuelta. Pero este devenir ya no es más un círculo vicioso, ahora parece haber tomado forma de espiral. Se trata de "volver diferente". Con trabajo, con más conocimientos y conexiones, con una nueva actitud ante el consumo de drogas, con otra perspectiva. Esta transformación individual y social también puede ser conceptualizada como un proceso de inclusión. Porque el sujeto excluido no está "fuera de la sociedad", sino que se conecta con instituciones, personas y drogas de una manera particularmente nociva. Así, el "regreso" de Free Soul a "la L" adquiere otra dimensión. La circulación es también un asunto político.

De igual manera, la dimensión política de la circulación social y espacial es notable en las innovaciones gestadas al interior del programa de reducción de daños del barrio Sucre en la ciudad de Cali. En este caso podemos conceptualizar como circulación política a las estrategias de agrupamiento e incidencia de los operadores pares. En los centros de escucha y en el Programa se considera que las personas consumidoras de psicoactivos u otras situaciones asociadas al sufrimiento social son 
sujetos de derecho. Reconocerles como tales es medio y fin de ambos dispositivos. Lo distinto está en que en el Programa se ha realizado un trabajo de agrupar a los operadores pares para que discutan y replanteen sus derechos en materia de salud mental y en general como consumidores de psicoactivos. El trabajo de reconocerse como agentes, reflexionando sobre las modalidades de restitución de derechos se ha llevado a cabo entre los pares del servicio de intercambio de material para inyección, al igual que con los del tratamiento piloto con metadona que se asocian en un grupo de apoyo. Esto supera la agencia individual y apunta el empoderamiento y a la incidencia política de los usuarios de drogas.

Por último, las diversas modalidades y dimensiones de la circulación comparten un elemento clave sin el cual no se podrían lograr dinámicas de inclusión social. Sin autonomía económica, la posibilidad de recaer en ocupaciones ilícitas es elevada. Por esto la oportunidad de acceder al trabajo remunerado es clave para lograr impactos sostenibles en los usuarios de los dispositivos comunitarios.

\subsection{Tensiones políticas, legales y técnicas}

Este tipo de procesos nos enfrentan directamente con el asunto de la sustentabilidad. Un tema difícil se presenta cuando los procesos comunitarios no pueden demostrar el impacto requerido por los entes financiadores. Sumado a esto, las lógicas de financiamiento de los proyectos contraponen coberturas a procesos, es decir, privilegian intervenciones sociales rápidas cuyos resultados son evaluados en términos del número de personas impactadas. Esta clase de indicadores alimenta el asistencialismo, promueve la cooptación de la participación e impide acompañar a las comunidades. El tema se agudiza cuando la estructura burocrática ha sido debilitada por la flexibilización laboral y las reformas neoliberales a los sistemas de salud y trabajo. Tiempos adversos de contratación hacen que los equipos roten y que los técnicos formados deserten o tengan que trabajar sin recursos esperando el financiamiento. El efecto de estas tensiones va a ser siempre el mismo: generar desesperanza, sobreintervenir y usar a las comunidades locales.

Pensar en sustentabilidad es pensar también en las barreras de acreditación para el trabajo de los operadores pares, agentes fundamentales en las intervenciones comunitarias. Puesto que generalmente no tienen grados de educación formal, no es posible vincularlos debidamente a los proyectos pagándoles salarios dignos, lo cual significa que su trabajo casi siempre es "voluntario" y de "poco valor". Esto dificulta la participación sostenible y genuina de agentes comunitarios en las intervenciones sociales.

La inversión debe estar conectada con la producción de evidencia y la respuesta a las preguntas producidas por la propia comunidad. Se trata de conseguir buenos análisis estimulando la generación de mecanismos alternativos para la producción y circulación de conocimiento que aporten a mejorar las condiciones de vida y a propiciar redes de cuidado y convivencia. Pero el dónde invertir también tiene que ver con el papel de las autoridades locales. Cuando hay compromiso de estas 
instancias los procesos perviven y dan frutos, pero cuando sucede lo contario, lo que encontramos son organizaciones civiles trabajando aisladamente, compitiendo por recursos y debilitando la confianza de la comunidad.

Hay poca capacidad de respuesta para tratar adicciones graves, esto debe ser recalcado, pues cuando hablamos aquí de lo comunitario no estamos diciendo que en ciertos casos no se necesiten las intervenciones clínicas institucionalizadas, sino que los abordajes deben dialogar mientras sean éticos y estén enmarcados en los derechos humanos.

La institucionalidad tiene la tendencia de "convertir todo en servicios", de formalizar lo informal e integrarlo a la máquina de gobierno, y eso hace que lo informal pierda su fluidez y potencial para el cambio. Es importante observar qué se gana y qué se pierde cuando un modelo ha sido exitoso en lo local y se pretende reproducir a escala nacional. Otra cuestión relacionada con este tema tiene que ver con los riesgos de formalizar lo informal y de paso convertir las respuestas espontáneas en metodologías prefabricadas. Aquí ya no habría autonomía puesto que el método abstraído del contexto impide la transformación o como se dice coloquialmente, las cosas cambian para seguir igual. Lo anterior para decir que la idea de informalidad es polivalente y que los intentos por domesticarla pueden acarrear efectos inesperados pues informales son tanto los tratamientos dańinos que aíslan sujetos y violan sus derechos humanos, como las experiencias de autoorganización que configuran sus propias prácticas de prevención y regulación.

Cuando se trabaja en comunidades locales donde hay presencia de tráfico de drogas y de actores armados es difícil construir redes, mapas, diagnósticos, ubicar dónde están las personas y los lugares de riesgo, puesto que estas metodologías y procesos pueden constituirse en amenazas para los equipos que realizan las intervenciones. No hay que olvidar que la comunidad también está compuesta por personas y organizaciones (legales e ilegales, informales e institucionales) que se reciben beneficios del tráfico de drogas y que no tienen ningún interés en que su circulación de se reduzca.

La intervención comunitaria afronta varias dificultades: por un lado, la seguridad de los equipos está en juego, por otro, la satanización que se ha hecho de la droga y la criminalización del consumo fortalecen lo ilegal gracias a la analogía entre peligro y ocultamiento. Ante este panorama cabe preguntarse: ¿Cómo construir seguridad y vínculos en contextos inseguros? La respuesta que los dispositivos de inclusión social han encontrado es que esto se consigue "estando ahî", generando relaciones afectivas, de intercambio, de confianza y apoyo (con efecto terapéutico) que permiten construir seguridad en medio de la inseguridad, no solo para los equipos sino también para aquellos actores que se puedan sentir amenazados con una intervención de este tipo. 


\section{REFERENCIAS}

COLECTIVO FREE-SOUL. Renovando el olvido: ensamble de investigación social y creación artística - proyecto ganador Beca Bogotá Diversa para proyectos dirigidos a sectores sociales. Bogotá: IDARTES, 2017.

COLOMBIA. Ley no 11 , de 15 de septiembre de 1920. Sobre importación y venta de drogas que formen hábito pernicioso. Bogotá, 1920. Disponible en: <https:// bit.ly/34E6tsN>. Acceso en: 1 de sept. 2019.

. Ley no 116, de 24 de noviembre de 1937. Por la cual se dictan algunas disposiciones sobre especialidades farmacéuticas y drogas heroicas. Diario Oficial, Bogotá, n. 23671, 5 de enero 1938. Disponible en: <https://bit.ly/2WE9rsT>. Acceso el: 1 sept. 2019.

. Decreto no 14 , de 19 de enero de 1955. Por el cual se dictan disposiciones sobre prevención social. Diario Oficial, Bogotá, n. 28.661, 1965. Disponible en: $<$ https://bit.ly/2M47F27>. Acceso el: 4 sept. 2019.

Ley no 30, de 31 de enero de 1986. Por la cual se adopta el Estatuto Nacional de Estupefacientes y se dictan otras disposiciones. Bogotá, 1986. Disponible en: <https://bit.ly/38s5gG1>. Acceso el: 4 sept. 2019.

. Ministerio de Salud y Protección Social. Resolución no 2358, de 18 de junio de 1998. Por la cual se adopta la Política Nacional de Salud Mental. Diario Oficial, Bogotá, n. 43338, 13 jul. 1998. Disponible en: <https://bit.ly/34BKIJU>. Acceso el: 10 sept. 2019.

. Ministerio de la Protección Social. Hacia un modelo de inclusión social para personas consumidoras de Sustancias psicoactivas. Bogotá: República de Colombia, 2007a.

. Ministerio de la Protección Social. Política Nacional para la Reducción del Consumo de Sustancias Psicoactivas y su Impacto. Bogotá: República de Colombia, 2007b.

. Ministerio de la Protección Social; UNODC. La Política para la Reducción del Consumo de SPA al alcance de tod@s: Una herramienta para construir política en lo local. Bogotá: República de Colombia, 2008. . Ley no 1566 de 2012.

- Ministerio de la Protección Social. Caja de herramientas Tratamiento de Base Comunitario (CBT). Bogotá: República de Colombia, 2013a.

. Ministerio de Justicia y del Derecho; ODC - OBSERVATORIO DE DROGAS DE COLOMBIA. Ministerio de Salud y Protección Social. Estudio Nacional de Consumo de Sustancias Psicoactivas en Colombia. Bogotá, 2013 b. 
Ministerio de Salud y Protección Social. Diseño y validación de un modelo de gestión para el fortalecimiento y seguimiento de las estrategias y dispositivos de base comunitaria para la prevención y mitigación de impactos frente al consumo de sustancias psicoactivas SPA, sobre la base de las experiencias desarrolladas por las entidades territoriales del Valle del Cauca, Risaralda, Caldas y Cauca. Bogotá, 2014a.

. Ministerio de Salud y Protección Social. Plan nacional para la promoción de la salud, la prevención, y la atención del consumo de sustancias psicoactivas 2014-2021. Bogotá: República de Colombia, 2014 b.

. Ministerio de Justicia y del Derecho. Ministerio de Salud y Protección Social. Guía para orientar la identificación de recursos de financiación del plan territorial de drogas componente de reducción del consumo de drogas. Bogotá, 2016.

. Ministerio de Justicia y del Derecho. Ministerio de Salud y Protección Social. Reducción del consumo de sustancias psicoactivas en el ámbito universitario - Marco técnico de acción. Bogotá, 2018a.

. Ministerio de Justicia y del Derecho. Ministerio de Salud y Protección Social. Generación de alternativas y oportunidades para jóvenes, familias y comunidades en situación de alta vulnerabilidad frente al consumo de drogas y vinculación a economías ilegales - Marco técnico de acción. Bogotá, 2018b.

. Ministerio de Justicia y del Derecho. Ministerio de Salud y Protección Social. Reducción del consumo de sustancias psicoactivas en el ámbito penitenciario y carcelario - Marco técnico de acción. Bogotá, 2018c.

. Ministerio de Salud y Protección Social. Resolución no 089/2019. Política Integral para la Prevención y Atención del Consumo de SPA. Bogotá: República de Colombia, 2019.

COMISIÓN ASESORA PARA LA POLÍTICA DE DROGAS EN COLOMBIA. Lineamientos para un nuevo enfoque de la Política de Drogas en Colombia. Bogotá, 2015. Disponible en: <https://bit.ly/2LLfFET>. Acceso el: 10 sept. 2019. CNRDD - COMISIÓN NACIONAL PARA LA REDUCCIÓN DE LA DEMANDA DE DROGAS. Plan Nacional de Reducción del Consumo de Drogas 2009-2010. Bogotá: República de Colombia, 2008.

DECENAS de habitantes de calle fueron arrastrados por una creciente en Bogotá. Revista Semana, 18 de agosto de 2016. Disponible en: <https://bit.ly/3mJMLBY>. Acceso el: 11 de septiembre de 2019. 
FERGUSSON, S. Reducción de daños en la Rioja. Zonas de mitigación: una estrategia para la reducción del sufrimiento social, 2017. Disponible en: $<$ https:// bit.ly/2KpKaQn>.

Acompańamiento psicoafectivo integral a jóvenes del colectivo Free Soul - Proyecto Maquetiando, Premio Ibermuseos. Museo Nacional de Colombia, 2019.

FERGUSSON, S.; GÓNGORA, A. La relación entre personas y drogas y los dispositivos de inclusión social basados en la comunidad: críticas y perspectivas desde América Latina. In: CONFERENCIA ANUAL COPOLAD, 2., 2012, Bruselas, Bélgica. Anais... Neip, 2012.

FOUCAULT, M. Microfísica del poder. Madrid: Las Ediciones de la Piqueta, 1979. GÓNGORA, A; SUÁREZ, C. Por una Bogotá sin mugre: violencia, vida y muerte en la cloaca urbana. Universitas Humanística, v. 66, n. 1, p. 107-138, 2008.

GÓNGORA, A. Redes riesgos y drogas: hacia una antropología de las formas de gobierno. In: ESPINOSA, N.; TAPIAS, C.; GÓNGORA, A. (Comps.). Nuevas antropologías colombianas: experiencias metodológicas. Montería-Medellín: Editorial Zenú, 2012. p. 152-183.

. Redes que curam: riscos, danos e políticas de drogas na Colômbia. Dissertação (Mestrado) - Programa de Pós-Graduação em Antropologia Social, Museu Nacional, Universidade Federal do Rio de Janeiro, Rio de Janeiro, 2013a.

. Curar comunidades: gubernamentalidad, reducción de daño y políticas de drogas en Colombia. In: EPELE, M. (Comp.). Padecer, cuidar y tratar: estudios socio-antropológicos sobre consumo problemático de drogas. Buenos Aires: Editorial Antropofagia, 2013b. p. 101-130.

. El Gobierno de las Redes: Una etnografía de la reducción de daño en Colombia. Mana, v. 2, n. 22, 2016.

Farmacopeia Política: Uma etnografía do antiproibicionismo e das lutas pela libertação da maconha na Colômbia. Tese (Doutorado) - Programa de Pós-Graduação em Antropologia Social, Museu Nacional, Universidade Federal do Rio de Janeiro, Rio de Janeiro, 2018.

GÓNGORA, A. et al. La Maqueta de "La L": Experimentación etnográfica, antiprohibicionismo y espacios heterotópicos. In: Etnografía y espacio: tránsitos conceptuales y desafíos del hacer. Medellín: Universidad de Antioquia, 2019. (no prelo). HINCAPIE, A. Legalización de la Droga. Graficas Mundial, 1989. 
Centros de Escucha en Colombia: políticas y escenarios para la reducción de daños en comunidades locales

IDIPRON - INSTITUTO DISTRITAL PARA LA PROTECCIÓN DE LA NIÑEZ Y LA JUVENTUD. Plataforma estratégica: plan estratégico. Alcaldía Mayor de Bogotá: Bogotá, 2017. Disponible en: <https://bit.ly/2Kf8t3H>.

LARVIE, P. Managing desire: AIDS, sexual citizenship and the new Brazilian homsexuality. Dissertation (PhD), University of Chicago, Chicago, EUA, 1998.

LOMNITZ, M. Globalización, economía informal y redes sociales. In: BARAÑANO, A.; GARCÍA, J. L. (Coord.). Culturas en Contacto: encuentros y desencuentros. Madrid: Ministerio de Educación Cultura y Deporte, 2003. p. 129-146. MACHÍN, J. Modelo ECO2: redes sociales, complejidad y sufrimiento social. Revistas REDES, v. 18, n. 12, jun. 2010.

- Redes Sociales e Incidencia en Política Pública: Estudio comparativo México-Colombia. México D.F.: CAFAC, 2011.

MAMACOCA. Legislación. Disponible en: <https://bit.ly/38sQJcZ>. Acceso el: 1 sept. 2019.

MILANESE, E. Interregional Cooperation to establish a common response to drug use and its consequences in Latin America and the Caribbean - Final Report. Freiburg: Caritas Germany, 2005.

. Harm reduction and community based treatment of drug consequences - Evaluation: process and results. Freiburg: Unesco - Caritas Germany, 2007.

. Tratamiento comunitario de las adicciones y de las consecuencias de la exclusión grave. México: Plaza y Valdés/Cafac, 2009.

. Tratamiento Comunitario de las Adicciones: anotaciones teóricas. In: ENCUENTRO DE LA RECOISS: REDES E INCIDENCIA POLÍTICA, 5., 2010, Panamá. Anais... Universidad de las Américas, 2010.

. Tratamento comunitário: manual de trabalho I. Brasil: Secretaria Nacional de Politicas de Drogas; Instituto Empodera, 2012.

MILANESE, E; MERLO, R.; LAFFAY, B. Prevención y cura de la farmacodependencia: una propuesta comunitaria. México: Plaza y Valdéz, 2001.

MILANESE, E; MERLO, R; MACHÍN, J. Redes que previenen. México D.F.: Instituto Mexicano de la Juventud y Centro Cáritas de Formación, 2000.

MITCHELL, J. Networks, norms and institutions. In: BOISSEVAIN, J. M. Network Analysis: Studies in Human Interaction. París: The Hague, 1973.

MUNICIPIO DE SANTIAGO DE CALI. Caracterización de la Comuna 9 Plan de Desarrollo 2008-2011. Santiago de Cali, 2008. 
MNC - MUSEO NACIONAL DE COLOMBIA. La Esquina Redonda: Co-laboratorio de creación y memoria, proyecto Bronx Distrito Creativo - Informe de gestión. Bogotá: Ms, 2019.

ODC - OBSERVATORIO DE DROGAS DE COLOMBIA. Reporte de Drogas de Colombia 2016. Bogotá: Legis, 2016. Disponible en: <https://bit.ly/3nDHs8r>. Acceso el: 10 sep. 2019.

OCHA - OFICINA DE NACIONES UNIDAS PARA LA COORDINACIÓN DE ASUNTOS HUMANITARIOS. Informe Final MIRA: Municipio Santiago de Cali (Valle del Cauca) - Comunas 9, 15, 18 y 21. Sept. 2014.

SCOTT, J. Social Network Analysis. London: Sage, 1991.

SICACHA, D. Más De 1.000 jóvenes participaron de la estrategia para la prevención del consumo de drogas. Noticias - Secretaría Distrital de Salud de Bogotá, oct. 2018 Disponible en: <https://bit.ly/3aCUYWb>. Acceso el: 20 sept. 2019.

SOCARRÁS, J. Las Farmacodependencias en Colombia: medidas prohibitivas y educativas para prevenirlas. Paris: Organización de las Naciones Unidas para la Educación, la Ciencia y la Cultura, 6 abr. 1976. Disponible en: <https://bit. ly/3aDpTSo>. Acceso el: 1 sept. 2019.

VÁSQUEZ CHACÓN, E. Tratado Jurídico de las Drogas. Bogotá: Ediciones Librería del Profesional, 1982. Disponible en: <https://bit.ly/3rm7hfx>. Acceso el: 10 sept. 2019. 
ANEXO A

CIEN AÑOS DE POLÍTICAS DE ATENCIÓN AL USO DE PSICOACTIVOS EN COLOMBIA

CUADRO A. 1

Principales hitos jurídicos y administrativos

\begin{tabular}{|c|c|}
\hline Documento & Síntesis \\
\hline Ley no 11, de 1920 & $\begin{array}{l}\text { Con esta norma se da comienzo a la restricción del mercado de las sustancias que } \\
\text { pueden formar "hábito pernicioso". Hasta entonces existía un régimen de libre } \\
\text { mercado proveniente de la segunda mitad del siglo XIX, en donde la producción de } \\
\text { alcohol y sustancias similares era libre (Ley no } 84 \text { de 1916), al igual que el ejercicio de } \\
\text { la profesión médica: "Toda persona podrá abrazar cualquier oficio y ocupación honesta } \\
\text { sin necesidad de pertenecer a gremio de maestros o doctores" (Acto legislativo } 1 \text { de } \\
\text { 1918). El primer castigo que hubo para la venta de ciertas drogas sin fórmula médica, } \\
\text { instituido por la ley no } 11 \text { de 1920, fue simplemente una multa. A partir de este } \\
\text { momento a través de normas similares (Acto Legislativo } 1 \text { de 1921, Resolución } 146 \\
\text { de } 1921 \text { de la Dirección Nacional de Higiene, Ley no } 99 \text { de 1922, Leyes no } 12 \text { y no } 88 \\
\text { de } 1923 \text {, Ley no } 88 \text { de 1928, Ley no } 47 \text { de 1930) se instalan mecanismos de vigilancia } \\
\text { y regulación del mercado del alcohol, de la profesión médica, y de la salud pública, a } \\
\text { escala nacional y departamental. }\end{array}$ \\
\hline Ley no 118, de 1920 & $\begin{array}{l}\text { Desde } 1920 \text { hasta } 1928 \text { no hubo pena de prisión para la venta de drogas susceptibles } \\
\text { de "hábito pernicioso" sin fórmula médica, luego se estableció una pena de seis meses } \\
\text { ante la reincidencia. Esta misma ley alarga la lista de las sustancias así consideradas, } \\
\text { restringe la importación postal de jeringuillas, y establece en la Dirección Nacional de } \\
\text { Higiene la autoridad para incluir nuevas sustancias en la lista. También se estableció } \\
\text { que las personas que tuvieran el "hábito pernicioso" del "uso indebido" debían ser } \\
\text { sometidas a tratamiento forzado. }\end{array}$ \\
\hline Decreto no 1377 , de 1938 & $\begin{array}{l}\text { Restringe la importación sin licencia de cocaína, ecgonina, opio, morfina, heroína, } \\
\text { benzoilmorfina, cáñamo indio, marihuana, y de sus sales, preparaciones y derivados, } \\
\text { dejando a la Dirección Nacional de Higiene la reglamentación de la importación y } \\
\text { prescripción de tales sustancias. }\end{array}$ \\
\hline Ley no 95, de 1936 & $\begin{array}{l}\text { La criminalización del consumo y distribución de las llamadas "sustancias narcóticas" o } \\
\text { "estupefacientes" apareció con el código penal de 1936, como delito contra la salubri- } \\
\text { dad pública. Quienes consumieran eran sometidos a "medidas de seguridad" (reclusión } \\
\text { en manicomio criminal, colonia agrícola, libertad vigilada, etc), mientras que a quienes } \\
\text { las distribuyeran les correspondía un arresto como pena. }\end{array}$ \\
\hline Ley no 116, de 1937 & $\begin{array}{l}\text { Prohíbe el procesamiento del opio y la coca salvo permiso del gobierno concedido a } \\
\text { ciertos laboratorios. Los "toxicómanos" podían ser recluidos en "sanatorios privados" } \\
\text { como alternativa a las medidas de seguridad administradas por las autoridades. }\end{array}$ \\
\hline $\begin{array}{l}\text { Resolución no 313, de } 1937 . \\
\text { Resoluciones no } 25 \text { y no } 95 \text {, de 1938, } \\
\text { del Ministerio de Trabajo, Salud y } \\
\text { Previsión Social }\end{array}$ & $\begin{array}{l}\text { Impiden la comercialización abierta de hoja de coca, restringiéndola a la venta en } \\
\text { droguerías o farmacias bajo prescripción médica. }\end{array}$ \\
\hline Ley no 36, de 1939 & $\begin{array}{l}\text { Instituye un monopolio estatal sobre las "drogas que formen hábito pernicioso" cuyo } \\
\text { producto se destinaría a la lucha contra las "toxicomanías". Más adelante el Decreto } \\
96 \text { de } 1940 \text { reglamenta esta ley en el sentido de que las importaciones de estupe- } \\
\text { facientes solo las puede hacer el gobierno a través del Ministerio de Trabajo, Salud y } \\
\text { Previsión Social. }\end{array}$ \\
\hline Decreto no 1959, de 1939 & Prohíbe la importación de heroína. \\
\hline $\begin{array}{l}\text { Resolución no 645, de 1939, del } \\
\text { Ministerio de Trabajo, Salud y Previsión } \\
\text { Social }\end{array}$ & Prohíbe el cultivo de cannabis sativa. \\
\hline
\end{tabular}


(Continuación)

\begin{tabular}{|c|c|}
\hline Documento & Síntesis \\
\hline Ley no 12, de 1943 & $\begin{array}{l}\text { Establece un sistema de represión del tráfico de "drogas estupefacientes", castigando } \\
\text { las distintas actividades de la cadena, y aún la tentativa de éstas o sus actos prepara- } \\
\text { torios. }\end{array}$ \\
\hline Decreto no 896, de 1946 & Prohíbe el pago de salarios en la forma de alcohol, hojas de coca, o similares. \\
\hline Ley no 45, de 1946 & $\begin{array}{l}\text { Amplía las medidas de la ley no } 12 \text { de } 1943 \text { a todos los eslabones del cultivo y la } \\
\text { conservación de plantas de las que puedan extraerse las "drogas estupefacientes". }\end{array}$ \\
\hline Ley no 84, de 1946 & Regula el ejercicio del oficio de farmaceuta, y restringe la venta de barbitúricos. \\
\hline Decreto no 25, de 1947 & $\begin{array}{l}\text { Encarga al Ministerio de Higiene el control de estupefacientes y la "policía sanitaria } \\
\text { nacional". }\end{array}$ \\
\hline Decreto no 1472, de 1947 & Prohíbe el establecimiento de nuevos cultivos de coca. \\
\hline Decreto no 923, de 1949 & $\begin{array}{l}\text { Establece penas de seis meses a cinco años de cárcel para quien trafique cannabis } \\
\text { sativa o marihuana. Dispone la destrucción de los cultivos existentes. Respecto al uso, } \\
\text { cuando no se aplicaba la medida de seguridad oficial, es decir bajo el régimen de los } \\
\text { sanatorios privados, la terapia de electrochoques o electroconvulsiva fue una de las } \\
\text { prácticas que médicos y psiquiatras emplearon para "curar" el consumo de marihuana. } \\
\text { Consiste en hacer que la persona convulsione aplicándole descargas eléctricas, } \\
\text { esperando borrar así los recuerdos ligados a la droga. Existen testimonios conocidos de } \\
\text { personas que fueron sometidas a esta práctica al menos hasta finales de la década del } \\
40 \text { (Vélez, 1959). }\end{array}$ \\
\hline Decreto no 1858, de 1951 & $\begin{array}{l}\text { Dispone una pena de "relegación a colonia penal agrícola" de dos a cinco años por } \\
\text { cultivo, tráfico, uso o inducción al uso de marihuana (cannabis sativa o indica). }\end{array}$ \\
\hline Ley no 27, de 1963 & Reconceptualiza tales conductas como "antisociales". \\
\hline Decreto no 1669, de 1964 & $\begin{array}{l}\text { Desprende la "toxicomanía" de las conductas llamadas "antisociales", lo que tiene } \\
\text { como resultado que el uso no se enfrenta mediante relegación a colonia agrícola, sino } \\
\text { con medidas sanatorias aplicadas en lugares especiales hasta obtener la rehabilitación } \\
\text { completa. }\end{array}$ \\
\hline $\begin{array}{l}\text { Ley no 47, de } 1967 \\
\text { Decreto n 257, de } 1969\end{array}$ & $\begin{array}{l}\text { Se reorganiza la vigilancia farmacológica, incluyendo la regulación el oficio de farma- } \\
\text { ceuta, y la reglamentación del funcionamiento del "Fondo Rotatorio de Estupefacien- } \\
\text { tes" vinculado al Ministerio de Salud Pública. }\end{array}$ \\
\hline Decreto no 522, de 1971 & $\begin{array}{l}\text { Establece multas para el cultivo, porte o "auspicio" de la marihuana, el opio y la coca, } \\
\text { considerando este tipo de conductas una "contravención especial que afecta el orden } \\
\text { social". }\end{array}$ \\
\hline Decreto no 1206, de 1973 & $\begin{array}{l}\text { Crea el Consejo Nacional de Estupefacientes para que asesore al gobierno nacional } \\
\text { en la adopción e implementación de políticas antidrogas que abarquen cuestiones de } \\
\text { producción, tráfico y consumo. }\end{array}$ \\
\hline Ley no 1988, de 1973 & $\begin{array}{l}\text { Elimina definitivamente la relegación a colonia penal agrícola por impráctica, y diferen- } \\
\text { cia el arresto y la multa a aplicar por cultivo, de lo correspondiente al porte y uso de la } \\
\text { Ilamada "dosis personal", quedando esta última con una multa más elevada, pero con } \\
\text { un arresto de menor duración. }\end{array}$ \\
\hline Decreto no 1188 , de 1974 & $\begin{array}{l}\text { Expide el primer Estatuto Nacional de Estupefacientes, que articula de forma coherente } \\
\text { el sistema que se había venido construyendo a lo largo de las cinco décadas anteriores } \\
\text { de manera dispersa. Mantiene la pena de arresto para el delito de porte de "sustancia } \\
\text { estupefaciente o droga". Establece que una "peritación médico-legista" es necesaria } \\
\text { para determinar la cantidad y calidad de las sustancias reguladas que puede ser } \\
\text { considerada "dosis personal", para lo que establece una pena atenuada y tratamiento } \\
\text { obligatorio. }\end{array}$ \\
\hline Ley no 17, de 1975 & $\begin{array}{l}\text { Reitera la creación del Consejo Nacional de Estupefacientes y la represión de las } \\
\text { diversas conductas relacionadas con las drogas. Establece la presunción de que quien } \\
\text { sea sorprendido con la dosis mínima o personal es un traficante, y la consecuente } \\
\text { necesidad de probar la condición de "farmacodependencia". }\end{array}$ \\
\hline
\end{tabular}




\section{Centros de Escucha en Colombia: políticas y escenarios para la reducción de daños en comunidades locales}

(Continuación)

\begin{tabular}{|c|c|}
\hline Documento & Sintesis \\
\hline Resoluciones no 10 y no 2996, de 1977 & $\begin{array}{l}\text { Adicionan las listas de sustancias restringidas, adecuándolas a las convenciones } \\
\text { internacionales celebradas en las décadas anteriores. Establecen en el Fondo Rotatorio } \\
\text { de Estupefacientes el monopolio completo sobre dichas sustancias. }\end{array}$ \\
\hline $\begin{array}{l}\text { Decreto no 1249, de } 1976 \\
\text { Decreto no } 1109 \text {, de } 1977\end{array}$ & Restringen levemente la venta de bebidas alcohólicas. \\
\hline Decreto nำ2144, de 1978 & $\begin{array}{l}\text { Militariza las "acciones antinarcóticos" tales como la represión penal, la incautación, } \\
\text { y la erradicación forzada, incluyendo la fumigación con glifosato. Desde entonces ha } \\
\text { habido controversia sobre las consecuencias del uso de glifosato en la salud y el medio } \\
\text { ambiente. }\end{array}$ \\
\hline Decreto no 2955, de 1980 & $\begin{array}{l}\text { Restringe la entrada al país de extranjeros que hayan traficado "estupefacientes", } \\
\text { "drogas alucinógenas" o similares. }\end{array}$ \\
\hline Decreto no 669, de 1984 & $\begin{array}{l}\text { Penaliza como delito y contravención a las actividades relacionadas con el comercio de } \\
\text { las sustancias químicas "precursoras", empleadas en la elaboración y procesamiento de } \\
\text { las sustancias psicoactivas, a lo que en principio corresponde arresto de un año. }\end{array}$ \\
\hline Decreto no 1060, de 1984 & $\begin{array}{l}\text { Fortalece las penas frente a las conductas relacionadas con el mercado de las sustan- } \\
\text { cias "que produzcan dependencia física o síquica". Por ejemplo, el cultivo o porte de } \\
\text { plantas como marihuana, coca o amapola, estableciendo el encarcelamiento de cuatro } \\
\text { a diez años y una multa elevada. }\end{array}$ \\
\hline Ley no 30, de 1986 & $\begin{array}{l}\text { Un segundo Estatuto Nacional de Estupefacientes reitera la estructura del primero, in- } \\
\text { corporando algunas modificaciones recientes como la intensificación de las penas. Fija } \\
\text { la dosis personal con criterios de finalidad y cantidad; en el ejemplo de la marihuana se } \\
\text { tiene por dosis personal la cantidad inferior a } 20 \text { gramos, siempre que se destine al uso } \\
\text { personal. La dosis personal sigue teniendo consecuencias penales atenuadas y dando } \\
\text { lugar a ciertas formas de tratamiento obligatorio. }\end{array}$ \\
\hline Decreto nำ423, de 1987 & $\begin{array}{l}\text { Atribuye principalmente a la Policía Nacional (que en Colombia es un organismo } \\
\text { militar y no civil) el control de los cultivos ilícitos y las conductas relacionadas con } \\
\text { estupefacientes. }\end{array}$ \\
\hline $\begin{array}{l}\text { Decretos no } 1856, \text { no } 1860, \text { no } 1896, n^{\circ} \\
2105, \text { de } 1989\end{array}$ & $\begin{array}{l}\text { Se establece el decomiso de los bienes empleados en el narcotráfico y el control contra } \\
\text { el lavado de activos. También se establece la extradición administrativa (normalmente } \\
\text { hacia Estados Unidos) para combatir el narcotráfico, eliminando los controles al respec- } \\
\text { to de los que disponía la jurisdicción penal. El uso civil del espacio aeronáutico también } \\
\text { queda restringido a autorizaciones previas. Las penas de prisión y multa quedan } \\
\text { fortalecidas respecto a todas las conductas relacionadas con el narcotráfico. En general } \\
\text { se dan varias normas que fortalecen la represión violenta del narcotráfico y relajan los } \\
\text { controles civiles sobre ésta. Posteriormente, hacia } 1990 \text { (p.ej. Decreto } 2147 \text { de 1990), } \\
\text { esta tendencia continúa, pero ahora apunta también a facilitar el sometimiento a la jus- } \\
\text { ticia para los delitos relacionados con "los motivos de perturbación del orden público". } \\
\text { Ambas tendencias siguen durante años posteriores al menos hasta 1994. }\end{array}$ \\
\hline Sentencia C-221, de 1994 & $\begin{array}{l}\text { Las normas que imponían el tratamiento forzado y tomaban el consumo como contra- } \\
\text { vención, estuvieron vigentes hasta los primeros días de mayo de 1994. La sentencia } \\
\text { C-221 de 1994, expedida por la Corte Constitucional bajo la nueva Constitución de } \\
\text { 1991, despenaliza el porte y consumo de la dosis personal, argumentando que las } \\
\text { conductas meramente individuales no pueden ser objeto de regulación jurídica y que } \\
\text { debe tenerse en cuenta el "derecho al libre desarrollo de la personalidad". Durante } \\
\text { años posteriores se da un cuestionamiento de la erradicación forzada, especialmente } \\
\text { con glifosato, mediante canales de derecho constitucional comparables, sin embargo, } \\
\text { esa práctica se mantiene. }\end{array}$ \\
\hline Decreto no 1943, de 1999 & $\begin{array}{l}\text { El programa "Rumbos", operado por organizaciones de la sociedad civil, asume fun- } \\
\text { ciones nacionales en materia de prevención, tratamiento y rehabilitación en materia de } \\
\text { estupefacientes, de "los consumidores que no hayan cometido delitos". }\end{array}$ \\
\hline $\begin{array}{l}\text { Política Nacional de para la Reducción } \\
\text { del Consumo de Sustancias Psicoacti- } \\
\text { vas y su Impacto, } 2007 \text { (PNRCSPAI) }\end{array}$ & $\begin{array}{l}\text { Establece el modelo de inclusión social como táctica transversal a las estrategias de } \\
\text { prevención, mitigación, y tratamiento. }\end{array}$ \\
\hline
\end{tabular}


(Continuación)

\begin{tabular}{|c|c|}
\hline Documento & Sintesis \\
\hline Acto Legislativo no 2, de 2009 & $\begin{array}{l}\text { Procura "prohibir" el consumo y porte de la dosis personal, estableciendo conse- } \\
\text { cuencias "pedagógicas, terapéuticas o profilácticas" para la "infracción" de tal } \\
\text { "prohibición". }\end{array}$ \\
\hline Ley no 1566, de 2012 & $\begin{array}{l}\text { Establece la atención integral a la farmacodependencia de acuerdo con la política de } \\
\text { 2007, incluyendo el consentimiento informado. }\end{array}$ \\
\hline $\begin{array}{l}\text { Sentencia C-491, de 2012, de la Corte } \\
\text { Constitucional }\end{array}$ & $\begin{array}{l}\text { Aclara que no es posible, en derecho, penalizar el porte y consumo de dosis personal, } \\
\text { aún después del Acto Legislativo no 2, de } 2009 \text {. }\end{array}$ \\
\hline Plan 2014-2021 & $\begin{array}{l}\text { Es el primer plan que resulta en la sistematización de las acciones correspondientes a } \\
\text { la nueva política. }\end{array}$ \\
\hline $\begin{array}{l}\text { Sentencia del } 17 \text { de junio de 2015, } \\
\text { radicación no } 44891\end{array}$ & $\begin{array}{l}\text { Despenaliza el cultivo para uso personal de menos de veinte plantas controladas, } \\
\text { tomando, paradójicamente, la definición de "plantación" de la Ley no 30, de } 1986 .\end{array}$ \\
\hline Ley no 1801, de 2016 & $\begin{array}{l}\text { Establece el consumo en espacios públicos como una infracción administrativa castiga- } \\
\text { da mediante multas. }\end{array}$ \\
\hline Sentencia C-636, de 2016 & Protege el derecho al trabajo de usuarios de psicoactivos. \\
\hline $\begin{array}{l}\text { Acuerdos de Paz de La Habana y del } \\
\text { Teatro Colón, } 2016\end{array}$ & $\begin{array}{l}\text { Establece la participación de las comunidades en la atención a la oferta y demanda de } \\
\text { psicoactivos. }\end{array}$ \\
\hline Sentencia T-236, de 2017 & Restringe la aspersión con glifosato hasta que se pruebe su inocuidad. \\
\hline Decreto no 613, de 2017 & $\begin{array}{l}\text { En desarrollo de la Ley no 1787, de } 2016 \text { activa la posibilidad de obtener licencias } \\
\text { relacionadas con el mercado de derivados medicinales del cannabis y articula trámites } \\
\text { relacionados. }\end{array}$ \\
\hline Resolución no 89, de 2019 & $\begin{array}{l}\text { Adecúa los avances de la nueva política. Incorpora explícitamente el tema de reducción } \\
\text { de daños como estrategia para el manejo del consumo problemático de drogas. }\end{array}$ \\
\hline Sentencia C-253, de 2019 & $\begin{array}{l}\text { Elimina la prohibición general del consumo en espacios públicos, con criterios de } \\
\text { necesidad, proporcionalidad, y ponderación de derechos. }\end{array}$ \\
\hline
\end{tabular}

Elaboración de los autores.

\section{REFERENCIA}

VÉLEZ, J. Las llaves falsas: diario de un toxicómano. Bogotá: Iqueima, 1959. 
Centros de Escucha en Colombia: políticas y escenarios para la reducción de daños en comunidades locales

\section{ANEXO B}

MAPA B. 1

Ubicación de las ciudades en donde se realizó el estudio

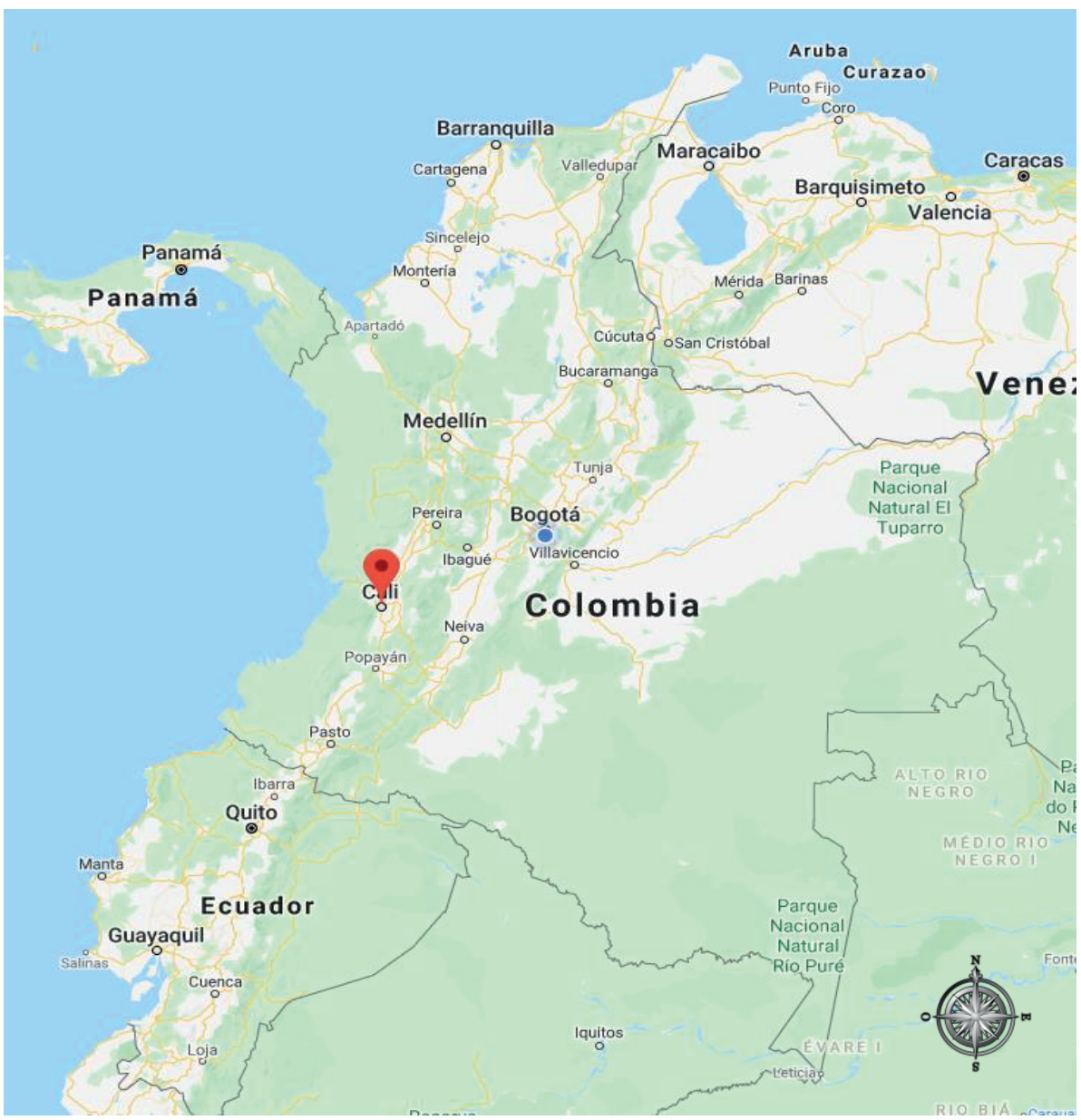

Fuente: Google Maps. 


\section{ANEXO C}

\section{FIGURA C.1}

Mapa conceptual política de prevención y atención de consumo de SPA (2019)

\section{Resolución 089 de 2019}

Política integral de prevención y atención de consumo de SPA

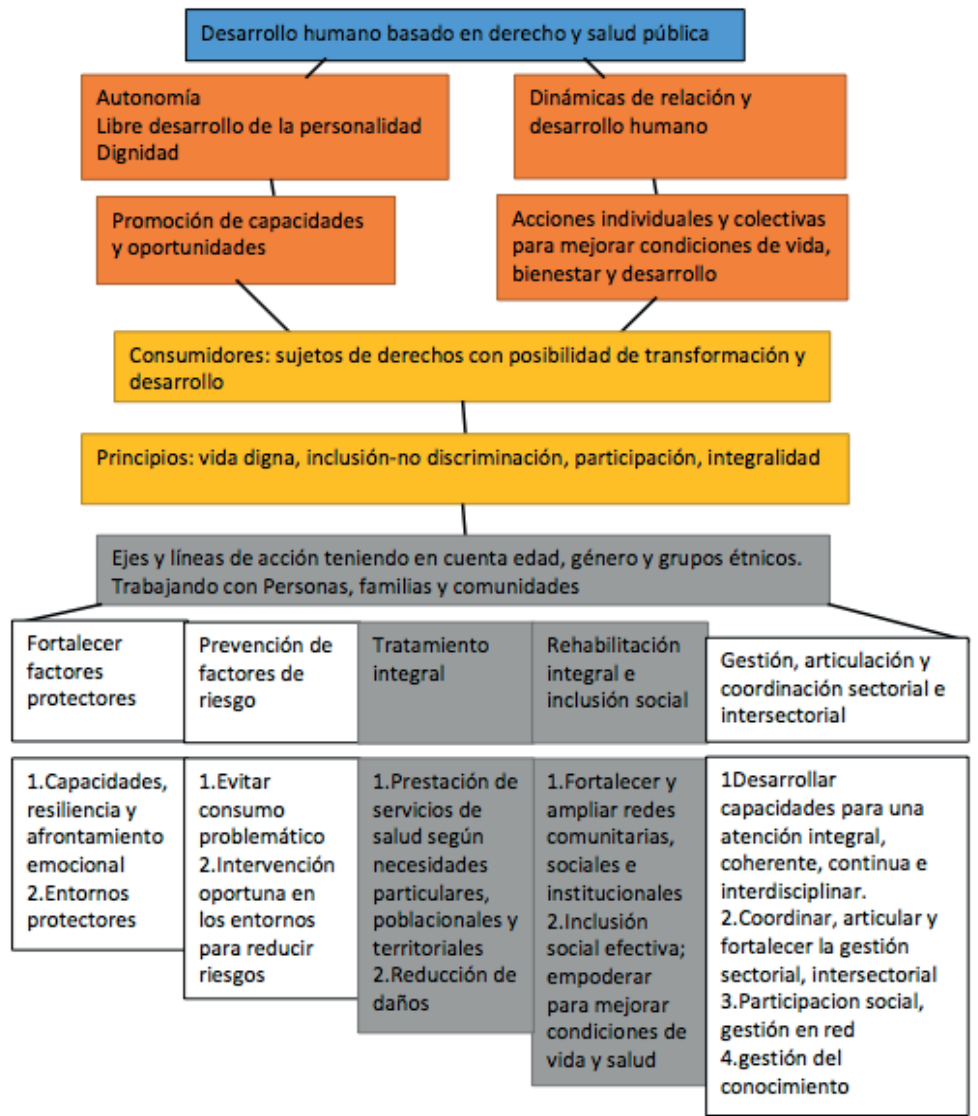

Elaboración de los autores.

Obs.: llustración reproducida en baja resolución y cuyos diseños y textos no pudieron ser estandarizados y revisados en virtud de las condiciones técnicas de los archivos originales (nota del Editorial). 

en comunidades locales

\section{ANEXO D}

MAPA D. 1

Ubicación de "La L" 0 "Calle del Bronx" en el centro de Bogotá

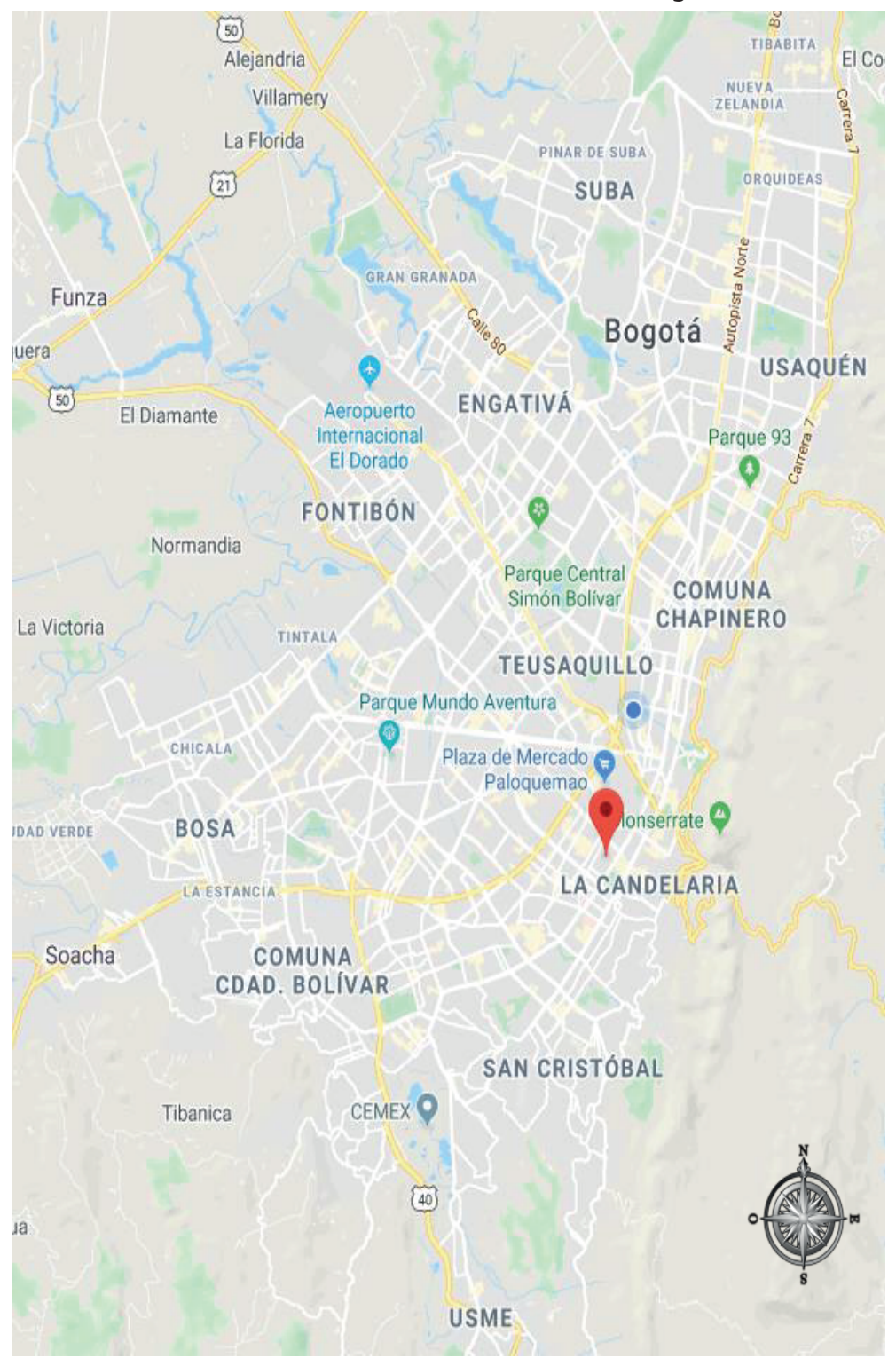




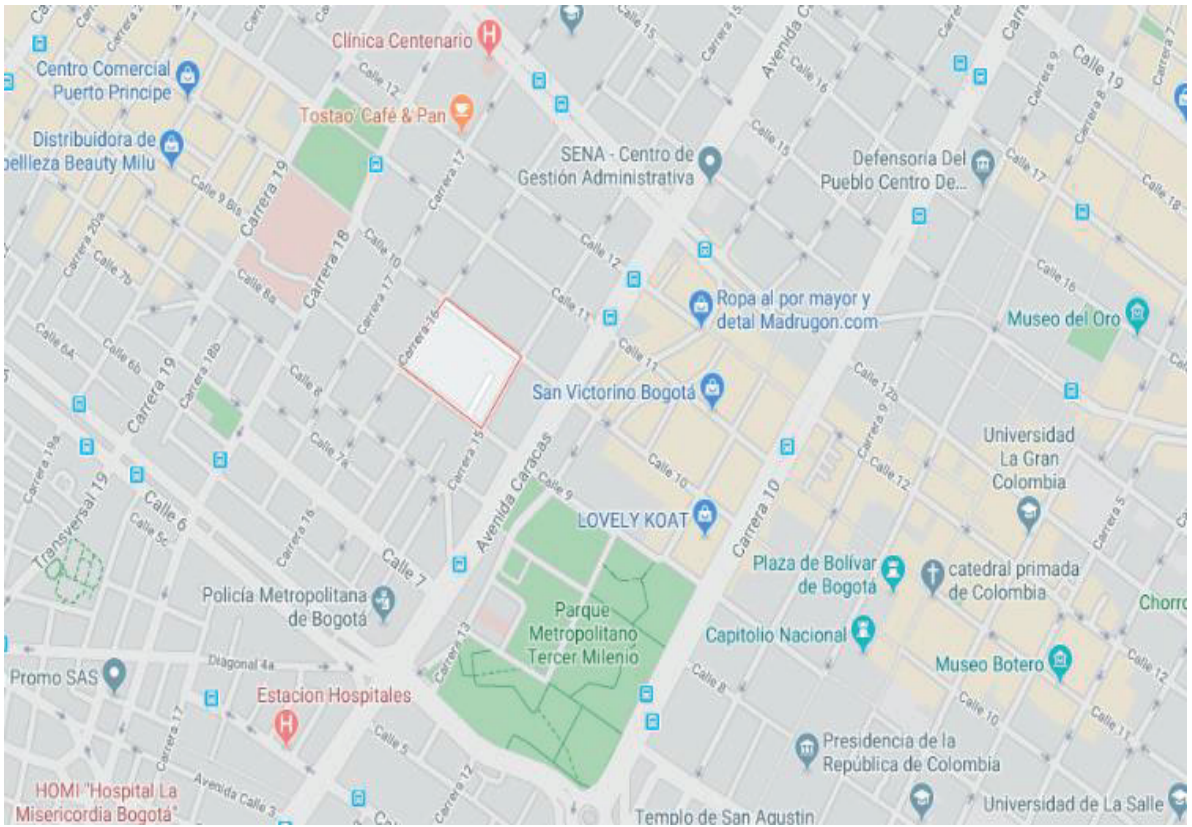

Fuente: Google Maps.

Obs.: imagen reproducida en baja resolución en virtud de las condiciones técnicas de los originales (nota del Editorial). 

en comunidades locales

\section{ANEXO E}

FIGURA E. 1

Mapa de procesos del Idipron

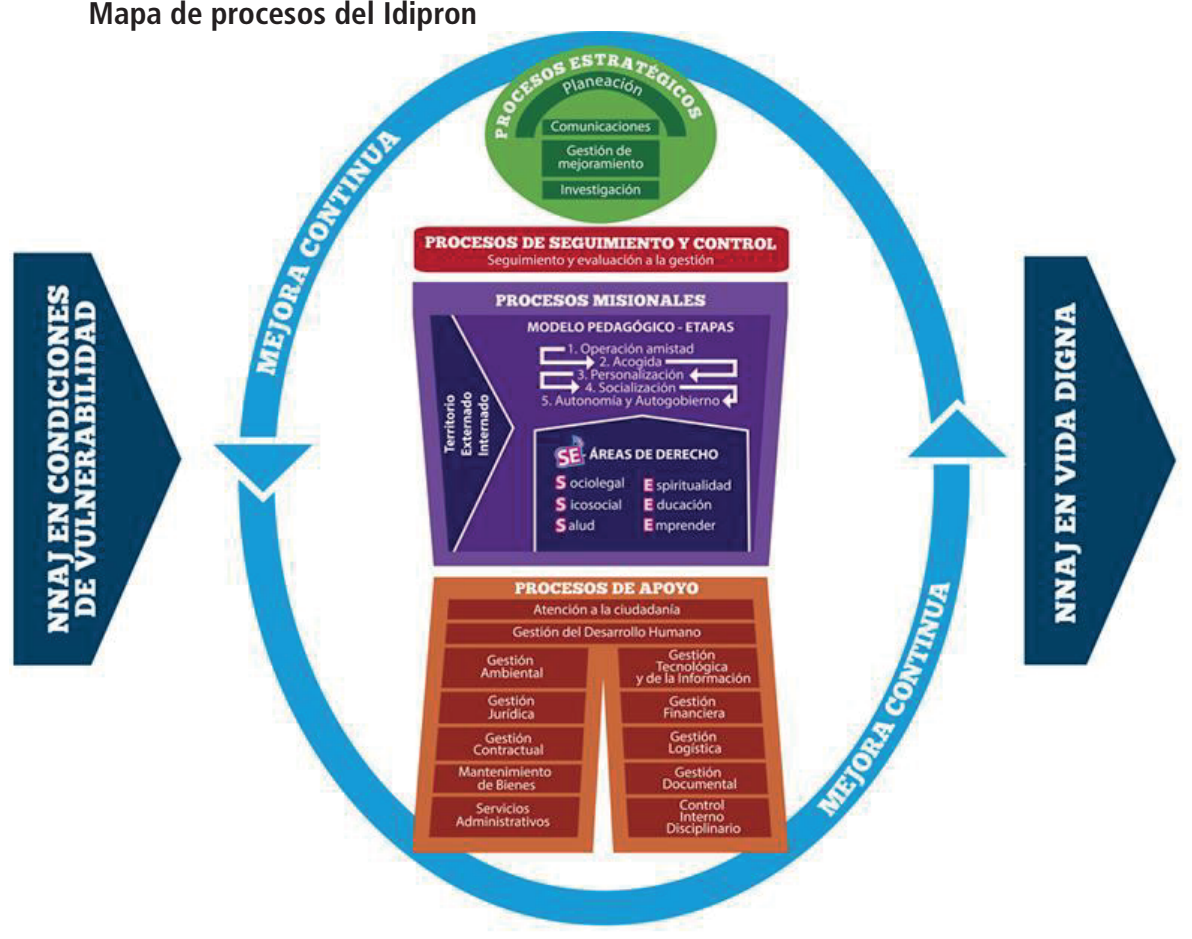

Fuente: Idipron, disponible en: <http://www.idipron.gov.co/mapa-de-procesos>.

Obs.: llustración reproducida en baja resolución y cuyos diseños y textos no pudieron ser estandarizados y revisados en virtud de las condiciones técnicas de los archivos originales (nota del Editorial). 


\section{ANEXO F}

\section{MAPA F.1}

Ubicación del Barrio Sucre en la ciudad de Cali
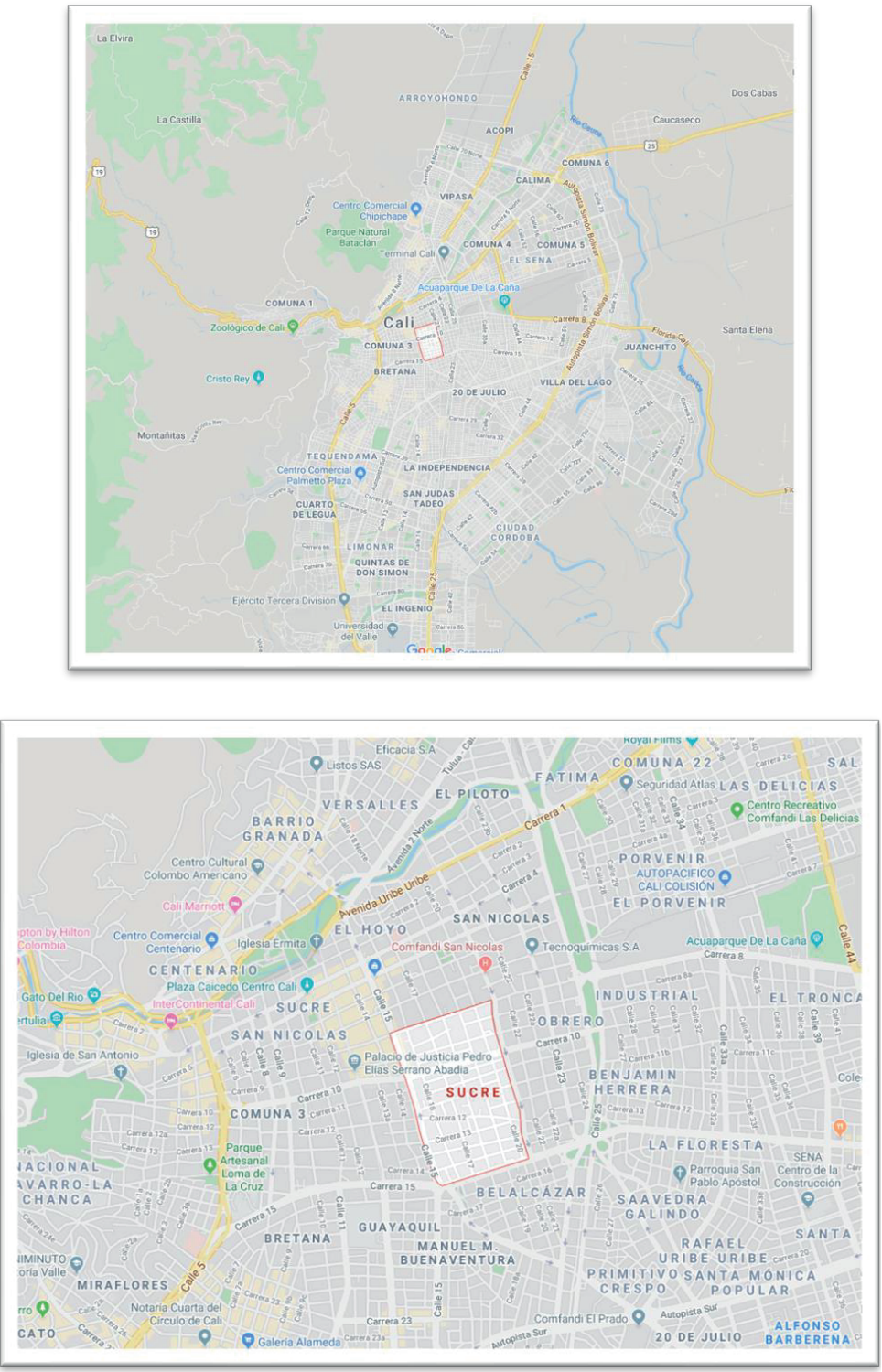

Fuente: Google Maps.

Obs.: imagen reproducida en baja resolución en virtud de las condiciones técnicas de los originales (nota del Editorial). 


\section{ANEXO G}

\section{MAPA G. 1}

Ubicación del barrio Llano Verde en la ciudad de Cali

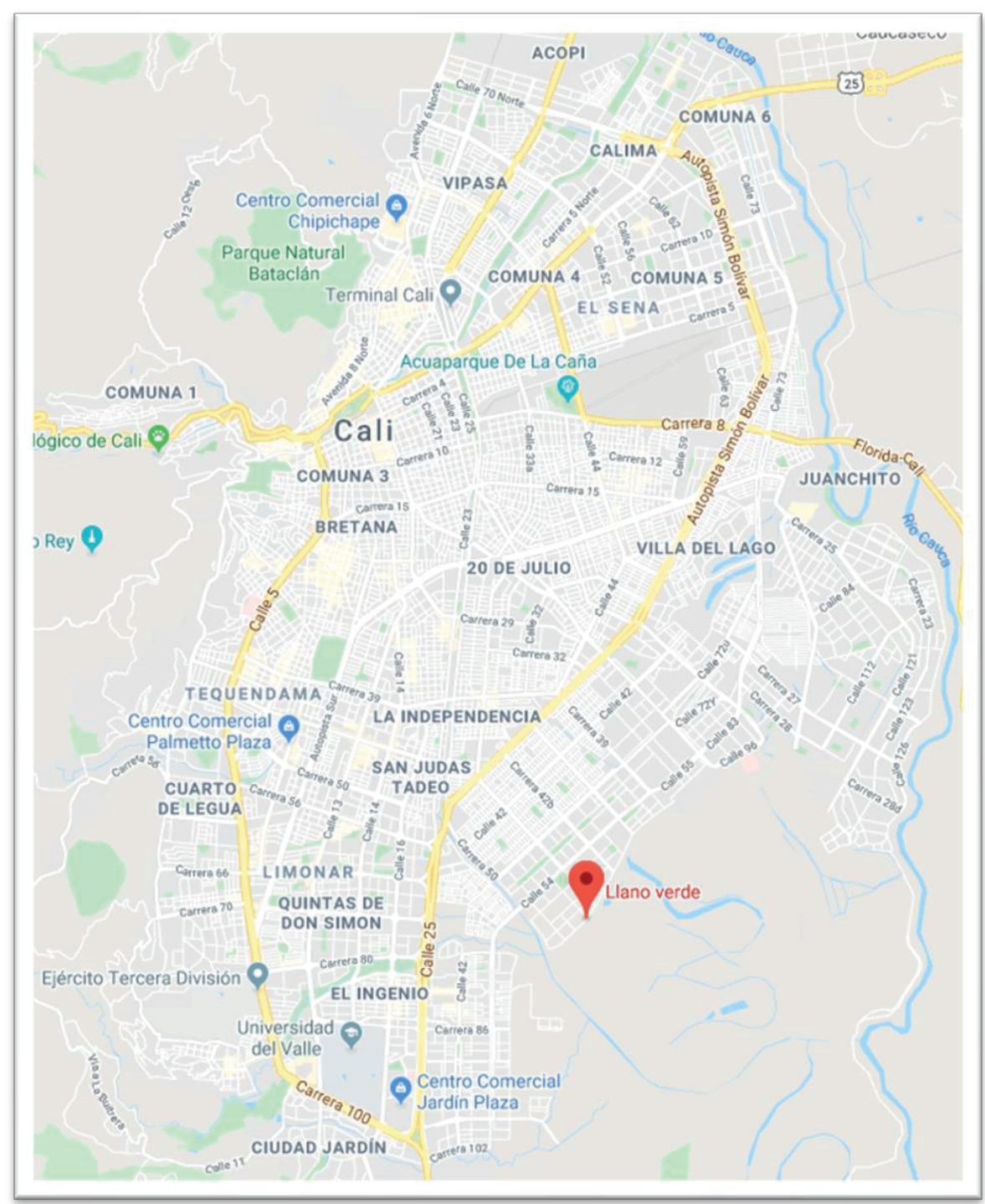

Fuente: Google Maps.

Obs.: imagen reproducida en baja resolución en virtud de las condiciones técnicas de los originales (nota del Editorial). 


\section{ANEXO H}

\section{FOTOGRAFÍAS DE ARCHIVO Y DEL TRABAJO DE CAMPO}

FIGURA H. 1

Primer centro de escucha, barrio Santa Fe, Bogotá

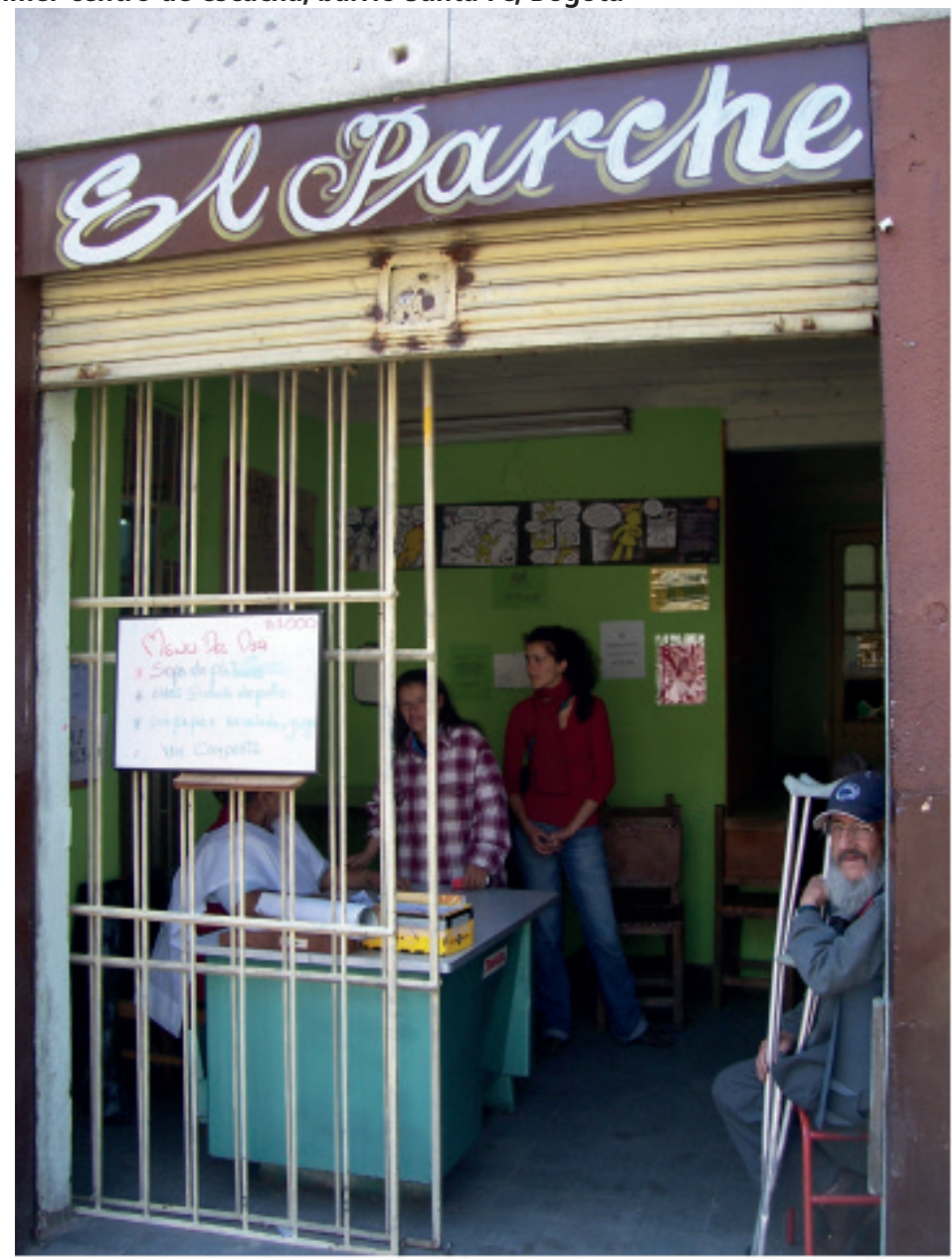

Elaboración: Susana Fergusson, 2006.

Obs.: imagen reproducida en baja resolución en virtud de las condiciones técnicas de los originales (nota del Editorial). 
Centros de Escucha en Colombia: políticas y escenarios para la reducción de daños en comunidades locales

FIGURA H.2

Free Soul en el Festival de arte callejero del "Bronx"

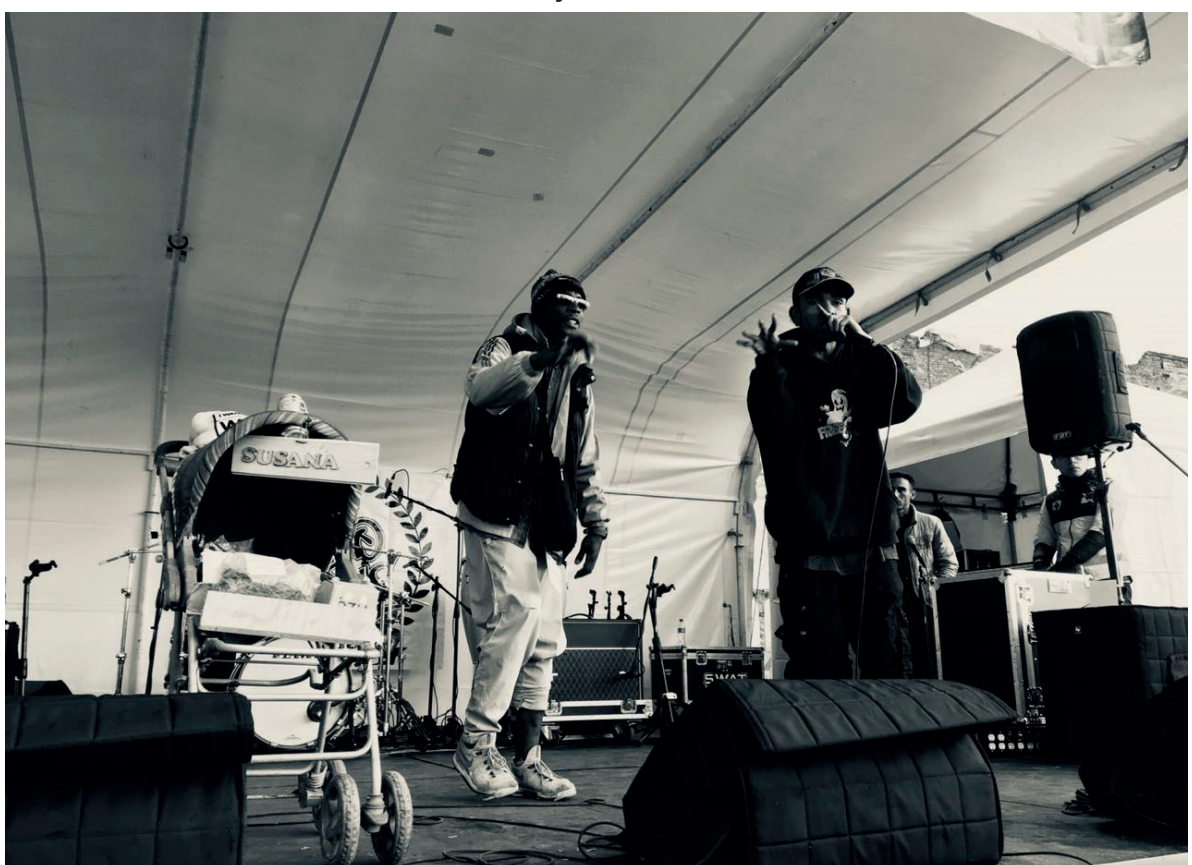

Elaboración: Andrés Góngora.

FIGURA H.3

Centro de escucha en el antiguo "Bronx"

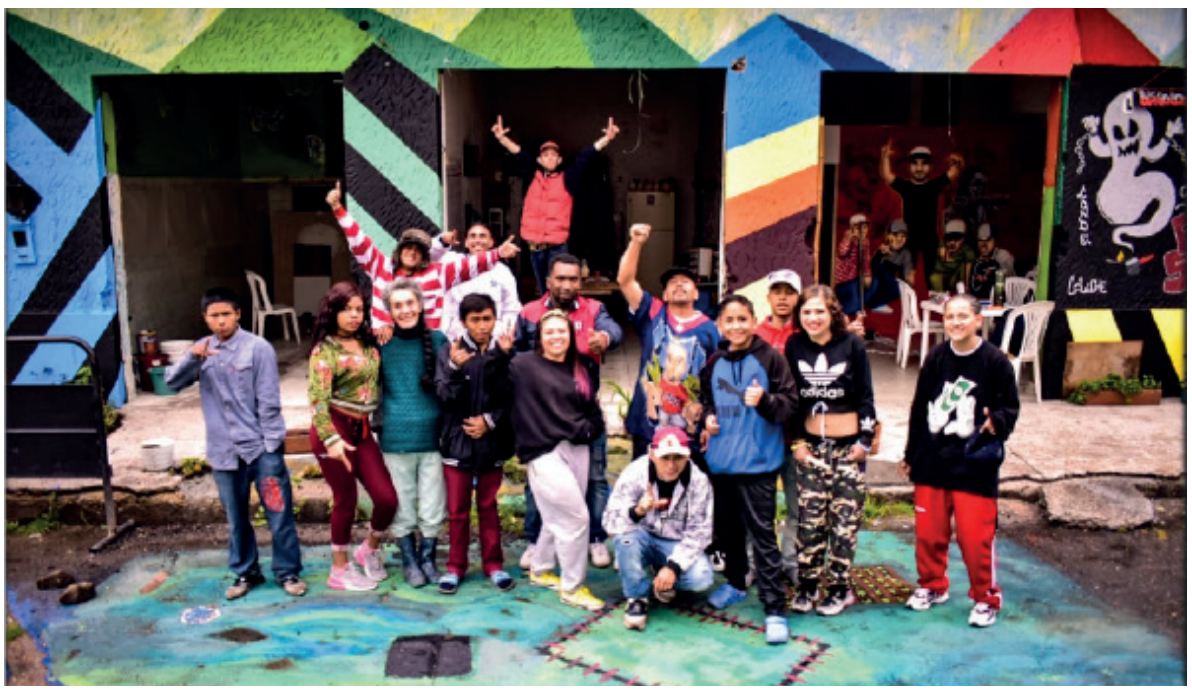

Elaboración: Jefferson Ortíz. 
FIGURA H.4

Material informativo - programa de reducción de riesgos y daños

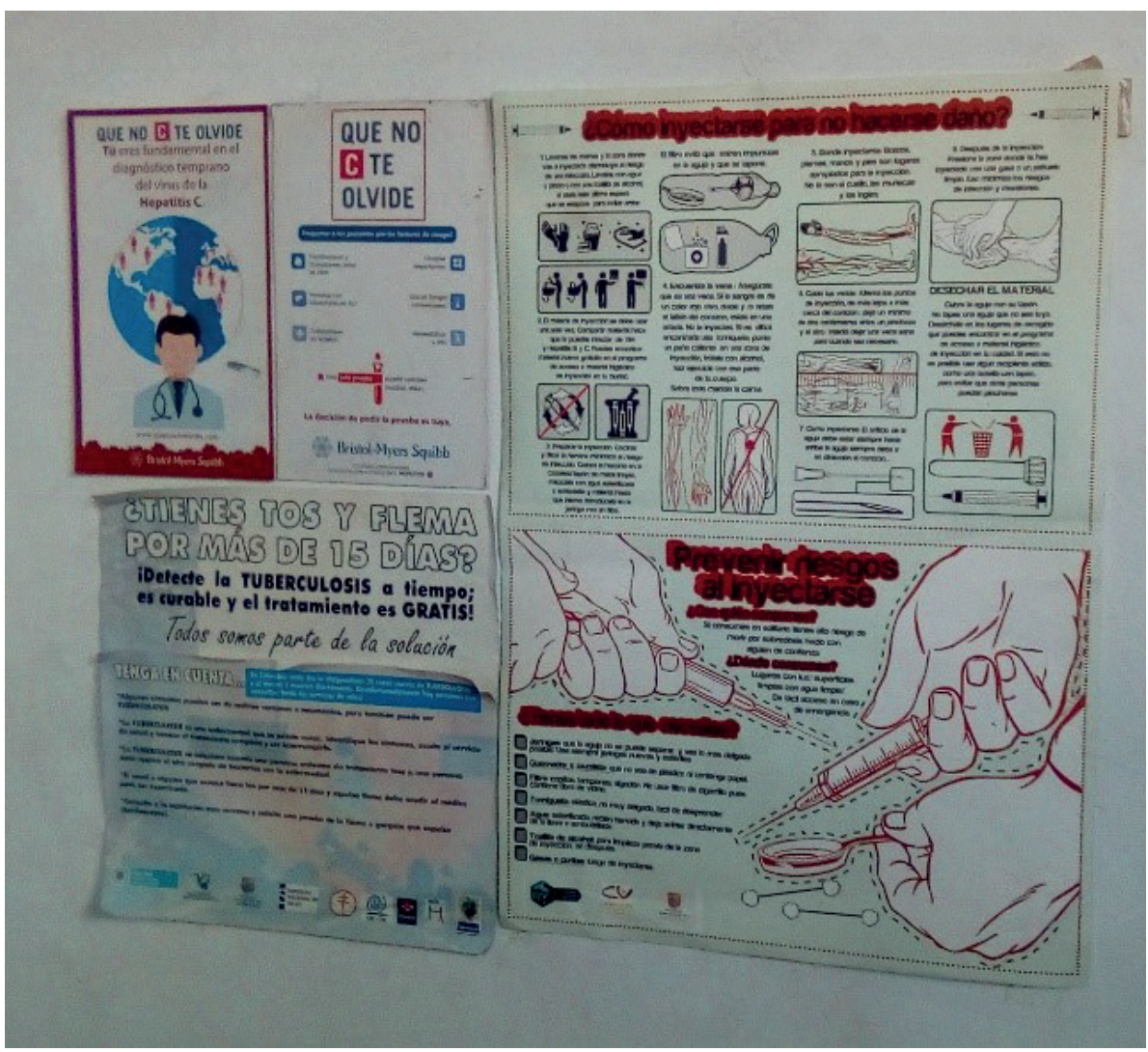

Elaboración: Ramiro Borja.

Obs.: imagen reproducida en baja resolución en virtud de las condiciones técnicas de los originales (nota del Editorial). 
Centros de Escucha en Colombia: políticas y escenarios para la reducción de daños en comunidades locales

FIGURA H. 5

Kit higiénico - programa de reducción de riesgos y daños

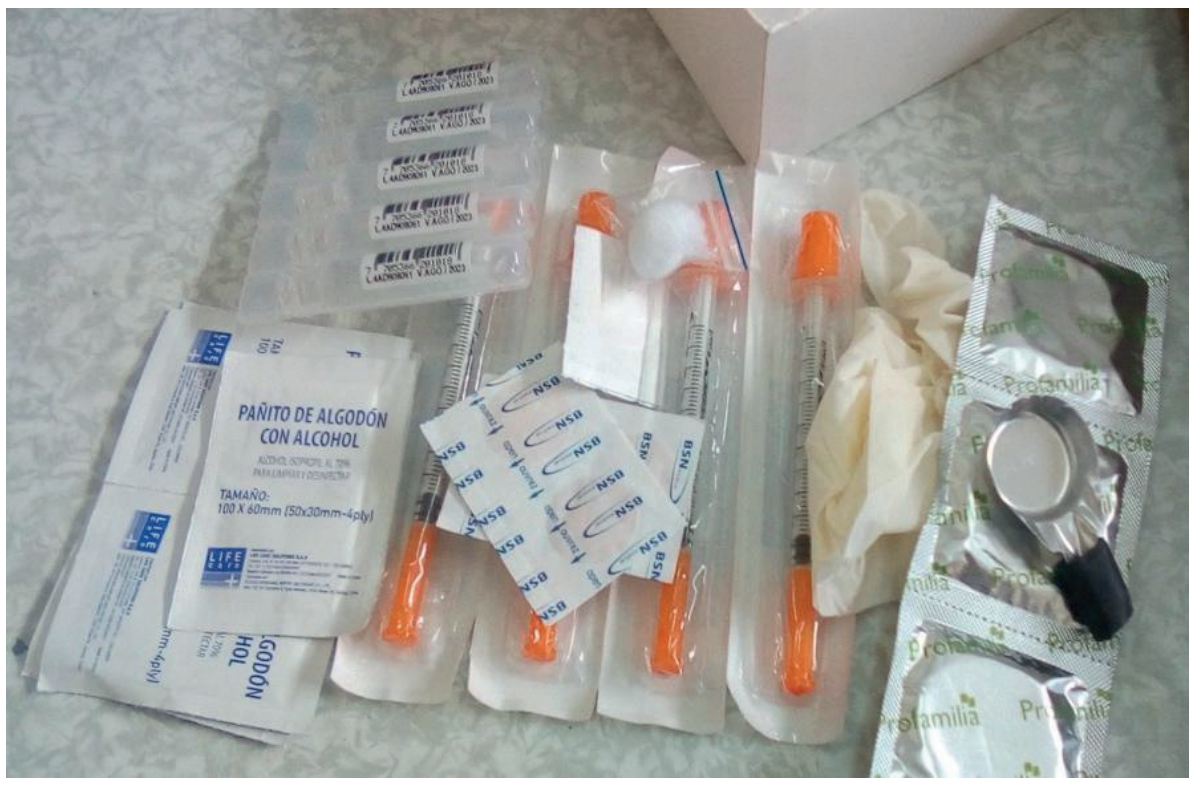

Elaboración: Ramiro Borja.

FIGURA H.6

Feria de sabers, centro de escucha Llano Verde

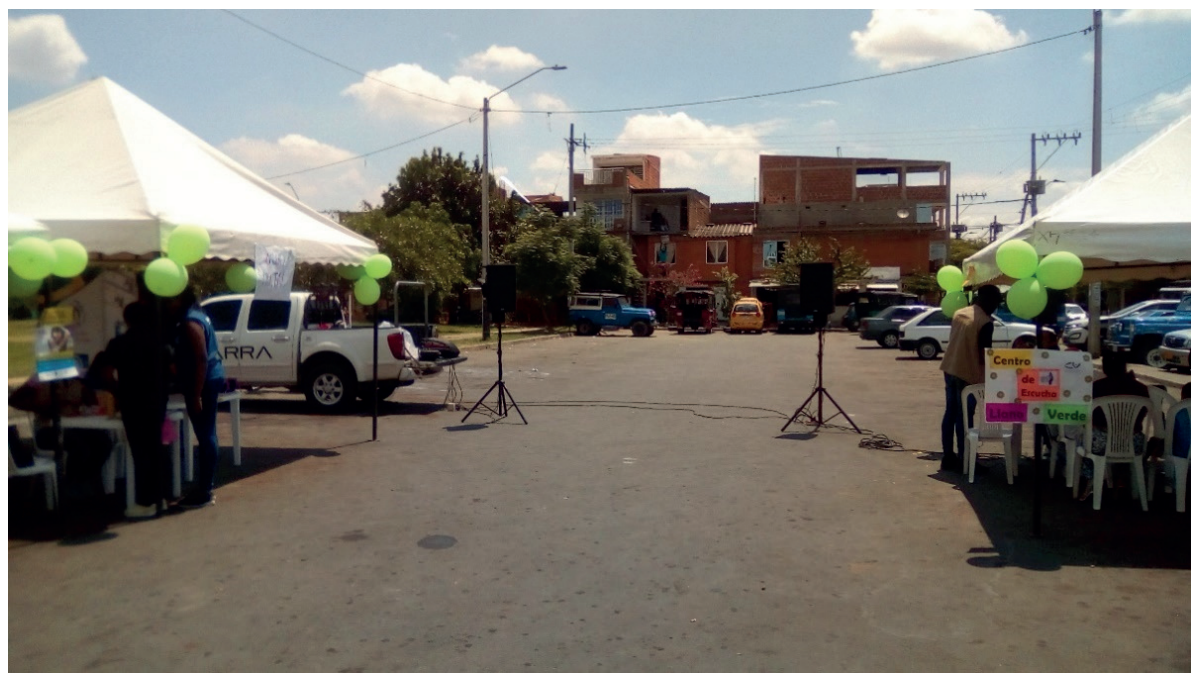

Elaboración: Ramiro Borja. 



\section{EL SISTEMA DE ATENCIÓN Y CUIDADO AL USO PROBLEMÁTICO DE DROGAS EN MÉXICO: AISLAMIENTO, ESTIGMATIZACIÓN Y DESAMPARO}

Angélica Ospina-Escobar ${ }^{1}$

\section{INTRODUCCIÓN}

En este capítulo se analiza la manera cómo se estructuran actualmente los arreglos institucionales para la atención al uso problemático de sustancias psicoactivas en México. El documento busca responder a cuatro preguntas centrales: ¿Cuáles son las características del sistema de atención al uso problemático de sustancias en México?, ¿Cómo se conformó históricamente dicho sistema?, ¿Cómo opera en la práctica este sistema?, ¿Cuáles son los retos que enfrenta actualmente?

Para responder a estas preguntas se hizo una revisión documental a través de la cual se recuperaron los hitos históricos que marcaron la formación del sistema actual de cuidado y atención al uso problemático de drogas, se realizaron algunas entrevistas a personas que han participado en la formulación de dicho sistema y se realizó un estudio de caso de cómo opera el sistema en el estado de San Luis Potosí, al considerarlo un estado prototípico en términos de la oferta y demanda de estos servicios en el país.

Este capítulo está organizado en cuatro secciones, más allá de esta introducción y las conclusiones finales. En la sección 2 se narra la historia de los hitos que conformaron los arreglos institucionales de atención al uso problemático en México. En la sección 3 se describen las características del sistema de atención, los actores involucrados y la manera en que se concibe de manera oficial el uso de sustancias y el tratamiento. En la sección 4 se describe la estrategia metodológica a partir de la cual se recopiló y analizó la información de San Luis Potosí. En una quinta sección se presentan los resultados de la información analizada, con lo cual se busca describir cómo funciona en la práctica el sistema de atención. Por fín, se cierra este capítulo con unas consideraciones en torno a los retos institucionales frente a la oferta de servicios públicos de tratamiento para el uso problemático de calidad y en estricto apego a los derechos humanos.

1. Cátedra en el Consejo Nacional de Ciencia y Tecnologia (Conacyt); profesora Investigadora del Programa de Política de Drogas del Centro de Investigación y Docencia Económicas (CIDE); y consultora bajo el Programa de Cooperación de la Comisión Económica para América Latina y el Caribe (CEPAL) y del Ipea. 


\section{INSTITUCIONALIZACIÓN Y AISLAMIENTO: BREVE HISTORIA DEL SISTEMA DE ATENCIÓN Y CUIDADO AL USO DE DROGAS EN MÉXICO}

En México, el discurso oficial en torno a la atención al uso problemático de drogas surge en el marco del establecimiento y consolidación del régimen prohibicionista frente a las sustancias a partir de la segunda década del siglo XX. De este modo criminalización y medicalización del uso de sustancias fueron procesos que caminaron de la mano. La consolidación de esa relación se gesta en cuatro momentos históricos en los cuales cambian las formas de nombrar el uso problemático de sustancias y las estrategias o dispositivos para su atención.

\subsection{La aparición de la toxicomanía y la rehabilitación (1920-1969)}

Si bien en México desde mediados del siglo XIX se fueron haciendo cada vez más eminentes opiniones e iniciativas que buscaban prohibir el uso de narcóticos (Pérez González, 2017; Pérez Montfort, 2016), es sólo entre 1920 y 1930 en el marco del impulso internacional de la prohibición, que estos esfuerzos se materializaron en reformas que prevalecieron en el tiempo y que dieron lugar al nacimiento de aparatos institucionales encargados de regular la producción, comercialización y uso de sustancias psicoactivas.

La primera de estas reformas fue la prohibición de la importación de opio y todos sus derivados en 1915 (Pérez Montfort, 2016) y las reformas subsiguientes al código penal y al de salubridad hicieron evidente la preeminencia de una perspectiva criminalizante frente al uso de sustancias psicoactivas. Así, la reforma al código penal de 1926 estableció por primera vez en la historia de México la compra de drogas como delito federal. Desde ese momento, la cárcel y, en menor medida el hospital psiquiátrico, se erigieron como las principales instituciones de control para los usuarios pobres que no tenían acceso a prescripciones médicas, ${ }^{2} \mathrm{y}$ que quedaban por tanto a merced de los nacientes mercados negros de las drogas recientemente ilegalizadas ${ }^{3}$ (Pérez González, 2017).

En los hospitales psiquiátricos los "toxicómanos" pobres eran objeto de experimentación con diversas terapéuticas que no mostraban efectividad sobre los comportamientos adictivos, que resultaban altamente riesgosos para los

2. Hasta1976 las personas con dependencia a opiáceos podían acceder a medicamentos y preparados que contenían morfina, opio, heroína y otras sustancias consideradas "enervantes" en farmacias con prescripciones médicas otorgadas por psiquiatras certificados.

3. Sólo durante un corto periodo (de febrero a junio de 1940) se implementó un nuevo reglamento que planteaba abiertamente una perspectiva médica para el "control de las toxicomanías" (Astorga, 1996, p. 45) y que identificaba además de los elementos individuales, el papel que jugaban los mercados ilegales en el desarrollo éstas. Partiendo de esta concepción más estructural de "el problema de las drogas", durante cuatro meses la Secretaría de Salud puso en operación dispensarios de morfina en la Ciudad de México, dirigidos a "toxicómanos" que debían darse de alta como "pacientes" en la Secretaría de Salud. La medida duró poco, pues Estados Unidos interpuso un embargo para la importación de narcóticos, apelando al Narcotics Import-Export Act de 1922 (Campos, 2017). Ante la falta de medicinas esenciales, el gobierno de México cambió el reglamento y el experimento regulatorio de drogas fue suspendido (Campos, 2017; Enciso, 2015). 
pacientes (Sacristán, 2005). La falta de criterios médicos homogéneos en torno a las "toxicomanías" alimentó estas prácticas de experimentación, lo que no quiere decir que los médicos no tuvieran interés en esta población, sino que no existían los desarrollos tecnológicos que permitieran vislumbrar un tratamiento posible (Pérez González, 2017).

Sólo hasta 1944 los desarrollos en los discursos y tratamientos médicos permitieron la aparición en 1944 de dispositivos específicos de atención para el uso problemático de drogas, denominadas “Granjas de Recuperación”. La atención en estos hospitales-granja estaba basada en la terapéutica por el trabajo (Sacristán, 2005) y partía de una concepción del uso problemático de drogas como un problema individual de "malformación del carácter", por lo que el tratamiento debía dirigirse a lograr un proceso de "reconstrucción de la personalidad y desarrollo de una forma disciplinada de vida" (Garbi, Touris y Epele, 2012, p. 869).

En estos hospitales-granja se acuñó el concepto de "rehabilitación”, entendido como terapia ocupacional aplicada al uso problemático de drogas (Escohotado, 2005) y se empezó a implementar el modelo de tratamiento de los grupos de Narcóticos Anónimos formados en 1947 en Estados Unidos (Cook, 1988).

\subsection{La construcción del farmacodependiente y la descentralización de la atención en salud (1970-1989)}

La terapéutica del trabajo y el modelo de tratamiento de Narcóticos Anónimos fue retomado y mejorado por los Centros de Integración Juvenil (CIJ), una asociación civil creada a finales de los años sesenta e incorporada a la Secretaría de Salud (SSA), con la finalidad de atender el "problema" del consumo de drogas.

Los CIJ iniciaron una nueva era en términos de prevención y atención al uso problemático de drogas en México, al consolidar el modelo médico de atención ${ }^{4}$ y un discurso que introdujo el concepto de "farmacodependiente", reemplazando al de "toxicómano". Desde este discurso, se concibe al uso de drogas como "una enfermedad sin cura que requiere un proceso continuo de recuperación" (Cook, 1988). Por lo tanto, desde los CIJ todo uso de sustancias psicoactivas fue considerado abuso, orientando el tratamiento hacia la abstinencia. La oferta de servicios del CIJ creció a tal velocidad que, una década después de su creación, había centros en todos los estados de la República.

4. Los CIJ importaron el modelo Minnesota, originado en los años 50 del siglo XX en Estados Unidos, bajo el cual se complementa el modelo de 12 pasos construido por Alcohólicos Anónimos, con el acompañamiento médico y psicológico (Cook, 1988). 
En medio de una fuerte crisis económica y paralelo a la creación de los CIJ aparecieron en la década de 1970 en México los "Anexos", 5 grupos de ayuda mutua, basados en los principios de 12 pasos de Alcohólicos Anónimos (Brandes, 2002) que atendían principalmente a personas de escasos recursos. Así mismo, las granjas de recuperación tomaron un segundo impulso gracias a grupos de AA que ofrecían alternativas de internamiento a alcohólicos y "farmacodependientes" (Rosovsky, 2009) también a personas de bajos ingresos. Al finalizar la década, surgieron las Comunidades Terapéuticas, que sistematizaban desde una perspectiva profesional el tratamiento ofrecido por los grupos de ayuda mutua.

Aunado a la aparición de la "farmacodependencia" como "enfermedad crónica incurable" y de instituciones especializadas en su atención, se creó el andamiaje institucional ${ }^{6}$ necesario para su evaluación epidemiológica y se levantaron las primeras encuestas de consumo de sustancias en escolares en 1976 y en hogares en 1988 , instrumentos que persisten a la fecha.

La década de 1980 marcó en México el inicio del proceso de descentralización del sistema de salud (Abrantes Pêgo y Almeida, 2002, p. 981). En este contexto, se crearon por mandato federal, los Consejos Estatales Contra las Adicciones (Cecas), quienes debían coordinar las acciones de prevención y control de usos de drogas en cada estado bajo el marco normativo federal (Conadic, 2012). Con este discurso, la atención a salud mental y las adicciones pasaron a ser responsabilidad de los estados. ${ }^{7}$

\subsection{El VIH y el auge de los modelos comunitarios de atención (1990)}

La aparición del primer caso de VIH en una persona inyectora de drogas en el norte del país en 1986, detonó durante los noventa la puesta en marcha de nuevos sistemas de vigilancia epidemiológica en esa población particular de usuarios de drogas (Magis-Rodríguez y Parrini Roses, 2006), así como la movilización de estrategias comunitarias de atención. ${ }^{8}$ En este contexto apareció el discurso de la reducción de daños a nivel institucional y comunitario como estrategia de atención a personas con uso problemático de sustancias.

\footnotetext{
5. En un principio los "Anexos" eran cuartos anexos a los espacios de grupos de AA de 24 horas donde los alcohólicos que no tenían dónde vivir o tenían dificultades para mantenerse sobrios asistiendo tan sólo a las juntas podían alojarse sin costo durante varios meses. Durante su estancia debían ayudar al grupo con servicios de limpieza o en la cocina, reciben apoyo y se reincorporan al mundo exterior cuando su estado lo permite (Rosovsky, 2009, p. 12).

6. En 1972 se creó el Centro Mexicano de Estudios en Farmacodependencia (CEMEF), encargado de coordinar los esfuerzos institucionales para disminuir la demanda de drogas ilegales a través de investigación científica y capacitación de profesionales (CIA, 1976). El CEMEF coordinó en 1976, la primera Encuesta de Consumo de Drogas en Población Escolar de Secundaria, Preparatoria y Técnica (ENCODE). En 1979 el CEMEF fue absorbido por el Centro Mexicano de Estudios en Salud Mental (CEMESAM), que dio origen al Instituto Mexicano de Psiquiatría (Conadic, 2012), institución que en la década de 1980 impulsó la investigación epidemiológica a través de la implementación de las primeras Encuestas Nacionales de Adicciones (ENA), del Sistema de Reporte de Información en Drogas de la Ciudad México y de la creación en 1990 del Sistema Nacional de Vigilancia Epidemiológica de las Adicciones (SISVEA).

7. Recuérdese que México es un estado federal, conformado por 32 entidades federativas autónomas.

8. En 1988 se creó el primer programa comunitario de intercambio de jeringas en Ciudad Juárez por parte de la organización Programa Compañeros A.C., bajo el paradigma de promoción y desarrollo comunitario, con un componente de educación de pares
} 
También en la década del noventa México firma el tratado de libre comercio con América del Norte (TLCAN), que tiene dos efectos en el tema que nos atañe. Por un lado, la consolidación de México como principal exportador de drogas a Estados Unidos y como país con problemas importantes de "farmacodependencia". Por otro lado, el TLCAN propició una nueva crisis económica en el campo que generó una nueva oleada de migrantes a las grandes ciudades, quienes se enfrentarán al final de la década al surgimiento de mercados locales de drogas en sectores urbanos vulnerabilizados y aumentarán la demanda de servicios de tratamiento.

En este contexto y gracias al apoyo internacional de Caritas, se robusteció la oferta de estrategias comunitarias de atención al uso problemático de drogas, principalmente en centros urbanos y dirigidos a personas que viven en situaciones de extrema marginación y sufrimiento social. ${ }^{9}$ Estas estrategias plantearon críticas importantes al modelo médico hegemónico de atención y sus postulados del internamiento como una condición necesaria para el tratamiento, la abstinencia como meta única y la concepción de usuario como enfermo sin capacidad de agencia sobre su "adicción" (Machín, 2015). Algunas de estas estrategias dieron lugar al modelo comunitario de atención ECO2, ${ }^{10}$ que promovía una aproximación contextual y sociocultural frente al uso de sustancias y una concepción de la reducción de daños como principio de intervención y como filosofía basada en el respeto y promoción de los derechos humanos de las personas usuarias.

Los esfuerzos de las organizaciones de la sociedad civil por posicionar el modelo ECO2 en diferentes países de la región durante los primeros años del siglo XXI, la falta de vinculación de la iglesia católica mexicana en las estrategias comunitarias de atención y la falta de legitimidad de las instituciones que implementaban reducción de daños ante las autoridades médicas que instituían la atención al uso problemático de drogas, fueron elementos que limitaron la posibilidad de que el modelo ECO2 y su concepción sociocultural del uso de sustancias permeara las políticas públicas y los programas gubernamentales de atención al uso problemático de drogas (Juan Machín, conversación personal, febrero 2020).

\footnotetext{
9. Por ejemplo, La Carpa, Hogar Integral, Luz y Esperanza, Ama la Vida en la Ciudad de México; Cultura Joven en Cuernavaca; Alternativa Joven en Cuautla; CEJUVER en Veracruz; Agrupo en Morelia; CASA, Programa Compañeros, Misericordia y Vida al paciente con SIDA, Tienda de Cristo en Ciudad Juárez (Juan Machín, conversación personal, febrero de 2020). La mayoría de estas experiencias tuvieron como antecedente la formación en el modelo Uomo en Italia gracias al financiamiento de Caritas internacional (Sánchez-Mejorada, 2013). El financiamiento internacional favoreció la construcción de redes entre las organizaciones que implementaban estos acercamientos comunitarios al uso de drogas, entre ellas la REMOISS y gracias a ello, algunas de estas experiencias fueron sistematizadas y dieron lugar al modelo ECO2 que fue exportado a diferentes países de América latina. El financiamiento por parte de cáritas estuvo vigente hasta 2005 (Machín et al., 2006). La búsqueda por exportar el modelo a otros países de la región debilitó la capacidad de incidencia a nivel nacional y fracturó el movimiento auspiciado por Cáritas Internacional (Juan Machín, conversación personal, febrero de 2020).

10. El modelo ECO2 propone como eje de la intervención el territorio y las redes sociales que existen en dicho territorio, las cuales dotan de recursos de todo tipo a las personas que allí habitan. La formación de agentes de promoción social es uno de los pilares del modelo ECO2, en conjunto con el desarrollo de actividades de integración, contención y dinamización comunitaria (Mendoza, 2015), con el fin de contrarrestar los procesos de exclusión social grave que enfrentan algunas poblaciones de usuarios problemáticos (Machín, 2015)
} 
Esta hegemonía médica en la manera de concebir el uso de sustancias y el tratamiento se institucionalizó en el primer Programa Nacional para la Farmacodependencia, el Alcoholismo y el Tabaquismo, coordinado por el Consejo Nacional contra las Adicciones (Conadic) creado en 1995 (Benassini, 2001) y en la primera norma oficial para la prevención, tratamiento y control de las adicciones (NOM-028) publicada en 1998, que en primera instancia no incluyó las estrategias de reducción de daños ni dio a lugar discursos ni dispositivos comunitarios de atención.

\subsection{Guerra contra las Drogas y pugnas regulacionistas (2000-2019)}

A principios del nuevo milenio se fortaleció el discurso prohibicionista frente a las drogas en México que devino en 2006 en una estrategia de ataque frontal al narcotráfico lo que en la práctica ha fortalecido la criminalización de las personas usuarias de sustancias (Pérez-Correa, 2012; Pérez-Correa y Silva Mora, 2014) y un discurso a favor de su institucionalización, en detrimento de modelos de atención comunitarios.

La llegada de miles de militares a distintos centros urbanos de la república debilitó aún más las estrategias comunitarias de atención, pues los barrios pobres fueron los principales territorios de patrullaje donde se reportaron múltiples eventos de abuso de autoridad. Los discursos oficiales contra las drogas consolidaron el imaginario del joven pobre usuario de sustancias como sujeto peligroso, lo que legitimó las continuas violaciones a los derechos humanos de que eran objeto por parte de militares y policías. El incremento en la violencia criminal junto con la desproporcionalidad en el uso de la fuerza por parte de las autoridades, fueron erosionando aún más los vínculos comunitarios que los dispositivos comunitarios de atención intentaban fortalecer. En este contexto de acoso, la violencia y la falta de financiamiento las estrategias comunitarias de atención al uso problemático de drogas fueron despareciendo, fortaleciendo la idea del internamiento como única opción.

Ante las quejas y denuncias crecientes por las graves violaciones a los derechos humanos que tienen lugar en los centros de tratamiento no gubernamentales en modalidad residencial, se fortalecieron procesos de regulación de este tipo de establecimientos, mediante la institucionalización de procesos de acreditación según los criterios de la recién creada NOM-028. ${ }^{11}$ En este marco, Conadic y los Programas Estatales Contra las Adicciones han ofrecido desde entonces programas de capacitación a los centros de tratamiento no gubernamentales ${ }^{12}$

11. Según Galaviz y Odgers (2014), este proceso de promoción de la acreditación no fue una decisión exclusivamente gubernamental, sino que fue promovido por algunas de las instituciones que brindaban estos servicios y que buscaban desvincularse de aquellas que tenían un carácter más improvisado e incluso violatorio de los derechos humanos de las personas que atendían. En este marco se creó la Federación Mexicana de Comunidades Terapéuticas en el 2000 con el fin de garantizar unos mínimos de identidad y calidad de los servicios ofrecidos (Sánchez-Mejorada, 2013)

12. Por ejemplo, se ha propiciado la acreditación académica de las personas que toman un mínimo de los cursos que ofrece Conadic, ofreciendo el título académico de consejeros en adicciones, un título técnico que cuenta con reconocimiento por parte de la secretaría de Educación Pública. 
(Galaviz y Odgers, 2014) y otorgaron "becas"13 entre 2010 y 2018 a los centros certificados. A partir de 2019 se suspendió el financiamiento público a estos establecimientos por decreto presidencial.

Paralelamente a inicios del 2000 se puso en marcha una segunda reforma del Sistema de Salud, bajo la cual se crearon las Unidades Médicas Especializadas (Unemes), con la finalidad de fortalecer la atención primaria de atención a diferentes padecimientos, entre ellos, el uso problemático de sustancias. Las unidades médicas para la atención ambulatoria a uso problemático de drogas se abrieron en 2011 bajo el nombre de centros "Nueva Vida" o "Capa" y buscaban también ampliar la oferta de servicios de prevención que incluían un componente comunitario. También en 2011 el tratamiento para el uso problemático de drogas se incluyó en el Seguro Popular, el seguro público de salud (Schneider, 2010).

Por otro lado, y ante el auge de la epidemia de VIH en personas que se inyectan drogas en la frontera norte, el Centro Nacional para la Prevención y Control del SIDA (CENSIDA), abanderó la promoción de las estrategias de reducción de daños, que durante los noventa habían sido implementadas de manera aislada por organizaciones de la sociedad civil sin apoyo estatal. La promoción de algunas estrategias de reducción de daños desde Censida, ${ }^{14}$ favoreció la reforma a la NOM-028 en 2009 para incluir la reducción de daños como una estrategia efectiva de prevención de VIH. Sin embargo, el énfasis en VIH y drogas inyectables no permitió una discusión más amplia sobre la reducción de daños como filosofía frente al uso de sustancias, lo que ha dificultado su vinculación como un componente del tratamiento y/o de la prevención misma y limita su alcance de manera casi exclusiva a de las personas que se inyectan drogas.

Desde 2015, a nivel legislativo se han aprobado una serie de sentencias que tienden hacia la regulación de los mercados ilícitos de Cannabis, para uso medicinal en 2017 y para uso adulto en 2018. Sin embargo, a la fecha no se ha hecho efectivo un marco legal que permita ejercer el derecho al uso medicinal y/o adulto de cannabis, ya que no se ha expedido el reglamento de control sanitario de la Cannabis y sus derivados, lo que impide el acceso legal a estos medicamentos y tampoco se ha implementado una legislación para el uso adulto de la planta.

13. Para poder ser sujeto de becas, los centros debían hacer parte del directorio de centros certificados por Conadic, a los cuales las instituciones gubernamentales podrían remitir personas que necesitaban de estos servicios. Anualmente, el Conadic asignaba un monto de dinero a cada estado para el otorgamiento de dichas becas las cuales cubrían el tratamiento residencial de una persona por tres meses y la misma persona sólo puede ser beneficiada en una única ocasión. 14. Algunas acciones que implementó el CENSIDA entre 2000 y 2010 fueron la capacitación a proveedores de servicios de salud de la frontera en intervenciones de reducción de daños y la incorporación de la distribución gratuita de jeringas como parte de la estrategia nacional de lucha contra el sida. Bajo el apoyo institucional del CENSIDA, surgieron en la primera mitad de esta década, programas de intercambio de jeringas en Tijuana y Hermosillo y las primeras clínicas que ofrecen tratamiento sustitutivo con metadona en Ciudad Juárez y Tijuana operadas por los CIJ. La oferta de tratamiento con metadona se diversificó a otras ciudades a través de la operación de servicios privados que ofrecen el medicamento. Sin embargo, no se logró instaurar una oferta más diversa de tratamiento sustitutivo que contemple otros medicamentos. 
En 2019, el presidente Andrés Manuel López Obrador, en el marco de su programa de lucha contra la corrupción decretó el corte de financiamiento público a organizaciones civiles, lo que puso en jaque el funcionamiento de organizaciones que realizaban intervenciones de reducción de daños, proyectos comunitarios de atención a uso problemático de drogas, proyectos de asistencia social a poblaciones callejeras y centros de rehabilitación que operan bajo esta figura legal, lo que vino a fracturar aún más las estrategias comunitarias de atención al uso problemático.

Si bien los discursos médicos frente a la dependencia a las sustancias se han complejizado y se han incorporado cada vez más componentes en los modelos de atención, sigue primando un énfasis en la intervención individual, desligada del contexto en el que tiene lugar el uso de drogas y donde éste se puede tornar problemático tanto para los individuos como para sus comunidades. La preminencia del discurso médico frente al uso de sustancia y la falta de visibilidad de otras estrategias de tratamiento dificulta plantear alternativas de tratamiento distintas al internamiento que en la mayoría de los casos es compulsivo. En este contexto vale decir que la guerra contra las drogas no sólo ha generado aumento de la violencia y la criminalización de los usuarios de sustancias, sino que también ha favorecido la medicalización de esta práctica social.

A continuación, se describe cómo está organizado, el actual sistema de atención y cuidado para el uso problemático de drogas en México.

\section{EL SISTEMA ACTUAL DE CUIDADO Y TRATAMIENTO PARA EL USO PROBLEMÁTICO DE DROGAS EN MÉXICO}

La política de tratamiento de drogas en México opera a nivel federal, estatal y municipal. Desde el año 2000 todas las instituciones que ofrecen tratamiento contra las drogas están sujetas a la Política Nacional para la Prevención, el Tratamiento y el Control de las Adicciones, que se actualizó en 2009 (NOM-028-SSA2-2009, en lo sucesivo NOM-028). La NOM-028 clasifica las modalidades de tratamiento disponibles en México como ambulatorias o residenciales, cada una de las cuales puede ofrecer atención médica profesional, ayuda mutua, asistencial, modelos mixtos o métodos alternativos de tratamiento (México, 2009).

La Norma define el modelo profesional (médico) como aquel administrado por profesionales de la salud e incluye atención de emergencia y hospitalización. Los programas de ayuda mutua brindan apoyo entre pares basándose en el modelo de recuperación de 12 pasos, sin ofrecer servicios de atención profesional. El modelo mixto combina el tratamiento profesional y el de ayuda mutua en entornos como las Comunidades Terapéuticas y las casas intermedias. Finalmente, los modelos alternativos proporcionan métodos de tratamiento complementarios o alternativos que no se circunscriben a los anteriores (México, 2009). 
Los resultados de la última encuesta de consumo de drogas, alcohol y tabaco (Encodat, 2016) reportan que el $74 \%$ de las personas que recibieron tratamiento por su consumo de drogas acudieron a un servicio residencial (Villatoro et al., 2017 ) y el $26.4 \%$ a servicios ambulatorios.

\subsection{Servicios de atención en modalidad ambulatoria}

El anexo A resume la oferta de servicios de atención ambulatoria en México. Los servicios ambulatorios se ofrecen a través de los Centros de Atención Primaria a las Adicciones (Capa) los Centros de Integración Juvenil (CIJ) $)^{15}$ y, en menor medida, en los hospitales de salud mental. Los Capa son coordinados por los Consejos Estatales Contra las Adicciones que operan en los 32 estados de la República. Existen 343 unidades de atención de los Capa, 116 unidades de atención ambulatoria del CIJ, además de un centro de día y una clínica de metadona, todas unidades ubicadas principalmente en áreas urbanas. Adicionalmente, el país cuenta con 51 unidades médicas especializadas en salud mental y 38 hospitales psiquiátricos (SSA, 2018) que ofrecen atención ambulatoria para uso problemático, aunque su énfasis es la hospitalización y atención a personas con uso problemático de sustancias que presentan otras comorbilidades psiquiátricas.

El modelo de atención que ofrecen los CIJ y Capa es psicoterapia breve bajo el modelo cognitivo-conductual ${ }^{16}$ y ofrecen servicios especializados a jóvenes en situación de riesgo psicosocial, ${ }^{17}$ usuarios de drogas experimentales y ocasiona$\operatorname{les}^{18}$ y personas con dependencia. El tratamiento es una combinación de terapia farmacológica, terapias psicosociales, terapias familiares y terapias en grupo. Los servicios de Capa son gratuitos y los de CIJ tienen un costo de recuperación que depende del nivel socioeconómico de la persona, mismo que es determinado por trabajadores sociales al momento de la primera consulta.

El talón de Aquiles del modelo médico es la falta de profesionales de la salud, pues por cada 100,000 habitantes hay 1.5 psiquiatras, un médico general, tres enfermeras y un psicólogo (Marín-Navarrete, Medina-Mora, Tena-Suck, 2016). Por ello, no resulta extraño la cantidad de grupos de autoayuda que ofrecen tratamiento ambulatorio frente al uso problemático de drogas en México.

15. Aunque los CIJ aparecen como bajo la figura de una asociación civil, legalmente están constituidos como una paraestatal que hace parte de la estructura organizativa de la Secretaría de Salud y opera con presupuesto público federal, por ello, en este documento están considerados dentro de la oferta pública.

16. La terapia cognitiva es un sistema de psicoterapia que intenta reducir las reacciones emocionales excesivas y las conductas contraproducentes, mediante la modificación del pensamiento erróneo o defectuoso y las creencias desadaptativas, que subyacen a estas reacciones (Beck et al., 1993).

17. Jóvenes que tienen familiares que consumen sustancias psicoactivas ilegales o viven en contextos del alto consumo, vulnerabilidad y/o violencia

18. En estos casos, la atención consiste en una consejería médica o psicológica de no más de dos sesiones 
Marín-Navarrete, Medina-Mora y Tena-Suck (2016) reportan la presencia de más de 20,000 grupos de Alcohólicos y Narcóticos Anónimos. Bajo esta modalidad, los grupos sesionan en terapia grupal de hora y media al día y sus servicios son totalmente gratuitos (AA, 2019). Estos grupos suelen denominarse "tradicionales", porque respetan las tradiciones originales del movimiento, especialmente el ingreso voluntario a la agrupación y el carácter no residencial de la intervención original (Sánchez-Mejorada, 2013). Entre los tratamientos "no tradicionales" de Narcóticos Anónimos están los grupos de cuarto y quinto paso que implementan procesos intensivos, de un fin de semana para efectuar un "análisis de la personalidad y catarsis" (Sánchez-Mejorada, 2013) y los denominados "anexos" que operan en modalidad residencial.

Bajo la modalidad ambulatoria, se incluyen también las pocas intervenciones en reducción daños que han sobrevivido a la crisis y que son implementadas por organizaciones de la sociedad civil con financiamiento internacional, en la mayoría de los casos en comunidades de usuarios con muy alta vulnerabilidad. ${ }^{19}$ Las intervenciones no están reguladas por alguna instancia gubernamental, pero tampoco cuentan con financiamiento público federal. En esa medida, no existe un reporte oficial que permita conocer los tipos de atención particular que se ofrecen desde estas organizaciones, sino literatura que sistematiza algunas de las experiencias realizadas (Machín y Del Bosque, 2015; Leñero Otero, 2000; Milanese, Merlo y Machín, 2000) y sus páginas web y redes donde publicitan sus actividades.

\subsection{Servicios de atención en modalidad residencial}

El anexo B resume la oferta de servicios de atención residencial en México. El directorio de establecimientos especializados en el tratamiento de las adicciones en modalidad residencial reconocidos por Conadic (2018) registra la existencia de 268 establecimientos, de los cuales 49 son públicos, 30 son administrados directamente por la secretaría de salud, ${ }^{20} 11$ son administrados por los CIJ y 219 son privados. De estos 268 centros, sólo 36 están dirigidos específicamente a mujeres, en 83 reciben a hombres y mujeres, pero la mayoría (150) sólo recibe hombres. Entre los 38 centros públicos, sólo dos prestan servicios exclusivos para mujeres, mientras que existen 13 centros para hombres y 23 que reciben a hombres y mujeres.

En promedio, los programas públicos suelen tener una capacidad ocupada de 25 camas por centro (Conadic-Cidad, 2011), lo que permite estimar una capacidad de atención de 2,624 personas cada tres meses. En México la prevalencia de dependencia a sustancias ilegales es de $0.6 \%$ (Villatoro et al., 2017), lo que significa que alrededor de 500,000 requieren atención. De acuerdo con estas cifras, los servicios públicos de tratamiento sólo alcanzan a cubrir el $2.0 \%$ del universo de necesidad de atención.

19. La Carpa y ReverdeSer Colectivo, Biblioteca Cannábica, Brigada de Política de Drogas en la Ciudad de México; Programa Compañeros en Ciudad Juárez, Prevencasa en Tijuana y Verter en Mexicali.

20. Ocho de los cuales se encuentran dentro de reclusorios 
Los servicios públicos residenciales de atención se caracterizan por ofrecer el modelo médico, en el cual las personas pasan por un proceso de desintoxicación con una duración no mayor a tres semanas y tiene como objetivo eliminar el síndrome de abstinencia preparando al "paciente" para el tratamiento residencial (CIJ, 2019). El tratamiento se basa en el modelo de Comunidades Terapéuticas, donde participan diferentes profesionales con la finalidad de alcanzar la abstinencia. El modelo psicoterapéutico es cognitivo-conductual y la duración del tratamiento va de 30 a 90 días, dependiendo de la disponibilidad de la persona de permanecer internada, pues son de carácter voluntario (CIJ, 2019).

La brecha en la cobertura de atención al tratamiento para el uso problemático de droga es cubierta por entidades privadas y no gubernamentales que ofrecen estos servicios, sin que existan mecanismos suficientes de supervisión que garanticen la calidad de éstos. Según la Conadic (2018), sólo 219 establecimientos privados especializados en el tratamiento de las adicciones en todo el país están certificados. El último diagnóstico nacional de servicios residenciales en el tratamiento de las adicciones (Conadic et al., 2011) reporta la existencia de 2,291 centros no-gubernamentales en toda la república. Si tomamos como denominador este dato, asumiendo que no ha habido crecimiento de estos establecimientos en los últimos ocho años, sólo el 9.5\% de los centros estaría en línea con los requisitos estipulados en la NOM-028.

Los centros de tratamiento no gubernamental se caracterizan por la gran diversidad en los servicios que ofrecen. El $43 \%$ de los centros que hacen parte del directorio oficial de Conadic operan bajo el modelo mixto y $57 \%$ bajo el modelo de ayuda mutua (Conadic, 2018). Las estrategias de tratamiento más conocidas dentro del modelo mixto residencial son el modelo Minnesota y las Comunidades Terapéuticas. Por su parte, las alternativas terapéuticas de los centros residenciales de ayuda mutua, se pueden resumir en: i) anexos, albergues y granjas donde el tratamiento se sustenta en el apadrinamiento, la catarsis a través de la "tribuna" y la realización de un oficio que contribuye al sostenimiento económico del centro; ii) anexos fuera de serie, a donde son remitidos personas que han presentados comportamientos violentos en los anexos, albergues y granjas; y iii) Grupos Teo-terapéuticos, de inspiración cristiana que basan en el tratamiento en la aplicación literal de textos bíblicos para inducir un cambio de vida (Sánchez-Mejorada, 2013). ${ }^{21}$

21. Sin embargo, el nivel de religiosidad y la importancia que toma esta dimensión dentro del tratamiento no se puede establecer de manera absoluta, sino que existe un grado amplio de variabilidad que va desde los grupos abiertamente teo-terapéuticos hasta las comunidades terapéuticas (CT) e incluso, dentro de las mismas CT se encuentra diversidad en la centralidad de la espiritualidad y/o religiosidad en el proceso de tratamiento. Un estudio realizado en Tijuana encontró que en el $27 \%$ de los centros no-gubernamentales su terapia estaba orientada por principios explícitamente religiosos, y sólo el $8 \%$ declararon seguir modelos seculares de atención (Galaviz y Odgers, 2014). En el diagnóstico de centros de tratamiento residenciales $11 \%$ de los establecimientos encuestados reportaron el enfoque religioso como la principal estrategia terapéutica utilizada y el 50\% mencionó utilizar este enfoque en combinación con otras estrategias terapéuticas tales como programa de doce pasos (73\% como principal estrategia y $83 \%$ como estrategia combinada), y terapia psicológica (7\% y $57 \%$ respectivamente) (Conadic et al., 2011). 
Teniendo como referencia este marco general de los arreglos institucional, a continuación, se describe cómo este marco normativo toma vida en el caso de San Luis Potosí. Primero se presenta la metodología a través de la cual se accedió a la información y posteriormente se caracteriza la oferta de los servicios y se analizan los retos y brechas de atención al uso problemático de drogas en México.

\section{ESTRATEGIA METODOLÓGICA}

Este es un estudio de caso prototípico a través del cual se busca describir la manera cómo se organiza el sistema de cuidado y atención al uso problemático de drogas en México, a partir del análisis intensivo de la manera cómo se implementa la oferta de estos servicios en el estado de San Luis Potosí.

San Luis Potosí (SLP) es considerado para los fines de este estudio como caso prototípico por tres razones. En primer lugar, porque en 2019 el Conadic distinguió a este estado como aquel con las mejores respuestas en materia de atención al uso problemático de drogas, ello supone que la manera como están estructurados los servicios en SLP y la manera cómo opera su coordinación responde a las expectativas y normativas nacionales en la materia. En segundo lugar, al ser un estado ubicado en el centro del país, presenta problemáticas de uso de drogas similares a las observadas en otros estados del centro de la república, esto es, no es el estado con mayor prevalencia de uso problemático, tampoco presenta prevalencias excepcionalmente bajas, sino más bien promedio y tampoco exhibe dinámicas de uso particulares, como en el caso de los inyectores en el norte. En tercer lugar, no es un estado que se caracterice por su liberalidad o vanguardia en términos de política de drogas, como sucede en casi todos los estados de la República, lo que ofrece un escenario óptimo para analizar cómo se responde típicamente en el marco de una política pública pro-abstinencia frente al uso problemático y los retos que ello supone.

$\mathrm{Al}$ ser un estudio de caso, se recolectó toda la información posible para poder construir el contexto en el que se brinda la atención. Ello supuso realizar revisión de documentos institucionales, levantamiento de encuestas, entrevistas y visitas a los centros de tratamiento.

La revisión documental se realizó con el apoyo de la Secretaria de Salud quien proporcionó documentos oficiales que dieran cuenta de informes de gobierno, planes, programas y proyectos de prevención y atención al uso problemático de drogas de 2010 a la fecha, con el objetivo de recopilar datos contextuales e históricos de lo que ha sido la atención a este tema de salud pública en este estado de la República.

Paralelamente, se realizaron conversaciones informales con actores institucionales del área de adicciones y con asociaciones civiles para conocer en términos generales cómo se organizaba el sistema de atención y cuidado y cuáles eran los actores relevantes para incluir en el estudio. Esta exploración inicial permitió 
identificar que la oferta de servicios de atención al uso problemático de sustancias en SLP se limitaba a Capa, Cij, Instituto Temazcalli y Centros Residenciales de Tratamiento No-Gubernamentales. Posteriormente se corroboró con funcionarios de Conadic a nivel federal y con activistas en reducción de daños también a nivel federal, la no-existencia de estrategias comunitarias de atención al uso problemático de drogas en este estado de la República.

Adicionalmente, la Coordinación Estatal de Salud Mental y Adicciones (Cesma-SLP) proporcionó un listado de 56 centros de tratamiento no-gubernamentales registrados por la Comisión Estatal Para la Protección contra los Riesgos Sanitarios (Coepris) ${ }^{22}$ que funge como universo conocido de establecimientos residenciales no-gubernamentales (CTNG). Mensualmente, la Cesma-SLP, ofrece capacitaciones en diversos temas a los CTNG. En el marco de este espacio de capacitación, se presentó el estudio a representantes de los centros de tratamiento que acudieron a una reunión programada en diciembre de 2019 y se les invitó a participar. Se estableció contacto telefónico con los centros que no asistieron a dicha reunión para presentar el estudio e invitarlos a participar, sin embargo, no se obtuvo respuesta de ninguno de los centros contactados por esta vía.

Con los centros que accedieron a participar en el estudio, se levantó en primer lugar una encuesta de caracterización de su infraestructura, personal y servicios, que fue aplicada justo en el momento en que el responsable accedió a participar. La encuesta se aplicó, previa lectura del consentimiento informado, a través de una encuestadora capacitada y utilizando una tableta electrónica que facilitaba el llenado de información. Para garantizar el anonimato, no se registraron datos personales de los entrevistados ni de los centros de tratamiento que permitieran ligar los datos proporcionados con personas o establecimientos específicos.

Todos los centros de tratamiento asistentes a la capacitación convocada por la Cesma-SLP (22 en total), accedieron a responder la ficha de caracterización. Una vez terminado el llenado de la ficha, fueron invitados a participar en una entrevista estructurada donde se buscaba profundizar en algunos aspectos del tratamiento y en la percepción de los encargados de los centros y sus consejeros sobre las brechas de tratamiento existentes en el estado, las buenas prácticas en relación con la atención que ofrecen y los retos que enfrentan. Las entrevistas fueron realizadas por profesionales con experiencia en investigación cualitativa y en las oficinas de los entrevistados. Todas las entrevistas fueron audiograbadas tras la lectura del consentimiento informado. En total se realizaron 15 entrevistas

22. La Coepris es un órgano descentralizado de la Secretaría Estatal de Salud encargada de la regulación, control y fomento sanitario de establecimientos de salud, categoría dentro de la cual se ubican a los centros de tratamiento residenciales para el uso problemático de drogas. La Coepris emite diferentes tipos de autorizaciones sanitarias que permiten la apertura de establecimientos. Por ello, la apertura un centro residencial para el uso problemático de drogas, requiere de un aviso de funcionamiento que es otorgado por esta institución. 
a personal de los centros de tratamiento, algunas de ellas $(\mathrm{n}=4)$ grupales. Al momento de las visitas a los centros de tratamiento no-gubernamental se solicitó la posibilidad de observar cómo estaba organizado el establecimiento y tener acceso a usuarios de los servicios para invitarlos a participar del estudio respondiendo una entrevista. Estas entrevistas buscaban explorar los puntos de vista de los usuarios con respecto a los servicios de tratamiento que han recibido y las brechas de atención que perciben en el estado.

También se entrevistó a los funcionarios públicos que coordinan la oferta estatal de servicios de tratamiento para adicciones y quienes operan los Capa y CIJ. Así mismo, se visitó el centro público de tratamiento residencial (Instituto Temazcalli) y en la visita se aplicó la ficha de caracterización y se realizaron las entrevistas a usuarios y a personal administrativo y de consejería.

El cuadro 1 resume el total de participantes del estudio y el número de centros de tratamiento que respondieron cada uno de los instrumentos descritos en relación con el universo de centros de tratamiento registrados.

CUADRO 1

Universo de centros de tratamiento considerados, total de instrumentos aplicados en los centros de tratamiento, total de usuarios entrevistados (San Luis Potosí, México)

\begin{tabular}{|c|c|c|c|c|}
\hline $\begin{array}{c}\text { No. de centros listados } \\
\text { por la Coepris }\end{array}$ & $\begin{array}{c}\text { No. de centros partici- } \\
\text { pantes en la reunión } \\
\text { convocada por la SSA }\end{array}$ & $\begin{array}{c}\text { No. de centros que } \\
\text { respondieron la ficha } \\
\text { de caracterización }\end{array}$ & $\begin{array}{c}\text { No. de consejeros y/o } \\
\text { directores de centros } \\
\text { de tratamiento entre- } \\
\text { vistados }\end{array}$ & $\begin{array}{c}\text { No. de usuarios } \\
\text { entrevistados }\end{array}$ \\
\hline 56 & 22 & 23 & 26 & 16 \\
\hline
\end{tabular}

Elaboración de la autora.

Todas las entrevistas fueron audiograbadas una vez los y las participantes brindaron el consentimiento informado. La información se sistematizó en matrices analíticas a partir de un diseño preliminar de categorías y subcategorías de interés establecidas a priori. El protocolo de investigación fue aprobado por el comité de ética de la Secretaría de Salud de San Luis Potosí (ver anexo C).

Adicionalmente, se entrevistó a Juan Machín, creador del Modelo ECO2 con la finalidad de comprender desde su punto de vista, los factores que dificultaron la adopción de este modelo por parte de instituciones gubernamentales como sucedió en otros países de la región.

La principal limitación del estudio es el acceso a los centros de tratamiento. Sólo se tuvo acceso a los centros de tratamiento que acuden a las reuniones programadas por la Dirección de Salud Mental y Adicciones de la Secretaría de Salud. Es posible que los centros que no acuden a estas reuniones presenten condiciones de infraestructura y calidad de servicios distintas a las que aquí se expone. 
Así mismo, la participación en el estudio fue voluntaria, de manera que no se pudo constatar las condiciones de los servicios en aquellos centros que no aceptaron la realización de las entrevistas y las visitas. En esa medida, la información que aquí se presenta no puede ser generalizable al universo de centros de tratamiento de SLP o de México, sino que constituye una fotografía parcial de las condiciones en las cuales se brindan este tipo de servicios.

Pese a estas limitaciones, dada la falta de información sobre los servicios de tratamiento para uso problemático de drogas en México, los hallazgos que aquí se presentan sirven para sugerir acciones de política pública para mejorar la calidad y cobertura de estos servicios.

\subsection{El contexto del estudio}

San Luis Potosí (SLP) está ubicado en la región centro-norte de México (figura D.1, anexo D). En 2015, vivían en este estado de la república 2,717,820 habitantes, ubicándose a nivel nacional en el lugar número 19 (de 32 estados) en términos de volumen poblacional. En su capital, vive el 30\% de la población total del estado, esto es, casi 900 mil personas (Inegi, 2015).

Su ubicación geográfica, ha convertido a SLP en un estado clave en el tráfico de drogas, por lo que diversas organizaciones criminales se disputan su control territorial (Cartel Jalisco Nueva Generación y los Zetas principalmente), situación que ha impactado las condiciones de seguridad del estado y la prevalencia de uso problemático de drogas, particularmente de metanfetaminas, conocidas localmente como cristal.

En términos de uso de drogas, es de los estados con las prevalencias más bajas. La última encuesta nacional (Encodat, 2016; 2017), ubica a SLP en el 25 lugar a nivel nacional de incidencia acumulada (7.5\% vs. $9.9 \%$ a nivel nacional), en el lugar 26 en términos de prevalencia de uso en el último año $(2.0 \%$ vs. $2.7 \%$ ) y en el lugar 28 para prevalencia de uso en el último mes (0.6\% vs. $1.4 \%)$ (Villatoro et al., 2017).

\section{RESULTADOS: CARACTERIZACIÓN DE LOS SERVICIOS DE TRATAMIENTO PARA EL USO PROBLEMÁTICO DE DROGAS EN SAN LUIS POTOSÍ, MÉXICO}

El diagrama tres (anexo D) ilustra de manera general cómo se organizan los servicios de tratamiento para uso problemático de drogas en San Luis Potosí.

A continuación, primero se describe el funcionamiento de los Capa con la información obtenida en las entrevistas realizadas con el personal administrativo y operativo del Capa-Capital, con personal administrativo de la coordinación de Salud Mental y Adicciones de la Subdirección de Prevención y Promoción de la 
Salud de la Secretaría de Salud de SLP. ${ }^{23}$ Posteriormente se describen las características de la atención encontradas en los centros residenciales de tratamiento, comparando lo encontrado en el centro público con lo encontrado en los centros de tratamiento no gubernamentales.

\subsection{Centros de Atención Primaria en Adicciones: la hegemonía médica frente al uso de drogas}

Las fuentes consultadas permitieron identificar que la decisión de construir un Capa en un territorio determinado se hizo con base en los resultados de la Encuesta Nacional de Adicciones de 2002 y a través de la consulta a expertos en el tema. Así, Capa está ubicado de manera estratégica en los municipios donde en su momento (2007) había mayor volumen de personas con situación de consumo o situaciones de riesgo. De este modo, existen en SLP siete Capa ubicados en seis jurisdicciones sanitarias como se muestra en el mapa F.1 (anexo F).

Los documentos oficiales muestran una intención de realizar intervención comunitaria desde Capa, e incluso plantean como una de sus estrategias la investigación acción participante (Conadic, 2008). Así mismo, la argumentación territorial para decidir dónde ubicar el edificio de Capa, pareciera indicar que en su conceptualización, las actividades de prevención y tratamiento de uso problemático de drogas debían articularse con las actividades que realizan las instituciones educativas, sociales, comunitarias y empresariales existentes en cada territorio, lo que supondría un trabajo de gestión comunitaria para generar el involucramiento de las comunidades en dónde se insertaría orgánicamente cada Capa.

Sin embargo, al momento de la ejecución, no se creó una posición encargada de realizar el trabajo comunitario, sino que fue una tarea asignada al personal de psicología y trabajo social, quienes desde un principio tuvieron a su cargo la evaluación de casos y la implementación del componente de prevención y tratamiento.

El caso de SLP ilustra esta brecha entre el planteamiento conceptual de la propuesta de Capa y su ejecución. En cada uno de los siete Capa existentes en SLP, desde su inauguración y hasta la fecha, trabajan dos psicólogos, un trabajador social, un director y un administrador en un horario de nueve de la mańana a tres de la tarde. La percepción que tienen el personal operativo de Capa-Capital, es que están rebasados por la demanda de tratamiento y su prioridad es atender a las personas que llegan a solicitar consulta.

23. Conviene aclarar que dado que en el capítulo anterior se describió el funcionamiento de los Centros de Integración Juvenil (CIJ), y a que en SLP no hay oferta residencial por parte de esta institución para-estatal, no se consideró necesario describir aquí las características de sus servicios, por considerar redundante la información 
Cada psicólogo tiene en promedio entre seis y siete consultas programadas por día, lo que hace que el servicio esté siempre muy saturado. Vienen personas desde muy lejos a solicitar el servicio. Casi siempre son personas de muy bajos recursos económicos, que llegan caminando al centro, vienen aquí porque el servicio es gratuito, entonces nuestra prioridad es atenderlos. Para poder hacer las otras tareas, nos ha funcionado muy bien la capacitación de promotores comunitarios, quienes hacen detección y canalización con nosotros (Personal Capa-Capital).

A once años de operación de los Capa, ha aumentado la demanda de atención, pero se mantiene la misma oferta de servicios, es decir, no se han creado nuevas unidades de atención ni ha aumentado la plantilla de profesionales que laboran en ellas. Capa y CIJ son las únicas instancias públicas que ofrecen tratamiento ambulatorio, pues el Hospital de Salud Mental, sólo recibe casos cuando tienen comorbilidades psiquiátricas, de modo que, aunque en la descripción general de los servicios se plantea la existencia de una oferta más amplia de atención ambulatoria al uso problemático de sustancias, en la práctica, esta resulta más limitada.

Además de la insuficiencia de servicios y profesionales, de acuerdo con las personas entrevistadas, la oferta de entrada a tratamiento a cambio de medidas de prisión preventiva en caso de los primo-delincuentes no violentos por parte del sistema de justicia penal, es otro factor que ha contribuido a la saturación de los servicios de los Capa, sin que hayan contado con apoyo financiero por parte de este subsistema de gobierno.

Dado que el objetivo institucional de los Capa es "disminuir la incidencia y el consumo de drogas a través de acciones tempranas y oportunas en escuelas, grupos organizados de la sociedad civil y comunidad en general" (Conadic, 2015 , p. 8), el personal además de atender la consulta individual, debe realizar actividades de prevención y detección en escuelas y tienen metas de número de pruebas realizadas, número de charlas otorgadas y número de consultas, todos factores que inciden en que el trabajo comunitario no constituya una prioridad. Adicionalmente, su formación es clínica y la capacitación que reciben refuerza estas habilidades clínicas, por lo que tampoco tienen la formación necesaria para realizar trabajo comunitario.

\subsection{El usuario desde la perspectiva de los proveedores de los servicios}

En las entrevistas con el personal que trabaja en Capa y con quienes coordinan la dirección salud mental y adicciones se indagó por la imagen que tienen de los usuarios que reciben los servicios de tratamiento. En primer lugar, los usuarios son considerados "pacientes" lo que da cuenta de la perspectiva médica que impera en la institución. ${ }^{24}$ En términos generales, los entrevistados reportan que los “pacientes” de Capa son en su mayoría jóvenes, menores de 30 años, quienes son llevados a los servicios por un familiar, casi siempre la madre y con problemas de comorbilidades psiquiátricas.

24. De hecho en su nombre da cuenta de esta perspectiva médica, pues son Unidades Médicas Especializadas. 
Es persistente la idea de que los usuarios de los servicios son "pacientes difíciles", en tanto la mayoría "no tienen consciencia de enfermedad", son llevados por sus familiares o derivados de su escuela o trabajo y son de muy escasos recursos económicos, por lo que enfrentan múltiples barreras para acceder a tratamiento entre ellas el transporte, el horario del servicio que no se ajusta con las ocupaciones de escuela y/o trabajo. Desde estos lugares se explica la baja tasa de tratamientos terminados. ${ }^{25}$

Es muy común que deserten porque son pacientes muy difíciles, pues a la mayoría los llevan. Cuando una persona falta a su cita se reprograma hasta 3 veces y después de la tercera vez que la persona no acude, se realiza una visita domiciliaria. La mayoría de las veces en esa visita, el paciente manifiesta que no quiere regresar porque no tiene tiempo o simplemente no quiere regresar. Es que no tienen consciencia de enfermedad o no han tocado fondo y entonces no están decididos a realizar un cambio en el estilo de vida y dejar de usar drogas (Personal Capa-Capital).

Otro elemento que caracteriza la percepción que tiene el personal de Capa-Capital de los usuarios de los servicios de tratamiento es su alta prevalencia de comorbilidades de salud mental, lo que conlleva a que, en la mayoría de los casos, el tratamiento contemple un componente farmacológico, que requiere que la persona acuda con un psiquiatra y acceda a los medicamentos, lo cual no siempre es posible por la falta de estos profesionales dentro de la unidad y por el desabasto de medicamentos que de manera persistente enfrenta la Secretaría de Salud, en el caso de las personas derechohabientes, o por sus altos costos, en el caso de las personas sin ninguna protección en salud.

La mayoría de pacientes que consume drogas, tienen un padecimiento psiquiátrico aunado al problema del consumo (...) De cada 10 pacientes que acuden a consulta, calculo que unos siete requieren consulta psiquiátrica y aunque tenemos muy buena relación con salud mental [la unidad hospitalaria], es un servicio muy saturado y muchas veces no hay medicinas.... De nada nos sirve que el paciente esté yendo a psiquiatría si al final cuando el psiquiatra le receta un medicamento, este no está disponible, o hay uno pero no el otro y requiere los dos, ahí ya empieza a cojear el tratamiento, porque nuestros pacientes no tienen como comprar un medicamento de esos (Personal Capa-Capital).

La descripción de los procesos para acceder a los servicios, permiten pensar en la existencia de un filtro implícito que dificulta que personas con uso problemático de sustancias que viven en contextos de alta marginalidad social, pueden acceder a los servicios de Capa. En primer lugar, porque requieren de un acompañante y en segundo lugar porque el acompañamiento médico y farmacológico requerido en la mayoría de los casos, está por fuera de las posibilidades de personas que no cuentan con seguridad social y viven en situación de pobreza.

25. La directora del Capa-Capital reporta 60 tratamientos terminados en 2019 y 350 consultas de primera vez, lo que da una tasa de $16 \%$. 
Por otro lado, pareciera que los proveedores de los servicios de tratamiento han construido una idea del usuario como un sujeto menor de edad y/o como persona reducida en sus capacidades mentales, en ambos casos, ello revierte en la idea de una persona con poca capacidad de agencia, lo que explicaría la necesidad de tener un tutor del tratamiento aun en personas adultas. Por ello las explicaciones sobre la baja tasa de éxito del tratamiento no genera cuestionamientos en torno a los procedimientos o la forma de prestar los servicios, sino que recae sobre las características individuales de los usuarios.

\subsection{Meta del tratamiento}

$\mathrm{Al}$ indagar entre los proveedores de los servicios de atención y entre las personas que administran la Coordinación de Salud Mental y Adicciones por el meta del tratamiento, todos coinciden en que su objetivo es "mejorar la calidad de vida de los pacientes", o bien lograr la "reinserción social de los pacientes", entendida como "la recuperación del funcionamiento laboral, escolar y familiar". Al preguntar de manera explícita si ello supone o no abstinencia, las personas entrevistadas mencionaron que, dependiendo del cuadro de consumo, la abstinencia puede ser una meta o no. Sin embargo, las pruebas antidopaje hacen parte del proceso de intervención. ${ }^{26}$

No necesariamente es abstinencia [la meta del tratamiento], sería como engañarnos a nosotros mismos pensar que todos nuestros pacientes van a salir sin consumir nada (...) Nosotros cuando hablamos de un tratamiento exitoso, hablamos de una mejora en la calidad de vida del paciente, porque nos vamos a encontrar a lo mejor un paciente poliusuario que consume marihuana, cocaína, alcohol, anfetamina, metanfetamina y de todo, y si logramos que ese paciente deje todo y que a lo mejor se quede con marihuana y retome su actividad laboral y su vida familiar, podemos hablar de un tratamiento exitoso, y no porque pidamos que el paciente dejó de consumir todo (...) (Personal Capa-Capital).

En los manuales de operación (Conadic, 2015) se establece que la meta del tratamiento es abstinencia inmediata o reducción del consumo de manera gradual, de modo que de manera oficial la abstinencia es la meta del tratamiento a largo plazo. No existe una orientación formal por parte de la Secretaría de Salud en torno a la reducción de daños, más allá de la distribución de jeringas y la realización de pruebas de VIH en inyectores. Sin embargo, pareciera que el personal en campo está sensibilizado con la dificultad que enfrentan las poblaciones para vivir en abstinencia y entonces refuerzan el uso de sustancias de menor impacto, como la marihuana, priorizando la reinserción social de la persona.

26. En palabras del personal de Capa-Capital entrevistado: "Se aplica antidoping para confirmar que no está consumiendo, no tiene ningún costo. Se aplica a mitad de tratamiento, cuando el paciente afirma que no consume y el familiar dice lo contrario. También se aplica a los tres meses de concluido el tratamiento para verificar abstinencia." 
Dado la concepción limitada que desde la Secretaría de Salud se tiene de reducción de daños, el personal de Capa no está capacitado en estas estrategias, que podrían considerarse de prevención indicada en grupos de usuarios que no pueden o no quieren dejar de consumir y que podrían ser una manera de conectar a estas personas con los servicios de salud.

\subsection{Relaciones interinstitucionales}

Por mandato institucional, los Capa están obligados a formar y presidir los Cecas y los Consejos Municipales Contra las Adicciones (Comcas). En el caso de SLP, el Ceca está conformado por 32 instituciones que en la descripción dicen ser públicas y privadas ${ }^{27}$, con la finalidad de coordinar la respuesta en adicciones a nivel territorial. Los Comcas, por su parte, están conformados por representantes de las mismas instituciones que componen los Ceca, pero que operan a nivel municipal. SLP tiene en total 30 Comcas lo significa que poco más de la mitad de sus municipios (58 en total), cuenta con esta figura de coordinación interinstitucional.

$\mathrm{Al}$ revisar el listado de instituciones que conforman el Ceca y los Comcas, llama la atención que son principalmente instituciones públicas y que las instituciones privadas son todas universidades. Personas usuarias de drogas no hacen parte de estas instancias y la única asociación civil presente es alcohólicos anónimos, lo que da cuenta de la hegemonía del paradigma médico desde el cual se piensa el uso de drogas en general y la falta de trabajo comunitario, que permitiese establecer diálogo con otros actores que operan a nivel de base. En esa medida, se comprende que el trabajo de estas instancias se centra en la coordinación de capacitaciones en temas de "adicción", desde las cuales se fortalece, disemina y legitima la perspectiva médica frente al uso de drogas, su concepción del usuario como enfermo y el énfasis en la abstinencia. "Realmente es poco el contacto que tenemos con otras instituciones. Coincidimos en reuniones pues formamos parte de una mesa de trabajo en adicciones, compartimos experiencias, pero no compartimos casos" (Personal Capa-Capital).

27. Consejo Nacional de Fomento Educativo, Procuraduría General, Programas para el Desarrollo de Estado, Sistema Estatal para el Desarrollo Integral de la Familia, Instituto Potosino del Deporte, Instituto Potosino de la Juventud, Comisión Estatal de Derechos Humanos, Instituto de las Mujeres, Consejo Estatal de Seguridad Pública, Dirección General de Ejecución de Penas para Menores, Facultad de Psicología de la Universidad Autónoma de SLP (UASLP), Facultad de Medicina de la UASLP, Instituto Tecnológico Superior de SLP, Facultad de Ciencias de la Comunicación, Facultad de Enfermería y Nutrición, Secretaría de Educación Pública, CECYTE, CONALEP, COBACH, Universidad Tecnológica, Universidad Politécnica, Universidad Cuauhtémoc, Universidad San Pablo, Universidad Interamericana para el Desarrollo, Universidad TEC Milenio, Universidad del Centro de México, Universidad Marista de SLP, Universidad TEC de Monterrey, Universidad José Vasconcelos SLP, Federación Universitaria Potosina, Servicios Estudiantiles de la UASLP, Central Mexicana de Alcohólicos Anónimos, Instituto Temazcalli, Centros de Integración Juvenil, Instituto Mexicano del Seguro Social, Instituto de Seguridad y Servicios Sociales de los Trabajadores del Estado. 
Más allá de la convergencia en espacios institucionales como el Ceca y los Comcas, las instituciones con quienes los Capa mantienen relación más estrecha son la dirección del Hospital de Salud Mental, el Instituto Temazcalli (centro público de tratamiento residencial) y con instituciones educativas. La relación con el Hospital de Salud Mental facilita la rápida asignación de citas a los "pacientes" que son referidos. Con el instituto Temazcalli se realiza la referencia en caso de requerir internamiento ${ }^{28}$, sin embargo, el reto según el personal del Capa entrevistado es que las personas accedan a los servicios, dados sus altos costos, pues a pesar de ser públicos, no son gratuitos.

Por su parte, la relación con las instituciones educativas consiste en ofrecer conferencias de prevención de uso de sustancias, detección de adolescentes en riesgo o adolescentes que están iniciando el consumo y formación de promotores contra las adicciones. Así mismo, las escuelas refieren a los estudiantes a los Capa cuando encuentran alguna situación de consumo. Los casos son atendidos siempre en las instalaciones del Capa y no se involucra a la escuela en el proceso de tratamiento. La misma situación se repite en el caso de empresas a las que Capa ofrece capacitación, se reciben personas para tratamiento, pero la empresa en sí no es involucrada en el mismo.

Estas características en que se operativiza el trabajo interinstitucional dejan ver que el trabajo en uso problemático de drogas opera de manera fragmentada aún dentro de las instancias de la Secretaría de Salud y no como un eje transversal programático. Ante esta fragmentación del sistema, el trabajo interinstitucional se promueve no desde programas, sino desde intereses y voluntades personales. La fragmentación del trabajo en drogas, tampoco favorece que se implementen intervenciones en la escuela de carácter más comunitario.

\subsection{Trabajo comunitario}

Por ley, cada Capa debe promover la formación de Coaliciones Comunitarias Contra las Adicciones. El objetivo de estas coaliciones es, en palabras de los responsables estatales de Salud Mental y Adicciones "hacer partícipes a los colonos para que se organicen y sean proactivos en la identificación y resolución de sus problemáticas comunitarias". A la fecha sólo existen tres coaliciones activas en SLP, de las siete que en teoría deberían existir, una por cada jurisdicción sanitaria.

28. De acuerdo al personal de Capa entrevistado, una persona necesita internamiento por "su alto nivel de consumo, porque son adictos, es decir, porque su cuerpo les pide la sustancia. Es un paciente que necesita estar encerrado porque requiere de un manejo médico, requiere de un medicamento y requiere estar en un lugar donde no tenga acceso a la droga, porque cuando llega su necesidad, es necesidad real, es necesidad física la que tiene. Él puede decir no quiero, pero cuando los síntomas de abstinencia llegan, es su cuerpo lo que lo lleva a buscar la droga. Él puede decir no quiero, pero lo que su cuerpo siente es necesidad. Sudoración, taquicardia, dolor de cabeza, temblor. Eso es lo que lo lleva a buscarla. Es algo que él ya no puede controlar". 
De acuerdo al manual operativo de Capa (Conadic, 2015), la formación de las Coaliciones Comunitarias Contra las Adicciones debe ser liderada por personal de los Capa y debe partir de un mapeo de actores sociales y comunitarios en el territorio al que se adscribe cada Capa, quienes deben ser convocados directamente a ser parte de esta iniciativa. Una vez se formaliza la coalición a través de actas constitutivas, se realiza un diagnóstico comunitario participativo y se establece un plan de acción. El principal obstáculo para la formación y operación de estas coaliciones ha sido, en palabras de los funcionarios de Salud Mental y Adicciones, su carácter formal-institucional, además de la falta de recursos económicos y las condiciones de seguridad de las localidades. En otras palabras, las coaliciones no funcionan por la falta de trabajo comunitario de base por parte del mismo Capa que facilite la generación de las alianzas necesarias para responder al tema la seguridad y para generar apropiación de los proyectos y planes de acción por parte de los actores comunitarios y en esa medida compromiso con la coalición.

Hay municipios muy participativos y hay otros que requieren apoyo económico. Hace unos años tuvimos un programa de promotores de salud que recibían un estímulo económico por participar, lo que incentivó el trabajo, pero en este momento no contamos con los recursos para pagar a los colonos su participación. En la zona urbana es más complicado que las personas se organicen, mientras que en las comunidades rurales es más fácil que se junten, porque es la manera cómo naturalmente ellos resuelven sus problemas (...) También el trabajo se facilita cuando las mismas administraciones se comprometen en el trabajo, por ejemplo, en la delegación de Pozos, el mismo delegado asumió un rol activo y se comprometió a involucrar a diferentes actores y darle seguimiento a las acciones, lo que ha fortalecido la estrategia. Cuando no existe ese apoyo es más complicado, pues nosotros no tenemos jurisdicción, sólo recomendamos, pero no siempre tenemos poder de convocatoria (Responsable estatal de Salud Mental y Adicciones).

Aunque la obligatoriedad de formar coaliciones comunitarias, Ceca y Comcas, lleva a que estas instancias efectivamente se constituyan, al no haber suficientes recursos para realizar el trabajo comunitario en términos de al menos un profesional que se ocupe exclusivamente de generar y alimentar estas alianzas, entre otros recursos necesarios, ${ }^{29}$ la movilización comunitaria que suponen estas instancias termina siendo muy limitada.

Así mismo, la visión vertical en la conformación de las coaliciones y la perspectiva del uso de drogas desde el paradigma médico dificulta generar procesos comunitarios donde los usuarios tengan voz y donde las mismas comunidades puedan agenciar sus respuestas. Por ejemplo, es complicado esperar que las comunidades se ajusten a los horarios de trabajo de los funcionarios de Capa. En otro nivel, el

29. Como recurso de transporte y capacitación en torno al trabajo comunitario y los dispositivos comunitarios de atención. 
trabajo comunitario toma tiempo y las lógicas institucionales a las que responden los Capa en términos de metas de atención y capacitación que se establecen con Conadic, difícilmente corresponden con esos tiempos distendidos que requiere la inmersión comunitaria. En tercer lugar, el trabajo comunitario puede entenderse como la construcción de un contrato social tácito, agenciado por las personas y facilitado por la intensidad y frecuencia de interacciones entre ellas. Se requiere presencia continua y sostenida en la comunidad para poder construir ese contrato social. La lógica institucional desde la cual pareciera estar pensada la conformación de las coaliciones comunitarias supone el traslado de una lógica institucional a la informalidad de los encuentros y la solidaridad del trabajo comunitario y deja ver la necesidad de capacitación de los funcionarios al respecto.

Desde la percepción del personal que trabaja en Capa el principal obstáculo para realizar intervenciones comunitarias es la seguridad, pues en la mayoría de los casos son territorios donde operan grupos del crimen organizado, por lo que se tiene la percepción de que no tienen garantías para ir a campo.

Nosotras aquí somos puras mujeres, vamos en el vehículo institucional, pero nada nos garantiza que no nos pase nada. Vamos de buena voluntad. En ocasiones, es la misma comunidad la que nos dice que no vayamos porque la situación está especialmente complicada. Pero muchas veces vamos y nos ha tocado que que se nos quedan mirando, o un carro nos sigue todo el recorrido, desde que entramos al municipio... Es una situación compleja (Personal Capa-Capital).

Por estas limitaciones la principal acción comunitaria que realizan los Capa en SLP es la formación de promotores comunitarios en adicciones. ${ }^{30}$ Estos promotores comunitarios fungen como primeros contactos en situaciones de consumo, pero el enfoque de trabajo no es comunitario, sino intramuros, en tanto ellos refieren "los casos" a los servicios. En palabras de los funcionarios, los promotores comunitarios formados son principalmente docentes, psicólogos y consejeros y pasantes de psicología, de modo que, aunque el perfil de promotor comunitario no exige una formación profesional, al final terminan siendo personas que desempeñan un cargo dentro de instituciones educativas y/o de salud, reforzando la perspectiva médica frente al uso de sustancias y el carácter intramuros de la atención que se ofrece frente al consumo de drogas en SLP.

A continuación, se describen las características de los servicios de atención en modalidad residencial.

30. En 2019 se formaron 600 de estos promotores comunitarios, quienes fueron entrenados en la detección de consumo de sustancias ilegales, consejería y canalización a servicios 


\subsection{Los servicios de tratamiento residenciales de San Luis Potosí, México}

SLP cuenta con 56 centros de tratamiento residencial para el uso problemático de drogas registrados por la Coepris. De ellos, sólo cinco cuentan con reconocimiento por parte de Conadic, ${ }^{31}$ lo que significa que sólo el $8.9 \%$ de los establecimientos cumplen con los requisitos planteados en la NOM-028. ${ }^{32}$

En México, no se otorgan licencias de funcionamiento a los centros de tratamiento, por lo que es relativamente sencillo abrir este tipo de establecimientos, aún cuando se cuente con reconocimiento por parte del Conadic. Tener o no reconocimiento por parte del Conadic, no se traduce en la práctica en un beneficio adicional para los centros de tratamiento, más allá de contar con un certificado de calidad de la atención, por lo que los directores de estos centros no se sienten suficientemente motivados a reunir los requisitos marcados por la NOM-028, por la alta inversión especialmente en infraestructura que ello supone (alrededor de USD\$6000). En palabras de uno de los directores de los centros de tratamiento entrevistados "Nos exigen mucho y no nos dan nada. Nosotros con nuestros propios recursos ofrecemos un servicio a la comunidad que nadie más está prestando".

La insuficiente supervisión por parte de las autoridades en salud, en conjunto con la alta demanda insatisfecha de servicios de tratamiento facilita la apertura y mantenimiento de establecimientos que violan los derechos humanos de las personas que usan drogas y de establecimientos que aún sin cometer graves violaciones a los derechos humanos, no cumplen con criterios mínimos de calidad en los servicios que estipula la Norma Oficial. Aún más, la falta de una Ley General de Adicciones dificulta que establecimientos donde se conoce que se cometen graves violaciones a derechos humanos sean clausurados y sus responsables investigados, ${ }^{33}$ lo que a su vez favorece la continuidad de estas violaciones y su normalización por parte de los usuarios y prestadores de estos servicios.

Antes de trabajar aquí, trabajé en un centro para mujeres. En las sesiones las chicas me hablaban de golpes y al principio no les creía, pero luego vi los moretones, las marcas y entonces empecé a escribir los reportes en las historias clínicas. También escuchaba algunos lunes, que el fin de semana entraban hombres y las obligaban a estar con ellos. Todo lo escribía en las historias clínicas y un día el director me pidió que eliminara mis notas, me negué y me despidió. Fui a la Secretaría de Salud a denunciar las irregularidades y me dijeron que debía ir a la Fiscalía y que tenía que llevar pruebas, obviamente no tenía ninguna prueba, pues cuando me despidieron, básicamente me

31. Estos requisitos son verificados a través de una visita de supervisión, donde un oficial da cuenta de las condiciones de calidad de los servicios que se ofrecen en términos de infraestructura, procedimientos y calidad de la atención. Estos reconocimientos se renuevan cada tres años.

32. En apartados anteriores, se presentó un cálculo para el nivel federal y estimamos un máximo nivel de certificación a nivel nacional de $9.5 \%$ en los centros de tratamiento residenciales.

33. La Comisión Estatal de Derechos Humanos elaboró una recomendación al respecto, ver (CDHSLP, s/f). 

aislamiento, estigmatización y desamparo

obligaron a salir sin poder recoger mis notas ni expedientes. Fue una situación muy difícil. Ese centro sigue en funcionamiento, es uno de los pocos para mujeres aquí en San Luis y me genera mucha frustración no poder hacer nada por las mujeres que están allí encerradas (Psicóloga Centro de Tratamiento No Gubernamental).

\subsubsection{Infraestructura}

Las visitas a los centros de tratamiento permitieron identificar una gran variabilidad en términos de infraestructura. La diferencia más importante encontrada es entre el centro gubernamental y los no-gubernamentales (ver figura 1). El centro gubernamental se caracteriza por una alta calidad en sus instalaciones, consultorios amplios y múltiples, salas de espera, zonas verdes, área deportiva y dormitorios amplios y ventilados, todos con camas.

\section{FIGURA 1}

Vistas del centro de tratamiento gubernamental - San Luis Potosí, México (2019)
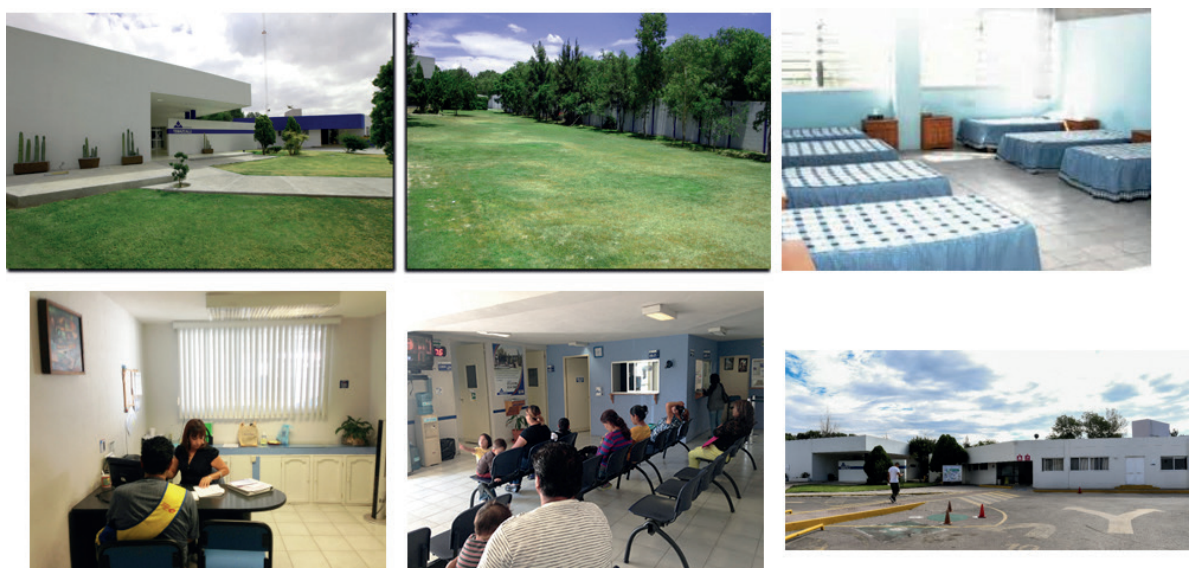

Fuente: Disponible: <http://temazcalli.gob.mx/nosotros.html>.

En contraste, los centros de tratamiento no gubernamentales, son, en la mayoría de los casos, casas habilitadas para tal fin (ver figura 2). Casi todos los centros pagan renta y sólo en algunos casos (3/22) el espacio fue donado por el Estado para realizar las actividades. 
FIGURA 2

Vistas de centros de tratamiento no gubernamentales - San Luis Potosí, México (2019)
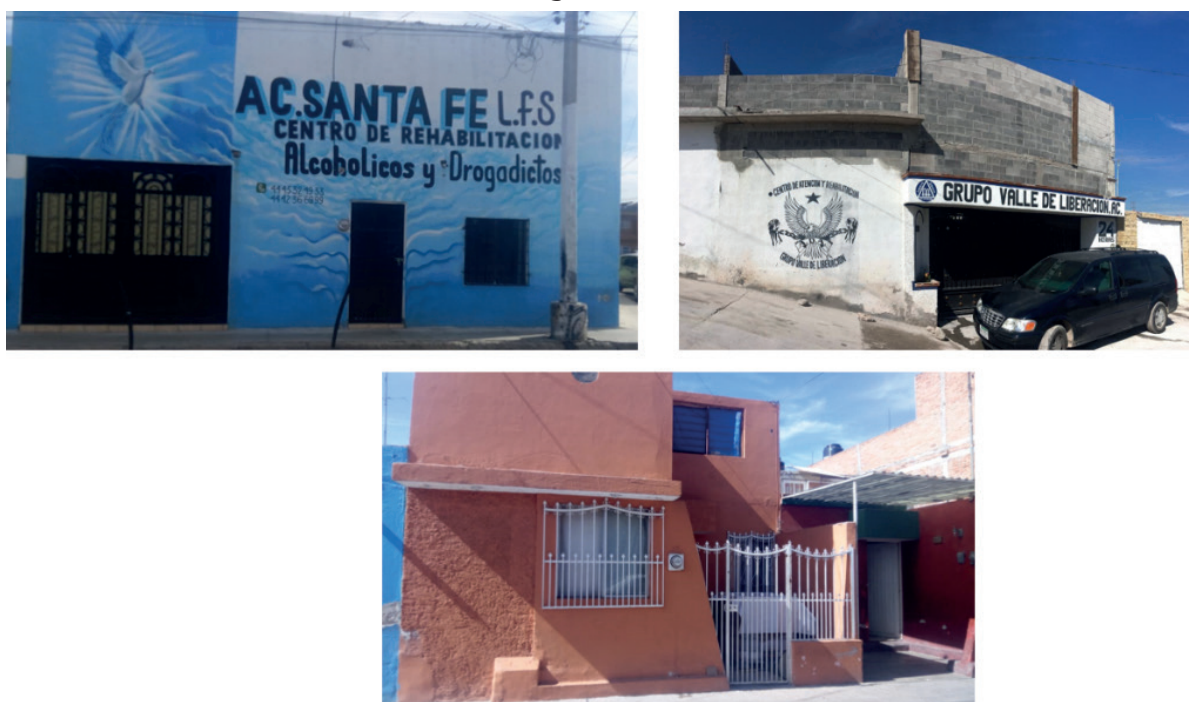

Fuente: Imágenes propias.

En términos generales, los edificios en los que operan los centros de tratamiento no gubernamentales no cuentan con zonas verdes y los consultorios suelen tener espacios muy reducidos (figura 3). El espacio de los centros no gubernamentales visitados se caracterizaba por tener un espacio de recepción, donde se encontraba expuestos los certificados y reconocimientos obtenidos, un escritorio y dos sillas. Después se encontraba una puerta que permanecía cerrada en la mayoría de los casos y que definía el adentro del internamiento.

\section{FIGURA 3}

Vistas interiores de centros de tratamiento no gubernamentales - San Luis Potosí, México (2019)
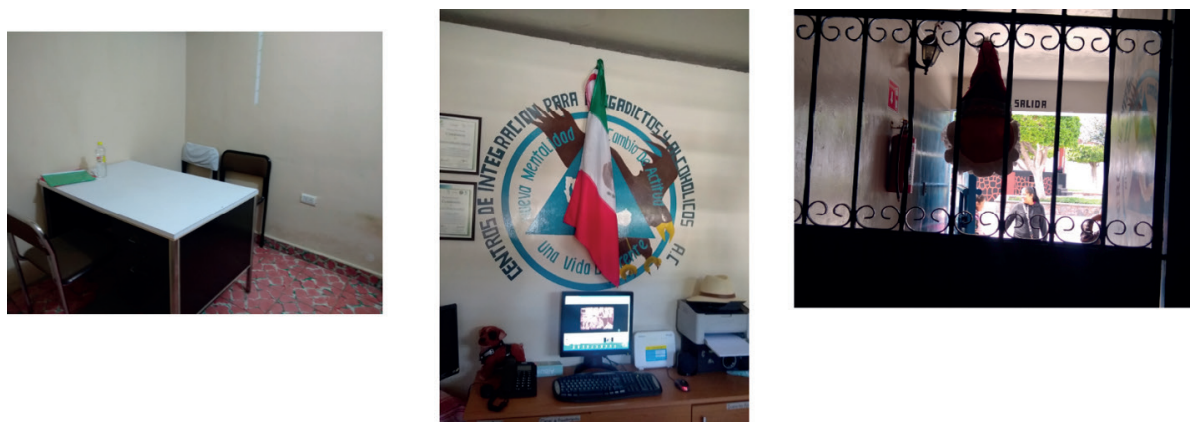

Fuente: Imágenes propias. 
Tras esa puerta, en la mayoría de los centros no gubernamentales visitados encontramos un patio donde los usuarios pasaban su tiempo libre, una cocina con el equipamiento básico para operar, el comedor y los baños. La mayoría de los centros visitados sólo contaban con dos cuartos, uno que operaba como dormitorio y otro donde realizaban juntas, tribuna, terapias y actividades grupales. En la mitad de los casos los dormitorios no contaban con camas, de modo que los usuarios dormían en colchones sobre el suelo, o simplemente sobre cobijas dispuestas en el suelo, en otros casos, los dormitorios estaban organizados con literas. Una de las principales quejas en los usuarios entrevistados fue precisamente la falta de mobiliario adecuado en los centros y particularmente la falta de camas.

Aquí está mejor, todos dormimos en cama, pero en el otro centro donde estuve, éramos muchos, como 40, y todos dormíamos en el piso, no había ni colchones, sólo ponían cobijas y órale, así nos la aventábamos. Se pasaba mucho el frio y no dormía bien. En mi opinión así nadie se rehabilita, no son condiciones (Usuario Centro de Tratamiento No-Gubernamental, hombre, 23 años).

Un tercio de los centros no gubernamentales visitados no tenían agua al momento de la visita. La falta de agua dificultaba que los usuarios pudieran bañarse diariamente y dificultaba el aseo de baños. Al preguntar de manera informal por esta situación, los representantes de los centros manifestaron que un problema común en las colonias donde se ubicaban y que lo resolvían comprando carrotanques de agua, en promedio al menos una vez a la semana, con un costo de $\$ 900$ (USD \$45). En contraste, el centro público de tratamiento contaba con todos los servicios y cumplía con los estándares de higiene que se esperan en este tipo de establecimientos.

\subsubsection{Capacidades y brechas de atención}

La capacidad de atención promedio de los centros es de 31 usuarios. El centro público reportó una capacidad de atención máxima de 30 personas, en los centros no gubernamentales el rango fue de 10 a 100, con un promedio de 32 personas. Sin embargo, la observación de las instalaciones visitadas permite cuestionar que en realidad puedan albergar a más de 30 personas en condiciones dignas y salubres.

Tomando como referencia una capacidad promedio de 30 personas por centro por un tratamiento de tres meses, estimamos una capacidad de atención anual de 6,720 personas en los 56 centros disponibles en todo el estado. Si consideramos sólo los centros certificados por Conadic, la capacidad de atención se reduce a 600 personas al año. Es decir, sólo 600 personas al año pueden recibir atención de calidad para el uso problemático de drogas en todo el estado de SLP. 
Considerando el volumen de población entre 12 y 65 años proyectado para 2020 (Conapo, 2020) y una prevalencia de dependencia de $0.6 \%$ (Villatoro et al., 2017), se estima que 12,028 tienen necesidad de atención al uso problemático de drogas en SLP, ello sin considerar la demanda de tratamiento por uso problemático de alcohol. Si tomamos en cuenta la capacidad de atención de los 56 centros registrados, la brecha de atención sería de 5,308 personas, es decir sólo el 44\% de la población que necesita atención tiene a servicios de tratamiento residenciales. Pero si sólo incluimos los cinco centros certificados, la brecha de atención asciende a 11,428 personas, en otras palabras, SLP sólo tiene capacidad para ofrecer tratamiento residencial de calidad al 5\% de las personas que requieren necesitan atención por uso problemático de drogas.

Analizar esta brecha de atención en relación con las desigualdades estructurales se torna fundamental para pensar sistemas de atención más democráticos. En el caso de SLP, el costo de los servicios residenciales y el requisito de contar con un tutor para poder ingresar, son características que dificultan que personas en mayor condición de vulnerabilidad puedan acceder a estos servicios.

En este análisis resulta evidente que a pesar de las insuficiencias, de la falta de calidad de los servicios, en incluso, a pesar de las violaciones a los derechos humanos que se reportan en algunos centros de tratamiento no-gubernamentales, estos son la única alternativa disponible de tratamiento frente al uso problemático de drogas para miles familias pobres en México.

$\mathrm{Al}$ analizar por género, se encuentra que existen pocos centros donde reciben mujeres (6/23) y sólo uno de ellos brindaban acceso exclusivo para ellas. Sin embargo, los servicios que se ofertan en este centro exclusivo para mujeres no son distintos a los que se ofrecen en los centros exclusivos de varones. En general, los centros no ofrecen información sobre salud sexual y reproductiva, elementos de crianza positiva, estrategias para elaborar situaciones relacionadas con las violencias de género que han enfrentado, ni espacios donde las mujeres puedan traer a sus hijos, por lo que ingresar a tratamiento supone renunciar a su rol de cuidadora y/o madre y por ello se observa, que en general, la mayoría de las mujeres que ingresan a tratamiento son menores de 19 años.

Yo empecé a darme cuenta que tenía una problema con el cristal, que no me estaba llevando a nada bueno, porque no más sólo quería usar, pero tampoco tenía a quien pedirle ayuda porque me daba temor que me quitaran a mi hija, por eso tampoco quería que me anexaran, porque no quería separarme de la nińa, pero ni modo, mi mamá llamó a los policías y me trajeron para acá, ella se quedó con la niña (Usuaria de centro tratamiento no gubernamental, 18 años). 
$\mathrm{Al}$ preguntar a los directores de centros de tratamiento no gubernamentales porque no reciben mujeres, su respuesta generalizada es que "son conflictivas" o "se meten con otros internos y generan conflictos". Es importante promover la perspectiva de género en los centros de tratamiento no gubernamentales y abrir una discusión mayor en la Coordinación de Salud Mental y Adicciones sobre las necesidades específicas de atención de mujeres con uso problemático de drogas.

Si bien todos los centros de tratamiento entrevistados manifestaron que no discriminan por género o preferencia sexual, tampoco se tienen lineamientos específicos para atender las particularidades de las personas lesbianas, gays, transgénero, transexuales y no binarias y para protegerles ante potenciales situaciones de violencia que puedan vivir al interior de los centros de tratamiento dadas las condiciones de hacinamiento y falta de privacidad encontrada en la mayoría de los centros no gubernamentales visitados. Nuevamente, sería necesario abrir la discusión desde la Coordinación de Salud Mental Adicciones sobre las necesidades específicas de atención a esta población. Al respecto conviene subrayar que no existen lineamientos nacionales que consideren las necesidades específicas de atención de estas poblaciones y tampoco existen instrumentos oficiales que permitan captar dichas necesidades.

\subsubsection{Concepción del usuario}

En todos los centros visitados, tanto el público como los no gubernamentales se nombra al usuario de los servicios como "paciente", lo que enfatiza en la perspectiva médica de la atención y la concepción del uso de sustancias como enfermedad. Desde este lugar de enfermedad, se legitima el tratamiento compulsivo en el caso de los centros no gubernamentales y la medicación a todas las personas ingresadas en el caso del centro público.

Un adicto es una persona enferma, pero a diferencia de otra enfermedad, él no se da cuenta que lo tiene, pero los que viven con él si, por eso los internamos sin su consentimiento. Cuando están aquí y después de desintoxicarse, se van dando cuenta del daño que causan y entonces empiezan a tomar consciencia de su enfermedad (...) Si los dejáramos afuera haciendo daño, nunca se darían cuenta que tienen un problema, porque así es la mentalidad del adicto, hace trampas para no dejar ver su vulnerabilidad (Director Centro de Tratamiento No Gubernamental).

Todos nuestros pacientes reciben medicamentos psiquiátricos todas las mañanas., hace parte de su rutina, y están obligados a tomarlos pues hace parte integral de su tratamiento. La valoración psiquiátrica a su ingreso permite identificar que todos tienen problemas de ansiedad, depresión y otras comorbilidades que requieren estos medicamentos. Además, esto les permite estar más tranquilas para enfrentar el encierro y tener mejor adherencia (Director Centro de Tratamiento Público). 
La medicación generalizada fue un punto crítico identificado por los usuarios del centro público de tratamiento

Aquí la atención es muy buena, en comparación con los anexos, ¿̇verdad? Lo único que no me gusta es que todos los días nos dan a todos medicamentos psiquiátricos. En mi caso, me quitan ánimo, me siento como extrańo, pesado, como desconectado de mi cuerpo... Me asusta que me vuelva adicto ellos una vez salga de aquí. Me gustaría que me preguntaran si quiero medicarme o no, porque aquí no te preguntan nada, tú simplemente tienes que seguir las indicaciones de los médicos, los enfermeros, de todo el personal (Usuario Centro de Tratamiento Público, hombre, 25 años).

Esta concepción del usuario y del uso de sustancias, conlleva al establecimiento de relaciones verticales entre quienes dirigen los centros (públicos o no gubernamentales) y los usuarios de los servicios, donde se espera que estos actúen con humildad, obediencia y sobriedad. Las personas que no cumplen con estas características son dadas de baja de los servicios, en el caso del centro público y en los centros no gubernamentales donde el ingreso no es voluntario, son características que ameritan castigos, que van desde el aislamiento, falta de comida hasta castigos físicos.

Yo siento que ya estoy listo para salir, ya llevo cuatro meses aquí, pero como mi familia sigue pagando para que me tengan aquí, no puedo salir. Lo único que puedo hacer es aguantar y portarme bien para que se convenzan de que ya puedo estar afuera. Si muestro alguna señal que es entendida como rebeldía por los que manejan aquí el centro, me arriesgo a que me castiguen o me dejen más tiempo, por eso toca cooperar (Usuario de Centro Público de Tratamiento Residencial, 23 años).

Aún más, la concepción del usuario como paciente tanto en los servicios ambulatorios como residenciales favorece la reproducción de las desigualdades sociales. El carácter involuntario del internamiento y el énfasis en la obediencia y el seguimiento de las normas dentro del centro son características que minan la capacidad de agencia de los usuarios y la oportunidad de pensar su consumo desde una perspectiva distinta a la culpa y a la falla autobiográfica del self(Bauman, 2001).

En ese sentido, el tratamiento mismo induce al sujeto a considerar su uso problemático de drogas como un padecimiento individual, independiente de las condiciones sociales, económicas, políticas y culturales en las que vive, lo que favorece la internalización la internalización del estigma, lo que a su vez, profundiza procesos de exclusión social y marginación que son sostenidos por la familia. Estos mecanismos explican que el uso problemático de drogas se constituya en México como un factor de agudización de la pobreza de familias que viven en contextos de vulnerabilidad social 


\subsubsection{Características del tratamiento}

El centro público de tratamiento es de carácter mixto y el tratamiento es estrictamente voluntario. El modelo de atención es profesional y el tratamiento está encabezado por el equipo de psiquiatras. Diariamente los usuarios reciben revisión de signos vitales por parte de enfermería y terapias psicológicas implementadas por profesionales, quienes son supervisados semanalmente a través del análisis de casos. El tratamiento tiene una duración de tres meses y la meta en palabras de su director es "evitar recaídas", por lo que abstinencia se mantiene como el principal indicador de éxito del tratamiento.

En contraste, sólo cinco de los 22 centros no gubernamentales visitados reportaron el carácter voluntario del internamiento. Justamente el internamiento compulsivo es quizás uno de los elementos más criticados por los usuarios de los servicios.

Los familiares te traen para deshacerte de ti y poder estar tranquilos ellos. Pero no está bien. A mucha gente la traen con engaños, a mí me trajeron cuatro cabrones y me ingresaron. Yo pienso que así no funciona, porque debe venir de uno la necesidad de rehabilitarse, sino, todo es peor. Sale uno pensando en cómo vengarse, cómo sacarse ese resentimiento y eso es drogándose más porque sabe que así uno les da en la madre (Usuario Centro de Tratamiento No Gubernamental, 32 años).

El modelo de atención que ofrecen los centros no gubernamentales entrevistados es principalmente mixto $(12 / 22)$, seis reportaron tener un modelo de ayuda mutua $(27 \%)$, tres un modelo profesional de atención (13\%) y uno modelo alternativo. ${ }^{34}$ En estos centros, la abstinencia fue la meta de tratamiento más comúnmente reportada $(12 / 22)$, seguida de reinserción social (3/22) y recuperación o rehabilitación (3/22).

La duración promedio reportada del tratamiento que ofrecen los centros de tratamiento no gubernamentales fue 4.5 meses, con un rango de tres a doce meses. La intervención "alternativa" a diferencia de las otras intervenciones no estableció un momento de fin de tratamiento, sino que lo representa en términos de un acompañamiento continuo para construir y fortalecer redes de apoyo psicosocial. Todos los consejeros y representantes de los centros entrevistados convergen en la idea de que tres meses es un periodo mínimo para desarrollar "consciencia de enfermedad", pero no cambios sostenidos en los estilos de vida.

En todos los centros visitados, tanto el público como los no-gubernamentales, tienen una rutina estricta que marcan la vida en una "institución total" (Goffman, 1972) y que tiene la finalidad de reestructurar la vida de los usuarios en torno a

34. El modelo alternativo consistía en una aproximación comunitaria ante la falta de un edificio donde poder implementar el internamiento. Es una intervención basada en la fe, donde el tratamiento consistía en acudir todos los días de seis a ocho de la noche al centro comunitario vecinal, para participar en diversas actividades como reunión de grupos de autoayuda (padres, madres, usuarios hombres y mujeres), talleres sobre manejo de emociones, conferencias, además de la atención psicológica que se ofrecía durante el día en consultorios privados donde los psicólogos tenían su práctica, actividades deportivas, vinculación laboral y la participación en actividades religiosas lideradas por una congregación cristiana. 
hábitos que favorecen la abstinencia. En consecuencia, se tiene una misma hora al levantarse que varía entre seis de la mañana en el centro público a ocho de la mañana en algunos centros no gubernamentales, participación en diversas actividades que se ofertan durante el día y las tardes, las cuales se repiten día a día, con excepción del fin de semana, comidas a una misma hora e ir a dormir entre las nueve y las once de la noche.

La diferencia entre el establecimiento público y los no-gubernamentales es la diversidad de actividades que pueblan la cotidianidad durante el internamiento. El centro público ofrecía además de las estrategias terapéuticas convencionales (psicoterapia individual, grupal y familiar, terapia farmacológica, tribuna), terapia ocupacional (carpintería), arte-terapia, mindufulness y yoga. En los centros no gubernamentales visitados 13 ofrecían terapia ocupacional y sólo uno ofrecía yoga. Las lecturas bíblicas hacen parte de las rutinas terapéuticas que se ofrecían en 10 de los 15 centros no gubernamentales visitados, en tanto son servicios gratuitos que prestan iglesias cristianas y evangélicas. Sin embargo, la tribuna ${ }^{35}$ fue la estrategia terapéutica más comúnmente reportada en todos los centros encuestados (20/23).

La falta de diversidad en las actividades y estrategias terapéuticas que ofrecen los centros no-gubernamentales fue una segunda queja reiterada entre los usuarios entrevistados.

Pues aquí la rutina es sólo tribuna, tribuna, tribuna y leer la biblia y limpiar, esa es toda la terapia. Te levantas y tribuna. Escuchas cada cosa que dice la gente que está aquí, desayuno y tribuna, después limpiar y al rato tribuna de nuevo. No es que sea mal, pero es tanto que enfada (Usuario de Centro de Tratamiento No-Gubernamental, 28 años).

Llama la atención que en la mayoría de los centros expresaron un interés por involucrar a las familias en el proceso terapéutico, por lo que al menos 16 de los 22 centros no gubernamentales entrevistados reportaron realizar algún tipo de terapia familiar. Sin embargo, en la mitad de estos establecimientos, esta terapia es coordinada no por un profesional, sino por un padrino. El acompańamiento de un familiar es una condición para ingresar a la mayoría de los centros entrevistados, sin embargo, involucrar a la familia en el proceso terapéutico es un reto. En algunos centros no gubernamentales la participación de familiares en la terapia y la asistencia a la visita son condicionantes de la permanencia del usuario.

35. La tribuna es una intervención en la que una persona se para frente a los compañeros en tratamiento y da testimonio de cómo era su vida cuando estaba usando sustancias, con un énfasis en los efectos negativos que tuvo esta práctica en sus relaciones sociales, familiares y laborales. También se utiliza para externar emociones negativas, a modo de catarsis. La forma de operar la tribuna cambia según el centro. En unos no se permiten intervenciones por parte de los demás asistentes, en otros los asistentes pueden confrontar a quien está dando testimonio y éste tiene que callar y escuchar comentarios negativos e incluso, derrogativos, lo cual hace parte del tratamiento en tanto debe transformar su ego y poder controlar su impulso a reaccionar ante agresiones percibidas. Dar testimonio en "tribuna" se considera un acto de humildad (García y Anderson, 2016). 
Lo que significa que aquellas personas que no cuentan con apoyo familiar tienen menores oportunidades de acceso a tratamiento y de terminación del mismo.

Muchas veces siento que las familias internan a su ser querido para encerrarlo y poder descansar tres, cuatro o cinco meses, pero que no tienen un interés real en que se mejoren, porque se les explica que la familia es parte fundamental del tratamiento, pero no vienen a las sesiones familiares, no vienen la visita tampoco, a veces los muchachos no tienen sus cosas básicas de aseo personal porque nadie viene a verlos, lo que les genera más resentimiento (Psicóloga Centro de Tratamiento No Gubernamental).

El costo promedio del tratamiento es de \$5,845 (292USD aprox.), con un valor máximo de $\$ 38,000$ (1600 USD aprox.) que corresponde al único centro público del estado. Cinco de los 23 centros encuestados reportaron ofrecer los servicios de manera gratuita y nueve reportaron costos menores a los $\$ 3,500$ (150 USD aprox.). En las entrevistas realizadas con el personal de consejería y dirección de los centros, el centro público mencionó que la asignación del precio a pagar por el tratamiento depende del estudio socioeconómico que se realiza al momento del ingreso. Los centros que operan bajo el modelo de ayuda mutua fueron quienes en mayor proporción reportaron ser gratuitos o con un costo máximo de $\$ 3,500$ (150 USD aprox.).

Conviene señalar que la mayoría de los centros no gubernamentales encuestados (20/23) reportó no recibir apoyo estatal de ningún tipo, mientras que sólo ocho reportó no recibir donativos privados. Los principales donativos que reportados fueron comida, insumos de aseo, ropa y dinero. Estos donativos no son aportes significativos, por lo que la principal fuente de financiamiento de los centros privados son las cuotas que cobran a las personas por ingresar. Los centros que reciben a mayor proporción de población sin capacidad de pago se enfrentan al dilema de bajar la calidad de la comida y depender exclusivamente del suministro público de agua, de modo que puedan cubrir los gastos indispensables (renta, servicios públicos y pago de profesionales), situación que afecta las condiciones de vida de los usuarios.

Con respecto a servicios complementarios, la mayoría de los centros encuestados (20/23) reportó que brindan acompañamientos a servicios de salud en casos en que la persona internada necesite algún tratamiento médico particular. Sin embargo, en la mayoría de los casos los familiares de las personas internadas deben cubrir los gastos de las visitas médicas y la compra de los medicamentos. Aunque es claro también que, cuando los internos no cuentan con este apoyo familiar y requieren la atención médica, el centro se hace cargo de los gastos. La entrega de medicamentos psiquiátricos controlados como parte del tratamiento fue reportado por 14 de los 22 centros no gubernamentales encuestados. 
Sólo dos de los centros entrevistados (el centro público y un centro no-gubernamental) cuentan dentro de su equipo con nutriólogo. En estos dos establecimientos, la valoración de las necesidades nutricionales de la persona hace parte de la valoración integral al momento del ingreso y con base en ello se diseńa una dieta, que es considerada parte del tratamiento. Aunque la mayoría de los responsables de los centros no gubernamentales entrevistados reconoce que la alimentación es una parte esencial de la recuperación, reconocen también que la falta de financiamiento incide en sus posibilidades de ofrecer una dieta adecuada.

Yo qué más quisiera que darles una buena dieta a los muchachos. Darles carne, darles proteína, pero muchas veces no alcanza sino para arroz, tortillas y frijoles. Es la realidad. Hace mucha falta el apoyo por parte del gobierno, porque nuestro trabajo beneficia a la sociedad. Nosotros aceptamos a todas las personas que solicitan el servicio, así no tengan lo del ingreso. Lo hacemos, porque sabemos que esa mamá está sufriendo, que esa familia está sufriendo y que no tienen a dónde llevar ese muchacho. Pero también es cierto que en veces nos quedamos cortos de dinero y fallamos en la alimentación (Director Centro de Tratamiento No-Gubernamental).

Todos los centros de tratamiento entrevistados, tanto público como no gubernamentales reportaron ofrecer seguimiento una vez la persona sale del internamiento, sin embargo, en las entrevistas realizadas, los consejeros y directores de los centros no gubernamentales reconocieron que son pocas las personas que regresan a las sesiones de seguimiento, en parte porque la mayoría entra a tratamiento de manera involuntaria, por lo que como lo menciona uno de los psicólogos entrevistados "cuando finalmente llegan a los tres meses, lo último que quieren es regresar al centro para hacer seguimiento".

\subsubsection{Personal y Perfiles Profesionales de Proveedores de Servicios}

El centro público no brindó información para caracterizar los perfiles profesionales de las personas que ofrecen los servicios. Sin embargo, la información pública disponible permitió identificar un equipo de 20 personas, todas profesionales con nivel mínimo de escolaridad de licenciatura y máximo de doctorado, con edades que van desde los 25 hasta los 50 ańos, organizados en las áreas de trabajo social, comunidad terapéutica, rehabilitación, nutrición, prevención, psiquiatría y laboratorio.

Por su parte, los centros no gubernamentales entrevistados reportaron funcionar con equipo conformado por nueve personas en promedio. En la mayoría de estos establecimientos a las únicas personas a quienes se les paga por su trabajo es a médicos y psicólogos, el resto (directores, subdirectores, consejeros) no son considerados "trabajadores" sino "pares". Ellos mismos representaron su trabajo en los centros como un servicio, un voluntariado que les permitía mantenerse en sobriedad y en esa medida consideraban que el servicio que prestaban hacía parte de su propio tratamiento. En otros casos eran personas que habían terminado su tratamiento pero preferían permanecer internados, por lo que ya no pagaban, pero a cambio de su 
permanencia realizaban algún servicio (cocina, aseo, seguridad). Esta situación obliga a que las personas que dirigen los centros tengan trabajos remunerados o negocios que atienden durante el día, por lo que su presencia en el centro es intermitente.

Nosotros no somos trabajadores. Somos parte de esto. Lo hacemos de muy buena voluntad para sacar adelante a las personas con drogadicción, ya que nosotros somos parte de alcohólicos anónimos y estamos para ayudar a los que lo necesitan (...) Las familias nos buscan para que les podamos dar ayuda (Director Centro de Tratamiento No-Gubernamental).

Dieciocho de los 22 centros encuestados contaban con psicólogos, 16 con médicos y tres con psiquiatra. Sin embargo, es importante aclarar que mientras los y las psicólogas reportaron trabajar un promedio de 30 horas a la semana y acudir cinco días a la semana, los médicos, reportaron trabajar en promedio nueve horas a la semana y acudir máximo tres días a la semana, siendo su principal actividad la realización de valoraciones a nuevos ingresos y responder urgencias ocasionales. Los psiquiatras sólo respondían a urgencias.

Los datos mostraron unas condiciones de trabajo bastante precarizadas en los centros de tratamiento no gubernamentales. En primer lugar, por la ausencia de remuneración para quienes prestan servicios no profesionales al centro. En segundo lugar, porque, aunque los psicólogos, médicos y psiquiatras que trabajan en los centros reciben un pago, este se realiza por consulta realizada y no cuentan con contrato. En promedio, a los psicólogos se les paga $\$ 80$ (4USD aprox) por consulta individual y $\$ 100$ (5USD aprox) por consulta grupal. A los médicos se les paga $\$ 500$ (25 USD aprox) por día de visita al centro.

Mientras las edades de los médicos oscilan entre los 40 y 50 años, las edades de los psicólogos están entre los 25 y los 35 ańos. Pareciera que los psicólogos que presentan los servicios en los centros de tratamiento no-gubernamentales son jóvenes recién egresados que están iniciando su trayectoria laboral y cuentan con poca experiencia, por lo que su trabajo en los centros representa su principal ingreso. En contraste, los médicos son personas con una trayectoria laboral ya establecida y el trabajo en el centro representa ingresos adicionales. La principal motivación de los psicólogos entrevistados para trabajar en los centros no-gubernamentales a pesar de las precarias condiciones laborales es la falta de oportunidades para trabajar en otros espacios, el deseo de especializarse en adicciones y las capacitaciones que ofrece Capa.

El análisis de los perfiles sociodemográficos de los directores de los establecimientos no-gubernamentales, muestra que la mayoría (10/22) tienen estudios de preparatoria completa o más, siete terminó la secundaria y cinco alcanzó sólo la primaria. La edad promedio de los directores son los 47 años, con un rango que va de los 29 a los 68 años. Todos reportaron tener experiencia propia en tratamiento para uso problemático de drogas, con un tiempo promedio de recuperación de 16 años, en un rango que va desde un año hasta 29. 


\subsubsection{Relaciones Interinstitucionales}

Las instituciones con quienes los centros de tratamiento no gubernamentales tienen más relaciones de referencia y contrarreferencia son el Hospital General (15/23) los centros de salud (14/23), y el Hospital de Salud Mental (11/23). Otras instituciones con las que los centros no gubernamentales establecen relación es el sistema de procuración de justicia, cuando la persona es enviada a internamiento por una orden judicial. Sin embargo, no se tiene un sistema de referencia-contrarreferencia, más allá de las anotaciones en las historias clínicas de los usuarios de los servicios utilizados.

Las entrevistas permitieron reconocer que los centros de tratamiento no gubernamentales, sólo acuden a los servicios públicos de salud en casos de gravedad que requieren un especialista. El procedimiento más común es llevar a los usuarios a una consulta médica privada y de bajo costo que se ofrece normalmente en farmacias cercanas o con un médico con quien tienen relaciones de confianza.

La Secretaría de Salud no ofrece ningún servicio a la población que se encuentra cautiva en los centros, como pruebas de detección de VIH u otras ITS, Hepatitis C, glucosa, o servicios de vacunación universal. Son las organizaciones civiles y grupos cristianos, quienes ofrecen talleres sobre género y sexualidad y estudios bíblicos una vez por semana.

En contraste, el centro de tratamiento público cuenta con buenas relaciones con diferentes dependencias de la Secretaría de Salud, lo que facilita los procesos de referencia y contrarreferencia y garantizar acceso a servicios de salud gratuitos y de calidad.

\subsubsection{Trabajo comunitario}

En general, la preeminencia de la perspectiva médica frente al tratamiento al uso problemático de drogas desde la cual se erige el trabajo del centro de tratamiento público y los no gubernamentales, no facilita que estos establecimientos piensen cómo involucrar a las comunidades a las que insertan en su intervención, más allá de las terapias familiares. Las intervenciones en la mayoría de los casos son estrictamente intramuros, de hecho, uno de los objetivos del internamiento es el aislamiento del usuario de su entorno social, al considerarlo nocivo.

Sólo dos de los 22 centros no gubernamentales entrevistados reportaron construir redes de apoyo con la comunidad, integrada por iglesias, pequeños negocios que operan en el área de influencia del centro y familiares de los usuarios de los servicios. A través de estas redes de apoyo, se intercambian servicios que favorece la inserción laboral de los usuarios. Por ejemplo, los jóvenes que reciben los servicios de tratamiento acuden a prestar servicios de pintura, jardinería, limpieza. Las iglesias donan alimentos o ropa, los negocios permiten la reinserción laboral de 
los y las usuarios de servicios. Las entrevistas evidencian que estas redes se crean por la iniciativa de los representantes de los mismos centros y que son los familiares de los y las usuarias quienes alimentan las redes a través de intercambios de servicios y apoyos. El estado no participa ni alimenta estas iniciativas.

Hay una estética que me ofreció una ayuda para capacitar a todas las chicas para que aprendan a maquillar, hacer peinados, poner uñas, pestańas y hacer cortes de pelo. Es una oportunidad que la misma comunidad le ofrece a los muchachos que están aquí, para que cuando salgan sepan hacer algo (...) También hemos conformado una red de apoyo con una iglesia evangélica, que tiene nueve iglesias en todo San Luis. El pastor promociona las cosas que los muchachos nuestros saben hacer y siempre salen trabajillos. En esta red de apoyo buscamos que los muchachos sean tomados en cuenta, que se les pague, porque siempre hay alguien que necesita un apoyo y los muchachos pueden hacerlo (Director Centro de Tratamiento No-Gubernamental).

Así mismo, los grupos ambulatorios de AA y algunos centros de tratamiento residencial que se apegan a esta filosofía, conforman una red informal de atención que facilita que las personas que requieren servicios de tratamiento residencial para el uso problemático de drogas encuentren un centro acorde a sus necesidades financieras y geográficas. La red permite además que aquellos usuarios que terminan el tratamiento puedan encontrar un grupo de apoyo a través del cual puedan permanecer en abstinencia. A su vez la red, favorece el acceso de manera informal a opciones laborales y educativas, siempre basándose en el capital social de sus miembros y sin recurrir a canales institucionales.

La desconfianza hacia el estado por parte de los centros de tratamiento no gubernamental fue un elemento reiterado en las entrevistas que no permite una interlocución más activa con el Estado, más allá de la asistencia a las capacitaciones que se ofrecen. En general, los directores de los centros sienten que el Estado no está suficientemente interesado en las personas que ellos atienden y que cualquier solicitud va a derivar en una negativa y/o en mucho trabajo burocrático. Dado que la mayoría de las personas que trabajan en los centros lo hacen a modo de voluntariado, tampoco cuentan con el tiempo y los recursos para ejercer presión ante el Estado y conseguir apoyos específicos en términos de mobiliario, acompañamiento profesional y alimentación. La concepción del usuario como enfermo o incapacitado mental, tampoco favorece que desde la sociedad civil se demande al Estado mayores y mejores servicios de tratamiento.

\section{CONSIDERACIONES FINALES}

La guerra contra las drogas en México ha tenido consecuencias fatales en términos de muertes, desapariciones forzadas y violaciones sistemáticas a los derechos humanos, sin embargo, su impacto en la criminalización y estigmatización de las personas con uso problemático de drogas no ha sido suficientemente evaluado. 
Por un lado, los discursos sobre los que se erige la guerra contra las drogas ha generado la polarización de la sociedad mexicana entre aquellos ciudadanos que merecen gozar de los derechos fundamentales y aquellos que no, por su contacto con grupos criminales. Si la ilegalización de las sustancias a principios del siglo XX convirtió en criminales a los usuarios, la guerra contra las drogas ha favorecido la normalización y legitimación de la violencia hacia estas personas sólo por su condición usuarios de sustancias ilegalizadas. El estigma construido tras 100 años de prohibición hacia las personas que usan drogas ha facilitado la invisibilización de su derecho a la salud y distraer a la opinión pública frente a la obligación del estado de garantizar este derecho fundamental.

Por otro lado, la severidad e intensidad de la violencia que ha generado la guerra contra las drogas en México, ha minado la salud mental de los y las mexicanas, especialmente de aquellos que viven condiciones de exclusión social. Numerosos estudios encuentran que vivir en condiciones de estrés se asocia a una mayor probabilidad de desarrollar dependencia a las sustancias (Kessler, 2004). En México, el aumento de la violencia ha generado una experiencia de la vida en riesgo constante, un clima emocional de miedo, incertidumbre y desesperanza. En este contexto, el uso intenso de sustancias ilegalizadas, se convierte, para ciertas poblaciones marginalizadas, en un mecanismo que facilita formas de sociabilidad, en una estrategia para hacer frente al desencanto y el aburrimiento cotidiano, y de encontrar placer. En ese sentido, el uso problemático de drogas no puede leerse por fuera de las impactantes experiencias de trauma, violencia, humillación, depredación y pobreza que viven millones de mexicanos y mexicanas.

El actual gobierno de López Obrador ha planteado la necesidad de un cambio de narrativa frente a las drogas, donde se ponga al centro el sujeto y no a la sustancia. En términos de los arreglos institucionales frente a la atención al uso problemático de drogas, ello supondría garantizar el acceso universal a tratamiento público, gratuito y de calidad. Para ello, es indispensable aumentar el presupuesto público para mejorar la oferta pública de estos servicios y supervisar la calidad de los existentes en estricto apego a los derechos humanos, con la finalidad, entre otras cosas de posicionar un enfoque de equidad e inclusión social.

Ello supone también fortalecer el trabajo colaborativo que ya existe a nivel local entre La Dirección de Salud Mental y Adicciones y los centros de tratamiento no-gubernamentales a través de programas de mejoramiento continuo de estos centros de tratamiento, proveyendo estrategias de alimentación, de adecuación del mobiliario, de acceso a profesionales de la salud mental. Desconocer el trabajo que realizan los centros de tratamiento no-gubernamentales en favor de las personas con uso problemático de drogas y sus familias y/o demonizarlos, no favorece las condiciones en las que las personas pobres acceden a tratamiento, antes bien, genera resistencias para acercarse a las instituciones públicas. 
Es necesario que el discurso médico-hegemónico dialogue con las prácticas particulares de atención que se ofrecen desde los centros de tratamiento no-gubernamental. Ofrecer apoyos gubernamentales para ayudar a los centros a mejorar la calidad de sus servicios, es una estrategia que favorecía el cumplimiento de los requisitos de la norma para el funcionamiento de estos establecimientos y fortalecería las redes de cooperación y trabajo integral entre estos centros y las distintas dependencias de salud pública.

En segundo lugar, cambiar la narrativa frente a las drogas poniendo al sujeto en el centro supondría cuestionar el modelo médico hegemónico y promover enfoques donde los usuarios tengan mayor participación en sus procesos de tratamiento. Ello pasa por generar un debate más amplio en torno a la manera como se concibe el uso de drogas y las personas usuarias, preguntándose por el papel que cumple el uso de drogas en las comunidades y plantear estrategias para erradicar el estigma y la discriminación hacia las personas que usan sustancias ilegalizadas.

En tercer lugar, cambiar la narrativa frente a las drogas supone reflexionar en torno al enfoque manicomial o institucionalizante que predomina en México como estrategia de tratamiento. Al respecto, es interesante constatar que sólo hasta 2002 se reconoce de manera oficial que los hospitales psiquiátricos son espacios donde se viola de manera sistemática los derechos humanos de la población internada y sólo hasta 2004 se plantea la necesidad de cerrar estos espacios y pensar nuevos dispositivos de atención. Trasladando la discusión al tratamiento frente al uso problemático de drogas, es necesario debatir sobre otros esquemas de intervención que han demostrado ser exitosos y que no se basan en la institucionalización y aislamiento de los usuarios (Barros et al., 2018; Fergusson y Góngora, 2012). Supone debatir públicamente sobre las implicaciones del internamiento compulsivo e invertir en modelos comunitarios de atención, donde el énfasis sea la inclusión social de las personas que usan drogas y de quienes enfrentan un uso problemático, abordar el tema del estigma y la discriminación, en lugar de promover el aislamiento de los sujetos considerados "enfermos".

Las coaliciones comunitarias promovidas por los Capa tienen el potencial de desarrollar intervenciones comunitarias frente al uso problemático de drogas desde una perspectiva menos clínica y más desde la intervención sociocultural, sin embargo, la falta de presupuesto específico para estas acciones y la falta de personal, aunado al difícil contexto de seguridad dificulta que este trabajo comunitario se fortalezca.

De este modo, aunque los Capa fueron diseñados para responder a realidades territoriales, el territorio no es un eje particular de la intervención, pues al ser fundamentalmente clínica, deja en segundo plano el tejido de relaciones sociales en las que el sujeto desarrolla su cotidianidad. La experiencia de los centros de tratamiento no-gubernamentales que realizan intervenciones comunitarias extramuros ha mostrado cómo estas ayudan a transformar el estigma y la discriminación 
persistentes en la sociedad mexicana hacia las personas que usan drogas y favorece la integración social de los usuarios de los servicios de tratamiento (Milanese, Merlo y Machín, 2000; Ti, Tzemis y Buxton, 2012).

Sin estos tres elementos el llamado a cambiar de narrativa es sólo una retórica que encubre la estigmatización y el desamparo institucional que hoy enfrentan las personas con uso problemático de drogas en México.

\section{REFERENCIAS}

ABRANTES PÊGO, R.; ALMEIDA, C. Teoría y práctica de las reformas en los sistemas de salud: los casos de Brasil y México. Cadernos de Saúde Pública, v. 18, n. 4, p. 971-989, 2002.

AA - ALCOHÓlICOS ANÓNIMOS. Los centros de ayuda mutua en México. Ciudad de México: AA, 2019. Disponible en: <http://aamexico.org.mx/ preguntasosg>.

ASTORGA, L. El siglo de las drogas: del porfiriato al nuevo milenio. Ciudad de México: Debolsillo, 2016.

BAUMAN, Z. La sociedad individualizada. Madrid: Ediciones Cátedra, 2001. BECK, A. et al. Terapia cognitiva de las drogodependencias. Ciudad de México: Paidos, 1993.

BENASSINI, Oscar La atención psiquiátrica en México. Salud Mental, v. 24, n. 6, p. 62-73, 2001.

BRANDES, S. H. Staying sober in Mexico City. Austin: University of Texas Press, 2002.

CAMPOS, Isaac (2017) A diplomatic failure: the Mexican role in the demise of the 1940 Reglamento Federal de Toxicomanías, Third World Quarterly,

CIJ - CENTROS DE INTEGRACIÓN JUVENIL. Guía de intervención clínica para terapia individual. Ciudad de México: CIJ, 2016. Disponible en: <https:// bit.ly/3bbsSla>.

Manual de organización de los Centros de Integración Juvenil. Ciudad de México: CIJ, 2019a.

. Tipos de atención. Ciudad de México: CIJ, 2019b. Disponible en: $<$ https://bit.ly/3olLdjf $>$. 
El Sistema de Atención y Cuidado al uso Problemático de Drogas en México: aislamiento, estigmatización y desamparo

CDHSLP - COMISIÓN DE DERECHOS HUMANOS DE SAN LUIS POTOSÍ. Informe Especial: sobre Centros de tratamiento de adicciones en modalidad residencial. San Luis Potosí: CDHSLP, (s/f).

CONADIC-COMISIÓN NACIONAL CONTRA LAS ADICCIONES. Manual de organización específico del Comisionado Nacional contra las Adicciones (CONADIC). Ciudad de México: Conadic, 2012. Disponible en: <https://bit. $1 \mathrm{y} / 3 \mathrm{pVhCNX}>$.

CONADIC - COMISIÓN NACIONAL CONTRA LAS ADICCIONES; SECRETARÍA DE SALUD. Modelo de atención Uneme-Capa - Centros de Atención Primaria en Adicciones "Centros Nueva Vida". Ciudad de México: Conadic; Secretaría de Salud, 2008.

Manual de procedimientos de las unidades de especialidades médicas-Centros de atención primaria en adicciones Uneme-Capa. Ciudad de México: Conadic; Secretaría de Salud, 2015.

CONADIC - COMISIÓN NACIONAL CONTRA LAS ADICCIONES et al. Diagnóstico de centros de tratamiento no gubernamentales. Ciudad de México: Conadic; Cenadic; Cicad; OEA, 2011.

CONAPO - CONSEJO NACIONAL DE POBLACIÓN. Proyecciones de la población de México y de las entidades federativas 2016-2050. Ciudad de México: Conapo, 2020. Disponible en: <https://bit.ly/3nnTJwG>. Consultado el: 10 feb. 2020.

$\mathrm{COOK}, \mathrm{C}$. The Minnesota model in the management of drug and alcohol dependency: miracle, method or myth? Part I. The Philosophy and the Programme. British Journal of Addiction, v. 83, n. 6, p. 625-634, 1988.

DEL BOSQUE, J.; MACHÍN, J. Organizaciones de la sociedad civil con programas de prevención y tratamiento de farmacodependencias para jóvenes: análisis de experiencias y modelos. Ciudad de México: Instituto Mexicano de la Juventud, 2020.

ENCISO, F. Nuestra historia narcótica. Ciudad de México: Penguin Random House Group Editorial, 2015.

ESCOHOTADO, A. Historia general de las drogas. Madrid: S.L.U. Espasa libros, 2005.

FERGUSSON, S.; GÓNGORA, A. La relación entre personas y drogas y los dispositivos de inclusión social basados en la comunidad: críticas y perspectivas desde América Latina. Bruselas: Copolad, 2012. Disponible en: <https://bit. ly/3hM9AEj>. Consultado el: 30 Mar. 2020 
GALAVIZ, G.; ODGERS ORTIZ, G. Estado laico y alternativas terapéuticas religiosas. El caso de México en el tratamiento de adicciones. Debates do NER, v. 2, n. 26, p. 253-276, 2014.

GARBI, S. L.; TOURIS, M. C.; EPELE, M. Técnicas terapéuticas y subjetivación en tratamientos con usuarios/as de drogas. Ciencia \& Saude Colectiva, v. 17, v. 7, p. 1865-1874, 2012.

GARCÍA, A.; ANDERSON, B. Violence, addiction, recovery: an anthropological study of Mexico's anexos. Transcultural Psychiatry, v. 53, n. 4, p. 445-464, 2016.

GOFFMAN, I. Ensayos sobre la situación social de los enfermos mentales. Buenos Aires: Amorrortu, 1972.

INEGI - INSTITUTO NACIONAL DE ESTADÍSTICA Y GEOGRAFÍA. Conteo nacional de población y vivienda. Ciudad de México: Inegi, 2015.

MACHÍN, J. Principales abordajes al tema de drogas. En: MACHÍN, Juan; MENDOZA, Anayeli. Meta-Modelo Eco2: apuntes sobre prevención, reducción de riesgos y dańos asociados al consumo de sustancias psicoactivas. Ciudad de México: Centro de Formación para la Atención de las Farmacodependencias y Situaciones Críticas Asociadas, 2015.

MACHÍN, J. et al. Comunidades terapéuticas: algunas experiencias y reflexiones sobre el tratamiento de las farmacodependencias. Liberadictus 741, 2002. Disponible en: <https://bit.ly/393NLfy>.

MACHÍN, J. et al. Reducción del daño: un pasaje del delirio utópico al realismo ecológico. Pp. 188-207. En: MILANESE, Efrem (Coord). Farmacodependencia y reducción de daños - Segundo Seminario de Expertos. Ciudad de México: Centro Caritas de Formación para la Atención de las Farmacodependencias y Situaciones Críticas Asociadas, 2006.

MAGIS RODRÍGUEZ C.; PARRINI ROSES, R. Nuestra epidemia, el Sida en México 1983-2002. En: MAGIS RODRÍGUEZ, C.; BARRIENTOS BÁRCENAS, H.; BERTOZZI KENEFICK, S. SIDA: aspectos de salud pública. Manual. Ciudad de México: Censida, 2006.

MARÍN-NAVARRETE, R.; MEDINA-MORA, M. E; TENA-SUCK, C. Addiction care in Mexico: A challenge for non-specialized health professionals. Salud Mental, v. 39, n. 5, p. 241-242, 2016.

MÉXICO. Secretaría de Salud. Norma Oficial Mexicana NOM-028-SSA2-2009, para la prevención, tratamiento y control de las adicciones. Ciudad de México: Secretaría de Salud, 2009. Disponible en: <https://bit.ly/3hVXKHO>. 
El Sistema de Atención y Cuidado al uso Problemático de Drogas en México: aislamiento, estigmatización y desamparo

MILANESE, E.; MERLO, R.; MACHÍN, J. Redes que previenen. Ciudad de México: Instituto Mexicano de la Juventud; Centro de Formación Farmacodependencias y Situaciones Críticas Asociadas, 2000.

OSPINA, A. Itinerarios de adversidad: biografías de uso de drogas, estilos de vida y ambientes de riesgo al VIH en varones inyectores de Tijuana, Cd. Juárez y Hermosillo, México. Tesis (Doctorado) - Centro de Estudios Demográficos, Urbanos y Ambientales, El Colegio de México, Ciudad de México, 2016.

PÉREZ-CORREA, C. (Des)proporcionalidad y delitos contra la salud en México. Ciudad de México: Centro de Investigación y Docencia Económica (CIDE), 2012.

PÉREZ-CORREA, C.; SILVA MORA, K. El estado frente al consumo y los consumidores de drogas ilícitas en México. Aguascalientes, México: Centro de Investigación y Docencia Económica (CIDE), 2014.

PÉREZ GONZÁLEZ, J. L. Toxicomanías. En: MOLINA, Andrés Ríos (Coord.). Manicomio La Castańeda y sus diagnósticos: una historia de la clínica psiquiátrica en México,1910-1968. Ciudad de México: Universidad Nacional Autónoma de México Instituto de Investigaciones Históricas; Instituto de Investigaciones Dr. José María Luis Mora, 2017.

PÉREZ MONTFORT, R. Tolerancia y prohibición: aproximaciones a la historia social y cultural de las drogas en México 1840-1940. Ciudade de México: Debate, 2016.

PARADA-TORO, I.; et al. Financiamiento de programas de farmacodependencia en la Ciudad de México: 1990-1994. Salud Pública de México, v. 42, n. 2, p. 118-125, 2000.

RAMÍREZ, T. La expansión de los tribunales de drogas en México. En: UPRIMNY, R. (Coord.). Informe técnico sobre alternativas al encarcelamiento para delitos relacionados con drogas, OEA, CICAD, 2015. Ciudad de México: ODC, 2016.

ROSOVSKY, H. Alcohólicos Anónimos en México: fragmentación y fortalezas. Revista Desacatos, v. 29, p. 13-30, 2009.

SACRISTÁN, M. C. Historiografía de la locura y de la psiquiatría en México: de la hagiografía a la historia posmoderna. Ciudad de México: Frenia, v.1., 2005.

SÁNCHEZ-MEJORADA, Fernández, J. Comunidad terapéutica para personas con consumo de sustancias psicoactivas guía para el tratamiento e integración social en materia de adicciones. Ciudad de México: Instituto para la Atención y Prevención de las Adicciones en la Ciudad de México, 2013. 
SCHNEIDER, S. Mexican community health and the politics of health reform. Albuquerque: University of New Mexico Press, 2010.

TI, L; TZEMIS, D; BUXTON, J. A. Peer engagement in the context of policy and program development: a review of the literature. Substance Abuse Treatment, Prevention, and Policy, v. 7, n. 47, 2012.

VILLATORO-VELÁZQUEZ, J. A. et al. Encuesta Nacional de Consumo de Drogas, Alcohol y Tabaco 2016-2017: reporte de drogas. Ciudad de México: Instituto Nacional de Psiquiatría Ramón de la Fuente Muñiz; Instituto Nacional de Salud Pública; Comisión Nacional Contra las Adicciones; Secretaría de Salud, 2017.

ZAMUDIO, C.; CHAVEZ, P.; ZAFRA, E. Abusos en centros de tratamiento con internamiento para usuarios de drogas en México. Ciudad de México: CUPIDH cuadernos de trabajo, 2015.

\section{BIBLIOGRAFÍA COMPLEMENTAR}

BERENZON, S.; MEDINA MORA, M. E.; LARA, M. A. Servicios de salud mental: veinticinco años de investigación. Salud Mental, v. 26, n. 5, p. 61-72, 2003. CHAPARRO, S.; PÉREZ-CORREA, C.; YOUNGERS, C. Castigos irracionales: leyes de drogas y encarcelamiento en América Latina. Ciudad de México: Colectivo de Estudios Drogas y Derecho, 2017.

CONADIC - COMISIÓN NACIONAL CONTRA LAS ADICCIONES. Directorio de establecimientos especializados en el tratamiento de las adicciones en modalidad residencial reconocidos por la comisión nacional contra las adicciones. Ciudad de México: Conadic, 2019. Disponible en: <https://bit. ly/3omxoAW>.

. Modelo de atención Uneme-Capa - Centros de Atención Primaria en Adicciones "Centros Nueva Vida”. Ciudad de México: Conadic, 2019. Disponible en: <https://bit.ly/3or5N1O>.

DE LA FUENTE, R.; CAMPILLO, C. La psiquiatría en México: una perspectiva histórica. Gaceta Médica de México, v. 111, n. 5, p. 421-436, 1976.

FRENK, J. et al. Evidence-based health policy: three generations of reform in Mexico. Lancet, v. 362, p. 1667-1671, 2003.

MADRAZO, A.; GUERRERO, A. Mas caro el caldo que las albóndigas. Nexos, 2012. Disponible en: <https://bit.ly/3baLvpn>. 
El Sistema de Atención y Cuidado al uso Problemático de Drogas en México: aislamiento, estigmatización y desamparo

MARÍN-NAVARRETE, R.; MEDINA-MORA, M. E.; TENA SUCK, A. Breve panorama del tratamiento de las adicciones en México. En: TENA SUCK, A.; MARÍN-NAVARRETE, R. (Eds.). Temas selectos en orientación psicológica VIII: orientación psicológica y adicciones. Ciudad de México: Manual Moderno, p. 1-7, 2014.

MARÍN NAVARRETE, R. et al. Estudio sobre la experiencia de hombres atendidos en centros residenciales de ayuda mutua para la atención de las adicciones. Salud Mental, v. 36, p. 393-402, p. 2013.

MEDINA MORA, M. E. et al. Del siglo XX al tercer milenio. Las adicciones y la salud pública: drogas, alcohol y sociedad. Salud Mental, v. 24, n. 4, p. 3-19, 2001.

MÉXICO. Secretaría de Salud; Subsecretaria de Prevención y Promoción de la Salud. Dirección General de Epidemiología. Sistema de Vigilancia Epidemiológica de las Adicciones (SISVEA). Informe 2016. Ciudad de México: Secretaría de Salud, 2017.

. Qué es el seguro popular. Ciudad de México: SSA, 2019. Disponible en: $<$ https://bit.ly/3njQFln>.

OPS - OPEN SOCIETY FOUNDATIONS. Informe Especial sobre Drogas y Derechos Humanos en la Ciudad de México 2012-2013 - Ni socorro, ni salud: abusos en vez de rehabilitación para usuarios de drogas en América Latina y el Caribe. Ciudad de México: OPS, 2016.

RÍOS MOLINA, Andrés. Locura y encierro psiquiátrico en México: el caso del manicomio la castañeda, 1990 Antípoda. Revista de Antropología y Arqueología, n. 6, p. 73-90, 2008.

TELLO, Angela. Proyecto Viviendo Suroccidente, elementos hacia la construcción de una propuesta de prevención regional. En: MILANESE, Efrem (Coord.). Farmacodependencia y reducción de daños. Ciudad de México: Centro Caritas de Formación para la Atención de las Farmacodependencias y Situaciones Críticas Asociadas, AC.; Caritas Alemania; Plaza y Valdés Editores, 2006.

WATT, P.; ZEPEDA, R. Drug war Mexico: politics, neoliberalism and violence in the new narcoeconomy. London, UK: Zed Books, 2012.

VILLATORO-VELÁZQUEZ, J. et al. Encuesta Nacional de Adicciones 2011 : reporte de Drogas. Ciudad de México: Instituto Nacional de Psiquiatría Ramón de la Fuente Muñiz; Instituto Nacional de Salud Pública; Secretaría de Salud, 2012. 


\section{ANEXO A}

\section{FIGURA A. 1}

Organización de la oferta de servicios ambulatorios de atención al uso problemático de sustancias en México (2019)

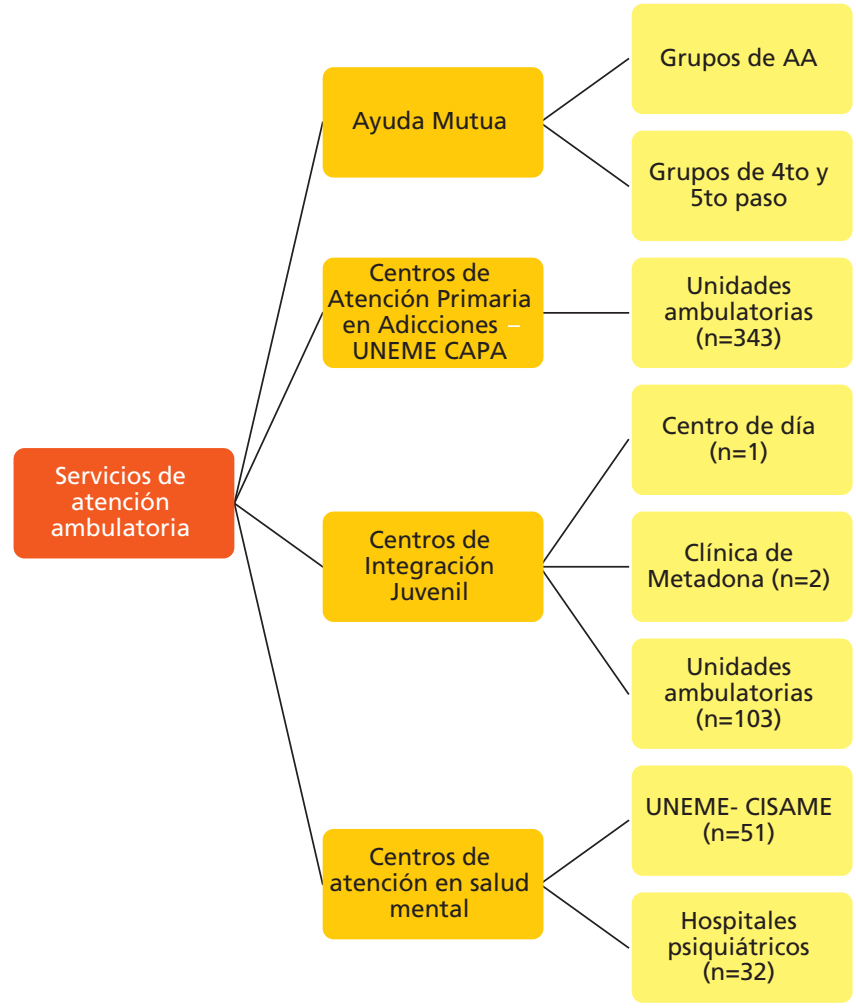

Fuentes: NOM-028 y documentos de la SSA.

Elaboración de la autora. 
El Sistema de Atención y Cuidado al uso Problemático de Drogas en México: aislamiento, estigmatización y desamparo

\section{ANEXO B}

FIGURA B. 1

Organización de la oferta de servicios residenciales de atención al uso problemático de sustancias en México (2019)

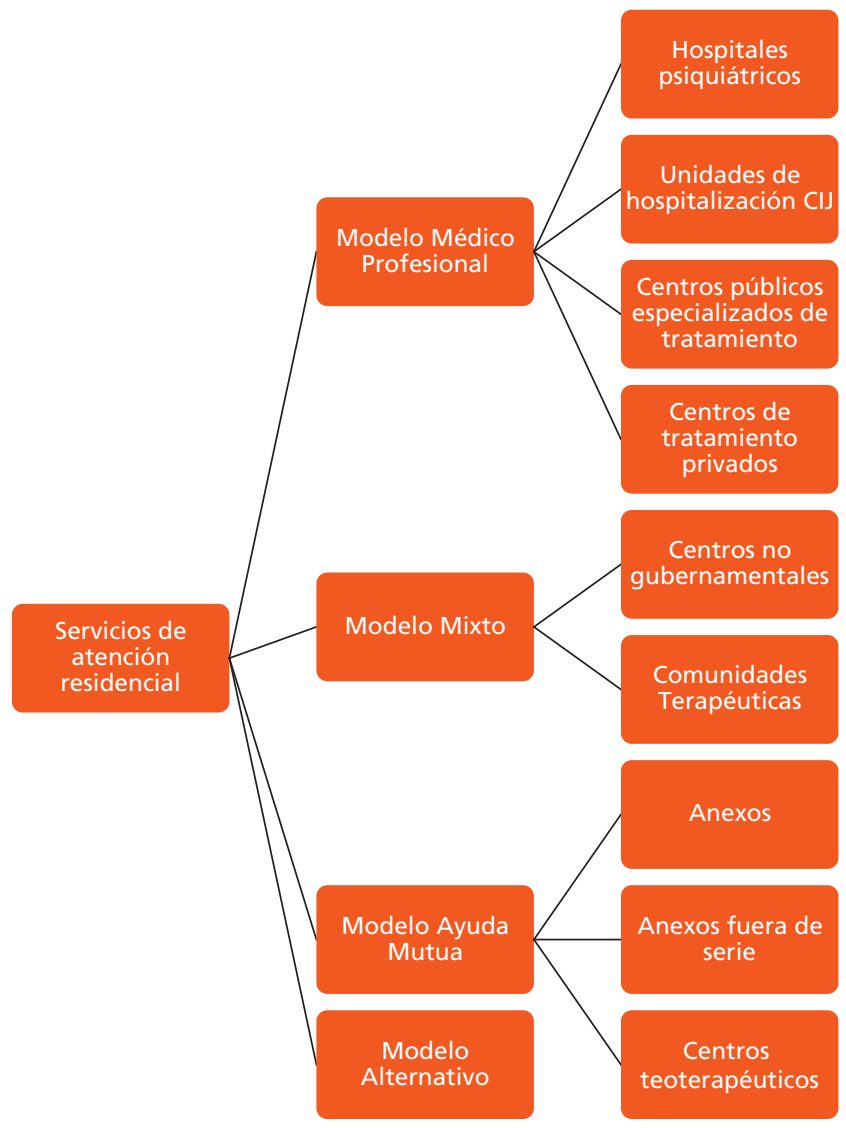

Fuentes: NOM-028 y documentos de la SSA.

Elaboración de la autora. 


\section{ANEXO C}

\section{FIGURA C. 1}

Carta de aprobación del estudio por parte del comité de ética de la Secretaría de Salud de SLP
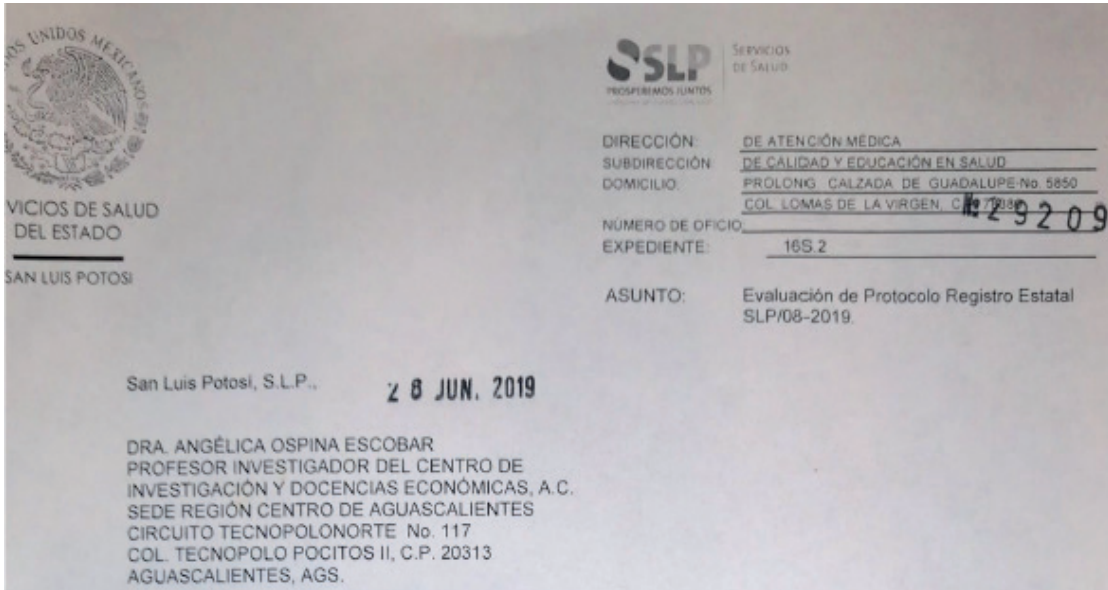

28 JUN. 2019

DRA. ANGELUCA OSPINAESCOBAR

PROFESOR INVESTIGADOR DEL CENTRO DE

NVESTIGACION Y DOCENCIAS ECONOMICAS, A.C.

CIRC REG TECNOPOLONORTE NO 117

AGUASCALIENTES, AGS.

Hago de su conocimiento que el pasado 14 de noviembre del 2019, en sesión extraordinaria del Comite Estatal de Etica en Investigación en Salud, se realizó la Evaluación del Protocolo de Investigación

\begin{tabular}{|l|}
\begin{tabular}{|l|} 
Tendencias del Uso Problemático de Drogas en San \\
Luis Potosi y Brechas de Prevención y Atención
\end{tabular} \\
\hline Centro de Investigación y Docencias Económicas, A.C. \\
\hline REGISTRO ESTATAL \\
SLPI08-2019 \\
\hline
\end{tabular}

Siendo el dictamen por consenso:

\section{OPINIÓN TÉCNICA FAVORABLE}

Lo anterior, con fundamento en el TITULO QUINTO de la Ley Estatal de Salud, que establece las bases. condiciones y normatividad en materia de Investigación para la Salud, y la NOM-012-SSA3-2012, que establece los criterios para la ejecucón de Proyectos de Investigación para la Salud en Seres Humanos

En base a la Guia Nacional para la Integración y Funcionamiento de los Comités de Ética en Investigación, el Comité tendrá la facultad de solicitar el seguimiento del estudio en cualquier fase de su desarrollo, su cumplimiento de acuerdo al Protocolo autorizado y a la guia de buena Práctica Clinica para garantizar la protección del sujeto participante al estudio y cumplir con las disposiciones que marca el Reglamento Interno del Comite Estatal de Etica en Investigación, Capitulo X. Articulo No. 45 , el Investigador Titular se obliga como parte de los compromisos adquiridos, a entregar con periodicidad semestral los avances de la Investigación al Comité Estatal de Ética en Investigación en Salud; y la Subdirecciôn de Prevención y Promoción para la Salud de estos Servicios de Salud, dará seguimiento, para colaborar con la información que requiere el investigador, $\infty$ n la finalidad de continuar con el desarrollo de los resultados obtenidos.

Reciba un cordial saludo.
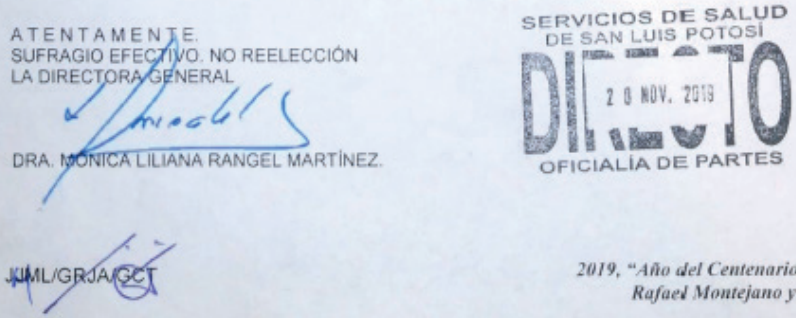

2019, "Año del Centenario del Natalicio de Rafaed Montejano y Aguiñaga"

Elaboración de la autora. 
El Sistema de Atención y Cuidado al uso Problemático de Drogas en México: aislamiento, estigmatización y desamparo

\section{ANEXO D}

FIGURA D. 1

Ubicación del estado de San Luis Potosí en el territorio mexicano

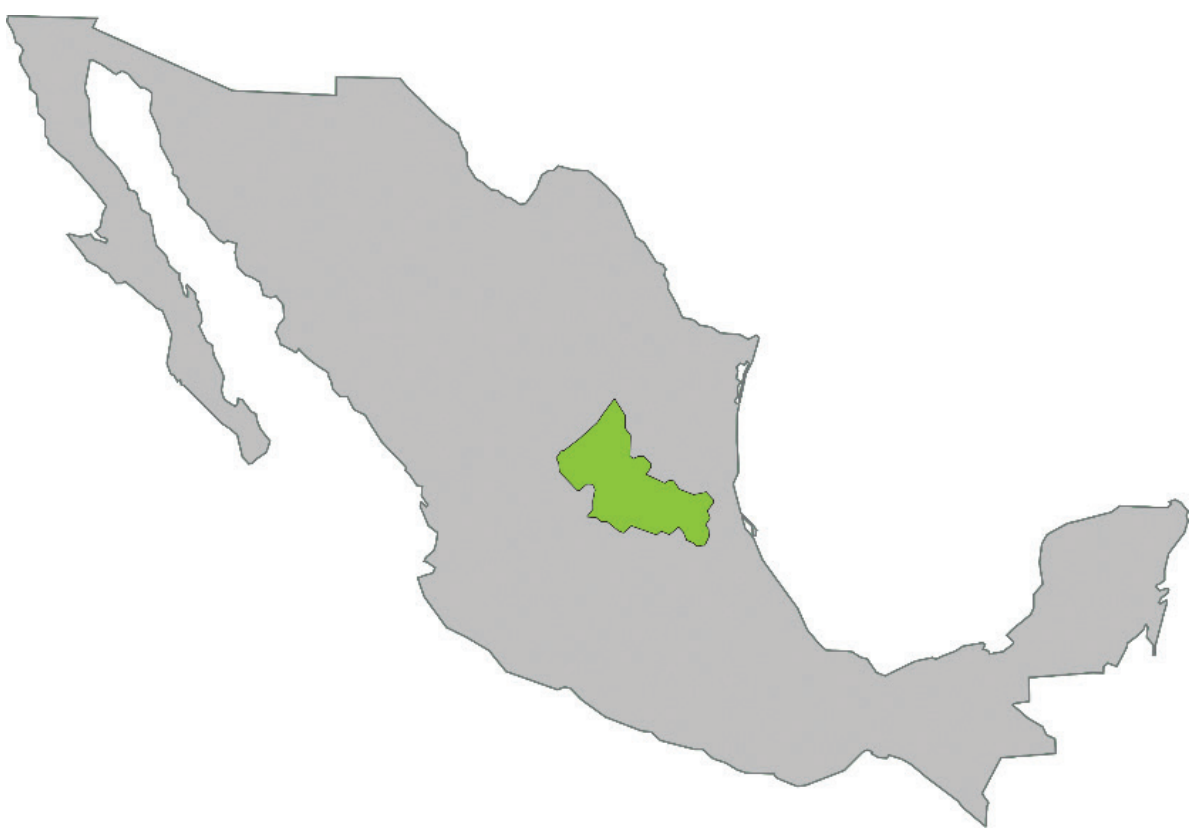

Fuente: Disponible en: <https://bit.ly/2Xiklos>. 


\section{ANEXO E}

\section{FIGURA E. 1}

Organización de los servicios de tratamiento para uso problemático de drogas en San Luis Potosí (2019)

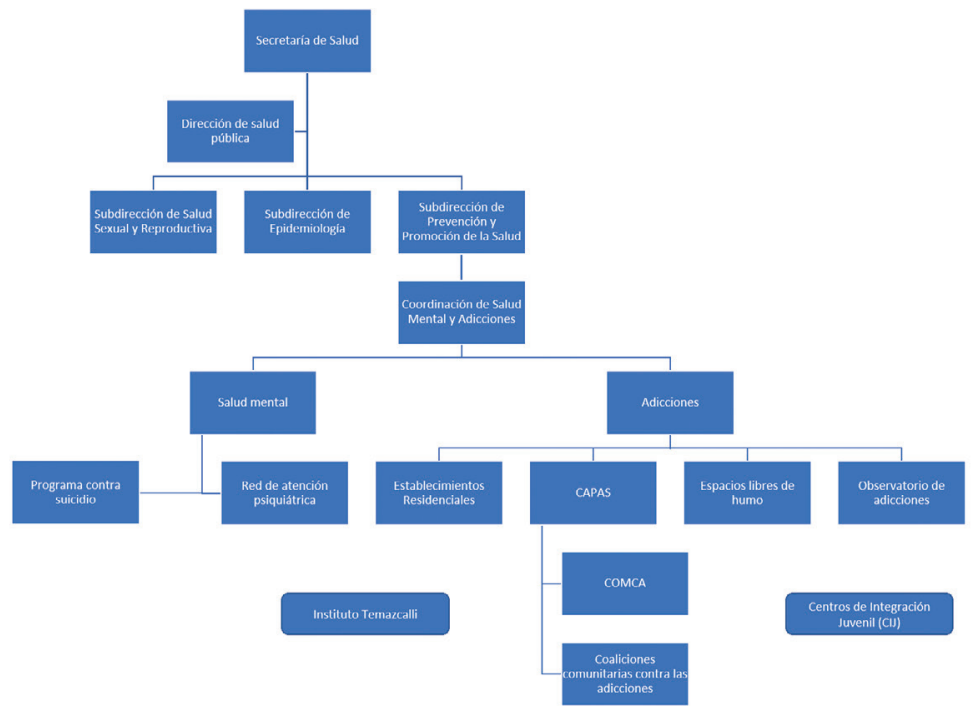

Elaboración de la autora.

Obs.: Ilustración cuyos diseños y textos no pudieran ser estandarizados y revisados en virtud de las condiciones técnicas de los archivos originales (nota del Editorial). 
El Sistema de Atención y Cuidado al uso Problemático de Drogas en México: aislamiento, estigmatización y desamparo

\section{ANEXO F}

\section{MAPA F.1}

Distribución de los Capa en el estado de San Luis Potosí

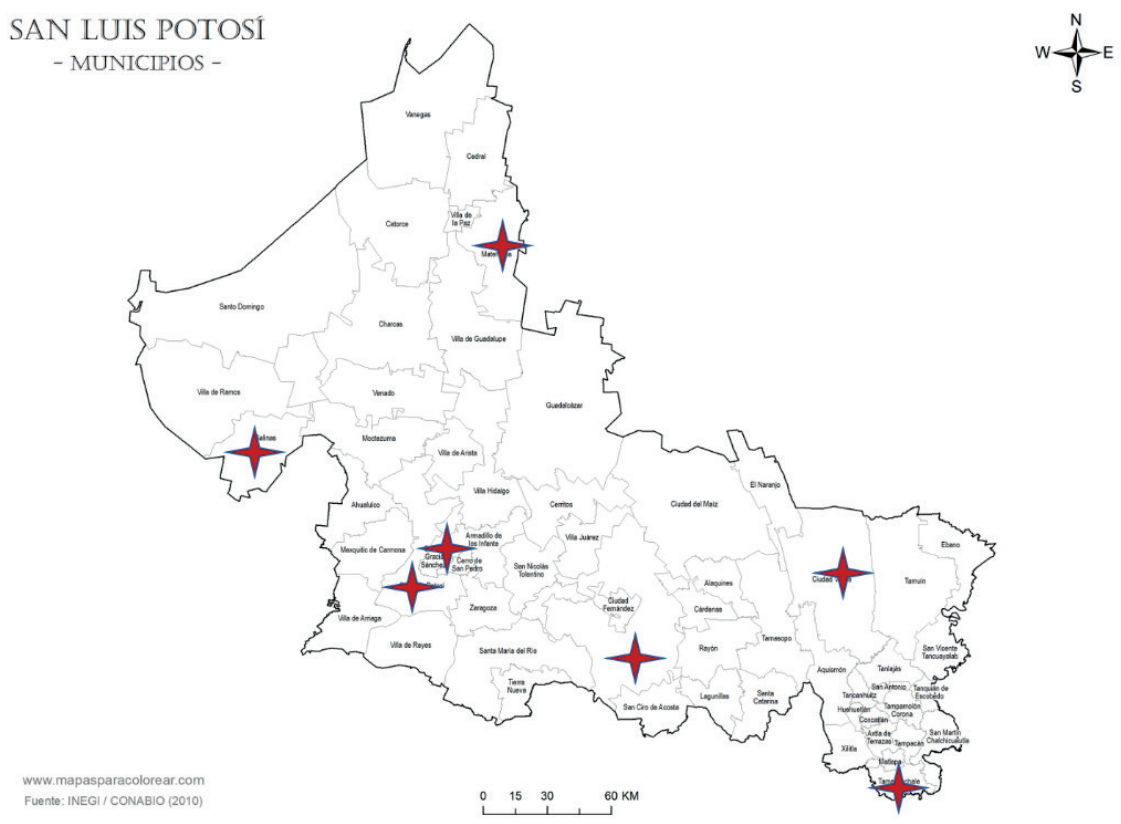

Fuente: Conabio (2010).

Elaboración de la autora. 



\section{POLÍTICAS DE ATENCIÓN A USUARIOS PROBLEMÁTICOS DE SUSTANCIAS PSICOACTIVAS: EL CASO URUGUAYO}

Clara Musto ${ }^{1}$

\section{INTRODUCCIÓN}

Comparado a otros países latinoamericanos, Uruguay suele ser caracterizado como un caso atípico en el control del uso de drogas. Esta excepcionalidad se inspira en el hecho de que el consumo de sustancias psicoactivas nunca estuvo penado en el país, así como a la importancia del estado en la regulación de estos mercados, con el tabaco y el cannabis como ejemplos paradigmáticos.

Otra característica distintiva del caso uruguayo en el continente latinoamericano es la coexistencia, o correlación, entre sus altos índices de desarrollo humano y de consumo de drogas legales e ilegales de su población. Seguido por el resto de los países del Cono Sur - Chile y Argentina - desde que existen registros Uruguay tiene altas cifras de uso de alcohol, psicofármacos, tabaco, cocaína y cannabis. La mayor expansión de los mercados ilegales de drogas, al igual que en el resto del continente se dio en la década de los dos mil, y entre ellos el de mayor desarrollo fue el de cannabis. En 2001 solo un 1,4\% de los uruguayos admitía haberla consumido en los últimos 12 meses, pasando a 9,3\% en 2014 y a 14,6\% en 2019. En Chile los registros muestran que en 1994 un 4\% la había consumido en el último año, en 2010 un 4,6\%, pero para el 2016 la cifra había saltado a 14,5\%. En Argentina alcanzaba a un 3,7\% en 2008, 9 años después se duplicó llegando a un 7,8\%. La evolución del registro oficial de consumo de cocaína muestra tendencias desiguales entre estos países, pero al 2019 los tres tienen las tasas de prevalencias más altas del continente suramericano; en Uruguay y Argentina 1,6\% de la población admite haberla consumido en el último año y en Chile 1,1\%. Otros dos fenómenos destacables de esta década fueron la aparición de un mercado de pasta base de cocaína entre las clases bajas, y más recientemente el empuje del mercado de éxtasis entre las clases medias y altas del Cono Sur (OEA, 2019). Chile, Argentina y Uruguay son, además, los únicos tres países de América Latina considerados como de desarrollo humano muy alto por el Programa de las Naciones Unidas para el Desarrollo (PNUD, 2019).

1. Docente e investigadora del Núcleo de Análisis de la Criminalidad y la Violencia (NACVI) en la Facultad de Ciencias Sociales de la Universidad de la República del Uruguay (UdelaR); y consultora bajo el Programa de Cooperación de la Comisión Económica para América Latina y el Caribe (CEPAL) y del Ipea. 
Esta significativa expansión y segmentación de los mercados de sustancias ilegales reconfiguró el vínculo entre droga, delito y corrupción, llevando a la seguridad ciudadana a ocupar uno de los principales temas de preocupación para la ciudadanía y para la competencia electoral (Lagos y Dammert, 2012). ¿Cuál ha sido la correspondiente evolución de la oferta de tratamientos para usuarios problemáticos de drogas en Uruguay? Para responder esta pregunta, en este capítulo se presentará el desarrollo reciente de las alternativas de tratamiento, diferenciando dos generaciones o "empujes" según la importancia de la sociedad civil y el estado en la construcción de propuestas. Esto permitirá discutir algunos problemas de gobernanza en el arreglo institucional actual sobre drogas. A continuación, se analizara el caso del Achique de Casavalle. Con ello se buscara identificar fortalezas y debilidades de la política pública de drogas en contextos de alta violencia. El artículo concluye argumentando que no es esperable una significativa disminución de la violencia asociada a los mercados de sustancias psicoactivas en la medida en que no se reduzca la brecha entre la demanda potencial y la real de tratamiento y el acceso a ellos. Para ello, se recomienda como herramienta a ser expandida y fortalecida las opciones descentralizadas de tratamiento ambulatorio.

\section{TRAYECTORIA Y ARREGLO INSTITUCIONAL DE LAS POLÍTICAS DE ATENCIÓN A USUARIOS DE DROGAS}

Los orígenes de la institucionalidad actual sobre drogas se remontan a inicios de la década de 1970, cuando el continente suramericano era conocido como "el patio trasero" de Estados Unidos por su alta influencia en las políticas domésticas de las dictaduras cívico militares de entonces (Weintraub, 1992; Marchesi y Yaffé, 2010; Yaffé, 2010). Las políticas de drogas son un ejemplo paradigmático de la transferencia norte sur de políticas públicas que se impulsó en ese contexto (Durán-Martínez, 2015). Así, por ejemplo, en 1973 se firma el Acuerdo Sudamericano de Estupefacientes y Psicotrópicos, auspiciado por la diplomacia del vecino del norte, con el objetivo de establecer la hoja de ruta para la armonización de las legislaciones regionales en base a los acuerdos internacionales de las Naciones Unidas sobre control de drogas de 1961 y 1971 (Garat, 2012). En los hechos, significo la formalización de la Guerra contra las Drogas en el Cono Sur, para lo que Chile actualiza su ley de drogas en 1973 (Ley no 17934) y Argentina y Uruguay en 1974 (Ley no 20.771 y Decreto Ley no 14297 respectivamente): estrictas penas de entre tres y quince años de prisión se hicieron obligatorias para los delitos de drogas, asimilándolos a delitos violentos contra las personas. A diferencia de los vecinos del Cono Sur, la nueva ley de drogas uruguaya de 1974 mantuvo la excepcional descriminalización del uso de estas sustancias (Reta, 1973). La salida de compromiso se basó en el "principio de indeterminación", según el cual quedaba en manos de la "convicción moral" del juez actuante en cada caso establecer si la 
cantidad y circunstancias debían considerarse para consumo o no (Ley no 14294 , art. 31, de 1974). La internación compulsiva a usuarios de drogas estaba, por su parte, prevista en la ley del psicópata de 1936 (art. 15).

En la década de 1980 se instala la piedra angular de la institucionalidad contemporánea sobre drogas con la creación de "Juntas" "Comisiones" o "Secretarias" Nacionales de Drogas - según adopta cada país -, pero en general directamente dependientes de presidencia, presidida por el Prosecretario de la Presidencia de la República e integradas por varios ministerios. En Uruguay, se le dio a la Junta Nacional de Drogas (JND) el "objetivo de encarar eficientemente la lucha contra el abuso de drogas y su tráfico” (Ley no 17.016/98, Decreto no 364/999). Se conforma con nueve subsecretarios ministeriales ${ }^{2}$ y un Secretario General. Posteriormente se agregaría el Secretario Nacional para la Lucha Contra el Lavado de Activos y el Financiamiento del Terrorismo (Senaclaft) en 2015. La JND establece las directivas relacionadas con la orientación de las políticas de drogas en las distintas áreas, como también su supervisión y evaluación.

Esta configuración institucional marcó desafíos importantes para la gobernanza de las políticas de drogas, ya que la JND y su Secretaria es quien teóricamente marca los lineamientos generales, pero son los ministerios, especialmente los del Interior y de Salud quienes implementan y gestionan los recursos. Como se analiza en este capítulo, bajo este esquema institucional el desarrollo de las políticas de drogas en Uruguay ha sido contradictorio y volátil; imponiendo importantes desigualdades al interior de la red pública de atención y un fuerte énfasis en la represión de la oferta por sobre la accesibilidad de las opciones de tratamiento, que al día de hoy continúan siendo escasas y altamente concentradas en el territorio.

\subsection{Primera generación: el empuje desde abajo (1990-2005)}

Al observar la evolución de las opciones de tratamientos para usuarios problemáticos pueden distinguirse dos generaciones de políticas de drogas, que caracterizaré como empujes "desde abajo" y "desde arriba". La diferencia fundamental entre ambos es el protagonismo que sociedad civil y estado tuvieron en estos periodos. Ambos movimientos son importantes para comprender la configuración actual de los tratamientos, y los desafíos que se presentan en Uruguay para la profesionalización de estas políticas.

El primero de estos empujes se observa entre 1990 y el 2005, periodo en el cual el fenómeno de las drogas se reconfigura en nuestro país. Los mercados de sustancias psicoactivas inician su paulatina expansión junto a la apertura democrática. Además del alcohol, la mayoría de los usos problemáticos registrados en esta época se vinculaban fundamentalmente a la cocaína y en menor medida al

2. Participan de la JND los ministerios de Relaciones Exteriores, Trabajo y Seguridad Social, Salud Publica, Defensa Nacional, Interior, Economía y Finanzas, Educación y Cultura, Turismo y Desarrollo Social. 
uso de inhalantes que podían conseguirse en el mercado legal. La participación pública en los tratamientos para usuarios problemáticos era prácticamente nula. Las pocas opciones disponibles se reducían a un centro hospitalario de toxicología "Maciel”, y a un hospital psiquiátrico "Viardebó", de internación compulsiva, ambos radicados en Montevideo. Las posibilidades de tratamiento público especializado en el interior eran aún más escasas. A nivel privado la oferta de servicios era muy limitada (OUD, 2019).

Frente a esta gran ausencia de políticas de estado en torno a las drogas, el rol de la sociedad civil se hizo eminente en los noventa. Así comienzan a establecerse en el país un conjunto de instituciones especializadas en el uso y tratamiento, con débiles vínculos con la esfera estatal, dependientes del financiamiento internacional y la militancia personal. Tres tipos de modelo de abordaje pueden diferenciarse en este "primer empuje": los abstencionistas de base profesional, los abstencionistas de base religiosa y la reducción de riesgos y daños.

La mayoría de los grupos adoptó un modelo abstencionista de trabajo; en 1990 "Narcóticos Anónimos" abre su primera casa, en 1993 se instala la Fundación Internacional Dianova, abriendo un centro ambulatorio y un residencial. En 1995 abre también una sede en Uruguay la Fundación Manantiales, ONG con inserciones en España, Brasil, Estados Unidos y Argentina, constituyendo la primera Comunidad Terapéutica de Internación registrada como tal funcionando en el país. Para 1996 se instala la Comunidad Terapéutica Centro Izcali. Al día de hoy, estas instituciones continúan siendo las principales referencias en tratamientos a nivel privado.

También durante la década del 90, se instalan dos instituciones vinculadas al modelo de reducción de riesgos y daños. En 1991 abre la ONG Delta con su programa de tratamiento "Grupo de Cavia". En 1995 la ONG el Abrojo abre un programa específico sobre drogas. Ambos grupos fueron claves en la importación y transferencia de herramientas vinculadas a la reducción de riesgos y daños que entraba en ese momento en auge en América Latina y Europa.

Finalmente, también comienzan a funcionar en Uruguay dos grupos de corte abstencionista y base religiosa, que al día de hoy captan una parte importante de usuarios que buscan ayuda; Remar, en 1993, y Beraca en 2002. Beraca es una institución vinculada a la iglesia evangelista Misión Vida y al Partido Nacional en Uruguay, con representación parlamentaria directa y que también recibe internaciones compulsivas derivadas desde el sistema judicial uruguayo (Pereira, 2019).

Este primer ciclo de consolidación de las alternativas de tratamiento impulsada "desde abajo" (1990-2005), encuentra un punto de inflexión durante el gobierno de Jorge Batlle, político perteneciente a la facción liberal del Partido Colorado. Dicho gobierno estuvo fuertemente signado por una doble crisis; la económica, 
del 2001 - una de las mayores en la historia del país - y la posterior irrupción del problema de la pasta base de cocaína (PBC). Si bien existen antecedentes de consumo de esta sustancia en países como Perú o Chile desde la década de 1960, en Uruguay no se había registrado su uso hasta entonces.

$\mathrm{La} \mathrm{PBC}$ es el producto del primer procesamiento de las hojas de coca, con concentraciones de cocaína como su principal alcaloide en proporciones altamente variables - de $18 \%$ a $80 \%$ - y de cafeína como el principal adulterante, en proporciones de $1 \%$ a $15 \%$ en el total de las sustancias estudiadas en Uruguay. Al ser calentada en recipientes o "pipas" de metal o plástico para su inhalación, el producto resultante es más barato, más fuerte y más toxico que el de otras sustancias derivadas de la hoja de coca (Pascale, Negrín y Laborde, 2010; Moraes, 2014).

La reseña de los indicadores sociales asociados al consumo problemático de PBC en el país muestran que esta es una población altamente vulnerable desde el punto de vista socio económico: adulta, predominantemente masculina, con bajos logros educativos formales, alta precariedad laboral y residencial (Prieto y Scorza, 2010; Rossal, 2013; OEA, 2014). Un estudio RDS (Respondent Driven Sample) para captar poblaciones de difícil acceso realizado en el 2012, concluyó que en Montevideo y su área Metropolitana había entre 6.500 y 14.500 usuarios problemáticos de PBC, lo que representaba el $0,2 \%$ de la población uruguaya. El mismo estudio replicado en 2018 estimó que se mantenía entre 7.500 y 9.900 la población de usuarios problemáticos de pasta base en Montevideo y el área metropolitana. La mitad de estos usuarios, personas en situación de calle (Suarez y Ramirez, 2014; OUD, 2019).

TABLA 1

Uso de PBC en Uruguay

(En \%)

\begin{tabular}{lccc}
\hline Sexo y edad & Distribución población general según Censo 2011 & Estudio RDS 2012 & Estudio RDS 2018 \\
\hline Varón & 47,4 & 89,3 & 86,3 \\
Mujer & 52,6 & 10,7 & 13,7 \\
Total & 100,0 & 100,0 & $\mathbf{1 0 0 , 0}$ \\
\hline 18 a 25 años & 20,9 & 41,5 & 23,3 \\
26 a 35 años & 24,3 & 37,8 & 38,2 \\
36 a 45 años & 20,4 & 17,1 & 28,1 \\
46 a 64 años & 34,4 & 3,6 & 10,5 \\
Total & 100,0 & 100,0 & 100,0 \\
\hline
\end{tabular}

Fuente: (OUD, 2019, p. 40).

Un estudio sobre la cobertura mediática de las sustancias psicoactivas en Uruguay encontró un cambio significativo en el perfil de noticias asociadas a infracciones a la ley de drogas difundidas entre 2002 y 2009. Para el final del periodo 
la $\mathrm{PBC}$ se convierte en la sustancia con mayor peso relativo entre este tipo de noticias, mientras que, en 2002, 7 de cada 10 notas periodísticas remitían al cannabis. La referencia a medidas vinculadas a la atención y tratamiento de personas con uso problemático de $\mathrm{PBC}$ y, en particular, a propuestas de internación compulsiva de sus usuarios se hicieron mayoritarias dentro del conjunto de noticias difundidas desde los medios, vinculando drogas y tratamientos (OUD, 2019).

La irrupción de la PBC generó una alarma social no solo en los medios de comunicación sino también a nivel del sistema político, habilitando un nuevo empuje de las opciones de tratamiento "desde arriba". El "problema de las drogas" se volvió objeto de legislación. En el 2010, por ejemplo, una comisión parlamentaria sobre las "Adicciones y su impacto en la sociedad uruguaya" fue convocada para trabajar sobre el tema. Tal como lo describían los representantes de los mayores partidos políticos de este país:

No ha habido en los últimos 50 años ningún otro fenómeno que se asemeje a este en cuanto a sus efectos en la convivencia social. Es un tema que al parecer nos desborda por su complejidad y por la falta de información de cómo enfrentar el fenómeno. (...) Esa madre seguramente llora frente a los vecinos, recurre a un profesional, plantea su situación en los servicios de salud, acude a la policía, implora en la baranda de un juzgado; y en ninguno de esos lugares se le brindan respuestas precisas. El gran problema de esa madre es cada vez más común en nuestra sociedad (Cámara de Representantes, Sesión de Presentación de la Comision de Adicciones, 7 abr. 2010).

Esta declaración política ilustra de qué manera la alarma social encendida por la PBC vino a exponer la debilidad de la red de instituciones existentes - "profesionales, servicios de salud, policía, juzgados que no dan respuesta" -, permitiendo al tema crecer en la agenda de la política pública. Así, tres años después de estallada la crisis del 2001, las victorias electorales del Frente Amplio en 2004, 2009 y 2014 abren un nuevo ciclo en las políticas de drogas del Uruguay. Este periodo está caracterizado por un fuerte desarrollo de la red de atención impulsada "desde arriba".

\subsection{Segunda generación: el empuje desde arriba (2005-2020)}

A partir del 2005 la red de atención en drogas se expande significativamente en Uruguay, sin embargo, este nuevo ciclo de desarrollo de política pública continúa siendo determinado por el problema de gobernanza planteado en la configuración institucional de la "guerra contra las drogas". Específicamente, en este segundo periodo, la Secretaria Nacional de Drogas (SND), órgano encargado de generar lineamientos estratégicos crece en importancia y visibilidad publica (Aguiar, Coitiño y Lemos, 2019), pero la mayor parte de la implementación de políticas se define a nivel de los ministerios, que responden a sus propias agendas, muchas veces descoordinadas y hasta contradictorias de los principios defendidos por la 
SND. A nivel de los tratamientos concretamente, la dependencia financiera es fundamentalmente con el Ministerio de Salud Pública y el de Desarrollo Social. Como el análisis del caso presentado en este informe ilustra, estos ministerios han demostrado muy poco interés en incluir este tema de forma específica y sistemática dentro de los servicios de salud y sociales del estado.

En Uruguay existe desde el 2007 un Sistema Nacional Integrado de Salud donde se fijan las prestaciones obligatorias para las Instituciones de salud públicas y privadas. Las mutualistas privadas tienen obligación de prestar servicio ambulatorio de tratamiento, pero su precio y el modo de funcionamiento especifico no está regulado por el gobierno, por lo que es altamente heterogéneo. En general, el costo es alto, y la práctica es la derivación a las instituciones privadas, descriptas en la sección sobre "el empuje desde abajo". Los servicios privados de salud tienen, a su vez, la posibilidad de pedir una subvención estatal para este tipo de servicios, siempre y cuando la sustancia involucrada sea tabaco, cocaína o pasta base de cocaína. No hay posibilidades de subvención para las sustancias que, junto al tabaco, son las más consumidas por la población como el alcohol y el cannabis. El procedimiento para acceder a la subvención es, además, altamente engorroso; la persona interesada en recibir el tratamiento tiene que plantear una petición a un comité que habilite la subvención de la terapia.

Sobre las prestaciones mínimas obligatorias impuestas en el Sistema Nacional Integrado de Salud, con el liderazgo de la SND, se estableció una Red Nacional de Atención en Drogas (Renadro). Para ello, a fines del 2013 la Junta Nacional de drogas, el Ministerio de Salud Pública, el Instituto del Niño y del Adolescente del Uruguay, la Administración de Salud del Estado y la Corporación Nacional para el Desarrollo, celebran un contrato de fideicomiso ${ }^{3}$ para el financiamiento de la Red. A continuación, se presentan las principales instituciones de derivación y tratamiento, y el incipiente desarrollo de programas de cercanías de bajo umbral de exigencia que componen esta red.

\subsubsection{Centros de derivación y de internación}

El primer centro público residencial especializado en usos problemáticos de drogas, "Portal Amarillo", se crea en el 2006 en Montevideo. El Portal Amarillo ofrece tres tipos de servicios: de internación, contando con 20 plazas mixtas para adultos y 15 plazas mixtas para adolescentes. También funciona un centro ambulatorio diurno, donde puede realizarse terapia de grupo, medicación, terapia familiar y un conjunto de actividades diversas como meditación, consejería,

3. Para la toma de decisiones, se constituye un Comité Técnico, integrado por 5 miembros designados por los representantes de los fideicomitentes. Su cometido es elaborar y aprobar los pliegos generales y particulares, y evaluar las diferentes ofertas que se presenten en los procedimientos competitivos que efectúe la Fiduciaria, exclusivamente por instrucciones de la JND. 
gimnasia y talleres. Además del centro residencial y el diurno, existe una serie de grupos terapéuticos dirigidos particularmente a personas que están iniciado el proceso de tratamiento.

La pasta base de cocaína es la principal sustancia referida en un 71,6\% de los tratamientos que allí se desarrollan, seguido por la cocaína (15,7\%), y la marihuana $(6,70 \%)$. Existe una alta coexistencia de morbilidad psiquiátrica en las personas que reciben esta atención, el 52,7\% de quienes estaban en tratamiento en 2012 decía haber sido diagnosticado con ansiedad alguna vez en su vida; el $38 \%$ con depresión; $2 \%$ esquizofrenia; $6 \%$ trastorno bipolar y un 7,33\% otros problemas de salud mental. La mayoría de estas personas había llegado al Portal Amarillo por iniciativa propia $(38,1 \%)$, o a través de sus amigos $(33,9 \%)$. Las referencias desde otras instituciones de salud, educativas, policiales o judiciales, y de unidades o programas específicos dedicados al abordaje de drogas, es prácticamente nula (Domenech et al., 2012).

En los años siguientes se suman dos dispositivos residenciales de características similares a la Renadro en los departamentos de Artigas ("CasAbierta”) y de Maldonado ("Jagüel”) con el objetivo de extender la cobertura de tratamiento en el norte y este del país. Complementariamente, se abre el dispositivo "Chanaes", en el departamento de San José, especializado en tratamientos con usuarios problemáticos de drogas con patología dual. Se trata de un centro residencial de mediana y larga estadía de hasta nueve meses de internación, referente a nivel nacional, que tiene capacidad para atender en forma simultánea a un máximo de 18 varones de entre 16 a 27 años. Funciona como una comunidad terapéutica y es gestionada por la Organización Internacional Dianova.

Por último, también conforma la Renadro la Comunidad Terapéutica Izcalí, de capitales privados pero que ofrece cupos residenciales a la Administración de Servicios de Salud del Estado (ASSE) a través de un convenio de partida fija.

Complementariamente a los centros residenciales, a partir del 2013 se instalan 26 centros públicos gratuitos de derivación, "dispositivos Ciudadela", en todo el territorio. Esas instituciones funcionan como centros de información, asesoramiento, diagnóstico y derivación a los centros de tratamiento residenciales. Respecto a las características y volumen de la población atendida, información facilitada específicamente para esta investigación por la Secretaria Nacional de Drogas indica que entre abril 2018 y julio 2019 de las 3543 personas ingresadas un $21 \%$ eran mujeres, el $79 \%$ varones y un $1 \%$ personas trans. El 26\% de este total habían sido derivados desde el sistema judicial (JND, 2019). 
Por último, se integran a la Renadro siete grupos terapéuticos, "grupos T", en barrios periféricos de la ciudad de Montevideo que funcionan como instancias de intervención puntual para la atención a usuarios problemáticos de drogas de poblaciones vulnerables.

\subsubsection{Programas de proximidad}

En los últimos años el estado uruguayo ha buscado dar algún paso en la apuesta por opciones de tratamiento de bajo umbral, con el objetivo de mejorar la accesibilidad al sistema de tratamiento. A nivel estatal, en el 2012 se crea la Unidad de Asistencia Móvil (UMA). La UMA fue el primer modelo publico extramuros de atención a usurarios problemáticos de drogas. Su creación sigue el modelo de los Consultorios $\mathrm{Na}$ Rua, desarrollados en Brasil, ${ }^{4}$ para la cual fueron fundamentales las actividades de intercambio organizadas por la SND con el especialista Antonio Nery durante ese año. La UMA ofrece oportunidades de intervención puntual allí donde el usuario lo requiera, pero no ofrece la posibilidad de un tratamiento ambulatorio.

En una línea similar, también en el 2012 se da inicio al programa Aleros, en el marco de un convenio entre la Intendencia de Montevideo y la JND. Los Aleros fueron diseñados como dispositivos con anclaje territorial que desarrollan sus intervenciones desde una perspectiva comunitaria. Se componen de equipos móviles de atención a usuarios de drogas, conformados por dos técnicos que recorren a pie determinadas zonas dentro de los municipios A, D, E, F y G de Montevideo. Lo más novedoso de los Aleros tiene que ver con el perfil de las personas que logran captar; usuarios problemáticos de alcohol y pasta base en situación de calle. El programa tiene como propósito general la prevención del consumo problemático, captación, diagnóstico, contención y derivación de los casos de adicciones, y el fortalecimiento de las articulaciones territoriales de servicios para la atención y su accesibilidad. Al igual que la UMA, los Aleros no ofrecen la posibilidad de un tratamiento ambulatorio.

Entre abril 2018 y julio 2019 los dispositivos de base comunitaria registraron 109 personas ingresadas de las cuales $16 \%$ eran mujeres, $83 \%$ hombres y $1 \%$ trans. El $43 \%$ son personas en situación de calle, un $27 \%$ tiene antecedentes de privación de libertad y un 5\% estaba cumpliendo medidas alternativas a la privación de libertad (SND, 2019).

4. Antonio Nery es fundador y coordinador del Centro de Estudos e Terapia do Abuso de Drogas (CETAD) de la facultad de Medicina de la Universidad Federal de Bahía. Nery es fundador del programa Consultório de Rua, creado en 1999 en el marco del CETAD, con el objetivo de ofrecer tratamiento al uso problemático de drogas en población de calle. 


\section{CUADRO 1}

\section{Dispositivos que integran la Renadro}

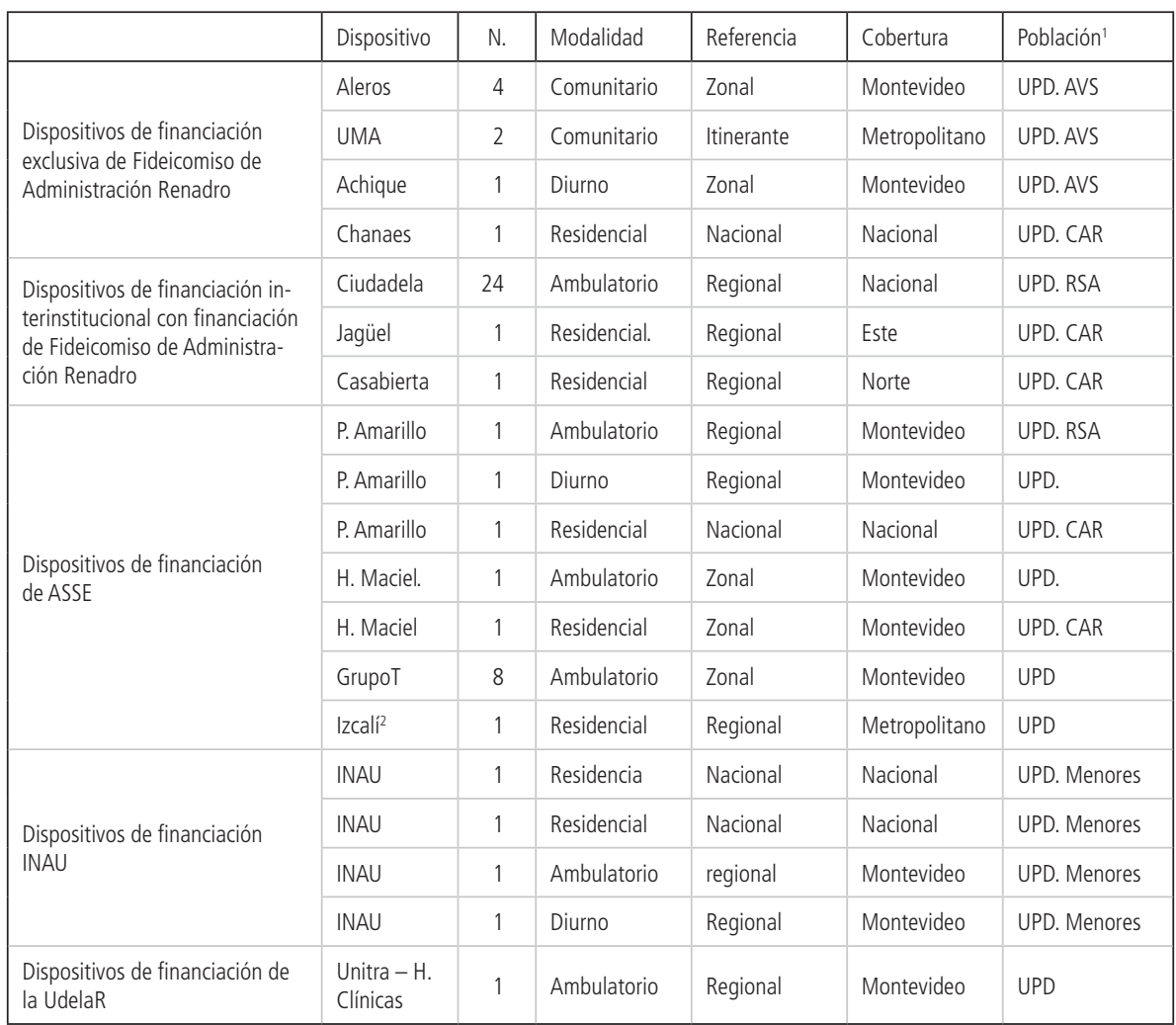

Fuente: SND (2019).

Notas: ${ }^{1}$ UPD - toda persona que presente demanda de tratamiento por uso problemático de drogas; RSA - referente socioafectivo de UPD; UPD. AVS - usuario problemático de drogas que presenta alta vulnerabilidad social añadida; UPD. CAR - usuario problemático de drogas que presenta conductas de alto riesgo asociadas al uso de SPA.

${ }^{2}$ Izcall es un emprendimiento de capitales privados que ofrece cupos residenciales a ASSE a través de un convenio de partida fija.

En resumen, la Renadro viene a funcionar como una red paralela dentro de los ASSE, pretendiendo aglutinar a las instituciones públicas y privadas que prestan tratamientos especializados en drogas. Los programas de proximidad, anteriormente reseñados, dependen en su totalidad del financiamiento exclusivo del fideicomiso de bienes decomisados por delitos de drogas. La participación de los ASSE es mayor cuando se trata de las instituciones de residenciales de internación para mayores de edad. Por último, en el 2013 se incorpora una Unidad de Trastornos Relacionados al Alcohol (Unitra) al interior del Hospital de Clínicas y que depende de la clínica psiquiátrica de la Facultad de Medicina de la UdelaR. 


\subsection{Brecha entre la oferta y la demanda}

El contraste entre el perfil de la oferta y la demanda de tratamientos para usos problemáticos de drogas indica que aún persisten brechas importantes para garantizar el acceso a la salud de estas poblaciones. A nivel de los usos problemáticos, el principal riesgo sanitario lo representa el alcohol, la sustancia con mayor número absoluto de usuarios. Respecto a la demanda efectiva, según el informe 2019 del Observatorio Uruguayo de Drogas, se calcula que aproximadamente 28.000 personas demandaron atención por alguna droga en los 12 meses previos a ese estudio. Esto representa un porcentaje bajo si se pone en relación la demanda potencial, indicada por el número absoluto de usuarios con signos de uso problemático con la demanda efectiva. Solo un $4 \%$ de los usuarios problemáticos de alcohol ha demandado tratamiento y un $5 \%$ de usuarios de tabaco. En contrapartida, la demanda de atención por sustancias ilegales es significativamente mayor, pero aún existen brechas importantes: un 33\% del número total de usuarios con signo de uso problemático de cocaína ha demandado tratamiento y un $26 \%$ para el caso de la pasta base. Como se hizo referencia en la sección anterior, pese a la baja magnitud del consumo de pasta base en la población general, esta tiene una importante incidencia en la población bajo tratamiento. Sin embargo, la proporción de usuarios problemáticos que accede a tratamientos es relativamente baja y además estos pedidos de ayuda se realizan en momentos bastante avanzados de las trayectorias de consumo. En lo que respecta a la PBC, entre el inicio del consumo regular y el primer pedido de ayuda transcurren, en promedio, cuatro años. En el caso de cocaína es de 8 y para el alcohol 15 años (OUD, 2019).

El perfil general de las personas que demandaron atención varía sustancialmente por tipo de sustancia considerada. Por alcohol, marihuana o cocaína hay una mayor preponderancia de varones, residentes en el interior, en la mitad de los casos con caracterización socioeconómica media y con un promedio de edad de 39 años. En las consultas por marihuana el promedio de edad es mucho más joven, mientras que el perfil de las personas que demandaron tratamiento por PBC es mayoritariamente varones y de nivel socioeconómico más bajo que para el resto de las sustancias (Ibíd.).

Respecto a los lugares donde se consultó tratamiento, el 50\% de los casos declaró haber solicitado ayuda profesional en Instituciones de Asistencia Médica Colectiva (IAMC) $)^{5}$ (mutualistas) mientras el sector público, en sus diversos servicios, atendió a por lo menos una de cada tres personas, distribuyéndose el resto en otros lugares y modalidades, como se observa en la tabla debajo. Son relevantes las diferencias según el tipo de droga por la cual se demanda atención. En el caso de pasta base, es el Estado el que atendió más del 50\% de los casos, en tanto recae

5. Las IAMC son el principal componente del subsector privado del sector salud en Uruguay. 
en las IAMC solo el $6 \%$ de la atención por el uso de esta droga. La referencia a las iglesias también es significativamente más elevada en el caso de los usuarios problemáticos de pasta base, que en el 2014 alcanzaba al 69\% de las referencias totales demandas de tratamiento. En contrapartida, el Estado atiende solo al 11\% de las personas que solicitan asistencia por alcohol, concentrándose la atención de esta demanda en las IAMC (Ibíd.).

TABLA 2

Lugares donde consultó por tratamiento de drogas

(En \%)

\begin{tabular}{|l|c|}
\hline \multicolumn{1}{|c|}{ Lugares } & $\%$ \\
\hline Alcohólicos Anónimos & 2,3 \\
\hline Narcóticos Anónimos & 10,3 \\
\hline Grupos de autoayuda problemas de tabaco y programas de cesación de tabaquismo & 16,7 \\
\hline Comunidades Terapéuticas & 5,2 \\
\hline Mutualista & 49,2 \\
\hline Consultorios externos & 7,2 \\
\hline Clínicas psiquiátricas particulares & 4,7 \\
\hline Policlínicas barriales & 6,2 \\
\hline Hospitales/Centro de atención mental públicos/esp. drogas & 18,9 \\
\hline Centro de tratamiento privado & 1,6 \\
\hline Iglesias/comunidad religiosa & 8,9 \\
\hline Portal Amarillo & 4,5 \\
\hline Atención telefónica Portal Amarillo/ ${ }^{*} 1020$ & 2,3 \\
\hline INAU & 0,3 \\
\hline Centro de escucha & 0,7 \\
\hline Otros & 8,5 \\
\hline
\end{tabular}

Fuente: OUD (2019, p. 114).

Obs.:. * Base: personas que demandaron atención en los últimos 12 meses.

** Respuesta múltiple: los totales pueden diferir de 100

La consolidación de la Renadro y la disponibilidad de instituciones especializadas en tratamientos de drogas fue fundamental para la ampliación del derecho a la salud, sin embargo, tal como sugiere el contraste entre demanda potencial, efectiva $y$ oferta de tratamientos persisten importantes barreras a la entrada que dificultan el acceso. Una en particular es el vacío en las posibilidades de tratamiento ambulatorio para usuarios problemáticos de drogas. Tal como apunta uno de los diagnósticos locales del problema de las drogas financiado por la propia JND, cuando familiares, vecinos y/o técnicos entran en contacto con usuarios problemáticos dispuestos a iniciar un tratamiento, las acciones se limitan a "escuchar", sin contar con instituciones descentralizadas de referencia para tratamientos profesionales (Barbero, 2012). 
Esta frustración generada por un problema de las drogas que se presenta como omnipotente en algunos barrios montevideanos y la falta de servicios profesionales de salud mental para trabajar el tema llevó a que en el 2008 un grupo de técnicos y vecinos de la zona norte de Montevideo iniciara una experiencia piloto que terminó ganando su lugar dentro de la red pública de atención en drogas. Por ello, conocer un poco más a fondo la experiencia del Achique es interesante en múltiples sentidos. En primer lugar, dado que la institución ocupa un lugar único dentro de la Red Nacional de Atención en Drogas, estudiar su composición y funcionamiento cotidiano nos permite identificar fortalezas y debilidades de la coordinación interinstitucional en la política pública de drogas. En segundo lugar, el Achique está ubicado en una de las zonas con mayor concentración de desventajas socioeconómicas y altos índices delictivos de Montevideo (Lombardo, 2005; Aguiar, 2017). La información disponible indica que la organización de los mercados de drogas es particularmente problemática en estos barrios, por lo que conocer las propuestas existentes de reducción de riesgos y dańos puede ser un factor de relevancia para la prevención de la violencia en estos contextos.

\section{PRESENTACIÓN DEL CASO DE ESTUDIO Y DE LOS PROCEDIMIENTOS DE PESQUISA}

La Cuenca de Casavalle es una zona al norte del departamento de Montevideo que abarca un área de 547 hectáreas, con un total de 95.800 habitantes. Casavalle es un mosaico de múltiples barrios y sub-barrios, asentamientos regularizados y no regularizados, cooperativas y complejos de vivienda. Incluye una zona rural, otra comercial y otra residencial, ubicada en el centro del territorio donde se concentran las mayores vulnerabilidades, alcanzando niveles críticos de pobreza en relación al resto de la ciudad. La evolución de Casavalle es un ejemplo extremo de los procesos de fragmentación territorial ocurridos en Montevideo desde la década de 1960. Desde hace ya varios años que la zona se ha identificado como un área de alta prioridad en la intervención, ya que en su territorio relativamente pequeño se concentran niveles agudos de criticidad de múltiples indicadores sociales, incluso en comparación a los barrios más pobres de la capital. Sin embargo, la inversión en políticas sociales y de seguridad pública no ha logrado revertir las tendencias observadas ni han mejorado significativamente la conectividad del barrio con la ciudad (Aguiar, 2017).

Según los datos provistos por el Ministerio de Desarrollo Social, al 2015, el $60 \%$ de sus habitantes tiene al menos una necesidad básica insatisfecha. El 53\% de los hogares residentes en esta zona tiene problemas de hacinamiento y casi igual porcentaje presenta riesgo alimentario. El 17,2\% de los hogares se encuentran en situación de indigencia, siendo el promedio para Montevideo de 3,5\%. El $21 \%$ de los hogares cuenta al menos con un desocupado y uno de cada dos personas económicamente activas que residen en la zona o está desempleado o 
está informalmente empleado. Casavalle presenta asimismo la estructura de edad más marcada dentro del departamento; el 52,8\% de su población es menor de 25 años, mientras que para Montevideo el promedio es de 36,5\%. La representación de los menores de 18 años dentro del barrio es incluso más del doble respecto a la agrupación de barrios por debajo de la media de pobreza; tres de cada cuatro niños de Casavalle son pobres. Constituye también un caso particular respecto al porcentaje de hogares con clima educativo bajo (menor o igual a 9 ańos) que supera el 85\%. El 43\% de los hogares con jóvenes de entre 14 y 24 años tiene al menos un joven que no estudia ni trabaja y solo el $27,4 \%$ de los jóvenes tiene acceso a la educación secundaria, mientras que la media de Montevideo es 69\%.

GRÁFICO 1

Pirámide poblacional por edad y sexo

(En \%)

$1 \mathrm{~A}-$ Casavalle

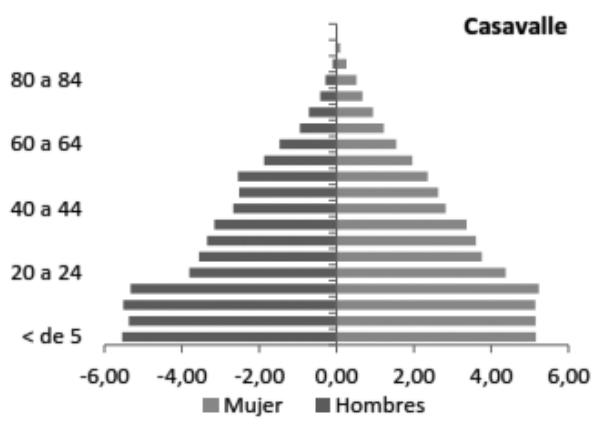

1B - Total del país

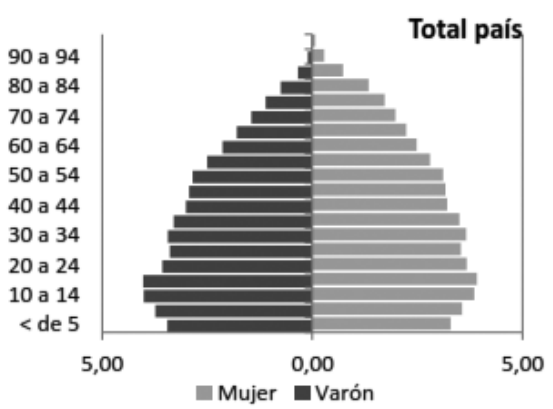

Fuente: (DAES, 2015, p. 2).

Obs.: imagen reproducida en baja resolución en virtud de las condiciones técnicas de los originales (nota del Editorial).

Casavalle es jurisdicción de la seccional policial no 17 y es usualmente caracterizada como "zona roja" delictiva, por los altos niveles de violencia contras las personas allí registrados. Entre enero y setiembre de 2018 se concentraron en esta zona el $20 \%$ de los homicidios y el $10 \%$ de las rapińas totales de la ciudad de Montevideo. Presenta una tasa de 25 homicidios cada 100 mil habitantes, compartiendo este indicador con más de 130 ciudades de América Latina y el Caribe que son consideradas "altamente peligrosas" según la Organización Mundial de la Salud. Residen en este barrio el 16\% de las personas liberadas por el Sistema Carcelario de Montevideo. Sin embargo, esta región representa apenas el 1\% del territorio de la capital (OUD, 2019).

Desde hace algunos años se han identificado grupos delictivos organizados o semi organizados operando en la zona, erigidos en torno a "clanes" familiares. A ellos se atribuye el control de algunos segmentos de los mercados ilegales de drogas, homicidios vinculados a "ajustes de cuentas" entre bandas criminales, amenazas a vecinos 
de la zona y desalojos ilegales ${ }^{6}$ (Baudean, 2017). Sin embargo, un estudio ventana realizado en esta seccional policial en el 2012 mostró que las denuncias vinculadas a drogas durante una semana "tipo" no correspondía ni a conflictos entre bandas organizadas ni a sustancias psicoactivas ilegales; sino a un perfil de hombres adultos, mayoritariamente relacionadas a la violencia doméstica y el consumo de alcohol. En base a entrevistas con vecinos de la zona, en este estudio también se reseña que

el discurso de los vecinos permite identificar en primer lugar la omnipresencia absoluta del problema de las drogas. Múltiples aspectos vinculados con las drogas - consumo, comercialización, consecuencias en los adictos y en sus familias, entre otras - aparecen como situaciones que si no se han vivido en carne propia, al menos se vivencian con proximidad, ya sea a partir de familiares, vecinos, conocidos o simplemente de "gente del barrio" (Barbero, 2012, p. 60).

Pese a la importancia de la problemática para los habitantes de la zona, llama la atención la escasez de instituciones especializadas en tratamiento de usos problemáticos radicadas en el barrio. Es por ello que entre los meses de octubre y noviembre del 2019 se realizó un acercamiento a la experiencia del Achique de Casavalle, uno de los pocos centros públicos trabajando en la zona. En ese periodo se realizaron siete entrevistas semiestructuradas al Secretario General de la Junta Nacional de Drogas, a los técnicos que trabajan en el Achique (cuatro psicólogos y una referente comunitaria) y a un usuario del dispositivo. La guía temática utilizada en las entrevistas cubría aspectos del surgimiento de la institución, roles y rutinas de trabajo, características de la población atendida, relacionamiento con el barrio y con otras instituciones clave, herramientas de monitoreo y evaluación de resultados, y fuentes de financiamiento. Las entrevistas duraron entre 30 y 90 minutos. La mayoría de ellas fueron realizadas en la sede donde funciona el Achique y una se realizó en la Facultad de Ciencias Sociales de la Universidad de la Republica. A los efectos de protección del anonimato y siguiendo procedimientos estándares de las Ciencias Sociales, las citas a las expresiones de los entrevistados son textuales y se referencian numéricamente del 1 al 7, junto a la fecha en que fueron realizadas.

Además de las entrevistas formales, se realizaron tres visitas al Achique para observar la dinámica cotidiana al interior y en el exterior inmediato. En esas ocasiones mantuve conversaciones informales con vecinos y con usuarios del dispositivo, con quienes también compartimos un almuerzo juntos. Agradezco sinceramente la amabilidad y apertura con que me recibieron, y su generosidad para compartir conmigo su historia y su reflexión sobre el importante trabajo que llevan adelante.

6. Por estos motivos, en abril del 2011 Casavalle fue protagonista del primero de una seria de "mega operativos" policiales "Mirador", planeados por el Ministerio del Interior como intervenciones policiales intensivas y focalizadas en barrios de alto conflicto delictivo. Seiscientos efectivos policiales fueron desplegados, además de patrulleros y helicópteros, realizando casi 70 allanamientos. Por algunas horas el barrio se mantuvo paralizado, impidiéndose la entrada y salida de los vecinos. 


\section{RESULTADOS DEL ESTUDIO EMPÍRICO}

La historia detrás del espacio físico que hoy ocupa el Achique ilustra muchos de los nudos críticos de las políticas públicas de atención en drogas. En primer lugar, muestra la persistente importancia de las instituciones religiosas en los servicios de salud mental. Anteriormente se hizo referencia a que para más de la mitad de los usuarios problemáticos de pasta base no son los ASSE sino las iglesias la principal institución de referencia para buscar ayuda. En el caso del Achique, fue la parroquia de la zona la que habilito un lugar donde poder trabajar. Tal como se recoge en las entrevistas realizadas, muchas instituciones gubernamentales reconocían la necesidad de contar con un servicio profesional de atención a usuarios problemáticos de drogas en el barrio pero nadie estaba dispuesto a hacer de ello una política pública propia.

nos reuníamos cada tanto con la gente de la Junta Nacional de Drogas, de la Intendencia de Montevideo, del Ministerio de Desarrollo Social, del Ministerio de Salud Pública, que eran todos los que habían decidido apoyar este centro de tratamiento. Pero, pasaban los meses, pasaban los meses, y no teníamos recursos. O sea, 'está todo bien, te apoyo, pero manejate'. (...) Entonces, como yo soy agente comunitaria, integro la parroquia de la zona [de las Acacias - Marconi], hablé con uno de los párrocos y le pedí una de las capillas que estaba vacía; la Capilla de la Luz. Desde ese momento existe el Achique (Entrevista 5, oct. 2019).

La Capilla de la Luz se encuentra en la esquina de Manuel Melendez y Cayambe, frente a una gran escuela pública y a una fábrica de productos agroindustriales. Es una capilla humilde, como el barrio al que pertenece. El cartel en su puerta anuncia en tiza que los servicios religiosos son los días sábados. El Achique abre sus puertas de lunes a viernes desde las 9 a las 15 horas. En mi primer visita un miércoles por la mañana, en el espacio correspondiente al Achique al fondo del predio, se estaba desarrollando un curso sobre "huertas, emprendedurismo y mantenimiento de espacios verdes".

El equipo técnico está conformado por tres psicólogos, una trabajadora social y una referente comunitaria, que es también estudiante de ciencia política. Este equipo atiende a entre 15 y 20 varones, en su mayoría personas que viven en situación de calle, usuarios de pasta base y de otras sustancias psicoactivas. Los entrevistados identifican tres tipos de población con la que trabajan. Un núcleo de alrededor de 15 personas que asiste cotidianamente el centro. Un segundo grupo, periférico; es una población de carácter "flotante; que va y viene. Que viene una vez a la semana, o que viene cada tanto". Un tercer grupo de gente lo visita puntualmente; "que tiene el lugar como referencia; porque estuvo antes, entonces cuando necesita viene. Porque le paso algo, para manejar alguna crisis puntual. Son situaciones infinitas" (Entrevista 1, octubre 2019). 
El Achique consta de un amplio espacio central, donde se ubica la recientemente inaugurada cocina; "el corazón del Achique", como lo describe una de sus miembros. La cocina es el corazón porque la alimentación es la base de muchas de las actividades que allí se desarrollan. Todos los días se comparte desayuno y almuerzo, que es elaborado por equipos rotativos de usuarios. Una de las pocas reglas que existe es que todos deben participar en su elaboración y en la limpieza. También hay horarios establecidos para el desayuno y el almuerzo. En palabras de una de las técnicas coordinadoras, el establecimiento de normas de convivencia es difícil debido a la alta desestructuración de las rutinas cotidianas de los usuarios:

Es difícil pero tenés que tener un horario porque si no se vuelve caótico y de alguna forma tenés que poner ciertas reglas básicas aunque sea un lugar de baja exigencia. Tenés una hora máxima de llegada, tenés una hora máxima para desayunar. Si querés desayunar vení antes de las 10, 10 máximo. Si querés venir y almorzar no podes llegar más de las 11. Básico, ¿¿no? Porque si no todo es conflicto. Porque si uno llega a las $10 \mathrm{y}$ cuarto y lo dejas desayunar el otro salta 'porque yo vine anteayer y vos no me dejaste desayunar, y eran $10 \mathrm{y}$ cinco'. 'Y este que viene a las 11.30, ¿por qué viene a las 11.30 ? Que yo estaba cocinando y éramos nueve y ahora vamos a ser 10. Y entonces ustedes ¿por qué dejan que entre? Porque entre ellos eso pasa mucho (Entrevista 1, oct. 2019).

Compartir la alimentación genera adhesión al dispositivo y cohesión dentro del grupo. A la izquierda de la mesa larga de madera con taburetes donde se comparte diariamente la comida, hay un espacio de recreación, con sillones, una tv, y una mesa de ping pong altamente utilizada. Atravesando este espacio central, de unos quince metros cuadrados, hay, separadas, una sala de estar pequeña con varias sillas en forma de circulo donde se realizan cursos y talleres, un espacio pequeño con una máquina de lavar ropa, y una oficina, donde transcurrieron las entrevistas. En una habitación contigua hay vestimenta donada por los vecinos para una feria de ropa usada que sería organizada en el mes para recaudar fondos para actividades de la institución y para los usuarios. La edificación toda es muy prolija pero muestra las marcas de largos años de poca inversión en el mantenimiento de su infraestructura. Según relatan los entrevistados, hasta recientemente eran habituales las goteras en el interior del edificio los días de tormenta.

En sus inicios se atendía tanto a hombres como a mujeres residentes en el barrio. Se empezó trabajando en la calle, recorriendo las inmediaciones, hablando con las personas que estaban consumiendo $\mathrm{PBC}$ e invitándolas a participar en el Achique. Sin embargo, este modo de proceder trajo aparejado inesperados conflictos de convivencia. En primer lugar había limitaciones impuestas por el espacio físico. En el Achique hay pocos espacios privados y el relacionamiento entre mujeres y hombres se hacía difícil, se generaban tensiones y peleas. En muchos casos, además, las mujeres estaban acompañadas de sus hijos a cargo, lo que sumaba nuevos y más complejos desafíos para el poco espacio físico disponible. 
Ante las dificultades planteadas y teniendo en cuenta que la población masculina que llegaba al dispositivo era más numerosa, los técnicos tuvieron que enfrentarse al dilema de incluir al género como un criterio de admisión, reconfigurándose como un dispositivo para hombres exclusivamente. En todas las entrevistas realizadas se reconoció la necesidad de que pudiera existir un dispositivo de este tipo para mujeres, ya que la demanda estaba planteada.

Otro giro en la población atendida percibido por los entrevistados refiere a la precariedad socioeconómica de los usuarios. Al inicio se trataba de una población más joven, residentes en la zona, que mantenían cierto nivel de vínculo con su núcleo familiar y con la educación, la salud o el trabajo; "era una población un poco más integrada". Actualmente, la mayoría de las personas asistentes no tiene una vivienda que le sea propia: duerme en la calle o en los refugios que ofrece el estado a través del Ministerio de Desarrollo Social.

En muchos casos, la relación de los usuarios del servicio con la ley es conflictiva. Según se relata la mayoría han pasado por varias experiencias de institucionalización, tanto en su niñez como en su vida adulta. Muchos han estado privados de libertad y luego retornan al barrio sin mayores posibilidades de reinsertarse en su comunidad.

Mucha gente que cae acá es gente que salió de prisión. Nosotros tenemos muchos que todavía están con la causa abierta, salen en libertad; a la nada. Se enteran que existe el Achique. Hay gurises ${ }^{7}$ que hace un año y medio que salieron de la cárcel y su vida es el Achique. Hacen su vida en el Achique y después se van al refugio. Antes trabajábamos con una población con consumo problemático de sustancias más local y todavía afiliada a las redes y a la familia. Ahora la población es más marginal, tiene más tiempo de calle (Entrevista 3, oct. 2019).

Este cambio en la población atendida, desde una población más local, de ambos sexos, más joven y relativamente más integrada, hacia una exclusivamente masculina, con mayores niveles de desestructuración y segregación, trajo aparejados transformaciones importantes en el modelo de abordaje para trabajar el consumo de drogas. Los entrevistados coinciden en señalar el año 2017 como un hito, un "momento refundacional" en la historia de la institución y su modelo de atención, donde se pasa de principios de trabajo más asociados a la psicología cognitiva conductual hacia un modelo que tiene como eje la reducción de riesgos y daños.

Previo al 2017, la atención era coordinada por una psicóloga, a la que se sumaba otra psicóloga que trabajaba dos veces por semana, haciendo el acompañamiento terapéutico de los usuarios y la coordinación de un taller de cocina. Una médica de familia que trabajaba en la policlínica del barrio también asistía algunas

7. Coloquial del español uruguayo para referirse a los jóvenes. 
horas por semana. Si bien la abstinencia del consumo nunca fue un requisito para la permanencia en la institución, en aquel entonces se realizaban controles de orina para premiar a quienes se mantuvieran sin consumir: "Había todo un sistema donde aquél que estaba atravesando el proceso de dejar el consumo era premiado con la posibilidad de obtener cosas. Daba pasos en favor de la rehabilitación y se le daba la oportunidad de acceder a un curso o de ir a una pasantía" (Entrevista 1, oct. 2019).

A las pasantías se accedía a través de un convenio con la Junta Nacional de Drogas, en modalidad de "trabajo protegido" en el estado, en particular, en las Obras Sanitarias del Estado (OSE). El trabajo protegido es un tipo de herramienta de discriminación positiva, donde se reservan plazas laborales dirigidas a grupos sociales que se consideran vulnerados y se realiza un seguimiento técnico y educativo del trabajador, para el fomento de sus habilidades transversales; como la puntualidad, presentación, comunicación, leyes laborales, entre otras. En general también tiene un régimen de sanciones más flexible que otros tipos de vínculos laborales. Desde el Achique se hacia el seguimiento de los usuarios que, terciarizados como cooperativa ("Achicando Caminos") accedieron a esos puestos. Si bien se reconoce esta primera etapa como más estructurada en las actividades ofrecidas, no existía un modelo de abordaje establecido, ni protocolos de actuación, ni criterios de admisión o egreso establecidos: en los términos de una de las técnicas entrevistadas; "no había nada escrito".

En el año 2017 el Achique se incorpora a la Renadro reseñada en la primera parte de este capítulo, para lo cual se firma un nuevo convenio con la JND. Los técnicos del Achique percibieron en este hecho político una oportunidad para intentar encuadrar el trabajo de un modo más formal, esta vez como una institución abocada a los principios de reducción de daños, eliminándose los controles de orina. La incorporación a la Renadro no parece haber tenido un impacto significativo en los recursos terapéuticos disponibles. Como explica uno de los técnicos del programa:

Hasta principios de este año teníamos una cuestión un poco más programada de qué es lo que hacíamos nosotros. En relación a cuestiones más grupales, había un día a la semana en que trabajábamos en grupo. Lo que sucede con esta población es que en realidad es muy difícil sostener los encuentros grupales. No solo por la falta de atención sino también por cuestiones emocionales que se ponen ahí en juego. Entonces lo que hacíamos nosotros era problematizábamos mucho sobre el funcionamiento del lugar y la responsabilidad de los usuarios en relación al centro. Después se trataban temas de consumo también pero se daban más bien en encuadres más informales. No poníamos una hora y un día sino que muchas veces se daban charlas acá [en el escritorio], o en la cocina, donde sea. Eso en lo que hace a actividades que nosotros podemos encuadrar en relación a los usuarios. Después, hasta el año pasado había actividades que dependían de [el departamento de] Equidad Social de la JND, que traían cursos vinculados a inserción laboral. Entonces teníamos cursos de construcción, 
pero también algún curso vinculado a derechos laborales y no recuerdo si había algún otro, pero eran dos o tres cursos que también eran actividades formales que estaban planificadas. Este ańo hubo completa ausencia de Equidad Social de la JND y no tuvimos en el centro otras actividades así (Entrevista 3, oct. 2019).

Más allá del encuadre general, para los entrevistados fue difícil delinear los contornos del modelo de abordaje seguido. Se consideró que "cada persona sigue su propio proceso: no hay una forma lineal de trabajar". Cuando se recibe a una persona, se realiza una primera entrevista evaluativa, para ver en qué situación está y si es apta para incorporarse al dispositivo. Los casos en que no se ha habilitado el ingreso son porque la persona presenta algún tipo de patología psiquiátrica aguda y no hay un seguimiento de un médico. Se considera que este tipo de problemática desborda las posibilidades terapéuticas de la institución.

$\mathrm{Al}$ inicio, a cada usuario se le da un contrato de convivencia que debe firmar, donde se explicitan las reglas básicas que deben cumplirse para ser parte del dispositivo: no hay violencia, no se roba y no se pueden consumir drogas adentro de la institución. El no cumplir cualquiera de estas tres normas implica la expulsión. La fortaleza terapéutica del Achique parece centrarse en su trabajo cotidiano. En particular, favoreciendo la reducción de riesgos y daños vinculada a las situaciones de fisura y de ocio compulsivo derivados de la vida en la calle. En palabras de uno de los usuarios del centro:

Un par de integrantes ahí, de usuarios (del refugio), venían para acá y me invitaron. Y nada, como yo estaba sin laburo, más o menos buscaba el que hacer día a día para no estar en la calle flotando, empecé a venir acá. Y la verdad me gustó mucho el lugar. (...) Nada... es un lugar donde podes estar tranquilo. Salís del refugio y no te tenés que ir a una plaza o debajo de un techo si está lloviendo. Venís para acá, sabes que tenés el almuerzo seguro. Haces algo, sea barrer, cortar el pasto, lavar un piso, cocinar. Es algo que haces para que se te pase un poco el día, para sentirte por lo menos un poco útil. Yo se lo he comentado a varios, por lo menos de los gurises que viven en el refugio conmigo que están en esa, ¿̇iste? De que no saben qué hacer. Se levantan y el día... vamos a ver que me depara el día, ¿entedés? Ahí en el refugio, como sin destino ni nada. Esta bueno salir de allá y saber que tenés por lo menos hasta las dos, tres de la tarde un lugar donde estar (Entrevista 4, oct. 2019).

El trabajo cotidiano se centra fuertemente en el individuo y según los entrevistados son excepcionales las instancias donde se contacte a la familia o el entorno de los usuarios. Sin embargo, gran parte del trabajo del Achique se basa en favorecer las redes de interacción barrial. Intenta conectar sus demandas de salud, de educación, de trabajo y de recreación con los recursos locales. Este anclaje territorial fue un elemento de fortaleza del dispositivo desde el inicio: el hecho de que las propias vecinas del barrio y la Capilla auspiciara la iniciativa ha sido un elemento de legitimidad fundamental para abrir y sostener el espacio. 
La imposibilidad que tienen los usuarios problemáticos de pasta base pobres para acceder a los servicios de salud es un problema importante para su integración social. Un psicólogo especializado en drogas que trabaja en una de las policlínicas del barrio lo evalúa de esta manera:

Es tremenda la problemática para insertar el tema en el sistema de salud. El primer problema es que vos tenés algunos técnicos que podrían trabajarlo pero no tenés una definición política clara de cómo se inserta el tratamiento de drogas en el sistema de salud. Ahí tenés la primera dificultad: cualquier psicólogo puede definir qué tema trabajar. La segunda dificultad es que aunque se quisiera intervenir sobre el tema de drogas no hay una formación clara para la especialización profesional. Empiezan a aparecer, y eso es bueno, personas que quieren formarse sobre el tema pero no hay donde. No tenés políticas claras, no tenés técnicos capacitados. Y son dificultades transversales a las políticas de salud mental. En la policlínica está inserto el tema porque lo priorice yo. Porque entiendo que es un problema para la comunidad, porque entiendo que es un problema que compete al sistema de salud, entonces tome la decisión de ofrecer ese servicio. Pero ni siquiera me animo a sacar un afiche para difundirlo porque colapso. Pero es una iniciativa individual, lo que hay es una suma de iniciativas individuales pero no hay una política pública a nivel ambulatorio (Entrevista 6, nov. 2019).

Esta falta de definición política sumada a los pocos recursos humanos especializados disponibles redunda en un bloqueo dentro del Ministerio de Salud Pública para poner a disposición tratamientos para usuarios problemáticos de drogas, así como para los servicios de salud mental más en general. Se deriva de ello que la nueva ley de Salud Mental (Ley no 19.529) aprobada en el 2017, no ha significado una ventana de oportunidad para la inclusión del tema en el sistema de salud. Esta ley incluye al consumo problemático de sustancias psicoactivas como un asunto a ser abordado en el marco de las políticas de salud mental (art. 5으. Contiene un amplio capítulo sobre prevención, buscando consolidar la integración de los servicios de salud mental como prestación general de las instituciones de salud. Complementariamente, comanda el pasaje del modelo asilar a uno de base comunitaria, ordenando un "proceso regresivo de cierre de estructuras asilares y monovalentes para ser sustituidos por estructuras alternativas" (art. 38), como centros de atención comunitaria, casas de medio camino y centros de rehabilitación. También se pretende jerarquizar los equipos técnicos del primer nivel de atención, como contacto y referente permanente en el proceso asistencial. Sin embargo, en las entrevistas realizadas no se percibe un impacto en las políticas públicas de tratamientos a partir de la aprobación de esta ley.

Como se explicó más arriba, con el objetivo de esquivar el bloqueo político dentro de las instituciones de salud pública existentes, en el 2013 la JND conforma una red paralela de atención en drogas; la Renadro. El problema de gobernanza planteado es que ni la JND ni la Renadro tienen fondos propios suficientes para 
la implementación de políticas, y dependen en gran medida de los fondos que se decomisen en los delitos de drogas. De ello se deriva que la mayoría de los cargos vinculados a la Renadro son terciarizaciones a ONGs de modo de evitar el régimen de contrato público, que tiene asociados mayores derechos laborales. La Renadro ofrece contratos de tres o seis meses de extensión, con posibilidad de renovación sujeto a que se incauten nuevos bienes a partir de delitos de drogas.

En el año 2016 el Achique se incorpora a la Renadro, en la forma de una tercerización con la ONG "Hermana Marta", y se generan los tres primeros cargos vinculados directamente a la institución. Así se contratan dos psicólogos y se formaliza el trabajo que ya venía haciendo la referente comunitaria. A través de la SND también se da apoyo financiero para los gastos cotidianos de la institución. A los pocos meses se incorpora un tercer psicólogo derivado de un "pase en comisión"8 desde el Banco República del Uruguay. La policlínica municipal del barrio también "cede" horas del psicólogo para la atención en el Achique, es decir, le permite cumplir una proporción de su tiempo en esta institución. El apoyo desde el Ministerio de Desarrollo Social es una canasta de víveres secos que distribuye trimestralmente. El gran problema con este esquema es la alta precariedad y desigualdad de los contratos laborales. En algunos casos los trabajadores tienen todos los derechos de alguien en relación de dependencia con el estado (caso Banco República e Intendencia de Montevideo), mientras que otros tienen cargos tecriarizados y de corto plazo, con renovación cada tres o seis meses (caso JND - Renadro).

Esta desigualdad laboral es percibida como altamente problemática por todos los entrevistados. Impone injusticias flagrantes entre los técnicos pertenecientes a la institución, generando diferente estructura salarial para roles similares. La precariedad laboral desincentiva la planificación de actividades y la identificación de metas e indicadores de proceso, como apunta un miembro del equipo: "si tu cargo se renueva cada tres meses, cada seis meses, no hay posibilidad de proyectar tu trabajo en el mediano plazo".

Por último, respecto a las coordinaciones institucionales dentro de la Renadro, el rol del Achique al interior de la red es percibido como poco claro por los entrevistados. De una parte, existe conciencia de la especificidad y de la necesidad del servicio que se brinda, por su baja exigencia y por la población a la que atiende: personas en situación de calle con uso problemático de sustancias. Como ya se hizo mención existe un vacío de instituciones de tratamiento ambulatorio y el Achique es una de las pocas que cumple ese rol. La necesidad de existencia del

8. Los pases en comisión son una forma de seleccionar trabajadores públicos de un área para que operen en una diferente, y está amparada por el artículo 15 de la Ley no 19.149. Esta normativa autoriza el traslado de funcionarios de organismos públicos estatales y no estatales que cuenten con más de tres años de antigüedad en la Administración para desempeñar, en comisión, tareas de asistencia directa al presidente, vicepresidente, ministros, subsecretarios 0 legisladores nacionales, por expresa solicitud de éstos. 
Achique para la Renadro también es geográfica; es uno de los pocos dispositivos referentes en uso de drogas trabajando en el área de Casavalle. Sin embargo, en los hechos, el Achique funciona como un dispositivo de captación hacia la Renadro, para las personas que deciden emprender un tratamiento residencial. Los casos de interacción registrados han sido derivaciones desde el Achique hacia el dispositivo Ciudadela ("para que conozca la oferta publica") o directamente hacia el Portal Amarillo. Pero no hay derivaciones desde el resto de la red hacia el Achique: el flujograma es unilateral.

\subsection{Avances y limitaciones}

La sensación de urgencia y necesidad frente a una demanda que estaba planteada pero que ninguna política pública daba respuesta llevó a que en el 2008 cuatro personas -una trabajadora social, una psicóloga, un médico y una vecina referente del barrio- que habían compartido un taller sobre uso de sustancias realizado en Casavalle, uniera esfuerzos para soñar una posible solución y para que los límites de lo políticamente posible cedieran:

Viendo [la dificultad de trabajar este tema adentro de las policlínicas], le empezamos a poner cabeza, nos empezamos a juntar entre nosotras y con consumidores que habían asistido a la policlínica. Y así surge la idea del Achique. Al Achique lo soñamos pensando en reducción de riesgos y daños y en un proceso de tiempo durante el día donde los gurises tuvieran menos exposición a los consumos. Simplemente ese pensamiento. Si están tres o cuatro horas en un espacio haciendo algo que les guste, les interese, esas horas no van a consumir. (...) Así que seguimos trabajando con el equipo, con la convicción de que teníamos que seguir construyendo, desde el territorio, porque no había otra respuesta en ningún otro lugar (Entrevista 5, oct. 2019).

$\mathrm{Al}$ principio el equipo técnico trabajó con lo que pudo, a fuerza de militancia personal y voluntad colectiva. Gestionó un espacio donde atender a las personas con la parroquia del barrio, los vecinos donaron equipamiento y se conseguían algunos fondos, siempre escasos, para el pago de salarios con la presentación a premios y fondos concursables que lanza periódicamente la JND. Esta alta precariedad hizo que en varios momentos el Achique estuviera cerca de cerrar sus puertas. Sin embargo, la evidencia de la necesidad de contar con instituciones públicas especializadas en tratamientos en drogas en la zona norte de Montevideo hizo que en el 2016 el estado uruguayo decidiera incorporar el Achique a la Renadro. Los entrevistados perciben este paso como un logro importante en el proceso de consolidación institucional.

En los más de diez años que pasaron entre que se realizaron los primeros esfuerzos para fundar la institución, en el 2008, y el 2019 en que se realizaron las entrevistas, la población participante del Achique tuvo cambios significativos. En sus inicios el Achique atendía tanto a hombres como a mujeres con uso 
problemático de sustancias, en particular, pasta base, residentes en el barrio. Actualmente, el Achique logró posicionarse como una institución de referencia para hombres en situación de calle que trasciende el barrio.

De las entrevistas realizadas se deriva que existe una alta adherencia de los asistentes. Alrededor de 15 personas participan de forma cotidiana en este dispositivo diurno, y otros 15 lo hacen de forma periódica o puntual. El nivel de satisfacción entre los concurrentes es alto, y en muchos casos son los propios usuarios los que contactan a nuevas personas con consumo problemático de sustancias para sumarlos a la propuesta. Para muchas de estas personas, el Achique es una oportunidad única de intervención sobre trayectorias vitales signadas por graves situaciones de exclusión, vulnerabilidad social y violencia. Hasta el momento, el mayor trabajo de reducción de riesgos y daños en estos contextos se vincula a los síndromes de abstinencia y al ocio compulsivo asociado a la vida en la calle.

Sin embargo, las dificultades y obstáculos a los que ha tenido que enfrentarse el equipo de trabajo ilustran muchas de las debilidades y limitaciones de las políticas actuales de drogas. La primera de ellas es la precariedad de las condiciones de trabajo. Los escasos recursos terapéuticos disponibles han redundado en una progresiva desestructuración de las actividades ofrecidas. En general los entrevistados coinciden en identificar como una dificultad para los procesos de integración social la falta de planificación de las actividades, así como la falta de identificación de metas de medio camino. Al reformularse como un centro diurno de acogida a población de calle, el Achique perdió especificidad como institución de tratamiento de drogas y en las actividades cotidianas existen pocos espacios formales centrados en ese aspecto.

\section{CONSIDERACIONES FINALES}

En los últimos años, el uso de sustancias psicoactivas así como el vínculo entre droga y delito han ganado notoriedad en la opinión pública y el sistema político. Sin embargo, un acercamiento al caso uruguayo muestra que al día de hoy persisten importantes brechas entre la demanda potencial, la efectiva y la oferta de tratamientos para usuarios problemáticos de estas sustancias. Con la expansión de las políticas sociales y de los servicios de drogas que se ha vivido en los últimos años se ha avanzado mucho en la identificación de las poblaciones más expuestas a los daños y la violencia de los mercados ilegales de drogas. Sin embargo, la falta de opciones de tratamiento especializado no residencial hace que no haya adonde derivar los casos una vez identificados, lo que a su vez redunda en la frustración de técnicos y vecinos.

En zonas de concentración de desventajas territoriales de la ciudad, esta falta de inversión en políticas públicas de salud parece conformarse como un factor facilitador de la organización violenta de estos mercados. De hecho, una de las 
mayores críticas que se realiza al modelo de política pública de "guerra contra las drogas" es el énfasis en la represión de la oferta ilegal por sobre la disponibilidad de opciones de prevención y tratamiento profesional para estas poblaciones.

La evidencia recopilada en este estudio sugiere una serie de posibilidades para acortar esta brecha. La primera opción es la jerarquización del tema dentro del sistema nacional integrado de salud. Uruguay cuenta con buenos indicadores de cobertura del sistema de salud lo cual es una ventaja para la ampliación de los programas de prevención y tratamiento para usuarios de drogas en todo el territorio. También cuenta con un nuevo marco legal vinculado a la salud mental que demanda la incorporación de los usos de drogas dentro del sistema salud y educativo, así como el fortalecimiento de las opciones no residenciales y comunitarias de tratamiento. De este estudio se deriva que además del desarrollo de recursos humanos especializados en el tema, es preciso un lineamiento de política pública claro y sostenido que jerarquice y encuadre esta prestación dentro del Sistema Integrado de Salud; con ello podría superarse uno de los más importantes bloqueos para la ampliación de los tratamientos.

La segunda posibilidad es avanzar hacia una tercera generación de políticas públicas de drogas, que necesariamente debe reducir la precariedad y desigualdades laborales actuales. El análisis de caso sugiere que la participación de la comunidad es un factor relevante para el éxito de las instituciones de tratamiento y para la reducción de riesgos y daños derivados del comercio ilegal de drogas. Sin embargo, tras la participación de diferentes actores públicos y privados aparecen desigualdades importantes en lo que refiere a los niveles de precariedad laboral. Buscar nuevas formas de asociación y cooperación entre el estado y la ciudadanía, más equitativas, parece clave para la gestión, adherencia y eficacia de este tipo de propuestas.

\section{REFERÉNCIAS}

AGUIAR, S. Acercamientos a la segregación urbana en Montevideo. Tesis (Doctorado) - Sociología, Universidad de la Republica, Montevideo, 2017.

AGUIAR, S.; COITIÑO, M.; LEMOS, F. Marihuana en los medios de comunicación en la era de la regulación en Uruguay. Montevideo: FCS/UdelaR 2019.

BARBERO, M. Diagnóstico local sobre la problemática de drogas en Casavalle. Montevideo: JND; OUD, 2012.

BAUDEAN, M. Línea de base para la evaluación y el monitoreo de la regulación del cannabis recreativo en Uruguay: objetivo seguridad y convivencia. Montevideo: Monitor Cannabis, 2017. 
DAES - DEPARTAMENTO ANÁLISIS Y ESTUDIOS SOCIALES. Informe Casavalle. Montevideo: Mides, 2015.

DOMENECH, D. et al. Estudio de la prevalencia de la comorbilidad entre el distres psicolgico y el abuso de drogas. Texto \& Contexto Enfermagem, v. 21, p. 174-184, 2012.

DURÁN-MARTÍNEZ, A. From acquiescence to rebellion? South America and the Global Drug Control Regime. In: IDLER, A.; GARZÓN, J. C. The International Drug Control Regime in the Twenty-first Century. Boulder: Lynne Rienner Press, 2015.

GARAT, G. Marihuana y otras yerbas: prohibición, regulación y uso de drogas en Uruguay. Montevideo: Debate, 2012.

JND - JUNTA NACIONAL DE DROGAS. Informe Renadro. Montevideo: JND, 2019.

LAGOS, M.; DAMMERT, L. La seguridad ciudadana: el problema principal de América Latina. Chile: Corporacion Latinobarometro, 2012.

LOMBARDO, C. Hacia la resignificación de Casavalle, Montevideo, Uruguay: lineamientos fisico-territoriales. Santiago de Chile: CEPAL, 2005.

MARCHESI, A.; YAFFÉ, J. La violencia bajo la lupa: una revisión de la literatura sobre violencia y política en los sesenta. Revista Uruguaya de Ciencia Política, v. 19, n. 1, 2010.

MORAES, M. Diez años de investigación en pasta base de cocaína en Uruguay. Archivo de Pediatria del Uruguay, v. 81, n. 2, p. 147-148, 2014.

OEA - ORGANIZACIÓN DE LOS ESTADOS AMERICANOS. Consumo de pasta base de cocaína en América del Sur. Washington D.C.: OEA, 2014.

Informe sobre consumo de drogas en las Américas. Washington D.C.: OEA; CICAD, 2019.

OUd - OBSERVATORIO URUGUAYO DE DROGAS. Personas, calle, consumo: dos estudios sobre uso de pasta base en Uruguay. Montevideo: OUD; JND, 2019a.

. Informe de investigación. In: VII ENCUESTA NACIONAL SOBRE CONSUMO DE DROGAS EN POBLACIÓN GENERAL, 7., Montevideo, Uruguay, 2019. Anais... Montevideo JND, dic. 2019b.

. (2019). Relatoria GEDAIS. Montevideo: SND, 2019c. No prelo.

PASCALE, A.; NEGRÍN, A.; LABORDE, A. Cocaine base paste: experience from the Montevideo Poison Control Center. Adicciones, v. 22, n. 3, p. 227-232, 2010. 
Políticas de Atención a Usuarios Problemáticos de Sustancias Psicoactivas: el caso uruguayo

PEREIRA, A. Drogas y procesos penales: medidas alternativas a la prisión preventiva. Trabajo final (Posgrado) - Diploma en Políticas de Drogas, Regulación y Control, UdelaR, Montevideo, 2019. No prelo.

PNUD - PROGRAMA DE LAS NACIONES UNIDAS PARA EL DESARROLLO. Human Development Report. Vienna: United Nations, 2019.

PRIETO, J. P.; SCORZA, C. Pasta Base de Cocaína. Montevideo: Instituto Clemente Estable, 2010. (Artículo de Difusión).

RETA, A. Enfoques jurídicos. Revista de la Asociación de Psiquiatría y Psicopatología de la Infancia y Adolescencia, v. 2, n. 17, p. 50-58, 1973.

ROSSAL, M. (2013). Dispositivos estatales, moralidades y dones envenenados: aproximaciones tnográficas a las relaciones de intercambio de pasta base de cocaína. Tesis (Maestría) - Universidad de la Republica, Montevideo, 2013.

SND - SECRETARIA NACIONAL DE DROGAS. (2019). Relatoría del grupo expertos en Desarrollo Alternativo, Integral y Sustentable para las políticas de drogas. Montevideo: JND, 2019.

SUAREZ, H.; RAMIREZ, J. Los desposeídos. In: UDELAR, O. Fisuras: dos estudios sobre pasta base de cocaína en Uruguay. Montevideo: JND, 2014.

WEINTRAUB, S. Western hemisphere free trade: getting from here to there. Sidney: BID, 1992.

YAFFÉ, J. Economía y dictadura en Uruguay, una visión panorámica de su evolución y de sus relaciones con la economía internacional (1973-1984). Revista Historia, nos. 61-62, p. 13-35, 2010.

\section{BIBLIOGRAFÍA COMPLEMENTARIA}

BARDAZANO, G. Respuestas estatales a los usuarios de sustancias psicoactivas en Uruguay: entre la alternativa y la profundización de la guerra contra las drogas. In: WOLA, C. En busca de los derechos: usuarios de drogas y las respuestas estatales en América Latina. Mexico: Drogas y Derecho, 2014.

DAMMERT, L.; ARIAS, P. El desafío de la delincuencia en América Latina: Diagnostico y Respuestas de Política. Santiago de Chile: Corporación de Estudios para Latinoamérica, 2007.

FERnANDEZ, J.; ROSSAL, M. Punto de Encuentro / Puntos de Mira. Montevideo: JND, 2016.

GARAT, G. Un siglo de políticas de drogas en Uruguay. Montevideo: FES, 2013. 
HIRSCH, A. Making the Second Ghetto: race and housing in Chicago 19401960. Chicago: University of Chicago Press. 1983.

URUGUAY. Ley no 18211, de 2007. Sistema Nacional Integrado de Salud. Parlamento Uruguayo, Montevideo, 2007. 
ANEXO A

\section{LISTA DE SIGLAS Y ABREVIATURAS IMPORTANTES}

ASSE - Asociación de Servicios de Salud del Estado

H. Maciel - Hospital Maciel

IAMC - Instituciones de Asistencia Médica Colectiva

INAU - Instituto del Niño y Adolescente del Uruguay

JND - Junta Nacional de Drogas

MIDES - Ministerio de Desarrollo Social

MSP - Ministerio de Salud Publica

OUD - Observatorio Uruguayo de Drogas

P. Amarillo - Portal Amarillo

PBC - Pasta Base de Cocaína

Renadro - Red Nacional de Atención en Drogas

SND - Secretaria Nacional de Drogas

UdelaR - Universidad de la República

UMA - Unidad Móvil de Asistencia

Unitra - H. Clínicas - Unidad de Trastornos Relacionados al Alcohol (Unitra) del Hospital de Clínicas 


\section{ANEXO B}

MAPA B. 1

Mapa com a localização do caso estudado no país em questão

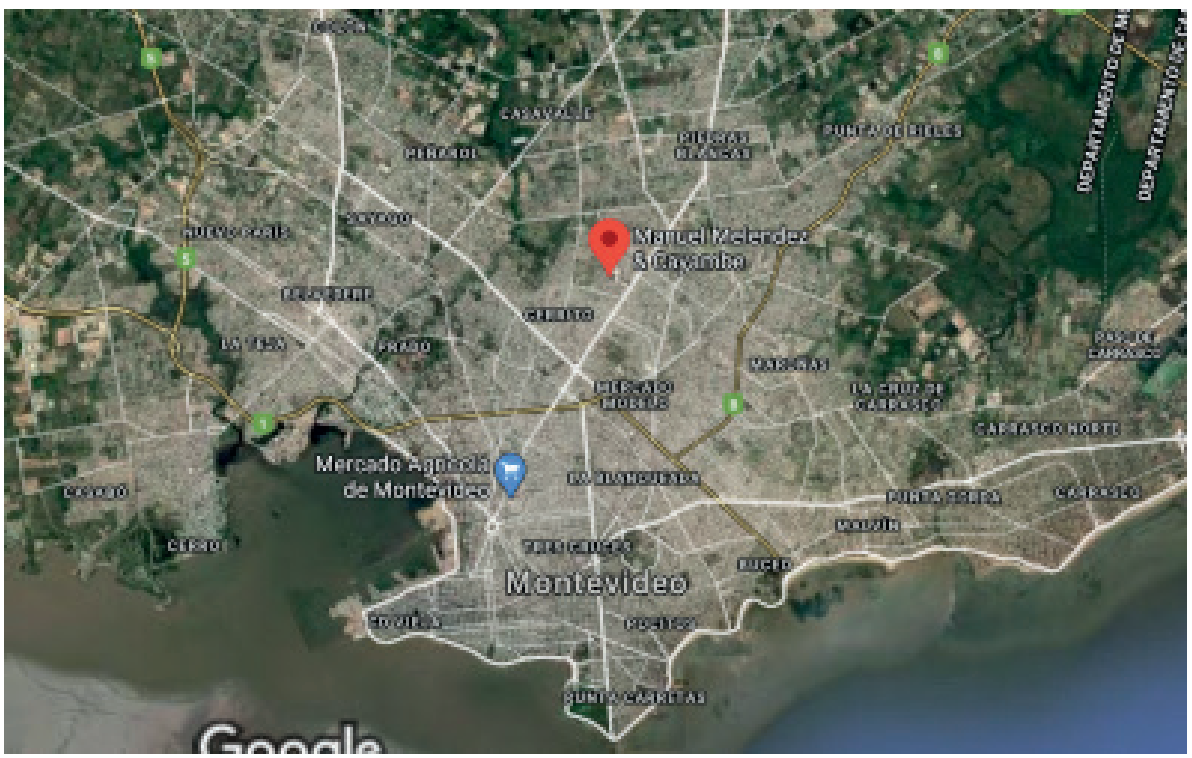

Fuente: Google Maps.

Obs.: imagen reproducida en baja resolución en virtud de las condiciones técnicas de los originales (nota del Editorial). 

el caso uruguayo

\section{ANEXO C}

FIGURA B. 1

Organograma
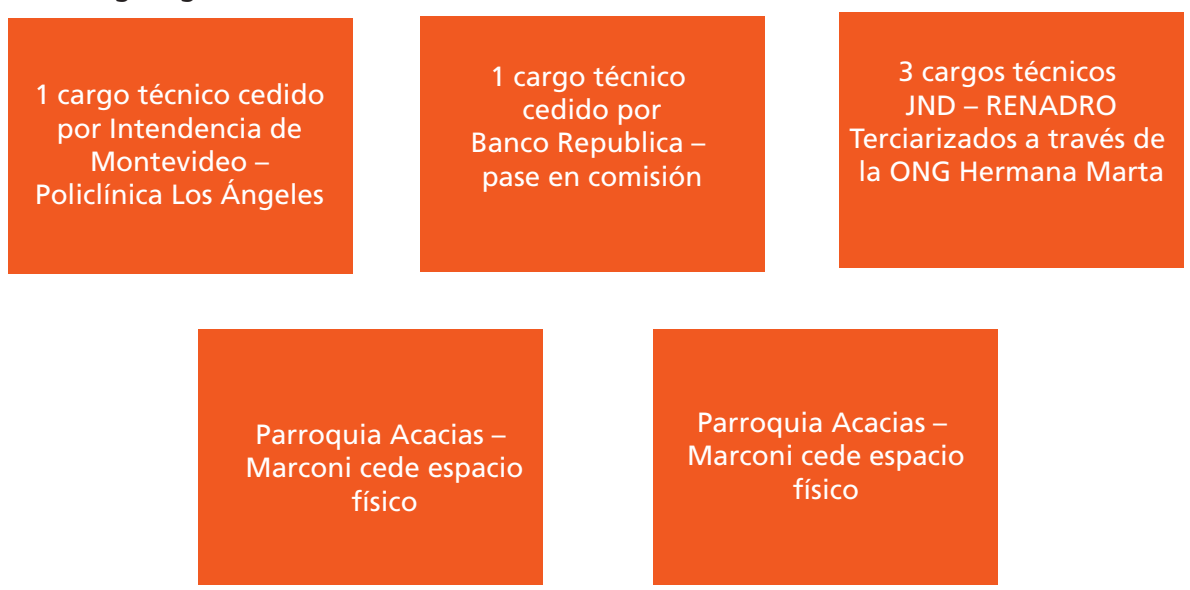

Elaboración de la autora. 



\title{
TENDÊNCIAS E DESAFIOS DAS POLÍTICAS DE CUIDADO A USUÁRIOS DE DROGAS NA AMÉRICA LATINA
}

\author{
Roberto Rocha C. Pires ${ }^{1}$ \\ Maria Paula G. dos Santos² \\ Luiza Luz Rosa ${ }^{3}$
}

\section{INTRODUÇÃO}

Nos capítulos anteriores, discutiu-se a trajetória histórica das políticas de atenção a pessoas que fazem usos problemáticos de drogas, o panorama institucional contemporâneo das ofertas de atenção a este público e políticas e programas atuais realizados em Argentina, Brasil, Colômbia, México e Uruguai. Neste capítulo, buscamos desenvolver um olhar transversal sobre os países e casos estudados, visando apontar tendências comuns às suas diversas trajetórias, nas últimas décadas, assim como indicar as potencialidades e desafios, descortinados por estes estudos, para o avanço de uma agenda de políticas assistenciais a usuários de drogas que cumpram com o objetivo de restituir direitos a estes sujeitos ao tempo em que contribuam para o enfrentamento das desigualdades sociais.

O capítulo toma como base e fonte de informação primordial os textos desenvolvidos por Corbelle (capítulo 3, neste volume), Góngora, Salazar e Borja (capítulo 5 , neste volume), Ospina-Escobar (capítulo 6, neste volume), Musto (capítulo 7, neste volume), e Santos e Pires (capítulo 4, neste volume) sobre cada um dos casos selecionados nos cinco países aqui contemplados. Ao longo do desenvolvimento do projeto Desigualdades sociais e implementaçâo de políticas públicas na América Latina: políticas de atenção e cuidado a pessoas que fazem uso problemático de substâncias psicoativas, foram realizados oficinas e seminários com estes pesquisadores, que propiciaram discussóes e reflexóes coletivas, as quais permitiram, além do entendimento de cada caso em sua singularidade, uma visão mais ampla da experiência comum destes países nesta área de política. Sistematizamos esta reflexão coletiva e internacional ${ }^{4}$ trazendo os temas que se destacaram na análise comparativa dos casos. Assim, cada uma das seçóes que se seguem apresenta achados que refletem questóes transversais aos diferentes casos nacionais.

1. Técnico de planejamento e pesquisa na Diretoria de Estudos do Estado, Instituições e Democracia (Diest) do Ipea.

2. Técnica de planejamento e pesquisa na Diest//pea.

3. Assistente de pesquisana Diest/lpea.

4. Apesar de tomar como base os trabalhos desenvolvidos pela rede de pesquisadores, eventuais imprecisões e equívocos são de inteira responsabilidade dos autores deste capítulo. 
A primeira seção argumenta que, ao longo das últimas décadas, está em marcha um processo de complexificação e diversificação das ofertas de atenção e cuidado a usuários de drogas nesses países. A partir desta constatação, analisam-se os principais vetores deste processo, bem como as características gerais dos arranjos institucionais adotados em cada contexto nacional (isto é, articulaçóes em nível sistêmico), em termos de políticas nacionais, sistemas e redes de serviços, além de mecanismos de regulação e financiamento das múltiplas ofertas existentes.

A segunda seção parte para um enfoque mais específico, concentrado nas novas modalidades de cuidado emergentes em cada país, em que se apresentam experiências representativas destas modalidades em seus contextos históricos e político-institucionais. Desenvolve-se, então, uma discussão sobre as potencialidades contidas nestas experiências, reveladas pelas pesquisas empíricas de inspiração etnográfica, que foram conduzidas especialmente para este projeto. Tais pesquisas tiveram por objeto serviços e dispositivos de atenção que representam estas novas modalidades de cuidado em seus contextos locais: os Centros de Atenção Psicossocial Álcool e Outras Drogas (Caps AD), no Distrito Federal (Brasil); os Centros de Atención Primaria a las Adicciones (Capa), em San Luis Potosí (México); os Dispositivos Integrais de Atenção Territorial (Diat); e os Dispositivos de Tratamento Comunitário (DTC), na regiāo metropolitana de Buenos Aires (Argentina); os Centros de Escucha, em Bogotá e Cali (Colômbia); e o Achique de Casavalle, na zona norte de Montevidéu (Uruguai). ${ }^{5}$

Finalmente, a terceira parte trata dos desafios enfrentados na implementação dessas experiências, que foram aqui agregados em três conjuntos: precariedades materiais (3.1), tensóes relacionais (3.2) e barreiras de acesso impostas aos grupos mais vulneráveis da clientela desses serviços (3.3). A superação destes desafios coloca-se como tarefa necessária à expansão e consolidação de estratégias assistenciais a pessoas que fazem usos problemáticos de drogas, que respondam ao imperativo do respeito aos direitos humanos e à urgência do combate às desigualdades sociais na regiáo.

\section{COMPLEXIFICAÇÃO E DIVERSIFICAÇÃO DAS OFERTAS DE CUIDADO E ATENÇÃO}

Uma primeira conclusão que podemos extrair da análise das trajetórias históricas e do panorama contemporâneo das iniciativas presentes em cada país estudado é de que há um claro movimento, nas últimas décadas, de complexificação e diversificação das ofertas de atenção e cuidado a pessoas com problemas associados ao uso de drogas. Ao longo da maior parte do século XX, em todos esses países, a oferta se restringiu a abordagens médico-institucionais e hospitalocêntricas, ou à ação de grupos de ajuda mútua e de organizaçóes filantrópicas e religiosas, todos

5. Os nomes e as siglas das experiências serão apresentados mais detalhadamente na seção 2 . 
voltados ao alcance da meta única da abstinência de substâncias. No entanto, a virada para o século XXI ensejou uma ampliação das modalidades de cuidado, no sentido de serviços ambulatoriais, dispositivos de base comunitária e no trabalho de articulação destes em redes integradas e intersetoriais de atenção aos usuários de drogas em seus territórios. Nessas novas modalidades, o foco exclusivo na abstinência cedeu espaço a outras possibilidades de se compreender o uso de drogas e as relaçóes, nem sempre problemáticas, entre os sujeitos e as drogas.

Os capítulos anteriores indicam que a introdução dessas mudanças acompanhou os processos mais amplos de redemocratização e ampliação dos direitos civis, políticos e sociais na regiáo. Embora com diferenças de forma e temporalidade entre os países, o contexto político do final do século XX propiciou a atuação mais incisiva de movimentos de luta antimanicomial e por reformas psiquiátricas, comprometidos com a garantia dos direitos humanos e com a defesa de possibilidades de tratamento voluntário, realizado em condiçóes de liberdade e dignidade, para pessoas com problemas associados à saúde mental. Estes movimentos culminaram na promulgação de novas normas e protocolos para o cuidado com a saúde mental (ou legislação análoga) nos países estudados. ${ }^{6}$

Além dessas reformas, o novo século também ensejou processos de revisão das leis penais relativas à produção, comercialização e posse de substâncias psicoativas, caracterizados por uma crescente distinção legal entre as atividades de tráfico e o uso de drogas, por meio dos quais deixaram de incidir, sobre os usuários, penas privativas de liberdade, as quais foram sendo substituídas por medidas destinadas a tratamentos de saúde. ${ }^{7}$ Tais mudanças, e seus desdobramentos, cumpriram papel importante para o reconhecimento de usuários de drogas como sujeitos de direto, assim como da dependência química como digna de políticas públicas assistenciais (saúde, assistência social, geração de renda e emprego etc.), relegando as internações de longa duração à categoria de recurso terapêutico excepcional.

As transformaçôes de âmbito nacional tiveram impulso a partir da difusão transnacional de ideias, abordagens e modelos de atenção voltados para grupos sociais em situação de vulnerabilidade, por meio, principalmente, do ativismo de grupos da sociedade civil. Entre estes, destaca-se a emergência da perspectiva e das práticas de redução de danos (RD), nos anos de 1980 e 1990. Em todos os países analisados, a RD entra em cena por meio das estratégias de controle da transmissão do HIV, desenvolvidas por organizaçóes da sociedade civil internacionais ${ }^{8}$ e locais.

6. Brasil, em 2001; Argentina, em 2010; Uruguai, em 2017; e México, em 2011.

7. À exceção do Uruguai, onde o uso de drogas jamais foi criminalizado. Mais detalhes em Soares (capítulo 2, neste volume) e Musto (capítulo 7, neste volume).

8. A Caritas Internacional apoiou a formação de grupos para o desenvolvimento desse tipo de trabalho em diversos países (Machín et al., 2006, apud Ospina-Escobar, capítulo 6, neste volume). MACHÍN, J. et al. Reducción del daño: un pasaje del delirio utópico al realismo ecológico. In: MILANESE, E. (Coord.). Farmacodependencia y reducción de daños. México: Cafac, 2006. (Por que as referências aqui? Não basta coloca-las ao final?) 
Naquele momento, o envolvimento governamental com estas iniciativas - seja por meio do seu financiamento e/ou de sua incorporação nas políticas formais de enfrentamento à Aids - variou bastante entre os países. No caso brasileiro, por exemplo, o internacionalmente reconhecido programa de DST/Aids do Ministério da Saúde financiou, a partir de 1994, a multiplicação de organizaçóes não governamentais (ONGs) que praticavam a $\mathrm{RD}$ nas cenas abertas de uso de drogas no país, disseminando informaçōes sobre saúde, ofertando insumos para o uso seguro de drogas e facilitando o acesso a serviços de saúde e assistência social (Passos e Paula Souza, 2011; Petuco, 2019).

Já na década seguinte, à medida que a atenção pública volta-se aos problemas decorrentes do aumento do consumo de "novas drogas" - como crack, paco, bazuco (pasta base de coca) etc. -, a RD transborda o campo específico da prevençáo do HIV e se associa ao campo do cuidado a usuários problemáticos de drogas (Petuco, 2019). Este transbordamento, no entanto, assume contornos diferenciados nos diferentes países estudados.

Nos casos de Argentina, Colômbia e Brasil, a RD alcançou o status de diretriz formal de políticas nacionais. Na Argentina, uma Lei de Saúde Mental, de 2010, inscreve a RD no rol dos serviços nacionais de saúde (Corda, Galante e Rossi, $2014^{9}$ apud Corbelle, capítulo 3, neste volume). Na Colômbia, a política de atenção ao consumo de drogas, instituída em 2007, assume primeiro a noção de "mitigação", tendo a RD como diretriz do modelo de inclusão social - um dos instrumentos da política. Em 2019, a RD torna-se estratégia central e explícita na política nacional colombiana (Góngora, Salazar e Borja, capítulo 5, neste volume). No Brasil, a RD foi incorporada à Política do Ministério da Saúde para a Atenção Integral a Usuários de Álcool e Outras Drogas - Pauad (Brasil, 2003) como um de seus principais princípios orientadores. ${ }^{10}$

Nos casos do México e do Uruguai, entretanto, observa-se a incorporação da RD num grau bem mais modesto. No Uruguai, embora tenha sido instituído financiamento público a programas de $\mathrm{RD}$, desenvolvidos por ONGs desde os anos 2000, a incorporação explícita e formal desta estratégia, pelas políticas de Estado sobre drogas, ainda náo se verificou (Musto, capítulo 7, neste volume). Já no caso mexicano, apesar de o país ter sido palco de experiências pioneiras na América Latina nos anos 1980, ${ }^{11}$ a RD teve pouca penetração nas políticas e instituiçóes governamentais ao longo dos anos 1990. Foi apenas nos anos 2000 que o Centro

9. CORDA, A. R.; GALANTE, A.; ROSSI, D. Personas que usan estupefacientes en Argentina: de delincuentes/enfermos a sujetos de derechos. Buenos Aires: Intercambios; Facultad de Ciencias Sociales de la Universidad de Buenos Aires, 2014. 10. No caso brasileiro, contudo, estão em marcha, desde 2019, retrocessos no sentido de um apagamento da RD, visando ao retorno de um foco exclusivo na abstinência. Mais detalhes em Santos e Pires (neste volume).

11. Como a de uma organização que atuava em Ciudad Juarez em 1988, com trabalho de troca de seringas, sob o paradigma da promoção e desenvolvimento comunitário, envolvendo a formação de pares (Ospina-Escobar, capítulo 6 , neste volume). 
Nacional para la Prevención y Control del Sida (Censida) assumiu formalmente a adoção da redução de danos para o enfrentamento da epidemia de HIV, na fronteira norte do país. Este fato acabou por favorecer a inclusão posterior da RD na política nacional de prevenção e tratamento a adiçôes (NOM-028, de 2009) do México. Contudo, esta inclusão restringiu-se à prevenção do HIV, dificultando a disseminação da $\mathrm{RD}$ em programas e serviços de cuidado e atenção a usuários de drogas em geral (Ospina-Escobar, capítulo 6, neste volume).

Outro processo comum aos países, que se mostrou relevante para a emergência de novas modalidades de cuidado a usuários de drogas, foi a difusão transnacional das estratégias de tratamento de base comunitária (TBC, ou community-based treatment-CBT), ancoradas no modelo da Epistemologia da Comunidade/Ética Comunitária (ECO2). ${ }^{12} \mathrm{O}$ TBC e o ECO2 podem ser entendidos como modalidades de redução de danos, na medida em que, como explicam Góngora, Salazar e Borja (capítulo 5, neste volume), partem de três premissas: i) a impossibilidade de "um mundo sem drogas" e, consequentemente, a inefetividade de terapêuticas que têm como ponto de partida, ou objetivo único, a abstinência de drogas; ii) a obrigação do Estado e dos serviços de proverem aos usuários de drogas os meios para que o consumo seja o menos prejudicial possível; e iii) a percepção de que as consequências nocivas do uso de drogas podem ser mitigadas por meio da modificação da estrutura de relações que compóem as redes sociais de cada indivíduo.

Assim, o TBC e o ECO2 envolvem ações, instrumentos e práticas voltadas para a melhoria das condiçóes de vida das pessoas que fazem uso problemático de drogas e vivem em situaçóes de vulnerabilidade e exclusão grave, apostando numa associação direta entre a vulnerabilidade dos usuários e as estruturas e densidades das suas redes sociais (Milanese, 2012). Para tal, assumem como eixo estratégico de intervenção o território e as redes sociais que nele se constituem, e visam dotar de recursos, de todo tipo, as pessoas que ali habitam. Trata-se de um trabalho que envolve a formação de agentes de promoçáo social e o desenvolvimento de atividades de integração, contenção e dinamização comunitária, com o objetivo de enfrentar os processos de exclusão social grave a que estáo submetidos os usuários problemáticos (Machín, 2015).

Tal como descrevem Góngora, Salazar e Borja (capítulo 5, neste volume), essas estratégias e modelos se difundiram na América Latina nas últimas décadas, a partir do apoio de organizaçóes internacionais, como a Caritas Internacional, a Organização das Naçóes Unidas para a Educação, Ciência e Cultura (UNESCO) e a Uniáo Europeia, que garantiram tanto a formação de agentes multiplicadores quanto o financiamento de experiências em diferentes países da região. O processo de difusáo inicia-se com uma experiência pioneira na Cidade do México. Porém, apesar do intenso ativismo local e do apoio internacional, o modelo ECO2 não

12. Para uma abordagem histórica da criação, difusão e evolução do ECO2, ver Machín (2010), Milanese (2016) e Fergusson e Góngora (2012). 
conseguiu penetrar nas instituiçóes governamentais daquele país, devido ao fortalecimento das concepçóes proibicionistas e à crescente criminalização dos usuários de drogas, nos anos 2000.

Nos casos do Brasil e do Uruguai, percebe-se, nas experiências analisadas, uma grande influência dos componentes territorial e comunitário, típicos do TBC, mas sem a vinculação explícita das políticas de atenção e cuidado ao modelo ECO2. ${ }^{13}$ Por outro lado, na Argentina esta vinculação é mais clara e explícita, tanto nos documentos das políticas da Secretaría de Políticas Integrales sobre Drogas de la Nación Argentina (Sedronar) como na criação de DTCs nos territórios de maior vulnerabilidade - que serão abordados detalhadamente a seguir.

Mas é certamente na Colômbia que o ECO2 alcança um maior grau de institucionalização. A partir de 2007, o modelo foi incorporado no país como marco teórico e técnico para as políticas de atenção a consumidores problemáticos de drogas. Por meio de uma parceria entre organizaçóes da sociedade civil e o Ministério da Saúde colombiano, as premissas e as estratégias do ECO2 foram introduzidas na Política Nacional para la Reducción del Consumo de Sustancias Psicoactivas y su Impacto, promulgada em 2007. Mais recentemente, tanto os fundamentos do ECO2 e do TBC foram adotados por boa parte das organizaçóes da sociedade civil que atuam com usuários de drogas, e as recomendaçóes de sua utilização foram reforçadas pelas revisôes da política de prevenção e atenção ao consumo de drogas, ocorridas em 2019.

Os movimentos ocorridos em cada contexto nacional, somados aos processos de difusão entre os países, vêm resultando em arranjos institucionais mais complexos e diversificados, quando considerada a totalidade das ofertas de atenção, cuidado e tratamento a usuários problemáticos de drogas, em cada país (quadro A.1, apêndice A). A complexificação e a diversificação de tais arranjos ocorrem em diferentes dimensóes nos países estudados. A primeira dimensão diz respeito aos atores envolvidos nas ofertas de cuidado. Para além de atores tradicionais do campo, como hospitais e clínicas privadas, grupos de ajuda mútua (alcoólicos anônimos - AA, narcóticos anônimos - NA etc.) e iniciativas caritativas e religiosas, incluindo as comunidades terapêuticas (CTs), passaram a compor o panorama contemporâneo das ofertas: i) novas organizaçôes da sociedade civil, envolvidas com projetos de redução de danos e focados em territórios ou segmentos específicos de usuários; e ii) diferentes organizaçóes do aparato estatal, atuantes em nível nacional, provincial ou local, em variadas áreas, tais como a regulação do consumo (secretarias, juntas, comissốes e conselhos nacionais), a saúde pública, a assistência social e o Poder Judiciário, entre outros.

13. Um antecedente muito importante no Brasil é o trabalho do professor Antônio Nery Alves Filho, do Centro de Estudos e Terapia do Abuso de Drogas (Cetad), da Universidade Federal da Bahia (UFBA). 0 modelo criado por ele, chamado de "consultório de rua", foi uma grande referência para a redução de danos na região. Mais detalhes em Consultório... ([s.d.]) e Nery Filho, Valério e Monteiro (2011). 
Outro elemento digno de destaque são os arranjos institucionais montados para a provisão de cuidado e atenção a usuários de drogas nos distintos países. Nos casos de Argentina, Brasil e México, o arranjo adotado combina organizaçóes públicas, em diferentes níveis das administraçôes estatais, com prestadores de serviços privados e organizaçôes da sociedade civil. Já nos casos da Colômbia e do Uruguai, observa-se menor presença de serviços públicos e maior proeminência de serviços prestados por organizaçōes da sociedade civil. No caso específico do Uruguai, até 2005 a presença de organizaçóes da sociedade civil na atenção especializada - NA, CTs e ONGs que praticam a $\mathrm{RD}$ - era bem mais expressiva do que a de uns poucos hospitais psiquiátricos públicos.

Outra dimensão relevante da complexificação desses arranjos é a que diz respeito ao financiamento das ofertas de cuidado. Para além dos serviços privados e filantrópicos tradicionais, percebe-se o incremento do financiamento oriundo de fontes tanto internacionais - organizaçóes do sistema da Organização das Naçóes Unidas (ONU) e ONGs - quanto públicas nacionais. As primeiras se direcionam principalmente a organizaçôes da sociedade civil, enquanto as segundas custeiam serviços prestados diretamente por agências estatais, ou por ONGs e entidades privadas, via fundos de fomento. Por fim, a diversificação está presente também nas metodologias e modalidades de cuidado, em que abordagens biomédicas hospitalocêntricas e religiosas - historicamente predominantes no campo - passam a conviver com ofertas inspiradas no paradigma psicossocial, com o uso da reduçáo de danos e do tratamento de base comunitária.

Esse processo resultou em múltiplas ofertas que se justapóem de forma fragmentada. As mais tradicionais e ainda dominantes - hospitais e clínicas, públicos e privados; grupos de ajuda mútua; e CTs - passaram a coexistir com as novas estratégias e modalidades assistenciais - centros de atenção especializada, serviços ambulatoriais, dispositivos territoriais e comunitários, programas de prevenção, programas de redução de danos - em agências públicas e organizaçóes da sociedade civil. Esta situação impôs a realização de articulaçôes em nível sistêmico, visando à coordenação entre os serviços, tendo em vista a garantia de acesso ao cuidado e seus fluxos, assim como à distribuição dos recursos financeiros. A seguir, apresentam-se os traços gerais das estratégias de articulação entre serviços e instituiçôes, em nível sistêmico, adotadas em cada país.

No Brasil, a Pauad organizou-se a partir dos mesmos princípios e diretrizes da política de saúde mental instituída pela reforma psiquiátrica (2001), apostando na atenção psicossocial de base comunitária, por meio de serviços ambulatoriais prestados pelos Caps $\mathrm{AD}$. Estes equipamentos são definidos como dispositivos estratégicos para a articulação da rede intersetorial de serviços voltados à atenção integral dos usuários - outros serviços de saúde (atenção básica e especializada), assistência social, educação, geração de emprego e renda, entre outros - nos diversos 
territórios. A partir de 2011, a articulação dos serviços de saúde foi formalizada por meio de portarias do Ministério da Saúde que instituíram as Redes de Saúde, entre as quais as Redes de Atenção Psicossocial (Raps). O mandato das Raps é "ampliar e diversificar os serviços do SUS [Sistema Único de Saúde] para a atenção às pessoas com necessidades decorrentes do consumo de álcool, crack e outras drogas e suas famílias", numa perspectiva intersetorial. ${ }^{14}$ Foram incluídos, então, nas Raps os serviços residenciais prestados pelas CTs, que, a partir daí, foram habilitadas a receber recursos do ministério e das secretarias de saúde de estados e municípios. Em paralelo, e de forma mais concorrencial do que articulada, foi também instituído o financiamento de CTs, por meio dos fundos de políticas antidrogas, frequentemente associados aos órgãos de justiça e segurança pública, nos níveis federal e estadual, além de fontes associadas às políticas de assistência social, no nível municipal. Para além da atenção realizada pelos Caps ADs e das CTs, existe ainda um parque de clínicas psiquiátricas particulares que atendem primordialmente às classes mais abastadas. Para terem acesso a estas clínicas, os segmentos mais vulneráveis podem recorrer por via judicial - ou seja, um juiz pode vir a determinar internação, a partir de demanda apresentada pelo próprio usuário, sua família ou alguma autoridade pública (Santos e Pires, capítulo 4, neste volume).

Na Argentina, a Sedronar, criada em 1989, passou por um processo de reestruturação interna em 2014, que envolveu uma mudança de paradigma em matéria de atenção aos consumos problemáticos de drogas. Suas atividades foram circunscritas a funçóes de prevenção, capacitação e assistência; e, com a intenção de "trazer a Secretaria para as ruas", concedeu-se reconhecimento e financiamento a diferentes experiências de abordagem comunitária, ao mesmo tempo que se criaram quatro dispositivos territoriais próprios, com forte ênfase na participação e integração comunitária.

Esses dispositivos (atualmente, Diat e DTC), além de melhorarem a acessibilidade nos territórios onde foram instalados, se somaram à oferta assistencial da Sedronar, oferecida por meio do Centro de Consultas y Orientación (Cedecor). Neste último dispositivo, se oferecem serviços de orientação, admissão e encaminhamento das pessoas que demandam atenção e/ou assessoramento. Ou seja, o Cedecor oferece uma primeira escuta, possui serviços de consultório externo e, caso seja considerada necessária uma internação, encaminha as pessoas a ONGs, que, em sua maioria, ainda operam com o modelo de CT. Mas também pode optar por fazer encaminhamentos para assistência ambulatorial, ofertada por dispositivos da própria secretaria (Diat, DTC e Casas de Atención y Acompañamiento Comunitario - CAAC) ou outros, ofertados por municípios e províncias, dependendo do que esteja mais próximo dos usuários.

14. A Portaria do Ministério da Saúde no 3.088/2011 define os seguintes serviços como componentes da Raps: serviços de atenção básica em saúde; serviços de atenção psicossocial especializada; serviços de atenção de urgência e emergência; serviços de atenção hospitalar, serviços residenciais de CTs, entre outros. Mais detalhes, ver Brasil (2011). 
Além da oferta assistencial da Sedronar, o sistema de saúde oferece serviços em hospitais gerais e especializados, centros de saúde mental, centros de atenção primária e centros-dia. Conta-se ainda com alguns dispositivos de assistência social ligados aos municípios e às províncias. Esta oferta se compóe majoritariamente de tratamentos ambulatoriais na modalidade de consultório na rua e hospital-dia. No que se refere a serviços de internação, existem programas de desintoxicação em alguns poucos hospitais gerais e especializados. Entretanto, a oferta de tratamentos residenciais de longo prazo se reduz àquela oferecida pelos hospitais especializados em saúde mental e consumos problemáticos, sobretudo para pessoas com comorbidades psiquiátricas.

No Uruguai, a oferta de serviços começa a se expandir significativamente somente a partir de 2005. Em 2013 é criada a Red Nacional de Atención en Drogas (Renadro), que passa a operar com recursos de um fundo administrado colegiadamente por diferentes agências públicas: Junta Nacional de Drogas, Ministério de Saúde; Instituto del Niño y del Adolescente; Administración de Salud del Estado; e a Corporación Nacional para el Desarrollo. A Renadro opera como uma rede paralela no âmbito dos serviços de saúde pública, articulando instituições públicas e privadas que prestam atenção especializada a usuários de drogas. Além disso, financia e articula os seguintes serviços: centros de internação, como os centros públicos residenciais em Montevidéu e nos demais departamentos; CTs; centros de informação, diagnóstico e encaminhamento (dispositivos ciudadela); grupos terapêuticos (Grupos T), em bairros periféricos de Montevidéu; e, finalmente, os programas de proximidade - como a Unidad de Asistencia Móvil (UMA), o Programa Aleros e El Achique -, que envolvem dispositivos territoriais e de abordagem de rua. Como apontado por Musto (capítulo 7, neste volume), apesar do avanço na consolidação dos serviços e na ampliação do direito à saúde, a Renadro ainda carece de possibilidades de tratamento ambulatorial para os usuários problemáticos de drogas, restando um vazio institucional entre as abordagens territoriais e de escuta, de um lado, e as internaçóes, de outro. ${ }^{15}$

No México, dos anos 2000 em diante, consolidou-se um sistema apoiado em dois pilares. O primeiro envolve o financiamento público de centros de tratamento não governamentais de modalidade residencial - CTs, Anexos e instituiçóes assemelhadas. A partir de denúncias de graves violaçóes de direitos humanos nesses centros, fortaleceram-se processos de regulação e certificação, levando à normatização oficial para a prevenção, o tratamento e o controle das adições (NOM-028), primeiramente promulgada em 1998 e posteriormente revista em

15. Musto (capítulo 7, neste volume) relata, com base em diagnósticos locais financiados pela Junta Nacional de Drogas, que usuários dispostos a iniciar um tratamento acabam encontrando ofertas que se limitam a ações de "escuta", não necessariamente envolvendo instituições descentralizadas para tratamento médico profissional. 
2009. Entre 2010 e 2018, este sistema de certificação foi a base para a concessão de financiamento governamental (becas) de vagas de internação para tratamento em entidades conveniadas. ${ }^{16}$

O segundo pilar assenta-se em reformas do sistema de saúde, que levaram à criação da categoria de unidades médicas especializadas, favorecendo a oferta pública de atenção primária à saúde de usuários problemáticos de substâncias. A partir de 2011, passaram a estar disponíveis serviços ambulatoriais - como os Centros de Atención Primaria a las Adicciones (Capas) e os Centros de Integración Juvenil (CIJs) - além de um seguro público de saúde, que visa cobrir o tratamento de dependentes químicos em estabelecimentos privados. Assim, o sistema se organiza a partir de duas modalidades de serviço: i) ambulatoriais, fornecidos pelos Capas, CIJs, grupos de ajuda mútua e hospitais psiquiátricos; e ii) residenciais, a cargo dos centros residenciais públicos, CTs, Anexos, grupos de ajuda mútua, albergues e grupos teoterapêuticos. ${ }^{17}$ Cada um desses serviços pode envolver combinações de atenção médica profissional, cuidado entre pares ou modelos mistos. Há também, em proporção residual, programas de redução de danos conduzidos por organizaçóes da sociedade civil (Ospina-Escobar, capítulo 6, neste volume).

No caso da Colômbia, desde o final do século XX, fortaleceu-se uma articulação entre CTs e hospitais psiquiátricos da rede pública em torno das Unidades de Atención Integral de las Conductas Adictivas (Uaicas), tendo em vista a provisão de serviços na área de saúde mental. Estes serviços promovem internaçóes para desintoxicação (geralmente envolvendo fármacos substitutivos) nos hospitais, seguidos de internação em CTs para tratamentos de base espiritual e moral. Na década de 2000, inaugura-se um novo pilar, com a consolidação gradual da nova política de atenção ao consumo de drogas, orientada pela perspectiva da RD. A Lei no 1.566/2012, que regulamentou a nova política instituída em 2007, garantiu a atenção a dependentes químicos no sistema geral de saúde, em serviços de desintoxicação e tratamento. A lei exige, contudo, o consentimento livre e informado dos usuários para estes procedimentos. Além disso, a nova política consolidou as bases para o desenvolvimento de estratégias alinhadas à redução de danos e para a ampliação e o fortalecimento de açóes de reabilitação integral e inclusão social, por meio de organizaçōes da sociedade civil (Góngora, Salazar e Borja, capítulo 5, neste volume).

Assim, é possível dizer que está em curso nesses países, nas últimas décadas, um movimento promissor de expansão e diversificação das possibilidades e modalidades de cuidado a usuários problemáticos de drogas. Em todos eles,

16. Em 2019, o governo recém-empossado suspende o financiamento público a este tipo de estabelecimento.

17. Conforme relatou Ospina-Escobar (capítulo 6, neste volume), uma pesquisa nacional, realizada em 2016, indicou que aproximadamente três quartos dos respondentes acessaram tratamentos em serviços residenciais e apenas um quarto, em serviços ambulatoriais. 
verifica-se um processo de multiplicação das ofertas, resultando em arranjos institucionais mais complexos, caracterizados pela convivência - mais ou menos conflituosa - entre ofertas tradicionais e novas modalidades de cuidado. Em cada um desses países, verificam-se também esforços governamentais no sentido de organizar esta convivência, por meio da instituição de sistemas de políticas nacionais, integrados por princípios, modalidades e categorias de serviços diversos, que coordenam os fluxos e a alocação de recursos financeiros entre eles.

\section{INTEGRAL, ARTICULADO, TERRITORIAL E COMUNITÁRIO: SOBRE A POTÊNCIA DAS NOVAS ABORDAGENS}

Após a análise mais geral dos sistemas e arranjos institucionais de cada país feita no item anterior, esta subseção reflete sobre as modalidades de cuidado a usuários de drogas que emergiram nas últimas décadas na região, tendo em vista compreender melhor suas características, formas de operação e potencialidades.

Como já mencionado, o projeto que deu origem a este livro envolveu a realização de pesquisas empíricas, de inspiração etnográfica, em alguns serviços, programas e dispositivos de cuidado representativos das estratégias emergentes no período recente, em cada contexto nacional - os Caps AD, no Distrito Federal (Brasil); os Capas, em San Luis Potosí (México); os Diats e DTCs, na região metropolitana de Buenos Aires (Argentina); os Centros de Escucha, em Bogotá e Cali (Colômbia); e o Achique de Casavalle, na zona norte de Montevidéu (Uruguai). Considerando que os capítulos precedentes apresentaram, com mais detalhe, os procedimentos metodológicos envolvidos e os resultados de cada estudo específico, esta subseção apresenta uma síntese dos casos estudados, salientando a inserção desses nos arranjos institucionais nacionais e suas principais conquistas e potenciais.

Os casos brasileiro e mexicano podem ser compreendidos como representativos de reformas conduzidas no interior dos sistemas de saúde de cada país, voltadas à ampliação da oferta de serviços ambulatoriais de atenção à saúde mental e a usuários de substâncias psicoativas, em contraposição às internaçóes hospitalares de longo prazo. Ambos os países apostaram na implantação de equipamentos públicos, descentralizados, de acesso gratuito, que conjugam diferentes recursos terapêuticos (atenção farmacológica, psicológica, além de atividades culturais e recreativas, entre outras). Porém, há importantes diferenças entre os dois casos no que diz respeito à incorporação da redução de danos e à articulação de redes de serviços e dispositivos de abordagem territorial. 
O caso estudado por Ospina-Escobar (capítulo 6, neste volume), no México, é o de um Capa, ${ }^{18}$ serviço criado por reformas do sistema de saúde, ocorridas a partir de 2011, que inauguraram a oferta pública de atenção primária a usuários de substâncias em equipamentos especializados. Em 2019, havia 343 unidades de Capas distribuídas pelos 32 estados da república mexicana, localizados nos municípios com maior presença de pessoas em situação de consumo e risco. Apesar de serem parte de uma estratégia de descentralização territorial da atenção ambulatorial, visando ao tratamento em liberdade, com a manutenção do convívio social pelos beneficiários, os Capas não incorporaram a redução de danos, nem os princípios do tratamento de base comunitária. São serviços ainda marcados por um foco prioritário no uso de substâncias (em contraste com um foco nos sujeitos) e na promoção da abstinência.

As equipes dos Capas são formadas por psicólogos, assistentes sociais, além de diretores e gestores, que oferecem serviços diurnos. Seu modelo de atenção inclui psicoterapia breve, segundo a abordagem cognitivo-comportamental, além de serviços especializados para jovens em situação de risco psicossocial, usuários de drogas experimentais ou ocasionais e pessoas com dependência química. O tratamento conjuga cuidado farmacológico e psicossocial, além de atenção aos familiares, por meio de terapias em grupo. Os Capas prestam serviços gratuitos para as comunidades situadas nos territórios em que estáo instalados. $\mathrm{O}$ trabalho de Ospina-Escobar (capítulo 6, neste volume) abordou a operação das setes unidades de Capa existentes na província de San Luis Potosí. ${ }^{19}$

No Brasil, o estudo empírico teve como objeto os Caps AD situados no Distrito Federal. Trata-se de serviço integrante do SUS, presente na maioria dos municípios brasileiros de grande e médio porte. ${ }^{20}$ Os Caps AD oferecem atenção ambulatorial especializada a pessoas com transtornos decorrentes de usos problemáticos de álcool e outras drogas. Dotados de equipes multiprofissionais - médicos, enfermeiros, psicólogos, assistentes sociais, entre outros - estes serviços oferecem consultas individuais, dispensaçáo de medicamentos, terapias em grupos, além de oficinas e atividades culturais e recreativas. As atividades sáo oferecidas diariamente, em período diurno (das 8 às 17h), havendo ainda uma modalidade de Caps $\mathrm{AD}$ que oferece acolhimento integral, permitindo aos usuários pernoitarem no equipamento por até quinze dias. Este acolhimento deve ser voluntário, não havendo qualquer tipo de cerceamento à entrada e saída dos acolhidos, mesmo durante o período em que estão hospedados.

18. 0 capítulo de Opina-Escobar abordou também a operação de um centro público de tratamento residencial e 23 centros de tratamento não governamentais. Trata-se de ofertas representativas das abordagens mais tradicionais do campo de atenção a usuários de drogas. Por isso, não serão objeto de destaque nestas análises de temas transversais às experiências associadas às novas modalidades de cuidado emergentes nas últimas décadas.

19. Em 2019, o Consejo Nacional contra las Adicciones (Conadic), do México, considerou a província de San Luis como aquela que oferecia as melhores respostas em matéria de atenção aos usos problemáticos de drogas, tanto no que se refere à maneira como estão estruturados os serviços quanto pela forma como opera a coordenação de sua atuação. 20. O SUS dispõe hoje de cerca de quatrocentos Caps AD em todo o território nacional, parte deles para atendimento em horário diurno (das 8 h às 17h) e outra parte para acolhimento integral - os chamados Caps AD III. 
Diferentemente dos Capas do México, os Caps AD brasileiros têm sua atuação formalmente orientada pela lógica da redução de danos. Neste sentido, a política atribui a estes equipamentos a função estratégica de articulação, em seus territórios de abrangência, das Raps, e destas com outras redes de serviços públicos (assistência social, educação etc.), bem como instituiçôes (empresas e ONGs). É por meio destas articulaçóes que se espera produzir a atenção integral aos usuários.

Além dos serviços ofertados no espaço dos Caps $\mathrm{AD}$, a política prevê também açóes extramuros, tais como visitas domiciliares e abordagens de rua, em cenas de uso. Estas açôes podem envolver outras organizaçóes parceiras (inclusive ONGs), além de redutores de danos. No capítulo correspondente, Santos e Pires (capítulo 4, neste volume) apresentam os resultados da pesquisa empírica conduzida nas sete unidades de Caps AD do Distrito Federal.

Os casos empíricos que foram objeto de estudo em Argentina, Colômbia e Uruguai exemplificam outra modalidade emergente na regiāo de atenção e cuidado a usuários de drogas. Trata-se de dispositivos territoriais e comunitários menos ancorados em serviços ou sistemas de saúde e mais voltados à ativação de redes sociais nos territórios, ainda que sob formas específicas, em cada contexto nacional. Os casos analisados nestes três países oferecem assistência básica imediata a pessoas em situação de vulnerabilidade, e caracterizam-se por imporem baixa exigência aos usuários, conforme o princípio da redução de danos.

Os serviços estudados por Corbelle (capítulo 3, neste volume), na Argentina - o Diat e o DTC -, inserem-se no conjunto das estratégias assistenciais desenvolvidas pela Sedronar a partir 2014. Segundo a autora, existem atualmente no país 62 Diats, em dezenove das 23 províncias argentinas; e 32 DTCs, em treze províncias. A maioria destes dispositivos (quinze e treze, respectivamente) se encontra na província de Buenos Aires, principalmente na região metropolitana. Os Diats são centros de caráter público e ambulatorial que prestam serviços gratuitos, a partir de arranjos de cogestáo entre uma ONG, a administração municipal e o governo provincial. São constituídos por equipes multidisciplinares, além de operadores e oficineiros, que desenvolvem trabalhos em torno de três eixos: i) abordagem territorial - identificação e mobilização dos atores inseridos na comunidade, e que podem contribuir para o enfrentamento dos problemas locais; ii) assistência - articulação de serviços e intervençóes terapêuticas que visam à (re)construção de projetos de vida e à inclusão comunitária dos usuários; e iii) promoção - recuperaçáo do acesso a direitos e mitigação de vulnerabilidades históricas, por meio de iniciativas voltadas ao fortalecimento de laços sociais, tais como açôes de formação nos campos cultural, desportivo, artístico e recreativo. Os três eixos devem agir de forma articulada, visando ao cuidado integral das pessoas, a partir de uma perspectiva de direitos. 
Os DTCs, por sua vez, operam com a metodologia do tratamento comunitário, tal como proposto pelo modelo ECO2. Constituem-se como dispositivos territoriais de baixa exigência (em termos de acesso e adesão), que se propóem a criar, visibilizar e fortalecer as redes locais, promovendo "a reorganizaçáo dos recursos da comunidade, de forma a aumentar as suas competências na prevenção, contenção e redução dos riscos e danos relacionados com o consumo de substâncias e outras situações críticas associadas" (Tufró e Carroli, 2018, p. 3, tradução nossa, apud Corbelle, capítulo 3, neste volume). ${ }^{21}$ As equipes do DTC são compostas por trabalhadores com distintos perfis - de profissionais de saúde e outras áreas a oficineiros, além de referências locais -, que realizam trabalhos na rua, fazem acompanhamento de casos e promovem ações de vinculação. $\mathrm{O}$ estudo de Corbelle (capítulo 3, neste volume) se concentrou na operação de um Diat e um DTC localizados em áreas de grande vulnerabilidade social de dois municípios ao norte da região metropolitana de Buenos Aires, ambos caracterizados pela heterogeneidade interna de suas condiçóes sociodemográficas.

$\mathrm{Na}$ Colômbia, o estudo empírico desenvolvido por Góngora, Salazar e Borja (capítulo 5, neste volume) se concentrou em um tipo de dispositivo característico da Política Nacional para la Reducción del Consumo de Sustancias Psicoactivas y su Impacto, promulgada em 2007 e posteriormente reforçada em 2012 e 2019. Trata-se dos Centros de Escucha - componente estratégico do TBC, que desenvolve um trabalho de vinculação, ativação de redes, articulação, além do desenvolvimento contínuo de pesquisas. São operados por organizaçōes da sociedade civil, devendo se localizar nas áreas de residência ou circulação cotidiana de seus usuários (por exemplo, colégios, prisóes, bairros carentes e cenas de uso), de modo a proporcionar amplo e fácil acesso.

As equipes desses centros envolvem profissionais de diferentes áreas (mas, em especial, das ciências sociais, humanas e da saúde), atores comunitários e pares (usuários e ex-usuários de drogas). Há uma grande plasticidade nas formas específicas de organização e operação dos Centros de Escucha, devido à sua inserção em diferentes contextos sociais. Porém, de forma geral, devem ofertar: i) escuta e avaliação de necessidades; ii) alfabetização e educação sobre HIV/Aids e drogas; iii) orientação sobre consumo de drogas e sexo seguros; iv) entrega de preservativos e "parafernália” para uso de drogas; v) assistência básica, incluindo alimentação, primeiros socorros, banheiros, duchas, lavanderia, roupeiro, alojamento etc.; e vi) inserção laboral. Há também casos de Centros de Escucha que se concentram

21. No original: "la reorganización de los recursos comunitarios, con el fin de incrementar sus competencias en materia de prevención, contención y reducción de riesgos y daños en relación a los consumos de sustancias y otras situaciones críticas asociadas". TUFRÓ, F.; CARROLI, M. Tratamiento comunitario, una experiencia de registro, sistematización, y evaluación de abordaje territorial integral. In: JORNADAS NACIONALES DE DEBATE INTERDISCIPLINARIO EN SALUD Y POBLACIÓN, 13., 2018, Buenos Aires. Anais... Buenos Aires, ago. 2018. 
em estratégias mais heterodoxas, como o trabalho envolvendo majoritariamente operadores pares, com ações de redução de danos em diferentes espaços, por meio de equipes móveis e parcerias com instituiçóes educativas e culturais. O trabalho de Góngora, Salazar e Borja (capítulo 5, neste volume) examinou a operação de Centros de Escucha em dois contextos diferentes: o primeiro, em cenas de uso nas áreas centrais de Bogotá; e o segundo, em dois bairros (um central e outro periférico) da cidade de Cali.

Por fim, no Uruguai, Musto (capítulo 7, neste volume) conduziu pesquisa sobre o caso do Achique de Casavalle, projeto inicialmente conduzido por um pequeno grupo de voluntários (2008), que passou a integrar o rol de programas de proximidade com a Renadro, quando esta foi instituída, em 2016. Desde então, o Achique pode beneficiar-se de incentivos e apoio governamental.

Os programas de proximidade se caracterizam como opçóes de atenção a usuários de drogas, de baixa exigência, voltadas a melhorar a acessibilidade ao sistema de tratamento (rede mais ampla), por meio da inserção de dispositivos em contextos marcados pela vulnerabilidade social e pela presença de cenas de uso. Este é o caso de Casavalle, localizado na zona norte de Montevidéu, regiáo com altos índices de criminalidade, onde se concentram populaçóes com grandes desvantagens socioeconômicas. Programas de proximidade, de forma geral, visam à prevenção do consumo problemático, além da captação, diagnóstico e encaminhamento de usuários problemáticos a serviços especializados. Atuam também em favor do fortalecimento das articulaçōes territoriais dos serviços.

O Achique é um serviço diurno, conduzido por uma equipe de psicólogos, assistentes sociais e referências comunitárias, que atendem pessoas em situação de vulnerabilidade (em grande parte, pessoas em situação de rua), fornecendo alimentação, espaço de sociabilidade, lavanderia, atividades recreativas e de formação (cursos, oficinas etc.), além de promoverem a articulação com diversos outros serviços (saúde, assistência social, educação, trabalho etc.) e de redes comunitárias.

Em conjunto, os cinco casos empíricos estudados permitem uma aproximação das abordagens emergentes na regiâo da América Latina nas últimas décadas, em sua diversidade, lançando foco simultaneamente em dois eixos (que podem ser pensados de forma articulada): i) nas reformas dos serviços de saúde, no sentido da criação ou expansão da atenção ambulatorial especializada em saúde mental e dependência química (Capa e Caps $\mathrm{AD}$ ); e ii) na criação de dispositivos de base territorial e comunitária (como os Diats, DTCs, Centros de Escucha e programas de proximidade, como o Achique de Casavalle). Importante frisar que não se pretende aqui reduzir a complexidade das ofertas presentes em cada país (a qual foi abordada na seção anterior). Até porque é possível que existam, em cada contexto nacional, experiências equivalentes e que se relacionem de forma complementar com 
os casos sob análise. A tipologia aqui adotada, contudo, nos permite lançar luzes sobre as dinâmicas de operaçáo destas novas modalidades de cuidado a usuários de substâncias psicoativas (SPA), assim como seus limites e suas potencialidades. A partir do exame das cinco experiências, destacamos, como pontos fortes, os seguintes aspectos.

- Acessibilidade ampliada. Os cinco casos representam esforços de ampliação do acesso ao cuidado de consumidores problemáticos de substâncias psicoativas. Esta possibilidade se torna ainda mais importante quando consideramos o histórico da região, de ofertas restritas, não somente em termos de modalidades, mas também quanto à natureza jurídica dos prestadores de serviços: na maioria dos casos, os prestadores estavam, até entâo, concentrados no setor privado (clínicas e hospitais). A ampliação do acesso se deu a partir de três eixos: i) universalidade, com gratuidade dos serviços, uma vez que se ampliaram as ofertas vinculadas a órgãos públicos, ou financiados pelo Estado; ii) maior atenção a segmentos vulneráveis, por meio da descentralizaçáo dos serviços ao longo dos territórios e da implantação de dispositivos em áreas carentes (seja no centro das cidades, seja nos bairros periféricos) e cenas de uso; e iii) baixa exigência das estratégias de cuidado, no que diz respeito às expectativas de adesão, a contrapartidas ou condicionalidades impostas aos usuários, com forte orientação para a redução de danos (com exceção do caso dos Capas, no México).

- Garantia ou restituição de direitos. As experiências analisadas indicam que as novas abordagens emergentes nesses países se orientam por uma perspectiva de garantia de direitos, em duplo registro: de um lado, porque se trata de metodologias de cuidado que respeitam direitos individuais e humanos, por meio da oferta de serviços de atenção em liberdade, prestados somente com consentimento dos usuários e seus familiares o que se contrapóe a uma longa tradição, ainda presente na regiáo, de tratamentos involuntários e compulsórios. De outro lado, os serviços também têm por objetivo a promoção do acesso a um conjunto de direitos (civis, políticos e sociais), muitas vezes perdidos ou retirados, em razão dos processos de vulnerabilização e exclusão social sofridos por muitos daqueles e daquelas que fazem usos problemáticos de drogas.

- Integralidade e redes. O conjunto dos casos estudados também adota a perspectiva da integralidade do cuidado, que visa abordar os sujeitos como um todo, isto é, em todas as suas necessidades e demandas, superando visóes fragmentadas por setores assistenciais, e ofertando um cuidado além das drogas. Para tanto, a busca pela construçáo de redes comparece 
como estratégia fundamental, seja para articular serviços de diferentes áreas (saúde, assistência social, educação, justiça etc.) e instituiçóes (do governo, da sociedade civil e do setor privado), seja para ativar e dinamizar os laços sociais que vinculam os usuários a suas comunidades de referência.

- Pluralidade de bases de conhecimento. Outra marca das experiências contemporâneas aqui analisadas diz respeito à valorizaçáo de variadas bases de conhecimento sobre o uso problemático de drogas, bem como das intervençóes inovadoras produzidas por elas. Esta pluralidade desloca, em alguma medida, a hegemonia anterior dos modelos médico e religioso ${ }^{22}$ no entendimento e enfrentamento dos problemas associados ao uso de drogas, e se manifesta tanto pela mobilização de profissionais com diferentes formações quanto pela articulação dos saberes profissionais com outros saberes menos institucionalizados. Em todos os casos estudados, os serviços são providos por equipes multidisciplinares, integradas por diferentes tipos de profissionais - tanto das áreas de saúde, assistência social e educação quanto das artes (visuais, música, dança etc.) -, além de outros dos campos das ciências humanas e sociais. No que tange às formas de conhecimento não profissionais, comparece nas experiências estudadas o trabalho de oficineiros, das referências comunitárias e, especialmente, o engajamento de pares (usuários ou ex-usuários de drogas) nos programas de reduçáo de danos e nas intervençóes em cenas de uso. Assim, destaca-se, nestas modalidades emergentes de cuidado, o empenho pela articulação de formas plurais de se entender e agir sobre a questão dos usos problemáticos de psicoativos.

- Singularidade. Uma das características mais definidoras das abordagens emergentes, e que contribui decisivamente para distingui-las das abordagens institucionais - hospitalocêntricas e religiosas -, é a busca pelo entendimento dos usuários e dos seus problemas com as drogas a partir do registro da singularidade. ${ }^{23}$ As abordagens mais tradicionais têm como marca fundamental o esforço de normalizaçáo e a modelagem dos sujeitos às instituiçóes e seus objetivos, por meio de um roteiro geral e de um modelo único de cuidado, aplicáveis a todo e qualquer indivíduo que a elas se submeta. Diferentemente, nas experiências contemporâneas aqui analisadas, os sujeitos são reconhecidos não só como portadores de direitos, mas também como sujeitos autônomos e capazes de assumir as rédeas dos seus projetos de vida. Neste sentido, cabe aos agentes do cuidado apoiar o desenvolvimento desses projetos, mobilizando os recursos

22. À exceção do México, onde mesmo as equipes multidisciplinares dos Capas são coordenadas por médicos e psiquiatras. 23. Novamente, o caso mexicano se distingue, na medida em que persistem ali as abordagens que assumem a falta de assistência às pessoas que fazem usos problemáticos de drogas. 
necessários nas redes institucionais e sociais disponíveis no território dos sujeitos. Assim, por meio da articulação de saberes variados, os meios institucionais são tomados em sua plasticidade para que se moldem e sirvam ao desenvolvimento dos sujeitos, com vistas à produção de uma atenção singular:

atentar para a singularidade de cada território e desvendar os modos locais de significados atribuídos ao consumo (...) [promovendo o desenvolvimento, e não de] uma resposta unívoca e linear (...) de múltiplas respostas que atendam a complexidade do cenário social em questão. Respostas comunitárias que atuam com e a partir dos territórios vulneráveis, que são acessíveis à população que neles reside e que atuam de forma integral em todas as dimensóes da vida dos sujeitos (Romero et al., 2019, p. 33, tradução nossa, apud Corbelle, capítulo 3 , neste volume). ${ }^{24}$

- Novos sentidos de efetividade. Finalmente, podemos depreender das experiências estudadas (e dos seus modelos subjacentes) um esforço de se redefinir o sentido de efetividade das açóes de atenção e cuidado aos usuários problemáticos de drogas. Por muito tempo, sustentou-se uma concepção de efetividade que se restringe à interrupção ou cessação total do uso de substâncias. Tal concepção está ainda fortemente presente nos contextos nacionais estudados, não apenas devido à predominância de ofertas tradicionais (baseadas nos modelos médico-institucional ou religioso), mas também por força da hegemonia dos próprios saberes que as sustentam, o que leva à resiliência das percepçóes e práticas tradicionais nos contextos cotidianos de implementação das novas abordagens. Isto foi observado nos casos dos Capas em San Luis Potosí, no México, assim como nas operaçóes cotidianas dos Caps AD, no Distrito Federal, no Brasil. No primeiro caso, ainda que em seus discursos os profissionais estabelecessem como meta do tratamento a melhoria da qualidade de vida e a reinserção social dos "pacientes", a utilização frequente de exames toxicológicos denuncia não só a importância conferida pelos Capas à abstinência, mas sua mobilização como moeda de troca para a viabilização do acesso de usuários a benefícios assistenciais concedidos no âmbito do programa de tratamento (Ospina-Escobar, capítulo 6, neste volume).

No caso brasileiro, a situação é ainda mais delicada, pois a política nacional que orientava a atuação dos Caps $\mathrm{AD}$, pelo menos até 2019, era explícita

24. No original: "atender la singularidad de cada territorio y desentrañar los modos locales de significados dados al consumo (...) [fomentando el desarrollo, antes que de] una respuesta unívoca y lineal (...) de múltiples respuestas que atiendan a la complejidad del escenario social en cuestión. Respuestas comunitarias que trabajen con y desde los territorios vulnerabilizados, que resulten accesibles para la población que reside en ellos, y que trabajen de manera integral en todas las dimensiones de la vida de los sujetos". ROMERO, C. A. et al. Modelo de abordaje integral territorial de los consumos problemáticos: una experiencia de política pública. Buenos Aires: Sedronar, 2019. 
em sua diretriz de adoção da lógica de redução de danos - o que não ocorre nos Capas mexicanos. Mesmo assim, como observaram Santos e Pires (capítulo 4, neste volume), alguns profissionais mantinham-se apegados à ideia de abstinência como meta principal e final do tratamento, encontrando formas de reintrodução da concepção hegemônica e tradicional no âmbito do novo serviço. Talvez no caso dos Caps $\mathrm{AD}$, sua inserçáo institucional no sistema de saúde contribua para a maior adesão dos profissionais do cuidado à percepção, bastante associada ao campo biomédico, de que o uso problemático de SPA caracteriza-se como uma doença, cuja cura reside na manutenção da abstinência. Não parece à toa que, de todos os cinco casos estudados, foi somente nos Capas e no Caps $\mathrm{AD}$ que identificou-se que os profissionais se referem à clientela dos serviços como pacientes.

Mesmo diante da resiliência da concepção restrita, e ainda hegemônica, de efetividade do cuidado a usuários de SPA - segundo a qual o sucesso do tratamento é representado pela abstinência -, as abordagens emergentes nas últimas décadas impóem o tensionamento de tal concepção, bem como das aspiraçóes a se alcançar um mundo livre das drogas.

Esse tensionamento vem sendo impulsionado pela noção de redução de danos e por metodologias orientadas para a integralidade e a territorialidade do cuidado, em bases comunitárias. A redução de danos abre possibilidades de alargamento das concepçóes de efetividade, na medida em que desloca o foco da substância (do seu uso e da necessidade de interrompê-lo) para o sujeito e sua qualidade de vida - sua saúde e sua inserção social. Nesta linha, o sucesso do tratamento depende menos da presença/ausência da substância na vida do sujeito, e associa-se mais aos ganhos cumulativos, advindos das melhorias das condiçóes de vida dos usuários, nas suas diversas dimensóes. Estas melhorias são compreendidas no registro da promoção da cidadania dos usuários, levando ao reconhecimento destes como sujeitos de direitos, titulares e merecedores da atenção pública.

Nos casos inspirados na metodologia do TBC, acrescenta-se ainda, como dimensão relevante de sucesso e efetividade, a ideia de inserçáo social via circulação socioespacial. Oportunidades de circulação por redes institucionais, comunitárias e intersubjetivas, oferecidas a sujeitos em situaçôes de vulnerabilidade, são tidas como recursos úteis à restituição de direitos, à (re)construção de projetos pessoais e à integração social e comunitária, em âmbito coletivo. Para além dos impactos nas vidas dos sujeitos sob cuidado, a circulação socioespacial destes atores 
promove transformaçóes positivas na própria sociedade, no sentido de mitigar a estigmatização, a discriminação e os preconceitos associados aos usuários de drogas.

Exemplo notável dessas repercussões resultam da experiência do coletivo Free Soul, de Bogotá, narrada por Góngora, Salazar e Borja (capítulo 5, neste volume). Neste caso, a circulação socioespacial promoveu uma adaptação de dupla via, constituindo-se simultaneamente num ato estético, político e terapêutico. Os usuários transformaram os próprios espaços pelos quais passaram a circular (por exemplo, museus, exposiçóes, escolas, eventos etc.), alterando representaçóes sociais sobre usuários de drogas vulnerabilizados. Ao mesmo tempo, eles próprios se viam compelidos a se acomodar aos diferentes cenários e a estabelecer, ou renovar, conexóes com diferentes atores.

- Além das potencialidades das novas abordagens de cuidado a usuários de drogas, os estudos empíricos também apontaram alguns desafios e limitaçóes importantes dessas estratégias, associadas principalmente à sua implementação. Este é o foco da próxima seção.

\section{PRECARIEDADES, TENSÕES E DESAFIOS NA IMPLEMENTAÇÃO DAS NOVAS MODALIDADES DE CUIDADO}

Apesar dos avanços representados pelas novas modalidades de cuidado a usuários de drogas, os estudos de caso revelaram importantes desafios à sua consolidação como alternativa aos modelos hegemônicos, sobretudo no processo de sua implementação. A análise transversal dos casos empíricos indica que estes desafios se expressam em três dimensóes principais: precariedades materiais, tensóes relacionais e desafios de inclusão. Os elementos que integram cada uma destas dimensões indicam fatores que comprometem a realização plena das potências identificadas na seção anterior, sugerindo, assim, uma agenda de intervençóes políticas práticas voltadas ao fortalecimento, ao aprimoramento e à difusão destas experiências.

\subsection{Precariedades materiais}

Como visto anteriormente, a partir dos anos 2000, houve clara expansão das ofertas alinhadas com as novas modalidades de cuidado e atenção, em todos os cinco países analisados. Porém, as experiências concretas estudadas em cada um deles revelaram que a escala destas ofertas ainda se encontra muito aquém das necessidades de cobertura de seu público. Nos países em que há pesquisas sistemáticas e regulares sobre prevalência de uso de drogas na população,${ }^{25}$ as lacunas de

25. Dos cinco países estudados, o Brasil se apresenta como o único caso em que não se dispõe desses dados de forma sistemática e regular. 
atenção se tornam evidentes, uma vez que o público potencial excede em muito a capacidade dos serviços disponíveis. Esta limitação não decorre apenas do número restrito de serviços, programas e dispositivos existentes, mas, também, de grandes restriçóes ao bom desempenho destes, causadas pela precariedade material com a qual se dão as suas operaçóes cotidianas.

Um primeiro indicativo de precariedade material se refere ao financiamento desses serviços, programas e dispositivos. Apesar de terem sido identificadas novas fontes de financiamento nos diversos países - especialmente a partir do setor público -, que se somaram às já existentes (ONGs internacionais, doação/ caridade e venda de serviços no mercado privado), os estudos de caso mostraram que as experiências concretas são marcadas pelo subfinanciamento crônico e pela instabilidade das fontes de receita.

De forma geral, o acesso às modalidades de cuidado emergentes concorre, em posição de desigualdade, com as ofertas mais tradicionais do campo, dos setores privados e caritativos, ou mesmo de hospitais psiquiátricos (ou assemelhados) do setor público. No caso uruguaio, a própria conjuntura que deu origem à Renadro, envolvendo um bloqueio político das instituições de saúde pública ao atendimento a usuários problemáticos de drogas, é indicativa das dificuldades de financiamento de serviços pautados nas novas modalidades de cuidado. Criada como uma rede paralela, a Renadro opera por meio de uma governança complexa, principalmente por náo dispor de recursos próprios para financiar seus programas. $\mathrm{O}$ financiamento da rede depende de recursos aportados por um conjunto variado de ministérios e da arrecadação de valores e bens oriundos do processamento judicial de crimes associados às drogas ilícitas.

À insuficiência dos recursos financeiros soma-se também a instabilidade do seu provisionamento. No caso de governos, ou setores de políticas públicas, em que as reformas neoliberais tiveram maiores avanços, a responsabilização do poder público pela manutençáo das atividades e serviços desempenhados por organizaçóes da sociedade civil se mostra bastante comprometida. Na Colômbia, o estudo dos Centros de Escucha, em Bogotá e Cali, revelou que, mesmo que sejam formalmente reconhecidos como parte importante de uma política nacional, estes dispositivos não têm financiamento garantido ao longo de todo o ano fiscal, e frequentemente o custeio de suas operaçóes básicas fica descoberto por alguns períodos.

A instabilidade do financiamento impóe aos projetos e dispositivos a necessidade de recorrerem continuamente a alternativas criativas de financiamento. Isto foi claramente ilustrado pelo caso do coletivo Free Soul, de Bogotá, em que a equipe profissional do projeto teve de recorrer a premiaçóes e editais de fomento, promovidos por museus e organismos internacionais, para viabilizar sua continuidade (Góngora, Salazar e Borja, capítulo 5, neste volume). Neste sentido, a busca 
incessante por fontes de financiamento - sempre de curto prazo - passa a ser mais uma das funçóes da equipe implementadora, consumindo tempo e energia que ela poderia dedicar exclusivamente ao cuidado. Além de precisarem preparar projetos e participar de concorrências pelos recursos, as equipes implementadoras se veem, em muitos casos, submetidas a exigências e pressóes por prestação de contas e demonstração de impactos - um conjunto oneroso de tarefas que transcendem as atividades-fim de prestação de serviços de atenção e cuidado.

O subfinanciamento e a instabilidade impóem grandes desafios à sustentabilidade dessas experiências no médio e no longo prazo. Mas, de forma ainda mais imediata, repercutem fortemente na qualidade da infraestrutura e na disponibilidade de recursos humanos dos dispositivos estudados. Em muitos dos casos estudados, foram identificadas precariedades relativas aos espaços em que funcionam os serviços e projetos. Por exemplo, o Achique de Casavalle (Uruguai) não conta com apoio de nenhum órgão governamental para estabelecer uma sede, e utiliza dependências de uma capela emprestada pela paróquia local. Por seu turno, o Diat JA (Argentina) utiliza espaço cedido e compartilhado por outros órgãos públicos. As instalaçóes em que funcionam os Caps $\mathrm{AD}$ do Distrito Federal brasileiro, embora próprias, ou alugadas pelo governo distrital, não se encontram, na grande maioria dos casos, em conformidade com as diretrizes preconizadas em portarias do Ministério da Saúde. Em todos estes casos, a ausência de manutenção das estruturas prediais é visível, e situaçóes como goteiras em dias de chuva, móveis e janelas quebrados, além de banheiros interditados, foram relatadas como habituais.

No que tange aos recursos humanos, chamam a atenção não apenas as equipes reduzidas, mas a precariedade dos vínculos laborais - com exceção dos Caps $\mathrm{AD}$, no Distrito Federal ${ }^{26}$-, decorrente do financiamento insuficiente e instável. Por exemplo, no caso do Diat JA (Argentina), o tamanho reduzido da equipe tem comprometido a implementação de algumas açóes previstas no modelo. Como relatado por Corbelle (capítulo 3, neste volume), o eixo promoção e proteção de direitos tem sido sistematicamente relegado a segundo plano no Diat JA. No caso dos Caps AD do Distrito Federal brasileiro, observou-se a incipiência das atividades territoriais, de acompanhamento de pacientes em situação de rua ou em domicílio. Não só as equipes são insuficientes para dar conta simultaneamente do atendimento interno e externo, como também não há veículos para o transporte de profissionais e usuários para atividades "extramuros" (Santos e Pires, capítulo 4, neste volume).

26. Embora nos Caps AD do Distrito Federal os trabalhadores mantenham contratos estáveis com o setor público, isso não constitui um padrão no resto país. Em diversas cidades, os trabalhadores dos Caps AD são contratados por meio de vínculos precários e instáveis, em geral, via intermediação de organização da sociedade civil. 
O caso dos Capas (México) traz ainda outro exemplo. O estudo de Ospina-Escobar (capítulo 6, neste volume) indicou que, apesar de os documentos formais da política nacional preverem a realização de um trabalho de gestão e intervenção comunitárias a partir dos Capas, as unidades pesquisadas não dispunham de um trabalhador designado para tal função, ou mesmo de um cargo, em seu quadro funcional, a ser ocupado por algum funcionário com a responsabilidade de desempenhá-la. Assim, as funçóes relativas ao trabalho comunitário acabam sendo realocadas a profissionais de saúde, já assoberbados com as demandas de avaliação, atenção e acompanhamento clínico dos casos. Esta situação compromete os trabalhos de ativação e articulação das redes territoriais e comunitárias, que muitas vezes são realizados por pessoas que, embora com formação clínica, não dispõem de habilidades e ferramentas metodológicas adequadas à condução do trabalho comunitário.

Outro aspecto que merece destaque diz respeito aos vínculos empregatícios dos trabalhadores que atuam nestes serviços. Na maioria dos casos (exceção apenas aos casos dos Caps AD do Distrito Federal e dos Capas), observou-se a utilizaçáo de contratos precários, muitos deles remunerados por bolsas (becas), o que não favorece a dedicação exclusiva de trabalhadores a estes serviços, ao tempo em que impóe desigualdades salariais importantes entre eles. Exemplo ilustrativo destas situaçóes encontra-se no Achique de Casavalle (Uruguai), onde os contratos de trabalho têm duraçáo de três ou seis meses, e são estabelecidos por meio de ONGs, para evitar o regime de contrato típico do setor público, associado a direitos trabalhistas. Trabalhadores contratados sob essas regras atuam, muitas vezes, ao lado e nas mesmas funçóes que outros, detentores de cargos públicos e titulares de direitos de proteção social e trabalhista. Verificam-se ainda desigualdades salariais importantes entre trabalhadores com tarefas semelhantes, e tudo isto é percebido por eles como injustiça flagrante, o que promove um ambiente de trabalho tenso e inadequado ao bom desenvolvimento das atividades.

Nos casos estudados na Colômbia, situaçóes semelhantes se somam a interrupçóes frequentes no pagamento dos salários, devido à instabilidade do financiamento. Isto impóe grande pressão sobre as equipes, que se veem diante da necessidade de dar continuidade aos projetos, mesmo sem receberem sua remuneração, em face do risco de que se fragilizem os vínculos construídos arduamente com os participantes dos projetos e suas comunidades.

Em suma, para que a oferta de novas modalidades de atenção e cuidado a usuários problemáticos de drogas supere a pequena escala - típicas das fases de experimentaçáo e prototipagem -, adquira maior cobertura e realize suas potencialidades, é necessário maior investimento nas condições materiais de sua operação. Isto necessariamente envolve a expansão do financiamento e do provimento de infraestrutura e recursos humanos adequados à implementaçáo destas novas abordagens, que têm como componente essencial o complexo esforço de produção e manutenção de redes interinstitucionais, territoriais e comunitárias. 


\subsection{Tensões relacionais}

Para além das limitaçóes materiais, a implementação das novas estratégias e modalidades de atenção enfrenta ainda desafios tipicamente associados à atividade de promover e manter a ação coletiva em redes de serviços. Se as articulaçóes em rede já são desafiadoras no contexto de qualquer política pública - em especial nas situaçóes caracterizadas pela escassez de recursos -, quando se trata da oferta de cuidado a usuários de drogas, emergem com frequência problemas, tensóes e dissonâncias específicas entre serviços, instituições e atores comunitários. A seguir, abordamos os desafios inerentes a este tipo de política, tal como observados nos casos estudados.

Considerando que os serviços e dispositivos representativos dessas novas modalidades de cuidado a usuários de drogas devem ser estrategicamente localizados em comunidades e territórios com maiores vulnerabilidades, a fragilidade socioeconômica das populaçóes atendidas soma-se às demais precariedades materiais já aludidas, impondo desafios redobrados ao trabalho destes dispositivos. Estas condições foram observadas em todos os casos estudados, mas o Achique de Casavalle (Uruguai) e os Capas, em San Luis Potosí (México), ilustram, com muita nitidez, diferentes manifestações deste fenômeno.

No início de suas operaçóes, o Achique atendia principalmente a uma população jovem, residente no território e dotada de algum vínculo (ainda que prejudicado) com suas famílias, com instituições de educação e de saúde e com o mundo do trabalho. Musto (capítulo 7, neste volume) destaca, contudo, que houve, no período recente, uma precarização ainda maior das condições socioeconômicas do público usuário do serviço, que passou a ser constituído por pessoas em situação de rua, várias delas recém-egressas do sistema prisional. Por conta destas condiçóes, este público experimenta limitações ainda mais severas em suas possibilidades de articulação e inserção comunitárias, além de enfrentarem dificuldades para cumprir os acordos estabelecidos com vistas à sua participação nas atividades ofertadas - como encontros grupais periódicos, oficinas e outras atividades coletivas. Estas dificuldades derivam de questóes materiais e emocionais complexas, inerentes às condições a que estão expostos (Musto, capítulo 7, neste volume). Não obstante, para muitos destes sujeitos, o Achique constitui-se na instituição mais central em suas vidas.

No caso dos Capas, a política pública que devem implementar lhes atribui responsabilidades de formação de Coaliciones Comunitarias Contra las Adicciones, as quais têm por objetivo propiciar a participação e o envolvimento das comunidades locais, de modo que seus membros atuem proativamente na identificação e resolução de problemas comunitários. Não obstante, o estudo de Ospina-Escobar (capítulo 6, neste volume) mostra que, dos sete Capas em operação em San Luis Potosí, apenas três contavam com coalizóes ativas no momento da pesquisa. 
Segundo a autora, os funcionários dos Capas identificaram, como obstáculos à efetivação destas coalizóes, a precariedade socioeconômica vivida pelos membros das comunidades e a ausência de condiçôes mínimas de segurança nas localidades, além da precariedade material do próprio serviço. Considerando que a intervenção dos Capas sobre estes fatores é restrita, as condições para formação e boa operação de tais coalizóes comunitárias tornam-se muito adversas. Assim, tanto no caso do Achique de Casavalle como no dos Capas de San Luís Potosí, as condiçóes de precariedade socioeconômica do público e dos territórios atendidos - ao lado da pouca ação dos poderes públicos para mitigá-las - afetam negativamente as expectativas e possibilidades de envolvimento, participação e coprodução dos serviços.

A questão da violência e/ou ausência de segurança nos territórios também comparece como desafio a ser enfrentado pelos serviços, uma vez que dinâmicas conflitivas, originadas em outros contextos, podem vir penetrar no espaço institucional e comprometer seu desempenho. É o caso das oficinas conduzidas no DTC Barrio Ceibo (Argentina), observadas por Corbelle (capítulo 3, neste volume), em que disputas entre facçóes inimigas e até brigas de família se reproduziam no interior do dispositivo, criando perturbaçóes ao seu funcionamento. ${ }^{27}$

De modo geral, o estabelecimento de parcerias em contextos territoriais marcados por violências pode implicar a necessidade de escolha entre potenciais parceiros, uma vez que a abertura de canais com alguns atores pode inviabilizar interaçóes com outros. Em tais contextos, é comum que o acesso a certos espaços comunitários seja interditado, assim como a livre circulação de pessoas pelas ruas. Em comunidades com forte presença do tráfico de drogas e de atores armados, por exemplo, a construção de redes e a elaboração de mapas, diagnósticos, bem como a identificação de pessoas e locais de risco - elementos essenciais ao TBC - ficam bastante prejudicados. Por seu turno, cumpre reconhecer que comunidades também são compostas por pessoas e organizaçóes ligadas a grupos vinculados ao tráfico de drogas, dos quais recebem benefícios diretos e indiretos, que acabam por não terem nenhum interesse no confronto com eles. Nestas situaçóes, os dispositivos de tratamento de base comunitária podem se ver condicionados a proverem respostas parciais e a reproduzirem, em alguma extensão e por algum tempo, as lógicas dos conflitos locais e das formas de exclusão pré-existentes nos territórios (Corbelle, capítulo 3, neste volume; Góngora, Salazar e Borja, capítulo 5, neste volume).

Por fim, um último tipo de tensão relacional observada em diversos dos casos estudados diz respeito a divergências entre parceiros de uma mesma rede territorial e às tensôes que emergem de conflitos derivados de seus distintos modos de conceber e ofertar o cuidado a usuários de drogas. As relaçóes entre os Caps $\mathrm{AD}$ e as CTs, no contexto do Distrito Federal do Brasil, talvez sejam o exemplo mais contundente deste fenômeno. 
Como discutido por Santos e Pires (capítulo 4, neste volume), as interaçóes entre estes dois tipos de instituição são frequentes no Distrito Federal brasileiro, e caracterizadas por dependência mútua, configurando uma verdadeira parceria. No entanto, fortes tensões e atritos são muito comuns nestas interações, dado que as concepçóes e as abordagens sobre consumos problemáticos de drogas de cada parte são bastante diferentes. Enquanto a metodologia dos Caps AD orienta-se pela lógica da reduçáo de danos, as CTs realizam tratamento por meio de internaçóes de média e longa permanência, orientado exclusivamente para a promoção da abstinência e, em muitos casos, com base religiosa. Neste sentido, propusemos a noção de "antagonismo cooperativo" para descrever a situação e explorar os prejuízos dela derivados para a atenção e acompanhamento dos usuários, em termos da perda ou enfraquecimento de vínculos causados pelas contradiçóes entre as abordagens (Santos e Pires, capítulo 4, neste volume).

Esse mesmo tipo de tensão também foi observado nos casos estudados na Argentina, em que os Diat e DTC precisam se articular com outras instituiçóes e iniciativas, cujo modelo de atenção está centrado na abstinência - como as CAACs e seus curas villeros (Corbelle, capítulo 3, neste volume). O estudo dos Diats e DTCs abordou ainda outra forma de manifestação das dissonâncias entre parceiros, que se dão em torno da abordagem de casos de violência doméstica. A autora observou que médicos do hospital local tendem, com frequência, a se omitir, ou a se recusar a reportar estes casos às autoridades policiais e judiciais. Além disso, padres atuantes na comunidade costumam desincentivar as vítimas de violência (em geral, mulheres) a fazerem denúncias das agressóes sofridas, visando a supostas preservação da unidade familiar e prevenção contra retaliaçóes. Estas situaçóes envolvendo atores que, a princípio, se colocam como parceiros dificultam o trabalho dos Diats e DTCs, de acompanhamento dos casos, promoção do acesso a serviços e restituição de direitos às vítimas de violência.

As divergências discutidas acima somam-se a situaçóes de sistemática recusa dos demais serviços de saúde a acolherem usuários encaminhados pelos serviços especializados em álcool e outras drogas. A resistência e a discriminação com relação aos usuários destes serviços, expressas por organizaçóes e profissionais dos serviços náo especializados, foram apontadas em praticamente todos os casos estudados. Nos cinco estudos, há relatos de que os serviços de saúde não recebem, ou tratam mal e humilham usuários de drogas que lhes são encaminhados. Esta recorrência ressalta, de um lado, a importância e os ganhos advindos da criação dos serviços de atenção especializada; mas, de outro, relembra os desafios enfrentados para o efetivo estabelecimento de redes de serviços entre diferentes setores de políticas públicas e seus agentes. As dissonâncias cognitivas, e até morais, entre estes agentes favorecem a formação de circuitos limitados aos serviços especializados, prejudicando os objetivos de circulação socioespacial dos programas de base territorial e encerrando seus usuários, mais uma vez, em circuitos marginais. 


\subsection{Desafios de inclusão}

Além da precariedade material e das tensóes relacionais, outro tipo de desafio que caracteriza a operação dos serviços e iniciativas associados às abordagens emergentes é a efetivação da inclusão social da população atendida, em especial dos segmentos historicamente desfavorecidos. Mesmo que estas novas abordagens se voltem à ampliação do acesso ao cuidado - a partir de suas diretrizes de gratuidade, descentralização, territorialização, baixa exigência, incorporação de pares etc., discutidas anteriormente como potencilidades destas abordagens -, a análise das operaçóes cotidianas destas experiências apontou limites, brechas de atenção e riscos de exclusão, que precisam ser enfrentados, para que a ampliação do acesso dos segmentos vulnerabilizados se efetive.

Muitas das experiências analisadas estão situadas em territórios e comunidades vulneráveis, o que facilita o acesso por parte da população ali residente. Porém, para além da localização, a acessibilidade dos serviços também é afetada pelos horários de funcionamento e atendimento. Entre os serviços estudados, vários deles não funcionam todos os dias da semana (por exemplo, o DTC Barrio Ceibo opera apenas três vezes por semana), ou têm horário de funcionamento restrito ao período diurno (Achique Casavalle, Capa, alguns Caps AD e o Diat JA. Este último funciona apenas de $9 \mathrm{~h}$ as $14 \mathrm{~h}$ ). Estas restriçóes dificultam a participação das pessoas que trabalham fora do território durante o dia. Horários de atendimento mais extensos ou flexíveis foram encontrados apenas nos Centros de Escucha e nas unidades de Caps AD 24h (que realizam acolhimento noturno).

Nessa linha, cabe refletir ainda sobre os trabalhos extramuros, na rua ou no território, desenvolvidos por estes dispositivos. É razoável supor que as pessoas em situação de extrema vulnerabilidade social tenham dificuldades para buscar os serviços com suas próprias pernas, ainda que estes estejam localizados proximamente. Tais pessoas tendem a manter relaçóes ambíguas com as instituiçóes estatais, que a elas se apresentam mais frequentemente por meio de seus aparatos repressivos do que de suas políticas assistenciais, levando a resistências e desconfiança. Assim, os serviços acabam restringindo sua atenção a usuários que chegam às suas instalaçôes, deixando de atender a parcelas do seu público-alvo, que não alcançam esses equipamentos. Neste sentido, estratégias como busca ativa, incorporação de pares, parcerias com organizaçóes que atendem nas ruas, ou em cenas de uso, são fundamentais à ampliaçáo do acesso ao cuidado.

Por fim, outro risco de reprodução de exclusóes já existentes diz respeito à relação dos serviços e dispositivos com mulheres e outros gêneros. Em todos os países estudados, são poucas as ofertas de atenção focalizadas nestes grupos. Algumas atividades e grupos terapêuticos específicos foram identificados (casos dos Caps AD e do Diat JA) para mulheres, homossexuais ou transgêneros. Porém, de forma 
geral, verifica-se que os serviços e dispositivos estudados atendem a um público esmagadoramente masculino, o que aponta para a necessidade de investigaçóes sobre possíveis barreiras de acesso aos demais gêneros.

Ainda que haja diferenças de prevalência do uso de SPA em funçáo de sexo e gênero, os estudos aqui compilados revelam resultados interessantes de iniciativas de alguns serviços, no sentido de buscar a ampliação do acesso do público feminino. As experiências de um dos DTC, na Argentina, e dos Centros de Escucha, na Colômbia, conseguiram elevar substantivamente o atendimento de mulheres, em função da ênfase que depositam nos trabalhos na rua e de aproximação, além do envolvimento de pares.

De outro lado, observamos também casos em que, dadas as restriçóes e os desafios já discutidos aqui, optou-se por uma exclusão explícita das mulheres no acesso ao cuidado - casos dos Capas (México) e do Achique de Casavalle (Uruguai). Nesta última experiência, após iniciar suas operaçóes, atendendo a todos os residentes do bairro, sem distinção de sexo ou gênero, a equipe se viu forçada a limitar o atendimento aos homens. A pouca disponibilidade de espaço físico e a baixa capacidade operacional levaram a conflitos de convivência inesperados. A ausência de espaços privativos e a presença de crianças acompanhando suas mães provocaram tensões e introduziram novos riscos no dispositivo. Diante destas dificuldades e levando em conta que a população masculina demanda aqueles serviços com maior frequência, a equipe decidiu encerrar o atendimento a mulheres. Embora esta medida possa ter sido necessária para lidar com condiçōes bastante adversas, ela reproduz a desatenção ao público feminino e os estereótipos de gênero, que definem a mulher principalmente como cuidadora, e não destinatária do cuidado (Musto, capítulo 7, neste volume).

Ainda que muitos dos desafios de inclusáo discutidos tenham por base as limitaçóes impostas pela precariedade material, é de extrema importância ter em mente seus efeitos potenciais de acumulação de desvantagens e reprodução de desigualdades já existentes. Isto é, mais do que simples acomodaçóes a um contexto de escassez de recursos, a precariedade institucional (dos serviços e dispositivos) pode representar elemento importante de manutenção da precariedade social, e transformar potencialidades de inclusão em mecanismos de reforço à exclusão (Sandim, 2018; Spink, 2019).

\section{CONSIDERAÇÕES FINAIS}

Os capítulos deste livro evidenciam que está em curso, em diversos países latino-americanos, uma mudança no panorama institucional das ofertas de atenção a usuários problemáticos de drogas. Essa mudança se expressa na complexificação dos arranjos assistenciais, aos quais agregaram-se novos atores; mas, principalmente, pela 
experimentação de novas modalidades de atenção, que, além do horizonte cerrado da abstinência, abrem outras possibilidades de cuidado - as quais admitem formas de relacionamentos náo problemáticos dos sujeitos com as drogas, que privilegiam a singularidade de cada um deles e promovem um cuidado integral. Os estudos conduzidos em Argentina, Brasil, Colômbia, México e Uruguai demonstram esta tendência, mas apontam também para a timidez das mudanças operadas, bem como para a resiliência das modalidades tradicionais de cuidado, que se justapóem às novas, com as quais desenvolvem relaçóes a um tempo cooperativas e conflitivas.

A cooperação se expressa no nível macro, por meio de medidas de articulação das políticas nacionais, bem como de sistemas, redes e esquemas de financiamento e regulação, adotados por governos nacionais. Mesmo com contornos específicos, todos os países aqui analisados têm notoriamente empenhado esforços no sentido de promover estas macroarticulaçóes. No nível micro, as conexóes formam redes de instituiçôes localizadas nos territórios, que oferecem serviços públicos, acesso a direitos e a novas oportunidades, além de (re)inserção comunitária.

Por outro lado, a dimensão do conflito se manifesta pelas tensóes relacionais, que emergem das próprias iniciativas de articulação dessas redes, agravadas pela precariedade material dos serviços e pela dissonância entre as concepçóes e as metodologias de trabalho dos diferentes parceiros. Tais tensóes não apenas tornam os esforços de produção e manutenção de redes ainda mais hercúleo, mas também introduzem riscos de desatenção e exclusão dos segmentos que já vivem em condiçóes de maior vulnerabilidade.

As abordagens emergentes e seus princípios norteadores - universalidade do acesso, integralidade, intersetorialidade, baixa exigência, participação social e comunitária - demonstram a possibilidade de mudanças paradigmáticas, muito necessárias no campo das políticas públicas de atenção e cuidado aos usuários problemáticos de drogas. As experiências em curso apresentam potencial inegável de renovação da forma como o consumo de SPA é problematizado nas sociedades contemporâneas. Porém, para além dos avanços em direçóes profícuas, são necessários maiores investimentos dos estados e das sociedades, tendo em vista a consolidaçáa destas transformaçôes. Os capítulos desta publicação deixam claro que é preciso alargarem-se as condiçóes de possibilidade das experiências em curso, por meio da superação da precariedade material, do processamento das tensóes relacionais e da radicalização da inclusão social dos segmentos tradicionalmente vulnerabilizados.

As respostas a esses desafios, para além das condições macro, forjam-se, como posto por Góngora, Salazar e Borja (capítulo 5, neste volume) no estando ahi: nos programas assistenciais, serviços e dispositivos que cotidianamente promovem relaçôes afetivas, de intercâmbio, de confiança e apoio, que permitem reconstruir segurança em meio a insegurança, criatividade em meio à escassez e resiliência em meio a riscos. 


\section{REFERÊNCIAS}

BRASIL. A Política do Ministério da Saúde para a atenção integral a usuários de álcool e outras drogas. Brasília: MS, 2003. Disponível em: <https://bit. ly/3oYSq $8 \mathrm{M}>$.

. Portaria no 3.088, de 26 de dezembro de 2011. Institui a Rede de Atenção Psicossocial para pessoas com sofrimento ou transtorno mental e com necessidades decorrentes do uso de crack, álcool e outras drogas, no âmbito do Sistema Único de Saúde. Brasília: MS, 2011. Disponível em: <https://bit.ly/2Wrnd1D>.

CONSULTÓRIO de rua: origem e trajetória. CETAD Observa, [s.d.]. Disponível em: <https://bit.ly/3r2909E $>$.

FERGUSSON, S.; GÓNGORA, A. La relación entre personas y drogas y los dispositivos de inclusión social basados en la comunidad: críticas y perspectivas desde América Latina. CONFERENCIA ANUAL DEL COPOLAD, 2., Bruselas, 2012. Anais... Bruselas, 2012.

MACHÍN, J. Modelo ECO2: redes sociales, complejidad y sufrimiento social. Revista Hispana para el Análisis de Redes Sociales, v. 18, n. 12, jun. 2010. $<$ https://bit.ly/3h0IKYq $>$.

MACHÍN, J. Principales abordajes al tema de drogas. In: MACHIN, J.; MENDOZA, A. Meta-Modelo Eco2 - apuntes sobre prevención, reducción de riesgos y daños asociados al consumo de sustancias psicoactivas. Ciudad de México: Cafac, 2015.

MILANESE, E. Tratamento cumitário: manual de trabalho I. Brasília: Secretaria Nacional de Políticas de Drogas; Instituto Empodera, 2012.

Tratamento cumitário: manual de trabalho I. Brasília: Associação de Formação; Reeducação Lua Nova, 2016.

NERY FILHO, A.; VALÉRIO, A. L. R.; MONTEIRO, L. F. (Org.). Guia do Projeto Consultório de Rua. Brasília; Salvador: Senad; Cetad, 2011. Disponível em: <https://bit.ly/2J3ukdN>.

PASSOS, E.; SOUZA, T. P. Redução de danos e saúde pública: construções alternativas à política global de "guerra às drogas". Psicologia e Sociedade, Minas Gerais, v. 23, n. 1, p. 154- 162, 2011.

PETUCO, D. O Pomo da discórdia? Drogas, saúde e poder. Curitiba: CRV, 2019.

SANDIM, T. Da vulnerabilidade social para a vulnerabilidade institucional: uma análise da Política Nacional de Assistência Social e de suas práticas em Belo Horizonte e São Paulo. 2018. Tese (Doutorado) - Fundação Getúlio Vargas, São Paulo, 2018. 
SPINK, P. Urban vulnerability from the other side of the street. In: INTERPRETIVE POLICY ANALYSIS CONFERENCE, 12., 2017, Leicester. Anais... Leicester, Jul. 2017.

WORCMAN, N.; MORGANTI, R. O proibicionismo introjetado. In: PIRES, R. (Org.) Implementando desigualdades. Brasília: Ipea, 2019.

\section{BIBLIOGRAFIA COMPLEMENTAR}

COLOMBIA. Ley no 1566 de 31 de julio de 2012. Por la cual se dictan normas para garantizar la atención integral a personas que consumen sustancias psicoactivas y se crea el premio nacional "entidade comprometida con la prevención del consumo, abuso y adicción a sustancias" psicoactivas. Colombia: Congreso de Colombia, 2012. Disponível em: <https://bit.ly/2LpPZxT>.

MACHÍN, J. Redes sociales e incidencia en política pública: estudio comparativo México-Colombia. México: Cafac, 2011. 


\section{APÊNDICE A}

\section{QUADRO A.1}

Políticas e programas de atenção a usuários de drogas - Argentina

\begin{tabular}{|c|c|c|c|c|}
\hline \multicolumn{5}{|c|}{ Argentina } \\
\hline Programa/política & $\begin{array}{c}\text { Nível de } \\
\text { implementação }\end{array}$ & Atores & $\begin{array}{l}\text { Principais fontes de } \\
\text { financiamento }\end{array}$ & Descrição \\
\hline $\begin{array}{l}\text { Secretaría de Políticas } \\
\text { Integrales sobre } \\
\text { Drogas de la Nación } \\
\text { Argentina (Sedronar)/ } \\
\text { Centro de Consultas y } \\
\text { Orientación (Cedecor) }\end{array}$ & Nacional & Sedronar & Público & $\begin{array}{l}\text { Serviços especializados } \\
\text { de escuta, atenção } \\
\text { ambulatorial e encami- } \\
\text { nhamentos pela rede } \\
\text { de atenção. }\end{array}$ \\
\hline $\begin{array}{l}\text { Sedronar/Dispositivos } \\
\text { Integrais de Atenção } \\
\text { Territorial (Diat) }\end{array}$ & Nacional/territorial & $\begin{array}{l}\text { Sedronar em cogestão } \\
\text { com governos } \\
\text { provinciais, municipais } \\
\text { ou rganizações da } \\
\text { sociedade civil (OSC) }\end{array}$ & $\begin{array}{l}\text { Público (Sedronar/ } \\
\text { governos provinciais } \\
\text { ou municipais) e misto } \\
\text { (Sedronar/OSC) }\end{array}$ & $\begin{array}{l}\text { Dispositivos de aten- } \\
\text { ção integral territorial. }\end{array}$ \\
\hline $\begin{array}{l}\text { Sedronar/Dispositivos } \\
\text { de Tratamento Comuni- } \\
\text { tário (DTC) }\end{array}$ & Nacional/territorial & Sedronar/OSC & Misto (Sedronar/OSC) & $\begin{array}{l}\text { Dispositivos de aborda- } \\
\text { gem comunitária para } \\
\text { população com alta } \\
\text { vulnerabilidade social. }\end{array}$ \\
\hline $\begin{array}{l}\text { Casas de Atención } \\
\text { y Acompañamiento } \\
\text { Comunitario (CAAC) }\end{array}$ & Nacional/territorial & Sedronar/OSC & Misto (Sedronar/OSC) & $\begin{array}{l}\text { Atenção especializada } \\
\text { com características não } \\
\text { homogêneas para po- } \\
\text { pulaccõ̃es em situações } \\
\text { de alta vulnerabilidade } \\
\text { social sem acesso aos } \\
\text { outros dispositivos. }\end{array}$ \\
\hline $\begin{array}{l}\text { Hospital Nacional em } \\
\text { Rede Especializado } \\
\text { em Saúde Mental e } \\
\text { Adicções "Lic. Laura } \\
\text { Bonaparte" }\end{array}$ & Nacional & Ministério da Saúde & Público & $\begin{array}{l}\text { Serviços ambulatoriais } \\
\text { e de internação breve } \\
\text { (desintoxicação) e } \\
\text { prolongada. }\end{array}$ \\
\hline $\begin{array}{l}\text { Hospitais especializa- } \\
\text { dos em Saúde Mental }\end{array}$ & Provincial/municipal & Saúde & Público & $\begin{array}{l}\text { Atenção ambulatorial, } \\
\text { internação breve } \\
\text { (desintoxicação) e } \\
\text { prolongada para pes- } \\
\text { soas com comorbidade } \\
\text { psiquiátrica. }\end{array}$ \\
\hline $\begin{array}{l}\text { Centros de Saúde } \\
\text { Mental }\end{array}$ & Provincial/municipal & Saúde & Público & Atenção ambulatorial. \\
\hline Hospitais Gerais & Provincial/municipal & Saúde & Público & $\begin{array}{l}\text { Serviços de saúde } \\
\text { mental e toxicologia } \\
\text { com atenção ambu- } \\
\text { latorial e, em alguns } \\
\text { casos, internação breve } \\
\text { (desintoxicação). }\end{array}$ \\
\hline $\begin{array}{l}\text { Centros de atenção } \\
\text { primária para a saúde } \\
\text { (Centros de Atenção } \\
\text { Psicossocial - Caps, } \\
\text { Centros de Salud y } \\
\text { Acción Comunitaria - } \\
\text { CeSAC etc.) }\end{array}$ & Provincial/municipal & $\begin{array}{l}\text { Área programática de } \\
\text { hospitais gerais }\end{array}$ & Público & $\begin{array}{l}\text { Assistência ambu- } \\
\text { latorial (consultório } \\
\text { externo, encaminha- } \\
\text { mentos). }\end{array}$ \\
\hline
\end{tabular}


(Continuação)

\begin{tabular}{|c|c|c|c|c|}
\hline \multicolumn{5}{|c|}{ Argentina } \\
\hline Programa/política & $\begin{array}{c}\text { Nível de } \\
\text { implementação }\end{array}$ & Atores & $\begin{array}{l}\text { Principais fontes de } \\
\text { financiamento }\end{array}$ & Descrição \\
\hline $\begin{array}{l}\text { Centros de atenção } \\
\text { ambulatorial (Centro de } \\
\text { Especialidades Médicas } \\
\text { de Referencia - Cemar, } \\
\text { La Otra Base de En- } \\
\text { cuentro - Lobe etc.) }\end{array}$ & Provincial/municipal & $\begin{array}{l}\text { Área programática de } \\
\text { hospitais gerais }\end{array}$ & Público & $\begin{array}{l}\text { Atenção ambula- } \\
\text { torial especializada } \\
\text { (consultório externo, } \\
\text { hospital dia). }\end{array}$ \\
\hline $\begin{array}{l}\text { Centros de intervenção } \\
\text { ou integração comu- } \\
\text { nitária (Centros de } \\
\text { Intervención Asistencial } \\
\text { Comunitaria - Ciac, } \\
\text { Centros de Integración } \\
\text { Comunitaria - CIC etc.) }\end{array}$ & Provincial/municipal & $\begin{array}{l}\text { Desenvolvimento } \\
\text { Social }\end{array}$ & Público & Atenção ambulatorial. \\
\hline $\begin{array}{l}\text { Centros especializados } \\
\text { em adicções (Centros } \\
\text { de Asistencia Social en } \\
\text { Adicciones - Casas, } \\
\text { Centros de Prevención } \\
\text { de las Adicciones - } \\
\text { CPA, dispositivos em } \\
\text { unidades penitenciá- } \\
\text { rias etc.) }\end{array}$ & Provincial/municipal & $\begin{array}{l}\text { Saúde ou Desenvolvi- } \\
\text { mento Social }\end{array}$ & Público & $\begin{array}{l}\text { Assistência ambulato- } \\
\text { rial especializada. }\end{array}$ \\
\hline $\begin{array}{l}\text { Comunidades tera- } \\
\text { pêuticas }\end{array}$ & - & OSC & $\begin{array}{l}\text { Misto (bolsas Sedronar } \\
\text { e outras) e privado } \\
\text { (particulares, obras } \\
\text { sociais e serviços de } \\
\text { medicina pré-paga) }\end{array}$ & $\begin{array}{l}\text { Internação prolongada } \\
\text { e, em alguns casos, as- } \\
\text { sistência ambulatorial } \\
\text { (hospital dia/noite). }\end{array}$ \\
\hline $\begin{array}{l}\text { Programas de redução } \\
\text { de danos }\end{array}$ & - & OSC & Privado, doações. & $\begin{array}{l}\text { Projetos de redução } \\
\text { de danos (campa- } \\
\text { nhas, treinamentos, } \\
\text { workshops etc.). }\end{array}$ \\
\hline $\begin{array}{l}\text { Profissionais especia- } \\
\text { lizados }\end{array}$ & - & Setor privado & $\begin{array}{l}\text { Privado (particulares, } \\
\text { obras sociais e serviços } \\
\text { de medicina pré-paga) }\end{array}$ & Consultório externo. \\
\hline $\begin{array}{l}\text { Centros e clínicas } \\
\text { polivalentes e espe- } \\
\text { cializadas em saúde } \\
\text { mental }\end{array}$ & - & Setor privado & $\begin{array}{l}\text { Privado (particulares, } \\
\text { obras sociais e serviços } \\
\text { de medicina pré-paga) }\end{array}$ & $\begin{array}{l}\text { Serviços ambulatoriais, } \\
\text { internação breve } \\
\text { (desintoxicação) e } \\
\text { prolongada. }\end{array}$ \\
\hline $\begin{array}{l}\text { Grupos de autoajuda } \\
\text { (narcóticos anônimos } \\
\text { - NA, alcoólatras } \\
\text { anônimos - AA etc.) }\end{array}$ & - & Paróquias locais & - & Grupos de autoajuda. \\
\hline
\end{tabular}

Elaboração dos autores. 
QUADRO A.2

Políticas e programas de atenção a usuários de drogas - Brasil

\begin{tabular}{|c|c|c|c|c|}
\hline \multicolumn{5}{|c|}{ Brasil } \\
\hline Programa/política & $\begin{array}{l}\text { Nível de implemen- } \\
\text { tação }\end{array}$ & Atores & $\begin{array}{l}\text { Principais fontes de } \\
\text { financiamento }\end{array}$ & Descrição \\
\hline $\begin{array}{l}\text { Redes de Atenção } \\
\text { Psicossocial (Raps)/ } \\
\text { Centros de Atenção } \\
\text { Psicossocial Álcool e } \\
\text { Outras Drogas (Caps } \\
\text { AD) }\end{array}$ & Municipal/territorial & $\begin{array}{l}\text { Ministério da Saúde/ } \\
\text { secretarias estaduais e } \\
\text { municipais de saúde }\end{array}$ & Público & $\begin{array}{l}\text { Serviços especiali- } \\
\text { zados de atenção } \\
\text { psicossocial, de base } \\
\text { comunitária e ambula- } \\
\text { torial, orientados pela } \\
\text { lógica da redução de } \\
\text { danos }\end{array}$ \\
\hline Raps/Caps AD III & Nacional/territorial & $\begin{array}{l}\text { Ministério da Saúde/ } \\
\text { secretarias estaduais e } \\
\text { municipais de saúde }\end{array}$ & Público & $\begin{array}{l}\text { Serviços especiali- } \\
\text { zados de atenção } \\
\text { psicossocial, de base } \\
\text { comunitária, orien- } \\
\text { tados pela lógica da } \\
\text { redução de danos para } \\
\text { acolhimento por 24h, } \\
\text { por até quinze dias }\end{array}$ \\
\hline Raps (outros) & Nacional/territorial & $\begin{array}{l}\text { Ministério da Saúde/ } \\
\text { secretarias estaduais } \\
\text { e municipais de } \\
\text { saúde (hospitais gerais, } \\
\text { hospitais psiquiátricos } \\
\text { públicos, unidades } \\
\text { de atenção básica, } \\
\text { atenção especializada } \\
\text { em saúde, unidades de } \\
\text { acolhimento etc.) }\end{array}$ & Público & $\begin{array}{l}\text { Serviços básicos e } \\
\text { especializados de } \\
\text { atenção à saúde. }\end{array}$ \\
\hline $\begin{array}{l}\text { Comunidades tera- } \\
\text { pêuticas }\end{array}$ & Nacional/territorial & $\begin{array}{l}\text { Ministério da } \\
\text { Cidadania (Secretaria } \\
\text { Nacional de Cuidados } \\
\text { e Prevenção às Drogas } \\
\text { - Senapred)/estados/ } \\
\text { municípios }\end{array}$ & $\begin{array}{l}\text { Público (Senapred/ } \\
\text { governos estaduais e } \\
\text { municipais)/privado } \\
\text { (comunidades terapêu- } \\
\text { ticas e outros) }\end{array}$ & $\begin{array}{l}\text { Serviços de atenção } \\
\text { residencial, por até } \\
\text { doze meses, baseado } \\
\text { em laborterapia e } \\
\text { promoção de disciplina } \\
\text { e espiritualidade. }\end{array}$ \\
\hline $\begin{array}{l}\text { Hospitais psiquiátricos } \\
\text { e clínicas }\end{array}$ & Territorial & $\begin{array}{l}\text { Serviços privados de } \\
\text { saúde }\end{array}$ & Privado & $\begin{array}{l}\text { Serviços médicos de } \\
\text { atenção especializada. }\end{array}$ \\
\hline Organizações religiosas & Territorial & $\begin{array}{l}\text { Sacerdotes e membros } \\
\text { de congregações } \\
\text { religiosas }\end{array}$ & Privado & $\begin{array}{l}\text { Grupos de escuta, } \\
\text { apoio e ajuda mútua, } \\
\text { não residenciais, de } \\
\text { base religiosa. }\end{array}$ \\
\hline Irmandades anônimas & Territorial & $\begin{array}{l}\text { Alcoólicos Anônimos } \\
\text {-AA/Narcóticos Anô- } \\
\text { nimos - NA/Grupos } \\
\text { Familiares AL-Anon } \\
\text { (grupos de familiares e } \\
\text { amigos) }\end{array}$ & Privado & $\begin{array}{l}\text { Grupos de ajuda mú- } \\
\text { tua não residenciais. }\end{array}$ \\
\hline
\end{tabular}

Elaboração dos autores. 
QUADRO A.3

Políticas e programas de atenção a usuários de drogas - Colômbia

\begin{tabular}{|c|c|c|c|c|}
\hline \multicolumn{5}{|c|}{ Colômbia } \\
\hline Programa/política & Nível & Atores & $\begin{array}{l}\text { Principais fontes de } \\
\text { financiamento }\end{array}$ & Descrição \\
\hline $\begin{array}{l}\text { Tratamento de base } \\
\text { comunitária (Viviendo) }\end{array}$ & Nacional/territorial & $\begin{array}{l}\text { OSC/Secretariado } \\
\text { Nacional de Pastoral } \\
\text { Social (SNPS)/Igreja } \\
\text { Católica/Caritas } \\
\text { Colômbia }\end{array}$ & $\begin{array}{l}\text { Não tem orçamento } \\
\text { fixo Cooperação } \\
\text { Internacional }\end{array}$ & $\begin{array}{l}\text { Atenção segundo a } \\
\text { lógica de redução de } \\
\text { danos e do modelo } \\
\text { da epistemologia da } \\
\text { comunidade/ética } \\
\text { comunitária (ECO2). } \\
\text { Ações de assistência } \\
\text { básica e inclusão } \\
\text { social. }\end{array}$ \\
\hline $\begin{array}{l}\text { Red Americana de } \\
\text { Intervención en Situa- } \\
\text { ciones de Sufrimiento } \\
\text { Social (RAISSS) en } \\
\text { Colombia }\end{array}$ & Nacional/territorial & $\begin{array}{l}\text { Rede de organizações } \\
\text { não governamentais }\end{array}$ & $\begin{array}{l}\text { Não tem orçamento } \\
\text { fixo Cooperação } \\
\text { Internacional }\end{array}$ & $\begin{array}{l}\text { Tratamento de base } \\
\text { comunitária. }\end{array}$ \\
\hline Échele Cabeza & Bogotá & $\begin{array}{l}\text { Ação técnica social } \\
\text { - ATS/Prefeitura de } \\
\text { Bogotá }\end{array}$ & - & $\begin{array}{l}\text { Projeto de redução de } \\
\text { danos. }\end{array}$ \\
\hline $\begin{array}{l}\text { Plano de intervenções } \\
\text { coletivas }\end{array}$ & Nacional/territorial & Municípios e Estado & $\begin{array}{l}\text { Secretarias de saúde } \\
\text { municipais/seguradoras } \\
\text { públicas e privadas } \\
\text { (EPS) }\end{array}$ & $\begin{array}{l}\text { Estratégias de mitiga- } \\
\text { ção e prevenção do } \\
\text { uso de drogas. }\end{array}$ \\
\hline Centros de escuta & Territorial & $\begin{array}{l}\text { Sociedade civil/ } \\
\text { comunidades locais/ } \\
\text { governos locais }\end{array}$ & $\begin{array}{l}\text { Não tem orçamento } \\
\text { fixo; cooperação } \\
\text { internacional }\end{array}$ & $\begin{array}{l}\text { Ações de mitigação e } \\
\text { inclusão social basea- } \\
\text { das no modelo de tra- } \\
\text { tamento comunitário. } \\
\text { Escuta de usuários. }\end{array}$ \\
\hline $\begin{array}{l}\text { Zonas de orientação } \\
\text { universitária }\end{array}$ & Territorial & $\begin{array}{l}\text { Sociedade Civil e } \\
\text { comunidades locais }\end{array}$ & Universidades & $\begin{array}{l}\text { Ações de mitigação e } \\
\text { inclusão social basea- } \\
\text { das no modelo de tra- } \\
\text { tamento comunitário. } \\
\text { Escuta de usuários em } \\
\text { ambiente escolar. }\end{array}$ \\
\hline $\begin{array}{l}\text { Zonas de orientação } \\
\text { escolar }\end{array}$ & Territorial & $\begin{array}{l}\text { Sociedade Civil e } \\
\text { comunidades locais }\end{array}$ & $\begin{array}{l}\text { Não tem orçamento } \\
\text { fixo; governos locais e } \\
\text { secretarias de saúde } \\
\text { municipais }\end{array}$ & $\begin{array}{l}\text { Ações de mitigação e } \\
\text { inclusão social basea- } \\
\text { das no modelo de tra- } \\
\text { tamento comunitário. } \\
\text { Escuta de usuários em } \\
\text { ambiente escolar. }\end{array}$ \\
\hline $\begin{array}{l}\text { Zonas de orientação } \\
\text { laboral }\end{array}$ & Territorial & $\begin{array}{l}\text { Sociedade Civil e } \\
\text { comunidades locais }\end{array}$ & $\begin{array}{l}\text { Não tem orçamento } \\
\text { fixo; governos locais e } \\
\text { secretarias de saúde } \\
\text { municipais }\end{array}$ & $\begin{array}{l}\text { Ações de mitigação } \\
\text { e inclusão social } \\
\text { baseadas no modelo } \\
\text { de tratamento co- } \\
\text { munitário. Escuta de } \\
\text { usuários em ambiente } \\
\text { de trabalho. }\end{array}$ \\
\hline $\begin{array}{l}\text { Centros de escuta } \\
\text { penitenciária }\end{array}$ & Territorial & $\begin{array}{l}\text { Sociedade Civil e } \\
\text { comunidades locais }\end{array}$ & $\begin{array}{l}\text { Não tem orçamento } \\
\text { fixo; governos locais e } \\
\text { diretivas dos centros } \\
\text { penitenciários }\end{array}$ & $\begin{array}{l}\text { Ações de mitigação e } \\
\text { inclusão social basea- } \\
\text { das no modelo de tra- } \\
\text { tamento comunitário. } \\
\text { Escuta de usuários em } \\
\text { prisões. }\end{array}$ \\
\hline
\end{tabular}


QUADRO A.4

Políticas e programas de atenção a usuários de drogas - México

\begin{tabular}{|c|c|c|c|c|}
\hline \multicolumn{5}{|c|}{ México } \\
\hline Programa/ Política & Nível & Atores & $\begin{array}{l}\text { Principais fontes de } \\
\text { financiamento }\end{array}$ & Descrição \\
\hline $\begin{array}{l}\text { Centros de Atenção } \\
\text { Primária das Adições } \\
\text { (Capa) }\end{array}$ & Estadual/territorial & $\begin{array}{l}\text { Conselhos Estaduais } \\
\text { Contra as Adicções }\end{array}$ & $\begin{array}{l}\text { Público estadual e } \\
\text { federal }\end{array}$ & $\begin{array}{l}\text { Serviços ambulato- } \\
\text { riais especializados } \\
\text { baseados na terapia } \\
\text { breve para jovens } \\
\text { em situação de risco } \\
\text { psicossocial, usuários } \\
\text { experimentais, frequen- } \\
\text { tes e problemáticos } \\
\text { que são encaminhados } \\
\text { para outros serviços } \\
\text { dependendo das } \\
\text { demandas. }\end{array}$ \\
\hline $\begin{array}{l}\text { Consejos Municipales } \\
\text { Contra las Adicciones } \\
\text { (Comcas) }\end{array}$ & Territorial & $\begin{array}{l}\text { Instituições públicas } \\
\text { locais }\end{array}$ & Público estadual & $\begin{array}{l}\text { Coordenaçãa inte- } \\
\text { rinstitucional para a } \\
\text { prevenção de uso de } \\
\text { drogas. }\end{array}$ \\
\hline $\begin{array}{l}\text { Centros de Integração } \\
\text { Juvenil (CIJ) }\end{array}$ & Nacional/estadual & Secretaria de saúde & Público federal & $\begin{array}{l}\text { Plano de intervenção } \\
\text { primária; consulta ex- } \\
\text { terna básica; consulta } \\
\text { externa intensiva; e } \\
\text { serviços de internação } \\
\text { especializado. }\end{array}$ \\
\hline $\begin{array}{l}\text { Hospitais de saúde } \\
\text { mental }\end{array}$ & Estatal & Secretaria de saúde & $\begin{array}{l}\text { Público estadual e } \\
\text { federal }\end{array}$ & $\begin{array}{l}\text { Para casos de síndrome } \\
\text { de abstinência e em } \\
\text { casos de comorbidades } \\
\text { psiquiátricas. }\end{array}$ \\
\hline $\begin{array}{l}\text { Grupos de autoajuda } \\
\text { (NA, AA) }\end{array}$ & Territorial & Sociedade civil & Doações & $\begin{array}{l}\text { Serviços ambulato- } \\
\text { riais e de internação } \\
\text { baseados no programa } \\
\text { de doze passos. }\end{array}$ \\
\hline Serviços da OSC & Territorial & Sociedade civil & Apoio internacional & $\begin{array}{l}\text { Grupos que realizam } \\
\text { intervenções de } \\
\text { redução de danos para } \\
\text { populações com alta } \\
\text { vulnerabilidade social. }\end{array}$ \\
\hline RAISSS México & Territorial & Sociedade civil & Apoio internacional & $\begin{array}{l}\text { Grupos que realizam } \\
\text { intervenções de } \\
\text { redução de danos para } \\
\text { populações com alta } \\
\text { vulnerabilidade social. }\end{array}$ \\
\hline $\begin{array}{l}\text { Profissionais especia- } \\
\text { lizados }\end{array}$ & - & Privados & $\begin{array}{l}\text { Pagamento pela pres- } \\
\text { tação de serviços }\end{array}$ & $\begin{array}{l}\text { Serviços ambulatoriais } \\
\text { com especialistas de } \\
\text { atenção aos usuários } \\
\text { problemáticos de SPAs. }\end{array}$ \\
\hline $\begin{array}{l}\text { Serviços de atenção } \\
\text { residencial privados }\end{array}$ & - & Privados & $\begin{array}{l}\text { Pagamento pela pres- } \\
\text { tação de serviços }\end{array}$ & $\begin{array}{l}\text { Serviços de internação } \\
\text { especializados com } \\
\text { atenção multidisci- } \\
\text { plinar. }\end{array}$ \\
\hline $\begin{array}{l}\text { Serviços de atenção } \\
\text { residencial públicos }\end{array}$ & Estatal & $\begin{array}{l}\text { Conselhos estatais } \\
\text { contra as adições }\end{array}$ & Estatal & $\begin{array}{l}\text { Serviços de internação } \\
\text { especializados com } \\
\text { atenção multidisci- } \\
\text { plinar. }\end{array}$ \\
\hline
\end{tabular}


QUADRO A.5

Políticas e programas de atenção a usuários de drogas - Uruguai

\begin{tabular}{|c|c|c|c|c|}
\hline \multicolumn{5}{|c|}{ Uruguai } \\
\hline Programa/política & Nível & Atores & $\begin{array}{l}\text { Principais fontes de } \\
\text { financiamento }\end{array}$ & Descrição \\
\hline $\begin{array}{l}\text { Sistema Nacional } \\
\text { Integrado de Salud } \\
\text { (SNIS) }\end{array}$ & Nacional & $\begin{array}{l}\text { Mutualistas privadas/ } \\
\text { Ministério da Saúde } \\
\text { Pública }\end{array}$ & $\begin{array}{l}\text { Fondo Nacional de } \\
\text { Salud (Fonasa) }\end{array}$ & $\begin{array}{l}\text { Assistência ambula- } \\
\text { torial. }\end{array}$ \\
\hline Renadro & Nacional & $\begin{array}{l}\text { Junta Nacional de } \\
\text { Drogas/Ministério } \\
\text { da Saúde Pública/ } \\
\text { Instituto da Criança } \\
\text { e do Adolescente do } \\
\text { Uruguai/Administração } \\
\text { de Saúde do Estado/ } \\
\text { Coorporação Nacional } \\
\text { para o Desenvolvi- } \\
\text { mento }\end{array}$ & $\begin{array}{l}\text { Fundo Fiduciário } \\
\text { Renadro }\end{array}$ & $\begin{array}{l}\text { Rede pública assisten- } \\
\text { cial para receber casos } \\
\text { de intoxicação aguda e } \\
\text { uso abusivo de drogas. }\end{array}$ \\
\hline Portal Amarillo & Nacional & $\begin{array}{l}\text { Secretaria Nacional de } \\
\text { Drogas (SND) }\end{array}$ & $\begin{array}{l}\text { Fundo Fiduciário } \\
\text { Renadro }\end{array}$ & $\begin{array}{l}\text { Centro público residen- } \\
\text { cial especializado em } \\
\text { uso abusivo de drogas. }\end{array}$ \\
\hline CasAbierta & Nacional & SND & $\begin{array}{l}\text { Fundo Fiduciário } \\
\text { Renadro }\end{array}$ & $\begin{array}{l}\text { Centro público residen- } \\
\text { cial especializado em } \\
\text { uso abusivo de drogas. }\end{array}$ \\
\hline Jagüel & Nacional & SND & $\begin{array}{l}\text { Fundo Fiduciário } \\
\text { Renadro }\end{array}$ & $\begin{array}{l}\text { Centro público residen- } \\
\text { cial especializado em } \\
\text { uso abusivo de drogas. }\end{array}$ \\
\hline Chanaes & Nacional & SND & $\begin{array}{l}\text { Fundo Fiduciário } \\
\text { Renadro }\end{array}$ & $\begin{array}{l}\text { Serviço de internação } \\
\text { prolongada. }\end{array}$ \\
\hline Dispositivos ciudadela & Nacional/territorial & SND - Sociedad civil & $\begin{array}{l}\text { Fundo Fiduciário } \\
\text { Renadro }\end{array}$ & $\begin{array}{l}\text { Centros ambulatoriais } \\
\text { para informação, } \\
\text { assessoria, diagnóstico } \\
\text { e encaminhamentos. }\end{array}$ \\
\hline Grupos T & Territorial & SND - Sociedad civil & $\begin{array}{l}\text { Fundo Fiduciário } \\
\text { Renadro }\end{array}$ & $\begin{array}{l}\text { Ambulatórios especia- } \\
\text { lizados na atenção de } \\
\text { populações vulneráveis } \\
\text { de usuários problemá- } \\
\text { ticos de SPAs. }\end{array}$ \\
\hline El Achique & Territorial & SND - Sociedad civil & $\begin{array}{l}\text { Fundo Fiduciário } \\
\text { Renadro }\end{array}$ & $\begin{array}{l}\text { Tratamento para } \\
\text { populações em desvan- } \\
\text { tagens socioeconô- } \\
\text { micas. }\end{array}$ \\
\hline $\begin{array}{l}\text { Unidade de Assistência } \\
\text { Móvel (UMA) }\end{array}$ & Municipal & SND - Sociedad civil & $\begin{array}{l}\text { Fundo Fiduciário } \\
\text { Renadro }\end{array}$ & $\begin{array}{l}\text { Modelo do consultório } \\
\text { de rua. }\end{array}$ \\
\hline Aleros & Municipal & SND - Sociedad civil & $\begin{array}{l}\text { Fundo Fiduciário } \\
\text { Renadro }\end{array}$ & $\begin{array}{l}\text { Intervenções de pers- } \\
\text { pectiva territorial para } \\
\text { a prevenção do uso de } \\
\text { SPAs e fortalecimento } \\
\text { de redes. }\end{array}$ \\
\hline
\end{tabular}

Elaboração dos autores. 



\section{NOTAS BIOGRÁFICAS}

\section{Andrés Góngora}

Doutor em antropologia social do Programa de Pós-Graduação em Antropologia Social do Museu Nacional, na Universidade Federal do Rio de Janeiro (UFRJ). Curador-chefe do Departamento de Etnografia do Museu Nacional da Colômbia e professor de antropologia da Universidade Nacional da Colômbia. É pesquisador do Grupo Conflito Social e Violência da Universidade Nacional da Colômbia, do Grupo de Pesquisas sobre Economia e Cultura da UFRJ e do Núcleo de Estudos Interdisciplinares sobre Psicoativos da Universidade de São Paulo (USP). Realizou estudos e exposiçóes com temáticas relacionadas a diversidade cultural, gênero, sexualidade, movimentos sociais, políticas de drogas, antropologia urbana, antropologia médica e economia popular.

\section{Clara Musto}

Licenciada em sociologia pela Universidade da República (UdelaR), Uruguai, onde também cursou economia. Em 2013, obteve a Bolsa Erasmus Mundus, da União Europeia (UE), para realizar seu doutorado em criminologia global e cultural nas Universidades de Kent (Inglaterra) e Utrecht (Holanda), na qual recebeu título, em 2018, com a tese que analisa o processo social e político de regulaçấo de cannabis no Uruguai. Desde então, especializou-se em problemas de crime organizado, mercados de drogas, violência e desenvolvimento urbano. Com outros jovens pesquisadores, compóe o Núcleo de Análise da Criminalidade e da Violência, da Faculdade de Ciências Sociais da UdelaR, a mesma em que realiza diversos trabalhos; entre estes, os de pesquisa, docência, extensão e consultorias.

E-mails: <claramusto@cienciassociales.edu.uy>; <mustoclara@gmail.com>.

\section{Florencia Corbelle}

Doutora, licenciada e professora de ciências antropológicas da Universidade de Buenos Aires (UBA), Argentina. Pesquisadora assistente do Conselho Nacional de Pesquisa Científica e Técnica (Conicet) e do Programa de Antropologia Política e Jurídica, sediados no Instituto de Ciências Antropológicas, da Faculdade de Ciências e Letras da UBA. É professora desde 2010 e docente da graduação desde 2016, além de participar da equipe docente em seminários de graduação e pós-graduação de diferentes universidades. Em suas pesquisas, tem analisado práticas policiais e judiciais, políticas públicas e reformas legislativas sobre o tema das drogas e do ativismo político dos usuários dessas substâncias. É autora do livro O Ativismo Político dos Usuários de Drogas: da clandestinidade ao Congresso Nacional (2018), assim como de capítulos e artigos em livros e revistas nacionais e estrangeiros. 


\section{Johanna Carolina Salazar Ballén}

Antropóloga e dançarina pela Universidade Nacional da Colômbia. Tem desenvolvido projetos artísticos e estratégias de investigação e intervenção social com populaçôes vulneráveis e excluídas, principalmente por meio da dança contemporânea e inclusiva. Atualmente, faz parte da empresa Movimiento Inclusivo, coordenando a área de pesquisa e sendo membro do corpo docente.

\section{Luiza Gomes Luz Rosa}

Graduada em gestão de políticas públicas pela Universidade de Brasília (UnB). Atualmente, é pesquisadora assistente do Subprograma de Pesquisa para o Desenvolvimento Nacional (PNPD), na Diretoria de Estudos do Estado, da Instituiçóes e da Democracia (Diest) do Ipea.

E-mail: <luiza.rosa@ipea.gov.br>.

\section{Maria Paula Gomes dos Santos}

Técnica de planejamento e pesquisa na Diretoria de Estudos e Políticas do Estado, das Instituiçóes e da Democracia (Diest) do Ipea. Mestre em políticas públicas e administração pública pelo Instituto de Ciências Sociais (ISS - em inglês, Institute of Social Studies), dos Países Baixos (Holanda). Doutora em ciência política pelo Instituto Universitário de Pesquisas do Rio de Janeiro (Iuperj). Desenvolve pesquisas a respeito de políticas sociais e políticas de cuidado a usuários de drogas. Organizou o livro Comunidades Terapêuticas: temas para reflexão, publicado pelo Ipea em 2018. É autora de artigos e capítulos de livros publicados no Brasil e no exterior.

E-mail:<mariapaula.santos@ipea.gov.br>.

\section{Milena Karla Soares}

Técnica de desenvolvimento e administração na Diretoria de Estudos e Políticas do Estado, das Instituiçôes e da Democracia (Diest) do Ipea. Bacharel em economia pela Universidade de São Paulo (USP), bacharel em direito pela Universidade de Brasília (UnB) e mestre em políticas públicas com especialização em regulação pela Universidade Nacional da Austrália (Australian National University). Possui experiência prévia em estudos nas áreas de economia do crime e, nos últimos anos, tem se aprofundado em temas relacionados à política de drogas, com particular interesse no papel da regulação (agentes reguladores, normas e instrumentos regulatórios) na definição dos contornos dessas políticas, bem como na função dos sistemas de justiça criminal na sua implementação.

E-mail: <milena.soares@ipea.gov.br>. 


\section{Ramiro Borja}

Mestre em ciências sociais e biopolítica global pela Universidade de Lapônia, Finlândia. Gestor de foco diferencial com ênfase em gênero e sexualidade, interseccionalidade e cultura cidadã. Como pesquisador em biopolítica, orienta-se pela análise do relacionamento de indivíduos e comunidades com seu entorno sociocultural. Trabalhou com grupos de usuários de substâncias psicoativas, mulheres trans e trabalhadoras sexuais.

\section{Roberto Rocha C. Pires}

Doutor em políticas públicas pelo Instituto de Tecnologia de Massachusetts (MIT), mestre em ciência política pela Universidade Federal de Minas Gerais (UFMG) e graduado em administração pública pela Fundação João Pinheiro (FJP). É técnico de planejamento e pesquisa na Diretoria de Estudos e Políticas do Estado, das Instituiçóes e da Democracia (Diest) do Ipea desde 2009, professor do Mestrado Profissional em Políticas Públicas e Desenvolvimento nesse instituto e professor do Mestrado Profissional em Governança e Desenvolvimento na Escola Nacional de Administração Pública (Enap).

E-mail: <roberto.pires@ipea.gov.br>.

\section{Semblanza Angélica Ospina-Escobar}

Professora pesquisadora do programa de políticas de drogas do Centro de Investigação e Docência Econômicas (Cide), doutora em estudos de populaçôes e mestre em demografia pelo Centro de Estudos Demográficos Urbanos e Ambientais do Colégio do México. Psicóloga pela Pontifícia Universidade Javeriana, Bogotá. É especialista na temática do uso problemático de drogas a partir das perspectivas de gênero, curso de vida e redução de danos. Desde 2008, estuda os usuários de drogas injetáveis e a perspectiva da redução de danos. Em 2012, passou a recolher e analisar relatos biográficos de pessoas pobres que enfrentaram situaçóes de uso problemático de drogas, na tentativa de traçar seus percursos, além de verificar a sobrevivência desse público diante dos eventos que perpassam as trajetórias de consumo e sua relação com outras trajetórias de vida. A partir de 2017, incorporou o componente socioemocional para analisar as trajetórias de consumo de substâncias. É ativista da redução de danos e promotora dos direitos humanos das pessoas que fazem uso problemático de drogas. 


\section{Ipea - Instituto de Pesquisa Econômica Aplicada}

\section{EDITORIAL}

\section{Chefe do Editorial}

Reginaldo da Silva Domingos

\section{Assistentes da Chefia}

Rafael Augusto Ferreira Cardoso

Samuel Elias de Souza

\section{Supervisão}

Camilla de Miranda Mariath Gomes

Everson da Silva Moura

\section{Revisão}

Amanda Ramos Marques

Ana Clara Escórcio Xavier

Clícia Silveira Rodrigues

Idalina Barbara de Castro

Luiz Gustavo Campos de Araújo Souza

Olavo Mesquita de Carvalho

Regina Marta de Aguiar

Hellen Pereira de Oliveira Fonseca (estagiária)

Ingrid Verena Sampaio Cerqueira Sodré (estagiária)

\section{Editoração}

Aeromilson Trajano de Mesquita

Anderson Silva Reis

Cristiano Ferreira de Araújo

Danilo Leite de Macedo Tavares

Jeovah Herculano Szervinsk Junior

Leonardo Hideki Higa

\section{Capa}

Jeovah Herculano Szervinsk Junior

The manuscripts in languages other than Portuguese published herein have not been proofread.

\section{Livraria Ipea}

SBS - Quadra 1 - Bloco J - Ed. BNDES, Térreo

70076-900 - Brasília - DF

Tel.: (61) 2026-5336

Correio eletrônico: livraria@ipea.gov.br 

Composto em adobe garamond pro 11/13,2 (texto) Frutiger 67 bold condensed (títulos, gráficos e tabelas) Brasília-DF 



\section{Missão do Ipea}

Aprimorar as políticas públicas essenciais ao desenvolvimento brasileiro por meio da produção e disseminação de conhecimentos e da assessoria ao Estado nas suas decisões estratégicas.

Este livro aborda as políticas públicas de cuidado ao uso problemático de drogas nos contextos de extrema desigualdade social que caracterizam as sociedades latino-americanas. Envolve um esforço de sistematização de informações sobre a trajetória histórico-institucional e o panorama contemporâneo das ofertas assistenciais em cinco países - Argentina, Brasil, Colômbia, México e Uruguai -, além de aportar dados originais, oriundos de pesquisa de campo, sobre a operação cotidiana de diferentes programas e serviços. Os capítulos evidenciam que está em curso na região uma mudança no panorama institucional das ofertas de atenção a usuários problemáticos de drogas. Essa mudança se expressa na complexificação dos arranjos assistenciais, a partir da experimentação com novas modalidades de atenção baseadas em princípios como a universalidade do acesso, a integralidade, a intersetorialidade, a baixa exigência e a participação social e comunitária. As experiências em curso indicam possibilidades de mudanças paradigmáticas, muito necessárias no campo das políticas públicas de cuidado aos usuários problemáticos de drogas. As análises empíricas dirigem também o olhar para a implementação dessas experiências inovadoras de política pública. São discutidos os desafios enfrentados na concretização das abordagens emergentes, seja em termos da escassez de recursos para plena viabilização dessas ofertas ou das tensões com as modalidades tradicionais de cuidado, assim como no enfrentamento de riscos de reprodução de históricas desigualdades sociais. As conclusões apontam claramente para a necessidade de serem alargadas as condições de possibilidade das experiências em curso, por meio da superação da precariedade material, do processamento das tensões relacionais e da radicalização da inclusão social dos segmentos tradicionalmente vulnerabilizados.

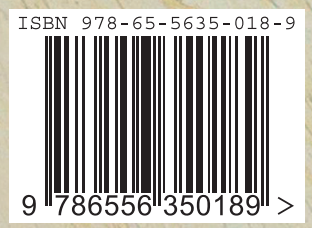

